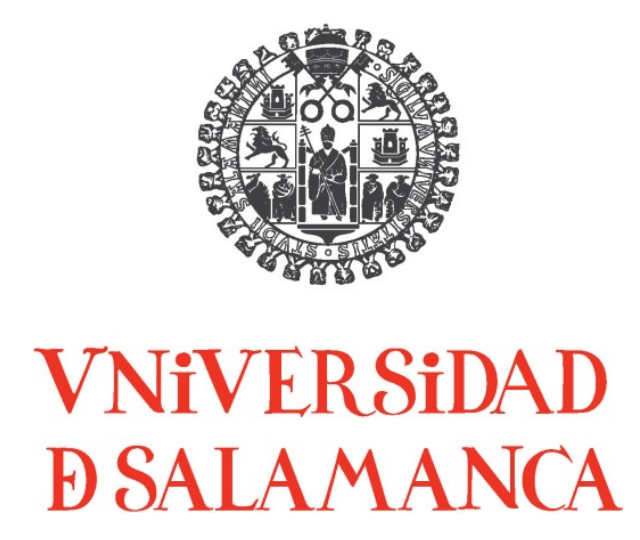

CAMPUS DE EXCELENCIA INTERNACIONAL

TESIS DOCTORAL

\title{
DERECHO DE LA MUJER A LA JOYERIA TRADICIONAL SALMANTINA: IMPLICACIÓN DE LAS ADMINISTRACIONES PÚBLICAS
}

Autora: Dña. María Eugenia Bueno Pastor

Directora: Prof. Dra. Da Maria Dolores Calvo Sánchez 
"CAMINANTE SÍ HAY CAMINO, HAY QUE SABERLO ENCONTRAR"

José Bueno Cordero

Catedrático de Matemáticas y

Profesor Emérito de la Universidad de

Salamanca 
Agradecimientos:

Agradezco a la Universidad de Salamanca, a la Facultad de Derecho $y$ en concreto al Departamento de Derecho Administrativo Financiero y Procesal la ayuda prestada para la realización de esta Tesis.

Agradezco a mi Directora de Tesis la Prof. Dra. Da María Dolores Calvo Sánchez sus conocimientos, inquietudes, ideas y ayuda inestimable, ya que sin ella hubiera sido imposible obtener el resultado que exponemos $y$ terminar esta Tesis tan novedosa en la que desde el principio confió.

Agradezco a todos los que han colaborado en esta Tesis en las diferentes áreas, Conocedores de lo Charro, Artesanos Joyeros, Arquitectos, Área Administrativa y Composición de Texto.

Agradezco a mi marido, a mi hijo, a mi familia y a mis amigos la comprensión, la paciencia y los ánimos. 
Derecho de la mujer a la joyería tradicional salmantina: implicación de las Administraciones Públicas

Dedicado a mi madre in memoriam. 


\section{ÍNDICE}

INTRODUCCIÓN AL DERECHO ............................................... 7

MATERIAL Y MÉTODO UTILIZADO .......................................... 25

1. Justificación teórica de la elección de fuentes cualitativas ........ 26

2. Fuentes orales locales: ...................................................... 39

2.1. Feli Cañada Miguel........................................................... 39

2.2. Antonio José Martín Sánchez ................................................ 44

2.3. José Luis Nieves Delgado ................................................... 46

2.4. Miguel Ángel Cordón Rodríguez............................................ 47

2.5. José Alfonso Jacinto Sánchez-Vasconcellos Bravo .................... 49

\section{CAPITULO I. LA EVOLUCIÓN HISTÓRICA DE LA JOYERÍA TRADICIONAL: ESTUDIO DESCRIPTIVO}

1. Introducción................................................................ 52

2. Espacio y tradición: La filigrana y sus antecedentes ............... 67

3. Las rutas hacia la Península Ibérica: procedencia e influencias. 78

4. El traje como soporte del aderezo joyero................................ 91

4.1. Aproximación al tema ............................................................ 91

4.2. Conversaciones con Feli Cañada ............................................. 99

CAPITULO II. TÉCNICAS AMANUENSES DE LA JOYA, SU PRAXIS EN: LA TALLA, LA FILIGRANA Y LA MICROFUSIÓN

1. Artesanos amanuenses en la creación de la joya: los Oreros .... 163

1.1. La praxis de la talla: Antonio José Martín Sánchez ..................... 163

1.2. La praxis de la filigrana: José Luis Nieves................................. 169

2. El proceso semiartesanal de la joya: La Microfusión .................. 179

2.1. Antecedentes históricos ........................................................ 179

2.2. La Microfusión para el caso particular de la filigrana Charra. Experiencia técnica en el taller del artesano Miguel Ángel Cordón.................. 187

3. La situación actual: Conversación con el empresario José Alfonso Jacinto Sánchez-Vasconcellos Bravo .............................. 219 


\section{CAPITULO III. DELIMITACIÓN CONCEPTUAL Y DOCTRINAL: LA FORMA}

1. Introducción.

2. Orígenes de la forma, dificultad e importancia de la delimitación conceptual: arquetipo, mandala y símbolo............................... 235

3. La geometría sagrada ....................................................... 282

4. Las medidas áureas del Botón Charro.................................... 300

5. Realidad o Mito: hipótesis de globalización .............................. 322

\section{CAPITULO IV. LA NECESARIA IMPLICACIÓN DE LAS ADMINISTRACIONES PÚBLICAS Y LA EMPRESA PRIVADA}

1. La necesaria implicación y tutela de las Administraciones Públicas

1.1. Administración Pública Europea ............................................... 331

1.2. Administración Pública del Estado .......................................... 342

1.3. Administración Pública Autonómica: CYL ................................ 360

1.4. Administración Pública Local .................................................. 375

2. "ARS GEMMARIA NOVA": un proyecto de actualización de la joya para la mujer del XXI ................................................ 380

2.1. Proyecto empresarial. Puesta en valor del estudio investigador.. 394

2.2. Valoración popular.................................................. 397

CONCLUSIONES ..................................................................... 412

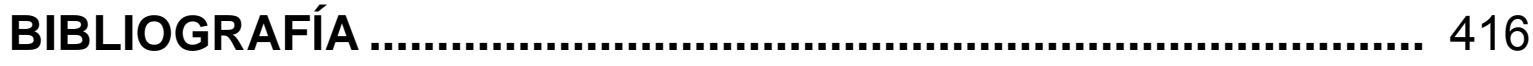

ANEXO, DVD:

1. Traje: Feli Cañada. Fotos de F-1 a F-153

2. Talla: Antonio J. Martín. Fotos de A-1 a A-19

3. Filigrana: a) José Luis Nieves. Fotos de $\mathrm{N}-1$ a N-152

b) Michel Cordón. Fotos de AN-1 a AN-13

4. Microfusión: Michel Cordón. Foto 1 a Foto 257.

5. Pdf "Ars Gemmaria Nova y 6. Pdf Tesis 


\section{INTRODUCCIÓN AL DERECHO}


La mujer tradicional tiene derecho a no olvidar su identidad y las Administraciones Públicas tienen necesariamente que proteger por imperativo legal, lo que constituye sin duda un bien público. El aderezo joyero es una de sus señas de identidad, muy poco o nada estudiado, nos ofrecerá un punto importante en el que encontrar mucho más que símbolos o simple herencia. Él nos guiará desde lo más remoto del tiempo hasta nuestros días y todo para darnos hitos dónde buscar quienes fuimos y quienes somos.

La velocidad del mundo en esta segunda década del SXXI, pone en riesgo la pérdida de su pasado por la falta del conocimiento de determinados objetos que en la actualidad han perdido su función y su sentido, pero que en otros tiempos fueron la única herencia personal que se trasmitía de madres a hijas dentro del clan familiar.

Estas piezas hasta ahora, apenas han sido objetivo de estudio universitario por no considerárselas dignas de ello. El riesgo que corremos es la desmemoria y con ella la pérdida de un patrimonio, que a pesar de ser mudo, forma parte de la mujer de este territorio y que como estudiaremos, la va a emparentar con otras mujeres muy alejadas de ella, tanto en el espacio como en el tiempo, pero que sin embargo las identifica.

La sustitución de una antigua y trasnochada mujer tradicional da paso a una mujer incorporada a todos los procesos productivos y a todos los ámbitos de la vida.

Una nueva visión de ésta mujer pone de manifiesto que sólo quienes conocen la Historia son dueños de su destino, rechazando así el olvido de aquello que le pertenece por derecho, aunque exista una tendencia generalizada a olvidarlo y sustituirlo. 
No atender estos aspectos violaría nuestra ética y nuestros principios, que pasan por dar el valor real que tienen fundamentándolo en que la importancia de las cosas es el tiempo el que se encarga de proporcionarle el lugar que les corresponde.

Se ha hecho un importante trabajo y esfuerzo para que quede constancia de que la clave de la supervivencia, cómo en todos los órdenes de la naturaleza y por supuesto aquí, es "La adaptación" como quedará demostrado con "Ars Gemmaria Nova".

Las Administraciones Públicas deben ser los garantes de que este patrimonio no solamente no desaparezca, sino que han de fomentar proyectos que lo mantengan en una sociedad predispuesta al olvido con mucha facilidad.

Salamanca tiene un patrimonio de joyería tradicional de una riqueza extraordinaria, no sólo por la belleza intrínseca de los objetos sino por el valor de identidad para las mujeres de este territorio, que no se puede permitir perder, y aún menos abocarlo a una muerte indigna provocada por la amnesia histórica.

Somos los universitarios a través de la investigación, los que debemos plantearnos estos aspectos estudiándolos y aportando soluciones, ya que es de justicia.

Basta un breve repaso por las hemerotecas para constatar que en la actualidad, en el ámbito de los estudios dedicados a la investigación del patrimonio joyero tradicional salmantino, no existe prácticamente nada. A pesar de que la literatura etnográfica histórica ${ }^{1}$ ha tratado estos temas, la realidad nos da un vacío bastante grande en el caso concreto que nos

\footnotetext{
${ }^{1}$ CEA GUTIÉRREZ, A.: Nos estamos refiriendo a los trabajos realizados por este profesor e investigador, que pertenece al Instituto de Lengua, Literatura y Antropología cuya línea de investigación se circunscribe al patrimonio, memoria e identidad. Consejo Superior de Investigaciones Científicas. Madrid.
} 
ocupa $^{2}$. Este hecho nos plantea un conflicto que es verdaderamente ingente, pues siguen quedando cuestiones de interés por debatir y desafíos a los que dar respuesta.

Si se repara en las noticias que aparecen en los libros, muy escasas, la mayor parte de las veces aparecen de forma anecdótica, considerando que hay que reivindicar un estudio más compacto que gire en torno a los verdaderos aspectos que hacen de este patrimonio la piedra angular de la herencia femenina de esta tierra, considerando su recuperación y valoración un tema de derecho femenino y de conciencia para no olvidar nuestra identidad ancestral.

El concepto de Derecho que nosotros vamos a utilizar en todo momento, excepto en la parte dedicada específicamente a las implicaciones de las Administraciones Públicas, va a quedar circunscrito al valor popular del mismo, entendiendo por ello lo que el pueblo y su conciencia de experiencia hacen que la mayoría considere como "de justicia". Aquí siempre está la valoración objetiva que da la propia vida quedando en la memoria colectiva aquello que el pueblo dice: "tengo derecho a...", “...esto es de justicia..." e incluso se apela a "la justicia divina".

Salvo excepciones resulta poco frecuente encontrar la experiencia escrita de la herencia joyera en sí misma, aunque suele quedar englobada en lo que tradicionalmente se conocía como el "Ajuar"3 del que también por desgracia hay poco.

Por ser de exclusiva propiedad de la mujer y teniendo en cuenta que ella no existía a efectos de poder, este tipo de objetos pasaban de unas a otras de manera familiar considerándose por derecho implícito el que ellas legaran sus bienes más personales a las hijas, sin que en ello hubiera

\footnotetext{
2 HERRADÓN FIGUEROA, M.A.: Cabe destacar de manera especial los trabajos realizados por esta investigadora a lo largo de su trayectoria. Tanto en la revista de Dialectología y Tradiciones Populares como a través de sus trabajos realizados en el Museo del Traje Español, Asociación Profesional de Museos de España, Museo Nacional de Antropología...

3 www.rae.es, Diccionario de la Lengua Española, "Ajuar": (Del ár. hisp. aššiwár o aššuwár, y este del ár. clás. šawār o šiwār): 2. m. Conjunto de muebles, alhajas y ropas que aporta la mujer al matrimonio.
} 
discusión familiar. Incluso en grandes patrimonios joyeros así se ha venido haciendo por tradición.

Probablemente sin saberlo y sin quererlo esta mujer silente, estaba sentando las bases de un futuro en el que su sexo poco tendría que ver con los verdaderos derechos que el paso del tiempo le concedería por derecho propio. Tampoco resulta fácil saber qué ocurre con esa herencia o cómo se desarrolla y resuelve el desencuentro entre pasado y futuro.

Semejante desconocimiento resulta especialmente grave en el caso de la desaparición de una importante parte de este patrimonio, que como veremos la propia sociedad se ha deshecho de él por considerarle pueblerino, paleto o simplemente trasnochado. De ahí la necesidad de la implicación por obligación de las Administraciones Públicas, para proteger este patrimonio en vías de extinción por éste y otros motivos que explicaremos a lo largo de nuestro trabajo.

El no reconocimiento del valor intrínseco y extrínseco de estos objetos, así como la cada vez menor mano de obra dedicada a ellos, constituyen uno de los principales problemas para la puesta en valor de los mismos. Durante mucho tiempo estos objetos, a todas luces identificativos de la mujer, en realidad no era infrecuente que supusieran más la identificación del poder masculino en una sociedad de doble dominación por parte del hombre, que ejercía su poder tanto económico como de clan.

Haremos un estudio del significado socio-económico de este patrimonio, con la intención de poner de manifiesto la importancia que ha venido teniendo hasta la segunda mitad del $S \mathrm{XX}$ que, apurando tiempos, podríamos ampliar hasta el último cuarto de dicho siglo.

Las técnicas utilizadas en la ejecución nos desvelarán aspectos que en tiempos pretéritos unían a los pueblos, cuando era impensable hablar de globalización. Sin embargo aparecen apuntes muy interesantes que harán volar la imaginación y que será el estudio de la forma y el significado de la misma, quien nos haga realizar hipótesis nada desdeñables. En este último 
sentido dedicaremos un espacio, a nuestro entender único, innovador y revolucionario, donde demostraremos los valores áureos de nuestro insigne Botón Charro y lo que ello significa. Nunca, hasta ésta tesis, se pensó que éste pobre objeto fuera algo tan extraordinario, al menos desde el punto de vista cultural y académico.

El proyecto tiene una parte centrada en el estudio sobre la Joyería Artesanal y Tradicional Salmantina, centrándonos fundamentalmente en la Filigrana Charra y entendiendo la misma, como un reflejo socio-económico de una sociedad vinculada a un espacio geográfico determinado: la provincia de Salamanca, siendo el territorio el enmarque y soporte de la misma. En este área concurren líneas de confluencia que no se dan en otros territorios.

Estudiaremos cómo rutas y mercados exteriores a la Península Ibérica, han conformado lo que tenemos en este territorio, demostrando que no es nada casual.

Acogeremos puntualmente en este trabajo el "traje o vestimenta" como soporte joyero y su dispersión geográfica, puesto que él es el soporte de la joya descansa y la forma de los dibujos puede que nos ofrezca ciertas explicaciones hasta ahora no contempladas.

La mujer tiene costumbres según el lugar que ocupa en el espacio, así mismo se identifica con una manera de vestir fruto de la tradición y de la climatología. Estos aspectos también hay que tenerlos en cuenta para explicar los comportamientos y los usos. Los paños pueden ser un testigo real de la influencia de otros territorios.

Analizar, estudiar e indagar la procedencia y la tipología de nuestra joyería tradicional como son: la Filigrana y la talla vinculada a la Filigrana, es muy necesario para comprender por qué estos objetos han perdurado durante tanto tiempo y sobre todo tener en cuenta que la técnica nos vinculará a otros espacios, incluso otros continentes, y que con ella sin duda también nos infiltraron sus costumbres respecto a la mujer. 
El proceso industrial de la Microfusión, para el caso concreto de la Filigrana Charra, se convertirá en otro eje de nuestro estudio. Esta técnica ha favorecido la no desaparición de esta herencia y ha socializado el acceso a estas piezas por un gran número de mujeres con menor poder adquisitivo.

Pretendemos indagar y explicar en qué situación se encuentra este sector económico, que habiendo tenido un peso específico importante en nuestra provincia, en la actualidad está a punto de desaparecer.

Desaparecer implicaría renunciar a nuestra identidad. Comprobar un sector económico importante del pasado, supone aceptar la importancia que para la mujer tradicional tenía este legado para su prole femenina. Se puede considerar a la joyería como el mejor legado socio- económico de poder y de identidad que trasmitía y que debería seguir transmitiendo la familia en su rama femenina, sin olvidar que el hombre también heredaba la suya, pero como hemos acotado el ámbito de estudio a la mujer por este aspecto pasaremos de soslayo ya que en el fondo mantiene las mismas estructuras y contenidos que el de la mujer ya que ambos comparten el mismo ámbito.

Estudiaremos la Forma pues con ella nos llegarán luces hasta ahora ocultas y que sin embargo pertenecen al género humano y en especial al femenino. Plantearemos el derecho que nos da esa identidad ancestral y propondremos soluciones a futuro, dónde la mujer actual tendrá mucho que decir.

Si estudiamos la técnica y estudiamos la forma, ambos parámetros de estudio, nos servirán para demostrar que somos herederas de un legado ancestral donde seguramente la naturaleza tenga mucho que decir. Si somos capaces de demostrar ese patrimonio ancestral, tendremos que levantar la voz para evitar que semejante patrimonio cultural y femenino desaparezca en el siglo XXI.

Plantearemos un territorio de conflicto pero intentando siempre aunar: tradición, identidad, mujer y futuro. 
En este orden de cosas plantaremos Ars Gemmaria Nova como elemento vertebrador de futuro y ejemplo de sostenibilidad de una forma de entender, trabajar y de seguir dando una herencia a una mujer que viene realizándose en este territorio desde hace miles de años.

A las Administraciones Públicas la propia sociedad le otorga el papel de garante de esta identidad y la norma la responsabilidad que tienen de mantener para el futuro, un bien público único hasta ahora poco estudiado, de las mujeres silentes de esta parte de la Península Ibérica.

Nuestro estudio investigador buceará sobre la realidad forense de las Administraciones Públicas en los ámbitos europeo, estatal, autonómico de Castilla y León y Local de Salamanca, veremos su grado de implicación y tutela, pero no menos interesante resultará, traer al estudio los pronunciamientos formales que estas Administraciones vienen realizando sobre el patrimonio cultural en general y de sus bienes materiales muebles e inmateriales, en particular.

La normativa vigente, junto a la Jurisprudencia más relevante habida sobre la materia en estudio, es traída sin otra pretensión que poner la evidencia legislativa existente y el soporte legal a nuestra mayor pretensión, el reconocimiento y estima de nuestra joyería tradicional charra a través de su mayor exponente : El Botón Charro.

La doctrina, escasa pero potente sobre el tema, resulta de suma utilidad $^{4}$, por cuanto nos dicta el recto camino a seguir y sus pronunciamientos hacen más patente, si cabe, la relevancia del valor histórico y patrimonial de la cultura que tenemos. Por ello, no pretendemos hacer cuerpo doctrinal alguno, sino una toma de consciencia de la relevancia del tema en estudio desde la perspectiva jurídico-social y empresarial.

\footnotetext{
${ }^{4}$ Alonso Peña, J,R. Nuevos modelos de gestión cultural en la crisis del siglo XXI
} 
Una vez que hayamos estudiado, valorado, definido y después de otorgarles todos aquellos valores que son objeto de este trabajo, procede plantearse nuevos horizontes que permitan tanto a Administraciones Públicas como a particulares, proyectos que puedan potenciar en el futuro esta joyería y donde la mujer pueda sentirse orgullosa de portar sus señas de identidad. De ahí el Capítulo IV, verdadera propuesta de innovación y apuesta de futuro.

Este tipo de patrimonio joyero se ha convertido en un vértice, habitualmente oculto y no siempre valorado de las incertidumbres científicas que se plantean en el contexto femenino. El difícil manejo de la relación entre la mujer tradicional y una sociedad marcadamente futurista y globalizada, requiere que sea necesaria la voz de los investigadores que ponga de manifiesto el valor de su pasado y la esperanza de su futuro.

Es precisamente la comprobación de estos aspectos lo que nos ha conducido a tratar de establecer una perspectiva muy poco o nada frecuente, que pretende contemplar los problemas destacando las consecuencias de la no valoración de ésta riqueza tradicional e identificativa de la mujer de ésta tierra y llevar a cabo las reivindicaciones necesarias para recuperar una conciencia tanto en la sociedad como en las Administraciones Públicas.

Con este enfoque no es nuestra intención obviar la amenaza que puede suponer para la integridad del conocimiento de la posición de la mujer ante comportamientos y usos llevados a cabo en las sociedades más tradicionales. Debemos plantear procedimientos que resulten viables, aunque para algunas voces ${ }^{5}$ sean soluciones poco ortodoxas y conflictivas con la tradición pura y dura.

Lo que se pretende en este trabajo es poner en relación los conocimientos del pasado, los derechos de una mujer rural silenciada en la

\footnotetext{
${ }^{5}$ Opiniones vertidas en el libro de la Sala de Exposiciones de Santo Domingo tras la exposición de "Ars Gemmaria Nova". Recogido en el punto 4.2.2 del Capítulo IV del presente trabajo.
} 
Historia y posibles soluciones para que, esos valores lejos de desaparecer, estén en alza con la debida tutela de las Administraciones Públicas.

Frente a este tipo de situaciones, surgen otras más novedosas, como la creación de una opción complementaria a la tradición que esté entroncada con la nueva mujer del Siglo XXI, muy alejada de aquella de la que nos llega esta herencia. En este caso paradójicamente, la modernidad nos pondrá de manifiesto que al descontextualizar estas piezas lo resultante nos colocará en otros territorios muy lejanos al nuestro. No obstante estas piezas del S. XXI siempre serán solidarias con las históricas para evitar su vulnerabilidad, pretendiendo con ello contribuir a la socialización y la humanización de las Administraciones Públicas, asignatura pendiente hoy día.

Este tipo de proposiciones cuestionarán los límites de lo que académicamente $^{6}$ se entendía por tradicional, pasando a identificar a una mujer nueva que por supuesto no reniega de su pasado, pero que se adapta al futuro y con ello los objetos que la complementan. Esto guarda más relación con cuestiones de avance social que con asuntos que atañen a la estricta moral academicista de dejar las cosas en un pasado que carece de futuro. De ahí la necesidad de abordar una revisión conceptual que, en cierta medida, redimensiona el problema del inmovilismo frente a la posibilidad de dar otras pautas para este patrimonio sin olvidar o alterar nada de su pasado pero situándolo en un plano donde los nuevos usos no entren en conflicto con lo anterior, sino que sirvan de nexo entre lo tradicional y lo moderno.

De esta manera, más allá de las causas y consecuencias que acompañan a los objetos origen de estudio, se verá que el pasado nos explica los comportamientos femeninos, que si no hubiera sido por estas piezas jamás se hubieran conocido.

En tanto que las Administraciones Públicas no tengan un compromiso con la tradición joyera y las personas que conforman las instituciones

\footnotetext{
${ }^{6}$ Ya que la joyería no se ha estudiado metodológicamente desde el ámbito académico con la intensidad que requiere.
} 
académicas no valoren este tipo de trabajos de investigación, nos encontraremos en situación de difícil solución.

Por tanto, existe una obligación constitucionalmente ${ }^{7}$ reconocida de garantizar que este tipo de patrimonio no se vea relegado por otras subjetivas prioridades. Ello supone una concepción específica de la tradición de la mujer como bien, individual y colectivo, puesto que tanto políticamente como desde la perspectiva del derecho es de justicia que ella conozca su propia identidad a través de la herencia joyera hasta ahora poco estudiada. Esta manera de conocer parte de su identidad se le otorga a través de la función que tenían estos objetos dentro de la vida cotidiana y que nos la proporciona el conocimiento de los mismos. Este aspecto resulta importante en la medida en la que la protección de este patrimonio, bajo ciertas circunstancias, podría convertirse en un límite para el futuro si no se plantearan otras nuevas perspectivas para estos objetos.

El panorama que acabamos de plantear justifica, a nuestro modo de ver, el estudio de este patrimonio denostado pertinente para el análisis y la reflexión, tanto en el nivel de la relación económica como en el de sus implicaciones sociales. Por ello, en este trabajo, se pretende situar los conflictos de los límites entre lo tradicional y el futuro en su contexto, revisar ciertos conceptos asentados y contrastar el estado de la cuestión en los discursos de la etnografía, del derecho, saber de nuestro origen para, finalmente, establecer las condiciones para el ejercicio de las propuestas a futuro con la implicación de la Administraciones Públicas en función de planteamientos innovadores.

Para ello el trabajo de investigación que presentamos se articulará en capítulos, abordando así la estructura del estudio.

\footnotetext{
${ }^{7}$ Art. $46 \mathrm{CE}$, “Los poderes públicos garantizarán la conservación y promoverán el enriquecimiento del patrimonio histórico, cultural y artístico de los pueblos de España y de los bienes que lo integran, cualquiera que sea su régimen jurídico y su titularidad. La ley penal sancionará los atentados contra este patrimonio."
} 
Antes de comenzar con los Capítulos, el trabajo ofrece un apartado dedicado al Material y el Método utilizado en nuestra investigación donde justificaremos, por qué nos hemos inclinado por unas determinadas técnicas de investigación. La transmisión del conocimiento oral, se hará factible en el tipo de fuentes orales que hemos utilizado para nuestro conocimiento y aprendizaje.

Comenzamos en el Capítulo I con una introducción a la evolución histórica general del entorno de las piezas objeto de estudio. A continuación, iremos desde el pasado más remoto buscando las rutas y los lugares de relación comercial de donde procedían las influencias e incluso las técnicas dedicando a la Filigrana y sus antecedentes una parte importante de este apartado, dándonos claves para la posterior interpretación de la forma de los objetos, así como el marco justificativo-normativo que posteriormente deberá amparar y regula este bien de patrimonio cultural.

Si tenemos en cuenta el valor de la Historia, las voces del tiempo, la técnica, la forma y su significado como amalgama de una heredad femenina ancestral, tendremos los resortes donde buscar la implicación de las Administraciones Públicas para evitar que este interesantísimo y único patrimonio femenino se pierda. En este apartado encontraremos algunas de las causas justificativas para que insistamos en propuestas a las Administraciones Públicas para que pongan en valor y preserven tamaño patrimonio. Ello nos ayudará a cumplir el objetivo de poner de manifiesto, cómo a través del valor del origen debe existir un compromiso por parte de las Administraciones Públicas para evitar la desmemoria o la muerte de este patrimonio que durante tanto tiempo impuso su leyenda sobre una mujer que formaba parte de nuestra propia memoria histórica como grupo.

Más adelante evaluaremos las rutas confluyentes en la Península Ibérica por las que penetraron influencias técnicas y culturales. Con tal fin, se presenta la evolución histórica de los objetos que estudiamos buscando canales de encuentro y flujos comunes a un mundo conocido en la antigüedad que nada tiene que ver con el actual pero que sin embargo nos 
conecta con la realidad histórica de la tradición y de la mujer. La primera mujer o la mujer en el principio. Asistiremos a recordar los rasgos previos para llegar a los actuales y ver la incidencia de los cambios acaecidos en el surgimiento de una identidad femenina que cambiará con el paso del tiempo. Asimismo, se formulan los primeros enfoques desde los que pueden analizarse esos primeros signos de identidad, según se atienda a los intereses, los deberes, los derechos o las relaciones de poder que se establecen entre las partes implicadas: herencia de formas, técnicas y objetos.

Por último, hablaremos del traje tradicional como soporte de la joya, si bien es verdad que lo trataremos someramente pues no es objeto del presente trabajo. De los distintos trajes, dedicaremos especial atención al de la "charra central", poco estudiado y muy interesante, hablaremos del resto de los trajes única y exclusivamente como soporte y de el "Albercano" o "De la sierra" como ya ha sido estudiado mucho más ampliamente por otros especialistas en la materia ${ }^{8}$.

En el Capítulo II haremos especial hincapié en los distintos artesanos que, en la actualidad, siguen reproduciendo esas técnicas ancestrales con las que se llevaban a cabo las piezas objeto de estudio y que están a punto de desaparecer. En este capítulo nos centraremos en la praxis de las técnicas joyeras incorporándonos a los talleres de los artesanos de talla, filigrana y microfusión, realizando un amplio estudio documental y único sobre el caso concreto de estas técnicas en la joyería charra. En este Capítulo hablaremos del conflicto entre las técnicas y lo que ello supone para la supervivencia de estos objetos y por ende a nuestra identidad.

En el Capítulo III haremos un análisis importante del estudio de la "forma" intentando, a través de ella, llegar a territorios antes impensables y desconocidos hasta ahora. Para ello bucearemos en las diferentes definiciones de signo, arquetipo, mandala,... incluidos en las teorías filosóficas de Jung, Jacobi, Eco, Freud,...

\footnotetext{
${ }^{8}$ CEA GUTIÉRREZ, A. Cit. Ant.
} 
Este capítulo supone en sí mismo un reto. Basándonos en los resultados obtenidos, pretendemos plantear una teoría en la que tomando como base estos objetos que estamos estudiando, a todas luces ancestrales y con el mero hilo conductor de la mujer, podamos poner en orden parte del origen de una identidad que jamás se pensó encontrar en ello un pilar explicativo.

Estudiaremos la geometría sagrada donde hablaremos de las nuevas teorías del fractal y haremos estudios de diferentes elementos naturales intentando encontrar simetrías con nuestros objetos de estudio. También analizaremos las proporciones áureas del Botón Charro y veremos cómo este aspecto se convierte en un elemento de innovación esencial para el estudio $^{9}$. Más adelante hablaremos de la realidad o del mito y por supuesto, del conflicto que plantea esta teoría en contraposición con las posturas tradicionalistas. No obviaremos las críticas que esta posición avanzada puede poner como conflicto.

Por último en el Capítulo IV pondremos en valor todo cuanto hemos aportado a lo largo de todo el trabajo como justificación científica para la implicación de las Administraciones Públicas en el proyecto de recuperación y reactualización para el futuro de este patrimonio objeto de estudio. Para ello revisaremos los ámbitos jurídicos de la Administraciones Europea, Estatal, Autonómica: CyL y la Local: Salamanca.

Igualmente pondremos de manifiesto cómo y de qué manera la tradición se enfrenta a una nueva interpretación de la herencia femenina, teniendo en cuenta los gustos y tendencias de una mujer que busca que los objetos que una vez la identificaron lo sigan haciendo en el presente y en el futuro. Sin olvidar la tradición, "Ars Gemmaria Nova" propone alternativas reales que sienten precedentes para generaciones futuras y pretende crear escuela para otras herencias femeninas en otros territorios.

\footnotetext{
${ }^{9}$ No se encuentran estudios relacionando el Botón Charro con la teoría matemática y filosófica de las medidas áureas, ni de las teorías del fractal.
} 
Como problemas conceptuales concretos, se intenta demostrar que los límites entre la tradición y el futuro, desde un punto de vista más estricto, pasa por un diálogo donde, sin alterar la forma, pero "deconstruyendo" sus elementos y construyendo y fusionándolos con otros nuevos se abre un camino hasta ahora inexplorado para la obtención de nuevos objetos que en el futuro puedan tener marca de identidad también.

Así, plantearemos el proyecto empresarial que ponga en valor todo el estudio investigador, que aglutine todas las conclusiones y territorios nuevos a los que hemos arribado. A este proyecto se le denominará "NO HAY 2 IGUAL". Ello nos proporcionará la plataforma de lanzamiento para proponer nuevos horizontes acordes a una mujer nueva.

Pondremos de manifiesto la experiencia llevada a cabo con Ars Gemmaria Nova como referente único de ejemplo a seguir con las AAPP como patronas y garantes de un nuevo patrimonio que hunde sus raíces en la Historia. Demostraremos que si el trabajo se hace con rigor se pueden plantear opciones actuales que, además de identificar a la mujer del siglo $\mathrm{XXI}$, sirvan para afianzar una herencia ancestral a punto de desaparecer.

Dentro del abanico de conclusiones y propuestas se identifican dos extremos diferenciados: el modelo basado en la consecución de una tradición que nos identifica sin más y otra línea centrada en la mujer actual y sus propias dimensiones, que proporciona un lugar preponderante a los intereses y derechos de la mujer actual y del futuro, que otorga a la tradición su valor en el tiempo, pero no renuncia a su nueva identidad.

Ante la dificultad que plantea semejante polarización del problema, valoraremos los resultados de la propuesta de "Ars Gemmaria Nova" como apuesta de futuro, basada en una mujer nueva alejada en todos los aspectos de aquella mujer tradicional de la que nos ha venido el legado que hemos estudiado. Intentaremos superar estos aparentes modelos antagónicos. La propuesta recoge las principales visiones teórico-prácticas acerca de la interacción entre usuarias tradicionales y nuevas usuarias en el contexto de 
las reivindicaciones de identidad, atendiendo fundamentalmente a dos aspectos: la naturaleza de los objetos y el alcance de ellos en una sociedad donde se les otorga convicciones estéticas muy alejadas de lo que fueron en origen.

Igualmente, se defiende la deliberación argumentativa como fórmula procedimental para establecer los usos legítimos de estos objetos-joya de una mujer nueva que respeta y valora profundamente el legado de sus antecesoras en la línea de la identidad grupal. Igualmente, resulta preciso calibrar la repercusión que el reconocimiento de la tradición pueda tener sobre las demás formas de interpretar el futuro.

Finalmente, llegaremos a unas conclusiones y resultados obtenidos, exponiéndolos con el mayor grado de concreción, pragmatismo y operatividad desde el mayor rigor académico, siempre de la mano inestimable de la doctrina.

Respecto a la hipótesis y objetivos planteados, el punto de partida de este trabajo es la búsqueda del derecho de la mujer tradicional salmantina a encontrar una parte de su identidad a través del estudio de joyería tradicional como hilo conductor entre la mujer y su tiempo, como derecho cívico.

Hemos observado que la falta del aval académico puede conducir a un menosprecio o desprecio de estos objetos, que resultan ser claves a la hora de interpretar el propio comportamiento de la mujer en un determinado contexto. Un uso inapropiado del verdadero valor de éste patrimonio femenino, banalizándolo o sacralizándolo, puede ser consecuencia de que no se haya considerado el alcance, que la negativa influencia que este hecho ha infligido, tanto a su valor económico como a su valor sociológico.

De acuerdo con estas premisas, se pretende analizar las tensiones entre una realidad femenina carente de interés por su propia identidad y la necesidad de su conocimiento para poder aportar a la sociedad, otros criterios de valor, que la hagan replantearse la importancia verdadera de este patrimonio. Intereses, derechos y obligaciones que surgen entre las 
partes implicadas, así como las relaciones de poder que se establecen entre quienes ostentan el conocimiento experto y quienes se encuentran en situación de mayor vulnerabilidad.

Este análisis persigue identificar los problemas en los distintos niveles discursivos -de intereses, de derechos y obligaciones y de relaciones de poder- sin prescindir del contexto en el que esos problemas surgen. De ahí la atención prestada a la evolución de la relación entre la joya, desde una perspectiva histórica, y la necesidad de establecer el marco necesario en el que se plantee un futuro sin fisuras.

El tratamiento teórico que desde la Historia nos proporciona el estudio de la joya tradicional y su entorno femenino desde la sociología, nos ha de proporcionar la plataforma de lanzamiento para proponer nuevos horizontes, acordes a una mujer nueva. Todo este bagaje previo contribuye a establecer y justificar una serie de límites que condicionen el ejercicio de la libertad de nuevos planteamientos, a nuestro parecer novedoso y extrapolables a otros patrimonios joyeros que identifican a otras mujeres en otros territorios. Con ello, se aspira a ofrecer un marco histórico y de derecho a un futuro, que pudiera servir de referencia, para la resolución del concepto actual denostado de este patrimonio cultural, a partir de una concepción mucho más amplia y menos individualista de la que impera en la actualidad.

Como objetivos principales cabe plantear los siguientes:

- Identificar la existencia y las características específicas del patrimonio joyero de la mujer tradicional salmantina. La herencia de la Historia y su marco normativo.

- Determinar el impacto de este patrimonio en la identidad de la mujer salmantina. Para ello examinaremos distintos niveles de estudio en la forma desde el punto de vista de su significado intrínseco y extrínseco, haremos los cálculos oportunos para averiguar si el botón charro contiene la proporción áurea y analizaremos su valor estético. 
- Plantear y analizar críticamente la concepción y el tratamiento de lo tradicional para buscar aportes de innovación a futuro: "ARS GEMMARIA NOVA".

- Plantear y analizar críticamente el panorama actual, herencia del pasado, en relación con el tratamiento de futuro.

- Establecer los límites entre la tradición limitada en tiempo y espacio y la puesta en marcha de nuevas tendencias que lejos de denostar nuestro pasado lo engrandezcan y se perpetúe. Un ejercicio de libertad de una mujer nueva que no olvida las obligaciones con el pasado y reivindica que éste sea protegido legítimamente por las Administraciones.

- Formular propuestas formales respecto al reconocimiento institucional, lingüístico y su puesta en valor sobre la consideración mayoritaria que entiende que la tradición debe permanecer sin la posibilidad de que determinados aspectos puedan ser adaptados a los nuevos tiempos. El proyecto empresarial que nosotras aportamos como vía de futuro y proyección se materializará en" NO HAY 2 IGUAL". 


\section{MATERIAL Y MÉTODO UTILIZADO}




\section{Justificación teórica de la elección de fuentes cualitativas.}

Afrontar una cuestión como la que nos ocupa requería una decisión de método entre el cualitativo y el cuantitativo. Ambos forman parte de la investigación, pero convinimos utilizar mayormente el cualitativo planteando así un estudio articulado en torno a dos variables: aspectos tradicionales y futuro. Ambas metodologías son complementarias y necesarias para llevar a buen puerto este proyecto, teniendo como límite el espacio geográfico que previamente hemos elegido: Salamanca.

Para abordarlo lo haremos desde dos enfoques:

- Teórico-conceptual, con el fin de atender al fundamento histórico y normativo de los elementos objeto de estudio, sin los cuales sería imposible proponer acciones a futuro, ni conocer el derecho de la mujer a su identidad fruto de la tradición en esta tierra.

- Práctico-hipotético, con el fin de conocer la realidad de los objetos concretos, las consecuencias, las necesidades que nos lleven a nuevos territorios interpretativos que obliguen a las Administraciones Públicas a ser garantes del pasado y del futuro de esa identidad femenina.

No en vano ambas perspectivas, la epistémica y la práctica, están íntimamente interconectadas. Dado el carácter interdisciplinar del trabajo que abordamos, adicionalmente se integrarán aportaciones procedentes del ámbito etnográfico, sociológico, matemático y jurídico, cuyos intereses se solapan con los propios de la filosofía de este proyecto. 
Ello no supondrá en modo alguno abandonar la metodología propiamente humanística, que en este trabajo adoptará un patrón analítico basado en la argumentación lógica y en el análisis conceptual de las experiencias vividas con los muy diferentes protagonistas de este trabajo, intentando dejar constancia de los aciertos y también de los problemas detectados.

Igualmente, se tendrá en cuenta la investigación empírica presentando la casuística apropiada a cada caso, en la medida en la que constituye un elemento indispensable para la correcta definición, delimitación y reformulación de los conflictos entre tradición y futuro. En ese sentido, se tratará de aplicar un enfoque dónde la búsqueda de la identidad femenina sea siempre el puerto al que llegar.

El enfoque que aúna las dimensiones teórica y práctica y que proporciona coherencia al presente trabajo, se encuentra vinculado a la teoría de que buceando en este territorio joyero, encontraremos el derecho de una mujer sin nombre, para llegar a una identidad hasta ahora desconocida por la escasez de trabajos al respecto, siendo éste uno de los valores más novedosos del presente proyecto. Todo ello como camino indiscutible para buscar retos que impidan que este patrimonio femenino se pierda. Así nos moveremos en un área feminista y femenina a la vez.

A través de esa mirada, es posible explorar los modos en los que la mujer de esta tierra puede llegar a comprender mejor su ancestro y su destino ya que el conocimiento de lo que nos identifica le dará parámetros para la autocomprensión y las interacciones con los demás a nivel individual, colectivo e incluso plantearse el apoyo de las Administraciones Públicas porque ellas son o deben ser quienes mantengan el fuego del pasado y garanticen el del futuro.

La reivindicación de que las mujeres somos seres con identidad propia nos lleva a ir más allá de la constatación de un modo de vivir que 
tenemos tanto en estas tierras como en otras de nuestro entorno, de las que heredamos comportamientos y usos amén de costumbres.

Así, la concepción relacional del "nosotras" reconoce no sólo que las mujeres tenemos conexiones unas con otras, sino también que esa conexión con los demás resulta esencial para la propia existencia y desarrollo del grupo.

Nos definimos a nosotras mismas en relación con los otros y a través de las relaciones que establecemos con otros grupos. Desde esta perspectiva, las relaciones desempeñan un papel fundamental precisamente por la naturaleza intrínsecamente social de los seres humanos ${ }^{10}$.

Esta visión expuesta no implica una concepción del "nosotras" totalmente determinada por el entramado de relaciones económico-sociales e incluso ancestrales en la que nos movemos o nos hemos movido. También hemos de asumir nuestros propios cambios gracias a la evolución del tiempo, afortunadamente para nosotras. Por ello es tan necesario ir de lo tradicional o desde lo tradicional para poder arribar a un futuro más esperanzador.

Precisamente es el equilibrio entre esas dimensiones -lo ancestral y lo futuro- lo que constituye el principal reto que surge a la hora de afrontar los conflictos de identidad y de derecho; dicho de otro modo, el problema es cómo combinar la naturaleza colectiva mayoritariamente masculina con la naturaleza femenina y los vínculos y responsabilidades que se establecen entre ellas.

La centralidad que ocupan las relaciones, tras el conocimiento del mayor número de variables, nos ha habilitado para pronunciarnos sobre las hipótesis o teorías que expondremos.

\footnotetext{
${ }^{10}$ NEDELSKY, J, Reconceiving Autonomy: Sources, Thoughts and Possibilities, Yale Journal of Law and Feminism. 1989, pp. 7-36: 7-8.
} 
La búsqueda de lo femenino y de la libertad de la mujer en base a un tiempo pretérito de no identidad reconocida, supone un arquetipo necesario para mirar al futuro y justamente la joya nos ofrece ese elemento de identidad perdido.

En conexión con esos enfoques, lo que nos ha interesado destacar son las dinámicas y características que necesitarían ser promovidas para mejorar la relación tradición-futuro, para poder superar los propios sesgos y los vacíos que nos deja la falta de fuentes escritas dejando a la imaginación un vasto territorio donde fecundar. No obstante habrá que afrontar los conflictos que puedan plantearse de una manera abierta y reflexiva.

Asimismo, la opción por un enfoque feminista implica un compromiso con el reconocimiento de la opresión de un colectivo de mujeres que se encuentran más vinculadas a la tradición, en el más amplio sentido del concepto. La mayor vulnerabilidad de este colectivo les ha impedido valorar su propio pasado incluyendo por supuesto su patrimonio joyero, implicando esto el desprecio actual de estos objetos, así como las remembranzas que ellos puedan llevar intrínsecamente. Nos referimos fundamentalmente a las generaciones a partir de los años 70 del pasado S. XX hasta nuestros días.

Este conflicto pretendemos equilibrarlo con la apuesta y propuesta de "ARS GEMMARIA NOVA" y el proyecto empresarial de "NO HAY 2 IGUAL", donde el equilibrio tradición-futuro queda de manifiesto, eliminando subjetividades del pasado e incorporando nuevos aires fruto de una mujer nueva.

En ese sentido, la elección de este punto de vista no atiende a un mero pretexto teórico, sino que pretende, por un lado, arrojar luz sobre los claroscuros que se producen en torno a las reticencias de los puristas y las reivindicaciones que se hacen en nombre de una mujer que busca desde el pasado un nuevo destino, pero que no desea para nada renunciar a su identidad histórica; por otro, entender y responder a una necesidad de no 
desmemoria en la que las Administraciones Públicas tienen mucho que decir.

Respecto a los medios y recursos utilizados en la investigación, para la realización de este estudio se han utilizado diferentes tipos de fuentes bibliográficas teniendo en cuenta el carácter multidisciplinar del trabajo: Arqueología, Historia del Arte, Filosofía, Derecho, Sociología, Etnografía, Joyería...así como recursos electrónicos y diccionarios específicos.

Debido a la escasez de material bibliográfico en nuestro ámbito de estudio, hemos tenido que recurrir a "fuentes cualitativas", concretamente "fuentes orales" para poder entender y estudiar una parte de la cultura popular femenina que, a pesar de formar un micro-mundo, podemos considerarla como la representación estética y económica de una sociedad que, gracias a la joyería, ha podido dejarnos una herencia cultural que de otra manera habría desaparecido.

Entre ellos, han sido de inestimable ayuda los testimonios proporcionados por las fuentes personales consultadas ${ }^{11}$.

Nuestro objetivo es basar el estudio en "fuentes vivas" o "fuentes orales" ya que será a través de ellas, de donde podamos constatar la importancia y la fuerza de los elementos objetos de estudio. La base de nuestro estudio serán las fuentes cualitativas, convirtiéndose sus comentarios y aportaciones en uno de los ejes del texto. Este aspecto es tremendamente novedoso para una tesis doctoral en el ámbito doctrinal que nos encontramos.

Es nuestra intención desarrollar y organizar el trabajo de dos maneras: una con la forma tradicional de cualquier trabajo de investigación, que es estudiar los objetos desde el origen de su fabricación hasta la comercialización de los mismos. Y otra, utilizar un método de trabajo que va

\footnotetext{
${ }^{11}$ A lo largo del trabajo reflejaremos todas las experiencias orales y técnicas con los expertos en joyería charra: Feli Cañada, Antonio Sánchez, José Luis Nieves, Michel Cordón y José Alfonso Jacinto Sánchez-Vasconcellos.
} 
a ser justamente a la inversa. Es decir, basándonos en el uso del objeto (ubicación de la joya en el traje) haremos un estudio retrospectivo al origen.

Primero estudiaremos a los artesanos que hacen los originales, tallista, filigranista, para posteriormente, estudiar el proceso de semiindustrialización de esos objetos. Para ello dedicaremos un capítulo especial al proceso de la Microfusión y dentro de ella al caso especial de la Microfusión de la Filigrana Charra.

El motivo de hacer el estudio en esta dirección es, porque gracias al conocimiento purista de la fuente con la que vamos a trabajar, podemos evitar intoxicar desde el origen los elementos tradicionales de nuestra cultura joyera.

La otra dirección constatará la importancia del proceso semi-industrial para la supervivencia de los procesos manuales.

Recuperar el sentir de un pueblo, saber qué le hace latir, en nuestro estudio va a venir de la mano de la palabra, puesto que aún tenemos la suerte de contar con personas que pueden ayudarnos en ello.

Muchas veces la investigación viene del "buceo" en bibliotecas, hemerotecas, consultando legajos, documentos escritos, que el tiempo se encargó de dejarlos olvidados en estanterías públicas o privadas, e incluso, en cajones de cómodas o mesillas de noche.

Somos conscientes que el trabajo que nos ocupa, tendrá un valor excepcional si somos capaces de recuperar las voces del tiempo y a través de ellas, el uso de técnicas antiguas, que la experiencia nos ofrece. Así convertiremos en una fuente insustituible a aquellos artesanos que en el Siglo XXI aún trabajan como en la antigüedad.

Plasmarlo en el papel, hará que esta riqueza quede documentada para luego poder ser utilizada como fuente explicativa de muchos otros trabajos, que de otra manera, se perderían con la muerte y desaparición de sus protagonistas, debiendo ser conscientes de que hay que aprovechar 
toda esta riqueza oral que aún nos queda para que nos transmitan los usos, las costumbres y las técnicas que estamos convencidos desaparecerán, sino se ponen los medios necesarios en un plazo de tiempo corto. De ahí la importancia de la implicación de las Administraciones Públicas.

Usualmente se ha tendido desde el punto de vista de la investigación universitaria, a no valorar específicamente el conocimiento directo del individuo sin formación académica, aunque tuviera una gran riqueza de experiencia diaria y conocimiento didáctico de la resolución de los problemas que plantea el día a día, sin tener que teorizar sobre los mismos. Este aspecto que hemos obviado en los últimos tiempos, curiosamente en otras etapas de la historia, no se dio.

Mucho de cuanto conocemos en la actualidad nos ha llegado a través del legado oral, es decir: "esto es así, porque así me lo transmitió mi padre, a él su padre, y así hasta donde recuerdo".

Estamos asistiendo al final de una manera de entender el trabajo del individuo, en el que el maestro y el aprendiz, eran la sucesión lógica de los oficios. Aún en este sector queda algo de esta tradición secular, aunque ellos mismos son conscientes de que la dedicación que requiere la ejecución de este tipo de piezas no concuerda con el ritmo de vida que vivimos y están convencidos de que sus hijos no continuarán con un trabajo que viene de generaciones. No hay relación entre conocimiento, tiempo, destreza y precio.

El avance de la técnica y el uso de la misma, como elemento globalizador de la economía, pone en jaque un patrimonio de sabiduría, que de no recogerlo ahora se perderá definitivamente en el Siglo XXI, o quedará anclado en los libros de teoría.

Es obligación por parte de las Universidades, y de las Administraciones Públicas, no dejar perder aquellos testimonios, que son importantísimos, para la comprensión y explicación del devenir cotidiano de los días del individuo y su entorno social, simplemente porque de ellos nadie escribió y sobre todo, nadie valoró. A esto hay que sumar la importancia 
añadida que tiene para la identificación y la Identidad de la mujer, verdadera depositaria y trasmisora de este importante patrimonio cultural.

De nada valdrá darnos golpes de pecho a posteriori, cuando la obligación de la investigación, está en detectar los signos de alerta, no sólo de lo nuevo que ha de venir sino, de la desaparición de formas de vivir, de entender la vida y, sobre todo, de constatar que gracias al esfuerzo que otras generaciones hicieron en el pasado, hemos llegado hasta donde estamos.

La experiencia y el conocimiento heredado de padres a hijos en el hacer de los oficios, nos dan la oportunidad de estudiar de manera directa, los acontecimientos que acontecen en el tiempo, aunque esto se haga a través del estudio de objetos de uso doméstico.

Por todo ello hemos optado por dar un valor de excepción a voces doctas en la materia, aunque no doctoradas, simplemente porque les avala la experiencia y el conocimiento de los años en las materias para las que les hemos requerido, pues son herederos de oficios que vienen de varias generaciones atrás.

En este trabajo contaremos con estas fuentes, porque son de gran valor y complementarán las fuentes doctrinales. Ninguna es más importante que otra, ni ninguna es mejor que otra. No ha sido el azar el que nos ha llevado a contar con estas personas ya que cada una de ellas es referente en su materia y en nuestra tierra.

Dicho, esto queda ampliamente justificado y explicado por qué nuestra investigación la vamos a basar fundamentalmente en fuentes cualitativas orales.

Evidentemente la documentación y bibliografía que existe sobre el uso, beneficio y contradicciones de las fuentes cualitativas respecto de las cuantitativas es amplio y diverso, estando a disposición en muchísimos foros 
para ser consultado. Pero nosotros estamos convencidos que para nuestro caso de estudio es la mejor opción.

Convenimos plenamente con Yanetsys Sarduy ${ }^{12}$, cuando plantea que para el análisis de información hay que tener un amplio dominio de la Metodología de la Investigación; siendo esta el basamento y punto de partida para esta labor, lo que conlleva a un necesario conocimiento de los métodos que componen esta disciplina.

Existen diferentes tipos de investigación y según la naturaleza de la información que se recoge para responder al problema investigativo, estas pueden ejecutarse bajo dos paradigmas, la investigación cuantitativa o la cualitativa.

La producción bibliográfica cuantitativa se orienta principalmente hacia los estudios que exponen sólo clasificaciones de datos y descripciones de la realidad social $y$, en menor medida, hacia estudios que intentan formular explicaciones.

El producto de una investigación de corte cuantitativo será un informe en el que se muestre una serie de datos clasificados, sin ningún tipo de información adicional que le dé una explicación, más allá de la que en sí mismos conllevan. Viéndolo desde este punto de vista, se podría pensar que los estudios cuantitativos son arbitrarios y que no ayudan al análisis de los resultados más que lo que han mostrado por si solos. Esto no es tan así pues con un estudio de este tipo se muestra además las características de estos datos que han sido organizados.

\footnotetext{
12 SARDUY DOMÍNGUEZ, Y, El análisis de información y las investigaciones cuantitativa y cualitativa, La Habana, 2006. Esta licenciada en Biblioteconomía por la Universidad de la Habana (Cuba) en su publicación para la Escuela Nacional de Salud Pública (ENSAP), pone de manifiesto muy claramente el valor de las fuentes cualitativas. Por este motivo transcribimos su defensa porque nosotros no podríamos hacerla mejor.
} 
La investigación cuantitativa se dedica a recoger, procesar y analizar datos cuantitativos o numéricos sobre variables previamente determinadas. Esto ya lo hace darle una connotación que va más allá de un mero listado de datos organizados como resultado; pues estos datos que se muestran en el informe final, están en total consonancia con las variables que se declararon desde el principio y los resultados obtenidos van a brindar una realidad específica a la que estos están sujetos.

Además de lo antes expuesto, vale decir que la investigación cuantitativa estudia la asociación o relación entre las variables que han sido cuantificadas, lo que ayuda aún más en la interpretación de los resultados.

Este tipo de investigación trata de determinar la fuerza de asociación o relación entre variables, así como la generalización y objetivación de los resultados a través de una muestra. De aquí se puede hacer inferencia a una población de la cual esa muestra procede. Más allá del estudio de la asociación o la relación pretende, también, hacer inferencia que explique por qué las cosas suceden o no de una forma determinada. Todo esto va mucho más allá de un mero listado de datos organizados, como se puede leer en la afirmación antes expuesta.

Esta otra idea que se expone a continuación ofrece una visión más abarcadora y completa de la investigación cuantitativa. Por métodos cuantitativos de investigación se entienden los diseños experimentales y cuasi experimentales, la investigación por encuesta, los cuestionarios estandarizados, los registros estructurados de observación, las técnicas estadísticas de análisis de datos, entre otros.

Dentro de la investigación cuantitativa se pueden observar:

- Los diseños experimentales, donde se aplican experimentos puros, entendiendo por tales los que reúnen tres requisitos fundamentales: la manipulación de una o más variables independientes; medir el efecto de la variable independiente sobre 
la variable dependiente y la validación interna de la situación experimental.

- La encuesta social, que es la investigación cuantitativa de mayor uso en el ámbito de las ciencias sociales y consiste en aplicar una serie de técnicas específicas con el objeto de recoger, procesar y analizar características que se dan en personas de un grupo determinado.

- Los estudios cuantitativos con datos secundarios, los cuales, a diferencia de los dos anteriores, abordan análisis con utilización de datos ya existentes.

En general los métodos cuantitativos son muy potentes en términos de validez externa ya que con una muestra representativa de un total, hacen inferencia a este con una seguridad y precisión definida.

Otro aspecto de la Metodología de la Investigación son los estudios cualitativos, que se han venido retomando luego de un casi dominio de los métodos de investigación cuantitativos.

Son identificadas cuatro formas generales en las que se utiliza este tipo de investigación.

- Como mecanismo de generación de ideas.

- Para complementar un estudio cuantitativo.

- Para evaluar un estudio cuantitativo.

- Como método principal de investigación.

Ahora bien, cómo ejemplificar esta afirmación. Como mecanismo de generación de ideas se puede ver su utilización en la identificación y jerarquización de problemas y necesidades, en cualquier área del conocimiento. Además, en la evaluación de la calidad de planes y programas; como complemento de un estudio cuantitativo. Los métodos de 
investigación cualitativos sirven para evaluar estudios cuantitativos en los casos de validación de encuestas, para que los resultados no se queden sólo a escala numérica y porcentaje. Como método principal de investigación, los métodos cualitativos ofrecen un amplio espectro de posibilidades de investigación, mediante la conjugación de varias técnicas.

La investigación cualitativa exige el reconocimiento de múltiples realidades y trata de capturar la perspectiva del investigado.

Desde este punto de vista, se aprecia que en las investigaciones cualitativas es un hecho sumamente importante el sujeto o las fuentes a investigar. Los resultados están muy en dependencia de las emociones o de los análisis exhaustivos del contenido de las fuentes de información.

La investigación cualitativa permite hacer variadas interpretaciones de la realidad y de los datos. Esto se logra debido a que en este tipo de investigación el analista o investigador va al "campo de acción" con la mente abierta, aunque esto no significa que no lleve consigo un basamento conceptual, como muchos piensan. El hecho de tener mente abierta hace posible redireccionar la investigación en ese momento y captar otros tipos de datos que en un principio no se habían pensado. En otras palabras, la investigación cualitativa reconoce que la propia evolución del fenómeno investigado puede propiciar una redefinición y a su vez nuevos métodos para comprenderlo.

En los métodos de investigación cualitativos los investigadores no sólo tratan de describir los hechos sino de comprenderlos mediante un análisis exhaustivo y diverso de los datos y siempre mostrando un carácter creativo y dinámico.

Lo antes expuesto se puede comprobar en la definición de investigación cualitativa dada por Rojo Pérez ${ }^{13}$ : "La investigación cualitativa es un tipo de investigación formativa que cuenta con técnicas especializadas

\footnotetext{
13 ROJO PÉREZ, N, La investigación cualitativa, aplicaciones en salud, MINSAP, ENSAP La Habana, 2002.
} 
para obtener respuesta a fondo acerca de lo que las personas piensan y sienten. Su finalidad es proporcionar una mayor comprensión acerca del significado de las acciones de los hombres, sus actividades, motivaciones, valores y significados subjetivos."

La investigación cualitativa estudia los contextos estructurales y situacionales, tratando de identificar la naturaleza profunda de las realidades, su sistema de relaciones, su estructura dinámica.

La investigación cualitativa cuenta con varias técnicas para la obtención de datos, como son:

- La observación.

- La entrevista.

- La revisión de documentos o análisis documental.

- El estudio de caso.

- Los grupos focales.

- Los cuestionarios.

Mediante la revisión de documentos los investigadores generalmente obtienen la mayor cantidad de datos. Esta es una de las técnicas que más se utilizan, unido al empleo de los cuestionarios.

En el caso de la observación, el investigador tiene una oportunidad única de obtener información que en otros casos no se logra y que pueden influir en los resultados. Mediante esta técnica, que en la mayoría de los casos se utiliza unida a la entrevista, se captan mensajes o ideas que pueden ser omitidas, ya sea voluntaria o involuntariamente por parte del investigado. A menudo las personas emiten gestos o presentan actitudes que van en contra de lo que están diciendo.

Con la técnica de los grupos focales el investigador, al seleccionar grupos de personas con características similares, puede dirigir el tema de 
discusión por la vía más conveniente para el estudio; sin que se presenten muchos problemas de discordancia. Además, al estar todos los integrantes del grupo expuestos, e intercambiando entre sí, se puede lograr que las personas más tímidas se habrán con sus opiniones y comentarios, enriqueciendo así la información de los resultados.

Algo que debe tener en cuenta el investigador con esta técnica es que debe seleccionar adecuadamente la muestra a estudiar, pues debe ser suficientemente grande como para que los criterios puedan ser variados y disímiles y a su vez en un marco estrecho para que cada integrante del grupo tenga la oportunidad de emitir sus opiniones.

Por eso se hace necesario, que un investigador combine varias de estas técnicas para que la información que obtenga sea más segura y confiable en el momento de la toma de decisiones".

En nuestro ánimo está utilizar fuentes cuantitativas y cualitativas, en sus diferentes afecciones, con el fin de poder dar un enfoque lo más concreto posible al tema que nos ocupa.

\section{Fuentes orales locales}

Teniendo en cuenta que para este trabajo vamos a utilizar fuentes directas sobre profesionales habidos en la materia, personas que gozan de reconocido prestigio en el ámbito que nos ocupa, pasamos a definir las fuentes orales que hemos utilizado, intentando dar de ellas un perfil lo más aproximado posible.

Utilizaremos como fuente para la ubicación de la joyería como complemento del traje tradicional a:

\subsection{Dña. Feli Cañada Miguel.}

Nació en Ventosa del Río Almar, provincia de Salamanca, el 4 de junio de 1936. Empezó a interesarse por todo lo relacionado con lo Charro cuando apenas contaba 17 años. 
Será en 1953, cuando se incorpora a trabajar en la Sección Femenina.

Es en estos momentos cuando toma contacto por primera vez de forma profesional con los Trajes tradicionales a través del "Grupo de Danzas de la Sección Femenina", grupo que desaparece en la época de la transición, pasándose a llamar Grupo de danzas Federico Lozano.

Es en la época de la Sección Femenina, cuando Feli Cañada empieza como hobby a restaurar Trajes charros, a la par que por encargo de la Sección Femenina empieza a datar, valorar, tasar y a comprar Trajes que se le pedían a dicha Sección para otras provincias con la intención de incorporar nuestro histórico atuendo tradicional a distintos museos, como es el caso del Museo Tradicional del Traje de Murcia. Como algo anecdótico podemos decir que hacia 1965, Feli Cañada valora un Traje en perfecto estado de conservación de un personaje conocido de la época, llamada señora Felisa, que ella misma restaura y que es enviado a la Feria Internacional de Nueva York. Con una valoración de escasas de pesetas de entonces, tras previo pago, se quedan con dicho Traje estando en la actualidad en Nueva York (The Hispanic Society of America).

El cometido de Feli Cañada, en la extinta Sección Femenina era junto a Carmen Redondo dedicarse a la Sección de la juventud, sin dejar jamás su inclinación hacia todo lo concerniente al Traje Charro y sus complementos.

Es en la época de D. Fernando Gil Nieto, Delegado de Cultura en Salamanca, año (1973) cuando a instancia de él, se realizan en Salamanca, unas jornadas denominadas "Jornadas de Oficios Perdidos"; se realizan en el Palacio de Garcigrande, patrocinándolas la antigua Caja de Ahorros y Monte de Piedad de Salamanca, hoy Banco de Caja España de Inversiones Salamanca y Soria, S.A. En aquellas jornadas, los oficios Perdidos eran los relacionados con los cencerros, el lino, y una de ellos era confeccionar el Traje Charro. 
Es a partir de estas jornadas, cuando a petición del propio D. Fernando Gil Nieto, se plantea la posibilidad de hacer cursos dirigidos al público, dando prioridad sobre todo a los profesores de magisterio, para que se pudieran llevar a cabo la restauración y la creación de nuevos Trajes charros, incluyendo en el proyecto, todos los elementos complementarios del atuendo.

Para tal efecto, se requiere a Feli Cañada, para que los imparta, convocándose estos cursos por la Delegación de Cultura y realizándose en la Casa de Unamuno, sita en calle Peña Primera. Los grupos de trabajo constaban de diez personas. Durante el periodo que duraron los cursos, éstos estaban repletos de personas deseosas de aprender, restaurar o confeccionar en nuevo el complicado y difícil Traje Charro. Como la mayoría de personas que comparecían a estos cursos era más bien gente mayor y se realizaban a instancia de la Casa de la Juventud, se consideró que no cubría las expectativas de dar formación a gente joven, y este es el motivo por el que estos cursos desaparecieron.

Cuando desaparecen, se hace la primera exposición de trabajos realizados nuevos como broche de oro de todas aquellas labores que se habían realizado en el periodo que duró dicha actividad; se realizó en la Delegación de Cultura, Plaza de la Constitución, en los locales actuales donde se ubica la junta de Castilla y León.

Un grupo de las personas que se formaron entonces, que con su esfuerzo y trabajo concluyeron en aquella exposición, decide formar lo que desde entonces hasta nuestros días se conoce como "Asociación del Traje Charro" (1985) sito desde entonces en la Calle Toro, en vista a que no se dejaran perder todas las labores realizadas.

El grupo de personas que en su día formaron la Asociación del Traje Charro fueron: 
La Asociación del Traje Charro tenía como presidenta a $D^{a}$ Agustina Criado Rosado, que permaneció en el cargo hasta hace poco tiempo que ha sido sustituida por $\mathrm{D}^{\mathrm{a}}$ Pilar Arévalo.

Dña Feli Cañada, compatibilizando con su puesto de funcionario en la Junta de Castilla y león, Sección de juventud, donde ocupaba el cargo de jefe de negociado hasta su jubilación en el año 2000, imparte cursos en la Asociación del Tarje Charro desde su creación hasta la actualidad, Asociación a la que le ha dedicado su tiempo, sus conocimientos y su vida.

Además de su docencia vinculada a la Asociación del Traje Charro, como consecuencia de la primera exposición de trabajos antes mencionada, D. Ángel Carril (uno de los impulsores del Centro de Cultura Tradicional de Salamanca que hoy lleva su nombre), propone a Feli Cañada, para que imparta clases de corte y patronaje, piezas de las que consta el Traje y bordados y complementos de los distintos Trajes típicos de la provincia de Salamanca. En el Centro de Cultura Tradicional, sito en la famosa Torre del Clavero. Para que ella pudiera acometer esa docencia, el entonces Delegado de Cultura Sr. D. Agustín Redero, le exime de parte de su jornada laboral como funcionaria en la Junta de Castilla y León, para que por la mañana imparta docencia en el Centro de Cultura Tradicional en parte de sus horas laborales a los futuros alumnos que así lo soliciten.

Es tal el éxito de la propuesta, que hay años que se forman hasta 200 personas haciendo Trajes. Sin recibir compensación económica alguna, se dedica a esta tarea durante 10 años, 2 horas por las mañanas. Cuando el resto de profesores del Centro de Cultura Tradicional consolida sus derechos como docentes y les garantizan sus derechos laborales (Seguridad Social), el horario que se le plantea a Feli Cañada, ya no es compatible con el de funcionaria, siendo este el motivo por el que abandona su enseñanza en el Centro de Cultura Tradicional, hoy Centro de Cultura Tradicional Ángel Carril. 
Como ella nunca dejó de colaborar con la Asociación del Traje Charro, en esta época sigue compatibilizando su trabajo como funcionaria, con la dedicación a la Asociación e impartiendo en horas personales formación para la Asociación, en la que permanece hasta día de hoy.

Exposiciones y exhibiciones en las que ha participado, organizado y montado Feli Cañada:

Primera exposición de trabajos realizados nuevos (Delegación de Cultura)

Exhibición de Trajes Charros en el año compostelano (cuando Suquía es el arzobispo de Santiago de Compostela) Más de 200 personas vestidas de charras son recibidas en la Catedral de Santiago de Compostela.

Exposición de Trajes Charros en Ciudad Rodrigo (hace unos 23 años)

Exposición de Trajes en la Casa de Unamuno. Sala de exposiciones Unamuno.

Exposición en el Palacio de Garcigrande. Caja de Ahorros y Monte de Piedad de Salamanca.

Exposición de Trajes charros en San Eloy.

Exposición de Trajes Charros en el Casino de Salamanca.

Exposición de Trajes Charros en el Museo de Salamanca.

Exhibición en Zaragoza de más de 100 personas ataviadas con el Traje típico charro para la ofrenda de la Virgen del Pilar.

Exhibiciones en Toledo, Burgos, Baracaldo,...)

Es a partir del año 2000 tras su jubilación cuando Feli Cañada tiene más tiempo para dedicarse en exclusiva, a lo que, parafraseándola, "ha sido mi vida", nos estamos refiriendo a la restauración y ejecución de el Traje 
Charro; incluyendo, corte, patronaje, bordado, etc., elementos todos ellos indispensables para ejecutar artesanalmente un oficio que ni ella se atreve a datar su origen.

La primera conferencia la hace en la casa de la Juventud, en la calle José Jáuregui, dirigida a profesores de magisterio, teniendo como base un "audiovisual de indumentaria Charra", preparando para esta conferencia el primer Mapa de Trajes charros por áreas geográficas de la provincia de Salamanca.

La segunda conferencia la da en Santiago de Compostela "La indumentaria en el Camino de Santiago", ponencia para España y Portugal.

Tercera Conferencia en Santander en las Cortes de Cantabria, a petición de la Asociación Cultural del Traje de Cantabria, con el Titulo "El Traje Charro: indumentaria de todas las comarcas de Salamanca".

Y de manera más reciente ha compartido mesa y ponencia en las Jornadas de Cultura Tradicional realizadas en Ciudad Rodrigo el 7 de noviembre de 2009, con el director del museo etnográfico de Castilla y León, Carlos Piñel.

Audiovisual para dar a conocer el encaje de nuestros trajes típicos a un grupo de europeos, en la Cámara de Comercio e Industria de Salamanca. Noviembre 2009.

Utilizaremos como fuente para el estudio de la joya tallada charra a:

\subsection{Antonio José Martín Sánchez.}

Empezó a trabajar a los 14 años al terminar la escuela, como muchos niños en los años 60-70, había que ayudar en casa.

Su familia no tenía nada que ver con la joyería, pero parecía que apuntaba maneras de artista ya que el cura de la parroquia de Santo Tomás orientó a sus padres para que le enviaran a la Escuela de Artes y Oficios, 
antes situada en la Cuesta Santi Espíritus. Estuvo dos años en ésta y otro más en otra escuela donde perfeccionó su dibujo.

A la vez un vecino suyo que trabajaba en un taller de joyería en la Rúa Mayor le llevó con él para que aprendiera el oficio, así fue como comenzó en este mundo. En aquel pequeño taller aprendió lo primero a grabar a mano; ser grabador por aquellos entonces era buen oficio, y en el futuro le abriría puertas a nuevas joyerías. Poco a poco fue aprendiendo más cosas, pues allí nadie se estaba parado, había que aprovechar el tiempo. Empezaban a ir señoras que ahora ya con nietos o bisnietos son sus clientas más habituales. Durante tres años aprendió lo más importante del trabajo de joyería.

Para seguir avanzando pasó por otros dos talleres donde fue asimilando más conocimientos, y desarrollo todo lo que llevaba dentro.

A los 30 años montó su propio taller junto con un vecino y amigo suyo. Alli ha pasado la mayor parte de su vida, aplicando todo lo que fue aprendiendo y además innovando, desarrollando nuevas ideas.

A la muerte de su compañero se traslada a la que es su actual joyería, un local amplio, bonito, elegante, luminoso. Fue un nuevo comienzo con aires nuevos y limpios que le dio un nuevo impulso. Los clientes le siguieron, cualquiera que conozca su arte lo haría sin dudarlo, y aparecen otros debido al nuevo emplazamiento en la calle Pinto.

Es un joyero completo, dibuja sus propios diseños, traspasa una idea a papel en apenas unos minutos, consiguiendo que veas la joya como si realmente la tuvieras entre las manos. Luego esos diseños los elabora y desarrolla por completo. Talla, engasta, esmalta...

Es autodidacta, ha ido aprendiendo según le han ido surgiendo las cosas, innovando y perfeccionando sus propios métodos, tiene infinidad de piezas y testimonios que lo corroboran. 
El vivir en una ciudad como Salamanca ha hecho que parte de sus joyas sean propias de la artesanía charra, veneras, botón tallado a mano con diamante, en todos los tamaños, para gemelos, sortijas, alfileres, pendientes.

También tiene una magnífica colección de los cuatro monumentos más importantes de Salamanca: la Plaza Mayor, la Fachada de la Universidad, la Catedral con el Puente Romano y las Dueñas. Están tallados a mano, convertidos en magníficos bastones para coleccionistas, llaveros o abrecartas. Realizados en sus ratos libres a partir de una mera fotografía de la maravillosa ciudad.

Además de joyas espectaculares también ha hecho caprichos para los clientes al más mínimo detalle, como el anillo del Señor de los Anillos, colgantes como un "atrapa sueños", un cuadro de números naturales, campanilla, caballitos de mar, angelitos de plata como regalo para bodas, una peonza de plata y una "zolacha" como trofeos, coronas para distintas vírgenes, el Cristo de los Milagros, la Virgen de la Encina de Macotera, escudos, bellotas como pin o llavero, monteras y alamares de los toreros,...

Utilizaremos como fuente para el estudio de la filigrana charra a:

\subsection{José Luís Nieves Delgado.}

Nació en Ciudad Rodrigo el 21 de julio de 1956. Procede de una familia de filigranistas portugueses de Gondomar (Portugal). Su bisabuelo, más o menos hacia 1860 es ya filigranista en el país Luso.

Es su abuelo Germán Antonio Nieves, cuando hacia 1920 se traslada a vivir a Ciudad Rodrigo con su familia: su mujer y los hijos del matrimonio: María, Luis, Gracinda y Rosa.

Luis Nieves, nace en Portugal y con 8 o 9 años, viene con sus padres y se instalan en Ciudad Rodrigo donde se casa con Jacinta Delgado.

Del matrimonio de Luis y Jacinta, nacen José Luis Nieves (nuestra fuente) y Miguel. 
El abuelo, Germán, en un principio cuando llega a España, trabaja en su taller para la familia Vasconcellos, para posteriormente independizarse y crear su propio taller y tener sus propios clientes.

En un principio, llegan a tener en el taller doce trabajadores filigranistas, estamos hablando de la postguerra. Cuando Luis Nieves (padre), que aprende el oficio con su padre Germán, se hace cargo del taller familiar a principios de 1970, tan sólo quedan dos trabajadores en el taller. En la época de Germán y Luis Nieves, fundamentalmente trabajan por la demanda de las tiendas tanto de Burgos, Salamanca, Zamora, Valencia, de las piezas que salen de su taller. Cosa que en la actualidad prácticamente no hace nuestra fuente, la cual trabaja fundamentalmente para particulares.

La incorporación de José Luis Nieves al taller familiar, es prácticamente casual, empieza más por ayudar a su padre al mismo tiempo que estudia, estando intermitentemente en el taller familiar, al que se incorpora de manera fija y como heredero de la saga filigranista familiar en 1980. A partir de entonces, ha recorrido foros nacionales e internacionales explicando y demostrando una técnica milenaria como es la Filigrana, en el más estricto sentido artesanal.

José Luis Nieves, está casado con María Rosa Cañivano Vegas y tiene una hija que se llama Carmen.

Actualmente tiene su taller en la Avda. de Béjar, 141 en Ciudad Rodrigo. (Salamanca). Antes el taller se encontraba en la C/ Sepulcro.

Utilizaremos como fuente para estudiar la Microfusión en el caso concreto de la Filigrana Charra a:

\subsection{Miguel Ángel Cordón Rodríguez (Michel).}

Nació en Salamanca el 29 de septiembre de 1957. Comienza su andadura en el mundo de la joyería en 1979, trabajando en una importante fábrica de Madrid, MILAN, S.A. durante un año. 
Posteriormente, pasa al taller de su padre, José Manuel Cordón Elena, (nota: José Manuel Cordón Elena fue unos de los joyeros de mayor tradición en la Salamanca del Siglo XX). De sus manos y de su taller salieron obras de gran valor, entre las que cabe destacar la Corona de la Virgen de Argeme de Coria (Cáceres), o de la Dolorosa de Montagut de Salamanca, obras que le valieron dos medallas al mérito artesano. El padre de este artesano, José Cordón, realiza obras, como la corona de la Virgen de la Soledad de Zamora, siendo autor y saliendo también de este taller la Corona de la Virgen de los Reyes de Sevilla. Ellos pertenecen a la familia Elena Franquera, que se remonta a Jaime Franquera (1771) que perteneció al gremio de plateros de Salamanca, destacando ya entonces como uno de los mejores orfebres del Siglo XVIII Salmantino.), llevando la dirección del mismo durante nueve años y realizando infinidad de trabajos artesanales entre los que cabe destacar los siguientes: Llave de la Ciudad de Salamanca, entregada a S.S. Juan Pablo II, con motivo de su visita a Salamanca el 17 de noviembre de 1982.

Medalla de Diputado del Consejo de Castilla y León

Medalla de Diputado. Excma. Diputación Provincial de Salamanca

Medalla de Concejal Excmo. Ayuntamiento de Salamanca

Medalla de hijo predilecto de la Ciudad de Salamanca

Medalla de la Cámara Agraria de Salamanca

Bastón de mando Ilmo. Sr. Rector Magnífico. Universidad de Salamanca.

\section{Bastón de mando Alcaldía de Salamanca}

\section{Bastón de mando Ascenso a Coronel}

Así mismo, y con un fin totalmente altruista, realizó en 1985, una maqueta en plata de ley, de la Catedral de Salamanca, cuyas dimensiones aproximadas son $8 \mathrm{~cm} \times 5 \mathrm{~cm}$ y en la que empleó más de 100 horas. 
En 1983, participó en un cursillo de Microfusión, organizado por el Gremio de Joyeros y Plateros de Madrid, con la particularidad, de ser el único invitado de fuera de la comunidad de Madrid, recibiendo por ello el correspondiente diploma.

Tras 12 años de experiencia en Microfusión, en 1991, se establece por su cuenta, poniendo en marcha un taller en el que se realizan todo tipo de trabajos, como restauración de objetos antiguos, fabricación de modelos artesanales por encargo, o bien combinando la maquinaria moderna con lo manual, ya que en trabajos de Microfusión, tanto los modelos originales, como la terminación de las piezas, se realiza totalmente a mano. De esta manera, se consigue una mayor fluidez y por tanto, una mayor competitividad en el mercado.

Utilizaremos esta fuente como testimonio oral de la evolución de la creación y comercialización de la Filigrana en la zona de Ciudad Rodrigo, como punto de conexión por su proximidad con la frontera portuguesa a:

\subsection{José Alfonso Jacinto Sánchez-Vasconcellos Bravo.}

Nació el 23 de enero de 1932. Nieto de José Vasconcellos Bautista, artesano filigranista que se instala en Ciudad Rodrigo en 1860 procedente de Gondomar, a quien se le atribuye la primera joyería Vasconcellos. Aportamos el árbol genealógico ${ }^{14}$ de la familia Vasconcellos para que se pueda hacer una reconstrucción histórica.

En las conversaciones con él nos referimos a la joyería-artesana salmantina, que habiendo sido históricamente referente y punto de origen para muchos pedidos de joyería extra provincial, en la actualidad, se ve, no solamente muy reducido, sino que en muchos casos se encuentra casi en vías de extinción, dejándonos muy dependientes de las piezas que proceden de otras partes del territorio nacional, concretamente de la zona de Córdoba.

\footnotetext{
14 “Árbol genealógico de la familia Vasconcellos, Fuente familiar.
} 


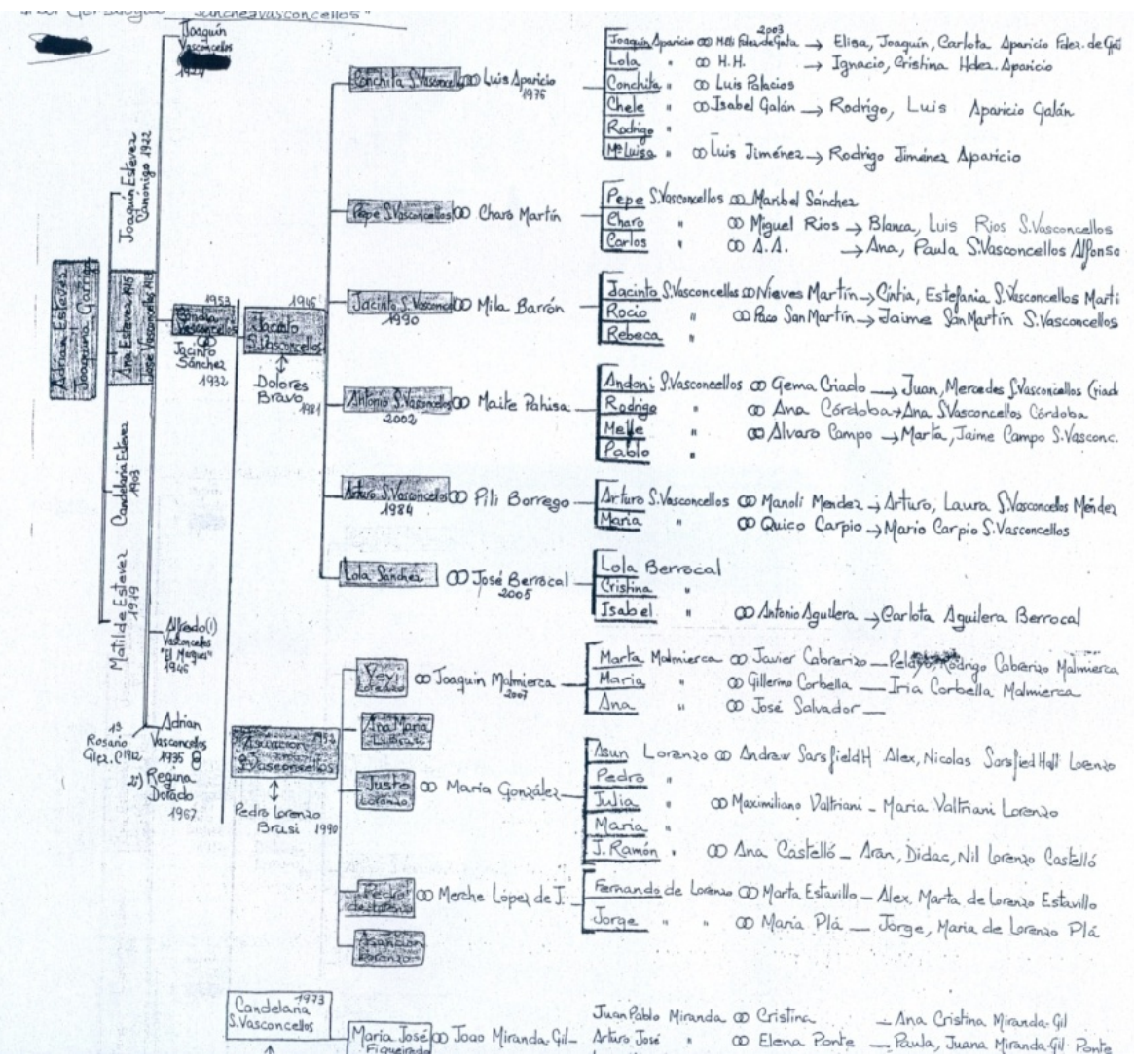

Aunque utilizaremos el método básicamente cualitativo, lógicamente manejaremos fuentes cuantitativas, escritas y publicadas a las cuales haremos referencia en notas bibliográficas. En el apartado de bibliografía quedarán reflejadas todas las obras consultadas a lo largo de todo el texto.

También hemos utilizado la red Internet como fuente que nos ayuda a cotejar, buscar e identificar aspectos con la rapidez de un medio que se ha convertido en un cajón de sastre que todos utilizamos. Gracias a ella, hemos agilizado una parte importante de la información que no cabe duda todo investigador actual utiliza. A tal efecto, la consideramos como fuente de las propias fuentes. Es interesante destacar, cómo del manejo de las nuevas tecnologías, se puede obtener contactos con otros especialistas en la materia con los que a través del correo electrónico, prácticamente las dudas y cuestiones que se plantean se pueden solucionar yendo directamente al autor de la fuente. 

TRADICIONAL: ESTUDIO DESCRIPTIVO. 


\section{Introducción}

Somos conscientes de que el uso que ha hecho y hace el hombre de los elementos decorativos del cuerpo como fruto de su creación, muchas veces tiene un significado que se escapa a la lógica y sólo el mito, la magia ${ }^{15}$ o la creencia ${ }^{16}$ pueden llegar a explicar.

Intentar acercarnos a la artesanía joyera limitándola al espacio geográfico de la provincia de Salamanca, no deja de ser un reto por dos razones:

1- La dificultad de obtener información de fuentes escritas por la escasez de las mismas.

2- La permeabilidad de los espacios. Es decir, hay objetos culturales ajenos a los límites administrativos y políticos, que pueden intoxicar los nuestros. Por este motivo, intentaremos localizar e investigar los elementos joyeros como adorno del traje tradicional. El traje es el soporte sobre el que se asienta la joyería y desde él, podemos buscar referencias que de otra manera sería imposible.

El hecho de considerar la joyería popular como elemento de estudio y de investigación universitaria no deja de ser cuanto menos diferente, por ello es necesario definir primero una serie de conceptos como son: Artes Aplicadas, Artesanía, Joyería y Orfebrería.

\footnotetext{
${ }^{15}$ CEA GUTIÉRREZ, A, Sobre Magia y Brujería, Revista de dialectología y tradiciones populares, Vol, LIX, Madrid, 2004. pp.3 y ss.

${ }^{16}$ CEA GUTIÉRREZ, A, La protección contra el mal en la cultura popular salmantina: Las joyas, L'espai del mal, Vol I, Madrid, 2005.
} 
Si bien es cierto que la "joyería" debemos de entenderla, para el caso que nos ocupa, como el estudio de objetos de adorno que decoran al hombre y a la mujer complementando su vestimenta, no debemos olvidar que la joyería, tiene un ámbito mucho más amplio y extenso, como veremos más adelante.

Los objetos que estudiaremos en este trabajo, tienen una dimensión diferente al vestuario, al bordado o a los paños (que por cierto, son riquísimos en Salamanca y provincia) y es que el material con que se hacian tenía un valor económico que nunca se le ha discutido: estar hechos de oro o de plata.

No obstante como veremos a lo largo del estudio, las fuentes de conexión existentes entre el traje y la joya, van a ponernos de manifiesto unas líneas de investigación bastante interesantes, y que curiosamente, hacen que la joya sea un elemento más de "transmisión" y de "comunicación" entre pueblos y culturas muy distanciadas en el tiempo y en el espacio.

El material del que está hecho la joya, ha colaborado de manera especial a que el pueblo llano hiciera de estas piezas un "bien familiar" que pasaba en forma de herencia de una generación a otra. Esto no sucedía con otros elementos que el tiempo ha hecho desaparecer y en muchos casos, utilizarlos en las lumbres como fuente energética de calor y de paso quitarse de en medio los "zarrios" 17 como se conoce en el medio rural a las cosas sin valor.

Así, podemos decir, que el adorno-joya que se pone la mujer y que lo vinculamos en nuestro caso al traje tradicional, no solamente tendría un valor económico: (dependiendo del material del que esté hecho, casi todo él en oro o plata al menos los más antiguos) sino que habría que sumarle el valor artístico (del que hablaremos posteriormente) al que hay que sumarle también un valor sentimental muy difícil de cuantificar como es el vinculado

${ }^{17}$ www.rae.es, Zarrio, (Del eusk. txar, defectuoso, débil).3. Pingajo, harapo. Enero.2012 
a la historia familiar, tanto de forma individual referida al núcleo familiar, como de forma colectiva referida a un pueblo determinado. Pero no podemos olvidar el valor mágico ${ }^{18}$ (“... Toda la joyería, ciertamente, puede tener su origen más en la magia que en el embellecimiento...) o totémico ${ }^{19}$, ya que hasta relativamente poco, e incluso dependiendo de las zonas hoy en día también, la joya era protectora contra el mal de ojo, enfermedades...así como podía ofrecer a su portadora beneficios incluidos en el metal o en las piedras.

Tal vez, la suma de estos tres factores, económico, artístico, sentimental-histórico, han constituido el punto de arranque para dedicarle un estudio a una serie de objetos bellísimos y que en la actualidad casi podríamos decir que asistimos a la agonía de los mismos en su vertiente más histórica ya que estemos en la última generación de hacedores "oreros" y artesanos que dedican tiempo, sabiduría e ilusiones, a un sector que en siglos pasados fueron agentes de una industria demandada y amplia. Incluso en la propia ciudad de Salamanca dio nombre a una calle como es la de la C/ Plateros y que hoy forma más bien parte del recuerdo y del nomenclátor urbano.

Es doloroso al ver cómo al referirnos a la joyería-artesana salmantina y sabiendo que hemos sido históricamente referente y punto de origen para muchos pedidos de joyería extra provincial, en la actualidad el sector está muy reducido y en muchos casos, se encuentra casi en vías de extinción, dejándonos muy dependientes de las piezas que proceden de otras partes del territorio nacional, concretamente de la zona de Córdoba.

Otro aspecto de este capítulo es constatar la vinculación directa de la joyería tradicional con el traje regional de nuestra provincia, que por cierto

\footnotetext{
${ }^{18}$ ANDRÉS PÉREZ, R, La Cueva de Salamanca y la Magia del Marqués de Villena, Ediciones Atlantis, enero, 2013.pág 171, cuando cita a Luck Georg en Arcana Mundi, Madrid 1995.

19 www.rae.es, Tótem, (Del ingl. totem, y este del algonquino nin-totem).1. m. Objeto de la naturaleza, generalmente un animal, que en la mitología de algunas sociedades se toma como emblema protector de la tribu o del individuo, y a veces como ascendiente o progenitor.2. $\mathrm{m}$. Emblema tallado o pintado, que representa el tótem.
} 
como veremos es muy variado, rico y diverso. Es cierto que los que más se han estudiado y donde abunda más documentación es para el caso concreto del traje y los complementos joyeros de la zona de la Alberca, aunque ya veremos más adelante, como lo que se considera único de la Alberca en realidad corresponde a toda la zona de la Sierra de la provincia de Salamanca.

Es este el motivo por el que no nos interesa dedicarle más espacio al ya famoso traje de Vistas, sino que lo que pretendemos es centrarnos en los complementos de unos trajes que son menos conocidos aunque no por ello, faltos de riqueza, preciosismo y variedad tanto en paños, bordados, como en joyería. Estamos convencidos de que estos otros complementos son también muy interesantes y atractivos.

Tenemos que hablar de la relación directa económico-cultural en toda la "Zona de La Raya", es decir, la zona fronteriza que tiene nuestra provincia con Portugal.

Muchas de las influencias en nuestra joyería provienen directamente del país vecino.

Debido a la histórica indiferencia que los españoles hemos tenido con nuestro vecino Portugal y teniendo en cuenta que para el estudio particular de la Filigrana Charra en Salamanca es condición imprescindible mirar al Oeste y al Atlántico, consideramos que hay que recalcar la importancia de mirar hacia nuestro Espacio Fronterizo.

Conscientes de esta importancia dejamos abierta la línea de consulta de las fuentes lusas que consideremos expertas en esta materia, siempre vinculado al espacio de La Raya.

En este orden de cosas, también hablaremos de otras líneas de influencia que hacen de la zona de Salamanca una encrucijada de culturas y de caminos, aspectos ambos, que han dejado su huella también en nuestra joyería tradicional. 
Constataremos como desde el inicio de la técnica decorativa de la Filigrana son los canales económicos y comerciales los que la traen a la Península Ibérica. Estos canales comerciales (concretamente eje SurNorte ${ }^{20}$ ) que construyen las culturas más antiguas ibéricas, son utilizados posteriormente por otros pueblos (cultura Amazigh del norte de África), que apoyándose en ellas, llegarán hasta nosotros. Roma utilizó este canal comercial eje Sur-Norte, entre otros para invadir militarmente la Península pero también para culturizarla. A partir de este momento se asientan en este eje de la Ruta de la Plata ${ }^{21}$, a través de la cual, llegarán a nuestro territorio todo tipo de influencias. Sobre este eje también se asentará posteriormente una de las ramas del Camino de Santiago, que también influirá en los motivos que aparecen en nuestra joyería tradicional.

Basaremos el estudio en "fuentes vivas" o "fuentes orales" ya que será a través de ellas, donde podamos constatar la importancia y la fuerza de los elementos objetos de estudio. La base metodológica de nuestra investigación estará en las fuentes cualitativas, convirtiéndose sus comentarios y aportaciones en uno de los ejes del texto.

En este capítulo estudiaremos a los artesanos que hacen los originales (oreros-filigranistas) y posteriormente estudiaremos el proceso de industrialización de esos objetos, para ello dedicaremos un punto especial al proceso de la Microfusión y dentro de él veremos el caso concreto de la Microfusión para la Filigrana Charra.

El motivo de hacer el estudio en esta dirección es, porque gracias al conocimiento purista de la fuente intentaremos evitar intoxicar los elementos tradicionales de nuestra cultura joyera.

\footnotetext{
${ }^{20}$ Mapa $\mathrm{n}$ 0 1.Ver más adelante.

21 GARCíA GONZÁLEZ, L, Los grandes ejes territoriales turísticos peninsulares: la dificultar de planificar, articular y consolidad productos turísticos espaciales: ejemplo de la Vía de la Plata, Cuadernos geográficos de la Universidad de Granda, № 34, 2004, pp 145-162.
} 
Trataremos de la importancia del proceso industrial para la supervivencia de los procesos manuales, aprovechando la voz de la experiencia ya que aún tenemos artesanos en activo.

Somos conscientes que el trabajo que nos ocupa, tendrá un valor excepcional si somos capaces de recuperar, las voces del tiempo y a través de ellas, el uso de técnicas antiguas, que el devenir de los tiempos nos ha traído hasta hoy. Así convertiremos en una fuente insustituible a aquellos que en el Siglo XXI aún trabajan como en la antigüedad.

La experiencia y el conocimiento heredado de padres a hijos en el hacer de los oficios, nos dan la oportunidad de estudiar de manera directa de técnicas y algunas de ellas milenarias.

Consideramos que es necesario hacer una diferenciación explicativa entre conceptos que pueden tener dificultad de límites. Es cierto que la Filigrana es a la vez, orfebrería, artesanía, joyería y forma parte de las Artes Aplicadas, pero cada uno de estos ámbitos, supone una ampliación o un nivel diferente de comprensión dependiendo de la profundidad de estudio al que nos estemos refiriendo.

Así, podríamos apuntar que la Filigrana y sus técnicas es el punto más alejado en el tiempo, por lo tanto, lo más antiguo, siendo el concepto de Artes Aplicadas y Oficios Artísticos, el concepto más próximo en el tiempo.

En este orden de cosas, si tomamos como referencia el punto de arranque, la técnica de la Filigrana, como si de una sucesión de puntos concéntricos se tratara, pasaríamos a la orfebrería de ahí a la artesanía de ahí a la joyería y por último a las Artes Aplicadas ${ }^{22}$ (cuadro adjunto)

\footnotetext{
${ }^{22}$ Cuadro de la posición de la filigrana dentro de las Artes Aplicadas. Realización propia.
} 


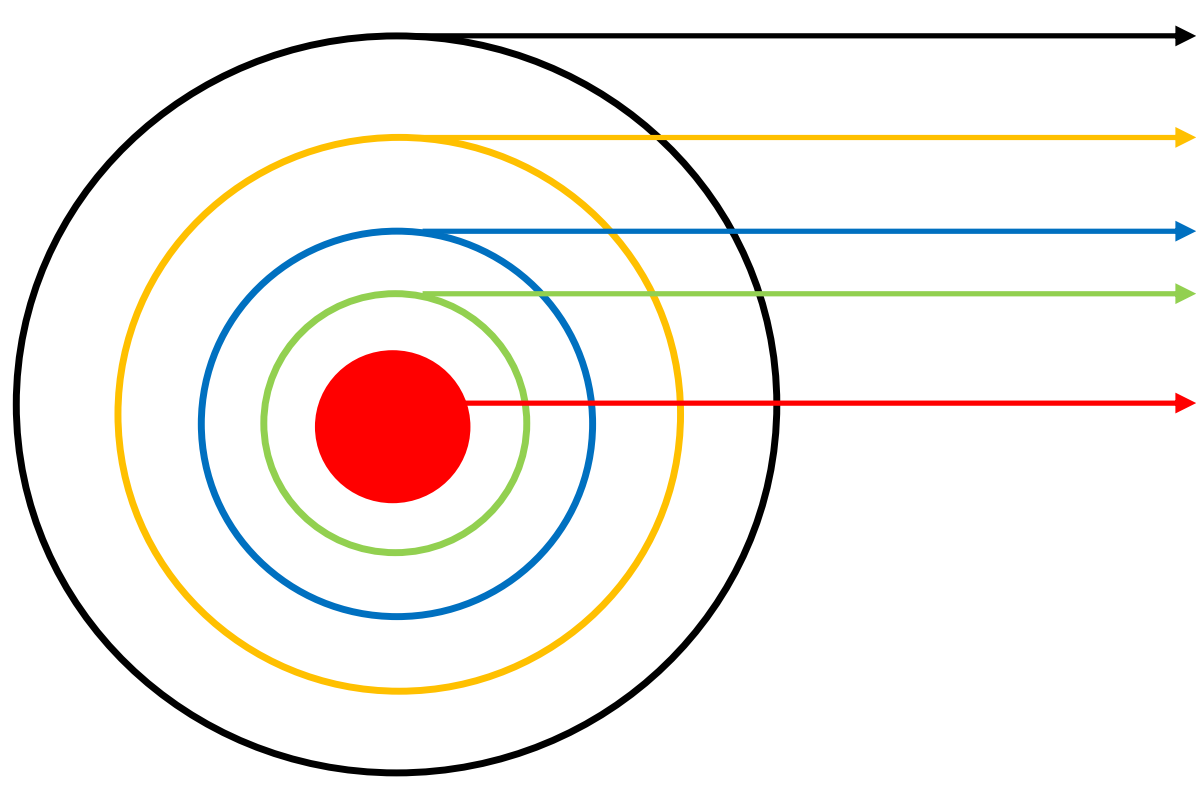

Artes Aplicadas

Joyería

Artesanía

Orfebrería

Filigrana

Hechas estas salvedades pasamos a analizar y definir los conceptos. La definición la vamos a hacer partiendo del concepto que engloba todos los demás, es decir, desde las Artes Aplicadas hasta la Filigrana.

Artes Aplicadas es una expresión que surge en contraposición a la de Bellas Artes. Mientras que las Bellas Artes sirven como estímulo intelectual y academicista para el espectador, las Artes Aplicadas incorporan los ideales de la composición y la creatividad a objetos de uso diario, como una taza, una revista o un banco decorativo del parque; aquí podemos añadir, cualquier pieza de joyería.

La idea de una actividad inferior dentro de las artes plásticas, se basó inicialmente en el enfoque a una producción múltiple y/o útil de la artesanía y el grabado. No obstante, el concepto cambiaría parcialmente en el Siglo XVIII con la Revolución Industrial, cuando la técnica se transformó en tecnología; haciéndola compartir un territorio cercano a la ingeniería. Es decir que actualmente, el Grabado y la Artesanía se encuentran en un punto medio entre las Artes Aplicadas y Plásticas.

Áreas como el diseño industrial, el diseño de interiores, el diseño de modas, el diseño gráfico y la publicidad; son englobadas por las Artes 
Aplicadas que, hasta en un contexto abstracto o amplio, también lo están la fotografía y la arquitectura.

Gracias a la aparición de franquicias, muchos objetos de arte aplicado pueden ser coleccionables; como los juguetes, stickers, joyas, coches, guitarras eléctricas, diversos carteles de películas o anuncios antiguos, etc.

El concepto de Joyería, basándonos en la división que hace $L$. Montañés ${ }^{23}$ se divide en seis apartados: joyería arqueológica, alta joyería, media joyería, joyería popular, nueva joyería y bisutería.

De estos aspectos, lo que más nos interesa es como define la Joyería Popular, pues consideramos que los objetos que nosotros vamos a estudiar se encuadran en este apartado 24: "de la joyería popular se ha dicho que es el lenguaje visual más inmediato que utiliza el campesinado para expresar su nivel económico. Pero también tiene otras varias significaciones en el mundo interrelacionado de las aldeas y las romerías. Se caracteriza porque generalmente no suele utilizar metales nobles y bastante menos piedras preciosas. Anterior a la bisutería, viene a ser una variante peculiar de ella, con la diferencia de que está hecha artesanalmente y que sus productores observan pautas de construcción y modelaje tradicionales y propias de orfebre. Claro es que si ha de seguir conservando estas características, pronto desaparecerá. La joyería popular refleja el modo de construir cierta tipología costumbrista de cada región y país; pero con variantes propias, a consecuencia de que son los aderezos necesarios al traje típico local, de origen campesino y para lucir en determinadas fiestas. Aunque hay que tener presente que siendo en tantas ocasiones el aderezo un motivo del "regalo de pedida", estas joyas pueden también estar realizadas en metales preciosos. Modernos estudios se han dedicado a analizar y explicar las características de la joyería popular comarcal de la que creemos hay un coleccionismo muy extendido"

\footnotetext{
${ }^{23}$ MONTAÑÉS FONTENLA, Luis, Diccionario Antiquiaria Joyas, Antiquaria S.A. Ediciones, Madrid, 1987.

${ }^{24}$ Op. cit.
} 
El término Artesanía se refiere al trabajo realizado de forma manual por una persona sin el auxilio de la energía mecánica, en el que cada pieza es distinta a las demás, diferenciándolo del trabajo en serie o industrial.

Con el objeto de definir a la artesanía y distinguirla de la industria, podemos apuntar que se entiende por Artesanía ${ }^{25}$ "toda técnica manual creativa, para producir individualmente, bienes y servicios" y por lo tanto esto lo diferenciaría de la industria ya que esta queda definida como "toda técnica mecánica aplicada, para producir socialmente, bienes y servicios".

Para muchas personas, la artesanía es un término medio entre el diseño y el arte. Para otros es una continuación de los oficios tradicionales, en los que la estética tiene un papel destacado pero el sentido práctico del objeto elaborado es también importante.

También quedan algunos artesanos que se dedican a los llamados «oficios tradicionales», pero cada vez son menos.

Uno de los principales problemas de la artesanía es la competencia con los productos procedentes de procesos industriales de bajo coste, con apariencia similar a los productos artesanos, pero con menor precio y calidad. Este es uno de los grandes riesgos que corren nuestras piezas joyeras.

Otra dificultad para los artesanos es la forma de comercializar sus productos, ya que es una característica de la artesanía, que se realiza en talleres individuales o de pocas personas, con poca capacidad para llegar al mercado. De ahí que el precio final sea más elevado y no sea equiparable al precio que otras piezas similares tienen en el mercado.

La etimología de la palabra artesanía ${ }^{26}$, deriva de las palabras latinas «artis-manus» que significa: arte con las manos. La artesanía comprende, básicamente, obras y trabajos realizados manualmente y con poca o nula intervención de maquinaria, habitualmente son objetos

\footnotetext{
${ }^{25}$ Op. cit.

${ }^{26}$ www.rae.es. Marzo.2012
} 
decorativos o de uso común. Al que se dedica a esta actividad se le denomina "artesano".

El origen de las artes manuales data de hace muchos siglos, no se sabe con exactitud cuánto tiempo. Lo que se sabe es que data de cuando la prehistoria ya que se han encontrado objetos hechos manualmente sin la intervención previa o completa de algún tipo de instrumento.

Las diferencias entre arte y artesanía se ponen de manifiesto a finales de la Edad Media y se consolidaron con el Renacimiento, dignificando la actividad y función social del arte con el artista, y subordinando la artesanía junto con el artesano dentro de la visión occidental.

La artesanía en España es muy diversa y variada, y cada comunidad autónoma dispone de diferentes productos identificativos, aunque generalmente destaca la elaboración de trabajos en cerámica (como los realizados en Castilla y León, la provincia de Granada, en Talavera de la Reina, en Asturias o en Canarias), en vidrio (cuyo centro se halla en Segovia, con la Real Fábrica de Cristales de La Granja), en madera (con focos en Galicia, Asturias, Cataluña, Castilla y León, Islas Baleares y Andalucía), en cuero (Huelva, Sevilla, Albacete y Madrid), en cestería y esparto (Andalucía, Extremadura, Castilla y León, Aragón o Valencia) y en varios metales (las espadas y damasquinado de Toledo y Éibar o la forja segoviana). Además, tiene una extensa representación en el sector textil, en el que se pueden encontrar tejidos (los conocidos de la Alpujarra granadina, las jarapas zamoranas y otras similares en León, Ezcaray y Galicia), bordados (como los de las provincias de Salamanca y Segovia o los de La Orotava tinerfeña) y encajes (comunes en Andalucía y en Almagro), siendo el más común el de bolillos, muy extendido.

En España, los artesanos pueden certificar la autenticidad de su producción mediante la obtención del carné artesano correspondiente a su oficio. Los carnés artesanos son otorgados por cada autonomía. Así, en Castilla y León, la Junta después de la presentación de un proyecto 
artesanal, en el que se explican métodos, técnicas y objetos que unidos a la creatividad histórica o novedosa procedente del artesano, da como resultado objetos calificados como artesanales. Después de debatir en un tribunal, capacita o no, al aspirante al título de artesano. En este sentido, creemos que se ha producido un adelanto importante, porque hasta hoy en día, solamente se acreditaban aquellos oficios o profesiones que previamente habían sido estudiadas en las aulas.

Se llama Orfebrería ${ }^{27}$ al trabajo artístico realizado sobre utensilios o adornos de metales preciosos. Los metales que constituyen los objetos de orfebrería propiamente dichos son eminentemente la plata y el oro o una mezcla de ambos que en la antigüedad se llamaba "electron o electrum". Con dichos metales se fabrican ya desde edades muy remotas utensilios muy variados como vasijas, piezas de adorno, joya, monedas, estatuas siguiendo el estilo, la ornamentación y el gusto propios de la época y de la nación que los elabora, como puede observarse recorriendo las principales civilizaciones.

Los primeros hallazgos de la metalistería fueron sencillas piezas de oro que datan del periodo neolítico seguidas muy pronto de las de plata, cobre y bronce, al abrirse la edad que recibe el nombre de estos últimos metales. Los objetos que se labraron con dichos materiales consistían en diademas lisas a modo de cinta, gruesos brazaletes y collares rígidos (o torques) de una pieza, terminada por bolas piriformes, otros collares formados por sartas de bolitas perforadas y, en fin, anillos y pendientes de forma circular sencilla. La ornamentación de tales preseas ${ }^{28}$, cuando existe, es puramente geométrica y se limita a surquillos rectos y en zigzag, dientes, circulillos, puntos hechos a martillo, etc. Como cosa excepcional, existe en el antiguo Egipto algún cuchillo de sílex con guarnición y vaina de oro, ornamentadas con florones y figuras de animales. Se labraron también de cobre y de bronce agujas, cuchillos y armas diferentes en forma de flechas,

\footnotetext{
${ }^{27}$ MONTAÑÉS, FONTENLA, L, Joyas, Diccionario Antiquaria. Ed. Antiquaria, S.A., Madrid, 1987.

${ }^{28}$ www.rae.es, Presea, (Del lat. Praesidia).1. Alaja, joya, tela, etc., preciosa" .marzo 2012
} 
espadas y hachas con alguna ornamentación geométrica en el puño y con un temple y corte bastante fino en la hoja.

La orfebrería toma una dimensión interesante en la época Carolingia, donde se trabajaba sobre todo con oro pero también con plata, esmeralda y otros metales a los que le daban forma y realizaban obras de arte. Estas las usaban para: decorar la cubierta de los libros, los relicarios y los frontales del altar; adornaban los relieves con piedras preciosas, esmaltes y marfil además de distintos tipos de esmeraldas.

Pero si hay algo que nos interesa de forma especial para nuestro estudio son las técnicas empleadas en el trabajo del oro en el inicio fueron muy sencillas en la región Sur de la Península Ibérica utilizaban el martillado en frío que proporcionaba láminas e hilos que podían adoptar formas diferentes. Posteriormente, se utilizaron el calentado y la fusión. Los avances técnicos supusieron una diversificación de las formas.

Podríamos describir de forma breve las técnicas de fabricación:

1.Fusión del material bruto: Obtenido el metal, se prepara en bruto fundiéndolo en un crisol a $1.063^{\circ} \mathrm{C}$ para eliminar impurezas, posteriormente se vierte en un recipiente y se deja fundir.

2. Martillado y batido: Separado el metal del recipiente, se realiza el batido y/o martillado, para el batido se necesita interponer un material flexible (cuero, tela,...) entre el metal y la herramienta para obtener láminas finas y evitar huellas o roturas. El martillado supone golpear directamente el metal para darle forma de lámina, lingote,... pero esta técnica vuelve el metal quebradizo, por lo que debe alternarse con el recocido en $400-800{ }^{\circ} \mathrm{C}$, lo que regenera y cristaliza el metal y evita la pérdida de maleabilidad y riesgo de roturas o fracturas.

3.Cortado y acabado: El cortado se realiza a través del simple doblado, marcando la línea de corte con una incisión. El acabado generalmente se practica por la cara externa o visible de la pieza y 
consiste en una limpieza o pulido por fricción o abrasión, valiéndose por ejemplo de arena.

4.Uniones mecánicas y ensambles: En la Península Ibérica, a partir del Bronce Final se documentan las piezas compuestas y las primeras aleaciones voluntarias.

5.Soldaduras:Se documentan sobre todo: Soldadura sin aporte de material soldante: basada en los distintos puntos de fusión de los elementos a unir. Soldadura por difusión en fase sólida: calentando por debajo del punto de fusión. Soldadura con aporte de aleación soldante: de composición Au-Ag-Cu (Oro-Plata-Cobre).

6. Vaciado a la cera perdida: Consiste en realizar un modelo inicial en cera de un núcleo con la forma deseada, que se recubre de arcilla; de este modo, al derretirse y quedar eliminada la cera del interior cuando se vierte el oro fundido, se consigue un molde de fundición hueco que, al solidificarse, reproduce la forma del núcleo.

7.Almas de bronce $u$ otro metal, chapados y dorados: El dorado con "panes de oro" ya era una técnica empleadas por los egipcios en el III milenio a.C. El tratamiento de superficie más espectacular es el conocido como «mise en couleur», que consiste en eliminar la capa superficial de cobre haciendo aflorar el oro, empleando una solución ácida del jugo de ciertas plantas y el calor, este procedimiento era adecuado cuando el contenido de oro era alto. Si las piezas eran de baja ley se utilizaba una solución corrosiva de origen mineral, hablándose entonces de «refinación artificial», que permitía jugar con diferencias acusadas de color.

En cuanto a las técnicas decorativas las enumeramos muy brevemente:

1.Remetido y embutido: El repujado se fundamenta en la realización de motivos con un cincel de punta roma para evitar que se corte la 
lámina, o bien con punzones que permitan curvar el metal sobre sí mismo y definir grietas profundas desde el reverso, para que salgan en el anverso. Si la pieza se trabaja por el anverso sobre un cuerpo ya en relieve, se trata de un «embutido», técnica que requiere trabajar sobre un soporte blando aunque consistente para que la lámina se mantenga fija.

2.Cincelado: En el terreno de la orfebrería merece especial atención; es todo un oficio en sí mismo. Si bien podría un artesano prescindir de este en el desarrollo de su obra, para quien lo aborde el cincelado podría, sin dudas, volverse el aspecto más importante de su recorrido en el camino de los metales. Puede ser el mejor ejercicio en donde fundir al oficio técnico con la naturaleza humana creativa ya que tal vez sea en su dominio que se establezca la separación entre el artesano y el orfebre. Al igual que las demás ramas de este oficio, esta ha cambiado muy poco sus métodos de trabajo en el curso de los siglos; los recursos que mejor complementaron a esta disciplina fueron con seguridad el dibujo y la escultura pues de estos se nutre de modo constante y directo. Los cinceles y sus correspondientes martillos, de forma particular por la posibilidad de precisión que pueden brindarnos, median nuestras dos manos con las placas metálicas sobre las cuales se imprimirá una forma artística determinada. El primer paso para aprender a cincelar consiste en familiarizarse con estos atípicos instrumentos en su proceso de coordinación mutua. Hay tantos cinceles como colores, la variedad es muy amplia. A partir de tener el dibujo ornamental en una chapa preparada, previamente colocada con un poco de calor dentro de un cajón que contiene brea como soporte para los golpes, se comienzan a hundir sus primeros volúmenes sobre lo que consideremos el dorso de la misma llamando a esta fase el embutido de las formas. Una vez finalizada esta tarea y despegada la futura pieza de la brea, se podrá apreciar sobre su cara frontal la versión en positivo, por explicarlo de algún modo, del resultado obtenido hasta aquí, cuya característica 
particular será la falta de detalles definidos. Mediante este sistema descrito, logramos altos relieves en nuestros trabajos. La siguiente fase denominada modelado es la etapa del cincelado que encara a esta chapa desde su lado frontal y retomando los volúmenes antes embutidos va a ir recorriendo con cinceles específicos las diferentes partes de aquel dibujo para finalmente llegar a uno de los puntos más elevados dentro de este gran arte, momento este del proceso que insiste, por su profundidad espiritual, en hacernos creer que se ha llegado a lo máximo que de los metales pudiera pretenderse, en la relación entre contenido y forma.

3.Puntillado: Esta técnica decorativa se realiza con un cincel desde el reverso de la pieza, obteniendo motivos a base de puntos en relieve por el anverso.

4.Decoración incisa: Se consigue mediante la incisión con un buril sobre la pieza y bajo un soporte firme que sujete el objeto.

5.Estampado: Consiste en presionar a golpe de martillo con un punzón metálico sobre el reverso de una lámina; en el extremo del punzón se halla el dibujo que se quiere reproducir en relieve. Cuando el punzón deja su marca sólo por una cara del metal se llama «estampación por impresión», mientras que cuando deja un relieve por una cara y un hueco por otra se denomina «estampación repujada».

6.La Filigrana: Es un esquema decorativo diseñado mediante hilos que se sueldan a una lámina de base. Para fabricar los hilos hay dos métodos: en un caso, se parte de una lámina cortada en tiras estrechas que se enrollan sobre sí mismas sujetándolas por un extremo, lo que les deja marcas helicoidales de retorcimiento; y en el otro, se realiza un fundido previo en molde para obtener la forma de hilo y después se martillea hasta obtener la sección deseada. Se llama «Filigrana sentada» cuando los hilos se sueldan sobre una base, y «Filigrana al aire o calada» cuando los hilos se 
unen entre sí, sin base. La Filigrana es una técnica orfebre que consiste en hacer finísimos hilos con un metal precioso (oro y plata) generalmente y con ellos hacer trabajos delicados en joyería, constituyendo el núcleo mismo de nuestra investigación.

7.Granulado: Se basa en el mismo principio, y en él los hilos se sustituyen por pequeñas esferas de oro. Consiste en soldar pequeños gránulos o esferitas de oro a una superficie formando diversos motivos. Generalmente «Filigrana» y «granulado» se combinan entre sí, y a veces también con otras técnicas, alcanzando una gran complejidad compositiva

\section{Espacio y tradición: La filigrana y sus antecedentes.}

La joya de Filigrana es la "joya ligera" por excelencia. La Filigrana propiamente dicha es una joya cuya ornamentación se ejecuta por medio de dos hilos de oro o plata muy finos torcidos a un tiempo, mediante tenazas imitando una cuerda sumamente tenue. A primera vista, esa cuerda parece un hilo grabado.

La Filigrana es conocida en occidente históricamente, pero también fue conocida por varios pueblos de la América precolombina. Entre ellos hay que citar a los mixtecos, que fueron orfebres cuyo trabajo alcanzó una gran difusión en el área de Mesoamérica. Numerosos objetos trabajados con Filigrana de oro se han encontrado en varios sitios de la Región Mixteca, como Coixtlahuaca y Yanhuitlán, a pesar de la destrucción de las joyas precolombinas que en muchas ocasiones fueron fundidas para formar lingotes de oro que se enviaron a Europa. Una de las piezas más conocidas de la joyería de Filigrana mixteca es el pectoral del Dios de la Muerte, encontrado en la Tumba de Monte Albán (Oaxaca). 
La etimología de la palabra Filigrana para algunos autores como es el caso de E. Echegaray ${ }^{29}$ considera que proviene del italiano filigrana; de filo, hilo, y grano, porque la primera filigrana era una sarta de granos pequeños. Lo define como la obra formada de hilos de oro o plata unidos y soldados con mucha perfección y delicadeza. En esta misma línea lo define J. Corominas ${ }^{30}$, considerándola procedente del italiano, con origen latino.

No obstante, y atreviéndonos en esta interpretación, otras fuentes que hemos consultado, nos han apuntado la posibilidad de que la palabra Filigrana se incorporara al castellano directamente del latín y no como voz procedente del italiano. Si nosotros consultamos el diccionario LatínEspañol $^{31}$ de Vázquez Fraile, aparece el término grani, orùm, m. pl. Isid. Trenza (de cabellos), que sería el plural de granum, que significa grano. Si nosotros a filum le unimos la concepción de grani, nos daría como resultado, hilo en trenza. Somos conscientes de que esta es una interpretación subjetiva, pero después de la experiencia en la ejecución de la filigrana, nos hace considerar la posible interpretación que hemos dado anteriormente. Así las piezas de joya que nosotros estudiamos estarían realizadas con la técnica de la Filigrana en este sentido que acabamos de exponer, como hilo en trenza, al que uniríamos la técnica del granulado, utilizando tanto los granos de metal como los casquetes semiesféricos del mismo como se verá más adelante ${ }^{32}$.

No obstante para la mayoría, la palabra Filigrana deriva de dos voces: latinas Filumm que significa hilo y, Granum, que quiere decir grano. Una traducción literal nos llevaría a concluir que se trata de "hilo granulado". Esta definición surge por la apariencia granulada que puede presentarse la superficie de algunas piezas clásicas, ya que los hilos de plata se van envolviendo para ser acomodados en el área que se desea trabajar.

La elaboración de una pieza de Filigrana requiere de una paciencia proverbial; exige precisión y aguda visión, para que el producto se asemeje a

\footnotetext{
${ }^{29}$ ECHEGARAY, E,Diccionario General Etimológico de la Lengua Española,Tomo III,Madrid, 1887. pág. 390

${ }^{30}$ COROMINAS, J, Diccionario Crítico Etimológico Castellano e Hispano, Vol. III, pág. 362

${ }^{31}$ VAZQUEZ FRAILE, A, Diccionario Latín-Español, Pág. 767

${ }^{32} \mathrm{CD}$ 1: Anexo 3.1
} 
un encaje y para que tenga la firmeza del metal dentro de lo suave de sus líneas y sus formas, alcanzando sin embargo un gran movimiento y plasticidad.

Otra fuente L. Montañés ${ }^{33}$ define la Filigrana: “... etimológicamente... en realidad se trata de dos hilos muy finos trenzados. La joyería de Filigrana, técnica muy antigua importada por los colonizadores griegos y fenicios tomó carta de naturaleza en España y Portugal siendo hoy sus centros de producción, Salamanca y Guimarães. Se realiza utilizando dos hilos de diferente espesor, usando el más grueso, para esculpir el contorno de la pieza y el otro mucho más fino, para crear los minuciosos detalles característicos de la Filigrana. Un extremo de cada hilo es enrollado en una minúscula espiral, colocado en el lugar correspondiente y cortado con tijeras según la longitud deseada. Este trabajo de relleno, lo suelen hacer habilidosas y pacientes mujeres ${ }^{34}$ en su domicilio. Una vez rellena, es sumergida en agua y espolvoreada con aleación para soldar. Esta se compone de 625 partes de aleación de oro, a $800 \%$, 250 partes de cobre, 62,5 de plata y 62,5 de cadmio. Puesta la pieza sobre un lecho de carbón vegetal, se espolvorea con la limalla de soldadura y se suelda con lamparilla de alcohol o soplete, al blanco, para que se quede sujeto. Finalmente es adornada y formada a mano y su superficie coloreada con una solución de salitre, sal o ácido nítrico, en ebullición. Finalmente se pulen o frotan con el bruñidor de acero."

Investigar sobre la joyería en general y concretamente en la Península Ibérica, implica una serie de dificultades a la hora de su estudio. No hay duda, que para un buen conocimiento de las joyas, es importante tener en cuenta, que estas incluyen datos sociales, económicos y culturales,

\footnotetext{
${ }^{33}$ MONTAÑÉS, FONTENL, L, Joyas,Diccionario Antiquaria. Ed. Antiquaria, S.A. Madrid 1987.

34 El trabajo de la filigrana (según la fuente oral de José Luis Nieves y J. Sánchez Vasconcellos) originariamente era realizado por las mujeres ya que esta técnica requiere de gran paciencia y habilidad. Se hacía generalmente en casa y suponía un ingreso complementario a la economía doméstica. Algo similar ocurría también con otros trabajos artesanales como eran el bordado, el encaje de bolillos o la ejecución de puntillas.
} 
y para ello es preciso hacer una retrospectiva en cuanto a las técnicas de joyería que desde antiguo se vinculan a la Península Ibérica.

Juzgar el valor relativo que tuvieron estos objetos, los materiales y los diseños en la antigüedad no es tarea fácil, y para ello normalmente se suele hacer referencia a algunas culturas de la antigüedad dónde las técnicas que nosotros estudiamos tuvieron un valor muy significativo.

Es una teoría consensuada, que el carácter de las joyas se manifiesta de una manera muy similar en la antigüedad a la de hoy en día. Tanto es así, que podemos destacar tres elementos esenciales que son comunes a la joya a lo largo del tiempo:

a.-El símbolo distintivo de riqueza que posee

b.-La identificación de la joya con un determinado rango social, que puede manifestar además un poder político o religioso dentro de la comunidad.

c.-El carácter que poseen estos objetos de amuletos contra las fuerzas malignas así como su carácter protector $^{35}$ para la persona que las porta.

Todas las joyas, además del carácter decorativo propio de cada una, el diseño y a veces la forma confieren a la pieza un significado místico o religioso. Hoy en día este tipo de atribuciones continúan, tanto es así, que incluso volvemos al poder particular de las gemas o de los metales, cosa que también se hacía en la antigüedad. También en la actualidad la joya es utilizada por los miembros de la comunidad como emblemas que reflejan su "status".

Desgraciadamente para los periodos más antiguos de la joyería en la Península lbérica ${ }^{36}$, nos falta información de las fuentes escritas, que nos aclaren el sentido dado a las joyas, su rango, los artesanos joyeros y la utilización de las mismas.

\footnotetext{
${ }^{35}$ CEA GUTIÉRREZ, A, La Protección contra el mal en la cultura popular Salmantina. Las joyas, L'espai del mal. Vol 1. 2005

${ }^{36}$ DE LA BANDERA ROMERO, M, Introducción al Estudio de la Joyería Prerromana Peninsular: técnicas, Revista Habis, 17 515-135, Universidad de Sevilla, 1986.
} 
Los investigadores de estas épocas, suelen apoyarse en las noticias suministradas por otras culturas como han sido, las orientales y la egipcia, basándose muy especialmente en los restos materiales de ellas.

De las fuentes escritas se desprende que ya desde el III milenio a. C. la joyería toma carácter importante hasta el punto de que los orfebres tenían un rango social elevado y era un oficio que dependía o bien de los templos o bien del poder civil. Así en Sumeria los orfebres y joyeros trabajaban directamente para las autoridades del templo. En Ur, en la tercera dinastía, lo que se producía formaba parte del tempo como propiedad del dios. Esto incluía no sólo objetos, como vasos y armas, sino, las joyas con que se adornaban las estatuas de los dioses que se conformaban en lotes según los ritos para los que se emplearan. También las sacerdotisas y los sacerdotes que se encargaban del culto, se adornaban con las joyas.

Son los instrumentos y las técnicas que se utilizaron probablemente en la fabricación de estos objetos, los que pueden darnos una pista, sobre ellos.

En cuanto al tema de los instrumentos de trabajo desde el II milenio a. C. los métodos técnicos de los orfebres y joyeros, permanecen casi inalterables. Los instrumentos en verdad han cambiado, pero sólo en el aspecto material. Los procesos se han mecanizado, pero siguen siendo los mismos. Para cualquier trabajo de orfebrería y en particular para la joyería, se necesitaba un instrumental básico, que prácticamente sigue siendo el mismo en la actualidad.

Las principales herramientas eran: el yunque, las sierras, las limas, las brocas, los alicates, las tenazas de varias puntas, los mazos de madera, los martillos de distintos tamaños, los cinceles, los punzones, los buriles ${ }^{37}$, elementos muy parecidos a los que se utilizan en la actualidad en este sector.

En cuanto a las técnicas de ejecución los elementos primarios de los que parte la joyería antigua son: láminas de metal, alambres y en menor

\footnotetext{
${ }^{37}$ PLA BALLESTER, E, Instrumentos de Trabajo Ibéricos en la Región Valenciana, Primera Reunión de Historia de la Economía Antigua de la Península Ibérica, Valencia, 1968. Pág. 168
} 
cantidad elementos fundidos. Utilizando la soldadura como elemento de unir piezas y algún otro medio para dar alguna terminación que embelleciera más los procesos decorativos secundarios. El proceso técnico empleado para su realización puede ser de: batido, chapado, fundido, forjado y a veces la soldadura, que en nuestro caso es lo que más nos interesa.

Pero de todos estos aspectos a lo que nosotros le vamos a dedicar una atención especial es a las técnicas decorativas. El trabajo decorativo para embellecer una joya se realiza mediante dos procesos:

a) Actuando directamente sobre las láminas que forman el cuerpo o la pieza, que son: el repujado, el grabado y el cincelado (aspecto éste que nosotros no vamos a detallar porque queda alejado de nuestro objeto de estudio, a pesar de que algunos elementos de Filigrana se encuentran cincelados en su parte posterior, más como adorno que como finalidad dentro del objeto).

b) Sobreponiendo o añadiendo diversos elementos. Estas técnicas decorativas consisten en aplicar algún elemento o sustancia sobre el cuerpo de la pieza que se va a embellecer. Estas son: la Filigrana, el granulado, el nielado, el esmaltado y el dorado. De estas técnicas, nosotros vamos a estudiar, concretamente la Filigrana y el granulado, por ser las técnicas que identifican la base de los procesos de la joyería que nosotros estudiamos.

El proceso de la filigrana consiste en aplicar hilos sobre un cuerpo formando motivos decorativos. Estos hilos, son generalmente de poco grosor y de sección circular, lisos, o pueden estar torceados, o torneados formando un alambre perlado. En ocasiones se utilizan hilos de sección cuadrada o finas cintillas torceadas, como sucede en la orfebrería gaditana ${ }^{38}$.

La Filigrana se presenta en tres variantes:

1.Sentada, es decir, los hilos se sueldan formando la decoración sobre una base laminar.

\footnotetext{
${ }^{38}$ DE LA BANDERA, M, L, Orfebrería Gaditana: técnicas y decoración, Boletín del Museo de Cádiz, III , 1981-82. pp. 33-41
} 
2.Al aire, o calada, cuando los hilos forman la decoración soldándolos entre sí, sin apoyar sobre ninguna base laminar.

3.La Filigrana sentada se realiza con estrechas cintillas soldadas en pie sobre una base delimitando cápsulas o celdillas que posteriormente se rellenan de pasta vítrea. Es la Filigrana para esmalte.

Para realizar esquemas homogéneos se utilizan especies de matrices hechas con madera y alfileres, delimitando el dibujo por donde hay que ir colocando los hilos, una vez formado el motivo se traslada al cuerpo a decorar. En el caso de ser Filigrana calada, se sueldan los hilos entre sí, únicamente.

En la técnica de Filigrana ibérica, se da una forma peculiar de componer esta decoración. Consiste en montar los motivos realizados con hilo sobre estrechas láminas de metal que son las que después se sueldan sobre la joya que se quiere embellecer.

Esta técnica es de origen oriental, con una larga tradición que se remonta a mediados del tercer milenio en Mesopotamia. Su inicio, se encuentra en joyas de las tumbas reales de Ur, junto con la del granulado. Por medio de orfebres babilónicos, la técnica la encontramos en Biblios, hacia el 2000 a. C. Se expande a las costas palestinas, quizás con el movimiento de los pueblos hurritas desde el Norte de Siria (hacia el 1800 a.C.) apareciendo muchas joyas con Filigrana, granulado y esmaltes desde 1600 a. $C^{39}$. La técnica aparece en Egipto, en la XII dinastía por contactos asiáticos. Por las mismas influencias orientales la encontramos en Creta hacia el Siglo XVII a.C. En Grecia aparece hacia el 800 a. $C^{40}$. usada principalmente en su modalidad para esmalte y hacia el 600 a.C. va reemplazando poco a poco al granulado, aunque no totalmente, y es usada con su propio valor y con el de composición para esmalte.

\footnotetext{
${ }^{39}$ MAXWELL-HYSOLP, K, R, “Westerm Asiatic Jewellry.C.3000-612, B.C, Londres, 1971. pp 62-63

${ }^{40}$ HIGGINS, R, Greek and Roman Jewellry, Londres, 1961.Pág. 16
} 
En Etruria, la Filigrana alcanzó un gran desarrollo en el s. VII y VI a. C. destacando principalmente en su variedad "al aire".

En la Península Ibérica la Filigrana aparece tímidamente utilizada en la joyería del periodo Orientalizante ${ }^{41}$ (entre finales del s. VIII a.C. y durante el VII a. C.), como complemento a la técnica granulada, para disimular soldaduras, separar motivos decorativos, o decorando algunas láminas capsulares de anillos de chatón. A partir de finales del s. VI a.C. y coincidiendo con el movimiento griego, la Filigrana tiende a ser la técnica decorativa de la joyería ibérica, relegando el granulado a un segundo plano, siendo empleada en su carácter propio y en el proceso de decoración con esmalte. Su presencia, se detecta igualmente en la variedad al aire, en estilo Orientalizante y en estilo ibérico.

A partir del 400 aproximadamente, la técnica desaparece, quedando sólo algunos elementos aislados dentro de la cultura ibérica final.

El granulado:

Esta técnica consiste en soldar diminutos granos de oro (todos de la misma medida) sobre una base laminar, bien delimitando los motivos y rellenando el campo de base o inversamente, cubriendo los motivos decorativos. Esta técnica presenta una doble dificultad en su realización; una es la obtención de los granos diminutos, otra la de su fijación a la base.

Para algunos investigadores ${ }^{42}$, los gránulos se obtenían fundiendo en una llama, la punta de un hilo de oro y recogiendo las gotas que de él caían. Otro de los procedimientos para la obtención de los gránulos pudo ser el de cortar una alambre, de sección circular (como nosotros veremos con el orfebre que nos explica la técnica de la Filigrana) alisado en pequeñísimos fragmentos discoidales, los cuales se mezclan con carbón en un crisol y se

\footnotetext{
${ }^{41}$ DE LA BANDERA ROMERO, M.L, Introducción al Estudio de la Joyería Prerromana Peninsular: técnicas, Revista Habis, 17 515-135, Universidad de Sevilla. 1986.

42 Op, cit, Pág 528
} 
sometía a fuego durante breve tiempo a una temperatura superior a la de fusión del metal ${ }^{43}$.

Otros autores ${ }^{44}$, apuntan también otros métodos, si bien los resultados aparentemente son los mismos.

En definitiva, al parecer, hay algunos investigadores que creen que estas técnicas diferentes de granulado fueron usadas por los orfebres protohistóricos peninsulares, como apunta González del Campo ${ }^{45}$ en sus "Notas sobre técnicas protohistóricas...".

De esta técnica, nos interesa rescatar lo que según G. Picard ${ }^{46}$ y $S$. Bordi se hacía en algunas piezas donde la soldadura se realizaba sin material de aporte fundente, simplemente aplicando una solución de bórax (este aspecto quedará constatado en el estudio concreto de nuestra Filigrana hecho en el taller del filigranista Nieves, como veremos más adelante, ya que esta técnica se sigue utilizando exactamente igual en la actualidad) que fija los gránulos a la lámina, la cual es de materia con punto de fusión inferior al de los gránulos, y así al aplicar el calor, ésta funde antes y suelda con los gránulos. También para A. Thouvenin ${ }^{47}$ de los seis posibles tipos de soldaduras en la antigüedad, para la Filigrana y el granulado, lo más utilizado y más empleado era la mezcla de fundante y bórax.

El granulado como la Filigrana es de origen oriental, apareciendo sus inicios igualmente en Mesopotamia, en las tumbas principescas de Ur, de mitad del III milenio.

En Egipto, no aparece antes de la XX dinastía, presumiéndose que llega de $\mathrm{Asia}^{48}$. De Mesopotamia pasa a Siria, donde encontramos piezas decorados como el medallón de Montet Jar, de finales del tercer milenio. Y de Siria pasa a las costas de Palestina.

\footnotetext{
${ }^{43}$ VERNIER, F, La Bijouterie et la Joaillerie Egytiennes, El Cairo, 1907, Pág 128 ss

${ }^{44}$ HIGINS, R, , Op. Cit. Pág 22

45 GONZÁLEZ DEL CAMPO, J, Notas sobre técnicas protohistóricas. Técnicas del granulado en la joyería antigua, Pyrenae, 1968. Pág 175 ss

${ }^{46}$ PICARDY, S, B, Salla oreticeri granulate etrusca, Studi Etrusqui, 1955, pp 361-363

47 THOUVENIN, A, La Soudre dans la Construction des oeuvres d'orfevrerie Antique et ancienne, Revue Archeologique de l'Est et Centre-Est, 1973, pp 53-54.

${ }^{48}$ MAXWELL-HYPSOLP, K.R., Op, cit, Pág 109
} 
En el mundo egeo, aparece poco después del 2000 a.C. en la joyería de las tumbas minoicas de Mesara. Poco después del 800 a.C. el granulado está presente de nuevo en Grecia, pasada la Edad Oscura, encontrándose poco después en Etruria.

La zona de donde se importa es con toda seguridad Siria, centro de las principales influencias orientales para estos puntos.

En la Península Ibérica, el granulado aparece hacia la mitad del s. VII a.C., en joyas de necrópolis de colonias fenicias, llegando sin duda a través del comercio con oriente, concretamente con el Norte de Siria ${ }^{49}$.

Esta técnica se distingue en una primera fase del periodo Orientalizante por ser predominante sobre la Filigrana y por las medidas de los gránulos, que son muy homogéneos y pequeños, al estilo fenicio. Algunas piezas por el contrario, de la fase final del periodo, se caracterizan por un diminuto granulado "arenilla", que recuerda el: "pulviscolo" del estilo etrusco.

A finales del S. VI a.C. aparece un tipo decorativo de gránulo más grueso llegando a tamaños tan grandes que sería más exacto hablar de técnica "globular"; además estos glóbulos aparecen no como motivo principal sino complementario de la Filigrana, técnica característica y predominante en el periodo Orientalizante final e Ibérico inicial.

Aunque como hemos dicho anteriormente, el resto de las técnicas (nielado, esmaltado y dorado) nosotros no lo vamos a estudiar, sí queremos apuntar que la técnica del esmalte sí ha sido complementaria en algunas de las piezas que nosotros hemos podido estudiar en el caso de la joyería charra. Es cierto que lo hemos encontrado muy puntualmente y tenemos ciertas dudas, si realmente son de nuestra zona o procedentes de la Submeseta Sur.

De las fuentes orales que nosotros hemos consultado ${ }^{50}$, sí parece que esas piezas con esmalte son de la zona nuestra de estudio, aunque la mayoría de lo que hemos visto, el esmalte prácticamente no existía.

\footnotetext{
${ }^{49}$ DE LA BANDERA ROMERO, M.L, La joyería orientalizante e Ibérica, mital sur penínsular. Tesis doctoral, Sevilla 1987

${ }^{50}$ NIEVES, J.L, CORDÓN, M., SANCHEZ-VASCONCELLOS, J.J.
} 
Teniendo en cuenta que el esmalte ha sido un complemento histórico de la Filigrana, no es de extrañar, que esta técnica, también llegara hasta nuestra zona. El esmalte, se coloca fundamentalmente en las zonas delimitadas por la Filigrana con la finalidad de darle más vistosidad y profundidad a la pieza.

La variante de Filigrana-esmalte, aparece en Grecia a principios del s. VI a.C. y en Etruria, pero es en Asiria, donde tiene su origen esta corriente (s. VII a.C.). Entre griegos, etruscos, escitas, etc., es frecuente en esta época, las rosetas con Filigrana-esmalte. En la Península Ibérica, la técnica del esmalte debió utilizarse a partir de la segunda mitad del s. VI a. $\mathrm{C}^{51}$.

Hay algunas piezas de las que nosotros hemos consultado que sustituyen el esmalte vítreo por una especie de esmalte frío, incluso a veces pintado, que da el mismo aspecto final que el vítreo pero siendo una técnica mucho menos costosa y más barata.

De las fuentes consultadas, sí podemos destacar que en los antecedentes de las técnicas que nosotros estudiamos para el caso de la Península Ibérica, es a partir del periodo Orientalizante, y como consecuencia de las aportaciones de las colonizaciones, cuando empieza a desarrollarse de manera extraordinaria, la actividad de la orfebrería y de la joyería. Se puede distinguir perfectamente como a partir de ese momento, se utilizan nuevas técnicas y cómo van evolucionando, hasta ser suplantadas algunas de ellas por otras en el Periodo Ibérico. En general durante este periodo, el laminado, el batido y el troquelado, así como el repujado con el granulado, el grabado y la Filigrana, se utilizan. En un momento del Orientalizante avanzado y también ya en su fase final, adquieren importancia destacada el granulado y la Filigrana que se utilizan en una misma proporción, realizándose entonces, piezas de extraordinaria belleza.

\footnotetext{
${ }^{51}$ DE LA BANDERA ROMERO, M.L, Op, Cit, Pág 533
} 


\section{Las rutas hacia la Península Ibérica: Procedencia e influencias.}

Relacionado con el capítulo anterior, planteamos una serie de rutas que posiblemente influyeron en la colonización de esta técnica en la Península Ibérica. Basándonos en los mapas que De La Bandera ${ }^{52}$ aporta en su obra, nosotros construiremos unas líneas de penetración de la técnica que nos llevará al espacio o territorio salmantino objeto del estudio.

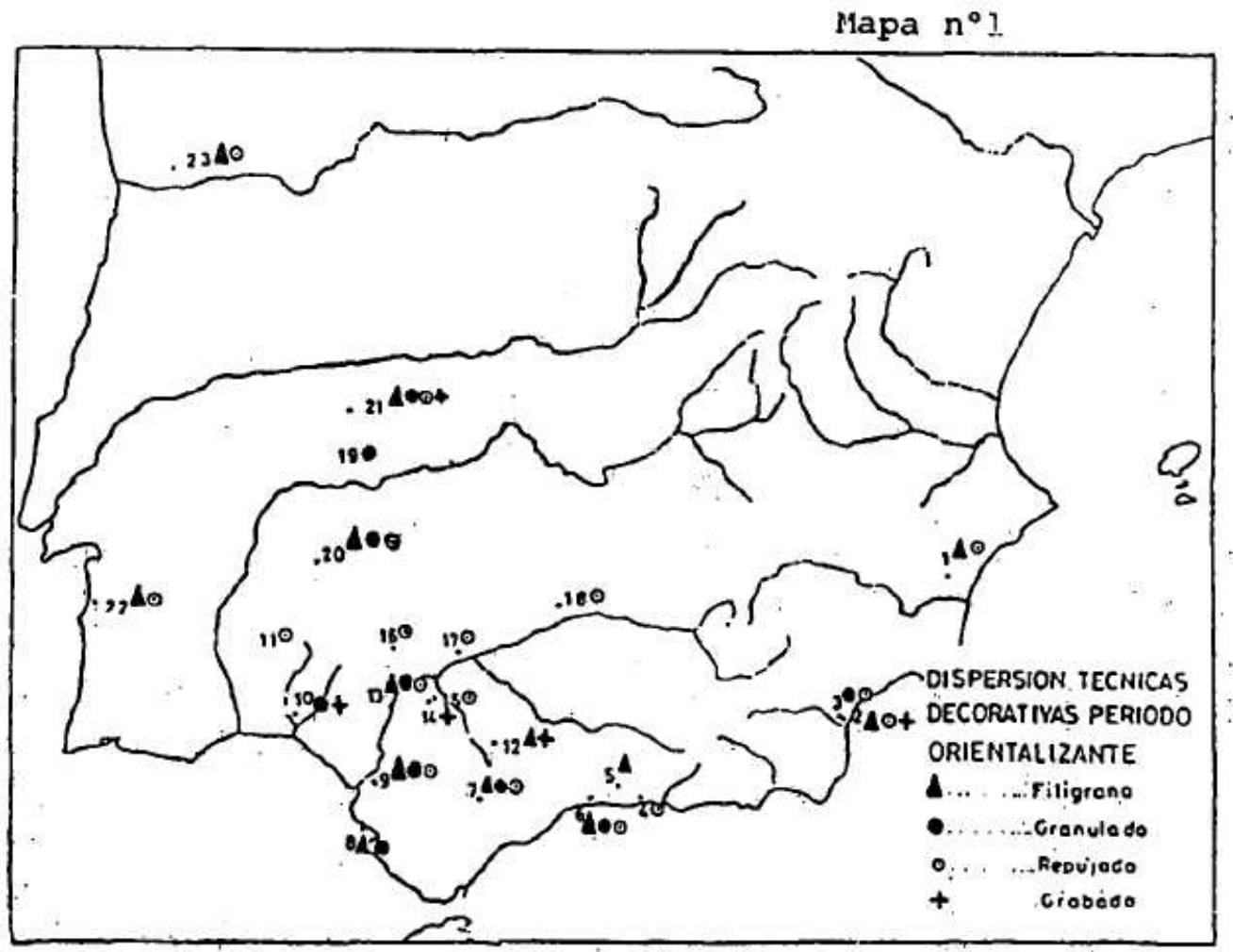

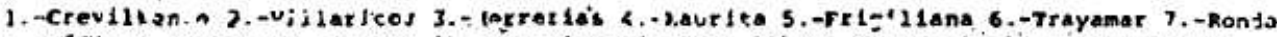

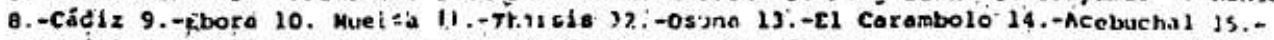

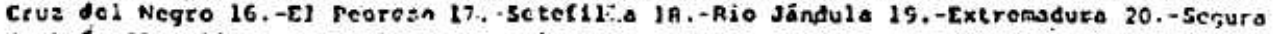
de León 21. -Aliseda 22,-sires 23.-2ajao

\footnotetext{
52 DE LA BANDERA, M.L., Op, Cit, pp, 537-538
} 


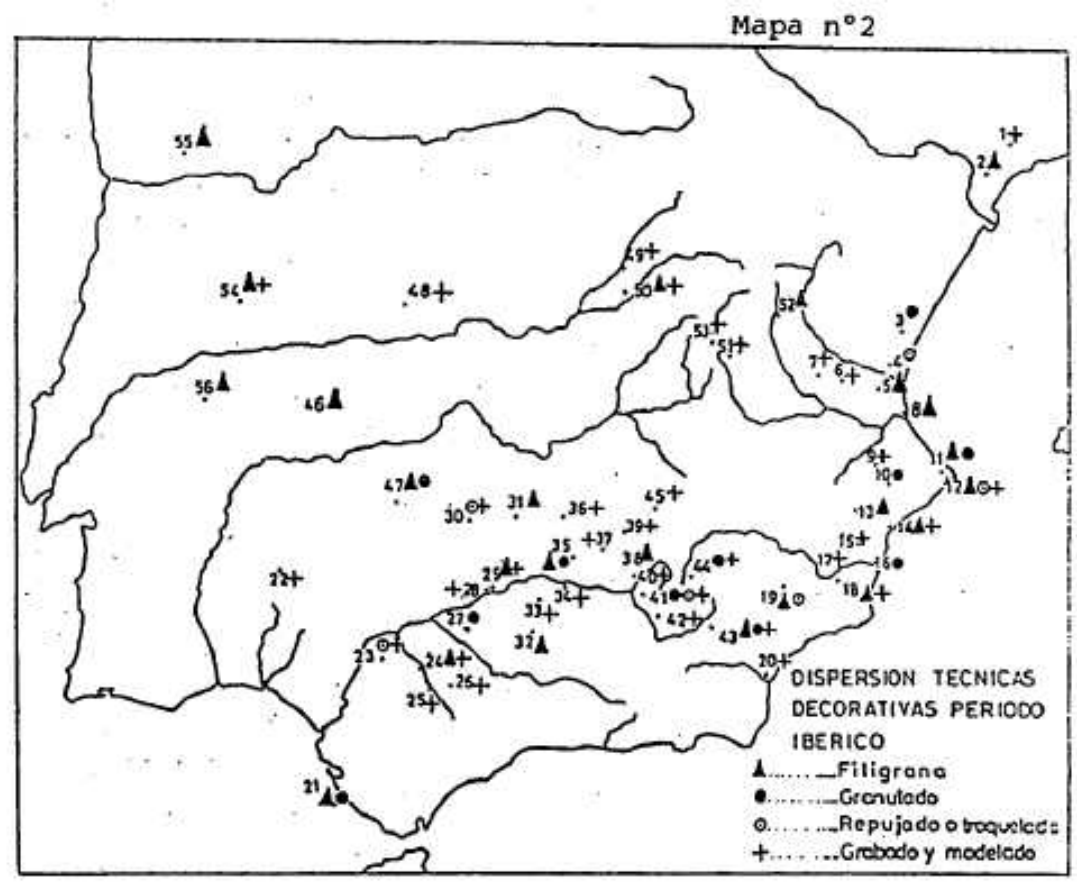

1.-Capsanes 2.-Tivisa 3,-Orley1 4.-Penya Rojo(Liria) 5,-Cheste 6.-Uciel 7,-10s villares 8.-Cuilera 9,-La bastida 10,-La Covalta 11.-Hongh 12,-Jávea 13,-Prov, Alicante 14,-20 Al

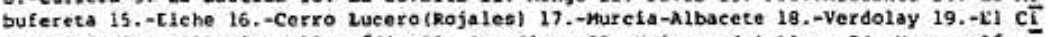
garralejo 20,-villaricos 21,-c5diz 22,-5an Sixto 23, - Hairena del Alcor 24,- Montenolf́n 25.-Pueb:a de cazslia 26. -Frov. Sevill d (osuna) 27.-Cerro Perea 28. -Córdoba 29. -Marrubíal 30.-Los Aladenes (Pezoblaneo) 31, =kzuel 32,-La Bobadilla (Alcaudete) J3.-Canote de lan Torres 34, -hengibar 35,-Linares $36,-E 1$ Centenillo (La Carolina) 37,-Santisteban del ruer so 36.-Castellar de Santistebun 39.-Chiclana de Sogura 40,-Mogón 41. -Tugia 42,-pozalobon 43.-Thtusi 44.-Santiago de 1a Espada 45,-Terre de Juan Abad 46.--xXtremadura 47,-Cancho Reano 48.-Canceleda 49.-La tuela de Taracena 50.-Driebes 51.-Valera de Arrita 52.-Salva calese 53,-7rov. Cuenea 54,-Monsanto de Beira 55. -Guiaes 56.-Portalegre

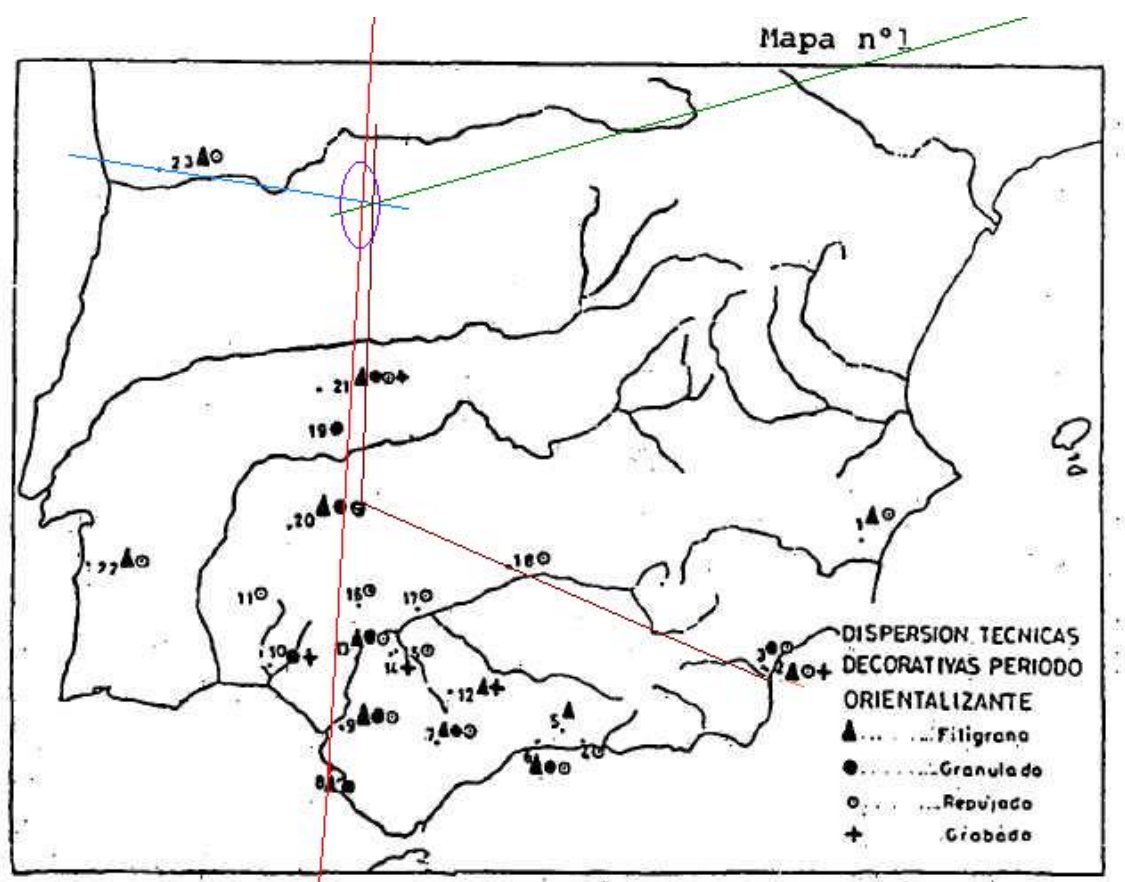

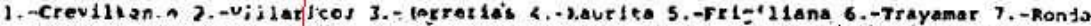

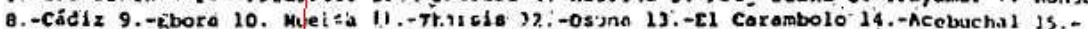

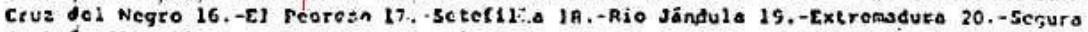
de Lé́n 21,-Aliseda 22,-sires 23,-9ajao 
De la información que hemos podido consultar estudiando la ubicación geográfica de los lugares donde se ha constatado, por estudios realizados, la existencia de la Filigrana y el granulado, consideramos que se puede hablar de un eje Norte-Sur, de penetración de este tipo de técnicas hacia la zona de nuestro estudio.

Podemos concretar que este eje, tiene dirección hacia el territorio salmantino.

\section{Eje Sur-Norte (S-N)}

Consultando los Mapas sobre la dispersión de las técnicas decorativas del periodo Orientalizante ${ }^{53}$, de la observación de los mismos, hemos detectado que existe una alineación que marca este eje que para nosotros es tremendamente importante, puesto que consideramos que se va a utilizar como vía natural de comercio de tal menara que sobre él se construirá la Ruta de la Plata, siendo además, un eje que se utilizará como vía de canalización de otras influencias como la que nosotros apuntamos procedente del Norte de África y concretamente de la cultura Berebere o Amazigh, como explicaremos más adelante. En este orden de cosas, hemos construido una serie de mapas dónde se aprecia la alineación de este eje. Quedaría gracias a las técnicas joyeras, (concretamente la Filigrana y el granulado) constatado que desde el periodo Orientalizante ya existía un canal de comunicación comercial y de penetración cultural en la zona Oeste de la Península Ibérica que comunicaría las cuencas del Guadalquivir y del Duero. (Mapa $1^{54}$ )

Además, consideramos que las influencias del Norte de África (Bereberes) en la joyería tradicional salmantina, también se implementan y aprovechan este canal de comercialización para llegar hasta nosotros. Hemos detectado gran concomitancia entre la joyería Amazigh (no sólo en formas, técnicas, sino además, en la simbología cultural de las mismas).

\footnotetext{
${ }^{53}$ DE LA BANDERA, M.L., Op. Cit

${ }^{54}$ Elaboración propia.
} 


\section{MAPA № 1:}

Eje Sur-Norte (S-N) - (Periodo Orientalizante)
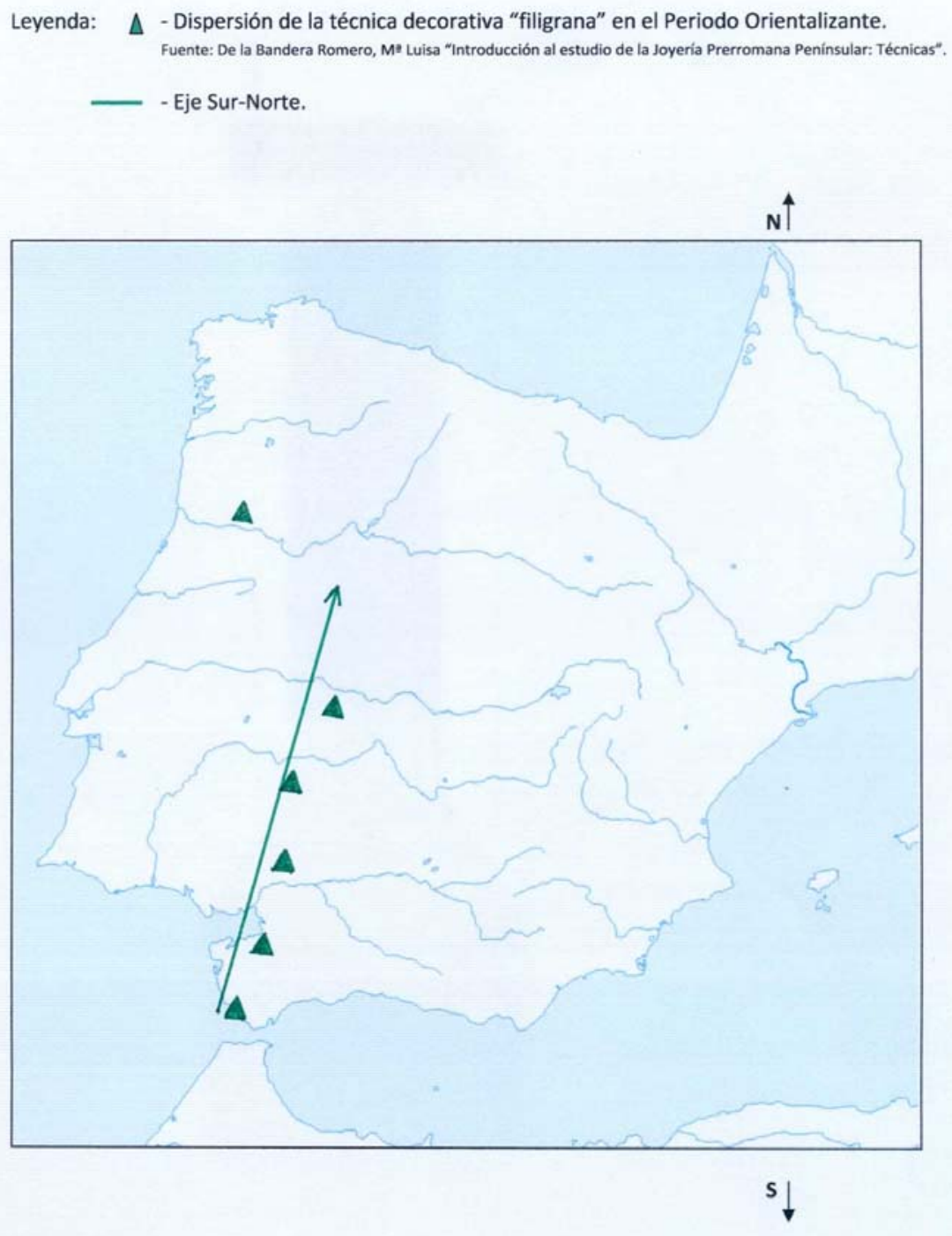

Los Bereberes, o imazighen en lengua bereber (sing. Amazigh pl. imazighen), son las personas pertenecientes a un conjunto de etnias autóctonas del Magreb, al Oeste del valle del Nilo. Se distribuyen del oasis de Siwa, en Egipto, al Océano Atlántico y del mar Mediterráneo al río Níger. Hasta la conquista de las Islas Canarias, en el Siglo XV, el ámbito de los pueblos Bereberes abarcaba también las islas Canarias, ya que sus aborígenes, los guanches, eran imazighen. 
Los musulmanes que entraron en Iberia en el año 711 fueron principalmente Bereberes.

Durante la época de las taifas, algunas dinastías eran Bereberes (como por ejemplo, los Ziríes, reyes de Granada). El periodo de taifas terminó cuando una dinastía de los almorávides se hizo cargo de Al-Ándalus, hasta que fueron sucedidos por los almohades, otra dinastía de Marruecos. Durante esa época, Al-Ándalus alcanzó su mayor esplendor cultural.

En la jerarquía de poder, los Bereberes se encontraban entre la aristocracia árabe y los muladíes.

La joya, es el máximo exponente de la cultura bereber, uno de los elementos que permite conocer mejor los rasgos culturales, antropológicos y sociales de los amazighs, pueblo milenario del Norte de África. La joya bereber va más allá de su valor puramente estético y nos permite mostrar el entorno geográfico, los rituales y los vínculos sociales, las creencias y la relación entre simbología y naturaleza, y, en definitiva, la relevancia que la mujer, principal portadora de este valioso patrimonio, tiene en el mundo amazigh

El derecho consuetudinario amazigh ${ }^{55}$, transmitido oralmente de generación en generación y perpetuado en gran parte de las tribus, es un tipo de justicia impartida por la jama'a, o asamblea tribal, representada por un colectivo de hombres con frecuencia ancianos. Este corpus legislativo autóctono, muy diferente entre los grupos Bereberes de un mismo país, convive con el fiqh o derecho islámico en el sistema social bereber hasta la homogeneización jurídica que llevaron a cabo los estados independientes a mediados del Siglo XX. Una de las diferencias más notables entre ambos derechos se refiere a la herencia. Mientras que el derecho islámico otorga a las mujeres la mitad de lo que reciben los hombres, el derecho amazigh reparte generalmente los bienes de la herencia entre los varones.

Las joyas son siempre propiedad de las mujeres (este concepto de propiedad y de herencia se ha trasladado exactamente igual hasta nuestro

\footnotetext{
${ }^{55}$ ALONSO MENESES, G., Cultura Amazigh e identidad étnica, Rev, África Internacional, no 19, lepala, Madrid, 1997.
} 
espacio de estudio, extensible seguramente a toda la Península Ibérica, pues prácticamente en todas las zonas o provincias del territorio nacional, son las mujeres las que heredan indiscutiblemente las joyas procedentes de la familia, nos referimos fundamentalmente a las joyas que utiliza la mujer. De esta manera, se evitaba que el patrimonio joyero familiar se disipara entre la línea de los varones. Curiosamente la joya es el único elemento no machista de los tiempos históricos ya que normalmente el resto de bienes económicos procedentes de la familia troncal seguían la línea masculina) y representan su independencia económica en caso de problemas o desacuerdo con el cónyuge. Normalmente pasan en herencia de madres a hijas, aunque las mujeres ${ }^{56}$ amazighs también las reciben de manos de sus maridos o de los padres de éstos cuando se casan, ya que constituyen su dote. La cantidad y calidad de las joyas que reciben al contraer matrimonio varía según el pacto familiar y, sobre todo, según el estatus familiar de los dos contrayentes. Así, un hombre que quiera casarse con una mujer de una familia con muchos recursos tendrá que dar una dote muy alta expresada en joyas y, si es necesario, también en dinero o especies.

Las joyas, al igual que los vestidos, identifican a los miembros de una misma tribu, de manera que sus formas, materiales y decoraciones nos informan tanto del origen tribal como geográfico de las mujeres.

Durante mucho tiempo, la dote se ha considerado una mercantilización de las mujeres. Ciertos investigadores franceses del Siglo $\mathrm{XIX}$ y de principios del XX creían que la dote era la prueba de que, en las sociedades magrebíes, el contrato matrimonial escondía una compraventa de la esposa. Para la mayoría, la dote señalaba los derechos adquiridos del marido respecto a la mujer mientras durara el enlace. Actualmente la dote se considera desde una perspectiva muy diferente: constituye la parte que le corresponde a la futura esposa por su participación en la creación y consolidación del nuevo vínculo familiar. La dote, además de representar un

\footnotetext{
${ }^{56}$ GIRALT, JOSEP, Las joyas, exponente de la cultura amazigh, Diálogos, Rev, Afkarjideas, Barcelona, 2005. pp 109-111
} 
reconocimiento social de la mujer, permite garantizar su autonomía económica ante cualquier situación adversa.

Consideramos que esta influencia cultural es extraordinaria, porque estamos convencidos que hay una parte importante de la riqueza en formas del traje berebere, que las podemos encontrar en algunos de los trajes de nuestra zona de estudio. (Mapa $2^{57}$ )

La fase de transición al Periodo Ibérico, no significa un cambio en las técnicas. Pero en las decorativas ${ }^{58}$, es la Filigrana la que se va utilizando en más proporción que el granulado, siendo esta etapa muy rica la Filigrana con esmalte.

El Periodo Ibérico pleno, supone un pequeño cambio más destacado en los tipos de joyas que en las técnicas y concretamente la Filigrana se aplica en sus dos variantes de simple y esmaltada. El granulado queda reducido a complemento de esta Filigrana (que como veremos con los testimonios ${ }^{59}$ de nuestras fuentes orales, es la que en la actualidad pervive), y aparece una variante más clara del mismo que sería más conveniente denominar "globular", como ya hemos comentado por el tamaño de los componentes más grandes. Esta Filigrana globular también llega hasta nosotros y podemos apreciar como esta técnica la siguen utilizando nuestros "oreros" salmantinos.

Un cambio más profundo se produce en la fase final del Periodo Ibérico, pasando a tener en este periodo más importancia el grabado que la Filigrana.

Estudiando y observando los Mapas ${ }^{60}$ consultados de este periodo, y viendo la distribución de las técnicas decorativas objeto de nuestro estudio en el Periodo Ibérico detectamos la existencia de otro eje, que nosotros denominamos Eje Mediterráneo-Costa de Levante.

\footnotetext{
${ }^{57}$ Elaboración propia.

58 DE LA BANDERA, M,L, Op, Cit, pág, 537.

59 Testimonios ofrecidos por nuestras fuentes, NIVES, J.L., CORDÓN, M.

${ }^{60}$ DE LA BANDERA, M,L, Op, Cit, pp 537-38.
} 


\section{MAPA № 2:}

Eje Sur-Norte (S-N) - (Influencias Norte de Africa-Amazigh)
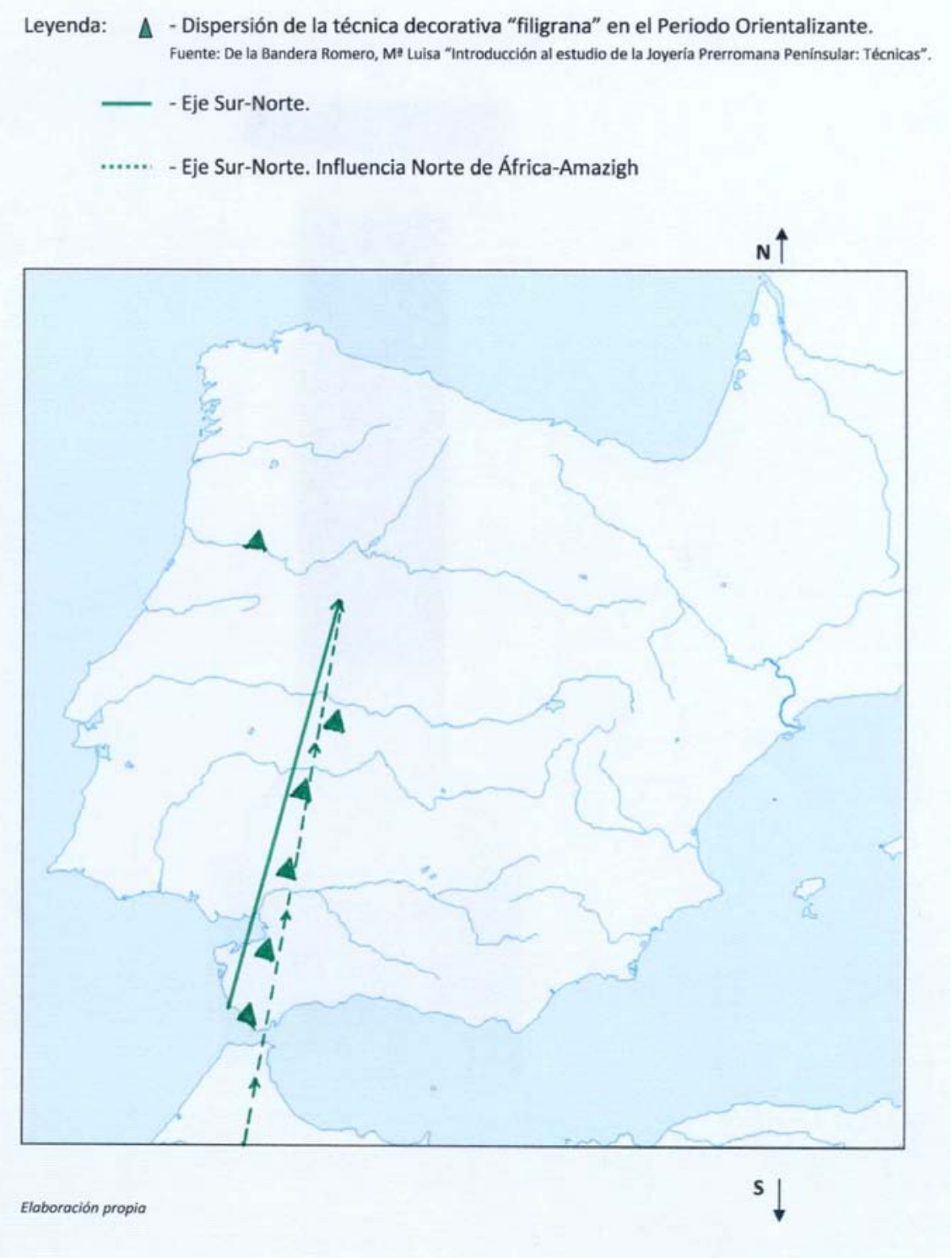

e

\section{Eje Mediterráneo-Costa de Levante (SE-NO)}

En este eje podemos apreciar cómo existe otro canal de penetración de estas técnicas desde la zona de Almería hasta nuestra zona de estudio y cómo atravesando las cuencas del Guadalquivir, Guadiana y Tajo, llegan hasta la vertiente Sur del Duero, justamente confluyendo con el eje SurNorte que ya hemos definido anteriormente, de tal manera que incluso 
podríamos decir que desde la vertiente Sur del Tajo se superpone con el eje Sur-Norte para coincidir en nuestra zona de estudio (Mapa 3) ${ }^{61}$. También consideramos que este eje que nosotros definimos, será utilizado como un canal por donde las influencias del Mediterráneo también lleguen hasta nosotros.

\section{MAPA № 3:}

Eje Mediterráneo-Costa de Levante (SE-NO)- (Periodo Ibérico)

Leyenda:

- - Dispersión de la técnica decorativa "filigrana" en el Periodo Ibérico".

Fuente: De la Bandera Romero, Ma" Luisa "Introducción al estudio de la Joyería Prerromana Peninsular: Técnicas".

— - Eje Mediterráneo-Costa de Levante

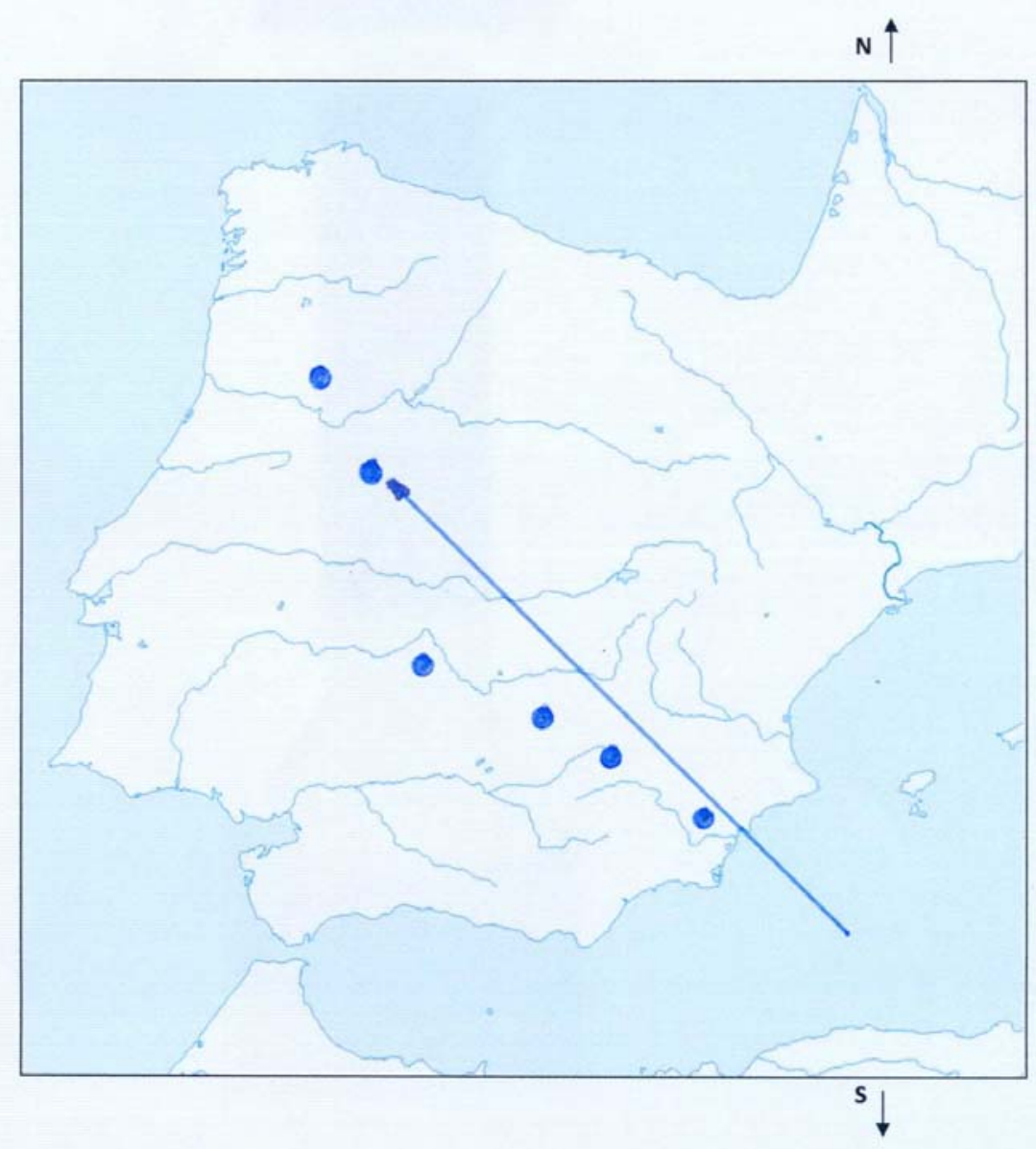

Elaboración propia

${ }^{61}$ Elaboración propia. 
Completando toda la información que hemos expuesto, tan sólo nos quedaría hacer hincapié en la importancia que han tenido las culturas babilónica, asiría y sumeria, 3.000 a.C. que fueron civilizaciones muy avanzadas y que desarrollaron una extraordinaria joyería, como lo demuestran los fabulosos tesoros encontrados en excavaciones de antiguas ciudades de estos pueblos, donde aparecieron gran cantidad de joyas y ornamentos de oro, plata, piedras preciosas y semipreciosas.

Entre las técnicas de joyería que desarrollaron destaca el granulado y la Filigrana, de las que ya hemos hablado suficientemente, siendo la incrustación de piedras preciosas o semipreciosas una de sus características.

De las fuentes que hemos consultado, detectamos una similitud en formas y en técnicas que nos recuerdan profundamente a lo que nosotros estamos estudiando, concretamente el Botón Charro, que aunque el estudio de la forma lo haremos en un capitulo posterior, sí podemos adelantar las similitudes observadas. Nos referimos fundamentalmente a la joyería Babilónica y Etrusca ${ }^{62}$ (Foto B-a y B-b) que aunque sus técnicas tuvieron origen en Mesopotamia, evidentemente nos han llegado a nosotros.

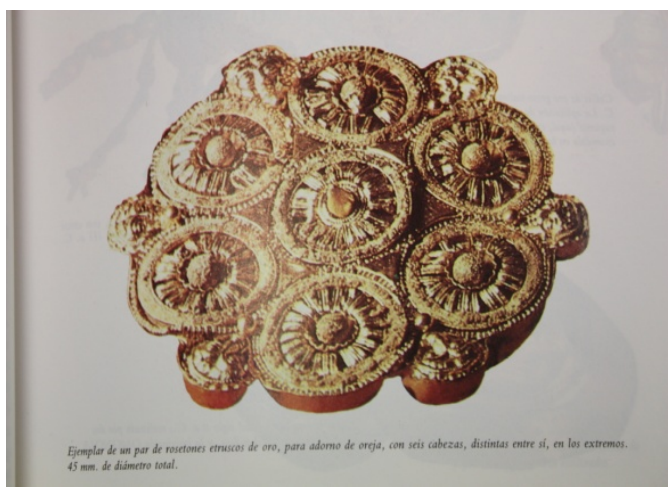

${ }^{*}$ Foto B-a Etrusco

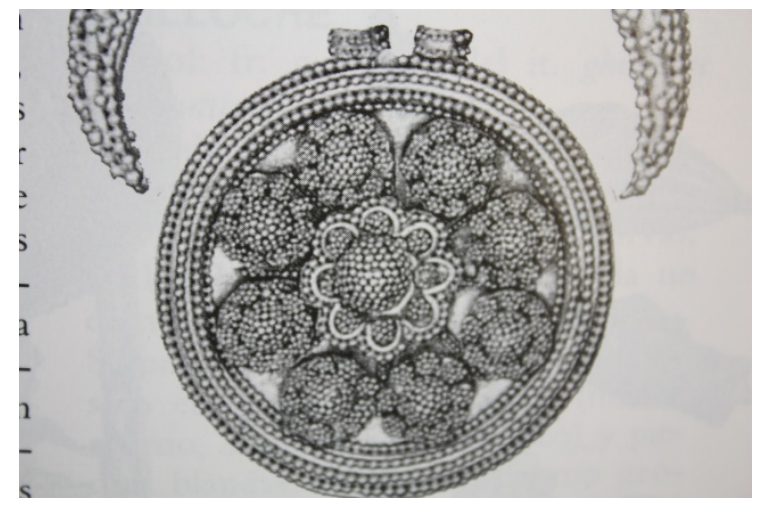

*Foto B-b Babilónico

\footnotetext{
62 MONTAÑÉS ,FONTENLA, L., Joyas Diccionario Antiquaria Ed. Antiquaria, S.A. Madrid 1997
} 
Como consecuencia de la documentación que hemos manejado, detectamos también que otra de las huellas más antiguas conocidas de los trabajos de Filigrana en la Península Ibérica ${ }^{63}$, está datada en Portugal ${ }^{64}$, en la Edad del Hierro, cuando se encuentran un par de pendientes en la Citania de Briteiros, en un asentamiento ubicado cerca de Braga, en la parte Norte del país. Piezas del mismo estilo y época, se han encontrado en otros yacimientos arqueológicos en la misma región. Lo curioso de estas piezas de joyería es que fueron encontradas en un área que todavía tiene una activa industria orfebre hoy en día, y más precisamente una industria dedicada exclusivamente a la producción de piezas de Filigrana.

Si a esta información le unimos que todas las fuentes referenciales vivas que tenemos en la zona objeto de nuestro estudio son de origen portugués, como dataremos a lo largo del presente estudio, detectamos otro eje importante que va a confluir en nuestra zona de estudio. Es lo que nosotros denominamos Eje Atlántico.

\section{Eje Atlántico-Portugués (O-E, E-O)}

Este eje, estaría asentado en la vertiente Norte y Sur del Duero. Creemos que la dirección de influencia marítima de la técnica de la Filigrana puede ser procedente de los puertos atlánticos del Norte de Portugal, a los que seguramente llegaron a través del comercio marítimo de estos pueblos; con lo cual la dirección de influencia sería Oeste-Este. Pero también intuimos que pueda existir una influencia terrestre procedente del eje SurNorte (ya definido), que se dispersara hacia el NorOeste de la Península Ibérica. Si tenemos en cuenta, que el origen de nuestros orfebres actuales los podemos constatar en 1800 en Portugal para luego trasladarse a España, cobraría más fuerza esa influencia atlántica por lo menos en tiempos recientes.

\footnotetext{
${ }^{63}$ DIAS, P., Portugal e Espanha entre a Europa e alem mar, IV Simposio Luso-Español de Historia de Arte, Instituto de Historia da Arte, Universidad de Coimbra, 1988.

${ }^{64}$ FUNDACIÓN ANTONIO ALMEIDA, Actas do Coloquio ourivesaria do Norte de Portugal, 1984.
} 
Lo que está claro, es que este eje Atlántico, confluiría justamente en nuestra área de estudio con el eje S-N y el eje Mediterráneo.(Mapa 4) ${ }^{65}$

\section{MAPA № 4:}

Eje Atlántico-Portugués (O-E, E-O)

Leyenda: —— - Eje Atlático-Portugués

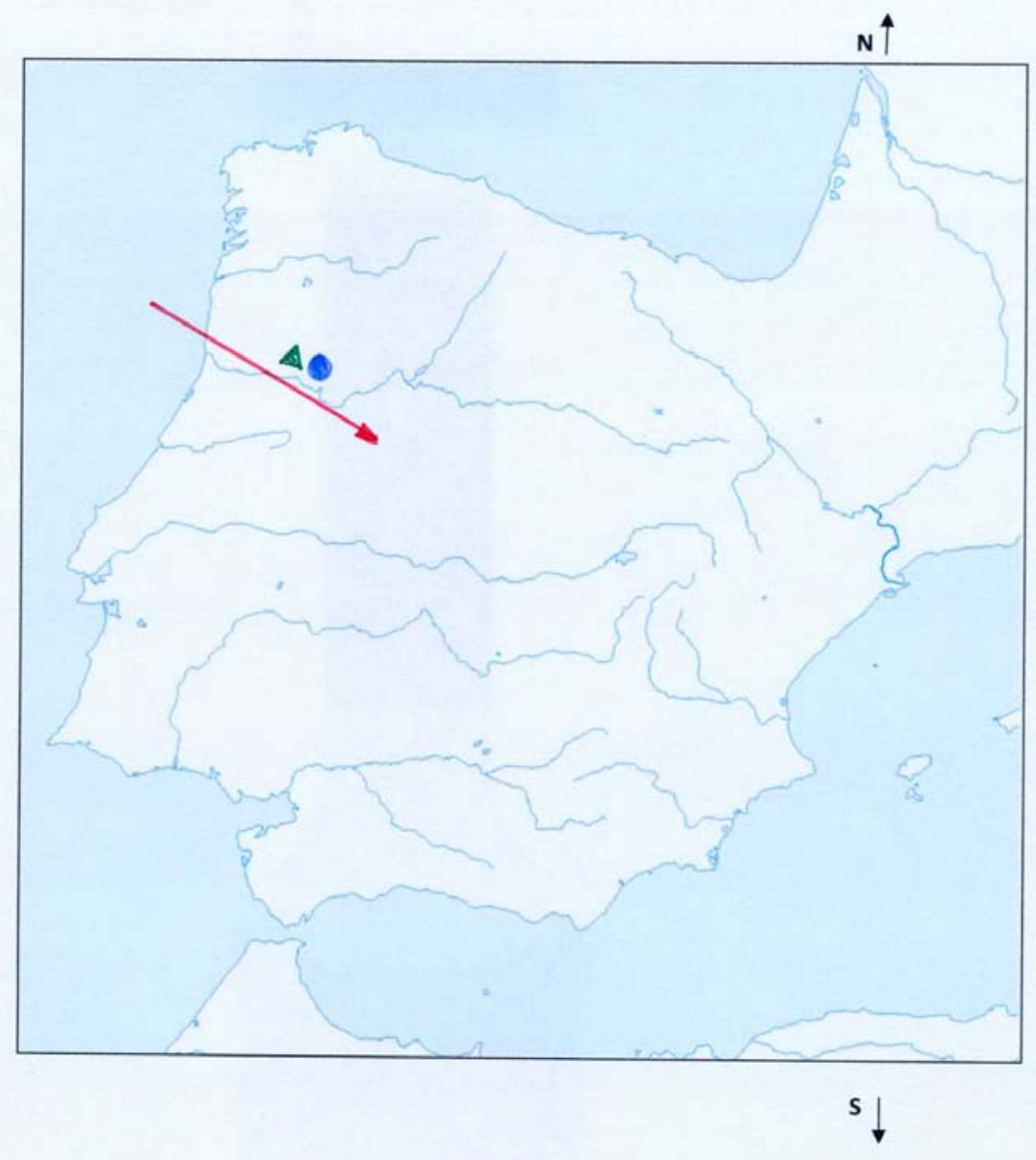

Elaboración propic

En este sentido, es nuestro objetivo completar información para poder constatar este eje Atlántico-Portugués, de muchísima importancia para nuestro estudio.

${ }^{65}$ Elaboración propia. 


\section{Eje Exportador Marítimo}

Para terminar, en este apartado del estudio querríamos dejar constancia de la existencia de unas vías de exportación cultural, compuestas por: técnicas, formas, tipologías de joyas,... que se llevan a América, con el descubrimiento desde la Península Ibérica.

\section{MAPA № 5:}

Eje Exportador Maritimo (de la Península Ibérica a América)

Leyenda: — - - Eje Exportador Marítimo

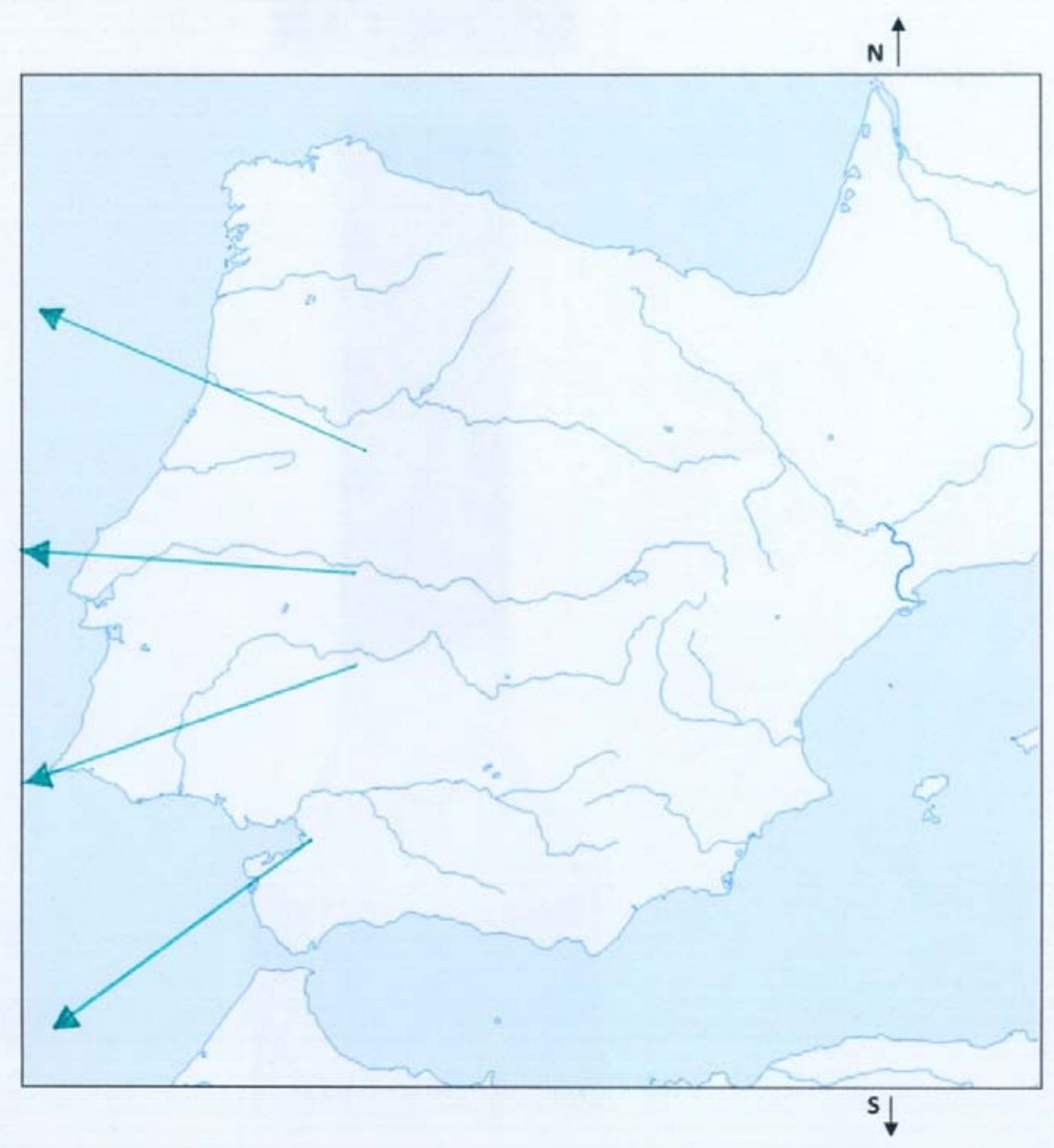

Elaboración propia

No nos cabe duda, que las técnicas ancestrales de la Filigrana y el granulado existieran en el nuevo continente. Lo que sí es cierto, es que con 
la llegada de los nuevos colonizadores, también llegaron la cultura y las técnicas de viejo mundo, además de sus costumbres, simbologías y usos. Esto es un hecho para el caso concreto de la joyería.

Así podremos entender cómo en la actualidad, hay una gran tradición filigranista en Latinoamérica como: en Colombia la Filigrana de Mompox, en Perú la Filigrana Ayacuchana, en Ecuador la Filigrana de Chordeleg y en México la Filigrana Mexicana, esta última, no solamente tiene la técnica, sino que además, importaron el nombre de Charro, conociéndose a los mexicanos como "Charritos". Evidentemente, técnica, concepto y nombre, proceden de nuestra zona de estudio. (Mapa 5$)^{66}$.

\section{El traje como soporte del aderezo joyero}

\subsection{Aproximación al tema.}

La joyería como ya venimos diciendo, va muy vinculada al Traje ${ }^{67}$. Sabemos que no todos los atuendos ${ }^{68}$ admiten joyas, y sobre todo, no todos los momentos del día y la actividad que se realiza, permite o recomienda el uso de las mismas.

Antiguamente, al igual que en la actualidad, el uso de la joya dependía mucho del momento.

Bien es cierto, que hay elementos, que concretamente la mujer siempre llevaba puestos, indistintamente del traje o de la actividad que realizase, simplemente lo que variaba era el "tipo" de pieza que se ponía. Me refiero concretamente al pendiente. Esta era una pieza que se ponía a las niñas nada más nacer y tal ha sido siempre su uso e implantación en la cultura mediterránea, que la mujer sin pendientes tenía y daba la sensación

\footnotetext{
${ }^{66}$ Elaboración propia.

${ }^{67}$ DE LA BANDERA, M,L, El atuendo femenino ibérico, Rev, Habis, 9, 1978. pp 410-440.

68 FIgUEROA HERRADON, M,A, Vestir la joyas, Museo del Traje, Centro de investigación de patrimonio etnológico, Ministerio de E.C.D., Madrid, Sept 2014.
} 
de desnudez o de falta de decoro. Hay un dicho que se utilizaba en el medio rural, para decir cuando no se llevaban pendientes era "estás mocha" que viene a decir, falta de terminación, incompleta o poco aseada...

No en todas las culturas, el pendiente ha tenido tanta aceptación. Es en las culturas más antiguas, donde el pendiente queda vinculado desde el inicio de la vida a la mujer, aunque hay que decir que a lo largo de la historia también el varón lo ha utilizado en tiempos pretéritos. Pocos son los hombres que usan hoy pendientes aunque en la actualidad hay cantantes o deportistas que sí lo hacen, depende de la moda, no es nada novedosa y si no, recuerden y piensen en los Piratas de los Mares del Caribe y de la piratería en general.

Anécdotas a parte, el pendiente es junto con la gargantilla con cruz y medalla, lo que tradicionalmente se usaba en cualquier edad, condición y lugar. Evidentemente estamos hablando del periodo histórico d. C.; aunque el signo de la cruz existía, pero no con la simbología religiosa que le da el cristianismo.

Para el caso del pendiente sólo la actividad o acto que se realizaba, hacía cambiar unos por otros.

Las niñas, por ejemplo, empezaban la vida con las "abrideras" o "añas" (procedentes de las amas de cría ${ }^{69}$ ) e iban cambiando de pendiente en fechas claves vinculadas a la edad: comunión y boda.

Las características del pendiente varían mucho en función del poder adquisitivo. Antiguamente, el oro era el metal, por encima de la plata, más utilizado en la joyería popular. Teniendo en cuenta la ley ${ }^{70}$, encontramos joyas antiguas que tienen una ley de 18 quilates, pero también las hay de 14 o incluso de 12, como explicaremos más adelante.

\footnotetext{
${ }^{69}$ FIGUEROA, HERRADON, M,A, Joyas para el ama de cría, Art, Altamira, Rev del Centro de Estudios Montañeses, no 79, 2010. pp 227-246.

70 MONTAÑÉS, L, Op, Cit.
} 
El pendiente, en la actualidad ha perdido una parte importante de la impronta femenina, ya que asistimos al uso de una nueva tendencia, que aunque no generalizada pero sí significativa, en la que los padres no perforan las orejas a sus hijas porque consideran que es una agresión física al bebé. Luego la coquetería, la moda y los usos hacen que tanto hombres y mujeres se perforen no una, sino muchas veces ambas orejas.

No obstante, el pendiente de forma histórica ${ }^{71}$, aparece vinculado a todos los trajes ${ }^{72}$, y haciéndonos eco de la experiencia como veremos en los testimonios recogidos, no sólo el traje definía el origen geográfico de la mujer, sino, que el "pendiente" indicaba con certeza su procedencia, por ejemplo: serranas, charras centrales, armuñesas...

La gargantilla, la medalla, la cruz o el escapulario ${ }^{73}$, también eran complementos comunes a todos los trajes y ocasiones, ya que hombres y mujeres llevaban en la mayoría de los casos, los signos del cristianismo y de la fe junto a sus corazones, de forma habitual, aunque luego se ponían otros aderezos más ricos que completaban sus trajes de fiesta.

Hasta hace relativamente poco, 20 ó 30 años, no más, a los recién nacidos también se les incorporaba una cadena con un signo religioso, fundamentalmente por creencia de que la deidad o los santos allí representados, ayudarían al neófito en su vida, tanto en la salud como en la consecución de un futuro digno. No olvidemos nunca que en el mundo rural y de interior, la religión y las creencias ${ }^{74}$ han sido la base fundamental de la estructura familiar y social. Es justamente en estas zonas, donde las influencias externas han llegado mucho más tarde, donde han permanecido las tradiciones ancestrales de forma más intacta.

\footnotetext{
${ }^{71}$ FOMENTO CULTURAL BENAMEX, Charrería, Arte y Tradición. Fundación Pedro y Elena Hernández, 2008.

72 ORTIZ ECHAGUE, J, España tipos y trajes, Edit, Mayte, Bilbao, 1950.

${ }^{73}$ CEA GUTIÉRREZ, A, Relicarios, cruces,...,Junta de Andalucía, 2007.

${ }^{74}$ CEA GUTIÉRREZ, A, La protección contra el mal en la cultura popular salamantina. Las joyas, L'espai del mal, vol. 1, 2005.
} 
Acceder a colecciones particulares no es tarea fácil, pues en el caso de la joyería, tiene un incalculable valor sentimental e íntimo. Mostrar la herencia joyera de una familia, es abrir las puertas al corazón y los recuerdos, entrando de lleno en el Sancta Sanctórum de la intimidad de cada familia.

La joya a igual que otros objetos etnográficos, tiene un valor sentimental y grupal, porque el uso de la misma se ha vinculado y se vincula a los actos sociales-familiares más importantes: bautizos, comuniones, bodas y funerales. Así como, eventos en general, donde no sólo se pone de relieve el gusto del propietario/a sino, el poder económico-social del individuo o de la familia que lo porta.

Hemos tenido en nuestras manos, piezas que llevaron abuelas y bisabuelas desde su nacimiento hasta su defunción, sin que nada o nadie fuera lo suficientemente importante como para quitárselas. Concretamente un caso ${ }^{75}$, en el que la propietaria actual del collar nos dijo que a su abuela siempre la conoció con él puesto y que no fueron capaces de quitárselo hasta después de su fallecimiento. Consideraba que era su guardián.

La costumbre, la superstición ${ }^{76}$ o la religiosidad, hacía que las niñas, fundamentalmente llevaran piezas colgadas desde su nacimiento. La costumbre hacía ley y no se quebrantaba. Desde aquí nuestro respeto y agradecimiento.

Tenemos que apuntar, que aunque no han sido muchos los casos (puede ser que en el futuro encontremos más), también hemos tenido negativas por parte de algunas familias que apoyándose en la intimidad ${ }^{77}$, no nos han permitido ni ver ni fotografiar las piezas de la joyería que obran en

\footnotetext{
${ }^{75}$ Familia de la sierra de Salamanca, Tradición oral.

${ }^{76}$ CEA GUTIÉRREZ, A, Sobre magia y brujería, Rev. de Dialectología y Tradiciones Populares, vol LIX, 2004. pp 3 ss.

${ }^{77}$ Estamos convencidos de que además de la intimidad, hay un gran miedo a desvelar la riqueza en oro de determinadas familias rurales. Sencillamente no se fían de nadie, y cuanto menos se sepa el patrimonio joyero que tienen, mejor. Cuestión de miedo. Esto supone una pérdida importantísima de conocimiento a favor de la investigación.
} 
su poder. No obstante, no perdemos la esperanza de que tal vez en otro momento cambien de opinión.

Hasta el último cuarto del Siglo $X X$, prácticamente con el advenimiento de la Democracia en España, se habían mantenido usos y costumbres $^{78}$ ancestrales, que hoy parecen lejanísimas en el tiempo, y que han desaparecido casi por completo.

Sin embargo consideramos que es muy pequeño el segmento temporal para la desaparición de usos y costumbres. Tal vez una serie de factores actuales como: que el Estado sea aconfesional, la globalización, la incorporación a Europa, el aperturismo ideológico y económico, han favorecido a que determinados cambios culturales, de uso y costumbres, se hayan producido con mucha rapidez en comparación al tiempo que se ha necesitado a lo largo de la Historia para que se produjeran cambios similares en otras sociedades.

Este aspecto, es tremendamente interesante pues, consideramos que si bien el uso de los elementos externos se ha volatilizado en la sociedad española de principios del Siglo XXI, somos conscientes de que ha habido un cambio de significado secular de los mismos, por ejemplo: el rosario, lo vemos hoy como collar y se ha dejado de usar masivamente por la sociedad como elemento religioso ya que solamente siguen dándole ese uso quienes continúan rezándolo.

Se está produciendo un fenómeno muy interesante. Históricamente el cristianismo dio forma religiosa a usos y costumbres paganas muy arraigadas en el pueblo. En la actualidad, pensamos que podemos estar asistiendo a un "flash back" , es decir, un camino de retorno hacia la paganización de la sociedad, folklorizando, determinados actos y costumbres que han tenido en tiempos próximos forma religiosa y que el mundo actual vuelve a dar una visión mucho más naturalista de ellos:

${ }^{78}$ CEA GUTIÉRREZ, A, Entre el tópico urbano y la realidad rural..., Nuevas y viejas tradiciones en ámbitos urbanos, Anthropos, vol, No volumen, Barcelona, 2004. pp 28. 
- Cristianizamos los símbolos. (Pasado)

- Paganizamos los símbolos. (Actualidad)

No sería justo generalizar este concepto para toda la población, pues aún existe una importante mayoría que sigue manteniendo las creencias del cristianismo que han dado una impronta importantísima en los últimos veinte siglos de la humanidad.

No obstante esto que comentamos coexiste también con un substrato social que sigue manteniendo determinados anacronismos simplemente por el temor de romper con el pasado más ancestral ${ }^{79}$.

Curiosamente, nuestra sociedad no es menos supersticiosa hoy en día, de lo que era en otros tiempos, simplemente ahora se denomina de otra manera.

Tampoco los miedos de nuestros ancestros han desaparecido del panorama humano.

La diferencia radica, en que antes en la joyería tradicional actuaba como antídoto para esas supersticiones y miedos y en la actualidad, han perdido ese valor, dejándolos en mero valor decorativo, económico (por el oro o la antigüedad) y como valor histórico-familiar vinculado a cada casa y a la herencia. En muchos casos, quedan guardados definitivamente en los cajones, siendo relegados por objetos más acordes al gusto y a las necesidades actuales, como pueden ser las joyas de acero o el uso del caucho.

Hechas estas salvedades, pasemos a estudiar, según la división de trajes que ha realizado Feli Cañada ${ }^{80}$, el aderezo joyero que lleva cada uno de estos trajes en la Provincia de Salamanca.

\footnotetext{
${ }^{79}$ DAMBRIM, P, Teoría ancestral de la tierra, Conferencia sobre domoterapeute, biología y medicina, París, 2013.

${ }^{80}$ Estudio no publicado, Feli Cañada.
} 
Para ello, reproducimos el Mapa del traje ${ }^{81}$ que ha realizado Feli Cañada basándose fundamentalmente en la tipología de prendas, colores, bordados, usos, etc., considerando que aunque todos tienen la identificación de "charros" ${ }^{\prime 2}$, cada área le imprime una característica particular de la zona en la que se ubica, muchas veces vinculado al tipo de actividad económica que se realizaba. Nada tiene que ver las partes donde la mujer se dedicaba fundamentalmente a la espigadera, que las partes en las que la mujer estaba más vinculada a la ganadería. Aquí también queda de manifiesto la diferencia que hay entre las dos partes tradicionales del medio rural salmantino ${ }^{83}$ : al Norte la zona extensa de agricultura cerealística y al Sur el Campo Charro.

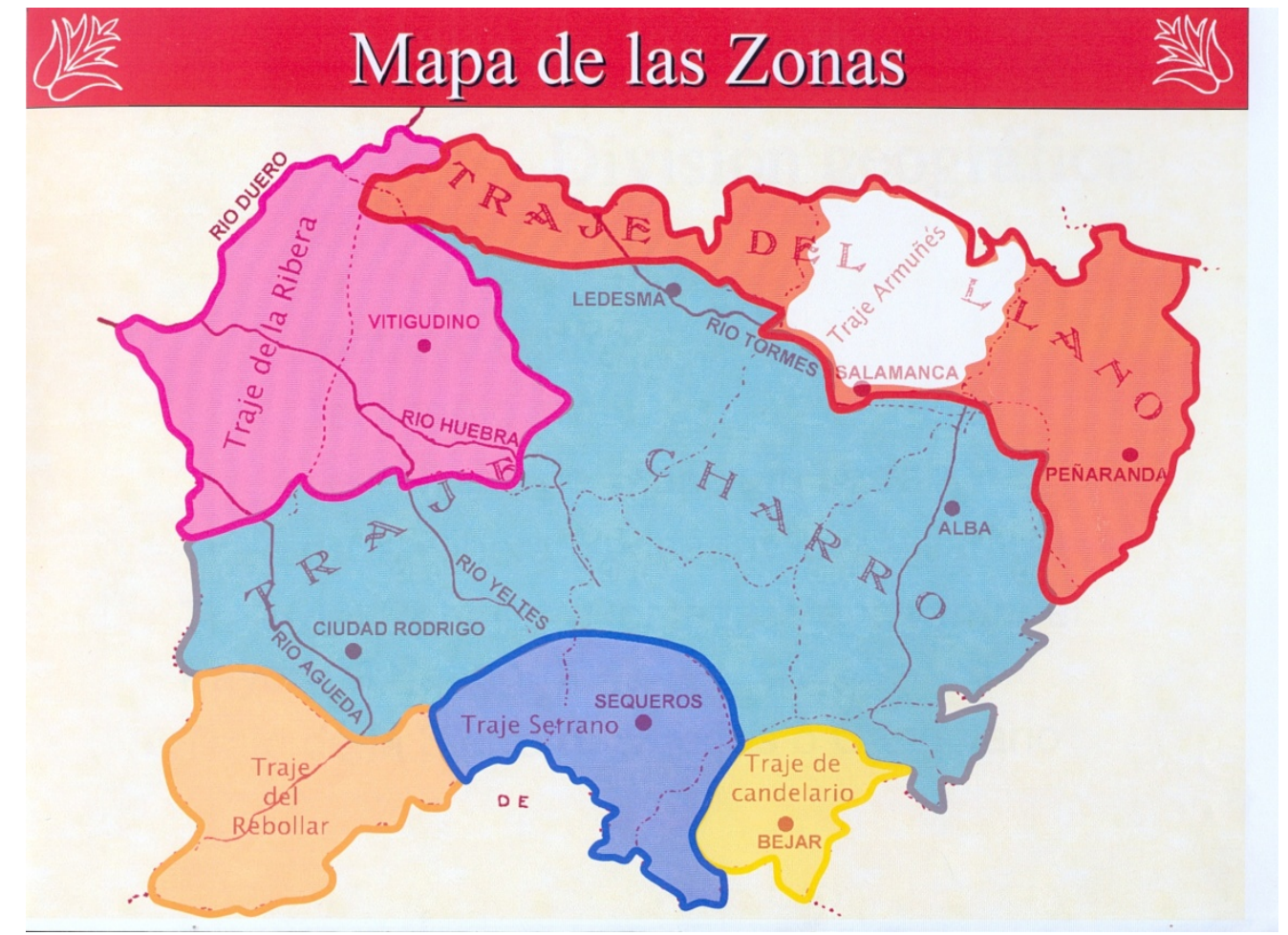

\footnotetext{
${ }^{81}$ Mapa realizado por Feli Cañada, no publicado.

82 HERNÁNDEZ MARCOS, L, Los charros, Etnografía Histórica e Identidad Cultural, Bubok Publishing, S.L., 2009.

83 HERRADÓN FIGUEROA, M L, Joyería Charra, Museo del Traje, Ministerio de Educación y Ciencia, Madrid, 2005.
} 
Esta división geográfica está realizada por nuestra fuente Feli Cañada ${ }^{84}$, que la ha confeccionado en función del conocimiento que ella tiene del traje tradicional salmantino.

A partir de esta división geográfica del traje pasaremos a analizar por zonas los mismos, considerándolos como el soporte natural de la joya.

Como consecuencia de la delimitación de espacios explicados en el cuadro anterior, nuestra fuente realiza esta división geográfica, en la que a cada espacio se le adjudica un tipo de traje. Basados en esta división, procederemos a la explicación de los objetos que estudiamos.

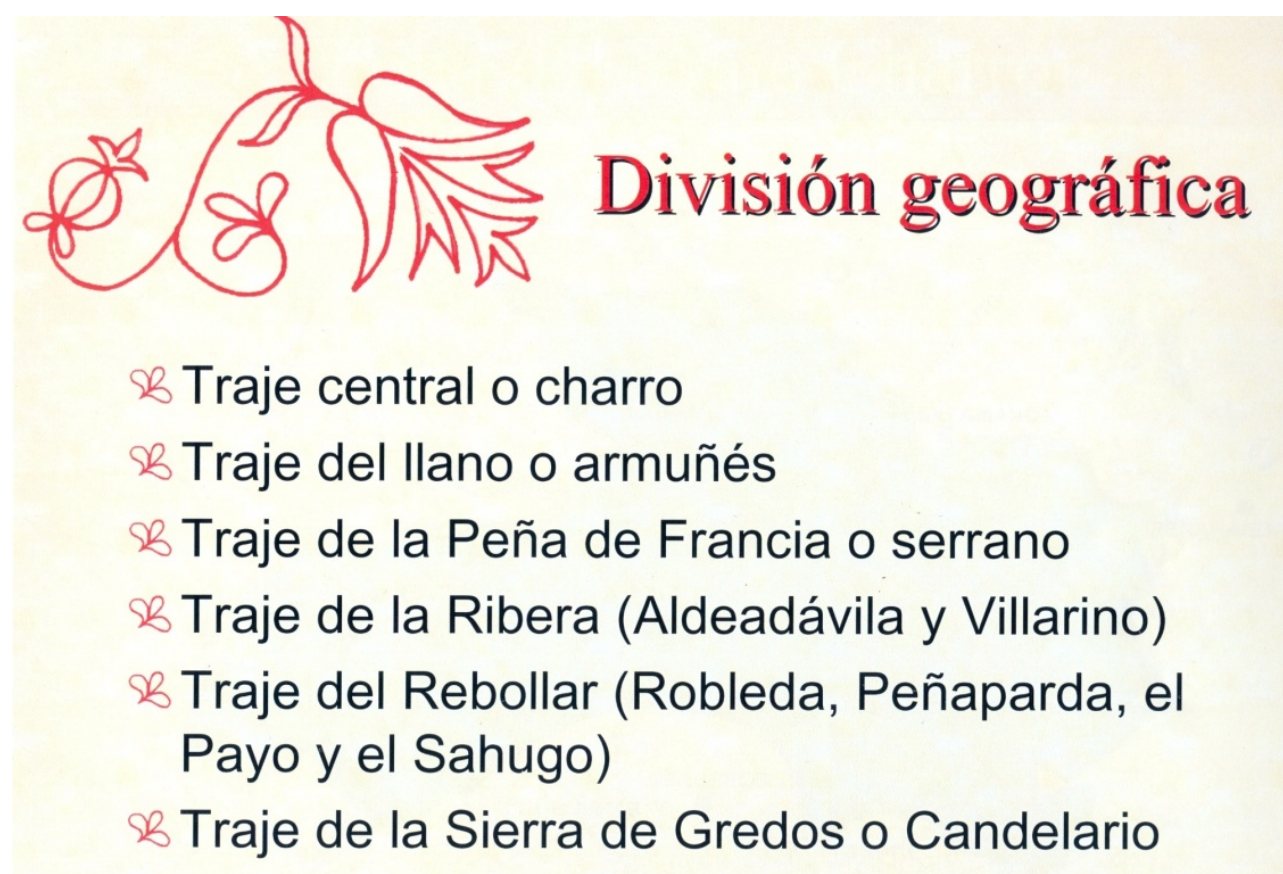

Esta división geográfica ${ }^{85}$ está realizada por nuestra fuente Feli Cañada, que la ha realizado en función del conocimiento que ella tiene del traje.

\footnotetext{
${ }^{84}$ Este mapa realizado por Feli Cañada se hizo para el audiovisual de indumentaria charra que se dio en la conferencia de la casa de la juventud en Salamanca.
} 


\subsection{Conversaciones ${ }^{86}$ con Feli Cañada}

\subsubsection{Preámbulos}

Ma Eugenia- Feli, ¿por qué es tan difícil el acceso a la artesanía, y en general el artesano, aquí en la zona de Salamanca?

Feli: yo he estado con diferentes artesanos desde hace bastantes años, y la conclusión que saco, es que el artesano se dedica en su taller a hacer artesanía. Hasta ahora la artesanía no ha estado ni bien reconocida ni bien pagada. Ha habido personas que han querido sacarles del anonimato, intentar que sus productos fueran más vendibles, pero el problema es que el artesano es una sola persona, y lo que tenemos es lo que sus manos y su mente pueden crear. También, quizás sea, que tienes un dinerito, lo metes ahí, lo guardas debajo de la cama con que tengas para subsistir y que tus hijos no pasen hambre ya se conforman, son muy conformistas y lo que está claro, es que le dices que pueden concebir ayudas de la Junta, de la Comunidad Europea, y al decirle Comunidad ya son palabras mayores. No se pueden permitir el perder el tiempo o dar un dinero a un gestor para que les lleve toda la documentación necesaria para acceder a todo eso.

M.E.- ¿No cree que eso pone en peligro real que desaparezcan determinados oficios?

F.- Yo ahora mismo creo que muchos oficios se han perdido porque ahora o te renuevas o te mueres. El producto de la artesanía estaba para ser usado; al usarlo se deterioraba o se rompía teniéndolo que reponer o volver a comprar. Un caso era la alfarería. Ha sido un oficio que ha habido alfareros por toda España, pero aquí el castilla el gremio es muy chico. Pero estaba claro que los productos al usarlos se rompen y había que reponerlos y se reponían en unas épocas del año. Yo recuerdo en casa que venían de un pueblecito de Badajoz y nos traían todos los años botijos de un barro

\footnotetext{
${ }^{85}$ Este mapa realizado por Feli Cañada se hizo para el audiovisual de indumentaria charra que se dio en la conferencia de la casa de la juventud en Salamanca.

${ }^{86}$ Estas conversaciones se realizaron en Salamanca con Feliz Cañada en el año 2010.
} 
estupendo y precioso. Aquello ya por mucho que queramos en ¿Cuántas casas hay un botijo? Puede haberlo pero no lo utilizamos y entonces no se rompe. ¿Qué ha pasado con la artesanía ésta? Pues que ha quedado de decoración. Esto es ampliable a todo el producto de la artesanía.

M.E.- Hay algún sitio, independiente de la Asociación del Traje Charro y de las clases que usted ha dado, que quede constancia y que en la actualidad se pueda saber cómo se ejecuta o cómo se ejecutaba el antiguo Traje Charro?

F- Yo llevo todos los años de mi vida haciendo esto, yo he enseñado a muchísimas personas, en la casa no sólo 1 sino 4,5 ó 6 trajes, y bueno, estas señoras a las que yo les he enseñado han reproducido los dibujos que yo les he puesto.

M.E.- ¿ha hecho escuela?

F- Yo creo que sí.

M.E.- Yo sé que el conocimiento que tiene del Traje Charro es enorme, pero el trabajo que a nosotros nos ocupa fundamentalmente, es el del aderezo del Traje Charro, el enriquecimiento externo, sobre todo el vinculado a la joyería para el Traje Charro. Hay dos tipos de adornos en el traje: unos que son los elementos intrínsecos al Traje que son los bordados y los encajes...y otros extrínsecos: es la joyería, tanto en hombre como en mujer, collares, botones, horquillas, pendientes, sortijas, hebillas, broches,...

F- Como elementos intrínsecos, el encaje y el bordado forman parte de la riqueza del traje. Los encajes eran de bolillos, suizos, hechos a mano, son muy antiguos, hay pocos, hoy en día muy difíciles de comprar por su elevadísimo precio. Para los bordados se utilizaban las agujas de coser y las agujas de gancho. Podemos considerar el bordado y el encaje, como la joyería de la tela. La joyería en metal (oro o plata) forma parte del traje que se utilizaba fundamentalmente para ocasiones como fiestas o bodas. A 
diario, la mujer utilizaba el pendiente de aro o arete, que se ponían desde niñas.

El Traje Charro podemos asegurar que estaba en familias pudientes, vienen de familias con dinero, de los terratenientes...El obrero asalariado no tenía para comprarse nada de eso, no digamos las joyas.

Es importante apuntar que mucha parte de la joyería tradicional nuestra, se perdió en la Guerra Civil, ya que muchas se dieron para fundir el oro y ayudar en la contienda, perdiéndose de esta manera un patrimonio imposible de recuperar hoy en día.

M.E.- ¿Cuándo utilizaban la mujer y hombre el Traje Charro?

F- La forma de vestir del hombre y de la mujer en la zona mía (Peñaranda), puedo decir, que aunque yo no conocí a mi abuelo, éste usaba el Traje Charro a diario, tanto es así que cuando murió le enterraron vestido de charro.

En el Traje de la mujer, las piezas son exactas en su composición. En cuanto a los adornos del traje, sí ha habido una evolución fuerte. Los más antiguos, no estaban adornados con tanto colorido como los de ahora. Antiguamente el traje de la mujer era negro, y como mucho los adornos, eran en azul oscuro y verde botella. Sin embargo, a los Trajes antiguos se les añadió posteriormente el colorido que nos ha llegado hasta ahora y que los hace tan preciosos.

A mí, por lo que me ha llegado, donde empezó a entrar el colorido fue en la zona de Macotera, porque allí hubo un convento de monjas, de no sé qué orden, que algunas de ellas habían estado en Roma y que supongo conectaron con el cristal de Murano y la porcelana; a su regreso debieron incorporar este tipo de abalorios a los Trajes. 
También he tenido la oportunidad de consultar algunas hijuelas ${ }^{87}$, que es donde plasmaban los padres lo que les dejaban en herencia a sus hijos y a sus hijas. Estas hijuelas estaban fundamentalmente en los domicilios particulares, metidas en unos tubos que no sé si eran de estaño o de plomo, junto con los documentos más importantes de la familia como escrituras, poderes notariales, deudas, papeles de compra, ... . Tuve la oportunidad de consultar en Babilafuente, con motivo de una exposición que se hizo sobre aperos de labranza, una hijuela que databa de 1810, que era muy curiosa; en ella, se detallaban los trajes Charros tanto de hombre como de mujer que había en la casa; de las piezas de los trajes se daba referencia de si estaban en buen o mal uso o si eran nuevos; numeraban, la cantidad de piezas que existían, el material del que estaban hechas tanto por el derecho como por el revés, así como los elementos de joyería pertenecientes a cada uno. Babilafuente tenía mucha importancia porque allí había una gran Botica donde surtían a todos los pueblos de alrededor, siendo esto una fuente de ingresos muy importante.

Todo ello me hace pensar que en 1800 se vestía con el Traje, $y$ asegurar que el traje, casi tal como lo conocemos ahora, es anterior a 1800.

En cuanto a la joyería, como ya hemos dicho, a diario se utilizaba el pendiente de arete y un hilo pequeño de "chocho de aceituna" o de "bola de gabanza" pequeña; el resto de piezas se usaba en las grandes ocasiones, al igual que el Traje. El botón más primitivo, creo que es el Turco, y el de Filigrana (anterior 1800), siendo el de talla con brillante o rubí, posterior. Muchos de ellos, trajes y joyas, se hacían nuevos para la boda, siendo habitual que el novio regalara a la novia, el mantón y el botón, que podía ser de talla o el de filigrana turco.

M.E.- Respecto al tema que nos ocupa y puesto que vamos a centrar nuestras conversaciones en los adornos externos (ya que hemos quedado en que los adornos intrínsecos al Traje, es decir que van sujetos al Traje de

\footnotetext{
${ }^{87}$ www.rae.es, Hijuela, 8.-Documento donde se reseñan los bienes que tocan en una partición a cada uno de los partícipes en el caudal que dejó el difunto. 9.- Conjunto de estos bienes.
} 
alguna manera como son: los bordados, los encajes, los dibujos los tocaremos colateralmente) vamos a centrarnos en los elementos externos: los aderezos para las mujeres y la botonadura para los hombres. Me gustaría que empezando desde la cabeza hasta el zapato, hiciéramos un repaso, de cuáles son los elementos decorativos que adornan el Traje Charro. Comprendo que hay mucha tipología, como usted ya tiene definido en su audiovisual ${ }^{88}$ del Traje Regional Salamantino que utilizó para la conferencia que dio y en el que divide la provincia de Salamanca en distintas áreas con trajes en cada una de ellas: El Traje Central o Charro, el Traje del Llano o Armuñés, el Traje de la Sierra de Francia o Serrano, el Traje de la Ribera (Aldeadávila y Villarino), El Traje del Rebollar ( Robleda, Peñaparda, El Payo y el Saúgo) y el Traje de la Sierra de Béjar o Candelario. ¿Cuáles son los elementos en adorno joyero que son comunes a todos los Trajes, si es que los hay?

F.- El elemento común son los dos tipos de bolas que llevan todos. Tenemos la bola de Gabanza ${ }^{89}$ que va de mayor o menor diámetro; solamente con medir la bola sabían los gramos que podían tener, y según los centímetros, se sabía la medida del collar porque la parte del cuello, bien sea para ahorrar bolas o para ser más cómodo, se utiliza la cinta. Estas bolas están en todos los Trajes. Depende en qué pueblos la llaman de una manera o de otra... Hay cantidad de palabras nombrándola que no están recogidas en ningún sitio. Está la bola de Gabanza, que es como un garbanzo, que se realiza en tres fases hecha con una placa de plata o de oro sobre la que se hace la Filigrana con unos dibujos utilizando uno o dos hilos finísimos de oro o plata (por lo que nosotros sabemos y cotejándolo con la información del joyero y artesano José Luis Nieves, tanto en la bola de Gabanza, como en el botón Turco ${ }^{90}$, en el botón de Piña o en el botón de Esmalte, siempre se hace la Filigrana con dos hilos redondos finísimos

\footnotetext{
${ }^{88}$ Audiovisual propiedad de Feliz Cañada, realizado por ella. Hemos tenido la oportunidad de verlo, pero no está publicado.

${ }^{89}$ Anexo DVD, carpeta 1 (Fotos del apartado dedicado a Feli Cañada, elaboración propia. Salamanca, 2011. Foto F-1.

${ }^{90}$ Anexo Cit, foto F-2.
} 
entrelazados para hacer las formas que adornan la chapa; a diferencia de la Filigrana calada donde se utilizan dos hilos finísimos pero planos, que van al aire sin chapa). Primero, se hace media bola y luego la otra media bola. Ambas se unen y posteriormente se pone una pequeña chapita a los lados que hace de fusel y que une las dos partes. Las hay de distintos diámetros, siendo las más grandes las que se encuentran en la zona de la Sierra. Fundamentalmente recogidas en el traje Albercano, aunque soy partidaria de no limitar a la Alberca el traje Serrano o de Vistas, puesto que estoy convencida que antiguamente se utilizaba en toda la zona de sierra, aunque en la actualidad prácticamente haya quedado reducido al espacio geográfico de la Alberca. Este tipo de bola de gran tamaño se la conoce con el nombre popular de "Abogalla"91 por su parecido al fruto del roble que se llama de la misma manera. La bola de chocho de aceituna ${ }^{92}$, que es como el hueso de la aceituna y que además está a la contra, va el buril metido y va haciendo como un cordón, pero no es un cordón puesto encima, sino que al trabajarla con el buril el cordón sale a la inversa.

No la he visto fuera de Salamanca, he visto algo parecido en las islas, en Tenerife, son más alargadas y bastante más grandes pero no se parecen a la nuestra.

M.E.- ¿Esa bola, con forma de abogalla, la ha visto en más Trajes de la zona o solamente en el Traje de Albercana o como usted dice de la zona de la Sierra?

F.- Ese tipo de bola solamente la llevan ahí, aparte de que ahora mismo, joyeros en Salamanca que trabajen como se hacía antiguamente son muy poquitos los que hay.

M.E.- Resumiendo, los elementos comunes que usted ha detectado en el Traje Charro son: la bola de Gabanza y la de Chocho de aceituna. Aparecen en todos los Trajes en unos sitios más que en otros. La de chocho de aceituna aparece mucho en la zona de las Arribes. Casi todas las familias

\footnotetext{
${ }^{91}$ Anexo, Cit, foto F- 3.

${ }^{92}$ Anexo, Cit, foto F-4.
} 
tenían ese collar. Y el de Gabanza está extendido por todas las zonas. ¿Tiene usted conciencia de cuando se incorpora la bola de Filigrana? ${ }^{93}$

F.- Son menos las bolas de Filigrana las que aparecen en el Traje. La bola de Filigrana se usa fundamentalmente para las horquillas apareciendo también en los gemelos de los hombres y en las puñetas de las mujeres.

M. E.- Para el aderezo de collar, entonces tenemos, la bola de Gabanza, la de chocho de aceituna y esa bola grande que llamamos de abogalla. Y la Filigrana se incorpora en las horquillas del pelo ${ }^{94}$ y botones. Hay otro tipo a parte de estos, que usted haya visto en nuestros Trajes?

F.- Personalmente no, sólo conozco esos. A lo mejor hay alguien que tiene algo diferente pero va a ser un poco difícil encontrar más.

M.-E.- ¿El diseño de la bola de Gabanza es el mismo para todas las zonas o hay diferentes diseños?

F.- Para la gente que es profana en esto, puede creer que es igual, pero cambia, porque al poner en la bola un cordón encima, no es lo mismo poner un cordón finísimo sobre la chapa que un cordón gordo. El efecto óptico no es el mismo. A veces hay que mirarla con lupa para saber que hay un cordón hecho con dos hilos de oro. Esto mismo le sucede también al botón Turco, no todos son iguales, muchas veces la diferencia viene de los hilos entrelazados que se usan para hacer las figuras.

M.E.- La bola de Filigrana hemos dicho que es fundamentalmente para el pelo. ¿No es así?

F.- Las bolas de Filigrana las tenemos en horquillas, horquillones y botones de puñetas de la mujer y también se encuentran en algunos botones que lleva el hombre en las bocamangas de la chaqueta. Es en los únicos sitios donde yo las he encontrado. En la actualidad la gente se las pone en

\footnotetext{
${ }^{93}$ Anexo, Cit, Foto F-5.

${ }^{94}$ Anexo Cit, FotoF- 6 y F- 6 bis.
} 
cualquier sitio, pero el uso tradicional las delimita a las zonas que le he comentado.

M.E.- Hay algún elemento que se utiliza para el pelo, por ejemplo para la zona centro de Salamanca, hay una rosetas, como unas castañas, que van en el pelo de las charras y ahí van puestos adornos tipo un poco como la Dama de Elche. Entonces, esas horquillas que llevan la bola de Filigrana, cuántas son, cómo se ponen...

F.- La charra, lleva tres moños en el pelo: dos van a los lados que se llaman rodetes y uno tercero alto, donde se ponen las cintas de "sígueme pollo"95, en el que se sujetaba el pañuelo que la charra se ponía sólo para entrar en misa ya que no se podía acceder a la iglesia si no se iba con la cabeza tapada con pañuelo o con velo ${ }^{96}$ y que se sujetaba al moño con dos horquillones $^{97}$ con bola de Filigrana para que el pañuelo no se cayera. Cuando la Charra salía de misa, se quitaba el pañuelo y se ponía los dos horquillones en el moño con las cintas anteriormente citadas. Como la charra se quitaba el pañuelo, los rodetes laterales iban todos adornados con horquillas con bolas de Filigrana cuajando todo el rodete. El pañuelo se quitaba para bailar por eso, se ponían tantas horquillas de Filigrana en los rodetes.

Actualmente, como el traje no se utiliza a diario y lo ponemos más como un teatro y además se tiene la idea de que el pañuelo (que hay gente que lo llama velo erróneamente porque hemos encontrado todo tipo de tejidos: sedas, encaje, tul, ...) si no lo lleva la Charra, no es Charra y sólo se adorna la mitad del rodete con horquillas de Filigrana.

Yo me he encontrado casas donde tenían hasta cuarenta horquillas. No se sabe si eran para distintas personas o se las ponía sólo una. He Ilegado a la conclusión de que más horquillas de unas 18 no entran en el rodete entero.

\footnotetext{
${ }^{95}$ Anexo Cit, Foto F-8.

${ }^{96}$ Anexo Cit, Foto F-9.

${ }^{97}$ Anexo Cit, FotoF- 6.
} 
M.E.- El Pañuelo de cabeza del Traje Charro Central, lleva sus rodetes con las horquillas puestas, ¿las horquillas matizan todo el rodete?

F.- Antiguamente sí, por la sencilla razón de que este pañuelo sólo era para misa y al salir se quitaba y se quedaba la mujer con los rodetes. No se sabe si cuanto más poder económico tenía la mujer más horquillas Ilevaba porque también tenemos algo muy claro, que los moños son obras de arte $y$ en sitios donde se diferencian mucho y son una maravilla es en la zona de Macotera. Tienen una coleta trenzada de cuatro ramales, que es tan bonito ver las horquillas como ver el moño. Entonces hay algunos sitios en el que ponían más y en otros sitios ponían menos, y también depende de las que tuviera... Normalmente se perdían mucho, porque la gente se ponía a bailar con el Traje y con el movimiento o se enganchaban con algo, y hay gente que ha perdido cantidad de ellas. La horquilla era antiguamente más pequeña que ahora. Es una bola de Filigrana hecha igual que los botones.

M.E. - El pañuelo de cabeza, ¿tiene alguna sujeción, alguna joya que se ponga para sujetarlo?

F.- Sí, hay dos. El pelo de la mujer, se divide con raya central, raya al medio, que ahora dicen que no favorece, pero yo siempre digo que el Traje favorece a las caras jóvenes. Se sujeta con dos horquillones también calados de Filigrana, bastante más grandes que las otras horquillas del rodete y algunos tenían una cadenita y venían adornados con algún cairel o con una bolita más pequeña...Los agujones $u$ horquillas se sujetan en un moño que lleva en la parte alta de la nuca simulando una pequeña peineta. El tipo de horquillas no es determinante, al igual que los collares. Depende de varias circunstancias:

a) del tipo de moño y su riqueza.

b) del gusto de la Charra 
c) de poder adquisitivo. Antiguamente, casi todas eran de plata o plata dorada. No he visto ninguna de oro; hay que pensar que tal vez era porque se perdían con mucha facilidad.

M.E. - El pañuelo de cabeza ¿lleva blonda o no lleva blonda?

F.- Hay alguno que lleva blonda entero. Hay unos encajes tan bonitos, son tantos los que hay, que hay unos que están hechos como la mantilla española. Ahora lo hemos introducido más; hay gente que dice que ahora lo hemos puesto porque se ha puesto de moda la mantilla, a raíz de la boda de las Infantas, pero no es verdad. Nuestro pañuelo es un cuadrado, lo único que al doblar los picos lo desmentimos, lo dejamos desmentido y parece que llevamos dos pañuelos en uno y con doble encaje. Los hay de seda natural, de batista y de tul.

M.E.- Para todos los Trajes Charros de Salamanca de todas las tipologías que hemos dicho, la sujeción del pañuelo de cabeza y los rodetes son los mismos. ¿Ha encontrado que haya habido diferencias en cuanto a los modelos de calado de unas zonas y otras o no?

F.- He encontrado unas horquillas que son similares pero se puede ver que el artesano no haya sido el mismo pero para eso tienes que precisar mucho.

M.E.- Podríamos resumir que tanto para los rodetes como para los tocados o como para los distintos tipos de peinado que se hacen en toda la zona de Salamanca son las horquillas de Filigrana de un tamaño u otro las que aderezan la cabeza de la mujer.

F.- Te digo otra cosa más que lleva que tampoco hay mucha gente que lo haya visto o lo haya vivido. La mujer cuando sale de la iglesia ya no lleva el pañuelo, pero sin embargo, de ese moño que lleva en la nuca que a veces parece una pequeña peineta que hace levantar el pañuelo, ahí lleva unas cintas colgadas, a veces de cuatro cintas, casi siempre; algunas de doble largura, otras se acortan haciendo un lazo y ahí van también 
horquillas. Hay gente que piensa que eso era para sujetar las cintas. Es un adorno más que si nos fijamos en las falleras valencianas ellas llevan peinetas y aquí son las cintas con las horquillas de Filigrana o Las Serranas con pequeñas palomas o pájaros también algunos gallos. Detalle en plata.

4.2.2. Peinado y joyas según la división de los trajes:

\section{a.Traje Central o Charro.}

Peinado: en el traje Central lleva raya al medio, dos rodetes (uno a cada lado de la cabeza tapando la oreja) con trenza calada y un moño alto que sale de la nuca hacia arriba, haciendo como una pequeña peineta.

Joyas:

1) Horquillas pequeñas de Filigrana calada que se ponen en cada rodete; si se adorna de forma completa el rodete entran alrededor de 14 agujas de Filigrana en plata. Dibujo ${ }^{98}$ :

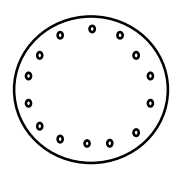

Antiguamente eran de plata, no se ha constatado ninguna de oro, aunque en la actualidad se ponen de plata dorada y adornan una trenza calada con la que se hace el rodete. En la actualidad como la Charra no se quita el pañuelo, con siete horquillas son suficientes, ya que son las que se ven, las cuales van adornando la mitad del rodete que queda libre. Dibujo ${ }^{99}$ :

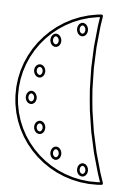

2) Horquillones $u$ agujones de Filigrana calada: son dos, sujetan el pañuelo al moño alto. Alguna vez cae de ellos una cadenita rematada en un cairel o una bola pequeña calada también.

\footnotetext{
${ }^{98}$ Dibujo elaboración propia, Fuente Feli Cañada.

${ }^{99}$ Dibujo elaboración propia, Fuente Feli Cañada.
} 
Cuando la Charra se quitaba el velo, estos horquillones se ponen en las cintas de "sígueme pollo", que van en el moño de atrás, después de lucirse por la parte delantera.

b. Traje llano o armuñés:

Peinado: La mujer del Llano o de la zona de la Armuña, va siempre tocada con pañuelo, la gorrilla encima y a veces también se pone la sobina. El peinado lo lleva raya al medio. La sobina sólo se pone para ir a misa, por lo tanto en la cabeza no hay ningún elemento joyero.

c.Traje de la Sierra de Francia o Serrano:

c.1.Traje de vistas

Peinado: Lleva raya al medio, va tapada y no lleva joyas en la cabeza.

\section{c.2. Traje de charra serrano}

Peinado: Lleva igual que el traje central, sólo varía que en el moño de la nuca se suele poner unas horquillas.

Joyas: Horquillas rematadas en palomas 0 gallos que son generalmente de plata tallada. Antiguamente todas eran de plata, ahora han introducido la plata dorada.

\section{c.3.Traje de zagalejo}

Peinado: moño en la nuca, rematado con bastantes horquillas. Se encuentran palomas o gallos los remates de las horquillas ${ }^{100}$.

Joyas: son las mismas que el traje Central o Charro. A parte llevan medallas hechas de Filigrana con imágenes esmaltadas de diferentes santos o vírgenes ${ }^{101}$.

c.4.Traje serrano propiamente dicho.

\footnotetext{
${ }^{100}$ Anexo, Cit, Fotos F-12 y F_13.

${ }^{101}$ Anexo, Cit, Foto F-14.
} 
Peinado: Raya al medio. Lleva pañuelo a la cabeza, por lo tanto no tiene ningún adorno joyero en la cabeza y otros llevan lo mismo que el de Zagalejo.

d. Traje de la ribera.

Peinado: Es el mismo que el traje Charro Central.

Joyas: Las mismas que el traje Charro Central.

e. Traje del rebollar.

Peinado: al llevar un pañuelo puesto, lo más seguro es que llevaran un moño.

Joyas: no lleva ninguna.

f.Traje de Candelario (Sierra de Béjar).

Peinado: El peinado es único y característico que se denomina "Moño de Picaporte". Por lo grande que es y la forma que tiene. Parece una gran aldaba. Es un moño alto y muy complicado de realizar.

Joyas: Lleva dos horquillones que se suelen poner en la parte de atrás del moño. Estos horquillones son de Filigrana calada al estilo de los que se encuentran habitualmente en el traje de Charra o Central.

4.2.3. Tipos de pendiente según la división del traje.

El pendiente es uno de los elementos que adornan la cara de la mujer. Como dice Feli Cañada, los trajes no son más o menos bonitos, sino que son las mujeres jóvenes quienes le dan una belleza especial al traje. El pendiente, nos explica que en la joyería tradicional salmantina lo podemos encontrar de dos tipos:

a) de talla ${ }^{102}$

b) de Filigrana ${ }^{103}$

${ }^{102}$ Anexo, Cit, Fotos F- 15 y F-16. 
Dependiendo del lugar y del traje en cuestión, encontramos uno u otro. En la actualidad, como muchos de los elementos que forman parte del atuendo joyero del traje tradicional, se encuentran en todas las partes de la provincia, hecho éste que antiguamente no sucedía.

M.E.- Otro elemento fundamental es el pendiente. Hay una parte importante de toxicidad en cuanto al tema del pendiente del Traje Charro. Yo querría que usted me definiera cuales son los pendientes que se utilizan atendiendo a la tipología de los Trajes como lo hemos hecho con los aderezos del pelo.

F.- Está clarísimo. Dependiendo del pendiente que llevaba la mujer se sabía la procedencia que tenía. La serranas, se sabía que eran serranas por los pendientes que llevaban. Sus pendientes son un arete ${ }^{104}$ más o menos trabajado de Filigrana, algunos de estos aretes llevan en el medio una especie de cuarto de luna que se mueve. Te guiabas por esos detalles para saber que era serrana. El arete es el pendiente más antiguo que ha habido. El arete o abridor sin nada, liso y pequeño se le ponía a las niñas recién nacidas. Estos pendientes se los ponían las parteras a las niñas. Son aros sin más. Siempre los llevaban puestos hasta tomar la comunión, momento en el que se sustituían por pendientes más trabajados y de mayor tamaño. Algunos se sustituían por unos pendientes algo mayores pero más ricos en Filigrana. El aljófar se le ponía a los pendientes de aquellas señoras con más poder adquisitivo.

M.E.- La areta o aro, tiene distintos tamaños. ¿Ha visto si hay algún modelo o tamaño que permanece en la zona de la sierra?

F.- Hay algunas aretas que terminan en la parte delantera con una bola pequeña de lo mismo que llevan los collares del cuello (bola de gavanza). Otras no llevan nada, van sujetas solamente y acaban ahí; y hay aretas de distintos tamaños y de distinta Filigrana dependiendo del joyero

\footnotetext{
${ }^{103}$ Anexo, Cit, Fotos F-17 y F-18.

${ }^{104}$ Anexo, Cit, Fotos F-19 y F-20.
} 
que las hiciera. En el Traje de la sierra de Francia o Serrano ahí hay cantidad de tipos de aretas.

M.E.- Yo he visto estos pendientes que usted me comenta, de un tamaño muy grande, enormes, ¿son nuestros?

F.- si si, yo he encontrado algunos en la Sierra que eran enormes; en la sierra todo era y es aparentar, "somos los más ricos... y lo que hay aquí no lo hay en ninguna otra parte."

M.E.- ¿Por qué esa ostentación tan grande en el Traje Serrano?

F.- Para ellos el oro era el no va más, incluso te lo dicen los mismos dentistas, se quitaban los dientes naturales para ponérselos de oro o se enfundaban los dientes con oro. Es increíble, en mi zona, Peñaranda, poca gente llevaba dientes de oro.

M.E.- Hay una diferencia enorme, no sabemos porqué entre unas zonas y otras. ¿no es así?

F.- La zona de la sierra era una zona un poco judía. Ahí siempre estaban trabajando, trabajadores de una tierra que no daba demasiado intentando sacar lo que fuese. Han aprovechado al máximo todos los recursos que había a su alrededor.

M.E.- ¿Usted tiene idea, si el tamaño de pendiente que se llevaba tenía relación con la clase económica o social de quien lo llevaba?

F.- Por supuesto. Normalmente la gente que no podía llevaba un arete con menos peso, pero todos eran de oro. También había plata, pero fue posterior. Para ellos era el oro el que adornaba los Trajes, tanto en hombres como en mujeres. Inclusive, ahora mismo se están haciendo, concretamente sé de una familia joyera que ha estado año y pico trabajando exclusivamente para una familia de la Alberca, y todo lo que les han hecho ha sido en oro y a mano.

a. Traje central o charro. 
M.E.- En el Traje Central o Charro, ¿qué tipo de pendientes ha visto?

F.- Muchos. Los que más se conocen y que la gente reconoce para esta zona es el de Almendra que no es el de Filigrana sino el de talla. El pendiente de talla lleva piedras preciosas y semipreciosas. Antiguamente metían el diamante rosa, otro que llamaban el diamante negro y en la actualidad meten desde circonitas hasta vidrio... Los antiguos también tenían semipreciosas. En el Traje Charro, el pendiente de Almendra es el que más se ve. Una charra Central nunca llevaba aretes, llevaba los de Almendra. Aunque en las herencias había joyas de todos los sitios. Muchas veces las mujeres de una zona se casaban con hombres de otra y esto es lo que ha hecho que hayamos encontrado elementos típicos de la sierra o de otras zonas, fuera de ellas.

b.Traje del llano o de la Armuña.

M.E.- En el Traje Armuñés ¿qué tipo de pendiente tenemos?

F.- Del Traje Armuñés, tenemos un montón de cosas afines con la Sierra. Hay unas cuantas cosas de León, de la zona Maragata, que las podemos ver en la Armuña. Yo tengo clarísimo que desde Galicia hasta Extremadura, tenemos un montón de piezas afines. Hay unas cuantas cosas de la zona de los maragatos que tienen que ver con nosotros y Zamora también.

M.E.- El pendiente Armuñés ¿cómo es?

F.- Tiene muchísimo de Almendra ${ }^{105}$, y luego hay unos que se llaman de Farol $^{106}$. Que tiene una especie de cuerpo Central y alrededor unos cuantos adornos pequeñitos que se mueven como si fueran farolillos, por eso lo llaman de farol. El pendiente de Farol es de Filigrana. El que haya diferentes tipos de pendientes de Farol, dependía del joyero que los hacía, si sacaba un modelo nuevo, la gente lo veía y de ahí dependía su venta. En el

\footnotetext{
${ }^{105}$ Anexo, Cit,Foto F-23.

${ }^{106}$ Anexo, Cit, Foto F-24.
} 
Museo Etnográfico de Zamora se encuentra alguno. En Salamanca no hay nada. Yo lo he visto en alguna propiedad privada de esta zona.

M.E.- ¿En el Traje Armuñés también hay pendiente de arete?

F.- Sí, también los hay pero muy sencillos. No tienen nada que ver con los Serranos. Ese pendiente se lo ponían cuando nacían y ya no se lo quitaban. Los aretes estaban en toda Salamanca, pero lo que es en el Traje sólo se ha quedado en el Serrano. Los pendientes de arete, tienen diferentes modelos.

M.E.- En el Armuñés, aparecen el aljófar y el coral. ¿Por dónde cree usted que vienen estos dos materiales de los cuales no disponemos en nuestra tierra?

F.- La certeza del origen yo la desconozco. Pero tengo mis teorías. Creo que la joyería tiene mucho que ver con el origen de los paños, ya que de donde se obtenían las piezas para confeccionarlos seguramente se obtenían alguno de los adornos que luego componían el traje. Si tenemos en cuenta que al mercado de Medina del Campo llegaban piezas de una parte importante de Europa, es de suponer que por esta vía entrasen en nuestra zona materiales y productos como pueden ser la perla o el coral. También pienso que otra vía viene por Portugal; hubo muchísimos portugués, inclusive sastres portugueses que vinieron a hacer los Trajes de hombre aquí a las fincas. Se estaban 2 ó 3 meses haciendo los trajes para la familia, no es de extrañar que elementos de ese país, a través de estos artesanos se hayan filtrado en nuestra zona.

M.E.- Según lo que apunta, podríamos decir, que en la zona de Salamanca hay tres líneas que confluyen y que influyen tanto en las características del traje como en la joyería que lo adorna. Una de ellas tendría dirección Sur-Norte y estaría vinculada al Camino de la Plata (Mapa $1)^{107}$, teniendo en cuenta que sobre este camino también se implementa una de las ramificaciones del Camino de Santiago. Otra que vendría de Europa

${ }^{107}$ Mapa 1, v. supra. 
y que confluiría en el Mercado de Medina del Campo por donde nos llegaban las telas, así como productos e ideas de Europa y que podemos considerar una ruta terrestre (Mapa 6). Eje Europeo (dirección: de Europa a Península Ibérica)

En esta dirección también se implantaría la ruta que procediendo de Europa llegaba a la Península Ibérica para hacer el Camino de Santiago en su rama francesa. Esta ruta de peregrinaje era portadora de nuevas ideas, costumbres de otros países...se convirtió en una puerta abierta a Europa por la que penetraban todo tipo de ideas y de influencias, que sin duda quedaban de una manera u otra en nuestro territorio. Si se le une que en esa área, próximo a nuestra zona de estudio, se ubicaba uno de los centros de mercado y trasacciones económicas más importantes del sur de Europa como era el mercado de Medina del Campo, pues podemos entender y explicarnos como algunas de nuestras piezas de joyería tienen mucho que ver con piezas de centro europa. Es una impresión que tenemos también sobre este eje es el lugar por el que entraban los pueblos nómadas cetro europeos, nos referimos al pueblo gitano que como se sabe ha estado y está repartido por Europa. Parte de estas joyas, tanto en su técnica como en sus formas en muchos casos nos recuerdan a las de este pueblo nómada en otras partes de Europa.

Y una tercera vía procedente de Portugal ${ }^{108}$ de donde obtendríamos la influencia de los artesanos filigranistas del Norte del Portugal que a su vez procedían de otras partes del mundo y que seguramente arribaron en este país a través del puerto de Oporto, y que daría origen a la instalación en el Norte de Portugal de los magníficos orfebres y joyeros que siempre ha tenido esta zona y que sigue teniendo en la actualidad. No es casualidad que los orfebres filigranistas que aún tenemos en Salamanca sean todos de origen portugués.

\footnotetext{
${ }^{108}$ Mapa 4, v. supra
} 
MAPA № 6:

Eje Europeo (dirección: de Europa a Península Ibérica)

Leyenda:

Eje Europeo

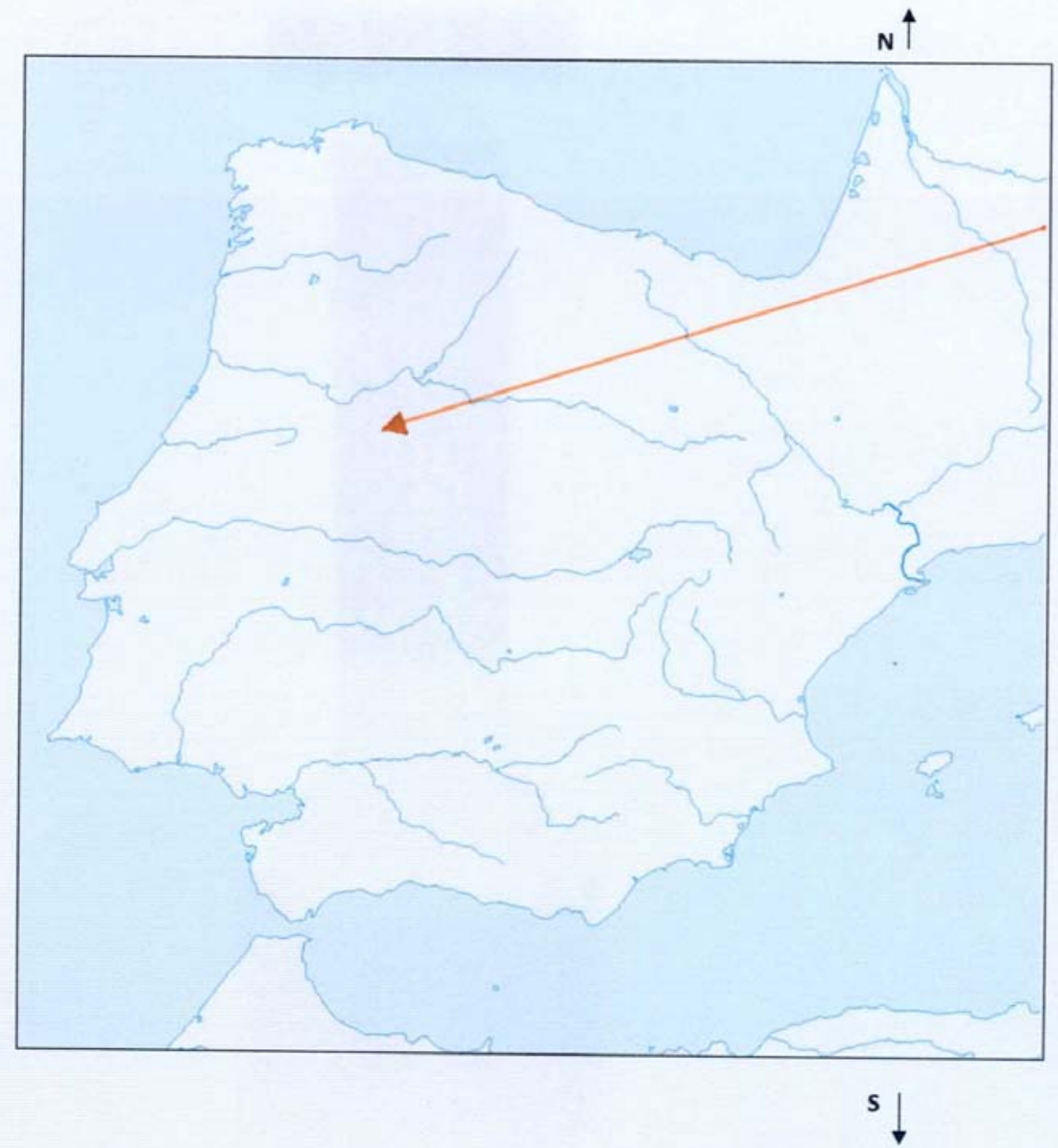

Elaboración propia

F.- Si yo hubiera tenido que explicarlo, no lo hubiera explicado mejor.

M.E.- Continuemos. Resumiendo en el pendiente Armuñés tenemos: el pendiente de Almendra de talla, el pendiente de Farol hecho en Filigrana, algunos de Aljófar, el de pera en Filigrana, ¿algo más?

F.- El Aljófar lo meten también mucho en el tipo de Almendra. Es decir, la talla nunca lleva aljófar pero a veces el joyero hace en Filigrana las 
formas del pendiente de Almendra y lo rellena de aljófar ${ }^{109}$. Es la misma forma de la Almendra pero cosido el aljófar dentro de la Filigrana. Por ejemplo, la roseta típica del pendiente de Almendra, suelen hacerla los joyeros en Filigrana y macizarla con aljófar.

M.E.-¿Hay algún tipo de elemento en el Traje Llano o Armuñés, aparte de la Almendra, el arete..?

F.- Puede que haya, pero el problema es que ese Traje se quedó como un uniforme pues la gente siempre lo repetía y se ponía lo mismo.

M.E.- ¿Ha visto si en algún momento determinado el Aljófar se ha incorporado a la horquilla del pelo?

F.- No, aljófar en las horquillas nunca he visto.

c. Traje de la sierra de Francia o serrano.

M.E.- El traje de la Sierra de Francia o Serrano que es el más conocido, ¿cómo es el pendiente de la zona de la Sierra de Francia? Y digo de la Sierra de Francia porque sé que usted considera que, tanto el traje como la joyería que se atribuye hoy en exclusiva a la Alberca (el de Vistas Albercano), antiguamente estaba repartido por toda la Sierra de Francia, aunque ahora haya quedado como patrimonio exclusivo de este pueblo, es por este motivo por el que yo me refiero fundamentalmente al traje de la Sierra de Francia.

F.- Por los entendidos se dice que es el más antiguo de Europa. El más rico por la joyería y aderezos que lleva. El Traje en sí mismo es muy simple y los paños que lleva son muy fuertes, son muy abatanados. Abatanado significa que es de pura lana, que se mojaba y se apaleaba para poderle dar una textura final impermeable a la nieve y al agua, muy parecido

${ }^{109}$ Anexo, Cit, Foto F-27. 
al paño de las casacas rusas. En los de la sierra te encuentras a diario con los aretes que es donde he visto los más grandes y con más Filigrana.

M.E.- ¿Cuántos tipos de Traje hay en la zona serrana?

F.- En la zona serrana está el Traje de Vistas (de boda) el Traje de Vistas de Viuda que es todo negro, el traje Serrano Charro, el Traje de Zagalejo y el traje de Serrano propiamente dicho.

Al que más importancia le estamos dando hoy es al traje de Vistas o Traje de boda. No sé por qué los demás pueblos no lo han reclamado también como suyo. Los había en Mogarraz, en Miranda...y en más sitios. Por eso a mí me gusta hablar de la Sierra de la Sierra de Francia. Ha sido gente de la Alberca los que han ido comprando todos los Trajes. Ese Traje lo había por toda la sierra y con la misma riqueza joyera. Los más antiguos llevan una pieza sobre los hombros que yo tengo la impresión que se usaba en toda la zona de la Sierra, aunque en la actualidad ha quedado solamente en el Traje de Candelario, me refiero al Serenero. El serenero, es una pieza de tela, que se ponía sobre los hombros de la mujer seguramente para evitar el frío, ese que todo el mundo entenderá cuando hablamos de dejar algo al sereno, es decir al frío de la caída del sol. Este serenero, yo lo he visto en algunos trajes de Mogarraz, aunque en la actualidad ha desaparecido del traje de la Sierra, quedando reducido al lugar que antes comentaba. Aunque estoy convencida que se usaba en toda la zona de la Sierra, tanto de la Sierra de Francia como la de Béjar. El Serenero, quedaba sujeto al Traje con unos cierres de oro tallado. El Traje de Vistas de la Sierra, es muy rico y se utilizaba fundamentalmente para las bodas, pero para mí el más impresionante es el que llevaban las mujeres viudas, que se caracteriza por un manto llamado de Ventioseno, que también se encuentra en las Arribes del Duero. En el cancionero es mencionado el Ventioseno, en la tonada del burro de Villarino: ..."todas las mujeres iban al entierro y la tía Joaquina con el ventioseno". Es un manto que pone desde arriba de la cabeza con una bola grande que case sobre la nariz y que llega por detrás hasta el manteo. 
Se caracteriza porque tiene diferentes terciopelos y dobleces. Este lo lleva la mujer serrana que va totalmente de negro, porque está de luto.

Además está el Traje Serrano Charro, que se diferencia muchísimo de los otros. Hay una variedad tremenda. Lleva el manteo de envuelta, los mandiles como las charras, los pañuelos como las charras. Los que más se conocen son las sayas plisadas y pintadas, que son las serranas auténticas las que terminaron vistiendo con ellas. Son sayas muy plisadas con muy poca cintura, con delantales enormes y bordados muy bonitos.

En la sierra, el traje de Vistas, lleva un pendiente de Filigrana muchas veces con aljófar y de tipo de farol.

M.E.- Los pendientes para estos cuatro tipos de Traje de la zona de la Sierra ¿siempre son los mismos?

F.- Yo a diario siempre las veo con las aretas. Cuando luego van vestidas con los trajes tradicionales te encuentras con un montón de pendientes diferentes.

M.E.-¿ El Traje de Vistas tiene algún otro tipo de pendiente?

F.- Yo siempre lo he visto así, pero lo mismo si buscamos encontramos alguna familia que tenga otro tipo de pendiente, pero hay que estar con la familia que lo tenga, porque de no ser el día del Corpus, que es cuando hacen esa exhibición tan enorme allí en la Plaza, no se puede encontrar apenas nada. Es muy difícil acceder a esta gente. Lo que tienen antiguo, prácticamente no lo sacan, lo que vemos son las reproducciones porque lo antiguo lo tienen en cajas fuertes y no te lo dejan. Las fotografías que yo he podido consultar de esa época y que están en Nueva York ${ }^{110}$, se pudieron consultar y fotografiar porque pensaban que lo que tenían no podía interesarle a nadie. Ahora, hay veces que si pretendes fotografiarlas se levantan el mantelo y te dicen que están hartos de fotos, son muy particulares.

${ }^{110}$ The Hispanic Society of America. 
d. Traje de la Ribera.

M.E.- Del Traje de la Ribera, de Aldeadávila y Villarino, ¿qué nos puede decir de los pendientes?

F.- En esa zona la mayor parte de ellas los llevan de Almendra, en sus distintas modalidades. Tienes el de almendra, y luego hay otro que no es de Filigrana, con otro motivo con 4 o 5 caireles, parecido al de farol. Estos también los he encontrado en la zona Central. El de gajos de Almendra también está en esta zona lo mismo que en la zona Centro. La roseta de talla ${ }^{111}$ también se ve.

M.E.- ¿Hay algún elemento diferenciador del Traje de la Ribera respecto a los otros en joyería?

F.- Es donde más bolas he visto yo de chocho de aceituna. Y también te encuentras ahí con bastantes crucifijos, cruces huecas ${ }^{112}$.

e.Traje del Rebollar.

M.E.- En cuanto a la zona del Rebollar, que encuadra, Robleda, Sierraparda, el Payo y Saúgo... ¿Cómo es el pendiente?

F.- Son aretes también, parecidos a la zona de la sierra. Son muy sobrios. No son de Filigrana. Es una areta muy sencilla. Algunos son el aro totalmente o sólo con un redondelito pequeño.

M.E.-¿Los cierres?

F.- Casi todos son de enganche. La zona del Traje del Rebollar es un arete muy sencillo, muy sobrio.

${ }^{111}$ Anexo, Cit, Foto F-28. 


\section{f.Traje de Candelario.}

M.E- ¿cómo es el pendiente de esa zona?

F. Los pendientes ahí son más parecidos a los pendientes de almendra, muy sobrios. Siempre son pendientes largos con movimiento. Hace más atractiva a la mujer cuando baila. Una manera de llamar la atención junto con las cintas del "sígueme pollo". Hay una canción que dice: "te voy a comprar unos pendientes, no marido no, tómalo para aguardiente". Para que se vea la subrogación de la mujer al hombre.

M.E.- Concluyendo ¿cuál es pendiente más espectacular y más ostentoso que ha visto?

F.- Sin duda el pendiente más espectacular, el más ostentoso, es el Serrano y los grandes aretes de esa zona ${ }^{113}$.

M.E.- Lo que nosotros conocemos en la actualidad como Botón Charro, ¿se lo ha encontrado vinculado al Traje como pendiente?

F.- Nunca. Eso ha sido una variedad comercial del Siglo XX. Nunca ha estado un Botón Charro (lo que se conoce vulgarmente como Botón Charro) como pendiente en la mujer. En el Traje únicamente iba como botones en las puñetas ${ }^{114}$. Nunca en pendientes, ni en pulseras, entre otras cosas porque la charra no lleva pulseras.

M.E.- ¿Usted se ha encontrado pulseras en los Trajes nuestros?

F.- Nunca.

M.E.- ¿Por qué cree que no había pulsera?

F.- Sencillamente porque iban tan tapadas que lo único que hacía una pulsera era molestarle. La pulsera como adorno era sustituida por la puntilla en el Traje, a estas puntillas se les llama puñetas que eran de encaje de

\footnotetext{
${ }^{113}$ Anexo, Cit, Foto F-30.

114 Sin embargo el botón charro, forma parte ancestral de nuestra joyería pero su descontextualización le dio una visibilidad hasta entonces no valorada.
} 
bolillos, muy finas y muy costosas de hacer, tanto por la destreza como por el tiempo. Tampoco he encontrado nunca brazaletes.

M.E.-¿ Hay alguna prenda tipo abanico en el Traje típico?

F.- Si. Lo que he encontrado son reproducciones de Microfusión ${ }^{115}$. Son unas peinas pequeñas, aproximadamente su anchura no sobrepasa más de 4 centímetros, es parecido a un abanico abierto. No sé porque todavía no he encontrado ninguna antigua, ni nadie que me pueda decir que eso era totalmente nuestro. Me parece más bien que ha venido de la parte de Valencia ya que ellas llevan bastantes peinas en el moño. Lo que sí puedo decirles es que la Charra no lleva abanico. Las fotografías que vemos del siglo XX de las Charras con abanico, estoy convencida de que era un aderezo que el fotógrafo ponía de manera aleatoria, como el palo en el hombre.

M.E.- ¿En la actualidad quienes lo llevan?

F.- Es en la Sierra donde va en el moño que lleva la serrana. La serrana no lleva rodetes, lleva un moño un poco bajo con un peinado muy bonito, para adornarlo se ponen estas peinas en forma de pajaritas pequeñas con las alas abiertas y unos gallos. No puedo decir, porque no lo sé, si antiguamente eso estaba en la provincia de Salamanca. Es verdad que el gallo es muy portugués.

4.2.4. Tipología de la espetera según la división de los trajes. Tipos de bolas.

M.E.- Vamos a hablar de los elementos que adornan el pecho, el busto de la mujer Primero hablamos de lo general para todos y luego vamos Traje por Traje.

\footnotetext{
${ }^{115}$ Tenemos que apuntar que en el taller de José Luis Nieves (filigranista) la pieza del abanico de filigrana, nosotros la vimos y son de extremada belleza. La forma de esta pieza la heredó del taller de su padre "libro de humos", Anexo, DVD, carpeta 3, fotos N-127 a N-152.
} 
F.- No es lo mismo el Traje de espigadora Armuñesa, que como su nombre indica se utilizaba para ir al campo a espigar y que evidentemente no lleva ninguna joya, o como mucho, lo que si llevaba era un hilo de oro de bolas de Gabanza al cuello, que la espetera de una Charra Central el día de fiesta.

Tipos de bolas.

F.- Antes de hablar de los tipos de bola creo que es necesario dejar claro un concepto que nosotros utilizamos muy a menudo. Me refiero al "hilo de bolas". Este hilo es lo que la gente confunde con el collar, el collar es el resultado de la utilización del hilo de bolas, tanto es así, que yo he encontrado en algunas familias hilos de bolas de los cuales luego salían los collares. Así podemos decir que el hilo de bolas es un elemento o cuerda que va metida dentro de la bola, es un hilo de estopa o de algodón,( no fibra plástica como ahora), algunos de ellos para fortalecerlo se daba con pez, y eso es lo que va pasando por cada bola para terminar su final con cintas de distintos colores que era lo que se ataba al cuello. Por el color de la cinta conocían de quién era cada collar. Algunos los tenían marcados al final de las cintas con lacre, era para distinguir la familia de la que procedían. En la actualidad van todos del mismo color y nos podemos encontrar algunos engarzados en cadena de oro.

Las cintas de los collares van atadas al cuello, excepto en el Traje de Vistas, que debido al peso de toda la espetera van sujetas al jubón o jubona.

Bola de Chocho de aceituna ${ }^{116}$

M.E.- Vamos a empezar por el collar en términos generales. De los hilos de bolas ¿cuántos tipos de bolas usted ha encontrado a lo largo de todos estos años?

F.- El primero que se conoce como más antiguo es el de "chocho de aceituna", recibe este nombre por la forma fusiforme muy parecida al hueso

${ }^{116}$ Anexo, Cit, Foto F-4. 
de una aceituna. Normalmente muchos de ellos eran de oro bajo, eran huecas, se estropeaban rápidamente. Yo he visto en muchísimas casas que se los dejaban a los niños para jugar, y éstos los mordían y los mellaban. Estas bolas donde más las he encontrado ha sido en la zona de las Arribes del Duero. No son lisas, tienen un dibujo en forma de espiral hechas a buril. Esta bola de chocho, la podemos encontrar de distintos tamaños, desde pequeñas que habitualmente se llevaban y no se quitaban para nada, hasta hilos con bolas de tamaño mucho mayor, como podemos apreciar en las fotos del fondo fotográfico de Nueva York y, se la ponía la mujer en días festivos. Las bolas de chocho de aceituna ahora no se encuentran con facilidad, seguramente porque eran más difíciles de hacer y porque al ser más blandas se han perdido muchas porque se han estropeado.

M.E.- ¿En qué partes se encontraba la bola de chocho de aceituna?

F.- El chocho de aceituna se encontraba en la zona limítrofe con Zamora, en la zona de las Arribes. Pero eso no quiere decir nada, porque yo por ejemplo pertenezco a la zona de Sierraranda y en casa de mis abuelos había este tipo de collares. Quizá estuvieran repartidos por toda Salamanca. En otros trajes fuera de Salamanca no he encontrado este tipo de bola, solamente es en las zonas limítrofes donde queda algo parecido, que es las zonas de Zamora y de León.

La bola de chocho de aceituna prácticamente ha desaparecido y como no se puede hacer por Microfusión y tienen que ser hechas a mano y de oro, pues evidentemente salen muy caras y con el poder adquisitivo que tenemos se encargan muy pocas. Esta bola, yo no la he visto nunca hecha en plata, antiguamente sólo las hacían en oro. Si en la actualidad hay alguna de plata, es muy reciente.

\section{Bola de Gabanza ${ }^{117}$}

Luego está el de Gabanza, de distintos tamaños. Yo creo que se llama de Gabanza porque nos recuerda mucho a los garbanzos. Esta bola

${ }^{117}$ Anexo, Cit, Foto F-1. 
se realiza de dos partes. Primero una mitad y luego otra. Yo las he visto de muchos tamaños, desde unas pequeñitas de menos de tres milímetros, hasta bolas enormes de más de dos centímetros que se llaman de abogalla. Se llaman así, por la similitud que tiene con el fruto del roble, árbol este muy propagado en varias zonas de Salamanca. La bola de gavanza la he encontrado en todas las zonas de Salamanca, me da lo mismo al Norte que al Sur que al este que al Oeste. En todas las comarcas y en todos los tipos de trajes está esta bola.

M.E.- ¿Cuáles son los tamaños de la bola de Gabanza?

F.- Los tamaños más grandes, que para mí no son los más bonitos, se encuentran en la Sierra, en el de Vistas, son inmensos, para dar la sensación de que eran los más ricos. Eran capaces de dar sopas de gato a sus hijos y tener una fortuna en oro. He visto algunas bolas tan sumamente minúsculas que el joyero tendría que tener una precisión a la hora de realizarlas porque en tan poco espacio ponían el hilo de oro para adornarla. Los tamaños los tenemos desde menos de tres milímetros, que ya hemos hablado de ellas. Para saber el calibre de la bola de Gabanza el joyero la mide teniendo en cuenta la terminación de la bola. La más habitual es la de once o doce milímetros, siendo las más grandes las de abogalla que pueden superar los veinte milímetros.

M.E.- ¿Cuál es el dibujo de la bola de Gabanza?

F.- La bola de Gabanza puede llevar un hilo sobrepuesto encima de la chapa haciendo círculos o un par de hilos trenzados haciendo un cordón que se superpone sobre la chapa de la bola.

\section{Bola de Filigrana}

F.- La Filigrana le da un concepto simétrico a todo, igual es un lado que otro. Es curioso cómo en el traje también, todos los adornos y bordados son simétricos, generalmente una mitad es idéntica a la otra. Yo creo que la simetría tanto en la joyería como en el bordado es la característica por 
excelencia a destacar. Hay otra bola que es la de Filigrana, esta bola es totalmente calada, la he visto también de diferentes tamaños. Esta bola habitualmente no se encuentra en la espetera de la mujer, sí en los gemelos de las puñetas y por supuesto en los aderezos de la cabeza (horquillones y horquillas $\left.{ }^{118}\right)$. Este tipo de bola aparece también indistintamente en todas las comarcas de Salamanca. Yo creo que algunos de los collares que hay de Filigrana, su origen eran bolas de rosario, que ante la falta de otras joyas se las ponían en el cuello.

Tradicionalmente esta bola, así como las demás no se ha visto nunca en pendientes.

Puedo decir que la bola se ha podido utilizar como medio de pago. Había familias que para pagar los servicios requeridos por profesionales (médicos, abogados, etc...) utilizaban las bolas de oro para saldar las deudas.

\section{a. Traje central o charro.}

M. E.- ¿Cuántos collares suele llevar la charra en el Traje Central Charro?

F.- El Traje de la charra, "siempre siempre", llevaba el busto completamente lleno. Hay un dicho muy bonito, que es encantador en este sentido que es: "A la buena charra se la conoce por la poca cintura, mucha cadera y más espetera". La espetera era donde llevaba todas las joyas habidas y por haber. Era la representación estética del poder económico de la familia. Ahora mismo eso ya no sucede. Desgraciadamente ha habido muchas familias, que se han desprendido de esta joyería tradicional y si no que se lo digan a los anticuarios, que les han llevado cantidad de piezas a vender, porque este tipo de joyería hubo un tiempo en el que cayó en desuso y ponérselo se asociaba a la "no modernidad". La mujer prefería incluso ponerse bisutería que estas piezas antiguas, para mi preciosas. Ha habido una época que cuando veías a una persona con una sortija charra

\footnotetext{
${ }^{118}$ Anexo, Cit, Foto F-6.
} 
decías: "mira que paleta". Si analizamos un poco las fotografías que nos han quedado como reflejo del uso tanto del traje como de la joyería tradicional, podemos observar, como la espetera de la charra era de una riqueza similar a la de la Dama de Elche, sobre todo en los rodetes. Hay un importante fondo fotográfico en manos de la familia Gombau, quien fotografió a muchas charras y charros en todos los eventos que hubo en su época de fotógrafo salamantino. La Charra lleva collares desde lo más alto del cuello hasta la cintura, no como en el Traje de Vistas de la Alberca, que las lleva hasta el final del mandil ${ }^{119}$.

M.E.- ¿Cuántos pueden ir en el Traje Charro?

F.- Tenemos los siete del cuello y podemos meter otros siete hasta la cintura. Las cintas que van al cuello de los collares se esconden debajo de la jubona. Hay veces que atan las cintas con imperdibles, no sólo no es ortodoxo sino que además es horrible. En la parte de atrás del cuello no va ninguna bola, van desde los hombros para abajo.

M.E.- ¿Usted tiene la teoría de que no todas las familias tenían collares?

F.- Yo lo tengo muy claro. Igual que existía el reparto de las tierras y que grandes latifundios se quedaron en minifundios, porque había muchísimos hijos y tenían que repartir, a los collares les ha pasado exactamente lo mismo. Puedo asegurarles, que no ha sido en ni una ni dos familias, dónde de los pendientes de Almendra se han hecho cuatro sortijas, dos de la roseta de arriba y dos de la Almendra. Seguramente ese es el origen de que en la sortija hayan aparecido la roseta y la almendra.

También podemos decir, que la espetera del Traje de Charra, se repartía entre los herederos, icómo no se van a repartir las joyas si se repartían las piezas del traje! No obstante, cuando había eventos importantes, se pedían las joyas entre los miembros de la familia, para mostrar a la sociedad que se seguía teniendo el mismo poder económico.

${ }^{119}$ Anexo, Cit, F-31. 
Así pasó cuando vino el abuelo del Rey, Alfonso XII, cuando estuvo en Salamanca, que de la parte de Ciudad Rodrigo vinieron aproximadamente unas cuarenta mujeres y hombres vestidos con el Traje Charro que era una auténtica maravilla verlos. Allí estaba D. Dámaso Ledesma que era un sacerdote que se preocupó mucho por el folklore de Salamanca, no tanto en vestimenta como en el cancionero. Y de esa ocasión hay unas fotos que son una maravilla como van las mujeres.

M.E. -¿Qué quiere decir que puedan llevar más o menos espetera?

F.- Pues hombre, la verdad es que si lleva una pechera llena de joyas, y están bien colocadas el impacto es espectacular, en lo primero que te fijas es en su cara y luego la riqueza de la espetera, y más abajo en la belleza del mandil. El mandil es una pieza clave del Traje. La hoja de Hiedra, que tiene forma de corazón y que yo la he visto en estelas funerarias, forma parte del bordado del Traje. Esta forma ha pasado también a la joyería, apareciendo un corazón, que es entre corazón y hoja, que popularmente se le llama Corazón de la novia, porque era el regalo que el novio le hacía a la novia antes de casarse ${ }^{120}$. El patrimonio de los Trajes, e incluso de la joyería, donde más se ha mantenido ha sido en la sierra, y yo estoy segura que esto ha sido porque las casas no se han demolido.

M.E. - En el Traje Central o Charro, además de esa gran cantidad de collares que vemos tanto con bola de Gabanza, como con bola de Chocho o de Filigrana, ¿qué otros elementos hay. Por ejemplo, la Venera, el Galápago, la cruz...

F.- Lo primero que llama la atención en la mujer charra, son los hilos de bolas que lleva ajustados en el cuello, que pueden ser seis, siete u ocho hilos. Estos hilos, pueden ser de bola de Gabanza o bola de Chocho de aceituna, aunque en el Central Charro son de Gabanza. Este hacinamiento de collares en el cuello, nos recuerda mucho a los cuellos repletos de aros de algunas tribus del Norte de África. En el último hilo de bolas, el más

${ }^{120}$ Anexo, Cit, Foto F-32. 
próximo a la nuez, pende el Corazón de la Novia. Estos corazones los hemos encontrado de chapa huecos, adornados con los hilos o cordones haciendo círculos como los botones turcos. Otros, la mayor parte de ellos, son de Filigrana hueca, siempre rematados con un cordón que sobresale bastante. Dice la tradición, que este corazón, solía regalarlo el novio a la novia antes de la boda. Para terminar, los encontramos de distintos tamaños, algunos son aproximadamente de 2 ó $3 \mathrm{~cm}$ hasta 5 ó 6 centímetros. En cuanto al origen pienso, que puede ser de influencia portuguesa, ya que como los "oreros" portugueses trabajan mucho la Filigrana y ellos han tenido mucha influencia en la Filigrana española, es posible que este elemento se haya filtrado por la frontera portuguesa.

M.E. - Debajo del Corazón, ¿qué suele llevar la espetera?

F.- Terminados los collares del cuello la Charra, suele llevar otro hilo del que en la parte central, pende una cruz. Esta cruz, suele ser más bien pequeña y de distintos modelos. A veces es sustituida por el tercer cuerpo de una Venera, que se pone de forma romboidal. Es de Filigrana o de talla.

M.E. - ¿Cuál es la siguiente pieza que lleva la espetera?

F.- Lleva un hilo doble; consta de dos hilos que antes de llegar al cuello, termina siendo un hilo. El efecto que hace sobre el pecho de la mujer, es de dos collares, pero a la hora de sujetarlo al cuello, lleva una sola cinta. Este collar, es el que ocupa la zona central y de él se cuelgan distintos elementos:

\section{-Las Cruces:}

F.- Se llevan muchísimas cruces. La cruz que se pone en la espetera de la Charra es de muchos tipos. Tenemos, desde la Cruz de Santiago (que es muy probable que viniese debido al paso del Camino de Santiago por Salamanca), cruces del Sur que es casi seguro que vinieran por la trashumancia, muchas cruces que se ponen en la espetera que provienen de los rosarios. Hay cruces latinas, griegas, con piedras, sin piedras, con Cristo 
y sin Cristo, lisas, de Filigrana, ricas y menos ricas. El cuerpo fundamental de la cruz puede ser en palo o cruz, embutido, liso o apanalado. El apanalado consta de cuatro partes o lados. Hay cruces impresionantes, ya que antiguamente el regalo más preciado que te podían hacer era un rosario y la cruz en el rosario, es la parte más valiosa. Yo he visto colgados en las espeteras charras crucifijos que incluso llevan el INRI, que se ponían fundamentalmente a los crucifijos de los rosarios, modelos inalterados que lo único que han hecho es pasar del rosario al collar (seguramente por herencias o por rotura de los propios rosarios por el uso). En el siglo XX los plateros ofrecen alternativas nuevas que nos pueden llegar a confundir.

Ha habido rosarios de muchísimo valor, cuyas cruces que eran muy buenas han acabado en los bustos de las mujeres charras. Rosarios de Filigrana, de capa hueca, cruz con el Cristo.

Hay cruces que en la roseta interior van esmaltadas en blanco y en azul cobalto. Últimamente se ha metido el esmalte, también, no sé en qué año, pero es moderno. El diamante y el brillante, también se encuentran, así como algunas piedras preciosas se encuentran en cruces más antiguas.

-Las Veneras:

F.- La Venera es una pieza que lleva tres partes de las que luego hablaremos. Podemos encontrar una cuantas diferentes. Una misma persona, a lo mejor llevaba 3 Veneras diferentes en el mismo Traje. La Venera es una pieza que en el caso de la Espetera Charra, fija la atención de la mirada porque queda justo en el medio del pecho.

La Venera consta de tres partes:

- La parte superior, suele llevar habitualmente un lazo o media luna, de distintas formas, pero siempre simulando estas formas.

- La parte central, viene a recordarnos una forma almendrada. 
- La parte inferior, viene a ser como una especie de rombo que pende de la anterior.

Las Veneras, pueden ser: talladas y de Filigrana. La Venera tallada, lleva piedras preciosas o semipreciosas. Yo he visto "entoñadas" (que es como se dice vulgarmente refiriéndose a piedras embutidas o engastadas), diamantes (hay un tipo de diamantes que el pueblo tradicionalmente los llama rosas, que tienen un valor relativo y también, otro tipo de diamantes más oscuros que se llaman diamantes negros, menos pulidos pero que también se han utilizado para ponerlos en las Veneras y en los pendientes y sortijas de almendra, como ya hemos dicho), brillantes e incluso granates $y$ esmeraldas. Dependiendo del tipo de piedra que adorna la Venera, el valor económico de la misma varía sustancialmente. Yo creo, que las que tienen esmeraldas y brillantes son del Siglo XVII y las de diamantes yo creo que son más antiguas ${ }^{121}$. La Venera de Filigrana se caracteriza fundamentalmente porque suele complementarse su trabajo minucioso con la incorporación en algunas de ellas del aljófar ${ }^{122}$, haciendo de ellas, verdaderas obras de arte en miniatura. También las hay sin aljófar, no restando este hecho valor y belleza a la pieza. Desde mi punto de vista, el aljófar vino del señorío, es decir, de las clases sociales más altas, no del pueblo llano, aunque luego éste lo ha incorporado como adorno al Traje. Es más, la pieza que tenemos de Filigrana de aljófar en la Venera, yo creo que es posterior a la que va con los brillantes, diamantes o esmeraldas.

M.E.- ¿Cómo se sujeta la Venera al collar de bolas?

F. - La parte superior de la pieza, lleva dos barras bastante fuertes ${ }^{123}$ de oro, en la parte de atrás, que es por donde metemos el hilo, donde luego se engarzan las bolas. De esta manera, la Venera queda sujeta siempre al collar.

M.E.- ¿Alguna vez la Venera se pone sólo con cinta?

\footnotetext{
${ }^{121}$ Anexo, Cit, FotoF- 33.

${ }^{122}$ Anexo, Cit, foto F- 34.

${ }^{123}$ Anexo, Cit, Foto F- 35.
} 
F.- En el Traje nunca, lo que pasa que si la quieres tener para ponértela con un Traje de fiesta, pues sí.

M.E.- ¿cuál es la siguiente pieza que adorna la espetera charra?

F.- Para terminar, la charra utiliza un último collar de grandes dimensiones que le llega casi a la cintura. Este collar pone de manifiesto el aumento del tamaño de la bola desde el cuello a la cintura. Si en los primeros hilos del cuello, el calibre de la bola es de $30 \mathrm{~mm}$ aproximadamente, la bola en función de la posición que ocupa en la espetera, va aumentando de calibre. Así, el calibre de la bola de donde cuelga la Venera puede ser de $1 \mathrm{~cm}$ para pasar a tener más de $1 \mathrm{~cm}$ en este último collar que nos ocupa. Igual que en las partes altas de la espetera si he visto bolas de Chocho de aceituna, en éste último collar no las he encontrado nunca.

Este collar admite varios adornos. Cruces, de las que ya hemos hablado, crucifijos, de los que también hemos hablado, que suelen estar repartidos de forma simétrica a derecha e izquierda para embellecer el busto, teniendo como eje central dos piezas que cuelgan y que hacen de eje para la simetría que son: el Galápago y la Tembladera.

-El Galápago:

F.- El Galápago lo llaman así por la forma que tiene. Es cóncavo. La parte de atrás, la configura una chapa, que puede ser de oro o de plata dorada o de plata pavonada. Sobre esta chapa va superpuesta otra pieza (cóncava) bien de Filigrana o bien de plata bruñida. Debido al aspecto que nos ofrece esta pieza, nos recuerda a la concha de un galápago, de la que presuponemos ha tomado el nombre. Esta pieza, en el Traje Central Charro, suele ser mucho más habitual que la Tembladera que vamos a definir a continuación, ya que la Tembladera, está más extendida en la zona limítrofe de nuestra provincia con Extremadura, si bien, la encontramos también adornando la Espetera de la Charra Central. 


\section{-La Tembladera:}

F.- Esta pieza es una joya popular cuyo diseño responde a la conjugación de rosetones (cuya parte trasera es de chapa y la delantera es de Filigrana y chapa) con motivos ojivales o romboidales que se utilizan para hacer una composición en la zona central que nos recuerda una cruz griega.

La Tembladera tiene tres cuerpos. El primero de ellos, parte de un rosetón grande del que en la parte trasera habitualmente se pone una argolla del metal en el que está hecho la pieza y por el cual se introduce el hilo donde van las bolas. Esta argolla puede estar cerrada o abierta con el fin de poderla utilizar en distintas partes de la Espetera, aunque tradicionalmente el lugar que suele ocupar es el que el que estamos describiendo ${ }^{124}$. De este rosetón salen otros rosetones más pequeños y de cada uno de estos cuelgan unas péndolas compuestas también por rosetones. El segundo cuerpo está formado por cinco rosetones y cuatro rombos y cuelgan de los extremos dos péndolas un poco mayores que las de la parte de arriba. El tercer cuerpo es idéntico al primero, con la diferencia de que la péndola que cuelga del centro es mucho mayor.

Todas las péndolas que cuelgan en esta pieza se mueven y este movimiento es de donde ha tomado el nombre o al menos es lo que nosotros pensamos. En la zona de donde yo provengo, (Sierraranda), no las he visto. Yo sólo las he visto en la Sierra, repito, creo que esto proviene de la influencia sobre todo con Extremadura y Toledo.

Prácticamente con lo que hemos mencionado, quedaría definida la Espetera que adorna el traje Charro de la zona centro.

M.E.- En el Traje Central o Charro, ¿aparece tanto la Venera como el Galápago?

${ }^{124}$ Anexo, Cit, Foto F- 36. 
F.- Más Veneras que Galápagos. Y más las cruces. La cruz de rayo que es preciosa ${ }^{125}$. Ese tipo de cruces era como las medallas que se ponen a los militares. Tenemos una que tiene un perfil exterior de oro sobre el que luego se cuaja la Filigrana, y en el centro (donde se cruzan los dos brazos de la cruz) aparece una roseta doble de Filigrana. Es preciosa.

M.E.- En el Traje Central, está: El corazón de la Novia, la Venera, el Galápago, las cruces, la tembladera y hay algún elemento más?

F.- Los crucifijos que ya hemos descrito.

\section{b. Traje llano o armuñés}

M.E. - ¿Cómo es la joyería del pecho del Traje del Llano o Armuñés?

F.- Lo más diferente que nos hemos encontrado en esta zona es el uso del coral. Quizá porque es limítrofe con Zamora y León, donde abundan mucho más los collares con coral. Yo personalmente, no sé ni de dónde venía ni porqué se utilizaba, sólo puedo decir, que lo llevaban. La Espetera en el traje del Llano, es muy poco recargada. La Armuñesa puede llevar 2 ó 3 hilos. Un collar en el cuello que casi siempre lo llevaba puesto a diario. Veneras yo ahí no he encontrado, ni Galápago. Las bolas que he encontrado en los hilos son de Chocho de aceituna y las de Gabanza. La bola de Chocho de aceituna está en todas partes. No es que se vean mucho porque son las más primitivas, y son más costosas de hacer que la de Gabanza.

M.E.- En el Traje del Llano o Armuñés, ¿hay algún elemento que la mujer se ponga cuando nace y lo lleve de continuo?

F.- Yo en ese tema no entro. Lo mismo en la sierra que en otras partes, nos metemos ya en superstición. Antiguamente, y yo creo que todavía queda alguna reminiscencia, sobre todo en las mujeres más

${ }^{125}$ Anexo, Cit, Foto F- 37. 
ancianas, se llevaban los evangelios, escapularios, medallas y otros amuletos colgados ${ }^{126}$ y cuando se quitaban la muda, se quitaban el evangelio para no lavarlo y luego se lo volvían a poner. Era un librito muy pequeño, que era como un escapulario de tela y con unas hojitas, siempre cerrado; eso se ataba al cuello. Sólo se encuentra en el Armuñés y en el de Vistas de la Sierra.

M.E.- ¿Podemos decir que el Traje del Llano o Armuñés es muy sobrio respecto a joyería?

F.- Si, pero en la Armuña también está el Traje Central. Lo que no se deben es mezclar.

M.E.- ¿La mujer del Llano o Armuñesa tenía dos Trajes?.

F.- Tenía dos o tres. El Armuñés se caracteriza fundamentalmente por la abundancia de colorido en el Traje; predomina fundamentalmente el rojo. Este es el motivo de que tuviera tan poca joyería; primero porque lo llevaba la gente más joven y entre lo alegre de los colores y la juventud de la zagala, ¿qué más quiere? Sobran las joyas. Este traje convive con el Traje Central que lo utilizaba la gente más mayor y con posibilidad económica.

M.E.- Cuando la mujer del Llano venía a Salamanca, ¿cómo venía? ¿Venía con joyas?

F.- El Traje de la Armuñesa venía muy sobrio, no se puede poner de otra manera, es absurdo pensar que con ese Traje se pudieran poner joyas. Llevaba sus collares, a lo más 3 y punto. No tenía más.

Se han encontrado las truchas. Las truchas eran totalmente movibles $^{127}$. Esa trucha, la cola, se la metían en la boca a los niños, para que hablaran pronto, para que tuvieran buena voz. Para que se les quitara el frenillo que tenían algunas veces no les notara. Le hacían esto, para prevenir que el niño no se quedara sin hablar o quedase tartamudo, (algo impensable

\footnotetext{
${ }^{126}$ Anexo, Cit, Foto F- 38.

${ }^{127}$ Anexo, Cit, Foto F- 39.
} 
en estos momentos). La madrina era la que le metía al niño la colita de la trucha en la boca y eso le ayudaría a hablar bien y a cantar mejor, claro.

c. Traje de la sierra de Francia o Serrano.

Los trajes de la Sierra de Francia o Serrano son: El de Vistas de la Alberca (de Viuda y el propiamente dicho, que se le conoce como el de Vistas), El Charro Serrano, El de Zagalejo y El Serrano propiamente dicho.

M.E.- ¿Qué lleva la mujer en el pecho en el Traje de la Sierra de Francia o Serrano?

F.- En el de Vistas, ella lleva todo lo habido y por haber. Lleva relicarios de todas las clases. A diario, aunque no llevaba el traje, siempre lucía unos aretes en las orejas y sólo hilo. La riqueza está en la joyería y platería dentro del Traje de Vistas. La variedad de hilos tan grande que llevaba, era imposible que lo llevara colgado al cuello, por su peso. Estos iban sujetos al jubón o jubona. El jubón era un cuerpo ajustado con unas mangas afaroladas o pegadas. Encontramos más las pegadas.

M.E.- De la joyería del traje de la Sierra, vamos a hablar poco, porque ya hay estudios suficientes que lo han investigado (Antonio Cea y Francisco Blanco, entre otros).No obstante, sí tendremos en cuenta cuales son las similitudes o los elementos comunes con los otros trajes de Salamanca, si es que los hubiera. Tal vez la importancia y la antigüedad del Traje de Vistas, ha ensombrecido el resto de trajes que conviven también en esa zona. ¿Cuándo se pone la mujer de la sierra todas las joyas? ¿En qué momentos de su vida?

F.-. Las bodas de la sierra eran nombradísimas. Cuando se casaban, porque claro, iban con toda esa joyería. Después hubo una época que no, que se avergonzaban hasta del Traje; esto nunca sucedió en la Sierra, sí en el resto de la provincia. Afortunadamente esta tendencia ha desaparecido y en la actualidad sí nos podemos encontrar novias vestidas de Charra. 
M.E.- Los elementos del Traje de la Sierra, (porque no sólo es de la Alberca), ahora está circunscrito a la Alberca, pero era de toda la sierra.

F.- Ahora mismo se ha quedado ahí porque los Albercanos han sido capaces de comprar todo lo que había alrededor. Yo sé de una familia de Mogarraz que lo vendió a un señor de la Alberca. De lo que estoy convencida es que lo que en la actualidad se considera exclusivamente de la Alberca, era de toda la zona de la Sierra. Tal vez lo que sí que hay que valorar de los Albercanos, es que justamente han sido ellos los que han mantenido aglutinado y valorado una riqueza etnográfica muy antigua, que de no haber sido así, hubiera desaparecido.

M.E.- Los elementos del Traje de la Alberca son: la plata y el oro, y el coral y el azabache.

F.- No hay ni perla ni aljófar. Aljófar en la Sierra no he visto, pero a lo mejor tiene. Lo que hay en la actualidad es muy reciente y responde fundamentalmente a las modas y más bien diría yo, que a la labor de los propios "oreros" y joyeros. Que son quienes lo han introducido últimamente.

M.E.- ¿La gente de la Alberca utiliza el Traje Central o Charro?

F.- Serrano sí, Charro no. Es decir, en la zona de la Sierra, está el Traje Charro Serrano, que se diferencia bastante del Traje Charro Central. Se diferencian sobre todo, en el peinado, en la Sierra no llevan rodetes ni pañuelo a la cabeza. En los zapatos llevan hebillas de las que luego hablaremos. Se les conocía rápidamente. En lo referente a la espetera y a su joyería, ahí sí que podemos decir que es muy parecido al traje Central o Charro. Es solamente en la cabeza donde aparecen los gallos y las palomas en los horquillones.

M.E.-¿En el Traje de la Sierra de Francia o Serrano habría algo que usted destacaría? 
F.- Lo que más me ha llamado la atención, son los carretes, que también están en Zamora ${ }^{128}$ y está también en la parte del Traje de León, el Maragato, pero nunca los vi en la zona de Extremadura. Esos carretes tampoco están en el resto de zonas de Salamanca.

Tal vez lo que sí podíamos destacar, es la abundancia de oro en toda la zona. Hay una parte importante de ese oro, que es oro bajo; mucho procede de Portugal, de dónde no me cabe duda, la influencia en cuanto las formas, es indiscutible. De allí nos viene la variación de cruces y corazones que tenemos. En Filigrana yo he visto en Portugal las Cruces de Rayos y muchos modelos de corazones y amuletos, como por ejemplo la mano de Azabache.

M.E.- Es verdad que los sastres Portugueses, incorporan a nuestros Trajes elementos portugueses? Si eso es verdad, ¿podría ampliarse a la joyería?

F.- El sastre, formaba parte de los trabajadores en algunas fincas de ganaderos. Hay un pueblo que ahora mismo no recuerdo el nombre, sí sé que es en la zona de la Ribera del Yeltes, donde pude consultar las escrituras de una familia donde se detallaba con pelos y señales el coste de un Traje de Charro, de hombre para casarse, al igual que el de un niño, aproximadamente de tres años, que se le encargaron a un sastre portugués que se mantuvo en la finca alrededor de tres meses, sólo para la ejecución de las trajes para la boda. No es que se lo hicieran y lo fueran a buscar a Portugal, estuvo allí el sastre en la finca trabajando, al igual que la modista.

Respecto al tema de la joyería, casi podríamos decir, sin temor a equivocarnos, que la influencia de la joyería portuguesa, es evidente. Es curioso porque yo he encontrado en algunas joyerías en Portugal, piezas muy parecidas a las nuestras. No sé si es que entró aquí por Portugal o que de España salió a Portugal.

M.E.- El Traje de Zagalejo, ¿qué joyería tiene?

${ }^{128}$ PIÑEL, C, La joyería popular zamorara, Editado Caja de Ahorros Provincial de Zamora, 1985. 
F.- Los pendientes son los de la Sierra, en sus distintas variedades. Respecto a la espetera es más liviana, lleva menos collares que el Charro Serrano. Yo creo que eso depende fundamentalmente (como le pasa al de la Armuñesa) que como este traje lo lleva fundamentalmente la mujer joven, el número de piezas de joyería es mucho menor. Volvemos a hacer hincapié, en que en estos trajes lo que prima es la belleza femenina, por la juventud.

M.E.- El Traje de Serrano propiamente dicho ¿qué joyería tiene?

F.- La joyería es la misma que del Traje Charro Serrano, la diferencia está en que toda la joyería va sobre mantones de manila preciosos. No Ilevan manteos, sino, sayas. En lo que respecta a la joyería, prácticamente no hay diferencia. Es el atuendo. Los collares van muy abiertos, prácticamente sujetos desde los hombros.

d. Traje de la Ribera.

M.E.- El Traje de la Ribera, de Aldeadávila y Villarino, ¿cómo es la espetera?

F.- Era muy llena. Los collares iban atados con cintas de colores y pueden llevar el mismo número de collares que los de la zona centro. Sobre el mantón llevan cantidad de collares de oro que se abren hacia los hombros para dar una imagen de más amplitud. Llevan Galápagos, llevan Veneras, Ilevan cruces, las cruces de rayos, no llevan coral, ni perla. No les he visto nunca relicarios, ni guardapelos, pero corazón siempre, que también lo lleva siempre el Traje de la zona centro y llevan bastantes medallas de Filigrana (diferentes modelos de Filigrana con una virgen en el centro). En esta zona es donde más cantidad de collares de chocho de aceituna he visto, de varios tamaños, desde los pequeños hasta los más grandes, llegando estos últimos a los $2 \mathrm{~cm}$ aproximadamente.

M.E.- $Y$ en las cintas de tela que lleva cada uno ¿se les pone el nombre? 
F.- Si, algunas estaban marcadas con cruces, otras las tenían puestas con una inicial, otras el nombre completo, hemos encontrado de todo. Las de seda natural se han ido cayendo a pedazos y a penas encontramos la marca que pudieran tener esos collares.

M.E.- ¿Aquí en el Traje de la Ribera encontramos coral y aljófar?

F.- No, aquí no hay coral ni aljófar.

M.E.- La bola... ¿hay Veneras caladas, o Veneras talladas?

F.- Tienen bastantes Veneras talladas, y las cruces igual. También hemos encontrado algunas cruces que yo creo que eran las que se ponían en los rosarios y en algunas ocasiones estaban en los "catres" (en las cabeceras de la cama), donde se colgaban estos crucifijos que luego se colgaban en la espetera. Tienen algunas cruces de este tipo, son cruces huecas, hechas con 4 chapas haciendo ángulo y luego está el crucifijo en medio. No tienen piedras preciosas. Otras veces las he visto en las pilas de agua que estaban también encima de las mesillas de noche.

M.E.- ¿Y guardapelos?

F.- Guardapelos ahí yo no he visto. Donde he encontrado todo tipo de amuletos y guardapelos y escapularios y cruces es en toda la zona de la Sierra.

M.E.- La mujer de la Ribera ¿qué utiliza más Filigrana o tallado?

F.- Bueno, es que si empezamos a ver, el de talla solamente lo que es talla, talla, es posterior y solamente se encuentra en los botones. En los de talla que son preciosos, el botón que lleva para sujetar el pañuelo. Y las Veneras que son con piedras preciosas y semipreciosas. Había algunas con preciosas y otras con semipreciosas las menos. En definitiva, utiliza tanto la Filigrana como el tallado. Todo lo que son horquillas y horquillones y alguna bola, son de Filigrana. 
M.E.- En el Traje de la Ribera, ¿hay algún elemento que es exclusivo y significativo que sea de la Ribera o no?

F.- Yo no he visto nada. Nada que me haya llamado la atención como en la Sierra.

M.E.-¿Qué pendiente lleva la mujer de la Ribera?

F.- He visto en esta parte y he encontrado los de talla de Almendra, los de farolillos $y$ he visto también los que tienen tres gajos, hasta cinco algunos.

e.Traje del Rebollar.

M.E.- En cuanto al Traje del Rebollar, en la espetara, ¿cómo es el adorno?

F.- Es muy sobrio, no creo que lleven más de dos collares, las más pudientes, porque lo habitual era uno o ninguno. Yo siempre las he visto con un collarcito al cuello y los aretes. Ahí sí que llevan aretes. El collar lleva la bola de Gabanza. La camisa lleva un puño precioso labrado y de ahí salen unos gemelos colgando con bastantes botones, otros con clavillos ${ }^{129}$ como los de los hombres, como los gemelos que llevan en la boca manga de la chaquetilla del hombre. El varilla fina que va para hacer el juego de gemelo es muy larga. Sólo lo he visto ahí. En la camisa que va debajo del jubón, o jubona, llevan un puño precioso, que es el bordado más bonito que tienen. $Y$ lo demás es sobrio. En la cabeza van con pañuelos siempre y no se le ve ningún adorno.

\section{f.Traje de Candelario (Sierra de Béjar).}

M.E.- En el Traje de la Sierra de Béjar, Candelario, ¿qué tipo de espetera lleva la mujer?

F.- La espetera es muy curiosa. La gente piensa, a veces que éstas no tenían joya. Nada más lejos de la realidad, lo que pasa es que lo que

${ }^{129}$ Anexo, Cit, Foto F- 41. 
ellas querían lucir era lo que llamaban corbata, que está bordadísima. La jubona de la mujer lleva un pizquitín de hombro, muy pequeño, entonces lleva todo el busto al aire. No lo cubre. A la cintura tiene lo que pueden coger cuatro dedos de anchura donde van unos ojetes y lleva una cinta verde que se cruza demasiado, como podías cruzar un zapato abotinado. La corbata que llaman, es bordadisima igual que está bordada la jubona que lleva la mujer. A parte de que tampoco se le pueden poner joyas porque lleva una pieza en los hombros que ha quedado exclusivamente ahí, que en la sierra he visto alguna, pero que se ha quedado en el Traje de Candelario, que se llama "Serenero". Es un rectángulo que se pone en los hombros las mujeres. Lo del nombre yo creo que viene por el frío que viene de la montaña a última hora de la tarde. El Sereno, es un término que puede provenir del dicho popular: "poner la ropa al sereno". Además, decían que se ponía al sereno porque se ponía más clara, creo que ese paño llevaba ese nombre por eso, para quitar el frío en la espalda. Entonces el serenero se cruza por delante y este va sujeto con un broche alargado muy parecido a una de las partes de la venera casi siempre con diamantes, es una pieza preciosa ${ }^{130}$. Llevan un collar en el cuello con bola de Gabanza y llevan varios botones Charros bastante grandes en el puño de la jubona, que depende como sea la mujer que le coge desde el puño hasta el codo; deben de ser como mínimo 6 u 8 botones. Eso sí que lo llevan las mujeres de Candelario. Son grandes pero son pegados, no es lo mismo que lo que hablaba antes de la zona del Rebollar, que esos los llevan colgando, para que se vieran, para lucirlo. En la parte de Candelario es pegado totalmente al puño del jubón que lleva la mujer.

Podemos encontrar algo más nuevo respecto a la parte del cuerpo de la mujer. Yo me he recorrido toda la geografía salmantina, y lo que puedo decir es lo que he visto. Donde puedo dar más señales es de la zona donde yo he vivido, el resto ha sido de visita y ha sido conectar con personas de esas zonas que son las que me han enseñado lo que sé.

${ }^{130}$ Anexo, Cit, Foto F- 42. 


\subsubsection{Los zapatos.}

M.E.- Yo creo que de la joyería nos quedaría prácticamente de la cintura para abajo, yo creo que en las medias no hay nada, a la cintura tampoco y sólo nos quedarían los zapatos, que hemos encontrado las hebillas de plata. ¿En el Traje Central o Charro hay hebillas?

F.- No.

M.E.- ¿En el Traje del Llano o Armuñés?

F.- No he visto tampoco, lo que pasa es que ahí hay algunos zapatos muy curiosos y muy bonitos y puede que en alguna casa alguien se hiciera ese tipo de zapatos. Tuve en mis manos y es posible que todavía tenga alguna foto para poderlo ver, en un pueblo, pero tampoco puedo asegurar, porque a veces se encuentran cosas y sólo se encuentra una, no se encuentran más. Puedes poner en duda que se casara alguien con personas de otra zona y lo llevaran y se quedó allí, pero estos zapatos a mí me llamaron la atención porque son los únicos que he tenido en mis manos. Este zapato que vi en Espino de la Orbada, es un zapato de tafilete abotinado, labrado, cortado el tafilete, entonces la figura queda como en relieve en el tafilete y el resto vaciado. El zapato tiene unas quimeras o leones preciosos en el tafilete, también tiene clavelinas y granadas, temas éstos que se repiten en los manteos.

M.E.- El Traje de la Sierra de Francia o Serrano.

F.- En ese sí, lleva alguna hebilla y algunas son preciosas; con caras de angelitos... Hay algunas colecciones de hebillas en algunos zapatos preciosísimas. Estaba a tono con el Traje. La hebilla en el Traje de la mujer también es importante. Mucho labrado que se parece al estilo plateresco. Muy bien trabajada y de distintos modelos. Todo es en plateresco, todo floral.

M.E.- En el Traje de la Ribera? 
F.- El zapato de algunas, inclusive hasta las zapatillas que se encuentran bordadas, las menos, pero es curioso porque al igual que ha evolucionado el zapato. No llevaban hebillas.

M.E.- ¿En la zona del Rebollar?

F.- Ahí llevan unos zapatos muy toscos de piel vuelta. Algunos son abotinados con unas hebillas muy normales.

\subsubsection{La joya masculina.}

Aunque el objetivo fundamental de nuestro trabajo no contempla la joya masculina por ser la femenina la que más razón de identidad le da a la herencia de la mujer, no podemos obviar que el hombre también dejaba en su heredad la joya que poseía que, en el caso de haber hombres eran ellos los que la heredaban y en el caso de no haber herederos pasaban directamente a la línea femenina. Por eso consideramos que debemos una referencia somera a estos objetos masculinos.

M.E.- Yo creo que el Traje femenino lo tenemos más o menos definido, vamos a ir al Traje masculino. La joya en el Traje masculino. En el Traje Central o Charro del hombre, ¿qué lleva?

F.- El hombre lleva el botón en la tirilla estrecha del camisón. Y hay tres tipos que yo conozca. El más antiguo es el que se llama Turco ${ }^{131}$. Es abultadísimo, luego lleva una Filigrana encima hecha con cordón depende de qué cordones, algunos son dobles otros hasta triples que van haciendo el adorno con una bolita y ese es el que yo he encontrado más antiguo. Lo he encontrado en oro de 24, de 18 y hasta de 14 quilates. En oro bajo portugués había bastante. Y luego encontramos otro botón también en el camisón, que es el de talla ${ }^{132}$ que lleva diferentes motivos. Los que más he visto son unos que llevan la talla de la hojita del trébol. Va entrelazado y luego lleva una piedra preciosa o semipreciosa. He visto brillantes, he visto diamantes, luego he visto también el rubí, hay otro de Filigrana rematado en

\footnotetext{
${ }^{131}$ Anexo Cit, Foto F- 44.

${ }^{132}$ Anexo, Cit, Foto F- 45.
} 
el centro con piedra. También alguna esmeralda he encontrado, pero eso sería ya en cuestión de gustos. Depende de la persona que lo mandara hacer. El tamaño es bastante más de un centímetro, pero la parte de arriba tendrá de centímetro a dos centímetros. Sólo va uno. Está primero el Turco, luego está el de Filigrana ${ }^{133}$, luego le sigue el de Talla y bueno he encontrado cosas que no sé si lo pusieron allí porque no tenían otra cosa, pero he encontrado otros que eran justo lo que era una moneda pequeña.

M.E.- El hombre del Traje Central o Charro ¿lleva botones en el camisón?

F.- Los botones del camisón la mayor parte de ellos son hechos a mano. Lleva dos en cada puño (he encontrado alguno con cuatro y con seis). Pero sólo en una familia encontré que los tenían hechos de plata. Eran una chapa pequeña de plata ${ }^{134}$ igual que llevan los botones del chaleco, ochavados o redondos con distinta talla bastante simple, con una flor en el medio, con motivos geométricos, la mayor parte de ellos haciendo ondas. Este tipo está en el chaleco ${ }^{135}$. Van siempre ocho de cada lado y también se encuentran las célebres monedas Alfonsinas, que son como unos gemelos pero con sólo una parte. Los chalecos llevan dos ojetes por donde pasaban la barra del botón. Y lo que se ve es la parte ochavada del botón. La chaqueta lleva en la manga una "cartera" y ahí lleva tres botones Charros ${ }^{136}$. Encontramos algunas variantes como los de clavillo, pienso que son los más antiguos, lo mismo que los de cristal de Murano en negro y en azul cobalto, que son bellotas y van en el puño de la chaqueta del hombre.

M.E.- La calzona del hombre del Traje Central o Charro.

F.- Nunca he encontrado en los pantalones botones de plata, aunque ahora sí los llevan. El Charro no lleva botones de plata, casi todos son con botón de piel y alguno he encontrado que son como si fueran de celuloide

\footnotetext{
${ }^{133}$ Anexo, Cit, Foto F- 46.

${ }^{134}$ Anexo, Cit, Foto F- 47.

${ }^{135}$ Anexo, Cit, Foto F- 48.

${ }^{136}$ Anexo, Cit, Foto F- 49.
} 
prensado. Hay otros que son de cristal, que vienen con el alambre metido dentro del cristal. Estos otros que te decía que llevan en algunas mangas de la chaqueta son las bellotas de cristal. El botón del hombre es plano y siempre de cuero forrado.

\section{M.E.-¿En el Traje Charro Central hay capa?}

F.- Con el Traje llevaban la capa. Aquí tenemos siempre la chaqueta que es una prenda de muchísimo abrigo, pero me imagino que también llevarían la capa en época de frío y algunas veces la "anguarina" (gabán sin mangas). Esas prendas las solían tener guardadas porque las que tenían burdas a diario, (había cantidad de ellas) para la nieve y el agua, son de paño abatanado para no mojarse. Ahí se encuentran cantidad de cierres en las capas, que yo me admiro lo que podían usar para cerrarlas. Se encuentra de todo, el águila bicéfala, broches con conchas, las quimeras o leoninas ${ }^{137}$ (que creo que son las más antiguas). No sé si la ruta de la Plata del camino de Santiago influiría en esto... Inclusive puede que los "oreros" y los joyeros se dedicaran a tener una pieza de estas y hacer copias. Estos cierres van en la tirilla de la capa y en la parte central de la anguarina, a la altura del pecho.

M.E.- En el Traje del Llano o Armuñés, ¿qué lleva el hombre?

F.- Lo único que cambia ahí es que llevan los mismos botones en el camisón, llevan sólo uno. Los pantalones son iguales; hay algunos que no van abrochados los llevan abiertos, para que se vea un poco el calzoncillo y no cambia apenas nada. Lo único que lleva es una chaqueta con coleto. Van cortadas hasta el medio y luego llevan unos cortes pero que eso también está en el zona del Rebollar. No llevan ningún adorno de joya. Llevan lo mismo en la parte de la manga. Los botones del camisón van a la par en unas partes $y$ en otras.

M.E.- El Traje de la Sierra de Francia o Serrano, ¿cuántos botones lleva en el cuello?

${ }^{137}$ Anexo, Cit, Foto F- 50. 
F.- Lleva dos enormes que dan lugar a pensar que sus partes son tan grandes que las lleva puestas hasta en el cuello. Es una camisa con cuello normal. Siempre se les diferenciaba cuando se les veía por la calle. Los botones son de oro y enormes. Excesivamente ostentosos. Siempre los he visto turcos. No los he visto de plata pavonada. Los he visto de oro o de plata dorada ${ }^{138}$.

M.E.-¿Dónde más lleva el hombre Serrano joyería?

F.- En el chaleco que es diferente porque va abrochado hasta el cuello, no es como el Charro que va cortado y se ve todo lo que tiene el camisón que es una joya porque es un encaje total en su pechera. Cuesta bastante hacerlo, había una profesión de mujeres que se dedicaban a todo esto. Se mandaban a hacer. En vez de hacer un par de puños, se hacían hasta tres pares porque era lo que se les estropeaba. Es un bordado ideal. Esas mujeres eran las Puñeteras. Cuando hablan de las puñetas del Traje de Charro son muy costosas de hacer y el dicho de que el hombre aquí en la zona nuestra te mande a hacer puñetas...está muy bien dicho porque costaba bastante hacerlas. No sé si sería con estas puñetas o con otras, que eran hechas con bolillos igual que son las que llevan los magistrados.

M.E.- En el Traje Serrano, hemos dicho que el chaleco va hasta arriba.

F.- Lleva un montón de gemelos de botones Charros. También se han encontrado las monedas Isabelinas. Donde más botones encontramos es en el calzón y en el bombacho, porque el hombre Serrano tiene ambas piezas en su vestuario que se ponen indistintamente. Según van andando se pega uno con otro $y$ van sonando. Son huecos $y$ algunos antiguos eran una maravilla todos hechos a mano. Se ven muy pocas chaquetas, porque como el tiempo que hace en la sierra es mejor que el nuestro pues es muy raro verlo con chaqueta. La llevan echada por el hombro. Estas chaquetas llevan solapa y en la solapita que lleva en la bocamanga también lleva botones

${ }^{138}$ Anexo, Cit, Foto F- 44. 
Charros. Hay una prenda que es como un gabán, un gabán enorme, con unas formas muy simples. Llevan unos cierres en esas capas muy curiosos $^{139}$ igual que en el cierre del dengue en la parte final en los Trajes de la mujer. El dengue es la pieza que lleva la charra encima del pañuelo de hombros para resaltar el busto. Es una pieza importante. Había algunos que llevaban unos cierres del mismo tipo que llevan las capas serranas. Todo lo que lleva en la capa para cerrarla es en plata y he encontrado cosas curiosísimas en motivos de águila bicéfala, conchas, botones. El botón Charro lo llevan bastantes capas...

M.E.- Hay algunas capas que llevan botones Charros y luego cuelgan bellotas, ¿eso es moderno?

F.- Yo creo que sí, que eso es bastante posterior. En los antiguos he visto algunas bolitas pequeñas, otros he visto, lo que llaman caireles, en forma de pera chiquitina. Quizá se encontrara alguna y por eso están sacando unos parecidos ahora, bastante grandes por cierto. He visto los colgantes con cadenas y detalles más pequeños, como son los botones dobles charros, los caireles y las bellotas.

M.E.- ¿El hombre Serrano lleva hebilla?

F.- El hombre Serrano tiene mucho zapato abotinado, hebillas no le he visto.

M.E.-¿Hay alguna cosa especial de la joyería del hombre que te llame la atención a parte de los grandes botones turcos del cuello?

F.- Hombre, en el Traje Serrano es de todo la ostentación. Algunos botones del chaleco llevan superpuestos en oro leones o perros pequeños imitando a las quimeras.

M.E.- ¿El hombre Serrano qué lleva (quitando los de la camisa) el resto es plata u oro?

${ }^{139}$ Anexo, Cit, Foto F- 51. 
F.- Lleva los botones de la camisa, los del chaleco y los del bombacho o calzón. Eran en plata casi siempre, pero alguno se encuentra en oro.

M.E.-¿Cómo era el Traje del hombre de la Ribera?

F.- La joyería del hombre es prácticamente igual que en la zona Centro.

M.E.-¿Y en la zona del Rebollar?

F.- En la zona del Rebollar el botón de arriba del camisón que se distingue porque lleva una especie de gola muy tupida; la puntilla está hecha a bolillo con hilo bastante grueso y es precioso. Van muy bordados. El encaje es muy parecido al de la zona Centro pero hecho en un tejido más burdo. Lleva botón en la tirilla, bastante grande ${ }^{140}$. Es el único que lleva botón de oro. La chaqueta de la zona del Rebollar es más pobre. El chaleco en la zona del Rebollar es muy simple. No le he visto demasiada abotonadura.

M.E.- ¿Cómo es el Traje de la Sierra de Béjar o Candelario?

F.- El Traje del hombre lleva el calzón más o menos como el de la zona Centro pero se diferencia en que la chaqueta y el chaleco son con solapa. No son cruzados como el de la zona Centro, es muy distinto. Los botones del de Candelario no te puedo decir porque al llevar solapa la chaqueta no sé si lleva algún adorno para sujetarla. Si lleva en la bocamanga. Al hombre no le ves casi nunca con chaqueta.

\subsection{7.Últimas consideraciones.}

M.E.- El botón que hemos visto de tipo de cristal de Murano, en ¿qué parte lo ha encontrado?

F.- Solo en la zona Centro. Se han encontrado bastantes, yo los que tengo vinieron de casa de mi abuelo que es de la zona de al lado de Sierraranda. Encontré más pero no sé de donde procedían. Sólo los he

${ }^{140}$ Anexo, Cit, Foto F- 46. 
encontrado en la zona entre Macotera, Cantalpino, Cantalapiedra, zona alta de la Armuña, Ledesma. No me explico de donde venían hechos. Creo que esto viene mucho más de Santiago de Compostela que de Murano. Ahora mismo todo lo que tenemos de azabache, venía de la zona de Galicia.

M.E.- ¿Y cómo llega a Salamanca?

F.- No sé, la importancia del comercio se desarrolló en Medina del Campo, que justo era el punto de comunicación con todas las partes del País. A partir de ahí he visto curiosidades tremendas. Por ejemplo los pañuelos que llevaba la mujer Armuñesa los que lleva debajo de la gorrilla, que es otra cosa importante que la gente desconoce, porque cuando las Ilevan puestas le dicen que son de Cáceres, ha quedado establecido en el Traje de Montehermoso por el sombrero, pero eso es una capota, no es una gorrilla. La gorrilla nuestra que ha quedado en el Traje de Armuñesa no tiene nada que ver, ni la forma, ni la manera de realizarla, ni el remate, ni los adornos. Estos pañuelos, estando yo en Glarus, un cantón de Suiza, que hablan Alemán, la familia donde yo estuve tiene una fábrica de algodón, que yo no sé las generaciones que tendrá esa fábrica, los vía que venían desde Suiza hasta Medina del Campo. Es un pueblo entero trabajando para la fábrica de algodón. Ahí me sorprendió mucho porque el abuelo de una alumna mía, tenía recogido cantidad de pañuelos, porque su ilusión era haber hecho un museo. Él ha donado muchísimo a museos etnográficos de allí de Suiza. Estuve un día con él, y me explicó cómo se podía conocer el algodón bueno. Depende de los sitios de donde viniera. Ahora está trabajando sólo con el algodón peruano, porque es más barato.

M.E.- ¿Y los bordados son parecidos a los nuestros?

F.- No, el bordado no, lo que tienen allí son los encajes suizos que son una maravilla. No se parecen nada a los nuestros. El encaje suizo son las puntillas que se utilizan en toda la ropa interior de la mujer, así como de casa. Entonces, me enseñó un libro que era curioso, porque tenían la facturación, tenían las direcciones a donde los mandaban, y venían a 
España (Medina del Campo). Entonces se los mandaban para la venta, lo que no sé si el distribuidor estaría allí o como sería. Pero son unos pañuelos totalmente de algodón que llevaba la Espigadora Armuñesa a la cabeza.

M.E.- ¿Usted ha visto cómo se enfilan los collares en general de los Trajes? Se enfilan con hilo, con cadena, con tela...?

F.- Los nuestros se han enfilado siempre con hilo. Terminando en cintas. Los enfilados con cadena son posteriores. Antes las bolas se enfilaban con hilos, de eso el nombre le viene dado y no decimos collares sino hilos. No había cierres. Exactamente igual que no hay cierre en el Traje, la mujer lleva a la cintura 6 cintas. Todas sus piezas van atadas a la cintura. Entonces la primera vez que te vistes de Charra, cuando te vas desvistiendo y acabas de desvestirte, la impresión sin todo ese peso es que parece que vas a echar a volar. Todo ese peso y todos esos atados, hay que tener mucho cuidado cuando se viste a la gente, porque si empiezas a atar sin poner una base sobre la piel puedes hacerle daño a la persona que va vestida. Es mucho peso lo que llevan en la cintura.

M.E.- Toda la joyería que lleva la mujer en general salmantina en cada uno de sus Trajes, ¿todos los llevan al cuello?

F.- No, al cuello la Serrana nunca lo podrá llevar por el excesivo peso que lleva (en el Traje de Vistas). Va metido en ojetes que se ponen a distinta altura en el jubón y luego lo prenden con imperdibles pequeños. El de Serrana sí van atados atrás en el cuello, pero se van abriendo en dirección a los hombros; también se prenden disimuladamente para que queden más bellos puesto. La Serrana lo lleva atado al cuello con todas las cintas, todos los colores habidos y por haber. Las formas de atar son diferentes y algunas, es curioso, porque van doblando en zigzag y cuando cae parece un acordeón, otras las Ilevan de distintos anchos. En ningún Traje se lleva ni pulsera ni reloj. No se les verían. Las puntillas caen sobre la mano y todo estorbaría para poner la puñeta. 
M.E.- ¿Podemos decir que la joya es el último elemento que se pone en el Traje?

F.- Hay un dicho que dice lo último que se pone ya es el zapato.

M.E.- Hemos comentado también, que muchas veces en los cantos quedan reflejados los aspectos de la vida, ¿hay algún canto, alguna estrofa, que se refiera a la joyería?

F.- Si hombre, como son muchos, casi todos eran picarones. Eran unos artistas. Hay una que es una pareja que le debía de gustar mucho beber a los dos y entonces le dice el hombre a la mujer, que le de dinero porque se viene a la feria y le va a comprar unos pendientes y entonces le dice ella: no marido no, déjalo para aguardiente. $Y$ ella dice: "con el vino sano yo marido, con el agua me pongo muy mala, muy mala." Hay otras sobre los zapatos: "más valen cien labradores/ con peales y en albarcas/ que doscientos señoritos con las hebillas de plata". "Las hebillas que te pones/ son de plata y oro fino/ bien puedes considerarte/ que se terminó el vestido"."El mozo que está en el baile/ le ruge la faldriquera/ el rosario y las medallas/ el oro y plata que lleva". "La molinera, la molinera/está mirando al río del agua que lleva/ tiene la molinera ricos collares/ tiene la molinera ricos collares/ de la harina que roba de los costales/. Tiene la molinera ricos pendientes/ tiene la molinera ricos pendientes/ de la harina que roba a los clientes".

M.E.- ¿Hay algún otro chascarrillo o estrofa donde se hable de que la joya es importante?

F.- Tengo que mirar porque seguro que sale. Sobre la ropa sale muchísimo, sobre las cintas, mantillas, sombreros, calzones, inclusive sobre la alpargata y sobre el zapato. El señorito que lleva el pantalón y el calzón. De joyería no es que hablen demasiado. Hay otro que dice, que algunas eran delgaditas que decían que esas no tenían novio porque podrían estar enfermas y se ponían rellenos en sus partes y cuando llegaba el día de boda, cuando el marido la empezaba a desvestir se quedaba asombrado, 
porque no la conocía sin todo el relleno y se la devolvía a la madre y le decía: mira a ver si la cuidas porque yo no me he casado con una mujer así (así de flaca). Se han dado casos en estos pueblos. Inclusive ahora en esta época llegas y te ve una persona mayor y si te ve delgada, delgada te dice: "Hija por dios, parece que estás tuberculosa." $Y$ sin embargo te ven gordita $y$ te ven guapísima: "iiqué guapa estás!!"

M.E.- ¿La joyería forma parte de la dote de la mujer charra?

F.- Sí, forma parte de la dote. En las hijuelas que han dejado describían en algunas los tejidos y los dibujos de las piezas. Había algunas personas que han sido tan meticulosas a la hora de hacer la donación a sus hijos que "casi casi", conocías la pieza sólo de cómo te la describían; conocías también el estado en el que estaban las piezas... Me encontré en Babilafuente una, con la que me ilusioné enormemente, como podías imaginarte al verla en qué condiciones se había quedado esa pieza después de habérsela puesto alguien durante cantidad de tiempo. $Y$ en qué condiciones había sido cuidada por sus hijos o sus hijas.

M.E.- ¿La joyería iba por línea Femenina?

F.- Casi siempre lo de la mujer, era curioso, porque si había mujeres en casa de no ser que estuvieran solteras, como no tenían descendencia o pensaban que no iban a tener descendencia, se lo dejaban a los hijos lo cuales tuvieran hijas, para que no se perdiera la tradición. Lo más doloroso era la división de joyas. Las tasaban y depende del precio que les dieran, hacían los lotes lo más iguales posible para repartirlas, pero en muchas ocasiones, intentaban que no se repartiera el Traje, que quedara completo; porque si te deban el Traje y no te daban las joyas te quedabas "coja".

M.E.- ¿Podemos decir que la joyería es el complemento perfecto del Traje? 
F.- Sí claro, a veces era mucho más el valor que tenía un solo hilo de oro, que era así como se llamaban, hilos de oro, que tenían tanto valor como el propio traje.

M.E.- ¿Un hilo de oro qué dimensión puede tener?

F.- Depende. En los del cuello, depende de la dimensión de la bola y del grosor del propio cuello. Se juntan a veces por grupos de dos o de tres, nunca se pueden poner los cinco. Ahora están haciendo los joyeros una barritas y los van colocando allí para más comodidad.

M.E.- Antiguamente era un hilo, otro hilo, otro hilo...

F.- Sí, hay algunos largos que se unen dos aproximadamente a la altura del pecho.

M.E.- O sea que no es un hilo de dos metros dado vueltas sino que son individuales. ¿de dónde proviene la joyería charra? ¿Usted cree que se hacía en Salamanca?

F.- Ahora mismo te digo, que creo que nos ha venido mucho del Sur y de la parte Norte de Portugal ${ }^{141}$.

M.E.- ¿Usted cree que nos viene más del Sur que de Portugal?

F.- No te puedo decir, porque lo que sí está claro es que en el siglo XVII, Salamanca tenía muchos "oreros" y muchos plateros.

M.E.- La joya que se compra en Salamanca ¿está hecha en Salamanca?

F.- Yo creo que sí.

M.E.- ¿El orero y el platero estaban en Salamanca capital o también tiene usted noticias que los hubiera fuera de la zona nuestra?

${ }^{141}$ Amexo, Cit, Foto F- 52. 
F.- Creo que en la zona de Ciudad Rodrigo, donde más filigranistas había. Y es donde los he visto, en sus propios talleres. Como la mano de obra ha sido últimamente más barata en Portugal, nos ha venido mucho de este país.

M.E.- Respecto al tema de la joyería, las calidades de todos los aderezos suelen ser de oro de distintos quilates o de plata dorada. ¿De plata sola no?

F.- De plata sola se ven menos. Siempre hay que aclarar, que la plata es más barata y el trabajo no se podía cobrar como la pieza en oro. La trabajan menos que el oro.

M.E.- ¿Usted cree que el tema del trabajo de la plata dorada es mucho más posterior?

F.- No lo sé, porque ahora mismo en nuestra zona, la forma de hacer el dorado (dorar la plata) es en el puchero. Pero sé, que en Córdoba y Granada lo están realizando con láser...Este dorado, es mucho más potente y de más duración que el dorado en puchero, y es por ello que es más caro.

M.E.- Qué diferencia hay entre nuestra joyería y la cordobesa?

F.- La verdad es que lo nuestro es curioso, porque no hay ningún sitio en España en el que el Traje regional vaya tan lleno de joyas como el nuestro, ni siquiera el valenciano. El Cordobés no lleva toda la pechera de la mujer, que es lo que más resalta en joyería.

M.E.- ¿Podíamos decir entonces que la riqueza de nuestros Trajes está en toda la joyería que llevan? A parte lógicamente de los bordados.

F.- Sí claro. ahora mismo si te encuentras los antropólogos que están trabajando muchísimo sobre los Trajes y están dándole la importancia a muchísimas cosas que se le deben de dar como por ejemplo los tejidos Perdidos ya que no se pueden recuperar, entonces al no poderlos tener, eso es una riqueza inmensa que debemos proteger y cuidar y meterla en vitrinas. 
Nosotros cuando hemos salido fuera de España con el Traje nos traemos el primer premio, no ya al baile, sino al Traje.

M.E.- ¿De lo que usted ha visto entonces en cuanto a la joyería el Traje es el qué más tiene, incluso más que el zamorano?

F.- Sí, es el que más tiene, Zamora tiene el de la viuda rica de Toro, que se le ve mucho oro, pero es porque va todo bordado en lentejuelas de oro, pero no porque sea más ostentoso en joyas.

M.E.- Haciendo una graduación, graduando la riqueza joyera de todos los Trajes que hemos visto, ¿cuál sería la lista?... Numéramelos.

F.- Hombre, el más rico en trabajo de joyas sería el de Vistas de la Alberca, luego el de la zona Centro (el Charro propiamente dicho), luego el de la Ribera, el de la Sierra de Béjar y el del Rebollar.

M.E.- En la zona serrana, a parte del Traje de Vistas... ¿hay alguno más?

F.- Está el Charro Serrano y el Serrano.... Luego está el Traje de Vistas y el que llaman de Zagalejo.

M.E.- Los carretes que van en el Traje Serrano, ¿sólo van en el de Vistas? Creo también que están en los Trajes de Zamora..

F.- Sí, en Salamanca sólo se encuentra en el de Vistas. Los podemos encontrar en alguna fotografía antigua de los trajes de Zamora y León. (Foto 53)

M.E.- Entonces, sólo lo hay en el de Vistas. Y esos carretes ¿son de plata o de oro?

F.- Son de plata. Ahora pasa como con otras piezas, que les están dando un baño de oro (plata dorada). 
M.E.- Es muy importante que me dijera, un apartado especial, de barbaridades que se están haciendo ahora mismo con la joyería en cuanto a cosas que se incluyen en ella y que no son...

F. - La mayor de ellas, es que se están uniformando muchísimos pueblos con Trajes rojos por ser más cómodos de hacer. Al mismo tiempo que por comodidad, no llevan más que las enaguas y a veces sólo el pelele o la enagua. A mi me dicen algunas veces que tengo yo parte de la culpa de que esto suceda y yo he enseñado todo tipo de bordados y manteos que había antiguamente. Antiguamente, había cantidad de manteos rojos, pero la mayor parte de ellos eran bajeros, y por encima, iba el Traje rico en bordados o encimero. Hay un dicho especial que dice, que: "no conocerás a un Charro hasta que se quite el séptimo chaleco y a la mujer la séptima enagua". Quiere decir que llevaba muchas piezas el hombre, dependiendo de la estación del año y la mujer igual. Desde que se pone la primera enagua de finísima batista ya que al no darle nunca el sol en su piel, tenía la piel como un bebe, delicadísima, y había que tener cuidado porque se le podía dañar.. Esta tela ahora no es fácil de encontrar y si la hay, es muy cara. Se hacía mucho de Barcelona pero venía mucho de Holanda y en algodón venía de Suiza. También venía de Madeira y de las colonias inglesas. En Suiza se sigue haciendo pero a un precio desorbitado. Venía al mercado de Medina y se distribuía por la red ferroviaria. Aquí en España hubo fábricas muy buenas. La industria nuestra debió de cerrar, no te lo digo seguro, pero del 65 al 70. En todo el conjunto, veo la falta de rigor a la hora de peinarse, porque como la raya al medio no favorece a todas, se peinan como quieren, sin rodetes, sin moño trasero, con flequillo... un auténtico disfraz.

M.E.- Igual que el paño proviene del Norte de Europa, ¿de dónde cree usted que viene la joyería?

F.- Exactamente, no sé de donde provienen nuestras joyas. Ahora mismo comprendo por qué en Turquía, encontramos joyas muy parecidas a las nuestras. Por ejemplo, el Botón Turco... 
M.E- ¿Dónde ha visto usted el botón Charro en Portugal?

F.-En Portugal en el anca de un becerro que está en el Museo de Arte Contemporáneo.

Teniendo en cuenta que nuestra fuente oral tiene un amplísimo conocimiento del traje tradicional charro en todas sus modalidades, nos ha hecho considerar la posibilidad de otro eje de influencia en la joyería objeto de estudio.

Si realmente existe, como ella ha podido ver tanto en Rumanía como en Suiza, la similitud de dibujos, paños, encajes, cortes de piezas de vestimenta e incluso vestimenta completa, no es nada descabellado, pensar que el Mercado de Medina del Campo, fue un foco de atracción de las corrientes no sólo comerciales y económicas, sino de las culturalesetnográficas. La aparición del comercio en Medina del Campo, no es casual, ya que esa área de intercambio comercial existía desde tiempos muy antiguos. Desde la observación directa de nuestra fuente, también se nos constata, la similitud en algunos elementos de la joyería, lo cual nos hace pensar, que existe otro eje al que nosotros le denominamos, Eje Europeo, cuya dirección proviene desde Europa hacia la Península Ibérica y si lo prolongamos hasta Medina del Campo nos da un área donde confluyen los cuatro ejes que nosotros hemos definido. (Mapa 6.) $)^{142}$

Podríamos decir que la ubicación de la Filigrana Charra en el espacio geográfico que nosotros estudiamos no es una casualidad, sino, la prolongación lógica de los ejes de influencia que nosotros hemos estudiado.

Así, el territorio sería el marco fundamental en el que en cuadraríamos una tradición joyera que lo único que nos da en la actualidad es la memoria histórica de un pueblo.

A modo de resumen de cuanto llevamos estudiado hasta ahora: la implantación, ubicación y expansión de la técnica de la filigrana en la

${ }^{142}$ Mapa 6, v. supra. 
Península Ibérica representada en los mapas expuestos anteriormente y la influencia de Europa a través del Camino de Santiago y del mercado de Medina del Campo que queda constatada en el traje, hemos realizado un mapa resumen (Mapa 7) donde se aprecia cómo todo cuanto hemos estudiado confluye de manera no casual en el territorio objeto de nuestro estudio, en el que la mujer de estas tierras desarrollaba su existencia y su vida.

La influencia del canal de comunicación del sur de la Península Ibérica que supuso la entrada de influencias de la costa Norte de África, fundamentalmente de la Cultura Beber, así como la relación con Tartesos y posteriormente todo tipo de influencias a través de la Ruta de la Plata. La influencia de todo cuanto procedía del Este Peninsular procedente de la Cuenca Mediterránea y que nos llega por el eje Mediterráneo. La influencia de Europa, más la influencia atlántica, vemos como confluyen todas en nuestro territorio, que además propició la salida de esta riqueza por el Atlántico a América, fundamentalmente México.

De ello se desprende el valor histórico, representativo y de identidad de nuestros objetos como elementos de una herencia que gracias a esta mujer rural y tradicional de esta tierra, no se han perdido. 


\section{MAPA № 7:}

\section{Los ejes que confluyen al sur del Duero: Zona Charra}

..... - Eje Sur-Norte. Influencia Norte de África-Amazigh

— - Eje Mediterráneo-Costa de Levante

- Eje Atlántico-Portugués

- - Eje Exportador Marítimo

— - Eje Atlántico-Portugués

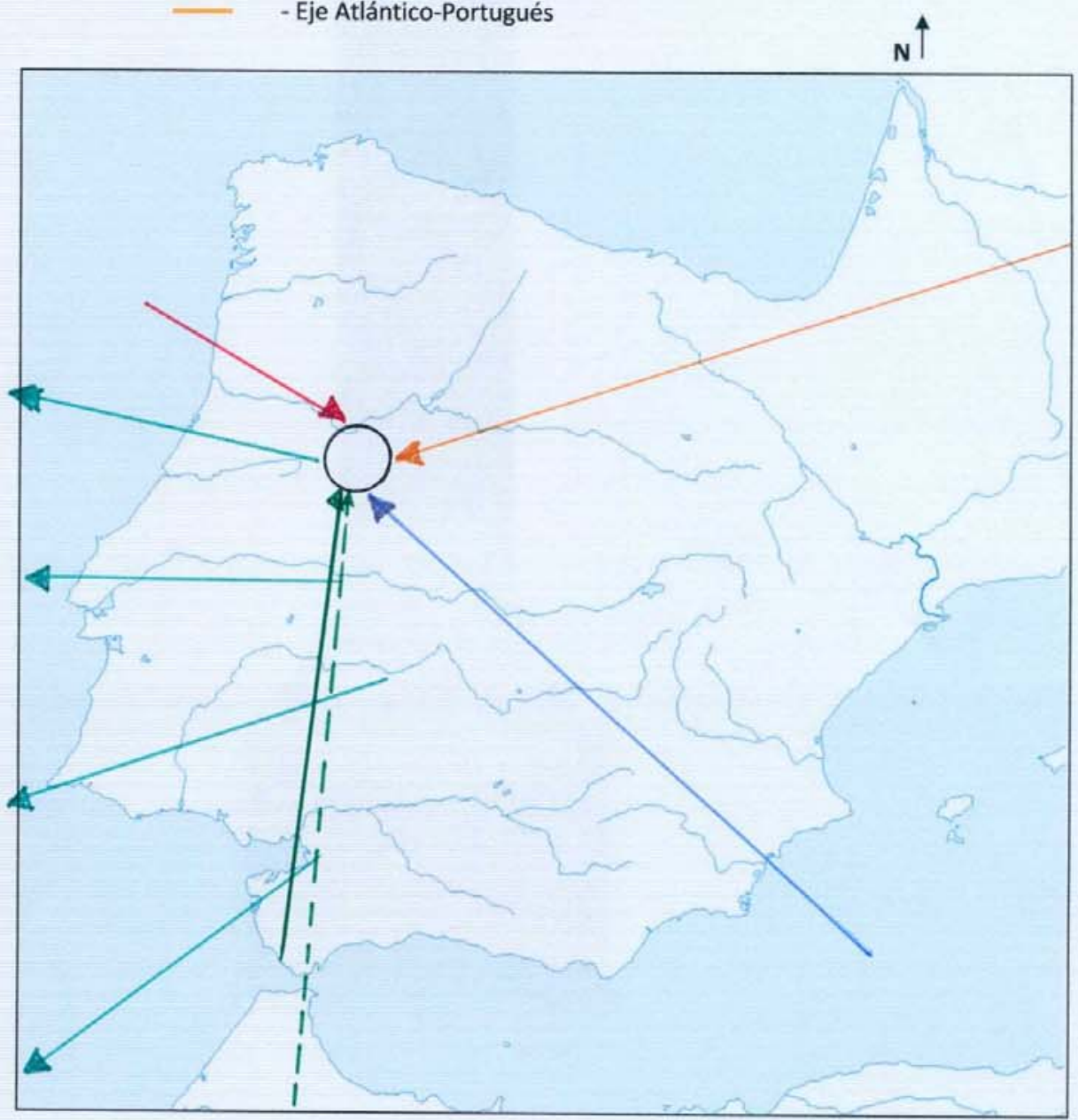

Elaboración propia 
CAPITULO II.

\section{TÉCNICAS AMANUENSES DE LA JOYA, SU PRAXIS EN: LA TALLA, LA FILIGRANA Y LA MICROFUSIÓN}




\section{Artesanos amanuenses de la joya, su praxis en: la talla, la filigrana y la microfusión.}

En este capítulo trabajaremos codo a codo y ahondaremos junto con los oreros tradicionales, en las técnicas ancestrales que utilizan aún hoy en día los artesanos joyeros y de las cuales resultan las maravillosas joyas de estas tierras. Para ello estaremos en los talleres de Antonio José Martín Sánchez (Toño) tallista, y José Luis Nieves filigranistas. Ambos "oreros" trabajadores del oro y metales preciosos, como se conoce a estos artesanos en esta tierra.

1.1.La praxis de la talla: Antonio José Martín Sánchez ${ }^{143}$ más conocido por todos como Toño.

Sería totalmente imperdonable, no hablar de la talla en el aderezo charro.

Somos conscientes que el objeto real de nuestro estudio, es la Filigrana como base fundamental del complemento joyero charro, pero aún así hemos querido tomar contacto con este artesano, porque él además de filigranista, es tallista de los botones de talla charros, de las veneras y de los complementos denominados de "almendra" que forman parte de la pechera de la charra, y que complementan las piezas de la Filigrana. Es el especialista que mejor conoce el procedimiento técnico del botón charro en talla, realizando los procesos como se hacían antiguamente.

\footnotetext{
${ }^{143}$ Antonio Martín Sánchez es joyero tallista especialista en este tipo de técnica que está vinculada a otro tipo de botón charro que no es el de filigrana, si no el de talla. En 2011 nos abrió las puertas de su taller y nos explicó todos los procesos que son necesarios en la ejecución de estas imponentes tallas, aportándonos incluso sus propios dibujos.
} 
Antonio, es como muchos de los artesanos, un hombre de taller.

Del tiempo que hemos pasado junto a él, podíamos apuntar:

- Considera que la realización del botón tallado tiene un doble esfuerzo: diseño del mismo y ejecución de la talla.

- Antonio trabaja exclusivamente el oro y el diamante, tanto como para el botón como para la venera, utilizándolo también para pendientes y sortijas de Almendra.

- En cuanto al diseño, este artesano, ha ido recopilando tipos de botones que él ha inmortalizado en sus dibujos para luego después plasmarlos en oro.

La tipología y morfología de la temática del botón tallado es siempre la misma. La forma exterior es redonda y cóncava, variando tan sólo el diámetro en función del uso que posteriormente se le da a la pieza: botón de camisa, de cuello, gemelo.

Los motivos del botón tallado, siempre son florales, y nos confiesa que diseñando una semicircunferencia, el botón está totalmente diseñado, porque el diámetro de la circunferencia sirve como eje de simetría en el botón, siendo el motivo ornamental de ambas semicircunferencias igual.

También nos comenta, que diseña por sectores circulares iguales, facilitando de esta manera la ejecución del mismo y la repetición de los temas florales que utiliza. Siendo el resultado simetrías radiales.

Así podemos decir, que haciendo un dibujo en un sector circular o "gajo" para hacer el dibujo en el sector circular contiguo, bastará hacer una simetría axial siendo el eje de simetría el radio común a los dos sectores circulares contiguos. Así, dibujando un "gajo" de la circunferencia, tenemos 
el dibujo igual en todos los gajos, de la misma, y el resultado será perfecto $^{144}$.

Ya adelantamos, que esta manera de trabajar la simetría (en cuanto al uso de la circunferencia) es la misma que se llevará a cabo en la ejecución del dibujo del botón charro de Filigrana.

Los temas florales y vegetales están presentes tanto en el botón, como en la venera; también en los dibujos de los paños de los trajes tanto en las piezas como en los dibujos, existe un eje axial que divide a las mismas en dos partes simétricas.

A este respecto podemos aportar que la simetría forma parte también del traje y de la Filigrana, haciéndose aquí verdad también, el concepto de equilibrio y composición que da la simetría en la decoración; ya es en el Siglo XVIII, donde fundamentalmente los ingleses producen los objetos decorativos de valor en pareja, también en Francia antes de las Guerras Napoleónicas, alrededor de 1755, también se utilizaba mucho el concepto de simetría para los objetos en decoración. Es la época de la duplicidad de cómodas, jarrones, guarniciones de relojes, espejos dos a dos,...

Este concepto de simetría axial en la decoración y en el uso doméstico hacía que la terminación tuviera un concepto de equilibrio y quedase compuesto el espacio. Aunque en un principio parezca exagerado comparar este aspecto con la joyería, no es del todo descabellado pensar que ese gusto por partes iguales en los objetos se reflejase también en algo tan particular como es la joya. No cabe duda que el concepto de simetría no sólo enfatiza el eje sino que equilibra la pieza haciéndola al ojo humano agradable y apetecible.

Cuando Antonio nos explicaba su manera de proceder a la hora de plasmar en papel la idea para luego tallarla, nos recordaba muchísimo ese

\footnotetext{
${ }^{144}$ Anexo, DVD, carpeta 2. Fotografías del taller de Antonio. Foto A-2 y A-,3. Documento elaboración propia, Salamanca, 2011.
} 
concepto de equilibrio que desde siempre se ha buscado en cualquier pieza de arte para obtener un objeto hermoso a los ojos del hombre.

a) Ejecución ${ }^{145}$ : hacer en talla una pieza, es realmente complicado, pues prácticamente no hay cabida al error. Cuando el cincel saca las formas en el metal, nos dice el autor que el tiempo no existe; cuando él hace los originales, el objetivo es la talla, terminarlo de tal manera que cuando se ejecuta un proyecto que se ha ideado, o se recupera del tiempo a través de una pieza desgastada o rota, el reto del artista no puede entrar en competencia con el tiempo dedicado. Tanto es así que en este proceso muchas veces se le olvida el número de horas que lleva delante de la pieza. Él nos comenta, que cuando realiza la talla original lo ideal sería empezar y terminar en el mismo espacio de tiempo sin interrupción, ya que la concentración en lo que se hace es muy importante en la consecución de un original lo más perfecto posible.

Toño, como así le gusta que le llamen, tiene todos los originales que ha creado (excepto los que ha realizado por encargo y el cliente compra la pieza sin posibilidad de reproducción. Es importante comentar aquí el precio que puede llegar a tener una pieza única) ya que las piezas que salen al mercado no son las tallas originales, sino que él, a través del proceso de Microfusión (del que hablaremos en un capítulo aparte) realiza las réplicas en cera, que luego retoca. Este artesano las réplicas que hace casi al $100 \%$ son en oro. El engastado de las piezas así como el terminado y el ensamblaje de las partes las hace de manera artesanal.

La utilización de este proceso industrial es para poder competir en un precio más asequible de mercado en unas piezas que de por sí, son escasas y caras. Como ya hemos explicado, existe un proceso manual muy importante a pesar de que la base de la joya sea réplica.

-Conversaciones con Toño.

${ }^{145}$ Anexo, Cit, Fotos A-4,5,6,7,8,9,10. 
M.E.- ¿Existe la posibilidad de comercializar originales?

La respuesta de Toño es rápida y clara.

T.- "Sería difícil calcular el precio final de un original. No es tanto la cantidad de materia noble que se utiliza (oro) y eso que en estos momentos el gramo de oro fino es carísimo, como el tiempo y el esfuerzo de realizarlo así como la imposibilidad de quedarte sin el original para realizar un molde del que se puedan sacar otras piezas en función de la demanda del cliente. No obstante si el cliente quiere una talla única se puede hacer perfectamente siempre y cuando esté dispuesto a: esperar el tiempo necesario y a pagar el valor de la pieza".

M.E.- ¿A pesar de todo compensaría vender tallas únicas?

T.- "Depende para lo que la quiera el cliente. Si es simplemente como adorno y complemento, creo que el resultado final de una pieza microfusionada (tal y como yo la realizo en el taller) a penas se diferencia de la talla original, sencillamente porque el retoque y el tiempo que empleo en ellas hace que el resultado final sea perfecto. Ahora bien, si lo que se pretende es una pieza única de colección, e insisto, está dispuesto a pagarlo, compensa por su puesto. Hay clientes que por encima de todo quieren piezas exclusividad, aunque son los menos."

M.E. - ¿Se demandan en la actualidad este tipo de piezas?

T. - "Si es cierto que en los últimos 10 ó 15 años sí ha habido una recuperación por el gusto en comprar este tipo de joyería. Pero proporcionalmente a la comercialización de otras piezas modernas la proporción es muy pequeña. Evidentemente, yo no vivo de ello, pero también es cierto que somos muy pocos los que hacemos este tipo de joyería con lo cual, cuando tienes estos encargos económicamente son rentables. Antes de trabajar en mi propio taller, me refiero fundamentalmente a la década de los 70, hubo una depreciación muy alta de este tipo de joyería. Se fundieron piezas maravillosas, que hoy ya no existen en el 
mercado (puede que existan en colecciones particulares) ya que en la actualidad prácticamente todo es de Microfusión y además dorado, que las piezas de oro son mucho más caras. Con la recuperación del traje tradicional y la creación de la Asociación del Traje Charro (1985) sí se notó el incremento de encargos. En la actualidad la demanda es muy pequeña".

Toño Martín, también ha realizado diseños basados en piezas antiguas y que aunque no se puedan considerar puristas, sí nos llama la atención que invierta tiempo y dinero en estas cosas, ya que cuando un objeto se permite evolucionar, simplemente es que no está muerto ${ }^{146}$.

Para las veneras, así como para todo el ornamento de almendra, el protocolo es exactamente igual que para el botón. A partir de los originales en talla hechos por él, en su taller se hacen los moldes en caucho para luego microfuisonarlos. Una vez ensambladas las piezas, rematadas y pulidas, pasa a engastar los diamantes en las veneras, pendientes y sortijas ${ }^{147}$.

Una vez terminado, damos fe de que la belleza de sus piezas es extraordinaria y nada tienen que envidiar a las que se hacían en el S.XVIII ${ }^{148}$.

Antes de finalizar con la talla, no queremos olvidar mencionar la importancia que tiene el envés (parte de atrás) de las piezas. El remate y el dibujo que llevan las piezas de talla, hace que esta parte de la joya, sea tremendamente bello, dando a las piezas un valor sobreañadido, teniendo esta parte un cincelado y decorado exclusivo ${ }^{149}$. En este sentido se sigue guardando la norma centenaria en la ejecución de estas joyas preciosas.

\footnotetext{
${ }^{146}$ Anexo, Cit, Fotos A-11,12,13.

${ }^{147}$ Anexo, Cit, Fotos A-14,15,16.

${ }^{148}$ Anexo, Cit, Fotos A-17.

${ }^{149}$ Anexo, Cit, Fotos A-18,19.
} 


\subsection{La praxis de la filigrana: José Luis Nieves ${ }^{150}$.}

Como venimos diciendo La filigrana es una técnica orfebre que consiste en fabricar finísimos hilos con un metal precioso, generalmente oro o plata, y con ellos hacer trabajos delicados en joyería.

La joya de filigrana es la joya ligera por excelencia. La filigrana propiamente dicha es una joya cuya ornamentación que se ejecuta por medio de dos hilos de oro o plata muy finos torcidos a un tiempo mediante tenazas imitando una cuerda sumamente fina. A primera vista, esa cuerda parece un hilo grabado.

El artesano José Luis Nieves, es el único artesano situado al noroeste de la provincia de Salamanca, que trabaja manualmente el hilo de oro y plata, para hacer con él objetos de Filigrana en su taller de Ciudad Rodrigo.

Entrar en el taller de Nieves, (como se conoce a este artesano en todos los ámbitos), es hacer una introspección en el pasado. Es como si una hipotética máquina del tiempo te trasladara al Siglo XIX como poco.

Nieves es un artesano, artesano. Aprendió el oficio del oficio de su padre, que a su vez él lo había aprendido del suyo. Éste es el motivo por el que este trabajo lo lleva en el fondo de su corazón, tanto es así que la fotografía de su padre ${ }^{151}$ es lo primero que ves cuando entras en su taller.

Ahora trabaja sólo, y por mucho que intentemos imaginar cómo serán los días de trabajo en el invierno castellano, se nos hace difícil comprender cómo la soledad es fundamental para la creación de sus obras. Después de conocerle y escucharle, comprendemos que la Filigrana sólo puede salir de la concentración y el silencio, aspectos éstos, que en la actualidad prácticamente quedan reducidos a los trabajos de laboratorio.

\footnotetext{
150 José Luis Nieves es el experto en filigrana. En 2010 pudimos hacer todo nuestro trabajo de investigación en el taller que posee en Ciudad Rodrigo. Nos realizó todo el proceso manual desde el principio hasta el final en la ejecución de la filigrana, poniéndonos como ejemplo el Botón Charro.

${ }^{151}$ Anexo, DVD, carpeta 3, Foto N-1a.
} 
Subiendo la angosta escalera que comunica el bajo con la planta superior, nos comenta que el trabajo de la Filigrana es sucio, porque quemar, pulir, volver a quemar,... hace que todo esté negro, y por supuesto sus manos. No exagera nada pues cuando accedemos al taller en la parte superior, parece más bien un espacio relacionado con el carbón más que con el taller de un joyero.

Nos llama la atención todos los artilugios manuales que tiene, todo nos cautiva y las preguntas se abarrotan. Él, con la calma de un hombre acostumbrado a manejar el tiempo nos propone empezar desde el principio.

Él lleva a cabo todo el proceso productivo: compra la materia prima, en pepitas de oro y plata $(960 \mathrm{~mm})$. En su filosofía, entra desde el principio el hacer todos los procesos para producir un objeto que sea asequible en precio, en un mercado que pone a nuestra disposición un montón de objetos atractivos a un precio muy pequeño. Funde el metal, hace barras en sus moldes del metal que en ese momento esté trabajando, para fundir utiliza uno $u$ otro recipiente si es oro o si es plata y nos explica: "aquí no se desaprovecha nada, sólo del uso cuidadoso del producto, impediremos perder material, que ya de por sí es muy caro." Una vez que obtiene las barras de metal, las convierte en hilos y una vez que tiene hilos empieza el verdadero proceso del filigranista. Él pule, él dora, y él comercializa y vende su propio producto. Le preguntamos por qué dedica tanto tiempo a hacer hilo, y nos responde que si tuviera que comprar el hilo ya manufacturado a precio de mercado, le saldría mucho más caro y no sabría si realmente el material utilizado tiene la pureza que el necesita para su trabajo.

Llevar a cabo todo el proceso productivo en el Siglo XXI, podemos decir que es prácticamente imposible. Es este el motivo por el que Nieves, puede poner en el mercado piezas originales a un precio todavía asequible para todos. Nos comentaba que en la época de su padre y de su abuelo eran muchos los que conformaban el taller. El paso del tiempo, los salarios, la masiva emigración de la zona rural a las ciudades y la búsqueda de trabajos menos sacrificados y mejor remunerados, impidieron que el taller 
continuara en la dimensión de aquella época. Era entonces, cuando ellos trabajaban para las tiendas, enviando producción a joyerías en Burgos, Zamora, Salamanca, Valencia,...

En la actualidad, la única manera de poder poner producto en el mercado a precio competitivo es trabajando sólo, para particulares (él no trabaja para ninguna joyería, ni hace joyería en serie) y que éstos tengan la paciencia suficiente de esperar. A veces, esperar por una pieza suya supone uno ó dos años.

Sólo desde las AAPP, se podrá intentar evitar la desaparición de este tipo de artesanos que en la actualidad está en vías de extinción.

Hemos llevado a cabo el estudio del proceso de ejecución del botón charro en el taller de José Luis Nieves, todo ese proceso de ejecución de nuestro botón charro en filigrana consta de los siguientes pasos.

a.Transformación de la materia prima en hilo.

b.Del hilo al botón.

c.De la Filigrana al papel.

d.El libro de notas o Libro de Humos.

e.El hilo se hace joya.

a. Transformación de la materia prima en hilo ${ }^{152}$

Nieves empieza su explicación, comentándonos que antiguamente se utilizaba el horno de forja. Con la manivela se atizaba el carbón y encima se ponían los recipientes para fundir. Ahora lo hacemos, calentando con bombona de butano porque es más cómodo y no siempre fundo.

${ }^{152}$ Anexo, Cit, Fotos N-1 a N-43. 
Cuando hago hilo, suelo dedicar una o dos jornadas para hacerlo, aunque yo sólo tengo dificultad para que no se enrede y tiene alguien que venir a ayudarme.

El material para trabajar y hacer Filigrana puede ser una barra (para el hilo) o en forma ovalada para luego hacer una chapa de plata. (960 mm).

Echo el metal en el "Riel" y obtengo las barras de metal para luego trabajarlas. Estas barras, las trabajo en la "Trefiladora" ${ }^{153}$ con la que se trefila el metal.

El metal para trabajarlo, hay que darle de vez en cuando calor, enfriándolo un poco, para que le metal al ser dúctil y maleable, al darle temperatura podemos estirarlo hasta hacer los hilos que necesitamos.

La trefiladora que tiene Nieves, procede de Portugal (Oporto) y está en la familia desde que su bisabuelo llegó a España. Una vez que se tiene la barra de metal a la que se da calor para trabajarla como explicábamos antes.

Una vez trabajado el metal pasándolo por las distintas ranuras de la Trefiladora, empezamos a pasar el metal por los carretes.

Los carretes se sujetan a la máquina de hilar y a base de cambiar los carretes, vamos adelgazando los hilos hasta dejar algunos como si fueran pelos.

El hilo resultante, se va enroscando para tener material en función del uso que le demos. El hilo que obtengamos, lo utilizamos para hacer las "Guías".

Las Guías, son hilos sencillos, no entrelazados, que son los que hacen las veces de armazón para albergar la Filigrana. La guía es el hilo de plata que perfila o delimita la Filigrana (como veremos en el apartado

\footnotetext{
${ }^{153}$ Trefiladora: es una máquina manual que tiene dos cilindros con curvas de diferente grosor para poder estirar las barras de metal naciendo que éstas, tenga cada vez una sección mucho más pequeña. Fuente oral.
} 
siguiente cuando estudiemos la ejecución del botón). Las guías generalmente son más altas que la Filigrana, esto es así, para poder sujetarla.

El hilo que utilizamos para la Filigrana propiamente dicho, ha de ser entorchado, es decir, entrelazados unos hilos con otros.

Nieves prepara los hilos para entorcharlos. Empieza a enroscarlos con los dedos y continúa el entorchado de los finísimos hilos, frotando dos maderas para obtener al final el hilo doble entorchado con el que se hará la Filigrana. Una vez que tenemos preparado este nuevo hilo doble, pasamos a "escarcharlo". Escarchar es aplastar el hilo doble con la máquina laminadora, y obteniendo como resultado un hilo plano. Todo este proceso se lleva a cabo en una máquina manual llamada "laminadora". La laminadora también se utiliza para laminar la plata. La plata se mete entre los dos rodillos y estos la van aplastando. Según se aprieten las ruedas, la presión será mejor y se obtendrán más fácilmente las planchas de plata. Hay que decir, que la Filigrana también se puede hacer sobre una plancha muy fina de o,4 mm, y en ella se trabaja poniendo hilos y granos. (Ej.: Botón turco). Además, las láminas también se necesitan en los elementos de los que hablaremos más adelante. .

El hilo entorchado y escarchado ya está listo para poder hacer la Filigrana. A partir de este momento, estamos en disposición para empezar a ejecutar el botón.

\section{b.Del hilo al botón ${ }^{154}$.}

El botón se hace en diferentes pasos. Esta pieza consta de 10 hojas que se unen todas ellas en un mismo punto concéntrico, dando como resultado una forma semejante a la de las margaritas. Lo primero que se hace es tomar el hilo (redondo, no aplastado o escarchado) que será el que nos valga para hacer la guía. El artesano ya tiene la medida exacta (aquí

\footnotetext{
154 Anexo, Cit, Fotos N-44 a N-112
} 
queremos hacer una salvedad, que complemente esta explicación. En el taller de Michel Cordón, él nos explica como en el taller de su abuelo se medían los hilos de las guías con un medidor, semejante a un triángulo rectángulo, dentado en el lado opuesto al ángulo (hipotenusa) utilizando cada sección en función del tamaño del botón que se quisiera realizar ${ }^{155}$. Este medidor es muy antiguo y forma parte del legado joyero de la familia Elena-Cordón. Este elemento, será fundamental a la hora de explicar en la futura tesis, las medidas áureas del botón que en el momento de redactar este trabajo estamos realizando y cuyas conclusiones y fórmulas aportaremos con posterioridad).

El artesano prepara el material para que el proceso se interrumpa el menor número de veces posible, ya que de la organización del mismo, depende el ahorro del tiempo en la ejecución de la pieza. Así, prepara el hilo ya cortado de la guía y deja preparado el instrumental que necesitará en el proceso. Los cortadores de metal, que aparecen junto al hilo, suele utilizarlos el artesano para sacar los círculos de plata que utilizará para realizar las casquillas (semiesferas que una vez hechas el artesano embute utilizando los embutidores, que veremos más adelante.)

Las manos de Nieves, se convierten en un instrumento ágil y ayudado de una pequeña pinza, que maneja magistralmente, comienza la ejecución de la guía sobre la que se macizará con Filigrana. Podemos apreciar cómo el artesano maneja con la habilidad de un tejedor el hilo de plata. Nos asombra, como hace fácil lo difícil y él, con la modestia de los grandes, nos comenta que no tiene nada de especial, que es la experiencia de los años, y de la ejecución de todos los que ha hecho, la causa de la habilidad en la ejecución.

En el proceso de la realización de la Filigrana, ya desde antiguo, supuso una gran incógnita saber cómo se unían los hilos y los granos, de tal

\footnotetext{
${ }^{155}$ Anexo, Cit, Fotos AN-1 a AN-13. Estas fotos corresponden a las fotos propiedad de Michel Cordón que en su taller de Matilla de los Caños pudimos consultar, dejándonoslas fotografiar ya que pertenecen a su familia.
} 
menara que apenas quedaba testimonio de cómo se producía la soldadura. El secreto, no es ni más ni menos, que utilizar una sustancia compuesta por lima de plata+agua+bórax. Ésta, se deposita suavemente sobre lo que queremos unir y dándole fuego queda perfectamente soldado sin que prácticamente quede testigo de la soldadura.

En este estado de cosas, ya tenemos preparada la guía que actúa como el armazón de la pieza y el artesano ayudado de su inseparable pinza, empieza a realizar las pequeñas espirales (en esta ocasión ya con hilo escarchado) que valdrán para empezar a rellenar la guía. Aquí empieza una parte apasionante de la Filigrana donde la minuciosidad y la pericia del artesano van conformando y macizando la figura inicial.

Terminada, se utiliza el dado de embutir. Este dado es un cubo metálico, de bronce, donde se encuentran los tamaños de las distintas semiesferas, donde Nieves (en función del tamaño del botón que realiza, o de la chapa que tiene que trabajar), utilizando un embutidor de madera de Boj, golpea suavemente la estructura de Filigrana para darle la forma al futuro botón. Previamente utilizando el mechero, y soplando, calienta la pieza para facilitar el resultado. En esta operación, la utilización de la madera de Boj, no es casual; se utiliza, porque esta madera es muy dura pero, no daña para nada ni el metal ni la Filigrana. El resultado es un casquete donde queda definida la base de Filigrana sobre la que posteriormente vamos a trabajar.

A continuación, Nieves, utiliza un muelle de plata donde va cortando pequeños círculos del muelle que coloca en una madera y a continuación utilizando de nuevo el mechero y dirigiendo la llama a través de la pipeta de metal por donde sopla, funde obteniendo unos granos de plata o bolitas que una vez frías, lleva con las pinzas a un círculo de embutir y utilizando un embutidor de hierro, (con la punta roma), golpea las bolitas, para obtener las casquillas o semiesferas, que se pondrán sobre la Filigrana dando el aspecto de bola maciza sobre la Filigrana. 
Nieves, utilizando la solución de soldadura que ya hemos explicado antes, y ayudado con una pinza (elemento indispensable en todo el proceso), va colocando cada una de las casquillas en la parte correspondiente. Así, hasta colocarlas todas. Terminada esta parte del proceso, vuelve a utilizar el fuego con la misma técnica que ya hemos conectado para dirigir la llama sobre el botón, y de esa manera con el calor dejar soldadas todas las casquillas. En este momento el botón empieza a tener la forma de lo que será al final.

En este momento del proceso, él ya tiene preparados dos círculos de hilo escarchado, que posteriormente colocará de forma concéntrica sobre el botón, utilizando la soldadura para colocar los aros sobre el botón y darle de esa manera el realce y la belleza al mismo.

Es en este momento, cuando vuelve otra vez a tomar otro muelle de plata (esta vez de diámetro menor), cortando círculos de plata que coloca de nuevo sobre la madera y aplicándoles de nuevo el fuego, los transforma en granos macizos mucho más pequeñitos, los cuales, colocará cuidadosamente con posterioridad. Antes de colocarlos, utiliza un perforador, para dar el tamaño necesario a la segunda fila de Filigrana del botón. A continuación, pone el primer aro, coloca después las bolitas, coloca el segundo aro más pequeño y termina con una casquilla en el centro. En todo este proceso siempre impregna todos los elementos con la solución de soldadura.

Colocado y ordenado pasa de nuevo a darle fuego, quedando concluido en este momento la ejecución en Filigrana del Botón Charro.

Es a partir de este momento cuando entramos en otra fase que es la fase de terminación para su comercialización, que consiste en el lijado, pulido, y por último se le da la terminación que deseemos: plata brillante, pavonada, o sobredorada. Esta parte, la desarrollaremos ampliamente en el apartado correspondiente al Taller de Michel Cordón. 
c.De la Filigrana al papel ${ }^{156}$

En esta jornada de trabajo apasionante, de entre las muchas cosas que Nieves tiene en su taller, desde el principio nos llamó la atención, los dibujos exactos que tenía de las piezas de Filigrana que realiza.

Desgraciadamente coincidir en su taller con obra terminada, es muy difícil, puesto que como él trabaja por encargo, una vez que los tiene terminados, los clientes los retiran inmediatamente. Este es el motivo por el que me llamaron la atención los dibujos que tenía y al preguntarle como los realizaba y cómo conseguía la exactitud de los mismos, fue cuando nos explicó y nos demostró la técnica del paso del dibujo de la Filigrana al papel.

Consiste en lo siguiente: él caliente la pieza, y cuando está al rojo vivo la pone sobre el papel. Con un cuadernillo la tapa y con el martillo golpea por encima. La magia está cuando al retirar el cuadernillo vemos que la pieza incandescente ha quemado levemente el papel, obteniendo de esta manera el dibujo perfecto de la pieza.

Este proceso lo suele realizar cuando quiere dejar constancia de alguna pieza especial que habitualmente no realiza, apuntando dimensiones y anotaciones o la casuística correspondiente a la ejecución de dicha pieza.

d.El libro de notas o libro de humos ${ }^{157}$

Todas las cosas que hay en el taller de Nieves: máquinas, utensilios, aparatos,... etc., tienen un encanto especial. Para un neófito en la materia, es entrar en un mundo lleno de interrogantes y de inquietudes. Verle trabajar, oírle hablar, y sobre todo, comprender la filosofía de una manera de trabajar anclada en el tiempo, hacen que el observador, en este caso nosotros, abramos los ojos de una manera diferente. Casi escudriñamos los rincones del taller, él nos deja, y gracias a ello, descubrimos en una caja un viejo libro de notas que al cogerlo hace que se nos encoja el alma.

\footnotetext{
${ }^{156}$ Anexo, Cit, Fotos N-113 a N-126

${ }^{157}$ Anexo, Cit, Fotos N-127 a N-152
} 
Este block de notas contiene los dibujos calientes de esta generación de artesanos, donde bisabuelos, abuelos, padres e incluso él mismo, han utilizado para dejar constancia de la memoria histórica en la ejecución de las piezas de Filigrana.

Aquí aparecen piezas, dimensiones, encargos, modelos, que evidencian el ajetreo y la riqueza de un taller que ha perdurado a lo largo de los siglos.

Desde aquí, nuestro más sincero agradecimiento a Nieves, que nos ha permitido fotografiar e incluir en esta parte del trabajo un documento inédito que forma parte de la historia familiar, y de ahora en delante de la historia de la Filigrana Charra salmantina.

Se llama libro de humos porque los dibujos se hacen con la pieza al rojo sobre el papel, quemando éste y así aparece a forma de grabado quedando como un dibujo.

\section{e.El hilo se hace joya ${ }^{158}$}

Es en este último apartado, donde podemos apreciar como el dibujo es la base de lo que posteriormente, utilizando la técnica de la Filigrana que ya hemos descrito, y siendo el hilo la base de todo el trabajo, éste, unido a la pericia, sabiduría y buen hacer de Nieves, se convierte en una joya única.

Cada vez que Nieves realiza una pieza, cuando la termina es única, puesto que, cuando realice otra (aunque el resultado sea aparentemente el mismo) el proceso será único e irrepetible para esa pieza. Este es el valor de las piezas de este artesano. Para quienes somos capaces de valorar el trabajo, la experiencia, la técnica y por supuesto la belleza, comprendemos el precio de mercado de estas piezas de arte que se realizan en un taller anclado en el tiempo, y que son parte de nuestra memoria.

${ }^{158}$ Anexo, Cit, Fotos N-153 a N-162 


\section{El proceso semiartesanal de la joya: la microfusión.}

\subsection{Antecedentes Históricos}

Compartimos opinión ${ }^{159}$ al pensar que la fundición a la cera perdida se viene utilizando ya desde hace 4000 años según unos o 6000 según otros, la literatura disponible en español sobre este tema es muy escasa. Aunque en la actualidad la Microfusión está siendo muy utilizada por la industria joyera no debemos olvidar que en realidad fueron los laboratorios dentales quienes la incorporaron a sus métodos de fabricación para prótesis a principios de Siglo XX.

La fundición es conocida desde tiempos muy remotos. En la antigüedad, el hombre descubrió que si calentaba el cobre hasta alcanzar el estado líquido, lo decantaba en un molde y lo dejaba enfriar, podía obtener una gran variedad de formas.

Los primeros moldes que se utilizaron eran de tipo abierto, de una sola pieza. Posteriormente, se fueron perfeccionando, hasta llegar a los de tipo cerrado, de dos piezas.

Con el tiempo, el proceso de fundición fue mejorando hasta alcanzar una técnica que permitió la reproducción de objetos, previamente creados en un material que más tarde pudiera ser eliminado, como la cera, utilizando moldes desechables. Fue el inicio del proceso de "fundición a la cera perdida".

El concepto de cera perdida, debe su origen a que este proceso se realiza con la ayuda de un modelo de cera, que se recubre con un material refractario con el que se forma el molde y que, más tarde, se quema para eliminar la cera que "se pierde".

Aunque existe una cierta diversidad de opiniones, la mayoría de autores se inclinan a creer que este tipo de fundición comenzó a utilizarse a

\footnotetext{
159 ALSINA BENAVENTE, J, La fundición a la cera perdida: la microfusión, Edit, Alsina, Barcelona, 1992. pp 120 ss.
} 
finales de cuarto milenio a.C., al mismo tiempo que la metalurgia y la extracción de metales de los minerales. No obstante el Knight' s American Mechanical Dictionary, sitúa a estos inicios hacia el año 2230 a.C.

Unos mil años, más tarde, en el tercer milenio a.C., se inició la metalurgia del oro, la plata, el antimonio, el plomo y las aleaciones de bronce. Las posibilidades aumentan considerablemente cuando se descubre que ciertos minerales que contienen metales pueden fundirse y que, los materiales obtenidos, pueden purificarse y volverse a fundir.

Egipto nos proporciona uno de los primeros trabajos de este tipo que se conocen. Se remonta a la época de Ramsés, unos 1400 años a.C.. Los etruscos, unos 1000 años a.C., ya modelaban con una habilidad magistral. Según se ha podido comprobar, también los antiguos griegos y chinos empezaron a utilizar esta técnica hace más de 2000 años.

Existen ejemplos de bellas piezas fundidas a la cera perdida, obtenidas por culturas tan diversas como: los sumerios de Ur en Medio Oriente, además de los griegos, egipcios y chinos.

En una época posterior que comienza unos 400 a.C., el proceso se desarrolló independientemente en el nuevo mundo, siendo utilizado por los Indios Precolombinos de América del Sur, y las civilizaciones Azteca y Maya de América Central, para reproducir las complicadas piezas de oro que ahora podemos admirar en las colecciones que se exhiben en algunos museos. Esta técnica también es practicada por algunas tribus africanas desde hace cientos de años.

Existen innumerables testimonios que confirman la antigüedad de la fundición a la cera perdida. En el libro de Isaiah, del año 712 a.C., se cita un ternero de oro realizado por Aarón, hecho de metal fundido y decorado con una herramienta de grabar. Una figura de bronce de Nero que fue fundida por Zenodorus, un artesano griego para el Coloso, junto al Templo de Venus en Roma y muchísimos más cuya enumeración resultaría demasiado extensa. 
Desde siempre y en todas partes se ha trabajado con cera y fundido en barro.

La fundición a la cera perdida ofrece dos posibilidades:

- Se funde el objeto en una sola pieza,

- o en varias partes que posteriormente se ensamblan.

Esta segunda posibilidad es conocida como "fundición por partes".

En los libros de historia se citan moldes de piezas y de fundición por partes producidos en el año 328 a.C..

A partir del Siglo XI en Alemania, fueron apareciendo florecientes fábricas. En 1022, Hildesheim fue una alta escuela. Dan fe de ello, las grandiosas puertas batientes de las cúpulas en 1015, las columnas de Bernwards en 1022 y, de la misma época muchos utensilios religiosos y pilas bautismales de fantástica belleza, fundidas en una sola pieza, totalmente irrealizables en fundiciones en arena.

La técnica de fundición a la cera perdida se consagró, alcanzando la perfección, en los trabajos Benvenuto Cellini, el orífice y escultor florentino que produjo preciosos trabajos de joyería en el Siglo XVI, llevó a cabo numerosas mejoras técnicas y dejó constancia escrita de sus métodos.

Después de Cellini, las técnicas de fundición a la cera perdida casi desaparecieron, excepto para algunos joyeros, muy pocos, entre los que se encuentra Karl Fabergé que creó preciosas y complejas piezas de joyería para el último de los Zares de Rusia, a principios del Siglo XX.

Son muy variados los procesos de fundición que actualmente siguen utilizando los joyeros $y$, en algunos casos, puede decirse que siguen aplicándose de la misma forma primitiva que lo hacían sus inventores. 
Otros, en cambio, se han inclinado por la utilización de técnicas muy refinadas, empleando materiales especialmente preparados para satisfacer la creciente demanda de precisión en la reproducción de los modelos.

Entre estas últimas destaca la fundición a la cera perdida, que hasta su aplicación en la tecnología dental, sobre 1907, puede decirse que no se había vuelto a utilizar...A pesar del éxito obtenido por los dentistas, tuvo que transcurrir un cuarto de siglo hasta 1930, antes de que los talleres de joyería descubrieran que podían utilizarlo. El factor que hizo posible la adaptación del proceso a la joyería moderna fue la circunstancia de que, utilizando moldes de caucho podían utilizar rápidamente duplicados de las piezas en cera.

En otras palabras, los joyeros añadieron una etapa al proceso utilizado por los dentistas, el molde de goma, lo que les permitió, de forma rápida y muy precisa, modelos de cera que posteriormente servirían para obtener piezas de oro, plata, platino o paladio, partiendo de un único modelo original.

En 1950, un nuevo grupo de artesanos comenzó a interesarse por el procedimiento. Trabajando separadamente, consiguieron crear un nuevo tipo de joyería fundida, estilizada y funcional.

Esta técnica, actualmente muy perfeccionada, se está utilizando para reproducir, prácticamente, cualquier pieza de joyería que quiera fabricarse en serie. Debido a su rápida y fácil aplicación, resulta indispensable si se quiere competir en precio y porque permite la obtención de volúmenes y formas imposibles de conseguir a mano. Es el medio perfecto para reproducir piezas de joyería, partiendo de un modelo original único, exactamente tal como el artista lo creo.

Hoy en día, hay tres grupos principales que utilizan la técnica de fundición a la cera perdida: 
- Los artesanos que trabajan directamente la cera para obtener piezas únicas.

- Los fabricantes que utilizan moldes de caucho para reproducir muchas piezas iguales $\mathrm{y}$,

- Los estudiantes de escuelas y centros de artesanía que emplean esta técnica con fines creativos y educativos.

1. Ventajas, limitaciones y controles

-Ventajas

El procedimiento resulta especialmente apropiado para la fabricación de anillos, engastes, piezas de hechura, cajas de reloj de fantasía, fornituras y para todas aquellas piezas cuyo proceso de fabricación o los medios necesarios para el mismo, exigen costes elevados, como pueden ser las operaciones de estampado, las soldaduras complicadas o cuando se requiera mucha mano de obra.

Aunque para algunas operaciones específicas se emplea mano de obra semicualificada, para los procesos más importantes, tales como la elaboración de los moldes de caucho y la propia colada se requiere mano de obra especializada.

Puede utilizarse cualquier aleación de plata, oro de color, oro blanco, paladio, platino, etc. de las que habitualmente se emplean para la fabricación de piezas de joyería. También puede emplearse el latón y otras aleaciones de metales comunes.

Si el proceso se emplea adecuadamente, pueden reducirse los costes de mano de obra porque, partiendo de un modelo hecho a mano, puede obtenerse cualquier cantidad de piezas, exactamente iguales al original, que sólo precisarán un ligero repaso. 
Pueden fundirse varias piezas al mismo tiempo.

La cantidad de metal de desperdicio 0 recortes queda considerablemente reducido.

Las piezas obtenidas por este procedimiento son más densas, presentan una estructura de grano más compacto y son menos porosas que las resultantes de cualquier fundición colada por gravedad.

-Limitaciones:

Para poder satisfacer las altas exigencias actuales sobre la obtención de piezas fundidas, para que presenten una superficie lisa, libre de poros y oquedades, es imprescindible poseer un conocimiento muy preciso de las técnicas de fundición para cada aleación en particular.

La elección de los modelos para inyectar, presenta algunas limitaciones. Cuando se trata de piezas cuyo tamaño queda por encima de la media, o de forma complicada, es aconsejable recabar la opinión de fundidores experimentados.

Es sabido, que las piezas de fundición no pueden proporcionar una superficie tan lisa y uniforme como la que se obtiene con material laminado. Incluso la superficie de una pieza pulcramente abrillantada puede presentar en su interior cuantiosos poros, oquedades y oclusiones.

La principal limitación de la función centrífuga con revestimiento, la determina el tamaño máximo de la pieza a fundir, en relación con las dimensiones del cilindro. Sin embargo, esto puede superarse planeando modelos en varias partes que, posteriormente, pueden unirse por medio de soldaduras, o cualquier otro medio, para obtener conjuntos con mayores dimensiones, en general, las piezas fundidas, no presentan propiedades estructurales, direccionales como ocurre por ejemplo, con las piezas forjadas o estampadas. Por este motivo, tienden a romperse cuando se doblan. También son menos flexibles que el metal forjado o extruido porque carecen 
de la dirección longitudinal de la estructura cristalina, presente en los metales formados por otros métodos.

-Controles:

Todos los modelos, deben examinarse cuidadosamente para determinar si resultan apropiados para la fundición.

También es necesario llevar a cabo un severo control de todas las fases de trabajo. Las imperfecciones en las copias de cera, grietas en moldes, inclusiones en el metal fundido y similares, se harán ostensibles en el producto final, por lo que deben eliminarse cuanto antes.

La acumulación de poros en una pequeña inclusión o un resto de óxido, más adelante pueden transformarse en una grieta. Esto casi nunca ocurre en las piezas fabricadas con material laminado.

2. Sistema operativo.

A grandes rasgos, es el siguiente:

- Cada reproducción procede de un molde, copia del original.

- El modelista prepara un modelo de cera que se prepara en el interior de un recipiente metálico.

- Se vierte yeso sobre el modelo hasta cubrirlo totalmente.

- Cuando el yeso ha fraguado se introduce el recipiente en un horno especial hasta que la totalidad de la cera fluye a través de unos canales previamente dispuestos.

- La cera, al abandonar el molde deja una cavidad que corresponde exactamente a la forma del modelo original.

- Se inyecta el metal fundido en la cavidad, ya sea por medio de fuerza centrífuga, el vacío, a presión, etc. 
- Cuando el metal inyectado ha solidificado, se enfría el molde, se elimina el yeso y se extrae la pieza fundida.

- A continuación, se repasa, se lima y se pule hasta lograr un acabado lo más perfecto posible.

- Utilizando este modelo metálico se prepara un molde de caucho.

- Después de cortar el molde caucho, se prepara el modelo metálico y se inyecta cera fundida, para obtener tantas copias como se quiera.

- Se forma el árbol y se sigue como se ha indicado para el modelo original de cera. Revestido, fraguado, quemado, inyectado, enfriado, separación de la fundición del yeso, corte de bebederos, repaso y acabado.

3. Precauciones a tener en cuenta.

- El procedimiento no conlleva ningún peligro que no pueda prevenirse convenientemente de forma sencilla.

- Deben elegirse ceras que, al fundir o al quemar, no desprendan vapores tóxicos.

- Si se quiere evitar que el polvo del revestimiento produzca daños en los pulmones, no debe dejarse que se disperse de forma irracional.

- Durante la fundición y la colada deben llevarse gafas protectoras y, si se trabaja con máquinas centrífugas, también deben disponer de protecciones adecuadas para evitar posibles salpicaduras de metal caliente.

4. Datos económicos.

En general, a través de este procedimiento, puede llevarse a cabo cualquier trabajo que justifique el coste de los moldes y del subsiguiente montaje. 
El proceso de fundición también ofrece ventajas, incluso con pequeñas cifras de producción, en especial cuando se trata de piezas complicadas.

Para obtener una fundición de calidad, son necesarias costosas instalaciones cuya adquisición queda condicionada a las disposiciones de capital y a las perspectivas de producción. El almacenamiento de las ceras, caucho para moldes, revestimientos, etc., resulta igualmente costoso, de forma que debe existir una producción mínima que garantice una cómoda amortización.

Las mazarotas y los canales de alimentación exigen mucho metal.

\subsection{La Microfusión para el caso particular de la} Filigrana Charra. Experiencia técnica en el taller del artesano Miguel Ángel Cordón ${ }^{160}$.

La intención que tenemos al realizar este apartado, es utilizar la experiencia de Miguel Ángel Cordón Rodríguez, que lleva realizando este proceso más de veinticinco años en su taller de joyería, como base para la comercialización de elementos joyeros charros, basados en su origen en la Filigrana Charra.

Esta fuente cualitativa que vamos a utilizar, tiene un valor incalculable. La práctica diaria de un proceso técnico, es la que en muchas ocasiones nos ofrece una información que dista mucho de la teoría escrita en los libros. La experiencia obtenida sobre el terreno, es la que vamos a intentar plasmar explicando literaria y gráficamente, un proceso en el que para el caso concreto de nuestro estudio, no hubiéramos podido obtener de bibliografía escrita.

\footnotetext{
${ }^{160}$ Miguel Ángel Cordón Rodríguez, conocido por todos como Michel, es joyero artesano. Realizamos con el todo el estudio del proceso de la microfusión para el caso concreto de la filigrana charra. Todo el aporte documentario fotográfico y teórico de este apartado, lo obtuvimos en su taller de Matilla de los Caños, Salamanca, 2011.
} 
Es de los errores, según apunta nuestra fuente oral, de donde más podemos aprender.

En este orden de cosas, el proceso de la Microfusión para el caso de la joyería charra, se convierte en un "caso particular" de la Microfusión general.

Tanto el orden como la observación directa de todos los factores que intervienen en la ejecución de una pieza reproducida, son los que se convertirán en el eje del éxito de un proceso, complicado para el espectador pero, diario y sencillo para el artesano.

La Microfusión para la joyería y Filigrana Charra, ha sido el instrumento técnico para poder alterar todos los elementos que intervienen en la comercialización de un producto dado. Al ser una técnica que nos ahorra tiempo de producción, ya que nos ofrece "producto en serie", el resultado es que se puede comercializar este producto de forma industrial. La ejecución artesanal de la Filigrana y de todos los elementos que intervienen en ella antes de obtener el producto final, hubiera sido imposible, tanto por tiempo como por el trabajo dedicado.

Gracias a la Microfusión se ha podido dar un "precio social", a piezas, que en su origen (Filigrana) eran de muy difícil adquisición, porque el precio hacía de ellas, elementos de lujo.

Este es el motivo de estudiar de manera especial la Microfusión desde el punto de vista industrial, y así poder explicar mejor el caso que nos ocupa.

2.2.1. Creación de un original artesanalmente.

Hay dos formas de hacer un original:

a.Talla o creación directa:

(Antonio José Martín Sánchez: tallados originales)

(José Luis Nieves: filigranista) 


\section{b.Talla o creación indirecta}

a.La pieza se crea directamente en metal: Esta manera de trabajar creemos que ha quedado ampliamente explicada tanto para el caso de la talla como para el caso de la Filigrana.

b.Utilizando las mismas técnicas manuales, se crea la pieza original en metal, a la que se le incorpora un bebedero de metal. Con esta pieza se lleva a cabo la creación de un molde. Terminado, de él se extrae la pieza original quedando su forma impresa en el caucho que hemos utilizado para el molde. A partir de este momento, este molde, nos servirá para reproducir las veces que necesitemos, la pieza en cuestión, utilizando para ello la cera o cualquier material que pueda quemarse después en un horno sin dejar residuo, como podrían ser resinas, plásticos, jabón, entre otros, aunque profesionalmente se recomienda la cera especialmente creada para Microfusión.

La pieza de metal es el original con el que hemos hecho el molde. Esta pieza, tiene que ser realizada por un artesano que además es un artista.

Algunos puntos importantes a la hora de realizar los originales son:

- Gruesos mínimos: Como norma general el grueso mínimo en los originales no deben ser inferior a 0,20 mm. Para el caso concreto de la Filigrana, este aspecto es fundamental porque si es inferior (hecho que sí pudiera darse en la Filigrana artesanal-manual) no sería factible para el proceso industrial por Microfusión.

- Los tamaños máximos: esto depende de cada taller artesanal. Hay que tener en cuenta el tamaño de la "MUFLA" (interior o cavidad del horno) y de los cilindros de los que se dispone en el taller, es decir, las posibilidades de la herramienta y maquinaria que se van a utilizar. 
- La Microfusión a la cera perdida, tiene siempre o casi siempre, una merma de un $3 \%$ ó $4 \%$ en el tamaño de las piezas reproducidas (respecto al original) este dato es muy importante especialmente en los casos de precisión.

\subsubsection{Creación de un molde industrial.}

Con la creación de un molde, alcanzamos el fin de reproducir una pieza en cantidades industriales. Para ello necesitamos un original de metal ${ }^{161}$ como ya hemos dicho en el punto anterior.

La materia principal para los moldes es el Caucho virgen, que se presenta principalmente en lonchas o láminas, las utilizaremos cubriendo el original usando la misma cantidad de estas láminas tanto por arriba como por abajo. Esta especie de sándwich se introduce en un marco de metal ${ }^{162}$ cuyo grosor y tamaño dependerá de la pieza original de la que pretendemos sacar un molde. Pieza, caucho y marco, se introducirán en una plancha o galvanizadora a $160^{\circ} \mathrm{C}$, de manera que la pieza original, queda atrapada en el interior del caucho fundido. Previamente se habrá colocado un "bebedero" de metal ${ }^{163}$ con salida exterior del molde.

Una vez realizado este proceso, se procede a la apertura del molde resultante $^{164}$, cortando con un bisturí (en este caso utilizamos uno del $n^{0} 11$ porque el artista considera que su forma triangular favorece la apertura del mismo).

Esta apertura tiene que ser precisa y previamente muy estudiada según cada pieza, ya que de su correcta ejecución, dependerá el éxito y buen funcionamiento del molde.

\footnotetext{
${ }^{161}$ Anexo, DVD, carpeta 4. Este anexo en este apartado contiene todas las fotos realizadas en el taller de Michel Cordón, elaboración propia. Salamanca, 2011. Fotos 1 y 2.

${ }^{162}$ Anexo, Cit, Fotos 3,4 y 5.

163 Anexo, Cit, Foto 6.

${ }^{164}$ Anexo, Cit, Fotos 7 a 37.
} 
Se trata de separar en dos mitades o "cachas" quedando la pieza entre ambas. Para esto, tendremos en cuenta la forma de la pieza evitando que los salientes queden en una sola cacha.

Es importante cortar la parte exterior del caucho en forma de zigzag ${ }^{165}$ para evitar, que se deslicen una sobre otra (las cachas) provocando una malformación en las piezas de cera que se van a reproducir posteriormente.

Una vez abierto, se retira la pieza de metal original ${ }^{166}$ con lo que nos quedará su hueco y el del bebedero ${ }^{167}$ que posteriormente será lo que se rellene con cera en el proceso de inyección de ceras.

Datos técnicos a tener en cuenta en este apartado:

- Temperatura de fusión del caucho: en todo caso será indicada por el fabricante ya que todas las planchas de caucho indican su temperatura de fusión.

- Elección correcta del marco. El grueso del mismo, así como el tamaño, dependerá de las dimensiones de la pieza a reproducir y el número de láminas que se utilizaran tanto arriba como abajo estarán en función del grueso del marco elegido.

- Situación del bebedero: es muy recomendable que el bebedero esté soldado a la pieza para evitar que se desplace mientras se hace el molde. Si no pudiera soldarse podremos pegarlo. La boca del bebedero debe de quedar al ras del marco $^{168}$ (Foto 11) para que esté visible y localizado a la hora de abrir el molde.

Este bebedero debe de colocarse de tal manera que favorezca el flujo de la cera que vamos a inyectar posteriormente con el fin de evitar retrocesos de la misma en la inyección.

\footnotetext{
${ }^{165}$ Anexo, Cit, Foto 27.

${ }^{166}$ Anexo, Cit, Foto 23.

${ }^{167}$ Anexo, Cit, Foto 25.

${ }^{168}$ Anexo, Cit, Foto 11.
} 
- Para introducir en la galvanizadora el conjunto de láminas de caucho, con la pieza en su interior y todo ello dentro de su marco ${ }^{169}$ debemos asegurarnos de que la temperatura de ésta sea al menos de $100^{\circ} \mathrm{C}$. El molde lo introducimos en la galvanizadora y la vamos cerrando poco a poco haciendo una presión mínima al principio, presionando nuevamente transcurridos los cinco primero minutos y repitiendo la operación cinco minutos después. La temperatura máxima de la máquina estará previamente programada.

Hay que tener en cuenta el tiempo que estará introducido, será en función del grueso del marco que será de 15 minutos por cada $5 \mathrm{~mm}$. de grueso. Así, un marco de $1 \mathrm{~cm}$. y medio de grueso, deberá permanecer en la galvanizadora 45 minutos permaneciendo en su interior hasta su enfriamiento total.

\subsubsection{Inyección de las ceras.}

Para inyectar las ceras, se coloca el molde haciendo coincidir el bebedero con la boca de salida de la inyectora ${ }^{170}$ que tiene en su interior ${ }^{171}$ cera especial para Microfusión a temperatura de licuación y con presión de aire para facilitar la inyección. Al empujar con el molde sobre la boquilla ${ }^{172}$ la cera se inyecta en el molde a través del bebedero rellenando el hueco que ha dejado el original en el molde, obteniendo así la primera réplica del original hecha en cera ${ }^{173}$. Se recomienda utilizar dos placas para presionar correctamente con las manos y evitar que el molde se abra y se salga la cera. La Filigrana Charra es especialmente sensible a la presión manual en la inyección de cera, ya que cualquier exceso de ésta, supondría que las formas y entresijos creados por los hilos, se obstruyan perdiendo el calado que es la base de la belleza y la idiosincrasia de estas piezas.

\footnotetext{
${ }^{169}$ Anexo, Cit. Foto 4.

${ }^{170}$ Anexo, Cit. Foto 38,39 y 40.

${ }^{171}$ Anexo, Cit. Foto 41.

${ }^{172}$ Anexo, Cit. Foto 42.

${ }^{173}$ Anexo, Cit. Foto 43 a 57.
} 
Dependiendo de cada molde, utilizaremos más o menos presión. Ejemplo: a mayor volumen de la pieza menos presión, a menor volumen como es el caso de la Filigrana, más presión con el fin de que la cera recorra, antes de enfriarse, todos los recovecos que tiene la Filigrana.

En caso necesario se variará la presión de la inyectora y nunca la temperatura.

Cuanto más alto es el punto de fusión de las ceras mayor contracción tendremos y al enfriarse habrá más reducción en el tamaño de las reproducciones.

Igual que en el caucho, la temperatura de fusión, dependerá de cada tipo de cera y será el fabricante quien nos indique la temperatura idónea en cada caso.

Para el caso de la Filigrana, así como objetos muy finos, se trabajará con una cera que tenga un punto alto de fusión.

Por supuesto, la cera que se desecha por piezas incorrectas ${ }^{174}$ puede volver a refundirse, pero se recomienda mezclarla con cera virgen en la siguiente proporción: $75 \%$ cera virgen, $25 \%$ cera usada.

La cera que se usa en Microfusión ha de tener memoria y elasticidad. La memoria, es la capacidad de esta cera para recuperar su estado original. Ejemplo: al sacar una cera de su molde puede doblarse o pandearse ligeramente, si la cera tiene memoria recuperará su posición original por sí sola. La elasticidad nos proporciona un resultado similar pudiendo trabajar con esta cera sin que se parta o desestructure.

Estas cualidades merman si reutilizamos la cera sucesivas veces.

Con el fin de no tener que variar continuamente la presión de la inyectora, en el caso de trabajar con varios moldes a la vez, procuraremos que estos sean similares y puedan inyectarse con la misma presión. Por lo

${ }^{174}$ Anexo, Cit. Foto 58 y 59. 
tanto es recomendable clasificarlos por grupos teniendo en cuenta este concepto a la hora de comenzar los trabajos de inyección. De esta manera aprovecharemos la variable económica "tiempo", que es un factor importantísimo para imputárselo después al precio final del producto.

La presión inyectora que se utiliza para un sello de caballero por ejemplo, será de 0,1 Bares de sobrepresión mientras que para el caso de la Filigrana Charra y piezas muy finas será de entre 0,3 y 0,6 Bares de sobrepresión equivalente a 22,5 cmHg y $45 \mathrm{cmHg}$. (1 Bar equivale a 75 cmHg (centímetros de mercurio) por lo que $75 \times 0,3=22,5 \mathrm{cmHg}$ y $75 \times 0,6=45$ $\mathrm{cmHg}$ ). Utilizamos el concepto de sobrepresión porque es la presión por encima de la atmosférica.

Resumiendo a mayor volumen menor presión y viceversa.

Si fuera necesario, en el molde, deberemos realizar unos pequeños cortes con el bisturí en las zonas más exteriores del hueco de la pieza, para facilitar de esta manera la expulsión del aire ${ }^{175}$. Esta tarea deberemos realizarla en las primeras pruebas de cera que realicemos, ya que si observamos que en el producto obtenido del molde se producen burbujas de aire, deberemos corregirlas inmediatamente. Aunque no siempre es necesario.

Todas las piezas que obtengamos de cera se revisarán meticulosamente,(especialmente las primeras) comparándolas siempre con el original ${ }^{176}$ observando hasta el más mínimo detalle, buscando errores para corregirlos si los hubiera, para que al final se pueda considerar el molde como válido.

Si observamos que en dos o más piezas seguidas se repite el mismo fallo, es muy probable que este se deba a una partícula de cera que se haya quedado en el molde obstaculizando el paso de la nueva cera inyectada. En

\footnotetext{
${ }^{175}$ Anexo, Cit, Foto 21.

${ }^{176}$ Anexo, Cit. Foto 1 y 2.
} 
este caso, localizaremos dicha partícula y procederemos a la limpieza correcta del molde.

En algunas ocasiones podemos utilizar polvo de talco en el molde para evitar que la cera se adhiera al mismo haciendo éste el efecto de desmoldeante.

Todas las piezas nuevas de cera que hayamos considerado correctas deberán colocarse en bandejas. En estas bandejas agruparemos los elementos por modelos, para facilitar con posterioridad tanto el recuento como la posterior creación de árboles o "enramado" que explicaremos a continuación.

Todas las bandejas que utilicemos para colocar los elementos de cera, deberán cubrirse mientras están almacenadas para evitar el polvo en las mismas, ya que este fenómeno complicaría el posterior éxito del proceso.

Todos los moldes, deberán estar archivados y colocados de tal manera que sea fácil acceder a ellos sin tener que perder mucho tiempo en la visualización particular de cada uno. En mi caso concreto, tienen un orden numérico y van archivados correlativamente en función de los temas y de las piezas $^{177}$.

\subsubsection{Enramado.}

Se trata de colocar las piezas mediante soldadura de cera en un tronco de cera, a modo de árbol ${ }^{178}$ utilizando un soldador eléctrico o bolígrafo eléctrico ${ }^{179}$.

Se coloca el tronco ${ }^{180}$ en una base de goma teniendo en cuenta la altura del cilindro que posteriormente vamos a usar de esa manera, las primeras piezas se colocarán en la parte superior del tronco a $1 \mathrm{~cm}$. y medio

\footnotetext{
${ }^{177}$ Anexo, Cit, Foto 60 y 61.

${ }^{178}$ Anexo, Cit. Foto 60 a 78.

${ }^{179}$ Anexo, Cit. Foto 65.

${ }^{180}$ Anexo, Cit, Foto 79 a 82.
} 
por debajo de la altura del cilindro ${ }^{181}$. Esto se hace para que el centímetro y medio de revestimiento que quedará entre la pieza y el ras del cilindro pueda soportar el impacto del metal a la hora del vaciado. Si no se mantuviese ese centímetro y medio de distancia mínima, se podría romper el revestimiento saliendo el metal líquido por fuera del cilindro pudiendo provocar serios daños tanto al operador como a las piezas en sí, que saldrían parcialmente rotas o directamente no saldrían.

Las piezas como ya hemos dicho, se colocan de arriba abajo teniendo cuidado de que no se toquen unas con otras (si bien la separación entre ellas puede ser mínima) de lo contrario, saldrían unidas por los puntos de contacto. Su colocación debe ser por este orden, ya que si se hiciese al revés podrían caer gotas de cera sobre las piezas ya colocadas abajo ${ }^{182}$.

También, hay que tener cuidado de no tocar con el bolígrafo soldador las piezas que ya vamos soldando y quedan colocadas porque las deformaríamos y saldrían defectuosas.

Es aconsejable y muy recomendable, colocar las piezas más delgadas en el parte superior y las más gruesas en la parte de abajo del árbol $^{183}$ todo esto en el caso de que el árbol se componga de piezas diferentes. Lo ideal sería, hacer árboles homogéneos. Para el caso concreto de la Filigrana, es recomendable que las piezas más finas y caladas, estén en la parte superior del árbol ya que el metal fundido llegará con más presión a estas zonas en el posterior proceso de centrifugado o vaciado por colada.

Es muy importante que las piezas colocadas en el enramado, tengan una inclinación con respecto al tronco y hacia arriba de al menos $45^{\circ}$, no inferior y por supuesto nunca perpendicular o inclinada hacia abajo ${ }^{184}$. Esta inclinación favorece el flujo del metal al centrifugar, ya que precisamente, por

\footnotetext{
${ }^{181}$ Anexo, Cit, Foto 82 y 83.

${ }^{182}$ Anexo, Cit, Foto 70 a 78.

${ }^{183}$ Anexo, Cit. Foto 76.

${ }^{184}$ Anexo, Cit. Foto 76.
} 
ser fuerza centrífuga nunca podrá fluir hacia atrás, por lo que las piezas colocadas en horizontal, tienen pocas posibilidades de éxito y las colocadas hacia abajo ninguna.

Las piezas inferiores, es decir las últimas que se colocan, deben guardar una distancia de $1 \mathrm{~cm}^{185}$ como mínimo con la base de goma ninguna de las piezas debe tocar la pared del cilindro.

Conviene en cada punto de unión al tronco, añadir una gota de cera para evitar que queden pequeños espacios que después al verter el revestimiento, se conviertan en pequeñas partículas de éste, que pueden ser fácilmente arrastradas con la entrada del metal fundido. Si estas partículas al ser arrastradas quedan en los huecos que forman la pieza, crearan una impureza que será asimismo una pequeña malformación que estropeará la pieza final. Si se trata de Filigrana, puede crear una obstrucción que no deje fluir el metal líquido quedando la pieza final sin rellenarse completamente. Sería el efecto de un trombo en el flujo.

El grueso del tronco debe adaptarse al agujero de la goma.

Antes de comenzar un árbol, debemos pesar la goma base y al finalizarlo pesaremos el conjunto (base+ceras) ${ }^{186}$ y restando a este total el peso de la base y así sabremos el peso de la cera, importantísimo para calcular el peso del metal que necesitaremos más adelante.

\subsubsection{El revestimiento ${ }^{187}$.}

Para entenderlo ${ }^{188}$ fácilmente, diremos que es una especie de "escayola" especial para este proceso de Microfusión que contiene, cristales de sílice entre otros componentes. Estos cristales se funden entre sí cuando

\footnotetext{
${ }^{185}$ Anexo, Cit, Foto 76.

${ }^{186}$ Anexo, Cit, Foto 84.

187 Anexo, Cit, Foto 85 a 118.

${ }^{188}$ Para el proceso del revestimiento recomendamos visionar las fotos indicadas de la 85 a la 118, ya que de esta manera se entenderá mucho más fácil el proceso. Aquí las imágenes son más explicativas que la palabra.
} 
el revestimiento se somete a una temperatura de (se indicará en la etiqueta de fabricante) aproximadamente $780^{\circ} \mathrm{C}$. Al fundirse los cristales, crean una película fina y resistente que le dará una textura lisa a la superficie de las piezas de metal, facilitando de esta manera la terminación de la pieza (repasado).

Pasos a seguir en el proceso de revestimiento:

- Mezcla: Cuando se haga la mezcla por primera vez, debemos conocer exactamente la proporción de agua/polvo que necesita cada cilindro. Para ello, llenaremos el cilindro de agua por la mitad más 1 $\mathrm{cm}$. y mediremos en una probeta aforada estrecha para menor margen de error y de esa manera sabremos el volumen de agua que necesita ese cilindro. Ejemplo: un cilindro por la mitad de agua más 1 $\mathrm{cm}$. nos da $300 \mathrm{~cm} 3$ (si queremos hacer la mezcla para ese cilindro al $38 \%$ de agua/polvo quiere decir que por cada 100 gramos de revestimiento añadiremos $38 \mathrm{~cm} 3$ de agua). Si aplicamos una regla de tres, entonces:

- $38 \mathrm{~cm}^{3} \_100$ gramos

$300 \mathrm{~cm}^{3}$

$X=\underline{300 \times 100 ; X=789,47}$ gramos de revestimiento. 38

Si fueran dos cilindros iguales juntos serían:

789,47 gramos x 2, y así sucesivamente.

La proporción de agua debe indicarla el fabricante del revestimiento. En la mayoría de revestimientos puede oscilar entre el $38 \%$ y el $42 \%$ si bien 
para cualquier revestimiento conviene utilizar o aplicar el $42 \%$ para piezas finas (Filigrana Charra y similar) y $40 \%$ o $38 \%$ para piezas más gruesas. A más agua, más fluida la mezcla y entra mejor por los entresijos de la Filigrana.

La temperatura del agua debe de estar siempre controlada entre $21^{\circ} \mathrm{y}$ $25^{\circ}$. A mayor temperatura menor tiempo de fraguado.

Hay revestimientos que tienen mucho cuarzo y silicio que tienen mayor defensa de rotura, es decir, que al entrar el metal la probabilidad de romperlos es menor. Otro componente del revestimiento es la silimanita. Ésta ayuda a formar la malla de fraguado. Si el revestimiento se bate a mano se seguirá el siguiente procedimiento:

- Pesar el revestimiento y echarlo sobre la cantidad de agua que le corresponda. Siempre el revestimiento sobre el agua, poco a poco para evitar grumos.

- Se bate durante 1 minuto y se hace el vacío de la mezcla durante 3 minutos con el fin de extraer todas las burbujas de aire posibles. Para esta función, se usa una vibrobatidora, que tiene un vacuómetro o medidor de vacío que sirve para indicar la fuerza del vaciado. Éste debe de ser el máximo posible que nos permita la máquina, esperando el tiempo necesario para conseguirlo. Las experiencias en Salamanca $(800 \mathrm{mtr}$. de altitud sobre el nivel del mar) es del orden de 70 a $75 \mathrm{cmHg}$, lo cual nos indica que se produce casi el vacío absoluto.

- Seguidamente se vacía la mezcla, ya sin burbujas de aire, en el cilindro donde esté el árbol de cera; lentamente y procurando que no caiga directamente sobre las piezas (algo parecido a cómo se hace con la cerveza para evitar que salga espuma). Previamente habremos colocado un papel alrededor del cilindro con mayor altura que éste, con el fin de poder sobrepasar el nivel ras del cilindro, ya que al efectuar un nuevo 
vaciado de burbujas en éste, el nivel bajará pero nunca por debajo del ras (cosa que pasaría si no pusiéramos el papel). Además, si utilizamos un papel absorbente (Ej.: papel de periódico) éste facilitará el secado de la mezcla. Se recomienda que el forrado del cilindro con papel quede bien ajustado para evitar que se filtre la mezcla entre el papel y el cilindro. Además, se pondrá una cinta adhesiva en la base para sujetarla a la goma y evitar que pueda desprenderse con el peso de la mezcla del interior.

- Una vez lleno el cilindro, se coloca nuevamente en la vibrobatidora (máquina de vaciado) durante otros 3 minutos, y una vez pasado este tiempo, se vibrará sin vaciado más lentamente otros 2 minutos para que acabe de colocarse y asentarse el revestimiento. Es importante insistir que esta vibración se hará suave y lentamente. La duración máxima de esta operación hasta el fraguado es de 15 minutos aproximadamente. Teniendo en cuenta que el porcentaje de agua que utilizamos en la mezcla es mayor para el caso de la Filigrana, el tiempo de fraguado también será mayor.

- A los 25 minutos de reposo y secado, se puede proceder al raseado de los cilindros. Para ello, retiraremos el papel y la base de goma, rasearemos ambas bases con una herramienta de corte ancho (espátula, cuchillo,...).

- Una vez finalizado todo el proceso y antes de calentar el cilindro en el horno, deberá reposar-secar un mínimo de hora y media, aunque lo ideal y tras la experiencia son dos horas y media. A partir de cuatro horas de secado, perdería demasiada agua, pudiendo provocar posteriores roturas. En caso de tener que esperar más tiempo, tendrán que cubrirse las bases de los cilindros con un paño húmedo en el tiempo de espera. 
- Se recomienda crear una tabla en la que numeraremos los cilindros y anotaremos sus pesos y características según cada cual. Todas las gomas deben estar numeradas, así no tendremos que pesarlas cada vez que las usemos.

\begin{tabular}{|c|c|c|c|c|c|c|c|c|}
\hline Cilindro $\mathrm{N}^{\circ}$ & $\begin{array}{l}\text { Peso } \\
\text { base }\end{array}$ & $\begin{array}{l}\text { Peso } \\
\text { base+cera }\end{array}$ & $\begin{array}{l}\text { Diferencia } \\
\text { peso cera }\end{array}$ & $\begin{array}{l}\text { Coeficiente } \\
\text { Peso } \\
\text { Específico }\end{array}$ & $\begin{array}{l}\text { Peso Neto } \\
\text { Peso de la cera } x \\
\text { coeficiente }\end{array}$ & $\begin{array}{l}\text { Peso } \\
\text { del } \\
\text { cono }\end{array}$ & $\begin{array}{l}\text { Peso } \\
\text { total }\end{array}$ & $\begin{array}{l}\text { Tipo de } \\
\text { Piezas }\end{array}$ \\
\hline 1 & $50 \mathrm{grs}$ & $70 \mathrm{grs}$ & $20 \mathrm{grs}$ & $\begin{array}{l}\text { Oro-16 } \\
\text { Plata-10,5 } \\
\text { Latón-7,95 } \\
\text { Oro verde-17 } \\
\text { Oro } \\
\text { apaladinado- } \\
17,5\end{array}$ & $20 \times 16$ & $\begin{array}{l}\text { Oro-30gr } \\
\text { Pl } 25 \mathrm{gr} .\end{array}$ & $\begin{array}{l}320 \mathrm{gr} \\
\text { oro }\end{array}$ & Filigrana \\
\hline 2 & & & & & & & & $\begin{array}{l}\text { Piezas } \\
\text { gruesas }\end{array}$ \\
\hline 3 & & & & & & & & \\
\hline
\end{tabular}

ACLARACIÓN: Peso del cono: es un peso de metal añadido que tomará la forma del cono de la goma y nos ayudará a no quedarnos cortos en el peso total del árbol.

Importantísimo saber las piezas que se meten en cada cilindro tanto por su colocación en el horno como por la temperatura del mismo a la hora de fundir. Las piezas de Filigrana necesitarán siempre más temperatura para que el metal permanezca más tiempo en estado líquido y pueda formar la malla de Filigrana antes de enfriarse.

${ }^{189}$ Elaboración propia. 
Una vez seco el cilindro, podemos extraer la cera antes de introducirlo en el horno con el fin de alargar la vida útil del mismo, evitando de esta manera producir restos y gases procedentes de la quema de la cera.

Para esto se utilizan unas máquinas llamadas "licuadoras de ceras" en las que se introducen los cilindros boca abajo de tal manera que es la máquina, la que se encarga de producir el calor necesario y adecuado para la licuación de la cera. Gracias a esto, podremos introducir los cilindros en el horno ya desprovistos de cera.

Con la experiencia del artesano, podemos aportar como innovación, la posibilidad de hacer nuestra propia licuadora de forma casera, consiguiendo de esta manera un ahorro considerable. Deberemos proceder de la siguiente forma:

- En un puchero, olla o cacerola, de dimensiones suficientes para el número de cilindros que solemos usar a la vez de forma habitual, colocaremos una rejilla en el fondo del recipiente a una altura del mismo aproximadamente de unos $13 \mathrm{~cm}$. En los $13 \mathrm{~cm}$ que quedan por debajo, pondremos agua, que deberá quedar a unos centímetros de la rejilla con el fin de que cuando ésta hierva no moje los cilindros. Colocaremos los cilindros sobre la rejilla y procederemos al calentamiento de la olla. A medida que vayamos calentando el agua, se irán calentando a su vez los cilindros y a medida que suba la temperatura irá cayendo la cera sobre el agua del fondo. Este proceso de vaciado de la cera se mantendrá durante aproximadamente una hora a partir de la ebullición del agua. El recipiente si se quiere se puede tapar. Lo importante es que se calienten los cilindros para que la cera se licúe. Como este es el principio básico de las licuadoras comercializadas, el resultado obtenido será el mismo sin tener que hacer la inversión económica.

La cera que queda en contacto con el agua es perdida y no se debe reutilizar. 
A continuación deberemos esperar el tiempo necesario para el secado del revestimiento (como ya apuntamos en el punto 5), el tiempo de secado si utilizamos la licuadora de cera, empezará a contar a partir de este momento.

Queda aclarar que la utilización de la licuadora de cera o el procedimiento anteriormente escrito solamente es interesante para alargar la vida productiva del horno, ya que no afecta ni interviene para nada en el resultado final de las piezas.

\subsubsection{Hornos.}

- Introducción

Los tipos de hornos que se pueden utilizar en el proceso de la Microfusión pueden ser dos según la alimentación energética que tengan: eléctricos o de gas.

Cuando se va a trabajar con un horno a estrenar, se deben de tener en cuenta los siguientes pasos.

- Mantener el horno a $200^{\circ} \mathrm{C}$, con la puerta abierta durante al menos 10 horas.

- Subiremos la temperatura a $300^{\circ} \mathrm{C}$ (2horas)

- Subiremos la temperatura a $750^{\circ} \mathrm{C}$ con la puerta cerrada durante 2 horas.

- Después apagaremos el horno y dejaremos enfriarlo con la puerta cerrada.

- A las 8 horas de haberlo apagado se volverá a encender y lo mantendremos a $750^{\circ} \mathrm{C}$ durante una hora más.

- Después apagaremos el horno y comprobaremos el tiempo de descenso de la temperatura creando un gráfico para calcular los horarios y las correspondientes temperaturas (suele bajar $100^{\circ} \mathrm{C}$ por hora). 
-Procedimiento para el calentamiento de los cilindros.

Antes de meter los cilindros en el horno subiremos la temperatura a $250^{\circ} \mathrm{C}$. Alcanzada esta temperatura meteremos los cilindros (de su colocación hablaremos más adelante).

En las tres primeras horas subiremos la temperatura progresivamente hasta $500^{\circ} \mathrm{C}$ y a partir de la tercera hora subiremos hasta $750^{\circ} \mathrm{C}$ manteniéndolo otras tres horas aproximadamente (si los cilindros son grandes se mantienen un mínimo de dos horas a $750^{\circ} \mathrm{C}$ y si son pequeños un mínimo de hora y media). Esto se realiza con el fin de que la temperatura que marca el indicador del horno $\left(750^{\circ} \mathrm{C}\right)$ alcance el corazón de los cilindros que es donde realmente necesitamos esa temperatura.

Después se apaga el horno dejando que baje por si sólo hasta la temperatura que cada aleación nos marque y que será de $150^{\circ} \mathrm{C}$ menos del punto de fusión del metal a fundir.

Ejm: si el punto de fusión del metal es de $850^{\circ} \mathrm{C}$ pondremos el horno a $700^{\circ} \mathrm{C}$ en el momento de fundir.

Ejm: oro de 750 milésimas (significa que de $1 \mathrm{gr}$. 0,750 gr son de oro puro y el resto se reparte tiene $125 \mathrm{gr}$ de plata fina y $125 \mathrm{gr}$ de cobre), cuyo punto de fusión es de $885^{\circ} \mathrm{C}$, se deberá proceder al vaciado del metal cuando el horno marque $735^{\circ} \mathrm{C}$. $\left(885^{\circ} \mathrm{C}-150^{\circ} \mathrm{C}=735^{\circ} \mathrm{C}\right)$.

A continuación indicamos unas normas generales para temperaturas en los siguientes casos: 


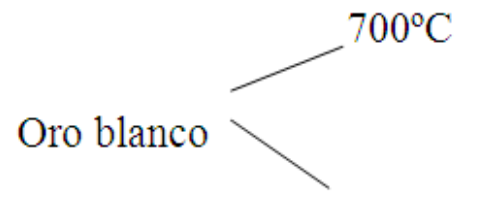

$600^{\circ} \mathrm{C}$

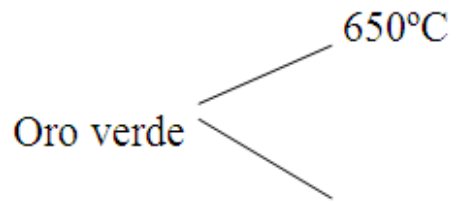

$600^{\circ} \mathrm{C}$

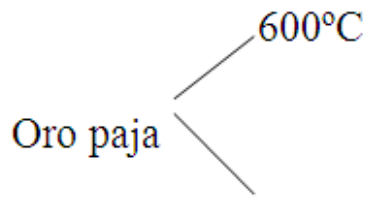

$550^{\circ} \mathrm{C}$

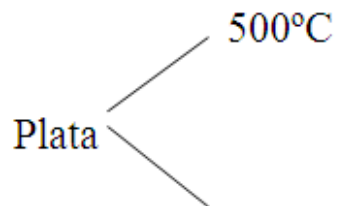

$450^{\circ} \mathrm{C}$

En el caso del oro paja por ejemplo si se deben vaciar piezas muy gruesas, bajaremos la temperatura del horno a $300^{\circ} \mathrm{C}$ ó $200^{\circ} \mathrm{C}$ y en caso contrario para piezas muy finas, como es el caso de la Filigrana Charra, subiremos la temperatura a $600^{\circ} \mathrm{C}$.

Es muy importante tener en cuenta la colocación de los cilindros en el interior del horno, con el fin de facilitar la inyección del metal.

Para ello, y consultando la tabla en la que indicamos el tipo de piezas que va en cada cilindro y que previamente hemos seleccionado finas por un lado y gruesas por otro, colocaremos en la parte interna del horno aquellos cilindros con piezas de Filigrana y similares ya que necesitan un mayor temperatura a la hora de la fundición. Esto se explica porque, aparte de recibir más poder calorífico en la parte más interna de la mufla ${ }^{190}$ del horno, cuando comencemos a extraer cilindros el proceso de abrir y cerrar varias veces la puerta del horno, provocaremos un ligero enfriamiento y éste podría ser perjudicial para las piezas más finas, mientras que para las piezas más gruesas este pequeño enfriamiento no sería de mayor importancia. En el caso de que todas las piezas fueran finas, tipo Filigrana que es lo que

\footnotetext{
${ }^{190}$ Anexo, Cit, Foto 122.
} 
estudiamos, se recomienda mantener ligeramente más alta la temperatura del horno mientras extraemos los primeros cilindros.

La mayoría de los hornos llevan incorporados unos dispositivos (temporizador, reloj ${ }^{191}$ mediante los cuales llevaremos a cabo el proceso de calentamiento de forma programada, subiendo paulatinamente las temperaturas como hemos indicado con anterioridad.

\subsubsection{Inyección y vaciado ${ }^{192}$.}

De los procedimientos que existen, nosotros tan sólo vamos a indicar tres, porque cualquiera de ellos puede ser utilizado con buenos resultados para la reproducción de piezas de Filigrana mediante la Microfusión:

\section{a) Gravedad}

Se procede al vaciado del metal en el cilindro, vertiendo el mismo y rellenando el hueco que ha dejado la cera perdida, simplemente utilizando la fuerza de gravedad. El proceso es manual y lento y se utilizan crisoles apropiados para ello. Se requiere pulso y experiencia. No es el más recomendable para la Filigrana aunque sí lo es para piezas gruesas y esculturas pesadas

\section{b) Absorción o succión}

El proceso es el mismo hasta llegar al horno. Cuando sacamos los cilindros del horno, estos se llevan a una máquina de absorción que lo que realmente hace es succionar a modo de vacío el metal, una vez que este entra en los cilindros. Para este método se utilizarán cilindros similares a los descritos pero con la diferencia de que estos tendrán agujeros por todo el perímetro para facilitar de esta forma la absorción. Esta succión es para que el metal llegue mucho mejor a los espacios más recónditos, siendo muy efectivo para la reproducción de piezas de Filigrana, ya que éstas se

\footnotetext{
${ }^{191}$ Anexo, Cit, Foto 123 y 124.

${ }^{192}$ Anexo, Cit, Foto 130 a 152.
} 
componen de hilos casi tan finos como un cabello. Esto se puede llevar a cabo gracias a que, el material que usamos de revestimiento es poroso, siendo factible la succión.

\section{c) Centrifugado}

- Preparación de la centrífuga ${ }^{193}$. La máquina centrífuga posee un brazo interno que tiene un contrapeso, un punto de giro central y un apartamento para el crisol y el cilindro en el lado opuesto al contrapeso.

Por lo tanto, debemos saber en qué posición se debe colocar el contrapeso según la cantidad de metal y peso del cilindro que vayamos a usar para cada caso (es recomendable tener en la centrífuga una tabla en la que podamos consultar la posición del contrapeso en función del peso del cilindro con el metal, para poder consultarla en cualquier momento, ya que este proceso requiere luego prontitud y celeridad).

El equilibrio del brazo debe de estar perfectamente calibrado y comprobado ya que de no ser así, el brazo bascularía de forma irregular en movimiento ascendente y descendente pudiendo provocar serios daños (salida del metal del crisol, perdida del metal precioso, quemaduras, e incluso accidentes mucho más graves como el desprendimiento del propio brazo de la centrifuga).

Por lo tanto, hay que comprobar siempre que la tuerca de sujeción central del brazo y el contrapeso estén correctamente apretados y encajados.

Comprobado pesos y sujeción se puede pasar a la ejecución.

- Ejecución del proceso.

Como su nombre indica, es la fuerza centrífuga la que se encarga de inyectar el metal líquido en el cilindro. Para ello, y después de haber

${ }^{193}$ Anexo, Cit, Foto 130 y 131. 
calculado la cantidad exacta del metal que lleva cada cilindro, fundiremos este en el crisol que habremos acoplado correctamente en la centrífuga (Crisol: es un recipiente de material refractario, de capacidades diferentes según las necesidades, donde se funde el metal. Su forma para el caso de las centrífugas hace coincidir su salida con la entrada de los cilindros una vez sacados del horno y colocados en la centrífuga. Para cada metal, oro, plata, etc...se utilizará un único crisol; es decir, el crisol que se utiliza para oro sólo se utilizará para el oro, el de plata para plata evitando que los restos depositados en el crisol se mezclen.

Una vez licuado el metal sacaremos del horno el cilindro correspondiente con la ayuda de unas tenazas largas, utilizando siempre guantes para no quemarnos y pasaremos a colocarlo en su posición para que coincida la boca del crisol con la boca del cilindro en la centrífuga.

Una vez comprobado de nuevo que los sistemas de sujeción del cilindro están correctos y sin retirar la llama del metal líquido, en el menor tiempo posible se activará la centrífuga dando lugar a la inyección del metal al cilindro gracias a la fuerza centrífuga.

Se dejará en funcionamiento (girando) durante el tiempo suficiente hasta que se enfríe el metal (esto se observa cuando el cono del árbol al estar al rojo vivo, forma una línea roja continua mientras gira la centrífuga que se irá atenuando hasta desaparecer, momento en el que se puede parar la máquina ya que esto nos indicará que el metal se ha enfriado suficientemente).

Como el cilindro permanecerá a temperatura elevada utilizaremos unas tenazas para retirarlo de la centrífuga procediendo a colocarlo siempre boca arriba sobre una superficie metálica o refractaria con el fin de no dañar o quemar el lugar en el que han de reposar.

Este reposo, será de unos 5 o 6 minutos, hasta que la temperatura del cilindro nos permita introducirlo en agua fría para que el cambio brusco de temperatura nos deje retirar la mayor parte posible de revestimiento sin 
dañar las piezas del árbol interior de metal, cosa que sucedería si el cambio de temperatura fuera excesivamente brusco.

\subsubsection{Retirado de revestimiento ${ }^{194}$.}

En un recipiente con agua fría se introduce el cilindro cuando aún está caliente después de haber reposado durante 5 ó 6 minutos como ya se ha descrito. La reacción provocada por el cambio de temperatura hace que el revestimiento se desprenda del árbol en su mayoría. Esta operación se hará con ayuda de unas tenazas y colocando el cilindro en posición horizontal para evitar así que el árbol, una vez libre de revestimiento, caiga dentro del recipiente con agua. Al estar el cilindro en posición horizontal, el árbol quedará en éste y sacándolo del agua en esa posición podremos extraer con la mano el árbol de metal ya frío.

Tras esta maniobra, el árbol tendrá todavía muchos restos de revestimiento entre las piezas y para volver a limpiar es recomendable meter los árboles tal cual están en el horno antes de que se enfríe del todo una vez terminada toda la fundición. Al someter el revestimiento que queda a este calentamiento brusco se vuelve frágil y puede ser eliminado o separado del árbol a golpe de martillo, es decir: sujetando todo el árbol con una mano y golpeando el cono o tocho que ha dejado la fundición. Esto se hará sobre una superficie en la que después podamos recuperar alguna pieza que pudiera desprenderse del árbol al ser golpeado.

Como siguiente paso de limpieza, podemos utilizar un ácido especial para la eliminación total de los restos de revestimiento, quedando así el árbol completamente limpio para poder proceder al posterior cortado de piezas.

No obstante para el caso que nos ocupa, el artesano lleva utilizando un método autodidacta que pasamos a describir por la eficacia y sencillez del mismo: una vez golpeado el árbol, se cortan las piezas y se introducen en un recipiente con un producto denominado "blanquimento" que es agua con un pequeño porcentaje de ácido sulfúrico, con el fin de ablandar y en su

${ }^{194}$ Anexo, Cit, Foto 153 a 168. 
caso disolver todos los restos de revestimiento que hayan quedado en las superficie de las piezas. Posteriormente introduciremos las mismas en un bombo magnético de agujas, que consiste en un recipiente con una gran cantidad de agujas de acero inoxidable muy finas sumergidas en agua; el bombo, posee unos imanes que una vez en marcha, hacen que las agujas giren y el roce de las mismas con las piezas introducidas hacen que éstas queden completamente limpias sin ser dañadas.

\subsubsection{Corte y manejo de las piezas ${ }^{195}$.}

Para el corte de los árboles se utilizan alicates de tipo cizalla de los que existen en el mercado diferentes formas y tamaños. Cada artesano escogerá aquellos que se ajusten al tamaño de sus piezas a cortar, aunque generalmente son más efectivos los de puntas más estrechas.

Existen máquinas industriales para el corte de árboles que son cizallas eléctricas que cortan pieza a pieza siempre que los árboles sean muy homogéneos, es decir, que tengan piezas iguales o semejantes.

Sin embargo, estas máquinas no son muy recomendables por su alto precio y poca efectividad en la mayoría de los casos.

Manualmente, a veces es necesario cortar algunos bebederos con "Segueta" (sierra de pelo de marquetería) por no poder hacerlo con el alicate de corte pero esto supone una merma (pérdida) de metal que en el caso del oro dado su elevado coste puede ser importante.

Una vez cortadas las piezas y separadas del tronco del árbol, se limpian de restos de revestimiento si tuvieran, para proceder al repasado que es el siguiente punto. Se empieza a cortar las piezas siempre por la parte inferior del tronco del árbol por comodidad al tener la inclinación de $45^{\circ}$ de la que ya hemos hablado al construir el árbol de cera.

${ }^{195}$ Anexo, Cit, Foto 169 a 176. 
2.2.10.Proceso manual de terminación de piezas ${ }^{196}$.

\section{a. Repasado}

Consiste en eliminar el bebedero, ya de metal y restos de rebaba si hubiera para devolver la forma original a la pieza. Esto se hace cortando, bien con segueta, bien con alicate, teniendo cuidado de no cortar ni perjudicar la forma de la pieza. Posteriormente se lima y se lija. Toda esta operación se realiza en la "Astillera" (mesa de joyero) en cuyo cajón caerán los restos de metal, bebederos, limaduras...etc., que después se fundirán junto con los troncos que han quedado cortados pudiendo reutilizarse para otros trabajos. El lijado se realiza, bien con el limatón de metal, bien con lija de papel, para dejar perfectas todas las formas, sin dañar la pieza.

\section{b. Preparación de la pieza.}

Según su destino: Es obvio que una pieza fabricada por Microfusión (por ejemplo un botón charro) puede ser destinada a diferentes creaciones como sortijas, pendientes, pulseras etc. por tanto, si vamos a fabricar una sortija debemos preparar este botón para que al soldar al anillo que le corresponda, este se adapte perfectamente, si el botón fuera para una pulsera deberemos soldarle las asas necesarias etc. Para el caso de la Venera, antes de ensamblarla se tendrá en cuenta que la pieza superior debe tener dos asas soldadas en la parte posterior para el paso de la cinta. En el caso de los pendientes, se soldará el palillo y así se harán distintas terminaciones para las distintas piezas, todo ello en función de su destino final.

\section{c. Terminación o acabado}

Llamamos acabado a las diferentes tonalidades finales que se pueden dar a los metales preciosos y estas pueden ser muy distintas: Pulido, mateado, chapado, pavonado. Otras terminaciones pueden ser, bruñido, cortes de brillo.

${ }^{196}$ Anexo, Cit, Foto 177 a 251. 
Pulido.- Después de lijar bien la pieza, se procede al pulido con ayuda de discos de tela y motores de pulir. Aunque también se puede hacer manual, pero no es aconsejable por el tiempo que se invierte.

La finalidad en todo caso, es conseguir el mayor brillo posible del metal sin perjudicar la superficie de la pieza ya que al ser ésta una terminación abrasiva, puede dañar la forma original.

Matear.- Consiste en dar una terminación satinada, es decir sin brillo, para lo cual utilizamos o un chorro de arena o directamente abrasivos específicos para ello (estropajo, lijas finas,...)

Algunas piezas pueden ir terminadas con estos dos procesos (pulido y mateado) simultáneamente.

\section{Pavonado u oxidación ${ }^{197}$.}

Esta terminación es sólo para la plata y en el caso de la Filigrana y la joyería charra, el pavonado hace que las partes más profundas tengan una coloración oscura y las partes más externas una coloración blanco plata consiguiendo un contraste único y específico de la Filigrana Charra.

Proceso del pavonado u oxidación:

La joyería charra en plata ha tenido históricamente la terminación oxidada o pavonada. Siendo un único proceso, a lo largo del tiempo no siempre se ha ejecutado de la misma manera.

Antiguamente era el mismo artesano el que fabricaba su propio óxido, que consistía en hervir sulfuro potásico, conocido por muy pocos como "hígado de azufre" hasta su disolución. Esta disolución, si se trabaja en caliente, ataca a la plata oscureciéndola hasta darle un negro azulado. Después, por frotamiento o abrasión, las partes más externas de la Filigrana pierden esta coloración, quedando visible nuevamente el color natural de la

${ }^{197}$ Anexo, Cit, Foto 189 a 226. 
plata, permaneciendo oscuras las partes más profundas y consiguiendo así, un efecto contraste de profundidad.

En la actualidad existen productos comercializados que funcionan y producen el mismo efecto en frío, hecho este que es una ventaja a la hora de ahorrar tiempo, sin embargo el coste de la operación es superior. Este producto se comercializa como Pátina, pavonado o coloración de plata vieja.

En el taller del artesano, realizamos el proceso del pavonado, típico de los objetos joyeros que estamos estudiando.

Se utiliza una pieza ya preparada, y se introduce en la sustancia química (que se aprecia perfectamente en el anexo fotográfico). Una vez que la pieza está negra, pasamos a limpiarla con polvo de piedra pómez. Esta etapa del proceso es muy interesante porque apreciamos cómo el simple hecho de frotar con la mano impregnada de polvo, descubre la plata pulida en las superficies que más sobresalen, permaneciendo las más escondidas y los recovecos de la pieza en tono oscuro.

Este contraste, le da profundidad a las piezas y una seña de identidad a nuestra joyería charra.

Una vez obtenido el efecto bicolor hay que utilizar agua muy caliente con jabón, donde introducir las piezas, y posteriormente limpiarlas muy bien para que el objeto no manche posteriormente al usuario.

\section{Chapado y Dorado ${ }^{198}$.}

A cualquiera de las dos terminaciones anteriores se puede añadir ésta, dando una apariencia de oro al metal que se quiera.

El chapado se realiza por electrolisis recubriendo primero la pieza de níquel y sobre este baño se dará otro de oro. Cuanto más tiempo dure el baño, más depósito de oro se adhiere a la superficie de la pieza. Por

${ }^{198}$ Anexo, Cit, Foto 227 a 251. 
consiguiente a mayor tiempo de baño, mayor duración de baño de oro, el cual a pesar del uso perdurará más en el tiempo.

El dorado lleva el mismo procedimiento anterior pero sin baño de níquel. En joyería, se utiliza para disimular la coloración de la soldadura que se ha utilizado, que al ser oro bajo es de distinto color que el oro de 18 Quilates o más, dando con el baño una tonalidad uniforme. Al no tener níquel, la duración es menor utilizándose sólo para la presentación final de la pieza. Esto sólo se utiliza para las piezas de oro.

Para el caso de la Filigrana se utiliza el dorado de la pieza, que también se conoce como sobredorado. Esta terminación tiene el siguiente proceso:

Dorado.-

Primero se enjabona la pieza a dorar y se limpia con un cepillo para quitarle toda la grasa e impurezas que tenga. Cuanto más limpia esté la pieza mejor se impregnará el dorado. Luego preparamos el amperímetro que tiene dos polos ( $+\mathrm{y}-$ ) en uno ponemos las láminas de oro fino, $\mathrm{y}$ en el otro el objeto a dorar. Conectamos el amperímetro e introducimos los dos polos en un vaso con la solución, que hará las veces de trasmisor.

Cuando empieza el proceso de la electrolisis, en el objeto a dorar comienza a salirle una espumilla que nos indica que se está ejecutando el dorado de la pieza.

Una vez que se termina el dorado, la pieza ha de limpiarse con bicarbonato sódico, con el fin de desprender cualquier impureza o resto de la disolución que haya quedado. Una vez limpio, aclaramos la pieza con agua para quitar todos los restos de bicarbonato y proceder al secado con una gamuza.

El resultado es espectacular, ya que la pieza parece totalmente de oro. 
La Filigrana de oro, es muy cara y gracias a este proceso, el acabado que se le da a las piezas de plata, da la posibilidad de lucir una pechera rica, a un precio mucho más asequible.

Con el paso del tiempo, puede que el dorado se vaya: el roce, el sudor, o simplemente el paso del tiempo, hace que el dorado se pierda, pero este proceso que hemos descrito se puede realizar las veces que sea necesario.

\section{Repaso manual a la Filigrana ${ }^{199}$.}

Por último, antes de terminar el proceso de la Microfusión, sí querríamos hacer referencia a que en algunas piezas microfusionadas, el artesano las repasa de forma manual utilizando un taladro de mano, para ampliar alguno de los intersticios de la Filigrana, y que parezca más calada, para luego retocar con la segueta.

Esto sólo se hace puntualmente en piezas especiales, ya que si el resultado de la Microfusión necesitara de este repaso, significaría que en algún momento del proceso hay errores, aspecto éste, que debería solucionarse y reiniciar de nuevo todo el proceso de Microfusión.

Sólo la cuidadísima ejecución de todos los procesos que hemos descrito en este apartado, puede considerarse la causa de la obtención de piezas que a veces cuesta mucho distinguirlas de su original. Es en este momento cuando podemos decir que le proceso de la microsufión ha finalizado.

Podemos decir que la Microfusión a la cera perdida es básicamente un proceso de fundición, sin embargo aplicado a la Joyería existen unos límites medidas (tamaño y peso) que el artista (artesano orfebre) aplicará siempre en beneficio de la belleza y utilidad de la pieza final. Para entenderlo fácilmente basta con decir que un pendiente excesivamente pesado o un anillo demasiado pequeño podrán ser bellos pero no útiles como joyas,

${ }^{199}$ Anexo, Cit, Foto 252 a 257. 
aunque es cierto que siempre se han creado piezas exclusivamente para exposición.

Debido a estas limitaciones (de ahí su nombre Micro-fusión) y a pesar de que este mismo proceso se puede utilizar en la creación de esculturas de gran tamaño (Bronce, Hierro etc.), es lógico pensar que un profesional de la Microfusión, no intentaría crear este tipo de piezas sin antes tener en cuenta las diferencias técnicas que existen y que, lógicamente, difieren mucho de su ámbito profesional.

En este orden de cosas podríamos aplicarlo a la creación de la Filigrana Charra por Microfusión, es decir, si la fabricación de grandes esculturas precisa de otros conocimientos técnicos por exceso, la Filigrana Charra requiere tener en cuenta una serie de conceptos sin los cuales la fabricación de éste tipo de género por Microfusión sería, si no imposible, sí defectuoso o de baja calidad.

A modo de conclusión, sí podríamos detallar qué partes del proceso necesitan un cuidado específico para el caso de la Filigrana Charra, ya que el éxito de obtener una reproducción que merezca la comparación con un objeto tan hermoso como es la Filigrana artesanal, depende de ello. Este es el motivo de que haya muchas reproducciones en Microfusión de Filigrana que son auténticas chapuzas.

A continuación detallamos algunos de estos conceptos:

1-Grueso mínimo de los hilos (Fili-). Hay hilos que por ser muy finos, su reproducción es dificilísima en la Microfusión, debiendo tener muy en cuenta la presión que se inyecta en el molde y la temperatura de la cera.

2-Tamaño mínimo de las bolas (-Grana). La misma explicación que para lo anterior.

3-Caucho especial para los moldes. La elección del caucho es muy importante, así como el mantenimiento del mismo, de su textura depende que se realice correctamente el molde del original. 
4-Corte del molde. Hemos explicado suficientemente la importancia del corte. Desmoldar correctamente la pieza es la base del éxito de futuras reproducciones.

5-Presión de inyección de ceras. Creemos que ha quedado suficientemente explicado. Este aspecto es importantísimo a la hora del éxito en la reproducción de la Filigrana Charra.

6-Enramado. Al ser las ceras de Filigrana muy delicadas la colocación de ellas en el enramado (árbol) es fundamental para no llevarnos sorpresas en el resultado final. De ello también hemos hablado ampliamente.

7-Vibrado y vaciado de revestimiento. Importantísimo para evitar burbujas de aire y desperfectos en las piezas a reproducir.

8-Temperaturas del Horno. Sólo la experiencia identifica la temperatura que debemos utilizar para la consecución de un objetivo correcto: para el caso de la Filigrana creemos que ha quedado suficientemente explicado.

9-Enfriamiento de los cilindros ya fundidos. Creemos que ha quedado suficientemente explicado pero para el caso de la Filigrana, por la delicadeza de estas piezas la rapidez de enfriamiento debe ser bien controlada.

10-Corte de los árboles. Muy importante a la hora de no dañar las piezas.

11-Tratamiento artesanal de terminación. Este aspecto es fundamental, es la parte más artesanal del proceso en el sentido, de que el retoque manual (tiempo de dedicación) le dará a la pieza reproducida un aspecto casi idéntico a la Filigrana.

De la suma de todos estos puntos se obtienen réplicas dignas de la Filigrana para un mercado cada vez más exigente y conocedor de la diferencia que hay entre un original (Filigrana) y esta "falsa Filigrana", que se obtiene gracias al proceso de Microfusión que hemos definido. 
Teniendo en cuenta todo lo anterior, y sobre todo el riesgo de desaparición tan importante que tuvo este sector económico en la década de los 70, es la única manera de entender por qué la técnica de la Microfusión entró de lleno en la joyería de la Filigrana.

Gracias a la Microfusión, que podemos considerarla como ya hemos explicado a lo largo de este documento, se pudo dar una vertiente industrial a un sector puramente artesanal. La Microfusión le ha dado a la Filigrana: cantidad de producto en el mercado, competitividad con otros elementos similares nacionales o extranjeros, precio y vida.

Este proceso industrial, si está bien hecho, (como ha quedado constatado de la mano de Miguel Ángel Cordón) complementa al filigranista, y no lo fagocita. La Microfusión no puede existir sin un original en Filigrana, por lo tanto, siempre será necesario por encima de todo un artesano filigranista, asegurando de esta manera, una tradición milenaria en la joyería.

No pretendemos entrar en lucha por defender a unos o a otros, y mucho menos levantar susceptibilidades por parte de nadie, pero nos inclinamos por respetar el proceso industrial de Microfusión para la Filigrana, dándole además el adjetivo de artesanal, aún a sabiendas que hablar de "Microfusión artesanal " aparentemente parece una contradicción, pero creemos que queda suficientemente constatado la importancia que tiene la mano del artesano que realiza la Microfusión, para obtener un objeto digno de representar a su original en Filigrana.

Afortunadamente los mercados al globalizarse nos dan clientes de todo tipo y de todo el mundo. Atenderlos, y explicar las diferencias existentes entre unos y otros procesos, nos dan la posibilidad de favorecer la difusión de algo tan nuestro como es esta tradición joyera.

Potenciar ambas técnicas (Filigrana y Microfusión de Filigrana), favorecerá a un sector que en nuestra provincia está en vías de extinción. Somos conscientes que el sector debe pasar, como otros muchos, por una transformación sin que ello suponga renunciar a ninguno, y mucho menos a 
las técnicas ancestrales, pero tampoco a la evidencia de las nuevas necesidades del mercado y a la implantación de nuevas técnicas que complementen a las antiguas.

Por supuesto, sí a la Filigrana ya que es imprescindible, pero sí también a la Microfusión de la Filigrana (con sus luces y sus sombras) pero sin menos preciar un sistema que apuesta industrialmente por la supervivencia de un arte pero sin negar la evidencia de los tiempos.

\section{Situación actual: Conversación con el empresario con} José Alfonso Jacinto Sánchez-Vasconcellos Bravo 200

Utilizaremos esta fuente como testimonio oral de la evolución en la creación y comercialización de la Filigrana Charra, circunscrita a la zona de Ciudad Rodrigo, como punto de conexión por su proximidad con la frontera portuguesa.

Ciudad Rodrigo, es la última Ciudad al Oeste de la provincia de Salamanca. Rica en historia, en productos y sobre todo en personas, pone el punto de partida al puente de comunicación, que desde tiempos históricos existe entre España y Portugal.

Las relaciones entre estos territorios nada tienen que ver con los límites políticos, puesto que tanto sus gentes como sus costumbres, son mucho más similares a uno y otro lado de La Raya, como se conoce a este espacio fronterizo entre Salamanca y Portugal, aunque sabido es de todos, que se continúa al Norte con Zamora y al Sur con Cáceres.

El corazón de La Raya, está justamente en esta Ciudad fortificada, que a pesar de estar cerrada por una muralla, siempre ha estado abierta a la influencia del país vecino más de lo que a muchos les gustaría. Decimos

\footnotetext{
200 José Alfonso Jacinto Sánchez-Vasconcellos Bravo. Conocido por todos como Pepe. Joyeroempresario jubilado de joyería Vasconcellos de Ciudad Rodrigo, Salamanca. Mantuvimos conversaciones con él en 2011.
} 
esto, porque es una realidad que, incluso desde la zona fronteriza, tradicionalmente se ha mirado más a Madrid que a Porto, y más a Salamanca que a Coímbra, cuando seguramente si la visión hubiera sido menos direccional, hubiéramos obtenido mejores réditos.

Para el sector que es objeto de nuestro estudio, la mirada con mayúsculas, es mucho más hacia el Oeste y Porto, que al Este con Salamanca y Madrid, ya que indudablemente, la influencia es mucho más del Oeste, que del Este, aunque no son excluyentes sino más bien complementarias.

Dedicar la atención a José Alfonso Jacinto Sánchez-Vasconcellos, Pepe Vasconcellos como se le conoce, es entender cómo de la fusión de ambas partes de La Raya, puede salir un proyecto industrial tan extraordinario y a la vez tan anómalo y nada conocido, como el que fue capaz de realizar la familia Vasconcellos, en una determinada etapa (entre 1940-1945) donde la industrialización era una asignatura pendiente en muchos territorios españoles, e incluso inexistentes en las zonas del interior y mucho más aún si éste estaba al Oeste del país. El Siglo XIX y hasta el último cuarto del S. XX son testimonio de lo que apuntamos.

Tenemos que reconocer que esta fuente nos ha apuntado un punto de vista inédito, pues nunca imaginamos la magnitud laboral que supuso la industria de la Filigrana. Cómo algo aparentemente tan frágil y de poco peso, supuso un recurso económico y un punto de referencia comercial no sólo para la provincia, sino para España e incluso, para el extranjero.

Conversaciones con Pepe Vasconcellos.

Pepe Vasconcellos, nos atiende en el despacho de la joyería que la familia tiene en la Calle San Juan $n^{\circ} 5$ de Ciudad Rodrigo, donde han permanecido desde el principio de la saga, aunque históricamente el taller más grande se situó en la calle Juan Arias, $n^{\circ} 7$ en la década de los 40 (que hoy ha desaparecido), y también poseen otra tienda en la Plaza Mayor de la Ciudad. Es un magnífico conversador, tiene una memoria excelente y la 
única diferencia con el pasado, es que ahora va a la tienda tarde y se retira pronto; por lo demás, continúa teniendo el espíritu que sin duda impregnó a la empresa desde su posición en el taller.

P.V.- Mi bisabuelo fue José Vasconcellos, que ya en 1860 estaba en Ciudad Rodrigo. Puso en marcha el primer taller de filigranistas. Era de Gondomar (Portugal) y vino a España como joyero. Ya en 1860, como decía, tenía su propio taller en el mismo lugar en el que hoy estamos hablando. Murió en 1913, dejando el taller a una de sus hijas, Concepción Vasconcellos, que se casa con Jacinto Sánchez. Tienen seis hijos, uno de ellos es Jacinto Sánchez Vasconcellos, que se casa con Dolores Bravo Arroyo (de Alameda del Gardón, frontera con Portugal). Tienen varios hijos, entre los que están:

- José Alfonso Jacinto Sánchez Bravo Vasconcellos (nuestra fuente). Que se hará cargo del taller.

- Jacinto Pedro Sánchez Bravo Vasconcellos, cuyos hijos Jacinto Pedro y Rebeca, permanecen en la actualidad en la joyería de la calle San Juan no 5 (Jacinto Pedro Sánchez-Vasconcellos Barrón y su hermana Rebeca).

- Antonio Avelino Sánchez Bravo Vasconcellos.

- Arturo Sánchez Bravo Vasconcellos, su hija María SánchezVasconcellos Borrego, permanece en la actualidad en la joyería de la Plaza Mayor.

La abuela estaba a cargo del negocio familiar, mujer de las de antes, que lejos de achicarse ante la adversidad, supo dirigir y mantener el negocio de su padre. Mi padre se incorpora al taller desde muy jovencito, para ayudar a su madre. En la época que mi padre se incorpora (1915), ya tenía en el taller dos oficiales nacionales y otros dos portugueses. El salto más importante en la estructura del taller se produce justo después de la Guerra Civil, en 1940 están trabajando entre 20 ó 25 mujeres realizando Filigrana en 
el taller. La mujer y la Filigrana han estado históricamente unidas. En Portugal, quienes hacían fundamentalmente la Filigrana eran las mujeres, ya que la paciencia y la habilidad manual las capacitaba mejor que a los hombres. Además, ellas de esta manera, obtenían un recurso económico complementario a las labores del campo y del hogar.

La terminación de la Guerra Civil, supuso disponer de mano de obra dispuesta a trabajar por encima del tiempo y del salario. Es en este momento cuando incluso mi padre, contrata a un representante para que venda nuestros productos por toda Castilla y León, siendo nuestros principales compradores Salamanca y Segovia.

Nosotros trabajábamos sobre todo la Filigrana, casi en exclusiva, en su mayoría de plata (broches, pendientes, pulseras, galápagos, rosarios,..) aunque el oro también se trabajaba mucho. Teníamos clientas, que no encargaban una pieza, sino que encargaban todas las piezas del traje.

En 1942, se abre el edificio nuevo en la calle Juan Arias $n^{\circ}$ 7. Allí estaba el taller y la casa de la abuela. Se inaugura oficialmente en 1944 y ella muere en 1946. En 1946, el taller tiene 114 obreros. El taller funcionaba con nueve grupos de trabajadores. Al frente de cada grupo había un jefe de grupo que era varón: se encargaba de organizar el trabajo y distribuía por mesas las piezas para ser rematadas. En cada grupo de trabajo, había seis especialistas, entre los que dominaba fundamentalmente las mujeres y se realizaban todas las piezas que posteriormente debían ser ensambladas 0 rematadas. Había 20 ó 30 mujeres que hacían las labores de llenado de la Filigrana, a las que se les denominaba "Ilenadoras". Tenía entonces el taller una capacidad de producción de Filigrana altísima.

En 1946, se exporta Filigrana a Estados Unidos, para hacerles regalos a las enfermeras de la II Guerra Mundial. El pedido salió del puerto de Valencia.

En 1950-51, me incorporo al taller. A mí, siempre me gustó de manera especial el movimiento y el ajetreo del taller, mucho más que la tienda. Tanto 
es así, que durante toda mi vida activa y profesional, donde realmente estuve vinculado fue al taller.

En los años posteriores a 1960, durante toda esa década, es cuando empieza a decaer el taller. Comienza todo el fenómeno de la emigración y la mano de obra empieza a escasear. Muchos de nuestros trabajadores se marchan de Ciudad Rodrigo, buscando nuevos horizontes y trabajos mejor remunerados y con menos dedicación. La producción en el taller también empieza a decaer y los gastos y los ingresos empiezan a igualarse tanto, que prácticamente a final de la década, sale lo comido por lo servido.

Yo creo que en este momento hay también un cambio de gusto demandándose menos este producto. Pero fundamentalmente, el precio de la mano de obra, hace que se dispare el precio de la Filigrana y empieza a ser un artículo más de lujo que de aderezo.

Es en estos momentos, más o menos hacia 1970 cuando incorporamos en el taller el proceso de la Microfusión, teniendo que adaptarse la mano de obra del el taller a esta nueva manera de trabajar, mucho más industrial, gracias a la cual el precio del producto en el mercado era mucho más competitivo, pudiendo además servir pedidos de gran tamaño en un tiempo impensable si fueran de Filigrana.

Entonces el taller tiene ya 35 filigranistas y se incorpora toda la electrónica "Cabello" gracias a la cual, se pone en práctica todo el proceso de la Microfusión.

En estos años tenemos un cliente de excepción llamado Joe Soler procedente de Miami, que venía a Ciudad Rodrigo, a nuestra casa, tres ó cuatro veces al año, y se llevaba toda la producción que éramos capaces de hacer.

En esta época de los años 70, vendemos mucho a Castilla y León, Galicia, Asturias, Extremadura y Andalucía. Concretamente para Andalucía trabajábamos una barbaridad, prácticamente trabajábamos para ellos. 
Supuso una inyección enorme en esta década complicada. Córdoba, Sevilla y Granada nos compraban una cantidad importantísima tanto de Filigrana como de Microfusión. Tanto es así, que en el taller hacíamos nosotros piezas en las que se ponía: "Recuerdo de Córdoba". Creo que todavía queda alguna por ahí en los cajones.

El año de la transición de Suarez, concretamente el quinquenio 19751980, fue el mejor de toda la historia en la producción del taller.

Pero como todo lo bueno también se termina, pronto vino la decadencia. Las importaciones de India, Turquía y China a finales de los 80 principios de los 90, prácticamente nos hundieron. No podíamos competir en precio ni en cantidad. Tanto es así que el taller empieza a perder trabajadores hasta que quedan más o menos seis, y en 1990, se cierra definitivamente. La eliminación de puestos de trabajo, fue uno de los tragos más duros que he tenido que vivir a lo largo de mi trayectoria profesional. Éramos una gran familia que gracias al trabajo en equipo vivíamos todos, patronos y obreros.

M.E.- ¿Qué supuso la entrada de la Microfusión en el taller?

P.V.- Adaptarse a los tiempos. No cerrar el taller. Emocionarse con un proyecto nuevo. Tener muy claro que la Filigrana siempre es la Filigrana, pero para que exista, con los costes tan enormes salariales y de impuestos, sólo la cantidad puede hacerte competitivo en el mercado, puesto que el precio manda.

Incuso teniendo en cuenta que en el proceso de la Microfusión hay que desechar entre un $20 \%$ o un $30 \%$ de ceras, y que todos los ensamblajes hay que hacerlos a mano, era rentable.

M.E.- ¿Qué ha pasado con todos los moldes que había en el taller?

P.V.- El problema de los cauchos es que se deterioran con el paso del tiempo. Por eso, nunca puede desaparecer la Filigrana, porque es el original. Sin un original hecho a mano, no podemos sacar un molde que merezca la 
pena. Todo ese patrimonio se ha perdido. Puede que quede puntualmente alguno, pero que puedo asegurar que sería inservible.

M.E.- Si ahora ya no hay taller que produzca, ¿de dónde procede todo lo que se vende de charro?

P.V.- Curiosamente de Córdoba. Se han hecho con el mercado. La vida es demasiado sorprendente.

También tenemos piezas que nos vienen de pequeños talleres artesanales de antiguos trabajadores de nuestro taller. Concretamente para la Filigrana tenemos un antiguo trabajador nuestro que tiene su taller en Torrejoncillo (Cáceres) y nosotros le encargamos muchas piezas de Filigrana y es un artista con la Filigrana y el aljófar.

M.E.- ¿Cree que los cordobeses se harán con todo el mercado?

P.V.- Si pudieran quedarse con el Botón Charro y llamarlo Botón Cordobés, lo habrían hecho hace mucho tiempo y nuestra tradición filigranista se habría perdido. No en lo referente a lo cultural pero sí en lo referente a la producción de nuestros objetos de identificación cultural.

M.E.- ¿Usted sabía que al taller de la C/ Juan Arias, $\mathrm{n}^{\circ} 7$, le llamaban "La Torre del Oro" porque allí era el lugar donde se manejaba más oro de la provincia de Salamanca?

P.V. - Algo sí había oído, pero no me imaginaba que hubiera traspasado las murallas de Ciudad Rodrigo.

De las conversaciones con este joyero empresario, hemos detectado, una serie de aspectos que son muy importantes dejar constancia de ellos.

La experiencia empresarial entendiendo por ella la inversión de capital y la contratación de mano de obra, para dar un producto de mercado competitivo, supondría tener un conocimiento exacto de la situación socioeconómica del país en cada momento. 
De todo ello hemos detectado una serie de factores que han influido muy negativamente en el sector, objeto de nuestro estudio:

La Guerra Civil, fue una gran demandante y devoradora de oro, pidiendo a las familias, entregar gran cantidad de joyas, muchas de ellas muy antiguas, para fundirlas con el fin de hacerlas dinero para la contienda militar. Siendo este aspecto, uno de los responsables de la desaparición de una parte importante del patrimonio cultural de este tipo de joyería.

Los años 60 y 70 del Siglo XX, fueron nefastos para esta joyería. Estas piezas vinculadas al traje regional en aquella época no estaban de moda. A la mujer de entonces, no sólo no le gustaban, sino que además no valoraba para nada. Fueron muchas, quienes cambiaron piezas, que hoy serían catalogadas de inmenso valor, por nuevas piezas más acordes con el gusto del momento. Es una época, donde le consumismo empieza a formar parte de la sociedad y se produce un desprecio de lo tradicional por parte de la nueva clase rica emergente, que al identificar sus orígenes con las áreas rurales, reniegan directamente de ellas. Esta joyería tradicional en estos años, se consideraba paleta, sin valor, anticuada y vieja, amén de "charra" en el sentido más despectivo del término; era bastante habitual (incluso ahora a veces por desgracia): "esto es una charrada", como equivalente a "feo".

Se convirtieron en un elemento de trueque para obtener pesetas simplemente por el peso del metal, sin entrar a valorar otros aspectos como podrían ser, la belleza, la dificultad de la ejecución de las mismas, e incluso la posibilidad de ser únicas o casi únicas en su especie.

Queremos destacar, que en nuestro ánimo y empeño está el seguir buscando a lo largo del territorio provincial más elementos que puedan evidenciar si se puede, la riqueza joyero cultural que estos mini objetos nos aportan, asegurando que en muchas ocasiones son auténticos obras de arte en miniatura. 
Otro de los elementos que hemos detectado es que como la Filigrana no pesa, no es maciza, los hilos y los casquetes semiesféricos de chapa fina que la conforman, le dan un aspecto donde nada parece ser lo que es. El hilo de plata o de oro, es a la Filigrana lo que el hilo de tejer es al encaje de bolillos. Ambos trabajos, curiosamente se han realizado siempre por manos femeninas, elemento interesante a tener en cuenta porque tradicionalmente se ha identificado, orfebrería, artesanía y joyería con el género masculino. La paciencia, la delicadeza y el tiempo son atributos más del carácter femenino que del masculino, aunque tradicionalmente o históricamente nunca se le haya valorado a la mujer.

Tenemos una teoría económica del por qué la Filigrana se ha asentado en la joyería como técnica que ha perdurado a lo largo del tiempo, en el caso específico del espacio geográfico que estamos estudiando. En zonas, donde los recursos económicos y el poder adquisitivo de los individuos eran escasos, la Filigrana ofrecía, unas características que otro tipo de joyas no las tenían. Hay una serie de razones económicas y sociales, que explican por qué históricamente, Filigrana y nuestro territorio están unidos. Como por ejemplo:

- Si se utilizaba poco metal, el producto final tenía poco peso. Si el precio final estaba en función del metal utilizado, al ser poco, el precio era pequeño, pudiendo ser adquirido por un sustrato de población con pocos recursos. Esto nos lleva a definir la Filigrana como "la joya de los pobres".

- La Filigrana tiene una característica que otras joyas no tienen. Aparenta mucho y el aspecto social que da es de gran poder adquisitivo por parte de su portador. Mientras que en otras partes del mundo, las joyas eran macizas, aquí, sólo parecían macizas.

- No conformes con el aspecto final de la Filigrana, la enriquecían con aljófar, seguramente para dar todavía mayor aparatosidad y boato a la pieza. Este trabajo, es costosísimo pues, se trata de coser con hilo de 
plata o de oro, pequeñísimas perlas sobre la base de la Filigrana. El aspecto que da, como decimos, es de más importancia, pero desde nuestro punto de vista se enmascara el verdadero valor artesanal de la Filigrana en sí misma. Aunque para nada renegamos de esta técnica, puesto que las piezas que nos ofrece son realmente espectaculares en belleza. Estamos convencidos de que este tipo de trabajo está vinculado al Siglo XIX, más vinculado al traje de época que al tradicional. Pasando del traje de época, al tradicional.

- Históricamente el tiempo (entendiendo aquí el número de horas dedicado para la obtención de un objeto de mercado) como factor determinante en el precio final del producto, no se contemplaba. Este parámetro, binomio tiempo-mano de obra, fundamental a la hora de realizar una pieza de Filigrana, era inexistente o repercutía muy poco en el precio final de la pieza. Tanto es así, que la Filigrana en Portugal, la hacían fundamentalmente las mujeres para sacar un dinero complementario a las tareas domésticas y del mundo rural. Estas piezas luego eran ensambladas y unidas por los artesanos y joyeros, pero el llenado de la Filigrana era fundamentalmente hecho por manos femeninas. Así nos lo ha constatado Pepe Vasconcellos, ya que esta tendencia se mantuvo en sus talleres durante la época de mayor auge productivo de los mismos.

Con el paso del tiempo, este factor, se ha convertido en el que más incide en el precio final. El coste de una hora de trabajo, de un artesano para realizar una labor de Filigrana Charra es muy elevado, siendo este junto con el número de horas necesario para ejecutar unas piezas, el que hace que en la actualidad el precio de estas piezas se dispare. No es comparable la proporción del peso con el precio. La causa, creemos queda clara.

En este orden de cosas, en la actualidad, si a la Filigrana se le une el aljófar, el precio todavía sube más.

Curiosamente, existe en la actualidad un segmento de clientes, que conocedores del trabajo y de la exclusividad de estos objetos, están 
dispuestos a pagar el precio final. El problema es que, los talleres artesanos, si incorporan más mano de obra, se les disparan los gastos, y como dicen ellos: "al final, lo comido por lo servido". Para ellos: "el cliente tiene que entender que deberá esperar el tiempo necesario, sin agobios y sin enfados para poder obtener algunas de estas piezas que a veces pueden tardar incluso un año"201.

Solamente cuando los salarios y el tiempo no eran factores demasiado importantes, se pudieron hacer la cantidad de piezas que se hicieron. En la actualidad el panorama es totalmente diferente.

De las fuentes que hemos consultado, se desprende un sentimiento común: piensa que su labor no tendrá continuidad. De aquí, la oportunidad científica de este trabajo. Esta es casusa suficiente y mayor para que se justifique este trabajo de investigación e intentar desde aquí involucrara a las AAPP para evitar que este patrimonio cultural de un pueblo y en especial de la mujer se pierdan.

¿Estamos asistiendo al final de una forma de entender la manera de trabajar que hemos heredado desde tiempos remotos? ¿Estamos asistiendo, tal vez, a la pérdida de un patrimonio que ha representado desde in ille tempore a la mujer rural de este territorio? No obstante, estamos convencidos, que un replanteamiento empresarial de este sector económico identificativo del espacio geográfico salmantino y de la mujer de esta tierra, es viable.

A tal efecto, es nuestra intención abordar este planteamiento a lo largo de nuestro trabajo con la intención de no permitir que se pierda una señal de identidad cultural y femenina que viene identificándonos desde muy antiguo como ha quedado demostrado en este capítulo.

${ }^{201}$ Palabras del filigranista José Luis Nieves. 


\section{CAPÍTULO III.}

\section{DELIMITACIÓN CONCEPTUAL. LA FORMA.}




\section{Introducción.}

El estudio y la comparación de la Forma, es un camino necesario recorrer. Tan solo haciendo un análisis de formas de algunas de las piezas emblemáticas de la Filigrana Charra, concretamente del Botón Charro, puede que nos de alguna de las claves de porqué estos objetos han sobrevivido al paso del tiempo.

Estamos convencidos de la importancia que supone analizar la Forma, porque seguramente de ello, obtengamos las pistas suficientes para entender por qué el Botón Charro, concretamente, ha perdurado de una u otra manera a lo largo de la historia, identificando a una mujer anclada al territorio al que él da nombre y toma nombre. Es importante apuntar que la forma del botón está intrínsecamente incluida en otras piezas como son las tembladeras o las veneras.

Creemos que ello nos llevará a relacionar nuestros objetos con otras culturas, incluso no vinculadas al territorio nacional. Utilizaremos los conceptos matemáticos necesarios para demostrar que nuestra intuición es una realidad hasta ahora desconocida e impensable. Este aspecto, será ampliamente tratado a lo largo de este capítulo. . Sin embargo aparecen apuntes muy interesantes que harán volar la imaginación y que será el estudio de la forma y el significado de la misma, lo que nos haga realizar hipótesis nada desdeñables. En este último sentido dedicaremos un espacio, a nuestro entender único, innovador y revolucionario, dónde demostraremos el valor áureo de nuestro insigne "Botón Charro" y lo que ello significa. Nunca, hasta ésta tesis, se pensó que éste pobre objeto fuera a ser algo tan extraordinario. 
Gracias a este estudio, pretendemos desterrar de una vez por todas, la identificación injusta que se ha hecho del término "Charro"202 con mal gusto, recargado y abigarrado, como así queda definido en una de sus acepciones.

Si se repara en las noticias que aparecen en los libros, muy escasas, la mayor parte de las veces aparecen de forma anecdótica las referencias al botón, considerando por ello la necesidad de un estudio más compacto que gire en torno a los verdaderos aspectos que hacen de este patrimonio la piedra angular de la herencia femenina (de la mujer del pueblo) de esta tierra, considerando su recuperación y valoración un tema de derecho femenino y de conciencia para no olvidar nuestra identidad ancestral.

El estudio de la forma nos dará parámetros interpretativos que nos pondrán en el camino de la comprensión e identificación de nuestro patrimonio local, con otros más internacionales.

Las formas utilizadas en la ejecución nos desvelarán aspectos que en tiempos pretéritos unían a los pueblos, cuando era impensable hablar de globalización.

Hay que tener en cuenta que la forma nos vinculará a otros espacios, incluso a otros continentes, y que con ella sin duda también nos infiltraron sus costumbres y cultura respecto de la mujer.

Estudiaremos La Forma pues con ella nos llegarán luces hasta ahora ocultas y que sin embargo pertenecen al género femenino nunca hasta ahora estudiado desde esta perspectiva.

Cuando nosotros observamos estas imágenes ${ }^{203}$

\footnotetext{
${ }^{202}$ www.rae.es: charro, rra. (del eusk. txar, defectuoso, débil). 3. adj. Dicho de una cosa: Recargada de adornos, abigarrada o de mal gusto.

${ }^{203}$ Imágenes obtenidas de Google referidas a la Geometría Sagrada.
} 

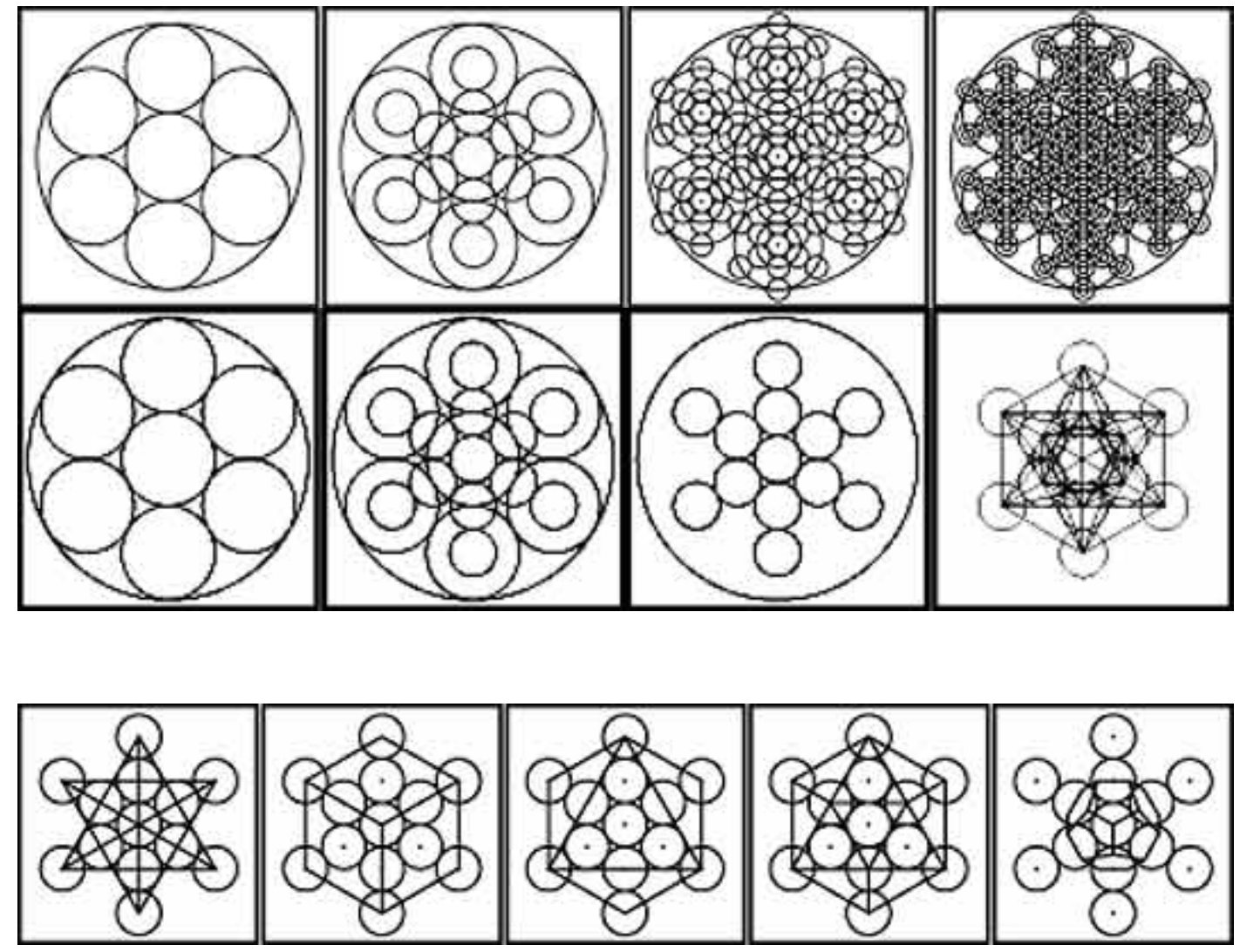

Estas fomas ${ }^{204}$ que vemos a simple vista nos recuerdan a las formas que componen algunos de los elementos que tenemos en nuetras piezas objeto de estudio. Pero no solamente en la forma última que ve el espectador en la tienda, sino en las formas preliminares que nosotros, en los distintos talleres de oreros dónde hemos estado, hemos visto. La mayoría de las veces la forma final es un compendio de formas superpuestas que unas sobre otras acaban dandonos el resultado que se nos ofrece para que sea parte del aderezo.

Formas similares las encontramos en la arquitectura. De entre muchos de los ejemplos tenemos las vidrieras ${ }^{205}$ de la Catedral de León.

\footnotetext{
${ }^{204}$ www.geometriasagrada.com, abril, 2014.

205 Imágenes obtenidas de Google. marzo, 2012.
} 


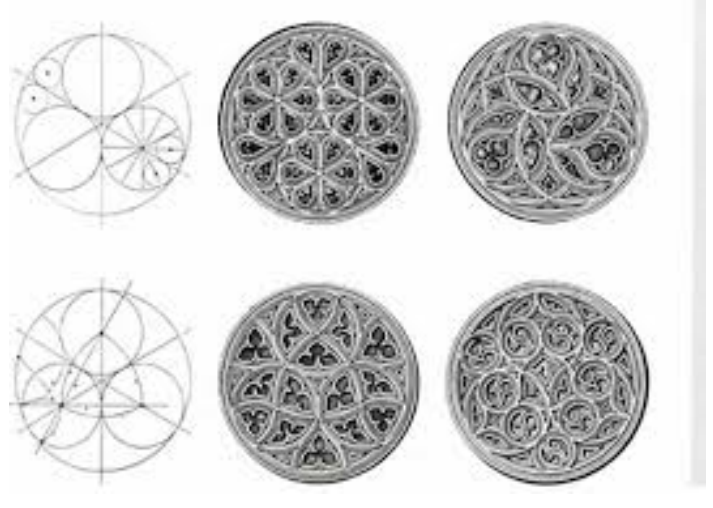

En ellas vemos implicitas las fomas de las que venimos hablando.

Estudiar la técnica y a posteriori la forma, como hemos hecho, ambas nos darán los ejes de éste trabajo de investigación para demostrar lo ancestral del origen de estos objetos y de lo novedoso que resulta un estudio de estas características a los ojos de los investigadores.

Recurrir al estudio de la forma ha sido una constante en la evolución del pensamiento humano, pues como veremos más adelante, ello ha conformado una buena parte de la filosofía y del arte en general. Desde el origen del pensamiento, en el hombre todo o casi todo viene de la observación de lo que tenemos a nuestro alrededor siendo la forma el continente de los objetos que nos rodean, y de esa observación el hombre ha creado nuevos objetos que, explícitamente o implícitamente, rememoran las formas que tenemos en derredor.

Si hay algo que siempre nos ha llamado la atención es la forma de estos objetos que encierran en sí mismos un universo entero, casi podríamos decir un microcosmos, amén de una belleza extraordinaria. Seguramente esa captura de la forma se basa fundamentalmente en la proporción, ya que es ella la que predomina y es base de los objetos más extraordinarios que ha llevado a cabo el ser humano. Lo interesante radica, que esa proporción, existe en la propia naturaleza y que se ha descubierto a través de estudiar su forma con ecuaciones matemáticas. Por lo tanto "matemáticas y forma" conforman un binomio inseparable. Investigando los orígenes de la forma llegamos a la naturaleza. 
Es este el motivo por lo que centramos en el estudio de la forma del botón que en su descomposición aparecerá la geometría sagrada.

\section{Orígenes de la forma, dificultad e importancia de la delimitación conceptual: arquetipo, mándala y símbolo.}

Hemos encontrado mucha documentación al respecto, pero adaptarla a nuestros objetivos y no diluirnos en teorías e irrealidades, es otra cuestión. Para ello hemos hecho un esfuerzo de síntesis muy grande para no perdernos en disquisiciones improductivas y nada resolutivas.

Podemos afirmar que la forma inquieta y preocupa al hombre desde el origen $^{206}$ “...del libro de Paccioli y sus láminas atribuidas a Leonardo da Vincci...encontré allí también, al resplandor del gran incendio de las ideas del Renacimiento, la austera claridad de la antorcha traída de Egipto por Pitágoras, y , dorada por la sonrisa de Platón, era propiamente la brillante mística del Número Puro, rigiendo y traduciendo todo orden, toda belleza, desde el suspiro de la flauta hasta la armonía de las esferas...como el audaz geómetra que antaño concibió la Gran Pirámide, como los arquitectos y filósofos de siglo de Pericles, el minorista de Bolonia y sus amigos, Pietro de la Francesca(que fue su profesor de geometría), Alberti, Leonardo da Vinci, Jacomo de la Barbari (que fue su discípulo), creían que en la naturaleza viva y en el arte, que es su emanción, resuena indefinidamente esta Ley del Número. Brabante, Rafael, Miguel Angel, Vignola, pensaban del mismo modo y estimaban también que el conocimiento completo de la Geometría, la meditación profunda de la Ciencia del Espacio eran indispensables a aquellos que con el pincel, el cincel o la cuerda debían crear o fijar las formas..."Los arquitectos actuales, dice Le Corbusier, no tienen el concepto de los volúmenes primarios".

\footnotetext{
${ }^{206}$ GHYKA MATICA, C.,Estética de las proporciones en la naturaleza y en las artes, Editorial Poseidon, S.L.,Barcelona, 1977. Prefacio.
} 
El estudio teórico de la forma en sí, contorno y volumen; el examen matemático de la estructura general y del crecimiento de los seres vivos, por un lado, de las creaciones del arte decorativo, plástico o monumental, por el otro, parecen propiamente denunciar la recurrencia de ciertas proporciones útiles o simpáticas, $y$, por lo general, ambas a la vez. ¿Nos complacen porque el ojo ha experimentado la larga disciplina e su costumbre, o porque son precisamente los pálidos reflejos de la trascendente Ley de los Números?. Sea de ello lo que fuere... la divina proporción de Lucca Paccioli se revela, cuando se le adjuntan características notables...Toda armonía puede expresarse o simbolizarse por números y que, a la inversa, de los números y de las notaciones matemáticas que traducen sus relaciones, se desprende a menudo una armonía rimada que justifica la aclamación de Spengler ${ }^{207}$.... La Matemática es un arte verdadero, junto con las artes plásticas y la música..."

Más tarde volveremos a la interesante obra de Matica, pero es importante hacer referencia a otras consideraciones de otros autores antes de profundizar en nuestras teorías.

Es importante para nuestro objetivo para delimitar el significado de algunos términos.

Investigando hemos podido consultar la tesis doctoral de Brian Silva Maldonado $^{208}$ con la que coincidimos en la idea de que los arquetipos son todo objeto, sin excepción, ya sea creado por la naturaleza o por la mano del hombre, es un ente con vida propia que inevitablemente emite algún sentido.

El ser humano está constantemente expuesto a estas erradicaciones psicológicas, cuyos efectos pueden permanecer en el subconsciente o pasar a la conciencia.

\footnotetext{
${ }^{207}$ SPENGLER, O, La decadencia de occidente, Edit Espasa Calpe, 2007.

208 SILVA MALDONADO, B, El inconsciente colectivo en la pintura moderna. La exaltación del “objeto" y la animalidad: aportes desde la psicología de Jung, Pontificia Universidad Católica de Perú, julio, 2012.
} 
Las grandes religiones mundiales sufren de anemia progresiva porque los númenes benéficos han huido de los bosques, ríos y montañas, de los animales y los hombres desapareciendo y sumergiéndose en el inconsciente.

Para Jung ${ }^{209}$ los arquetipos son esencialmente, formas universales del pensamiento, residuos de las reacciones eternas del género humano, con el que coincide algún otro autor ${ }^{210}$ (Malexeverría 2002).

Jung $^{211}$ las calificó también como imagos e imágenes primordiales que están presentes tanto en la naturaleza humana como en la historia y subyacen en el lado invisible del espectro del inconsciente.

Si pretendemos explicar más sencillamente el arquetipo, de acuerdo con Jung ${ }^{212}$, diríamos que es una tendencia tan marcada como el impulso de las aves a construir nidos $o$ el de las hormigas a formar colonias organizadas.

Por su parte, Malexeverríat ${ }^{213}$ agrega a través de una cita de Jung en la que reconoce que son como lechos de ríos que el agua ha abandonado, pero que puede volver a irrigar después de interrupciones de duración indeterminada.

Un arquetipo es algo semejante a una vieja garganta encajonada, por la que las aguas de la vida han corrido durante mucho tiempo. Cuanto más han ahondado en este lecho, más han conservado esta dirección, y más probable es que tarde o temprano vuelvan allí.

Si bien es cierto que la vida del individuo está regularizada, como en un canal, en el seno de la sociedad humana y en particular del Estado, no lo

\footnotetext{
209 JUNG CARL, G, Arquetipos en consciente colectivo, edit Paidós, Buenos Aires, 1989.

${ }^{210}$ MALEXEVERRÍA, I, Bestiario Medieval, Siruela, Madrid, 2002.

211 JUNG CARL, G, El hombre y sus símbolos, Edit. Paidós, Barcelona, 1995.

212 Op. Cit.

${ }^{213}$ Op.Cit.
} 
es menos que la vida de los pueblos es semejante al curso de un torrente bravío que nadie puede contener, como bien explica Malexeverría ${ }^{214}$.

Por otro lado, los arquetipos, al ser una suerte de complejos sociales, son elementos que Jung ${ }^{215}$ estudia en los ritos primitivos, religiones, mitos, sueños y otros conceptos que caracterizan colectivamente a una nación en relación a su historia. De acuerdo con él ${ }^{216}$, existe una diferencia entre arquetipo e imagen arquetípica. Los arquetipos no se pueden visualizar, lo que nos hace reafirmar su condición de elementos innatos que, al carecer de forma, se materializan con imágenes simbólicas generadas por los sueños.

Entonces lo que hace generar las imágenes arquetípicas son las experiencias que influyen en el hombre cuando llegan a su consciencia, es decir, son las imágenes arquetípicas ya decodificadas por el símbolo las que posiblemente dieron origen a las religiones y mitologías ancestrales quizá en un intento del hombre por encontrar un génesis a los elementos de su entorno.

Para Jung ${ }^{217}$, este sistema es el que categoriza al hombre como humano por ser este un constante creador de imágenes; así reafirma la importante reciprocidad que existe entre él y sus símbolos. Sobre los símbolos, Jung ${ }^{218}$ aborda el tema de los símbolos y refiere que son representaciones colectivas emanadas de los sueños de edades primitivas y de fantasías creadoras que no necesitan de una base racional y son de naturaleza desconocida para él.

Evidentemente las formas que nosotros estudiamos, tienen mucho de arquetipo, hasta tal punto que el poeta Antonio Colinas ante la forma del Botón Charro, siempre la identifica con un Mandala ${ }^{219}$.

\footnotetext{
${ }^{214}$ Op. Cit.

${ }^{215}$ Op.Cit.

${ }^{216}$ Op. Cit.

217 Op. Cit.

218 Op. Cit.

219 www.rae.es: mandala, (Del sánscr. máṇḍala, disco, círculo).1. m. En el hinduismo y en el budismo, dibujo complejo, generalmente circular, que representa.
} 
Haciendo referencia a este aspecto seguimos coincidiendo con Maldonado ${ }^{220}$ cuando apunta que podríamos también referirnos al carácter simbólico de la rueda estudiado por Jung ${ }^{221}$ quien asigna un significado espiritual que lo lleva a emparentarlo a un sol divino.

Siguiendo esta idea, el autor transfiere el carácter divino de la rueda al "mandala", una imagen simbólica que expresa un círculo mágico: El más antiguo de los dibujos mandálicos que conozco es una llamada "rueda solar" paleolítica, que fue descubierta hace poco en Rhodesia ${ }^{222}$. Este aspecto nos pone muy en contacto con la propia forma y simbología de nuestro botón charro.

Lo que es evidente es que todas estas cosas proceden del eco de la historia donde la humanidad toca las capas más profundas de lo inconsciente y posibilitan asirlas donde el lenguaje consciente se muestra como totalmente impotente. Tales cosas no pueden ser creadas por el pensamiento, sino que deben crecer de nuevo hacia arriba desde la oscura profundidad del olvido, para expresar los presentimientos supremos de la conciencia y la intuición más alta del espíritu y, así, fundir en uno la unicidad de la conciencia actual con el primitivo pasado de la vida.

Von Franz ${ }^{223}$ dice al respecto que Jung empleó la palabra hindú mandala (círculo mágico) para designar una estructura de ese orden, que es una representación simbólica del "átomo nuclear" de la psique humana, cuya esencia no conocemos.

Las imágenes simbólicas derivadas de los sueños están asociadas a: formas aborígenes, innatas y heredadas por la mente humana. Así podemos decir que una palabra o una imagen es simbólica cuando representa algo más que su significado inmediato y obvio. Tiene un aspecto "inconsciente"

\footnotetext{
${ }^{220}$ Opus, Cit.

221 JUNG CARL, G, El secreto de la flor del oro. Un libro de la vida china, Paidós, Buenos Aires, 1961.

${ }^{222}$ CHINCHILLA SÁNCHEZ, K, Conociendo la mitología, Universidad de Costa Rica, 2003.

${ }^{223}$ VON FRANZ, M L, Conclusión. La ciencia y el inconsciente en Jung. Paidós, 1965.
} 
más amplio que nunca está definido con precisión o completamente explicado. Ni se puede esperar definirlo o explicarlo.

Cuando la mente explora el símbolo, se ve llevada a ideas que yacen más allá del alcance de la razón como expresa Jung ${ }^{224}$, es decir su explicación es parcial e incompleta y no se podría definir inmediatamente debido a su ambigüedad. Los símbolos asumen una importancia vital cuando se trata de encontrar sentido a temas que el hombre no puede entender completamente.

No cabe duda que estas formas que estamos estudiando deberíamos ver hasta qué punto tienen intrínseco el valor del símbolo y es ahí donde podemos encontrar las causas de la permanencia de ellas a lo largo del tiempo.

El símbolo ${ }^{225}$ es un lenguaje universal que en la conciencia general prevalece y como por arte de magia, el individuo es capaz de reconocer independientemente de la cultura, la raza o el lugar.

Hablemos de los símbolos:

1. Coincidimos con Cassirer ${ }^{226}$ que en los símbolos los hombres se ponen de acuerdo para referirse o comunicar algo, por eso deben ser aprendidos y por eso también cambian de un lugar a otro (lo que no ocurre con las señales como el humo o las huellas).

El Hombre ha desarrollado un código de comunicación, la lengua, que le permite establecer relaciones con los demás individuos de su misma especie como ningún otro género animal puede hacerlo. Tan importante es esta capacidad humana que no es pensable ninguna vida social sin ella. El género humano, sin ella, no sería tal .Los gestos con las distintas partes del cuerpo, la vestimenta, los objetos, las artes, las ciencias son, en algún aspecto, lenguajes, porque constituyen las complejas formas de la comunicación entre los seres humanos.

\footnotetext{
${ }^{224}$ Op. Cit.

${ }^{225}$ CASSIRER, E, Filosofía de las formas simbólicas I el lenguaje. Edit. Fondo de Cultura, México, 1985. ${ }^{226}$ Op. Cit.
} 
En este sentido el ser humano es un animal capaz de atribuir significado a todo. Dentro de este complejo mundo del lenguaje, la lengua tiene un lugar privilegiado: es el sistema más complejo de todos, y que sirve para nombrar y dotar de significados a los demás lenguajes, inclusive a sí misma. La lengua nos permite nombrar el mundo de la naturaleza, el mundo humano e inclusive aquello que no existe; basta que algo surja en la mente de alguien para que pueda ser nombrado por ella.

2. Cassirer ${ }^{227}$ sostiene que la ciencia (y otras formas de conocimiento del ser humano) construye sus objetos y de alguna manera el mundo circundante, como símbolos intelectuales creados libremente.

La "actividad simbolizadora"228 (que se ejerce ante todo en el lenguaje verbal, pero también en el arte, la ciencia y el mito) no sirve para nombrar un mundo ya conocido, sino para producir las propias condiciones de cognoscibilidad de lo que se nombra ${ }^{229}$. El símbolo, en este caso, es lo mismo que el signo, o sea, el posibilitador de la cognoscibilidad del mundo.

3. El concepto de símbolo en Mircea Eliade, antropólogo rumano y autor de Historia de las Religiones ${ }^{230}$, pretende hacer un recorrido por todas las expresiones culturales que han sido dadas a lo sagrado, desde los más remotos ejemplos (pueblos premodernos que aún son nómadas) hasta las manifestaciones de las civilizaciones actuales que se erigieron alrededor de una de las grandes religiones del mundo (el judaísmo, el cristianismo, el islamismo, el budismo, el hinduismo, el taoísmo).

En esta búsqueda de interpretación de ese sentimiento que ha marcado al hombre en el transcurso de su historia, de esa relación con lo sagrado que ha dejado huella en el ser humano, Eliade se encuentra con un fenómeno capital: el símbolo ${ }^{231}$. Es así como este autor, en su intento de clarificar el recorrido y el significado de las diferentes religiones de todos los tiempos, tiene que emprender a su vez una explicación del funcionamiento

\footnotetext{
${ }^{227}$ Op. Cit.

228 Op.Cit.

${ }^{229}$ ECO, U, Semiótica y filosofía del lenguaje, Edit. Lumen, Barcelona, 1990.

${ }^{230}$ ELIADE, M, Tratado de Historia de las religiones, morfología y dialéctica de lo sagrado, Edit. Cristiandad, Madrid, 2009.

${ }^{231}$ ELIADE, M, Imágenes y símbolos, Edit. Taurus, 1999.
} 
del símbolo, al constatar que lo sagrado siempre se expresa al hombre por medio de éste.

El punto verdaderamente importante para Eliade en su estudio de los símbolos, los mitos ${ }^{232}$ y los ritos de las diversas religiones, no es llegar a una descripción y análisis histórico-cultural de cada uno de ellos, es decir, de su especificidad o "individualidad" cultural, su evolución o expresión histórica particular, sino la posibilidad de que estas instancias construidas por el espíritu humano, independientemente de sus propias coordenadas, esto quiere decir que puedan revelarnos al hombre como tal.

Los símbolos son capaces de revelar una estructura del mundo que no se hace evidente por ninguna otra forma de representación. Esto significa que el mundo nos habla a través de los símbolos, y éstos son portadores de una realidad más profunda y más fundamental, digamos que los símbolos religiosos que atañen a las estructuras de la vida revelan una vida más profunda, más misteriosa que lo vital captado por la experiencia cotidiana.

Las imágenes, los símbolos, los mitos, no son construcciones arbitrarias de un psiquismo infantil, desequilibrado o poético.

Los símbolos y todas estas construcciones que están por fuera de la razón y del lenguaje discursivo están ahí para algo específico, tienen una importante función; por lo tanto de alguna manera, son necesarios. Este algo específico es mostrarnos las características más secretas y escondidas del Ser. Esta constatación que parece tan rimbombante, pero que en el fondo es bastante simple, nos lleva a darnos cuenta de que los símbolos, y sus "allegados", nos muestran un camino de conocimiento del hombre, simplemente el hombre esto quiere decir, del ser humano concebido antes de su articulación en las condiciones históricas.

Estas construcciones (imágenes, símbolos, mitos) existen precisamente para poder mostrar y transmitir "la réalité ultime des

${ }^{232}$ ELIADE, M, Mito y realidad, Edit. Kairós, S.A, Barcelona, 1999. 


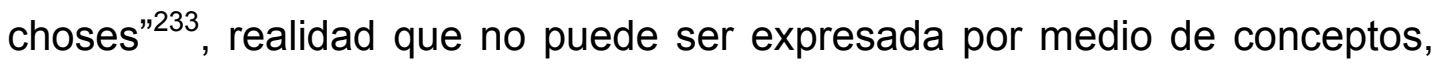
ya que se presenta al espíritu de una manera contradictoria.

4. Los símbolos son multivalentes. Esto quiere decir, tienen la capacidad de significar simultáneamente realidades heterogéneas y articularlas en un mismo sistema, y más aún, tienen la capacidad, en lo que coincidimos con Eliade $^{234}$ de articular situaciones paradójicas. Esta función será, primordial en la teoría junguiana. El simbolismo de la luna, por ejemplo, revela una solidaridad connatural entre los ritmos lunares, el devenir temporal, las aguas, el crecimiento de las plantas, las mujeres, la muerte y la resurrección, el destino humano, el oficio de tejedor, etc como apunta Eliade ${ }^{235}$ Esta yuxtaposición y articulación de fenómenos aparentemente heterogéneos, no se presenta a la reflexión y a la razón de una manera inmediata. Aunque algunas de estas relaciones parecen tener una explicación racional, el simbolismo de la luna no se agota con este tipo de causalidad.

En el caso del simbolismo lunar, ¿cómo estas diferentes significaciones pueden formar un sistema? Tenemos que tener en cuenta que se está trabajando con diferentes registros: El cosmológico, el antropológico y el espiritual. En este caso lo que el símbolo articularía en común de los tres registros sería las existencias que están sometidas a la ley del tiempo, pero en un devenir cíclico, o sea, a una vida que implicaría en sí misma la posibilidad de la muerte y el renacimiento.

En cuanto a la articulación de las situaciones contradictorias, lo que el símbolo le presenta al hombre es la posibilidad de asumir un mundo real que se escapa a su entendimiento.

En efecto, el hombre se vio abocado a un mundo "misterioso", a un mundo de contrastes contundentes y aparentemente inabarcables: la vida, la muerte, el bien, el mal, el ser, la nada, la creación, la destrucción, la angustia, la plenitud, entre otras. Estas fueron las características que el hombre premoderno encontró en eso que denominó "lo sagrado". Era la

\footnotetext{
${ }^{233}$ Op.Cit. Pág. 17.

${ }^{234}$ Op.Cit.

${ }^{235}$ ELIADE, M, Una nueva filosofía de la luna, Edit. Trotta, 2010.
} 
coexistencia en la divinidad de principios polares y antagónicos, reflejo directo de un mundo asimismo polar y antagónico. Todo esto se dio como el presentimiento de una realidad que podía ser concebida como un "Todo", como una "Unidad".

5. Todo símbolo auténtico lleva consigo una dimensión cósmica, una onírica y una poética. Pero, ¿Cómo se realiza este engranaje al interior del símbolo? La respuesta es: partiendo desde lo sagrado.

Bien es sabido, gracias a la historia de la humanidad, que una de las relaciones primordiales que el hombre siempre tuvo con la realidad que lo rodeaba fue su comunicación con lo divino. Pues bien, donde primero lee el hombre lo sagrado es en el mundo (el cielo, el sol, la luna, las aguas, la vegetación), y es por esto, coincidiendo con Ricoeur ${ }^{236}$, que estas realidades cósmicas son los primeros símbolos.

Este aspecto cósmico del símbolo no lo convierte en algo anterior ni extraño al lenguaje. Por el contrario, estas realidades cósmicas guardarían dentro de sí "dans un noeud de présence"237 un conjunto de intenciones significativas que antes que hacer pensar hacen hablar. O sea, estas realidades, que Ricoeur llama "símbolos-cosa", son matrices de innombrables símbolos hablados, "la manifestation par la chose est comme lacondensation d'un discours infini" ${ }^{238}$.

Esto estaría más claro: la "cosa cósmica" sería la posibilitadora de la expresión de un discurso infinito, de un sentido que es inagotable. Como ejemplo pone Ricoeur el cielo, matriz de innumerables sentidos que sería la misma cosa que decir que el cielo manifiesta lo sagrado y decir que el cielo significa lo alto, lo elevado e inmenso, lo poderoso y ordenado, lo clarividente y sabio, lo soberano, lo inmutable.

\footnotetext{
${ }^{236}$ RICOEUR, P, Teoría de la interpretación. Discurso y excedente de sentido, Edit. Siglo XXI, México, 1999.

${ }^{237}$ Op. Cit. Pág 18.

${ }^{238}$ Op.Cit. Pág 18.
} 
Convenimos con el autor ${ }^{239}$ en aclarar que en estas realidades cósmicas, la manifestación y la significación que llevan consigo se dan al mismo tiempo, son recíprocas, lo que quiere decir que la manifestación está también en el ámbito de un fenómeno del lenguaje: es, desde un comienzo, lenguaje.

Estas características sagradas de lo cósmico son las que nos permiten el paso a la dimensión onírica del símbolo. El sueño es el puente que comunica la función "cósmica "con la función "psíquica" de los símbolos.

Pero Ricoeur piensa que manifestar lo sagrado en el "cosmos" y manifestarlo en la "psique" es la misma cosa: "Cosmos et Psyché sontles deux pôles de la même "expressivité" "; je m'exprime en exprimant le monde; j'explorema propre sacralité en déchiffrant celle du monde"240.

A estas dos dimensiones del símbolo, se le agrega la dimensión poética. El símbolo poético, a diferencia de la modalidad hierofánica ${ }^{241}$ y onírica, nos muestra la expresividad en estado de nacimiento y, más que un relato, la imagen poética es verbo.

Ya hemos visto cuáles son las dimensiones del símbolo, lo que podríamos llamar las formas que lo constituyen.

A continuación, coincidiendo con las teorías de Ricoeur intentaremos hacer una aproximación a la esencia del símbolo para reconocer su estructura.

Como primera instancia, los símbolos son signos. Según Ricoeur ${ }^{242}$, incluso en las situaciones en las cuales los símbolos son elementos del universo o cosas, su calidad de signos queda intacta y con ella su pertenencia a un ámbito lingüístico, ya que la dimensión simbólica de estas realidades es adquirida precisamente en el universo del discurso.

\footnotetext{
${ }^{239}$ Op. Cit.

${ }^{240}$ Op.Cit. Pág 20.

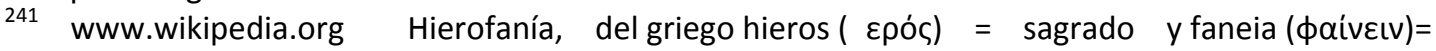
manifestar. Es el acto de manifestación de losagrado, conocido también entre los hinduistas y budistas con la palabra de la lengua sánscrita darśana. Neologismo aportado por Mircea Eliade en su libro El mito del eterno retorno, Edit, Alianza, S.A., Madrid, 2002.

${ }^{242}$ Opus, Cit.
} 
Algo parecido sucede con los sueños, los cuales muestran su proximidad a la palabra en el hecho de que pueden ser contados y comunicados en la vigilia.

En cuanto a la poesía, convenimos con este autor, que la imagen poética es esencialmente verbo y forma.

Pero no todos los signos son símbolos.

En el símbolo encontramos una intencionalidad doble: toda expresión significante apunta a una intencionalidad primera o literal, en los símbolos este funcionamiento es aún más complejo, ya que a partir de esta intencionalidad primera se vislumbra una segunda; el sentido literal y manifiesto apunta más allá de sí mismo.

Los signos técnicos nos entregan generalmente un significado directo, por lo que son perfectamente transparentes y no dicen sino lo que quieren decir. Por el contrario, los signos simbólicos son opacos, porque el sentido primero literal apunta analógicamente a un sentido segundo que no es dado de otra manera que en sí mismo, esto quiere decir, en el sentido literal habita resguardado el sentido simbólico

6. El modelo simbólico en Umberto Eco.

Veamos ahora la concepción "secular" de este autor, quien no ve en el símbolo más que un uso específico de los signos. Eco concibe la existencia de un modo simbólico más que la aparición exacta de una entidad llamada símbolo. Sin embargo, muchas tradiciones lingüísticas, filosóficas, teológicas, etc., han trabajado con el concepto de símbolo como una entidad específica, reconocible y aislable. Esta debe ser una de las razones por las cuales Eco comienza su capítulo sobre el modo simbólico ${ }^{243}$ con su etimología: el término símbolo viene del griego "arrojar con”, "juntar”, "hacer coincidir".

Símbolo sería originariamente un modo de reconocimiento de una moneda dividida cuyas dos partes deben coincidir. "Aun cuando de las dos

${ }^{243}$ ECO, U, Semiotica y filosofia del lenguaje (2a ed.) Lumen, 1995 
mitades una remita a la otra... esas dos mitades de la moneda sólo alcanzan la plenitud de su función en el momento en que vuelven a juntarse para reconstruir la unidad" 244 . Es por esto que Eco hace la comparación entre esta explicación del símbolo y la dialéctica del significante y el significado en el signo: en éste último la remisión es siempre incompleta, no se cierra, ya que al interpretar un signo siempre estamos construyendo uno nuevo, mientras que el símbolo parece implicar una remisión que llega a su término, "la conjunción con el origen". Pero esta concepción del símbolo no es precisamente la de Eco, sino más bien la que ha sido transmitida tradicionalmente. Para este autor el modo simbólico es un uso específico que se le da a los signos.

Esto significa que existen "experiencias semióticas" intrincadas, que aparecen oscuras, en las cuales la expresión es correlacionada con una "nebulosa de contenido", ya sea por el emisor o por el destinatario, es decir, el contenido está relacionado con una cantidad impresionante de campos diferentes que son difícilmente estructurables, y cada cual puede reaccionar de manera diferente, interpretar esta nebulosa de contenido según el campo que le parezca más adecuado, sin que haya un código que lo restrinja obligatoriamente .

Eco nos da un ejemplo de esto: la rueda de carroza ${ }^{245}$. ¿A qué nos puede remitir? Para comenzar puede ser un ejemplo de la clase de las ruedas (la insignia de un carretero), puede referirnos al mundo rural arcaico, o como "estilización", según Eco, puede indicarnos la sede del "Rotary Club".

Pero veamos ahora qué otras características tiene que le permitan trascender aún más en su contenido: la circularidad, la capacidad de avanzar tendencialmente hasta el infinito, la simetría de su forma. Como vemos, es totalmente extrapolable al caso concreto del botón charro.

Son estas propiedades las que permiten la construcción de una nebulosa de contenido, ya que pueden existir otras entidades de contenido

\footnotetext{
${ }^{244}$ Op. Cit, Pág 229.

${ }^{245}$ Op.Cit. Pág 229.
} 
que no son fáciles de representar con los signos convencionales, por ejemplo, el tiempo (que es circular y avanza), la divinidad (en la que todo es simetría y proporción), el eterno retorno, el carácter cíclico del proceso vida/muerte, la energía creadora en virtud de la cual desde un único centro se engendran armónicamente las perfecciones circulares de todos los seres. Volvemos otra vez a encontrarnos con nuestro objeto de estudio: el botón charro.

La rueda puede remitirnos a todas estas entidades en conjunto, y en la nebulosa de contenido que ellas constituyen también podrán coexistir entidades contradictorias como vida y muerte. Pues bien, esto significa usar la rueda conforme al modo simbólico ${ }^{246}$.

Parece que el autor en sus concepciones del círculo y la forma de la rueda estuviera refiriéndose a nuestro botón charro.

7. El símbolo en Freud y Jung.

Para Freud la explicación del símbolo eran simplemente contenidos de las relaciones individuales infantiles con los padres proyectados en las producciones culturales (la mitología, la religión, el folklore, las leyendas, los cuentos tradicionales, etc.); incluso pensaba que los pueblos primitivos eran la infancia de la humanidad, y de esta manera su forma de pensamiento (la plasmada en los mitos por ejemplo) era completamente infantil.

Jung, sin embargo, no se sintió satisfecho con esta explicación y vio en esta similitud la existencia de una instancia que era igual en todos los individuos y cuya prueba de realidad eran precisamente las construcciones culturales.

De esta manera postuló su hipótesis del "inconsciente colectivo", hipótesis que fue corroborada en su trabajo terapéutico personal y en sus investigaciones comparativas de la psicología de los pueblos y de la historia de los mitos ${ }^{247}$.

\footnotetext{
${ }^{246}$ Op.Cit. Pág. 286.

${ }^{247}$ FREUD, SIGMUND, Obras completas, Edit, Amorrortu, Buenos Aires, 1996.
} 
Un poco para contestar al concepto "infantilista" de Freud, Jung considera que si bien, en efecto, los pueblos primitivos son la infancia de la humanidad y su forma de pensamiento es arcaica, esto no significa que sea infantil. El pensamiento arcaico "como el de los mitos o los sueños" es una forma de conocimiento completamente estructurada y, aunque es más típico verlo en la infancia y en los pueblos premodernos, existe también en el hombre adulto civilizado.

"Aquellos antepasados del hombre provistos de bronquios, en modo alguno eran embriones, sino animales plenamente desarrollados, y así también el hombre que vivía y pensaba en el mito era una realidad adulta y no un niño de cuatro años.

Retomando un poco el hilo de nuestras ideas, tenemos que tener en cuenta que Jung nunca negó la existencia de un inconsciente personal, más bien lo que hizo fue adicionarle un inconsciente colectivo. Esto lo explica claramente una de sus discípulas, Jolan de Jacobi ${ }^{248}$ cuando comenta que mientras que el llamado inconsciente personal comprende contenidos que proceden de la historia vital del individuo, es decir, todo aquello que fue reprimido, rechazado, olvidado, percibido de un modo subliminal, etcétera, el inconsciente colectivo abarca contenidos que representan el sedimento de los modos típicos de reacción de la humanidad, desde sus orígenes más remotos - sin consideración a diferencias históricas, étnicas o de cualquier otro tipo - a situaciones como angustia, lucha contra el poder, relaciones de los sexos, de los hijos con los padres, figuras paternas y maternas, actitudes de odio y amor, frente al nacimiento y la muerte, al dominio del principio de la luz y la sombra.

Es decir, al lado de la psique individual, del abanico de contenidos que es la consecuencia de las experiencias personales, encontramos también una "psique objetiva", como la llamó Jung, o sea, un abanico de contenidos que es la consecuencia de las experiencias de la historia de todos los seres humanos.

\footnotetext{
248 JACOBI, J, La psicología de C.G. Jung, Edit Espasa Calpe, segunda edición corregida y aumentada,
} Madrid, 19963, Pág, 37. 
Pero ¿cómo llegamos a conocer esos sedimentos "de los modos típicos de reacción de la humanidad"? En esto Jung es bastante tajante, sólo conoceremos a través de los símbolos que produce esa misma psique objetiva, a los cuales denominó arquetipos.

Así surgió la Psicología Analítica, encargada de dilucidar la relación natural que establece el ser humano con los arquetipos de lo inconsciente colectivo.

Los arquetipos, aunque ya hemos hablado algo de ellos a lo largo de este trabajo aún podemos completarlos algo más.

Para Freud ${ }^{249}$ los arquetipos los instituyó como primera regla en el proceso de interpretación de los sueños el llevara cabo una "asociación libre", es decir, sus pacientes debían, con cada trozo de sueño, hacer asociaciones mentales sin importar su trivialidad o su no pertinencia, y de esta manera hacer un rodeo hasta llegar al verdadero significado engañando así a la resistencia (la fuerza que no deja aparecer los contenidos reprimidos).

Pues bien, en el transcurso de este proceso, este investigador se encontró en algunos casos con que sus pacientes, frente a un trozo específico del sueño, permanecían en el más absoluto silencio.

Al principio Freud pensó que esto era un efecto de la represión, pero después de hacer todos los rodeos posibles, de llevar a cabo toda clase de intentos vanos, en efecto parecía que el paciente no sabía nada en relación a esas partes del sueño, o era, por lo menos, el silencio lo que se imponía. A estos contenidos que excedían las relaciones personales del individuo Freud los llamó símbolos oníricos ${ }^{250}$.

En la descripción del simbolismo en Freud ${ }^{251}$, el cual no es más que una utilización indirecta y figurada del lenguaje, su concepción "estricta" de símbolo son representaciones que no dependen de factores individuales, y

\footnotetext{
${ }^{249}$ FREUD, S, La interpretación de los sueños, Obras completas Edit. Amorrotu, Buenos Aires, 1976.

${ }^{250}$ Op. Cit.

${ }^{251}$ FREUD, S, Introducción al psicoanálisis, Edit, Alianza, Madrid, 1986.
} 
cuyas demás características son sus contenidos, son temas inconscientes reprimidos que tienen una significación fija, que son arcaicos, que existe una conexión lingüística primitiva entre simbolizado y simbolizante, teniendo paralelismos en los campos del mito, el folklore y la poesía.

En conclusión, los símbolos son figuras sustitutivas.

Quizás la característica primordial de todas las que enunciamos sea la existencia de conexiones lingüísticas arcaicas, por ejemplo, la hipótesis de una identidad primitiva entre el lenguaje sexual y el lenguaje del trabajo. Considero que esta es la característica primordial, ya que fue la que le permitió a Freud pensar que los símbolos tienen una significación fija, además de ser la que explica más convincentemente el hecho de que sean suprapersonales.

Todo esto permitió que el fundador del Psicoanálisis creara un "código" mediante el cual los símbolos podrían ser interpretados y encontrara (¿cómo no?) su verdadero sentido sexual oculto.

En adelante, por ejemplo, todo objeto convexo o punzante sería símbolo del falo y todo objeto cóncavo o receptivo lo sería de la vagina, elemento este que podríamos identificar con la forma cóncava que tiene nuestro botón charro.

De esta manera vemos cómo Freud redujo la fuerza significativa del símbolo al mecanismo más simple de la alegoría, es decir, lo redujo a esas representaciones que "enmascaran" su verdadero contenido, en las cuales, en el trabajo de desenmascaramiento, muere su importancia significativa.

No ha de extrañarnos el hecho de que, investigando en un mismo campo, Jung se haya encontrado con el mismo fenómeno. A estas representaciones frente a las cuales se imponía un definitivo silencio, Jung las llamó arquetipos ${ }^{252}$ (símbolos de lo inconsciente colectivo). Son diversos los puntos frente a los cuales este autor difiere de la teoría freudiana.

252 JUNG CARL, G, El hombre y sus símbolos, Edit. Aguilar, Madrid, 1966. 
En el primero de ellos, siendo consecuente con su teoría de la libido no exclusivamente sexual, Jung rechaza la reducción a una explicación exclusiva en ese ámbito, viendo en los símbolos significados que trascienden las pulsiones sexuales.

Otro de los puntos es el considerar la imposibilidad de hacer un "código" de significaciones de los símbolos.

A pesar de que los arquetipos son realidades simbólicas que se repiten en individuos de diferentes razas y en pueblos de diferentes orígenes, su expresión siempre está dada en el marco de una psique individual o de una cultura específica, por esto, su significado sólo puede ser hallado en la articulación con una posición consciente individual(en la terapia) o con unos hechos culturales específicos (en el análisis de un pueblo).

Hacer un código de los símbolos es absurdo, porque en la gama infinita de posibles significados de todo símbolo (recordemos "el modo simbólico" de Eco $)^{253}$, la actualización de uno o varios de esos significados sólo es posible con base en una relación específica a algo en particular sea ésta psíquica o cultural.

El último de los puntos, que consideramos el principal, es el hecho de que los arquetipos no derivan simplemente de unas relaciones lingüísticas arcaicas, ya que testimonian una fuerza (afectiva, significativa, simbólica) que va mucho más allá de las palabras, característica que Jung denominó como efecto "numinoso" del arquetipo ${ }^{254}$.

Pues bien, la pregunta lógica que aparece sería ¿qué es específicamente el arquetipo? Para Jung, el arquetipo es un esquema de conducta innato que se expresa en forma de imágenes, o sea, a nivel psíquico

Si continuamos con el análisis de la esencia del arquetipo, a ningún biólogo se le ocurrirá afirmar que cada individuo que nace vuelve a adquirir

\footnotetext{
253 Op. Cit.

254 JUNG CARL, G, Simbolos de transformación, Edit, Sudamericana, Buenos Aires, 1964.
} 
nuevamente su modo de comportamiento. Antes bien, es probable que si el pájaro tejedor, una vez llegado a determinada edad, construye siempre su nido, eso se debe a que es un pájaro tejedor y no un conejo.

Del mismo modo, también es probable que un hombre nazca con un modo humano de conducta y no con el de un hipopótamo o con ninguno.

De su conducta característica también forma parte su fenomenología psíquica, que es diferente de la de un pájaro o de la de un cuadrúpedo.

Los arquetipos son formas típicas de conducta que, cuando llegan a ser conscientes, se manifiestan como representaciones, al igual que todo lo que llega a ser contenido de conciencia ${ }^{255}$, como bien explicaba Jung.

De esta afirmación se deducen varios puntos importantes característicos del arquetipo : Primero, el arquetipo no es más que una forma inconsciente, es decir, de alguna manera, una forma vacía : "El arquetipo es un elemento formal, en sí vacío, que no es sino una "facultas praeformandi", una posibilidad dada a priori de la forma de la representación" ${ }^{256}$. Segundo, como forma innata, pertenece al ámbito de los instintos: "Podríase asimismo llamarlo intuición del instinto en sí mismo o autorretrato del instinto" ${ }^{257}$ sería algo así como el factor psíquico del instinto. Tercero, los arquetipos no son representaciones heredadas, pensar lo contrario ha sido la base de una crítica contundente que se le ha hecho a la teoría junguiana: "No afirmo con esto, en modo alguno, la herencia de las representaciones, sino solamente de la posibilidad de la representación cosa que es muy distinta" ${ }^{258}$, es decir, lo que Jung afirma es la herencia de las formas que pueden servir de base para determinadas representaciones. Cuarto, el arquetipo es una forma vacía que es "Ilenada", por un lado, con la representación, y por otro, con libido (energía básica del organismo vivo): "Así, estas imágenes nos las hemos de figurar como exentas de contenido y, por ende, inconscientes. El contenido, la influencia y el estado consciente no lo alcanzan sino luego, al

\footnotetext{
255 JUNG CARL, G, Arquetipos e inconsciente colectivo, Edit, Paidós, Buenos Aires, 1970.

${ }^{256}$ Op.Cit, Pág 74.

257 JUNG CARL, G, Energía psíquica y esencia del sueño, Edi, Paidós, Buenos Aires, 1982. Pág 159.

${ }^{258}$ Op. Cit, Pág 83.
} 
tropezar con hechos empíricos que, al dar en la predisposición inconsciente, le infunden vida. ${ }^{259}$ ".

En conclusión, los arquetipos "Son en cierto sentido los sedimentos de todas las experiencias de la serie de antepasados, pero no son estas experiencias mismas" 260 .

La hipótesis de una instancia psíquica que es igual en todos los seres humanos permite la explicación de los más diversos fenómenos de la historia de la humanidad. ¿Por qué el hombre siempre se ha ocupado de los mismos temas, ha sido atravesado por las mismas pasiones, se ha hecho una y otra vez las mismas preguntas? ¿Qué hace que los individuos de las más diferentes culturas se sientan unidos por un mismo lazo que trasciende sus discrepancias reales para hacerlos coincidir en una hermandad de especie que no puede explicarse sólo por la biología? ¿Por qué el convencimiento de que el ser humano más ajeno a mí guarda en su corazón los mismos miedos y las mismas alegrías que han cruzado mi vida? Concebir la existencia de los arquetipos es darse la oportunidad de descubrir en lo humano la constancia de lo humano.

Si Freud nos permite ver en el inconsciente personal la posibilidad de explicación de toda pasión individual dirigida hacia toda clase de individuos, Jung nos permite ver en su teoría de los arquetipos la unificación de toda pasión hacia la humanidad entera.

Esta teoría nos posibilita además recobrar al hombre como sujeto, es decir, recobrarlo como fuerza vital, recobrarlo en su valor de naturaleza hecha por y para la naturaleza, no concebirlo solamente como el resultado de la intersección de las más diversas variables culturales o de aquellas creadas por convención, sino que, en su característica de estructura psíquica innata, el arquetipo permite la unión en el hombre de su carácter más animal con lo que tiene de más elevado: su propia humanidad.

\footnotetext{
259 JUNG CARL, G, El yo y el inconcsciente, Luis Miracle, 2ª edición, Barcelona, 1950.

${ }^{260}$ Op.Cid, Pág 156.
} 
Así, el símbolo se apuntala en la forma innata llamada arquetipo, aportándole una representación consciente y un quantum de libido.

Símbolo sería la denominación del momento en el cual el arquetipo obtiene una representación consciente.

Para hacer más claro este proceso arquetipo-símbolo vamos a seguir la explicación o aclaración de J. Jacobi ${ }^{261}$ en el cual intenta dividir por etapas el curso de la acción de este fenómeno: a) El arquetipo reposa en lo inconsciente colectivo como una forma o elemento que puede ser potencialmente cargado de significación. b) Por situaciones o avatares psíquicos individuales o colectivos, el arquetipo recibe un suplemento de energía que comienza a hacer eficaz su actividad. c) Con su nueva carga energética el arquetipo ejerce una fuerza de atracción sobre la conciencia que no es en un principio reconocida y que puede expresarse como una actividad emocional indeterminada, llegando en algunos casos a ser efectivamente percibido por la conciencia y entrando así en el ámbito propiamente psíquico. d) Al entrar el arquetipo en contacto con la conciencia tiene dos posibles caminos: puede manifestarse en el plano biológico o puede expresarse en el plano espiritual como imagen o idea.

Es en este último caso en el que surge lo que ha sido llamado específicamente el símbolo, por el proceso de unírsele al arquetipo una materia prima imaginaria y una configuración de sentido.

En conclusión, símbolo y arquetipo son dos pasos en el transcurrir de un mismo fenómeno psíquico, por lo cual serán utilizados como sinónimos en las elucidaciones que vienen a continuación.

Jung considera que existen dos formas de pensamiento. Al primero lo llama pensamiento dirigido, o lógico, o verbal; éste tiene una relación más fuerte con el afuera y se apuntala en la capacidad verbal, en el lenguaje analítico. El otro pensamiento es el sueño o fantaseo, el cual, en última ${ }^{261}$ JACOBI, J, Complejo, arquetipo y simbolo: en la psicología de C. G. Jung, Fondo de Cultura
Económica, México, 1983. 
instancia, es una sucesión de imágenes, se aparta de la realidad, es subjetivo y motivado interiormente, en él cesa el pensamiento verbal.

Se podría sacar la conclusión, incluso, de que se apuntala en otro tipo de lenguaje ${ }^{262}$ como afirma Jung.

El símbolo formaría parte de este último tipo de pensamiento.

Haciendo una analogía con Eco, podríamos pensar en una primera relación sígnica con el mundo, y una segunda relación que surge con el uso simbólico de los signos.

Jung también hace una diferenciación entre signo y símbolo ${ }^{263}$.

"Según nuestro modo de ver las cosas, y siempre desde una manera de no especialista, debería establecerse una rigurosa diferenciación entre el concepto de símbolo y el concepto de un mero signo.

El símbolo presupone siempre que la expresión elegida es la mejor designación o la mejor fórmula posible para un estado de cosas relativamente desconocido. De esta manera Jung se acerca a lo que ya había sido mencionado por Eliade, en el sentido de que el símbolo es la representación adecuada de todo aquello que no puede ser representado por el concepto. La declaración de la Cruz como símbolo del amor divino es semiótica, pues la expresión 'amor divino' designa el hecho que quiere expresarse mejor y más certeramente que una cruz, que puede tener muchos otros significados.

Es, en cambio, simbólica la declaración de la Cruz que, allende todas las explicaciones imaginables, ve en ella la expresión de un hecho ignoto aún, de un hecho místico o trascendente incomprensible.

Jung considera, igual que Eco, que existen casos en los cuales el carácter simbólico es dado gracias a la disposición de la conciencia de quien juzga y se enfrenta a los hechos, y esto es posible ya que ese algo que está

\footnotetext{
262 JUNG CARL, G, Simbolos de transformación, Edi Paidós, 2ª Edición, Buenos Aires, 1962.

${ }^{263}$ Op. Cit.
} 
siendo objeto de discriminación, puede ser visto no sólo como tal, como lo que es, sino expresando un hecho en sí desconocido.

Eco lo explicaba como la decisión del emisor o el receptor de interpretar de acuerdo al "modo simbólico", es decir, como un "voy a interpretar simbólicamente".

Sin embargo, Jung también encuentra casos en los cuales el carácter simbólico no depende de nadie; simple y llanamente el símbolo se impone. Y de esta manera es la mejor expresión posible de una realidad que en esencia es inexpresable, en contraposición al significado fijo del signo. Como le ocurriría al caso de nuestro botón charro.

En su teoría de los símbolos, Jung nos muestra una posibilidad de recobrar los puentes comunicativos que creemos fueron destruidos o que creemos que no existieron nunca; el símbolo se erige como la posibilidad de reavivar el fuego perdido en el centro del signo, de hacer viviente su anquilosado y árido saber.

Pero no es sólo una cuestión teórica, el símbolo nos ayuda a elevar nuestra vida a un plano superior, nos puede sanar de la enfermedad moderna que podríamos llamar "literalidad".

Jung nos da un ejemplo precioso cuando nos habla en "Los complejos y el inconsciente" de la forma en que curaban los médicos-sacerdotes egipcios: para enfrentar una picadura de serpiente, narraban al enfermo la historia del Dios-Sol que fue picado por una serpiente creada por la DiosaMadre, y cómo éste fue curado también por ella. De esta manera elevaban a un plano mitológico un accidente "concreto", y gracias al nivel psíquico en que estaban los egipcios de entonces, a su facilidad -aún no perdida- para ser sumidos en lo inconsciente colectivo mediante un simple relato, las imágenes profundas de la psique se apoderaban con tal potencia de ellos que "su sistema vascular y sus regulaciones humorales" restablecían el equilibrio corporal.

Ahí está la verdadera preocupación vital que se desprende de la elucidación que he hecho de la teoría junguiana. 
Todo cuanto hemos expuesto es para hacer entender el valor del símbolo y del arquetipo, pues consideramos que está intrínsecamente relacionado con los objetos en los que nosotros basamos nuestro estudio.

Consideramos que queda probado el valor ancestral del signo que representa nuestro Botón llevando implícito un micro-cosmos en el que quedan representados aspectos como el género femenino por su forma cóncava, el universo y sus planetas, las formas de las plantas y las formas de algunos de los accidentes meteorológicos de la naturaleza ${ }^{264}$.

Nuestro próximo apartado nos afianzará en la exactitud de una forma única en el transcurso de la humanidad y que viene representada por la medida áurea de los objetos.

No cabe duda de que la forma, según nosotros entendemos, es el reflejo de mucho más de lo que aparentemente nos refleja. La huella del hombre es clara en todos los objetos, donde prevalecen las líneas, los ángulos, los polígonos y por supuesto las curvas identificables en circunferencias-arcos-espirales...

Queda claro que la significación de arquetipo, mandala, símbolo y signo, confluyen para conformar un objeto tan interesante como es el botón charro.

Sabemos que el hombre en la construcción de los objetos aporta una Geometría que él simplifica. Nos referimos a la Geometría de Euclides, de Apolonio y de Descartes. A pesar de que las nubes no son esferas, las montañas no son conos, las costas no son circulares, las cortezas de los árboles no son lisas y los relámpagos no se desplazan en línea recta, los matemáticos, a lo largo de la historia, no han renunciado a interpretar con ojos científicos las formas y los fenómenos con los que la madre Naturaleza nos sorprende.

\footnotetext{
${ }^{264}$ Como explicaremos más adelante en el próximo apartado cuando hagamos las comparaciones de forma entre los copos de nieve y su representación circular que nos recordará a las estructuras formales del botón charro.
} 
En apariencia las hojas, las flores, las semillas o los frutos de las plantas están más cerca de la poesía que de las matemáticas. Sin embargo también podemos acercarnos a los misterios del crecimiento vegetal y animal a través de las curvas y de las ecuaciones, y además no demasiado complejas.

Para aproximarnos a esas ecuaciones es preciso que abandonemos nuestra mente cartesiana, es decir de coordenadas rectangulares y cartesianas, y las cambiemos por una visión circular, es decir que pensemos en "coordenadas polares"265.

Si en coordenadas cartesianas la ecuación de la recta más simple $y=b$, corresponde a una recta horizontal, en coordenadas polares la ecuación más sencilla: $p=b$, donde $b$ es una constante, en una circunferencia de radio $p$.

Con este simple cambio de perspectiva pasamos del mundo de las rectas al mundo de los círculos, que está más próximo a la realidad vegetal. Una curva mecánica, tan presente en la naturaleza como la Spira Mirabilis de Jacob Bernoulli, más conocida hoy por su nombre técnico "Espiral Logarítmica", "espiral geométrica o equiangular", ésta que vemos ${ }^{266}$ y la siguiente.

\footnotetext{
265 www.wikipedia.es: coordenadas polares, las coordenadas polares o sistemas polares son un sistema de coordenadas bidimensional en el cual cada punto del plano se determina por una distancia y un ángulo ampliamente utilizados en física y trigonometría. Enero, 2015.

${ }^{266}$ Ejecución propia, ésta y la siguiente.
} 

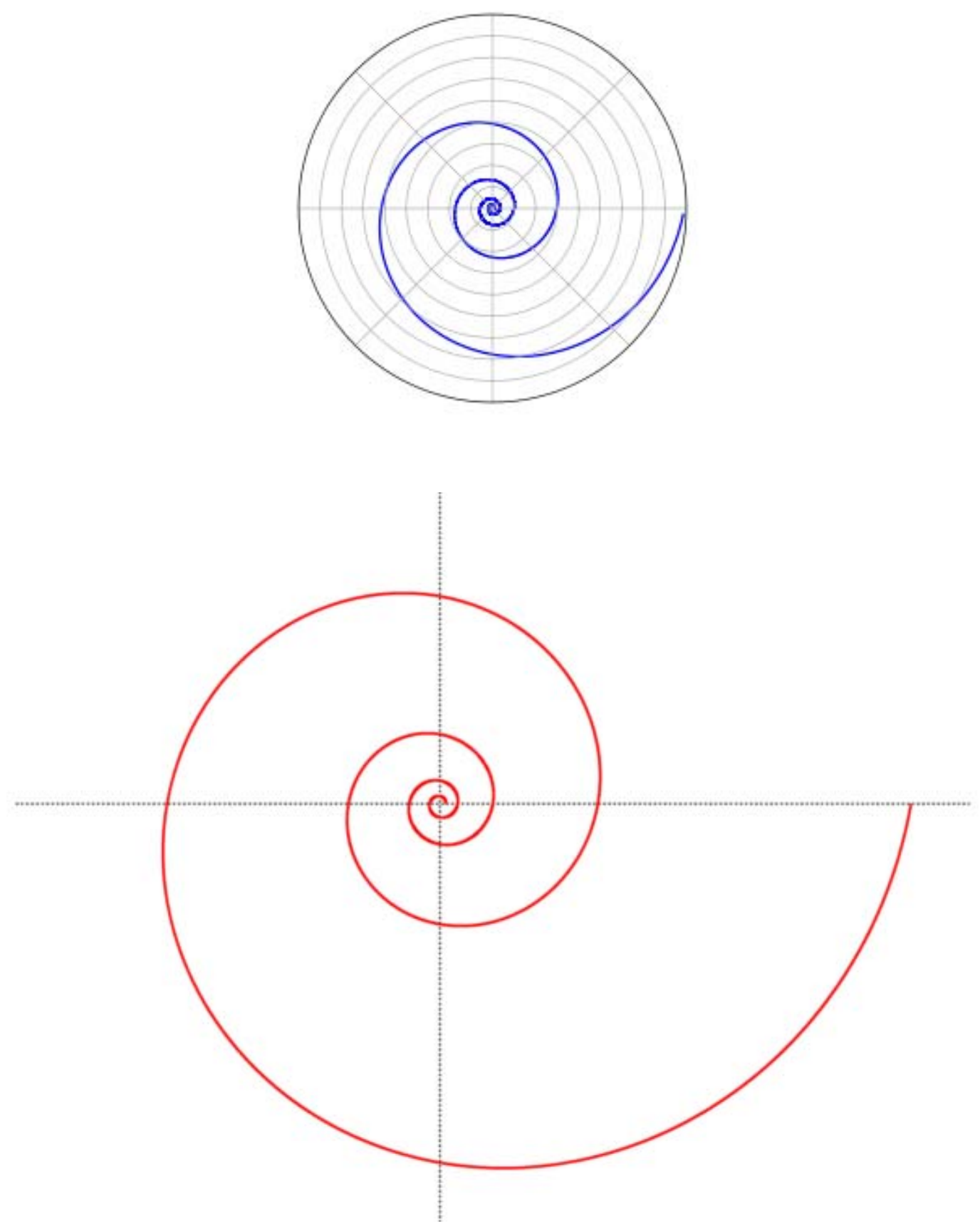

En la naturaleza la encontramos 


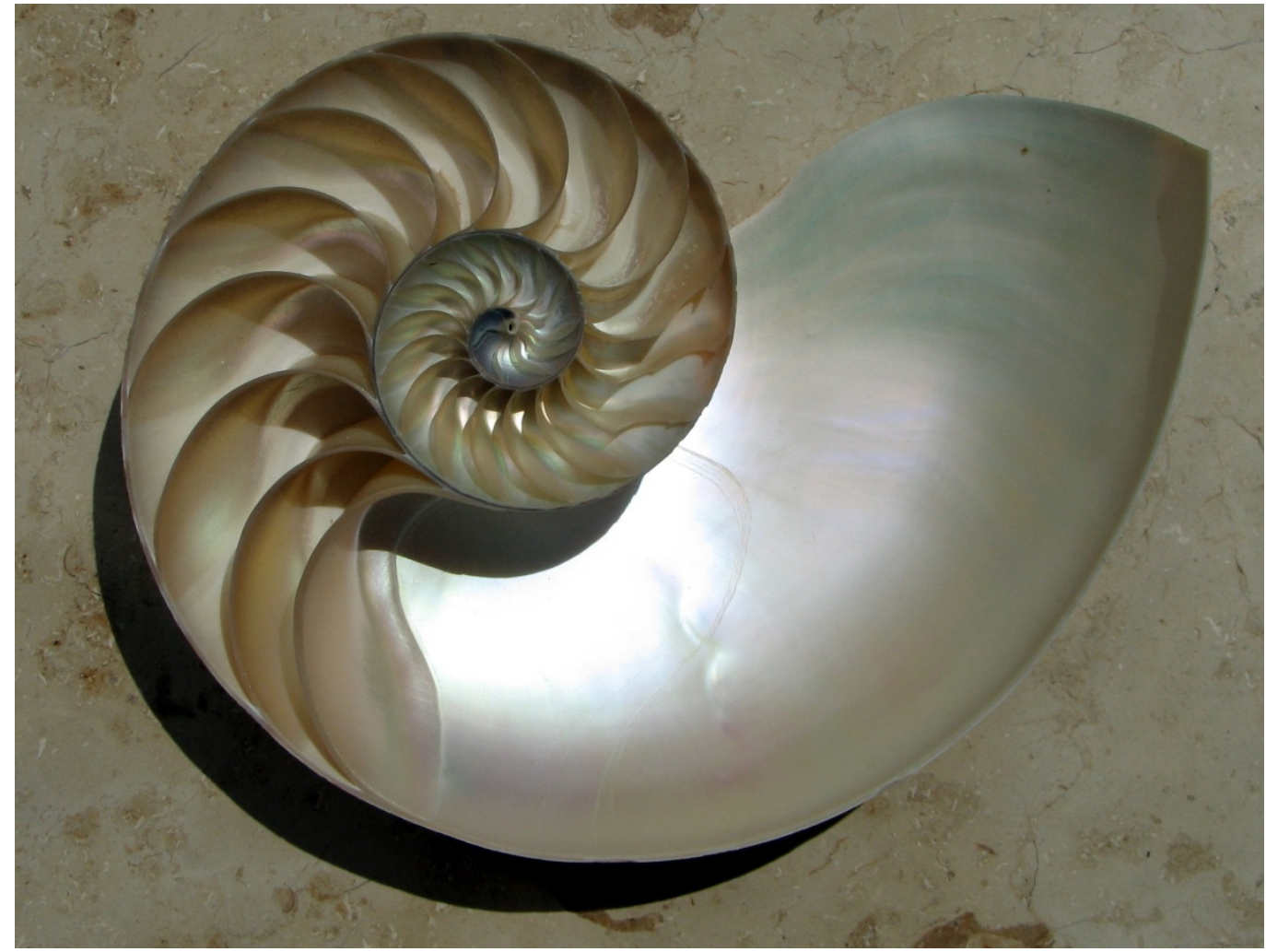

Esta espiral natural ${ }^{267}$ posee una ecuación matemática sencilla $\tau=\pi e^{\omega *}$.

Aunque esta curva fue estudiada por Descartes y Torricelli, fue Jacob el mayor de los hermanos Bernoulli, el que quedó cautivado por ella ya que la espiral logarítmica es la única curva que verifica que su evoluta, su involuta, su caústica y su podaría son, a su vez, una espiral logarítmica.

Dejando la espiral para más adelante, pues de ella obtendremos las medidas áureas de Botón Charro, existe una familia de curvas (investigadas en el siglo $\mathrm{XX}$ ) que parecen haber nacido para identificarse con algunas de las flores que encontramos en el campo. Se trata de la Concoide de Rosetón, también conocida como Pétalo geométrico ${ }^{268}$, que vemos a continuación.

\footnotetext{
267 Imagen obtenida de "Google imágenes".

268 Dibujo realización propia.
} 


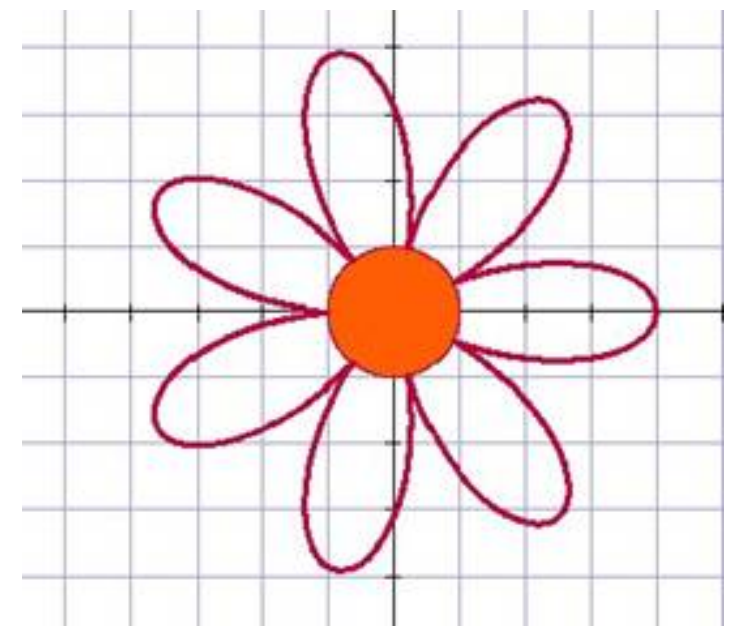

Esta es la base inicial de ejecución del Botón Charro cuando lo realiza el filigranista.

Por ello nosotros pensamos que la forma en la que se basa nuestra joyería tradicional, tiene mucho que ver con estructuras existentes en la naturaleza observada por el hombre. Si tenemos en cuenta que estas formas heredas se pierden en la noche de los tiempos y que estas que presentamos en estas imágenes se estudian recientemente, es un motivo más para poner en valor estos objetos que tradicionalmente no se les han dado valor que exceda más allá del meramente testimonial y de objeto femenino a no valorar, a no ser que sea por su valor económico o sentimental.

Estas formas combinadas, veremos cómo nos recuerdan a las formas de nuestra joyería charra tradicional. Estas imágenes ${ }^{269}$ nos recuerdan al principio de la ejecución del botón.

${ }^{269}$ Realización propia. 

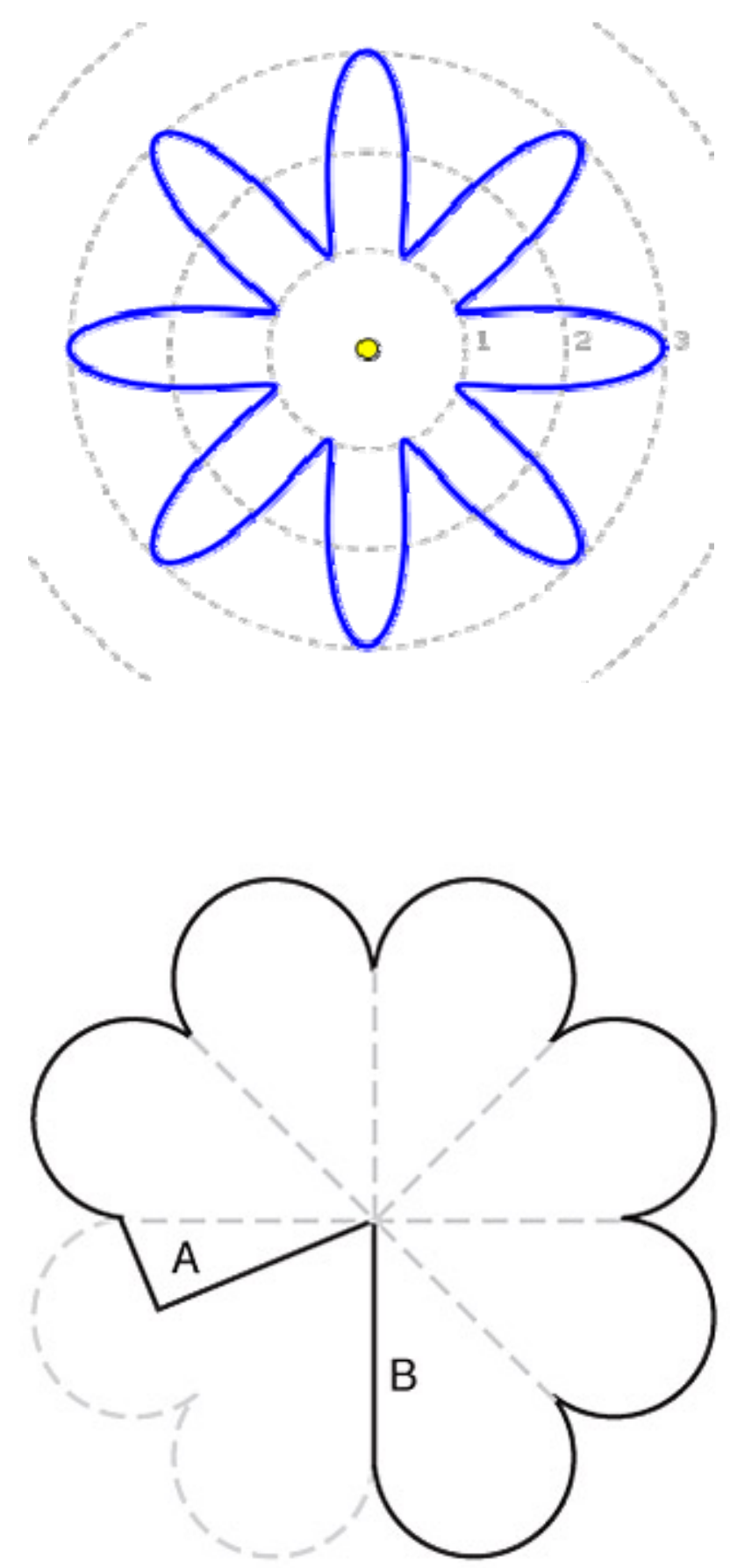

A continuación vamos a hacer una comparación entre las figuras anteriormente descritas y las fases de la ejecución del botón charro con la técnica de la filigrana que obtuvimos del taller de José Luis Nieves ${ }^{270}$.

\section{Todas las fases:}

\footnotetext{
${ }^{270}$ Cuaderno de Humos, propiedad de José Luis Nieves y consultados en su taller, Ciudad Rodrigo,
} 2011. 


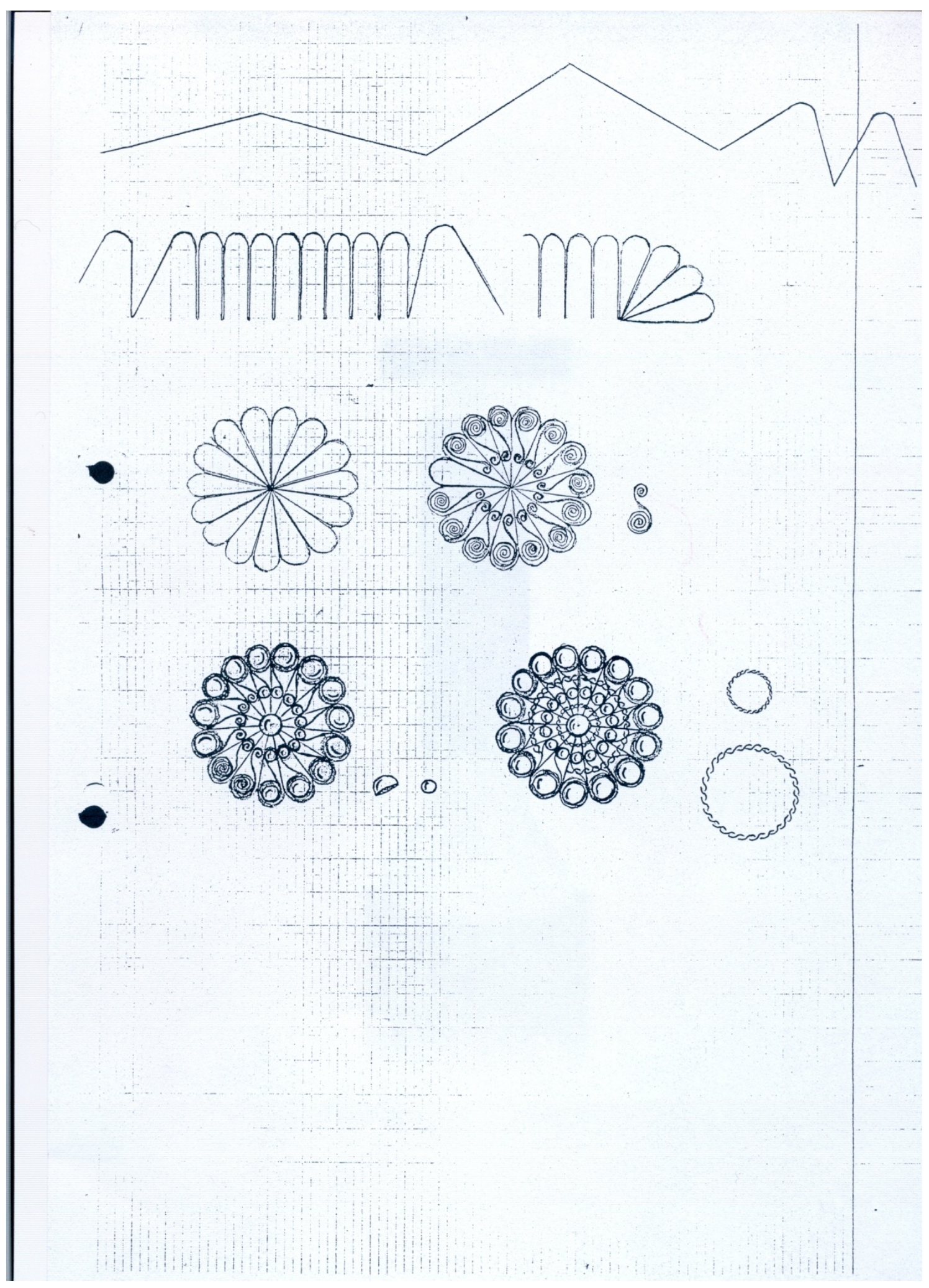

Aquí apreciamos cómo la línea pasa de coordenadas cartesianas a coordenadas polares. Esta representación para la ejecución del botón 
charro, nos recuerda inexorablemente tanto a las formas florales del "pétalo geométrico" como a la "rosa polar" de la Geometría Sagrada.

Asemejando formas, podemos ver en estos dibujos del orero los rosetones de las vidrieras de cualquiera de las catedrales españoles, (Burgos, León,...) o europeas como en Notredame, o cualquiera de las muchas que se reparten en las vidrieras de las catedrales europeas.

Evidentemente en el renacimiento italiano estas formas se repiten tanto en la arquitectura como en la pintura.
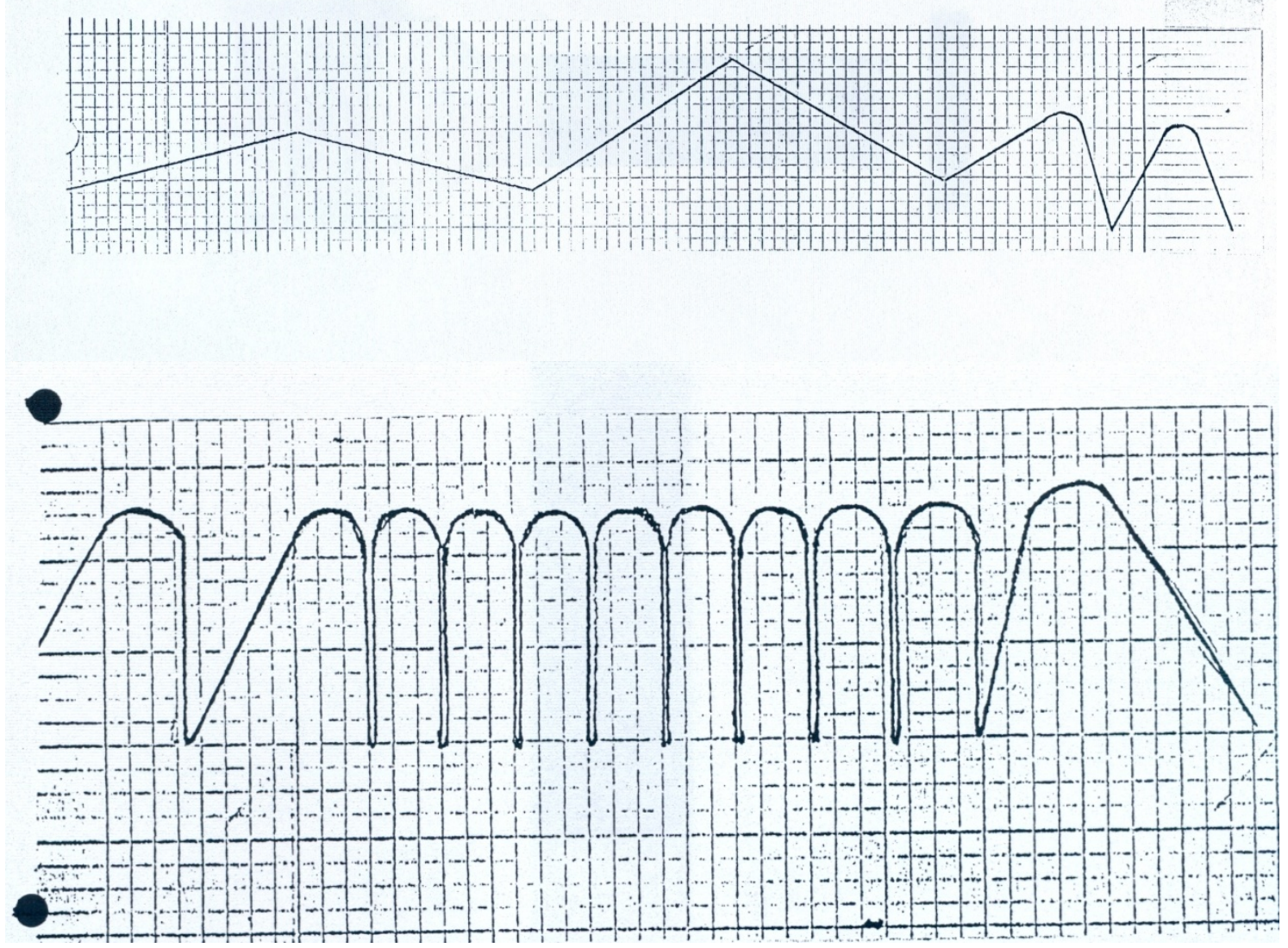

Estas imágenes ${ }^{271}$ corresponden a los dos primeros pasos de la ejecución del botón charro. Aquí el orero, siguiendo las medidas heredadas de sus antepasados, va construyendo desde el hilo sencillo de plata o de oro

${ }^{271}$ Libro de humos de José Luis Nieves. Elaboración suya. 
una forma que poco a poco nos dará como resultado el objeto que nosotros estudiamos.

Es importante añadir que esta es la base de ejecución de toda la filigrana pues lo único que hace, para obtener otras formas, es combinar estas para obtener otras formas más complicadas.

Observando y comparando con lo anteriormente expuesto, encontramos puntos de total coincidencia. Tal vez las formas que representan nuestros objetos de estudio están implícitas en otras muchas de nuestro entorno natural.

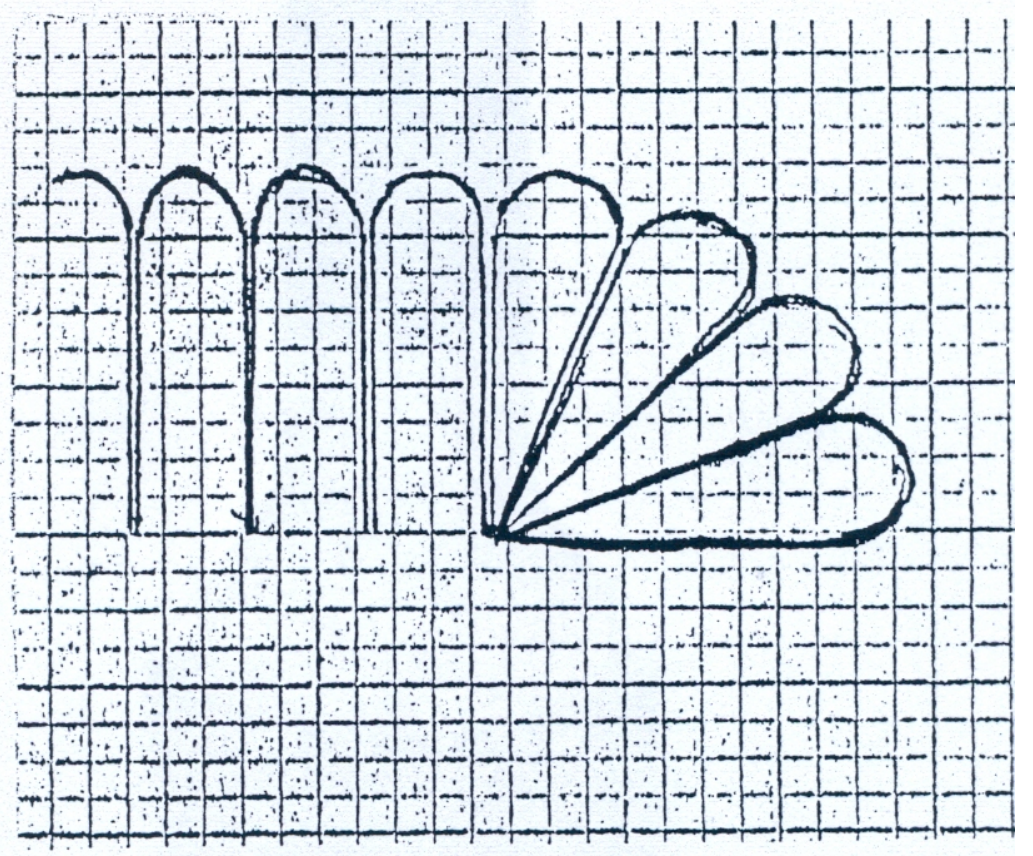


Como vemos en la imagen ${ }^{272}$, la consecución de la construcción nos va ofreciendo poco a poco una forma mucho más concreta. En las conversaciones con el orero José Luis Nieves, al preguntarle por el origen de la forma el nos responde que ignora el origen de ella y que tanto las fases de la ejecución como las medidas de los objetos son heredadas de forma oral de padres a hijos. El nunca se ha preguntado estas cuestiones simplemente responde que el lo hace como lo hacía su padre y éste como le enseñó el suyo y así sucesivamente perdiéndose en la noche de los tiempos.

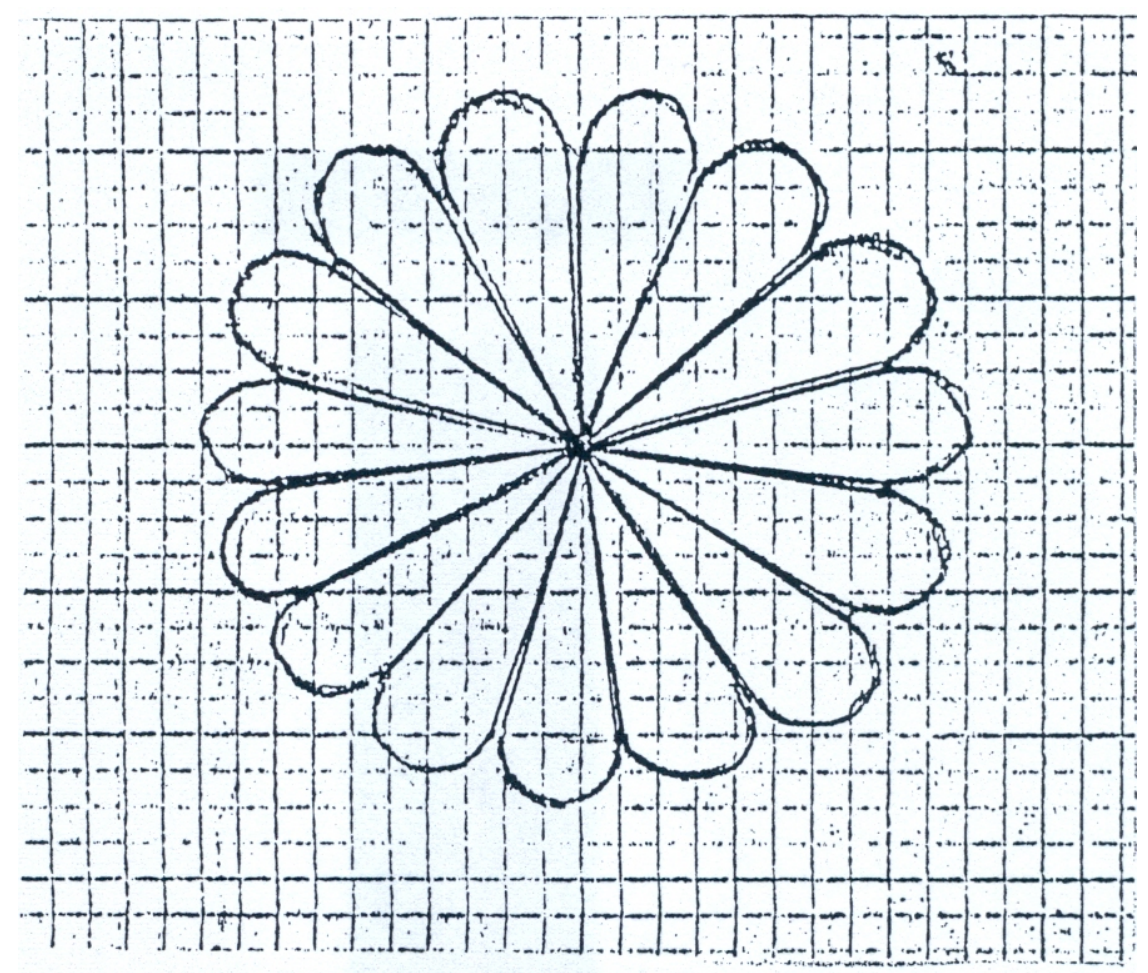

La forma, como vemos en la imagen ${ }^{273}$ va dando pasos donde las remembranzas de otras formas empiezan a superponerse, por ejemplo: rosetones renacentistas, rosetones de vidrieras góticas, elementos que aparecen en las nervaduras de las catedrales en sus bóvedas...

A medida que la forma se complica, se vuelve también muy hermosa y vemos como como la destreza del orero-filigranistas construye un mundo

\footnotetext{
${ }^{272}$ Cuaderno de Humos de José Luis Nieves. Elaboración suya.

${ }^{273}$ Cuaderno de Humos de José Luis Nieves. Elaboración suya.
} 
lleno de signos y de símbolos que hasta este estudio a nadie se le había planteado.

La forma conforma la percepción que el hombre tiene de su entorno y de su estudio se pueden obtener referencias extraordinarias como veremos más adelante.

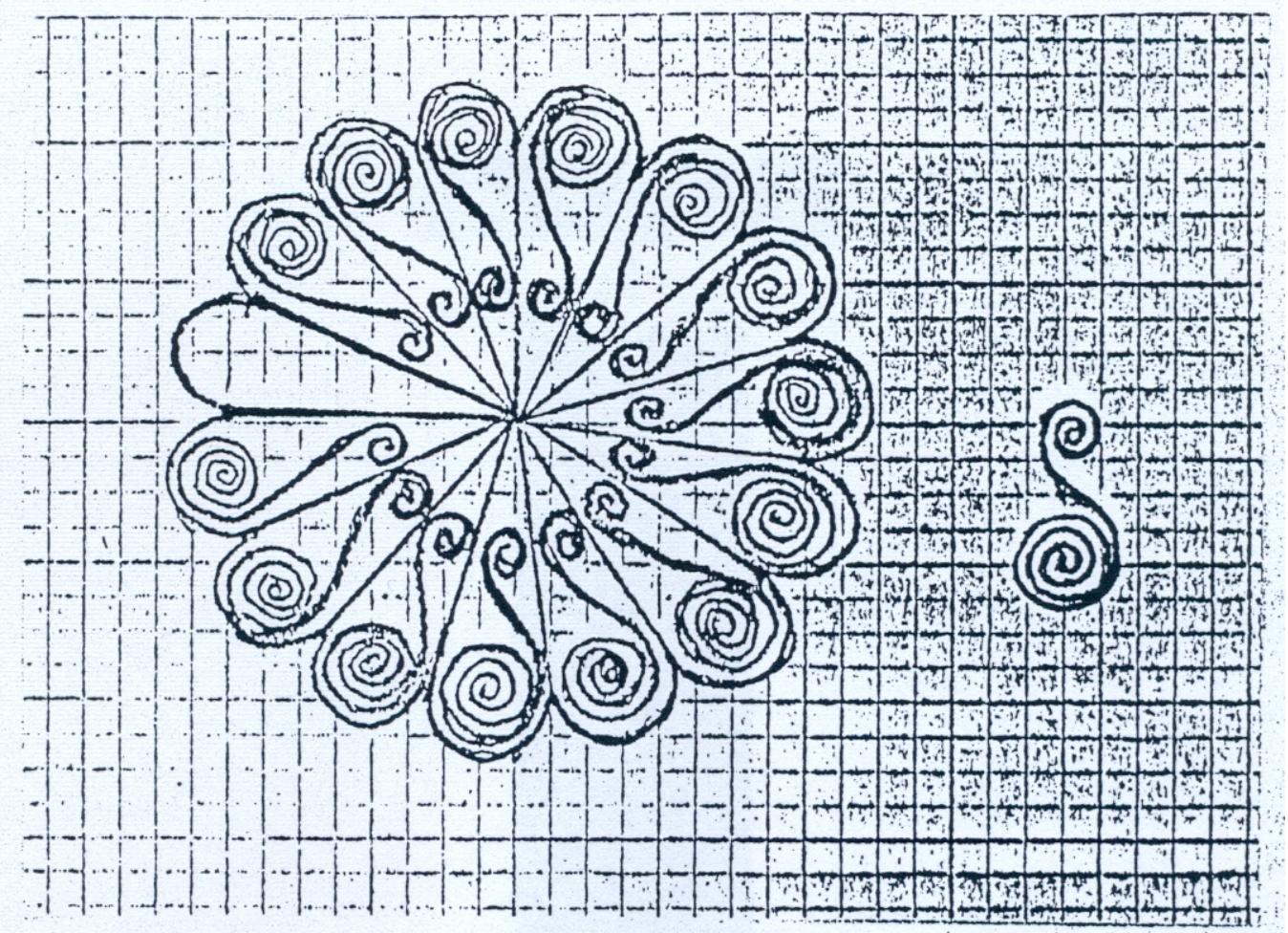


Como vemos en la imagen anterior, todos los elementos que macizarán el botón están basados en la espiral, en el círculo, en la circunferencia y en las variantes de la misma.

Si bien nuestro trabajo no lo es ni de dibujo ni de matemáticas, es necesario concretar que son ambos los que en su conjunción nos dan la forma.

La forma que aparece en la imagen en el ángulo inferior derecho, es una forma que desde la antigüedad adquiere un valor simbólico extraordinario pues nos habla de los opuestos y del principio y el fin. Aparece reiteradamente en la simbología antigua y curiosamente hace acto de presencia en nuestro Botón.

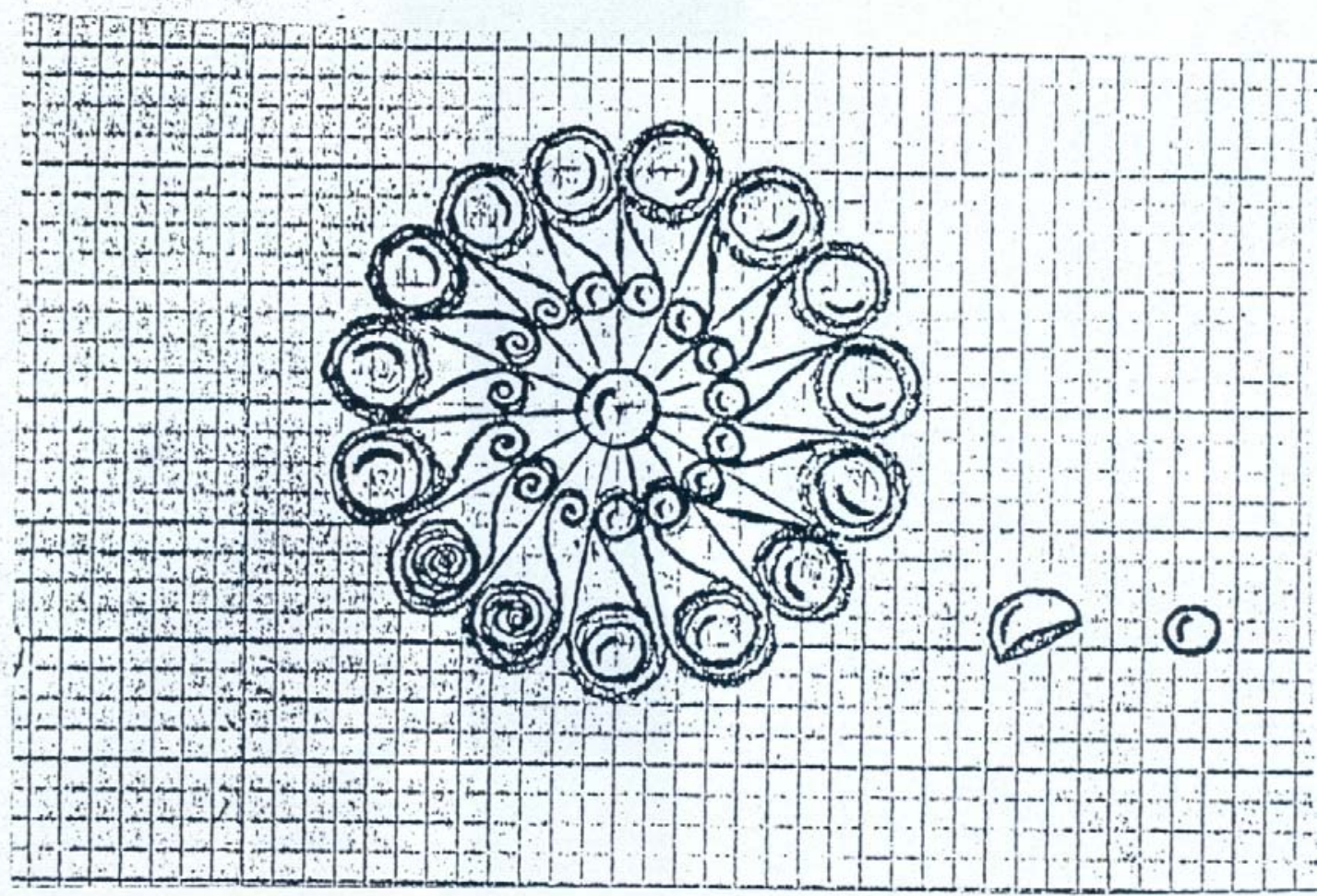




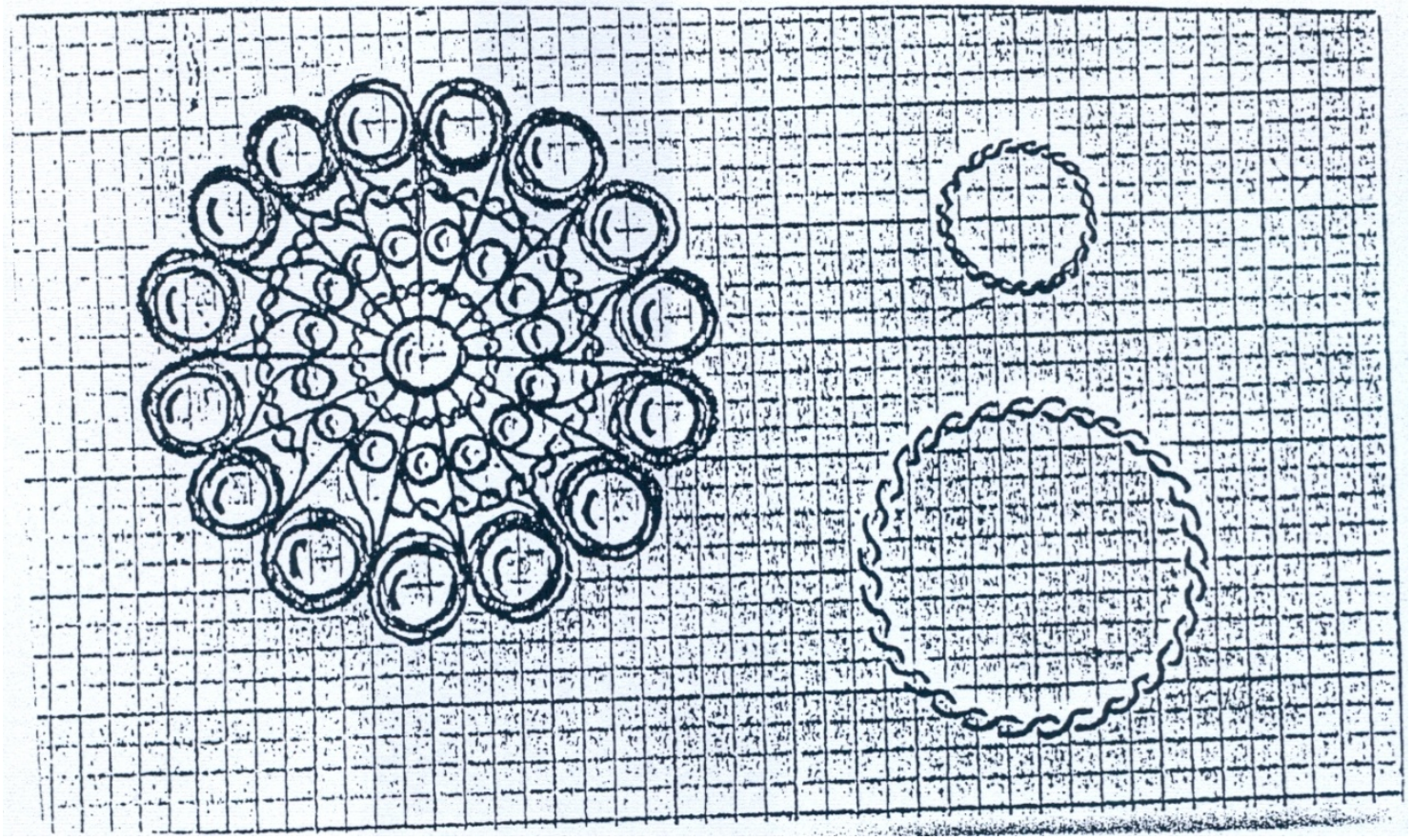

En las imágenes anteriores ${ }^{274}$ vemos las dos últimas fases de la construcción del botón donde la esfera, la semiesfera y el casquete forman la base de las etapas finales. Tanto la circunferencia, como lo cóncavo, siempre han tenido un significado simbólico identificado con la mujer, como hemos visto anteriormente a lo largo del estudio del símbolo.

Pero nuestra investigación de la forma no se queda en la comparación de estructuras florales con el mundo de nuestra joyería, hemos dado un paso más en profundidad haciendo un estudio de determinados copos de nieve a los que tratándolos con círculos nos han dado resultados sorprendentes.

En definitiva lo que hemos hecho ha sido pasar de coordenadas cartesianas a coordenadas polares y de esta manera hemos obtenido

${ }^{274}$ Cuaderno de Humos de José Luis Nieves. Elaboración suya. 
resultados muy sorprendentes. Esta transformación de coordenadas no está hecha matemáticamente hablando, si no hechas desde el punto de vista del concepto, es decir, pensando no en líneas rectas, si no en circunferencia y círculo.

Hemos elegido los copos de nieve porque consideramos que son estructuras tan antiguas como el mundo y al descomponer sus formas en circunferencias, nos hemos sorprendido del diálogo existente con la forma implícita y explicita de nuestro Botón Charro. Los copos de nieve los hemos elegido al azar, razón ésta mucho más de peso para evaluar los resultados.

Hemos de señalar que es la observación la que nos ha llevado a hacer semejante experimento aunque reconocemos que la respuesta es más geométrica que de expresión. Todas las imágenes ${ }^{275}$ han sido obtenidas de internet, sobre ellas hemos trabajado siendo las composiciones geométricas de elaboración propia.

Tan sólo lo que hemos hecho, como decíamos anteriormente, es abandonar el concepto de recepción cartesiana de nuestra mente y cambiarlo por una visión circular de la imagen plana que tenemos delante de los ojos y estos son los resultados.

${ }^{275}$ www.google.es/imagenescoposdenieve 


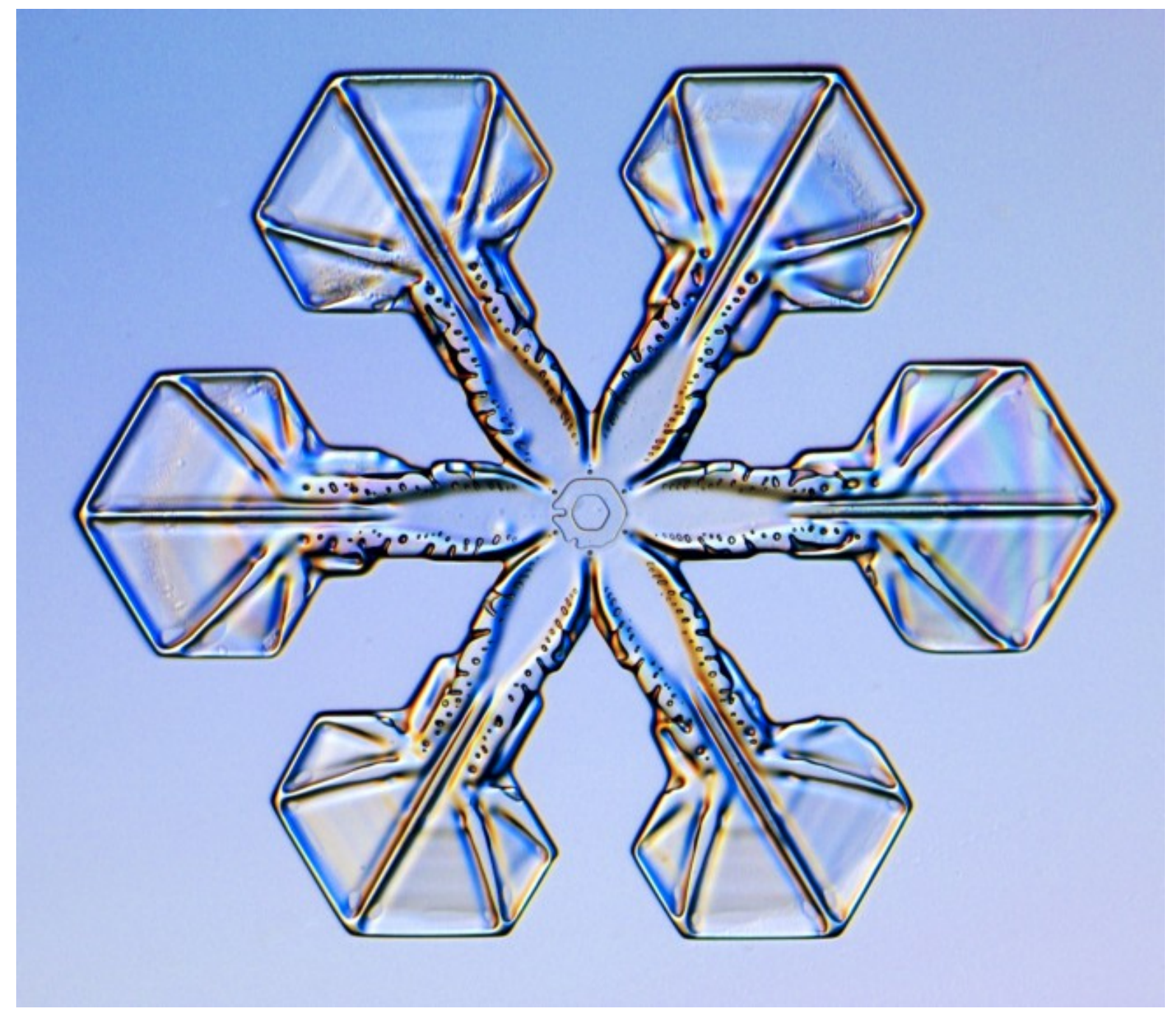



Derecho de la mujer a la joyería tradicional salmantina: implicación de las Administraciones Públicas

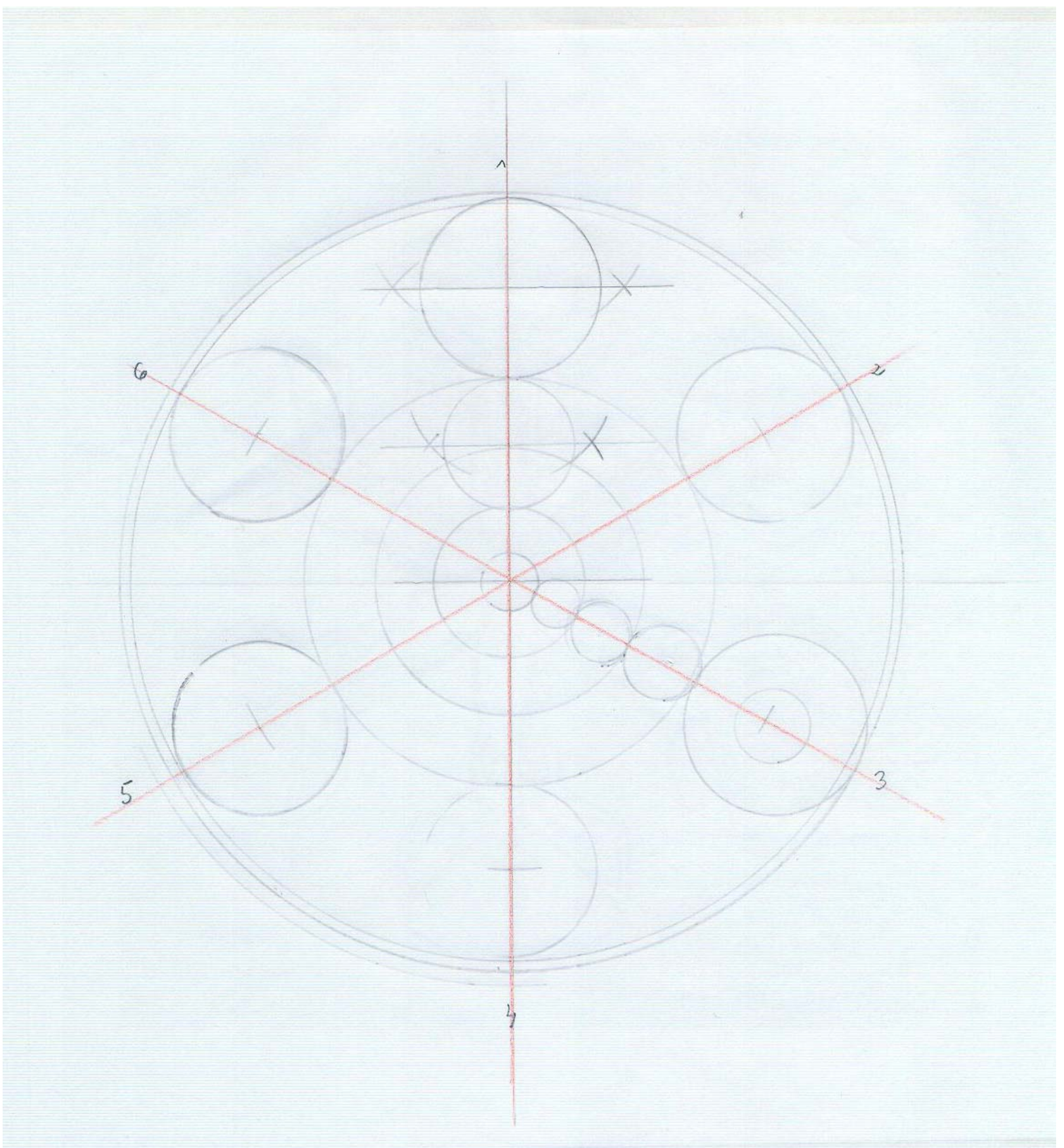




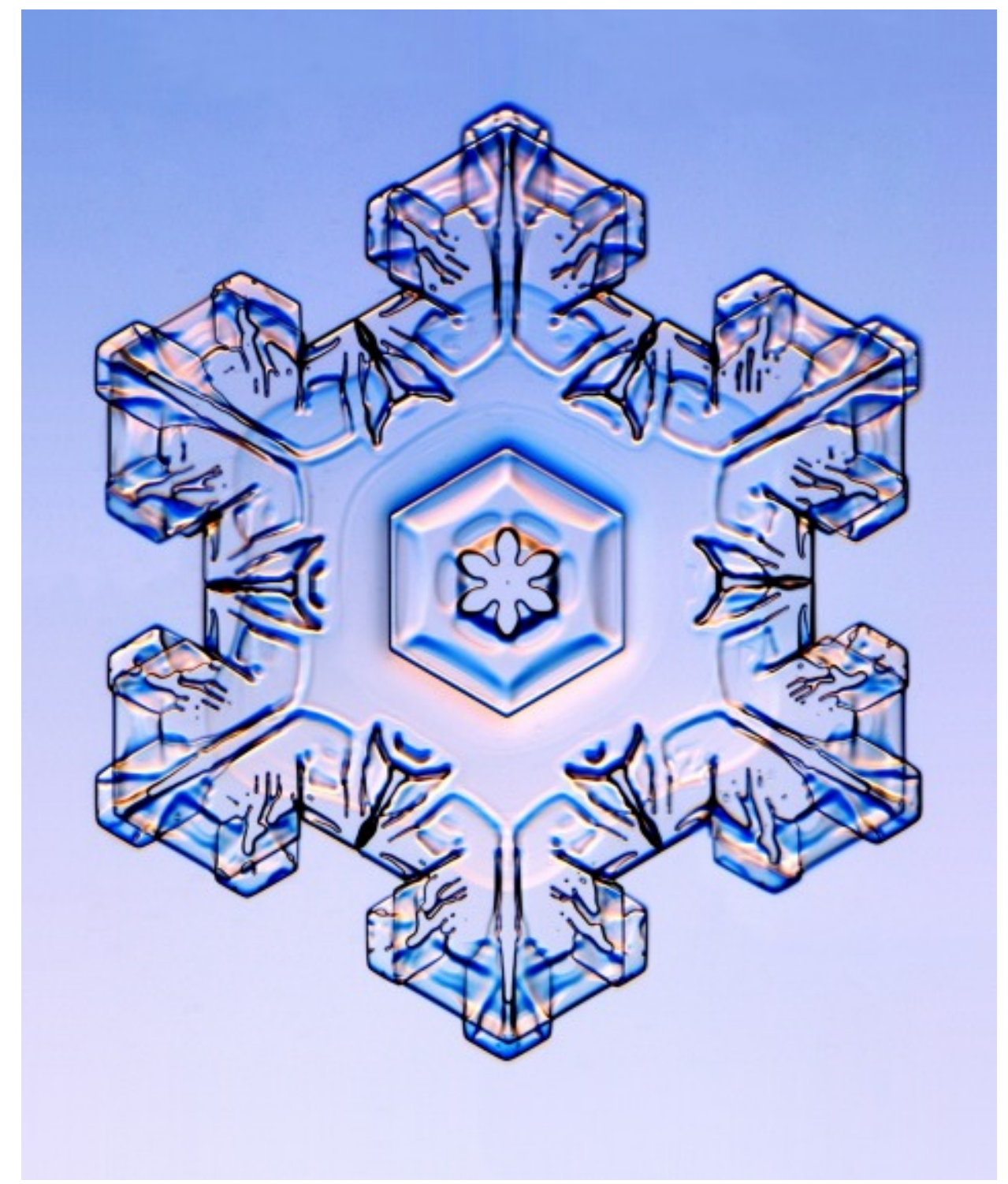


Derecho de la mujer a la joyería tradicional salmantina: implicación de las Administraciones Públicas

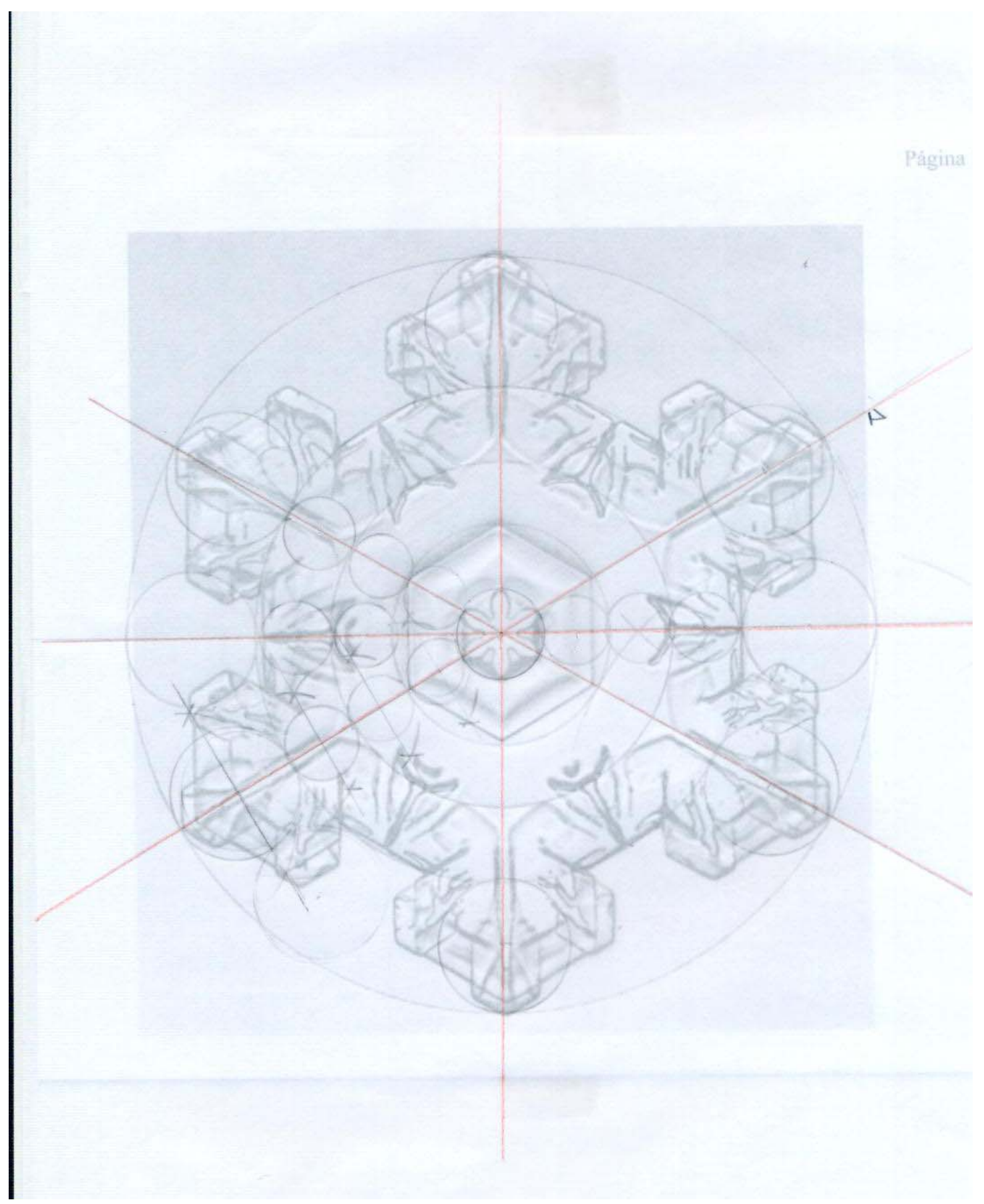


Derecho de la mujer a la joyería tradicional salmantina: implicación de las Administraciones Públicas

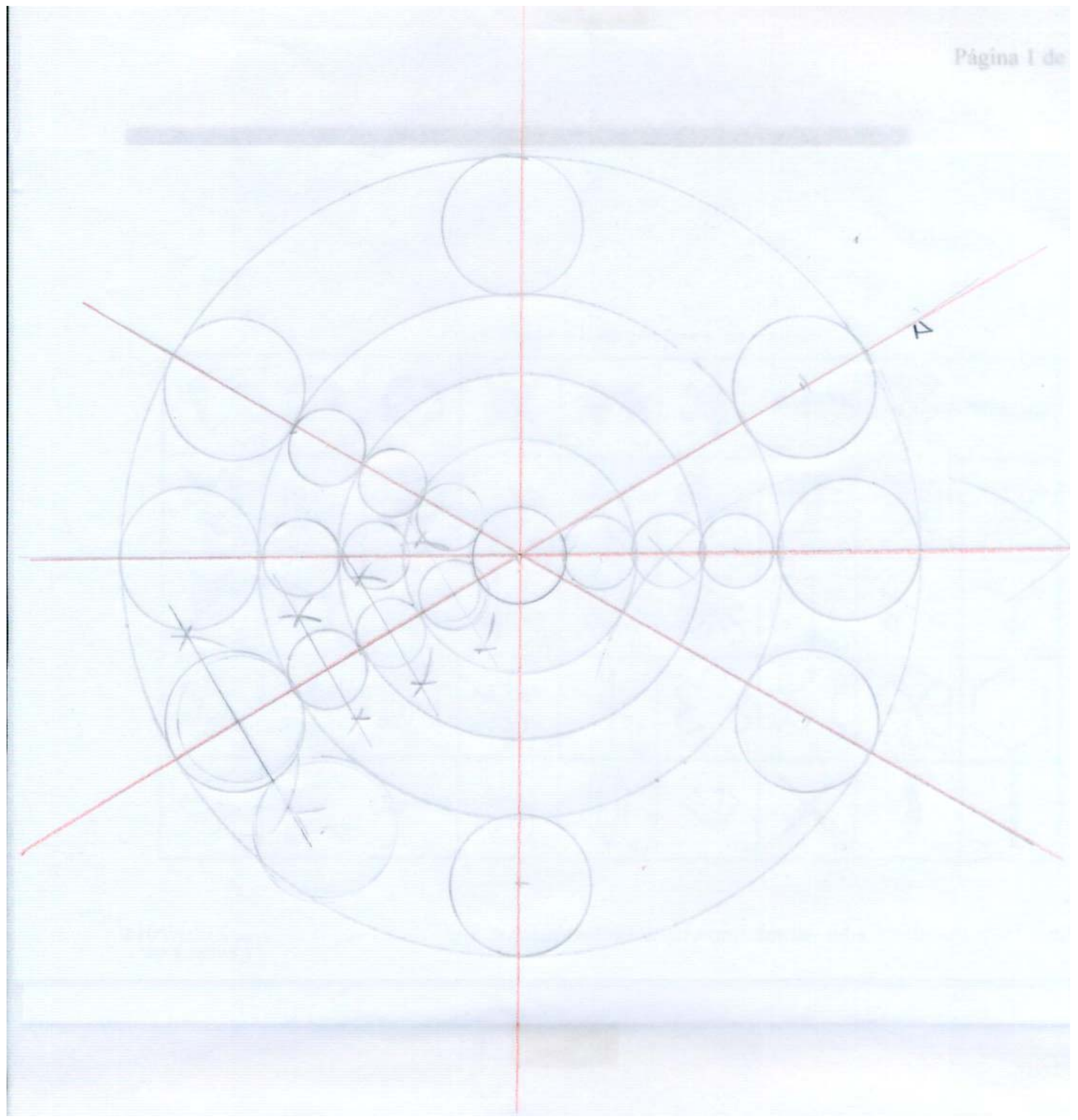




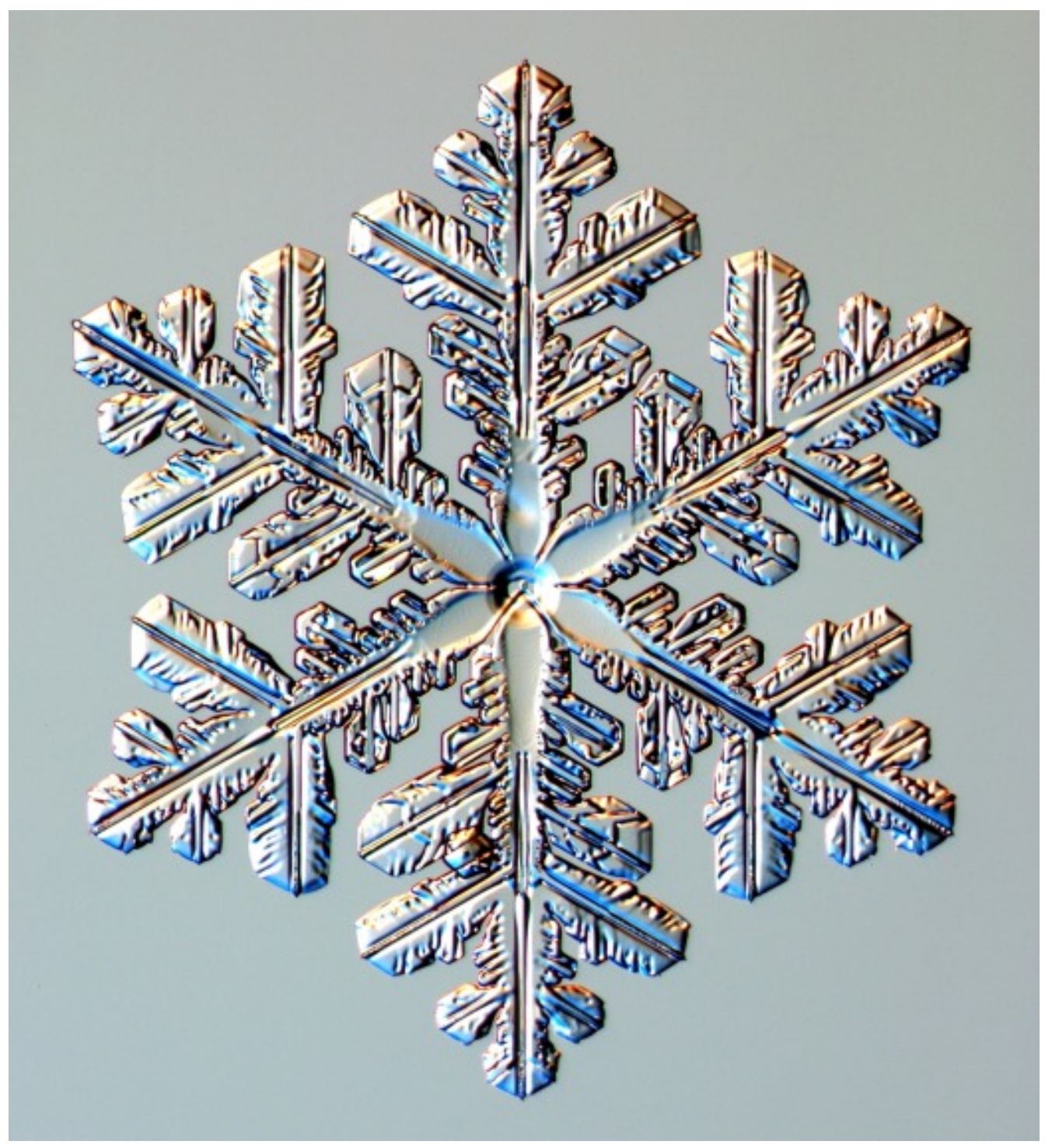


Derecho de la mujer a la joyería tradicional salmantina: implicación de las Administraciones Públicas

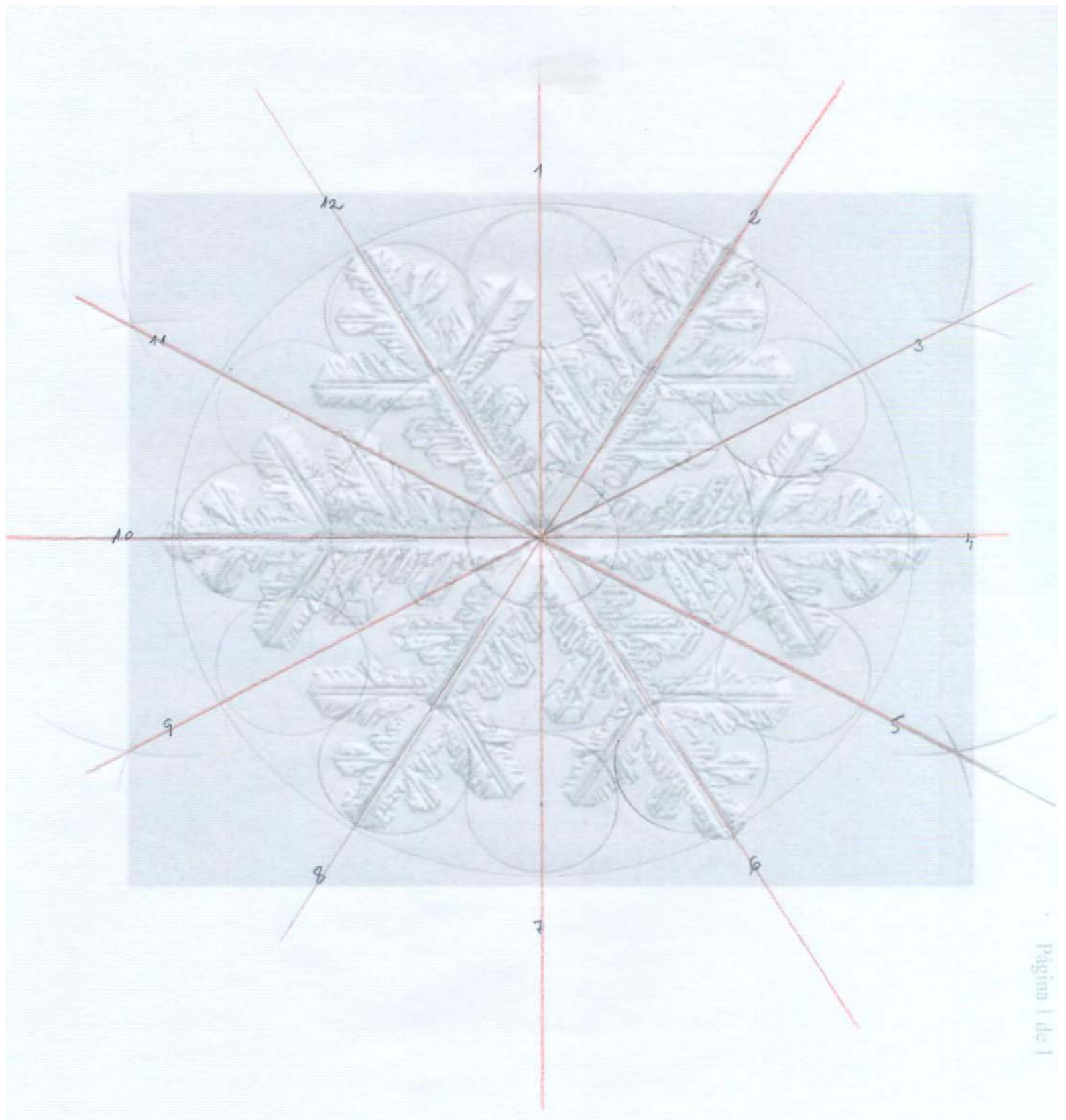




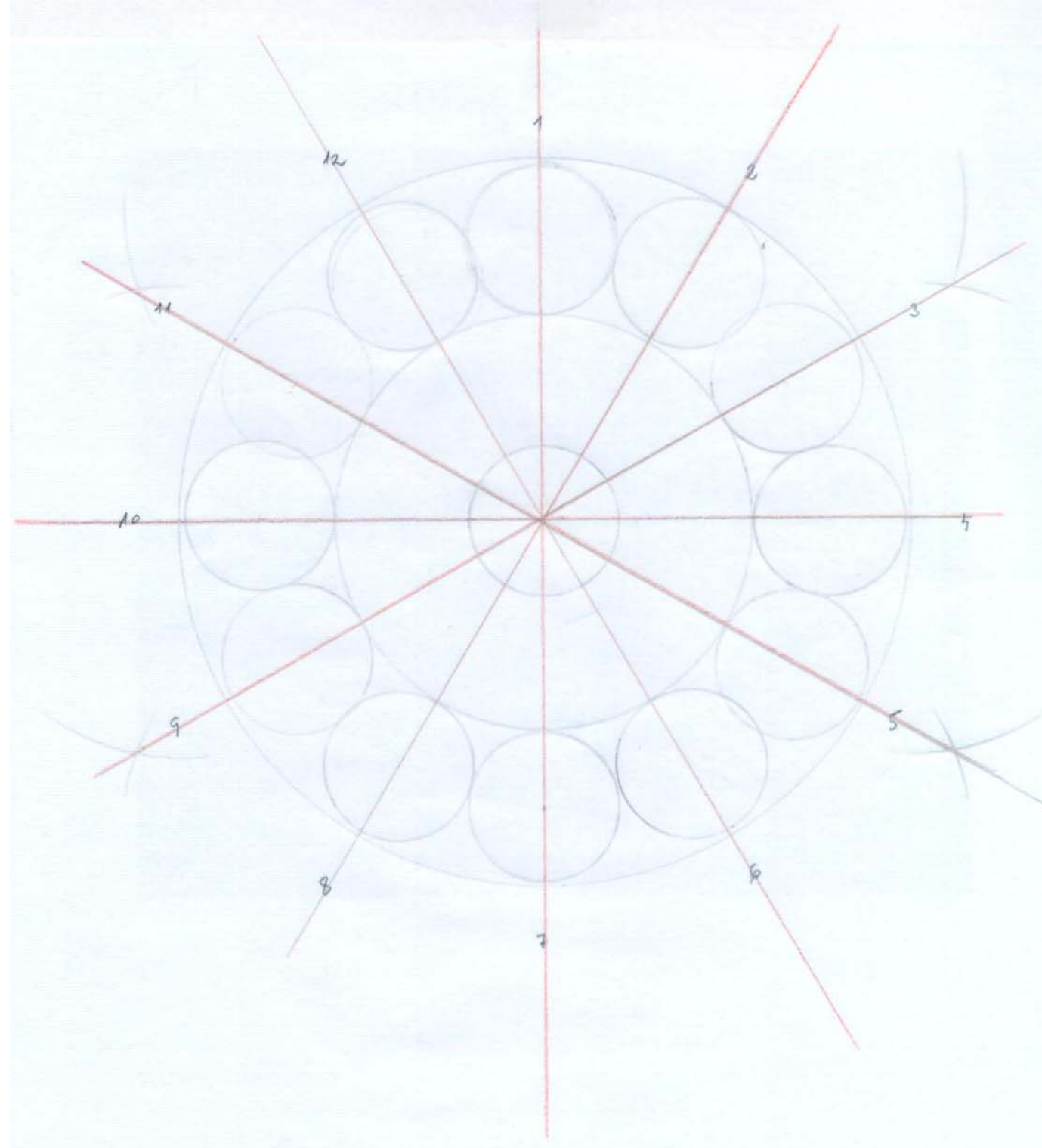

La ejecución de estas figuras, las hemos superponiendo sobre las figuras de internet y haciendo círculos según la forma lo pide al ojo, reduciendo todo a ejes y círculos y obteniendo imágenes nuevas. Al quitar la imagen del copo, obtendríamos esas imágenes en las que se aprecia el desarrollo en círculos de formas semejantes a nuestro botón y encontrando las formas que nos recuerdan a nuestra geometría sagrada. En cada copo de nieves hemos puesto los diferentes ejes de ejecución según los ramales del propio copo, reduciéndolo en circunferencias, haciendo círculos y 
buscando los puntos medios de distancia obteniendo una figura de circunferencias concéntricas y de círculos intercircunferenciales. En la última de todas, nos dará como resultado el botón charro perfecto en las doce partes y en porciones muy similares al objeto de nuestro estudio.

Es sorprendente cómo cuando abandonamos los parámetros habituales de visión, se pueden obtener otras formas muy diferentes que ponen en relación unos objetos con otros. Tal vez este es el origen de cómo veían nuestros antepasados las cosas cuando los arquetipos, los símbolo, ... se hacían en referencia al orden natural observado. Lo que de este estudio apreciamos perfectamente son formas simbólicas y elementos que podrían identificar perfectamente formas muy dispares entre las que se encuentra nuestro propio objeto de estudio.

Increíblemente al descomponer las formas hemos encontrado la imagen del Botón Charro como base de la estructura última de determinados copos de nieve. Si tenemos en cuenta que la base del resto de joyería Charra en filigrana, está basada en el modelo formativo de base del botón que luego se complica dando lugar a otras formas más complejas, podemos decir que en el origen de las formas de esta joyería está la composición natural y ese "inconsciente colectivo" del que hablaba Jung, nos referimos a esos arquetipos, mandalas, símbolos, de los que hablábamos anteriormente.

Bien es cierto que la descomposición a veces parece no acoplarse perfectamente, pero eso tan sólo obedece a la deformación de las imágenes obtenidas de la red y que estamos seguros se diferencian en milímetros de las originales.

Por este motivo no lo tendremos en cuenta a la hora de evaluar nuestros resultados, que en nada quedan empañados por este motivo que expresamos de antemano.

Podemos concluir en este apartado, que queda demostrado que la naturaleza, tanto en las plantas como en determinados fenómenos naturales, sus formas son las que el hombre en un momento antiguo decidió plasmar 
en objetos con el paso de tiempo tomaron función de joya y cuyo destino prioritario era la mujer.

No cabe duda que estas formas que hemos estudiamos tienen intrínseco el valor del símbolo y es ahí donde podemos encontrar las causas de la permanencia de ellas a lo largo del tiempo.

El símbolo es un lenguaje universal que en la conciencia general prevalece y como por arte de magia, el individuo es capaz de reconocer independientemente de la cultura la raza o el lugar.

\section{La geometría sagrada.}

Introducción la geometría sagrada.

La Geometría está presente por doquier en toda la naturaleza, está en el basamento de la estructura de todas las cosas desde las moléculas hasta las galaxias, desde los ínfimos virus hasta los grandes elefantes. A pesar de nuestra actual separación del mundo natural, nosotros seres humanos seguimos ligados a las leyes naturales del universo.

El término Geometría significa literalmente "medida o medición de la tierra".

Es una herramienta fundamental que está estrechamente ligada a todo aquello que sea hecho por las manos del hombre y desde tiempos antiguos a todo lo que significan las mediciones, que en esos tiempos eran consideradas como pertenecientes a una de las ramas de la Magia. En la antigüedad la magia, la ciencia y la religión eran de facto inseparables, constituyendo el fundamento del conocimiento de los sacerdotes y de las sacerdotisas.

La armonía inherente a la geometría fue comprendida como una de las expresiones del plan divino que sujeta al universo, un patrón metafísico que determina lo físico. La realidad interna, trascendente a las formas externas, ha permanecido a través de la historia como la base de las 
estructuras sagradas. Hoy día es tan válido construir un edificio moderno de acuerdo a los principios de la geometría sagrada como lo fue en el pasado en estilos como el egipcio, griego, románico, islámico, gótico o renacentista.

La proporción y la armonía se hallan íntimamente ligadas a la geometría sagrada, porque ella a su vez está ligada metafísicamente a la estructura íntima de la materia.

Los principios de la Geometría Sagrada

Los principios en los que se basan disciplinas tales como la geometría sagrada, la magia o aún la electrónica están ligados a la naturaleza del universo. Las variaciones en la forma externa pueden estar influidas por consideraciones religiosas o aún políticas, más los fundamentos operativos permanecen constantes. Un ejemplo lo encontramos en una analogía eléctrica. Para poder iluminar con una lámpara eléctrica es necesario cumplir con una serie de condiciones. Es necesario hacer circular por dicha lámpara una corriente eléctrica de determinada intensidad, para lo cual hay que aplicar una tensión eléctrica por medio del circuito y las conexiones adecuadas. Estas condiciones no son negociables, si algo se realiza incorrectamente la lámpara no ha de iluminar o se quemará. Todo aquél que realice tales tareas debe adherir a estos principios fundamentales o fallará en su intento. Tales principios son independientes de toda consideración política o sectaria, el circuito ha de funcionar ya sea bajo un régimen dictatorial como bajo uno democrático.

De manera análoga, los principios fundantes de la geometría sagrada trascienden las consideraciones religiosas sectarias. Como una ciencia que lleva a la reintegración de la humanidad con el todo cósmico, ella ha de obrar, como en el caso de la electricidad, sobre todo aquél que reúna los criterios fundamentales, sin importar de quién se trate. La aplicación universal de idénticos principios de geometría sagrada en lugares separados por vastos espacios de tiempo, lugar y creencia atestigua su naturaleza trascendental. Fue aplicada a las pirámides y templos del Antiguo Egipto, los templos mayas, los tabernáculos de Jehová, los zigurat babilonios, las 
mezquitas islámicas y las catedrales cristianas. Como un hilo invisible los principios inmutables conectan estas estructuras sagradas.

Uno de los principios de la geometría sagrada lo encontramos en la máxima hermética "como es arriba, así es abajo" y también en "aquello que se halla en el pequeño mundo, el microcosmos, refleja lo que se halla en el gran mundo o macrocosmos". Este principio de correspondencia se halla en la base de todas las ciencias herméticas, donde las formas del universo manifestado se reflejan en el cuerpo y constitución del hombre.

En la concepción bíblica el hombre ha sido creado a imagen y semejanza de Dios, siendo él un templo dispuesto por el Creador para albergar al espíritu que eleva al hombre por encima del reino animal. Por ello, la geometría sagrada no trata únicamente sobre las figuras geométricas obtenidas a la manera clásica con compás y escuadra, sino también de las relaciones armónicas del cuerpo humano, de la estructura de los animales y las plantas, de las formas de los cristales y de todas las manifestaciones de las formas en el universo. Platón en el Timeo da relación exacta de lo que venimos apuntando. No olvidemos que la geometría sagrada es la que comprende las medidas armónicas del universo. Dice la leyenda que Platón a la entrada de sus clases ponía un cartel que decía:" no entre aquí quien no sepa geometría". Platón fue seguidor y conocedor exacto de Pitágoras y de toda su matemática, que revolucionó el mundo. Pitágoras conocía perfectamente todo lo relacionado con las proporciones y las teorías matemáticas porque estudió en Egipto, dónde fue sacerdote del Templo de Tebas. Los sacerdotes, en aquél tiempo, eran conocedores de todo el conocimiento que se les negaba a los que no formaban parte de su casta. La geometría sagrada era la que Dios utilizó para la creación del Universo haciéndolo de manera armónica. Posteriormente Dios le dio a Moisés las medidas sagradas para la construcción del Tabernáculo que pasarían a David para llevar a cabo la construcción del Templo de Salomón, al que se le ha considerado ejemplo de perfección. 
Desde tiempos remotos la geometría ha sido inseparable de la magia. Aún las arcaicas inscripciones en las rocas siguen formas geométricas. Debido a que las complejidades y abstractas verdades expresadas por las formas geométricas solamente pueden ser explicadas como reflexiones de las más profundas verdades, fueron consideradas como misterios sagrados del mayor nivel y fueron puestas fuera de los ojos profanos. Estos profundos conocimientos pudieron ser transmitidos de un iniciado a otro por medio de símbolos geométricos sin que los ignorantes de ello siquiera tomaran nota que se efectuaba dicha comunicación.

Cada forma geométrica está investida de un significado simbólico y psicológico, como hemos estudiado en el capítulo anterior ampliamente. De esta manera todo aquello hecho por la mano del hombre que incorpore dichos símbolos deviene un vehículo para las ideas y conceptos incorporados en su geometría. A través de las edades de la humanidad las geometrías simbólicas han sido las bases para la arquitectura sagrada y profana. Algunas subsisten todavía como potentes arquetipos de fe: el hexagrama como símbolo del Judaísmo, la cruz en el Cristianismo...

Las formas y figuras geométricas

Unas pocas formas geométricas constituyen la base de toda la diversidad de la estructura del universo.

Todas estas formas geométricas básicas pueden ser fácilmente realizadas por medio de dos herramientas que los geómetras han usado desde los albores de la historia: la escuadra y el compás. Como figuras universales, su construcción no requiere de ninguna medida, ellas se dan también a través de formaciones naturales en el reino orgánico como en el inorgánico.

El circulo

El círculo ha sido seguramente uno de los primeros símbolos dibujados por el hombre. Es simple de dibujar, es una forma visible cotidianamente en la naturaleza, visto en el cielo como los discos del sol y la luna, en las formas de animales y plantas y en las estructuras geológicas. 
Muchas construcciones antiguas adoptaron esta forma, los tipi americanos y los yurt mongoles son los supervivientes de estas formas universales. Desde los círculos neolíticos británicos y a través de las formas megalíticas de piedra circulares de los templos, la forma circular ha imitado la redondez del horizonte visible, haciendo de cada construcción un pequeño mundo en sí mismo.

El círculo representa lo completo y la totalidad. En un antiguo tratado alquímico se lee: "Haz un círculo del hombre y la mujer, y dibuja fuera de él un cuadrado, y fuera del cuadrado un triángulo. Haz un círculo y tendrás la piedra de los filósofos".

El círculo ha sido empleado como símbolo de la Eternidad y de la Unidad.

Como eternidad porque no tiene principio ni fin y siempre retorna al mismo punto. También por esta razón simboliza el Universo, no hay punto donde comience ni punto donde tenga fin, entonces todo lo contiene y no hay nada fuera de él, por ello también es símbolo de la Unidad, especialmente cuando en él se hace presente el centro como símbolo de la primera manifestación.

También simboliza el Destino, Hado o Necesidad y la ley cíclica porque a medida que la rueda de la vida gira los ciclos retornan marcando en la naturaleza la repetición y renovación de los ciclos de vida y en la historia humana el eterno retorno de los arquetipos, como veíamos también en el capítulo anterior.

El cuadrado

Muchos templos antiguos fueron realizados bajo una forma cuadrada. Representando el microcosmos y con ello la estabilidad del mundo, esta es una característica saliente de las llamadas montañas del mundo, los zigurat, las pirámides y los stupas (Monumento funerario que señala el lugar de enterramiento de las cenizas o los restos de un santo budista; suele ser una construcción maciza coronada por una cúpula semiesférica). Estas estructuras simbolizan el punto de transiciones entre el cielo y la tierra, 
centradas idealmente en el omphalos (ombligo de la tierra en la antigua mitología griega), el punto axial en el centro del mundo, su ombligo.

Puede ser dividido en cuatro cuadrados haciendo una cruz que automáticamente define su centro. Orientado hacia los cuatro puntos cardinales, en el caso de las pirámides egipcias con excepcional precisión, puede ser además biseccionado además por diagonales, dividiéndolo en ocho triángulos. Estas ocho líneas, radiando del centro, forman los ejes hacia las cuatro direcciones del espacio, y los cuatro rincones del mundo, la división óctuple del espacio. Esta división del espacio está emblematizada en el óctuple sendero del Buddhismo y en los cuatro caminos reales de Bretaña, señaladas en la Historia de los Reyes de Bretaña. Cada una de las ocho direcciones en Tíbet, están bajo la guarda simbólica de una familia, una tradición similar a la de las ocho nobles familias de Bretaña.

- La Vesica Piscis

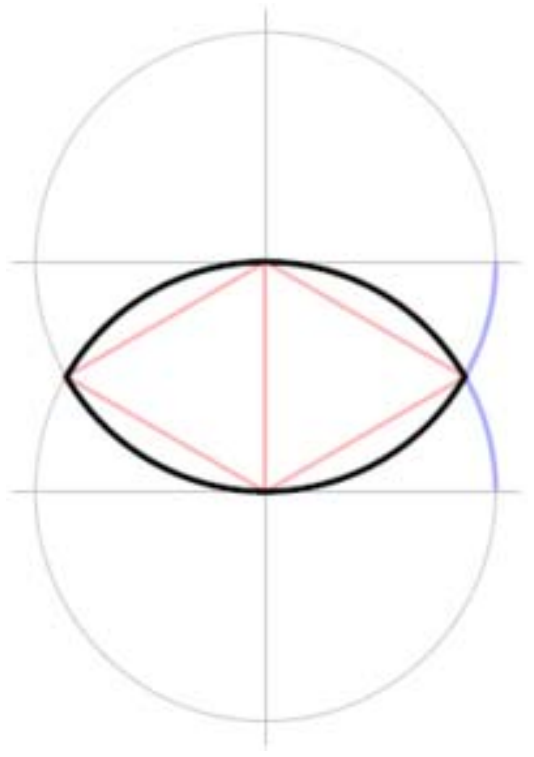

La Vesica Piscis es la figura producida cuando dos círculos de igual tamaño son dibujados hasta el centro del otro. Ha representado el vientre de la Diosa Madre, el punto del que surge la vida. Ha tenido una posición de primacía en la fundación de construcciones sagradas. Desde los antiguos templos y círculos de piedra hasta las grandes catedrales medievales, el 
acto inicial de fundación ha estado relacionado a la salida del sol en un día predeterminado. Este nacimiento simbólico del templo con el nuevo sol es un tema universal, relacionado con la también con la Vesica Piscis. La geometría de los templos hindúes, así como los de Asia Menor, norte de África y Europa, tal como ha sido registrado, derivan directamente de la

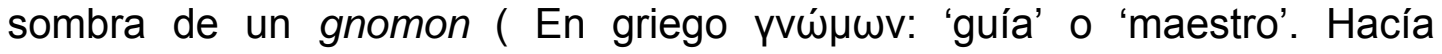
referencia a un objeto alargado cuya sombra se proyectaba sobre una escala graduada para medir el paso del tiempo). Hay un antiguo texto sánscrito referido a la fundación de templos, el Manasara Shilna Shastra, que detalla el plan para su orientación.

El sitio ha de ser elegido por un practicante de la geomancia, (en China es fundamental aún este tipo de procedimientos), clavándose allí un gnomon, alrededor del cual se traza un círculo. Este procedimiento fija el eje este-oeste. Desde cada extremo de este eje se trazan arcos, produciendo una Vesica Piscis, la que a su vez determina el eje norte-sur. De esta Vesica inicial, se dibuja otra en ángulo recto y de esta un círculo central y entonces un cuadrado dirigido a los cuatro cuartos de la tierra. El sistema utilizado por los romanos para la fundación de sus ciudades descrito en los libros de Vitruvio se muestra idéntico al sistema hindú aquí descrito.

El número de oro

El número de oro, o sección de oro, es una relación que ha sido usada en la arquitectura sagrada y el arte ya desde el período del antiguo Egipto.

Las construcciones y los objetos sagrados de egipcios y griegos tienen geometrías basadas en la división del espacio obtenida por rectángulos raíz y sus derivados. Los rectángulos raíz son producidos directamente a partir de un cuadrado por el simple dibujo con compás, entrando así a la categoría de la geometría clásica, producida sin mediciones.

Existe una serie de rectángulos raíz que se hallan interconectados. El primero de ellos es un cuadrado, el segundo es raíz de 2, el tercero es raíz 
de 3, el cuarto es el doble cuadrado y el quinto es raíz de 5. Si bien los lados de dichos rectángulos no son medibles en términos numéricos, los griegos decían que no eran realmente irracionales porque eran medibles en términos de cuadrados producidos de ellos. La posibilidad de medición en términos de área en lugar de longitud ha sido uno de los grandes secretos de los griegos.

Esto nos lleva a otro factor fundamental en diseño de arquitectura sagrada: la proporción y la conmensurabilidad. La música lo demuestra admirablemente en sus armonías, y de hecho de ella se ha dicho que es geometría convertida en sonido. La conmensurabilidad asegura completa armonía a través de una construcción u obra de arte, es una integración de todas las proporciones de las partes de tal manera que cada una de ellas tiene una forma y tamaño fijos. Nada puede ser añadido o removido sin alterar la armonía del todo. Ciertos rectángulos que son punto de partida de figuras geométricas relacionadas constituyen las bases para tales estructuras armonizadoras.

Los rectángulos con relaciones entre lados de 3:2, 5:4, 8:5, 13:6, etc. en los cuales las relaciones están expresadas en números enteros se los ha llamado rectángulos estáticos, mientras que rectángulos tales como los rectángulos raíz son llamados rectángulos dinámicos. Hay unos pocos rectángulos que combinan las propiedades de lo estático y lo dinámico: el cuadrado y el doble cuadrado. La diagonal de este es seguramente la forma más favorecida en las construcciones sagradas y es raíz de 5 , lo cual se halla directamente relacionado a la proporción de oro.

Esta importante razón, llamada por los griegos la Sección, la Divina Proporción por Luca Paccioli (1509), y bautizada por Leonardo da Vinci y sus seguidores la Sección Dorada o Número de Oro, tiene propiedades únicas que han cautivado a los geómetras desde tiempos egipcios.

Esta relación existe entre dos objetos o cantidades cuando la razón entre la mayor y la menor es igual a la existente entre la suma de las dos (la totalidad) y la mayor. 
Es simbolizada por la letra Phi, en honor a Fidias. Numéricamente posee propiedades excepcionales, tanto algebraicas como geométricas, Phi=1,618, 1/Phi=0,618 y Phi al cuadrado=2,618. En toda progresión o serie de términos que tenga a Phi como la razón entre sus términos sucesivos cada término es igual a la suma de los dos que lo preceden.

En términos numéricos esta serie fue primeramente conocida en Europa por Leonardo Fibonacci, nacido en 1179. Viajó con su padre a Argelia donde los geómetras árabes le enseñaron los secretos de la serie, pudiendo también introducir los números arábicos, revolucionando las matemáticas europeas.

Esta serie ha sido reconocida como el principio de la estructura de los organismos vivientes y de la estructura del mundo.

El número de oro ha sido honrado a través de la historia. Platón en su Timeo lo considera como la clave de la física del cosmos y hasta el moderno arquitecto Le Corbusier, padre de los edificios torre, diseñó un sistema modular basado en dicha proporción.

La geometría sagrada revela la construcción de muchas formas. De entre todas ellas, la Flor de la Vida es una de las más impresionantes, junto con sus derivadas: el Huevo y el Fruto de la Vida.

\section{Formas Fractales ${ }^{276}$ Básicas}

El círculo, representativo de la esfera, la forma más significativa y simple en geometría, es el punto de partida. De naturaleza femenina por sus líneas curvas, y por lo tanto dador de vida, el círculo servirá como unidad de la trama de diseño.

\footnotetext{
${ }^{276}$ Fractal:El experto en matemática Benoît Mandelbrot fue el responsable de desarrollar, en 1975, el concepto de fractal, que proviene del vocablo latino fractus (puede traducirse como "quebrado"). El término acuñado por el francés pronto fue aceptado por la comunidad científica e incluso ya forma parte del diccionario de la Real Academia Española (RAE). Un fractal es una figura, que puede ser espacial o plana, formada por componentes infinitos.

http://definicion.de/fractal/\#ixzz3PMlsPjkq
} 


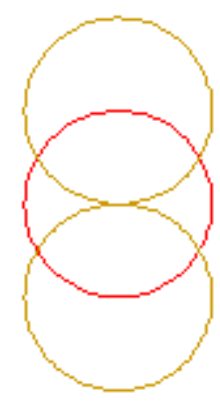

De acuerdo con varias escuelas, se pueden desarrollar una serie de figuras a partir de la repetición del círculo en relación con sí mismo.

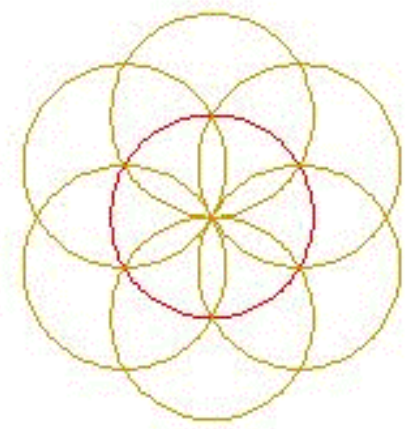

Notemos cómo a partir del giro del círculo alrededor de sí mismo se ha manifestado una flor, excelente ejemplo de la virtud generadora de vida de la feminidad.

Tan solo se necesita un compás para crear esta figura

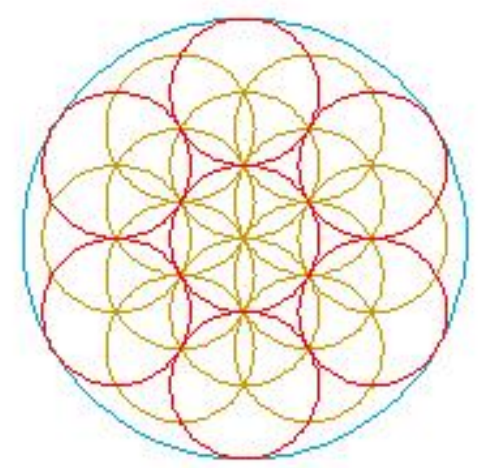

Un proceso evolutivo. Un proceso creativo. Notemos cómo surgen flores en los círculos interiores y la perfección de la geometría en su secuencia evolutiva. 


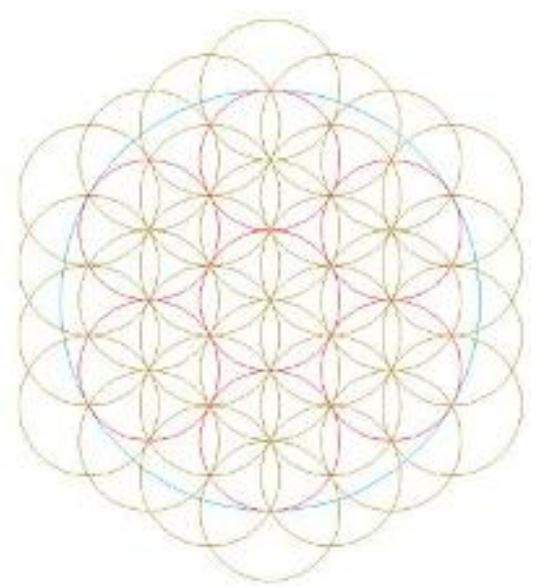

Una continuación del proceso.

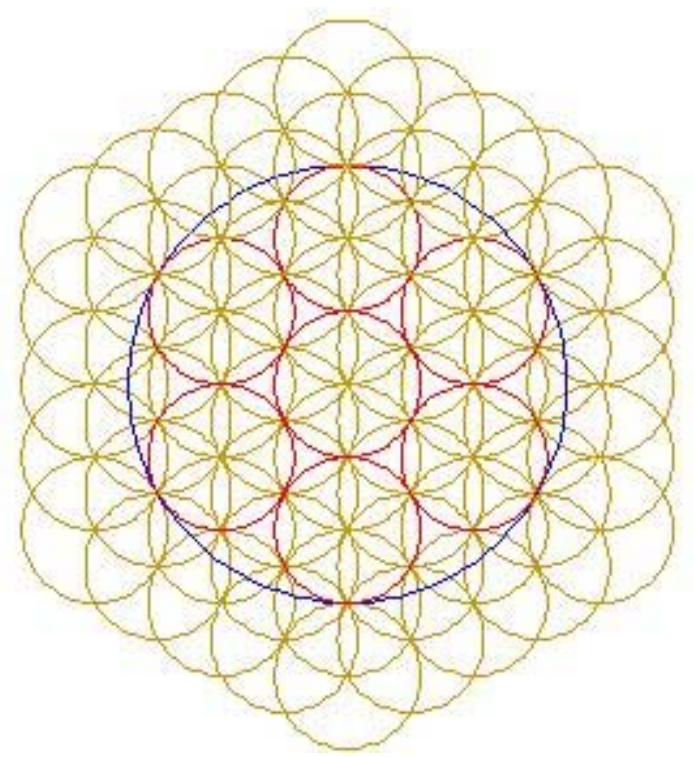

Ahora, el patrón de crecimiento está completo. Un círculo evolucionando alrededor de sí mismo genera esta extraordinaria figura, de la cual se deriva todo en la vida.

Este proceso dador de vida ha reproducido no sólo las energías curvilíneas femeninas, sino que ahora sugiere las energías masculinas rectilíneas, obvias en el hexágono manifiesto.

Completamos la figura de la Flor de la Vida (abajo izquierda) después de cortar algunas líneas sobrantes. Esta figura está presente en muchas de las culturas antiguas del mundo. 

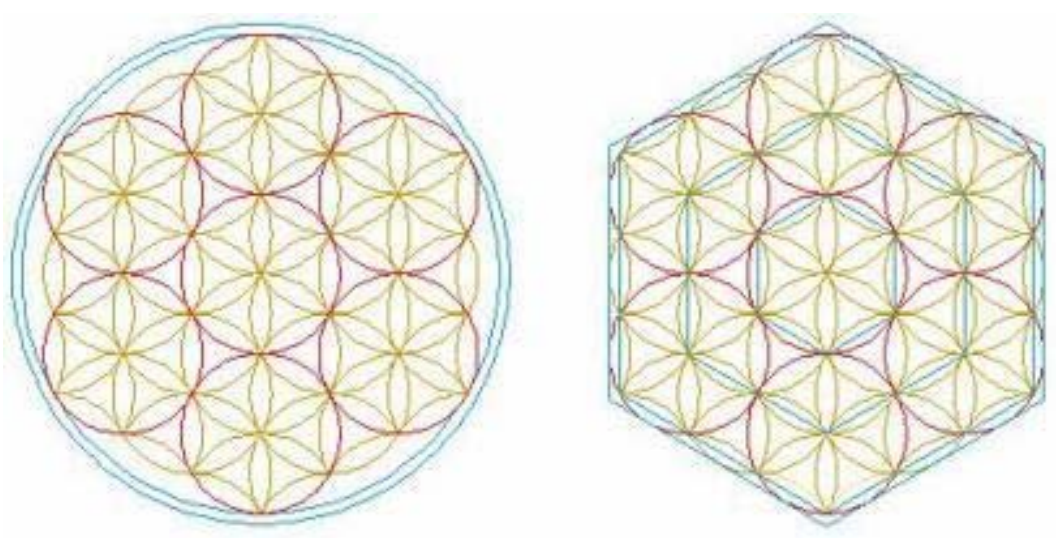

Siete círculos principales (en rojo) dentro de otro círculo, cada uno conteniendo una flor. Los seis círculos exteriores se tocan entre ellos en un solo punto y el círculo central toca a los seis externos, todo en una composición perfecta. Todas las flores se crean por la intersección de los círculos adyacentes siguiendo el patrón reproductivo; un patrón que permite a un círculo de naturaleza femenina dar vida tanto a otras formas femeninas como a las formas masculinas de líneas rectas (arriba izquierda).
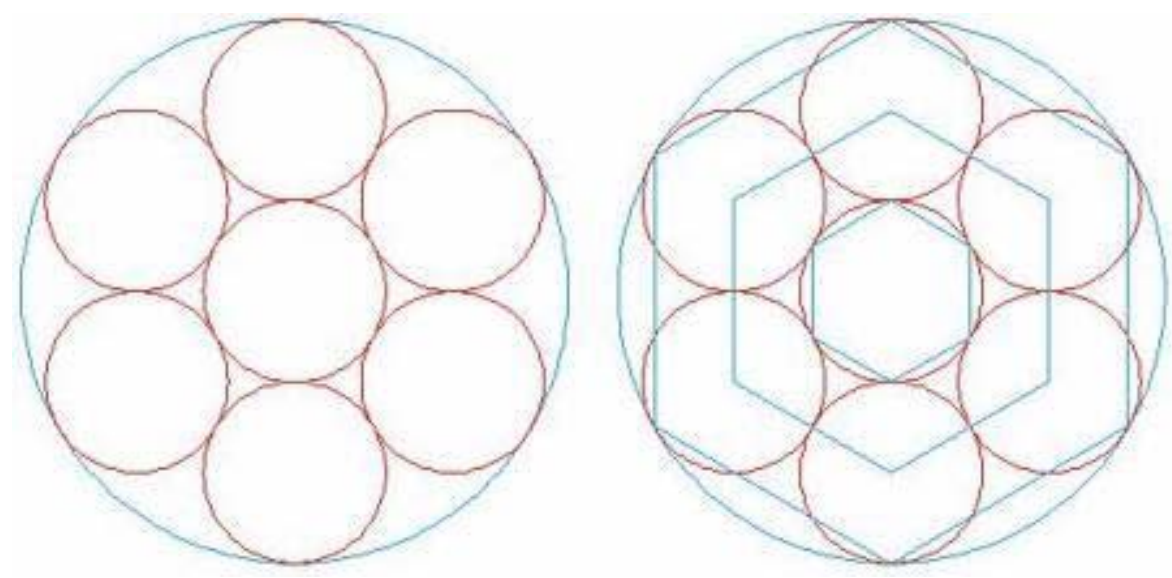

El Huevo de la Vida (arriba a la izquierda) se deriva de la Flor de la Vida: un círculo central rodeado por seis círculos, cada uno tocando a los adyacentes y todos inscritos perfectamente dentro de otro círculo mayor. A la izquierda, la versión masculina. 

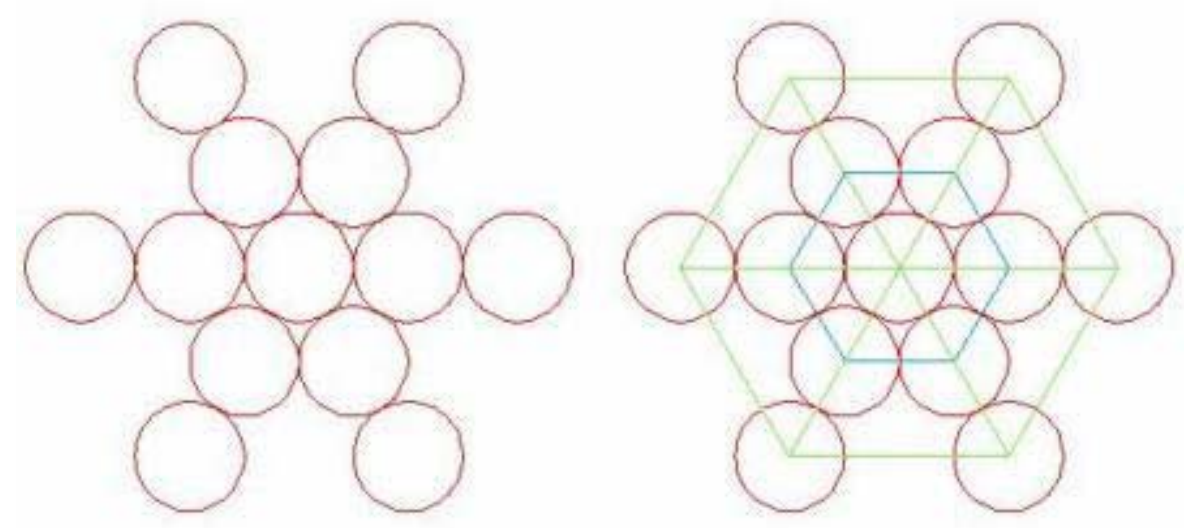

El huevo se quiebra. El Fruto de la Vida (arriba izquierda) se deriva del Huevo de la Vida. Notemos cómo el Fruto es una figura que tiene la intención de crecimiento, de expansión. Esta figura es la base de nuestra trama de diseño.

Podemos observar en la figura a la derecha que los hexágonos están presentes también en todos los niveles. Este es un bellísimo ejemplo de la integración de las energías femeninas y masculinas.

\section{La Trama de Diseño}

Abajo vemos el patrón de crecimiento que nos permite comprender la fractalidad del Fruto de la Vida - la perfección de su capacidad implosiva y explosiva. Cuatro niveles de crecimiento y cada serie de círculos mide precisamente el doble de diámetro que la anterior. Cada gráfico subsiguiente contiene a todos los anteriores. 


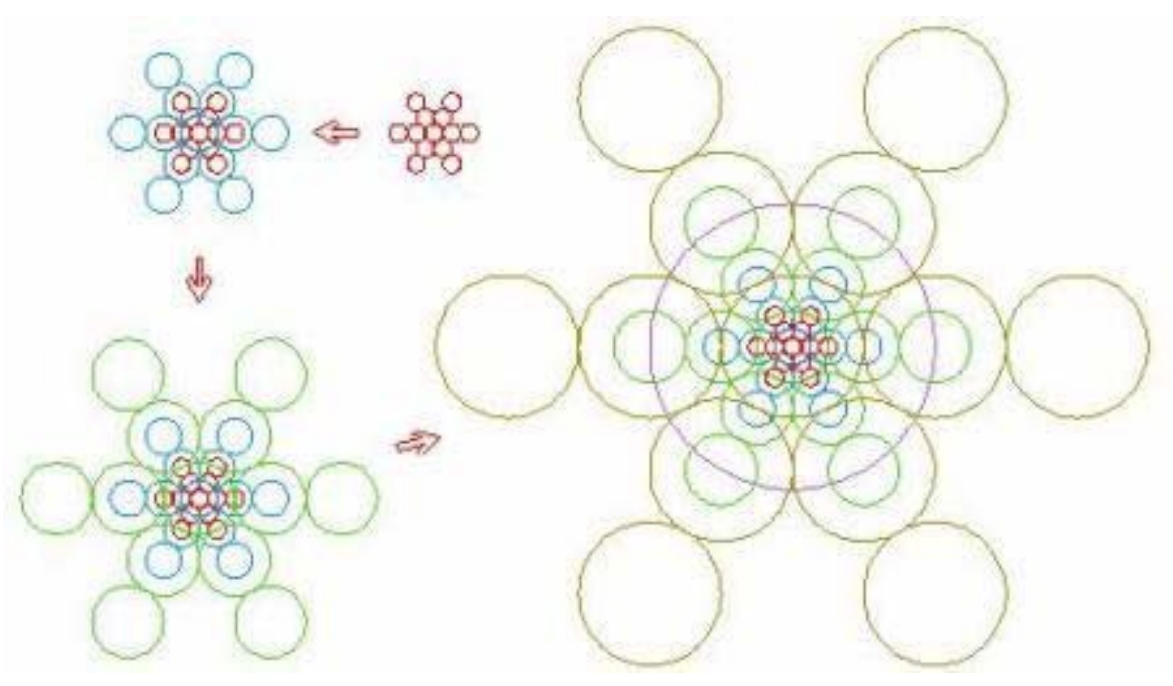

El todo es similar a la parte y viceversa. El todo se puede implotar (romperse con violencia un objeto hueco por exceso de presión exterior) a la parte y la parte al todo con un patrón armonioso y modular. Un ejemplo brillante de la fractalidad. Un fractal es una figura, que puede ser espacial o plana, formada por componentes infinitos. Su principal característica es que su apariencia y la manera en que se distribuye estadísticamente no varía aun cuando se modifique la escala empleada en la observación. Los fractales son, por lo tanto, elementos calificados como semi geométricos (por su irregularidad no pertenecen a la geometría tradicional) que disponen de una estructura esencial que se reitera a distintas escalas. El fractal puede ser creado por el hombre, incluso con intenciones artísticas, aunque también existen estructuras naturales que son fractales (como los copos de nieve) en la geometría y una manera fantástica de explicar el proceso de creación en la vida. 

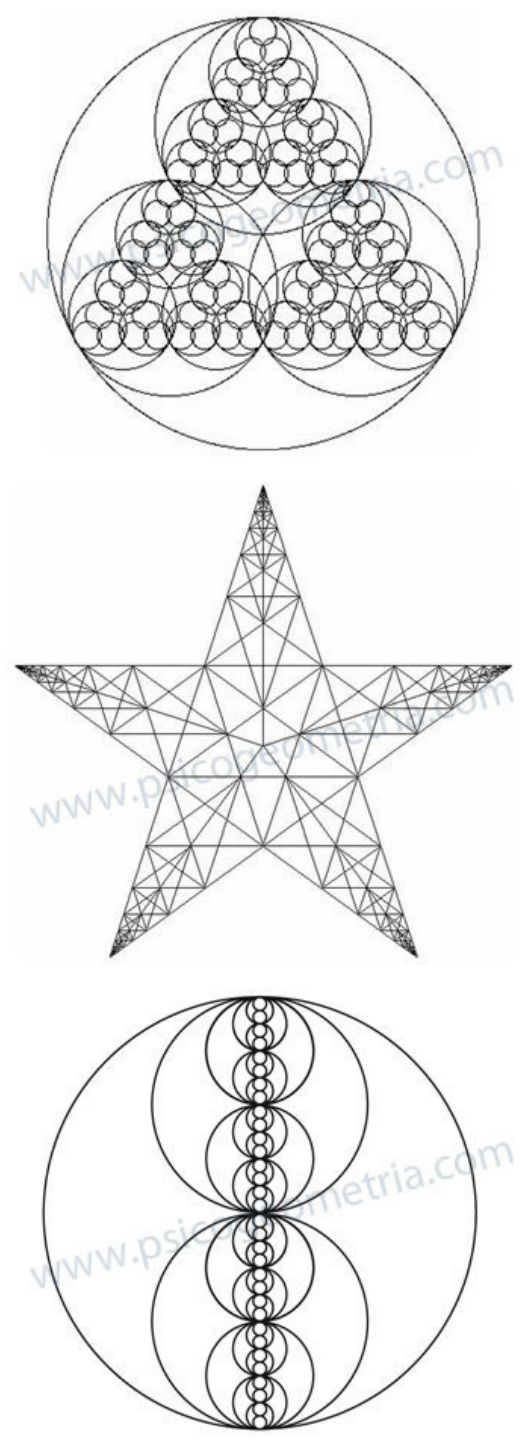

La Ley de la de fractalidad, nos dice que la suma de todas las partes se encuentra contenida en cada una de las partes. Repasando lo expuesto en un fractal es un patrón o forma geométrica construida con tales partes y proporciones, que en su conjunto, son idénticas al patrón total. Aunque se asocia la creación de fractales a modelos matemáticos, el universo en su conjunto es un fractal.

Un fractal es un objeto geométrico cuya estructura básica se repite en diferentes escalas $y$, en muchos casos, los fractales pueden ser generados por un proceso recursivo o iterativo, capaz de producir estructuras autosimilares independientes de la escala específica. Los fractales son estructuras geométricas que combinan irregularidad y repetición de estructura. Aunque muchas formas naturales tienen estructuras de tipo fractal, un fractal matemático es un objeto que tiene, por lo menos, una de las siguientes características: tiene detalles en escalas arbitrariamente pequeñas, es demasiado irregular para ser descrito en términos geométricos tradicionales, tiene autosimilaridad exacta o estadística y puede ser definido de forma recursiva. 
El problema con cualquier definición de fractal es que existen objetos que uno quisiera llamar fractal pero que no satisfacen ninguna de las propiedades anteriores. Por ejemplo, fractales de la Naturaleza como nubes, montañas y vasos sanguíneos tienen límites inferiores y superiores en detalle; no existe un término preciso para "demasiado irregular"; existen diferentes maneras para definir "dimensión" con valores racionales; y no todo fractal es definido recursivamente. Los fractales estocásticos están relacionados con la teoría del caos. En efecto, los fractales, como los seres vivos, satisfacen la mayor parte de las propiedades de la lista, pero algunos de ellos carecen de alguna de las características y, sin embargo, entran en la categoría correspondiente.

Algunas de las fórmulas matemáticas para la creación de fractales son: Mandelbrot ${ }^{277}$, Julia, Lindenmayer, Halley, Quaternion y Biomorph. En 1993, el investigador estadounidense M. Theroux incorporó el valor de phi en la creación de fractales, con ayuda del software Fractint $17.2^{278}$, y esto le permitió reproducir en realidad virtual, algunos procesos biológicos. En este proceso logró incorporar la creación de autosimilaridades (proceso que, al mismo tiempo que conserva la forma original de la especie, le permite evolucionar para que pueda interactuar con su medio ambiente).

Los patrones fractales han sido encontrados en el flujo del tráfico, en la música, en la cardiología, en la electrónica, en la meteorología, etc. Todos los fractales están hechos de retroalimentación positiva sin importar el medio. No son estables ni estáticos. Se balancean en el filo del caos. Un mínimo contacto y pueden volar en giros atrevidos, al igual que un fuerte

\footnotetext{
${ }^{277}$ El conjunto de Mandelbrot es el más conocido de los conjuntos fractales y el más estudiado. Se conoce así en honor al matemático Benoît Mandelbrot, que investigó sobre él en la década de los setenta del siglo XX. http://es.wikipedia.org/wiki/Conjunto de_Mandelbrot. Octubre 2014.

${ }^{278}$ Fractint es un patrón fractal generador / color ciclador. Originalmente, el programa era conocido como DKMandle, y más tarde como Fract386, antes de ser renombrado a FractInt con v 6 . Fractint rendirá 53 tipos diferentes de los fractales de forma predeterminada y se puede ampliar con conjuntos de fórmula adicionales. Proporciona una variedad de otros efectos de manipulación de imágenes (rotación paleta, starfields, estereogramas, rellenos de hormigas, etc http://eyecandy.gnugget.net/Fractint/.Enero2015
} 
tirón puede no moverlos. La predicción no está asegurada y, por supuesto, los deterministas se sienten incómodos con los fractales. El universo consiste en una serie de cuerpos espirales de tamaño diminuto, cada uno hecho de la eyección de plasma y modulado por un efecto espacial Coriolis: un universo fractal rotativo.

Gracias al advenimiento de la Geometría de los fractales, varias ciencias particulares pueden hoy tomar sus conceptos y aprovecharlos en sus respectivas áreas de conocimiento. Está surgiendo de este modo una compleja matriz científica que puede servir para hacer de soporte a todas las ciencias particulares, una suerte de Ciencia Madre. Las ciencias sociales, por ejemplo, pueden utilizar muchos conceptos abstractos de los fractales y de la teoría del caos, proponiendo nuevas teorías o profundizando en las clásicas, pero enriquecidas por el nuevo paradigma.

K. Marx realizó intuitivamente el análisis fractal de la economía política, estudiando la mercancía como la pieza raíz (la ecuación fundamental), de la cual se obtenía el "árbol" completo de la sociedad capitalista. En ese sentido, Marx veía el germen del sistema capitalista en su partícula económica celular, la mercancía, mínima expresión de la cual emanan todas las contradicciones sociales que luego se iteran a través de todo el sistema, preñándolo de su esencia contradictoria. La mercancía es la quinta esencia de la sociedad en la que vivimos. Un sistema simple (la mercancía) repercute (recursividad) y se despliega de tal forma que termina siendo un sistema complejo que es cualitativamente diferente de la partícula que le dio la información.

Si el aleteo de una mariposa en Pekín puede desencadenar un huracán en Miami, como postula la Teoría ${ }^{279}$ del Caos $^{280}$, ¿no puede una crisis económica repercutir en todo el sistema? Vemos confirmar esta teoría en las crisis que generan ciertas economías particulares (nacionales) sobre el conjunto de la economía mundial. De cualquier modo, una extrapolación

\footnotetext{
${ }^{279}$ Moon, Francis (1990). Chaotic and Fractal Dynamics. Springer-Verlag New York.

${ }^{280}$ Artículo: Deterministic nonperiodic flow, en el Journal of Atmospheric Sciences 20:69 (1976) http://www.geofisica.cl/English/pics5/FUM3.htm. Octubre 2014.
} 
demasiado esquemática de la geometría fractal a las ciencias sociales será siempre una utopía, ya que la sociedad no es una abstracción matemática.

En las matemáticas priman los entes estáticos, ideales: los números. Con una ecuación sumaria, o parámetros fijos, una computadora puede deducir una estructura, como pasa en el caso de las imágenes digitales que representan ecuaciones fractales. Sin embargo, una sociedad no puede hallar una ecuación sumaria que genere una estructura determinada, por el simple hecho de que los pilares de una sociedad son más elásticos que simples coordenadas ideales. Entonces se da lo que la teoría del caos denomina sensibilidad extrema a los estados iniciales de un proceso, que pueden redundar en cambios drásticos.

De este modo, en las ciencias sociales priman los elementos móviles, la sociedad en un movimiento incesante. Sin embargo, el análisis del "ADN social", o sea, todas sus tendencias internas de desarrollo, pueden ser estudiadas siguiendo los parámetros de esta teoría, que no es otra cosa que una teoría integral del desarrollo, del devenir. Dicho de otra manera, es una forma novedosa que puede tomar el método dialéctico que funda Marx, sobre la base de Hegel y Heráclito.

La ciencia tiene la predicción como uno de sus usos. Predecir determinadas leyes que se cumplan a cabalidad, con lo que el futuro sería previsible desde la razón. Muy diferente a la predicción escondida, este tipo de predicción científica se da con base en el estudio de las condiciones iniciales de un fenómeno. Allí se trata de observar sus principales tendencias vitales que se cristalizan en un tipo de desarrollo. Dos ejemplos: Newton, con su teoría de la gravedad, estableció leyes que permitieron resolver y predecir fenómenos que antes eran imposibles de estudiar. Otro ejemplo lo tenemos con el avance de la Biología Genética, ya que, con el estudio del genoma humano, lo que se está tratando de hacer es obtener las leyes que rigen el desarrollo del ser humano. 
Todo cuanto estamos analizando puede que en principio parezca que tiene poca o nula relación con nuestro objeto de estudio, pero nada más lejos de la realidad.

Consideramos que ha sido muy necesario dejar claros determinados conceptos filosóficos muy importantes para poder comprender el objetivo último de nuestra investigación: demostrar el valor numérico, conceptual y de forma de nuestro botón charro como eje de técnica y forma de la joyería femenina ancestral de nuestra tierra.

Para ello hemos tenido que introducirnos en la explicación y comprensión de unas teorías, que aun siendo muy antiguas, parece que es en la actualidad cuando empiezan a tener una atracción más generalizada por los estudiosos de las diferentes materias. Gracias a todo ello podremos entender lo que a partir de ahora vamos a plantear.

\section{4.- Las medidas áureas del Botón Charro.}

No cabe duda de que estas formas que estamos estudiando tienen intrínseco el valor del símbolo y es ahí donde podemos encontrar una de las causas de la permanencia de ellas a lo largo del tiempo. Pero no cabe duda de que no es única, sino que forma parte de otras entre las que ocupa un lugar importantísimo la relación número-forma geométrica. Si además esas formas tienen las medidas de la perfección y del equilibrio natural, entonces estaremos asistiendo a un patrimonio único hasta ahora desconocido por todos.

El plantearnos llevar a cabo semejante empresa no dejó de ser un tanto criticada fundamentalmente por los más escépticos. Siempre estuvo en nuestra intención hacer realidad lo que en un principio era una mera intuición.

El hecho de la insistencia en este capítulo y de este estudio, se basaba en que si quedaba demostrado el origen milenario de la técnica de 
ejecución de estos objetos y el valor extraordinario de la forma asociada a las medidas áureas, nos encontraríamos ante un fenómeno cultural hasta ahora desconocido y esto podría ayudar a este patrimonio a abordar el compromiso ineludible de las Administraciones Públicas ante tamaña herencia cultural femenina, hasta ahora despreciada, nada valorada y peor aún un riesgo cierto de desaparición.

¿Qué son las medidas áureas?

Desde el comienzo de los tiempos, el hombre ha intentado averiguar cuál es la proporción correcta de las cosas, o como llamó Luca Pacioli ${ }^{281}$ en el Renacimiento, cuál es la "divina proporción", o bien, cuál es la manera de crear una obra armónica. Aunque los egipcios ya conocían esta proporción, no aparece formulada por primera vez hasta los tiempos Griegos ${ }^{282}$ (Euclides s. III a.C). La sección áurea fue empleada por filósofos, científicos y artistas que terminaron llamándola en el Renacimiento la Divina Proporción, aunque lo increíble de todo esto es que esta proporción expresada matemáticamente se da también en 'construcciones' de la naturaleza, encontrándola por ejemplo en las formas de las galaxias, la estructura de caracolas marinas y en las formaciones de borrascas y tormentas.

Encontramos ejemplos de esta proporcionalidad aplicada al arte en todas sus vertientes y a lo largo de la historia. Las dimensiones del Partenón ${ }^{283}$ están basadas en la sección áurea.

La fascinación que el ser humano ha sentido durante muchos siglos por la proporción áurea se debe en gran medida a sus numerosas propiedades interesantes, entre las que destacan la armonía, la regeneración y el equilibrio.

\footnotetext{
${ }^{281}$ GARCíA CRUZ, J A, Las Matemáticas de Luca Pacioli,Seminario Orotava de Historia de la Ciencia, año X. La Orotava, Fundación Canaria Orotava de Historia de la Ciencia, Las Palmas de Gran Canaria, 2001.

282 TOLEDO AGÜERO, Y,Sección Áurea en Arte, Arquitectura y Música,cap. V-V.5. www.matematicas.uclm.es octubre 2014

${ }^{283}$ Op. Cit. Ant.capV-V.5. Arquitectura Antigua: Grecia y Roma.
} 
La armonía se manifiesta en las pautas de diseño que aplica la naturaleza en las plantas, las conchas, el viento y las estrellas.

La regeneración se pone de manifiesto en formas y figuras que constituyen la base de la realidad, desde la estructura del ADN hasta el contorno del universo.

El equilibrio que hallamos en la cóclea del oído interno tiene su reflejo en la evolución del embrión humano, que nos lanza a la existencia.

El nombre de proporción áurea tiene algo de mítico porque suena mucho más de lo que realmente se le conoce. Se le llama también divina proporción, número de oro, regla dorada, etc... La proporción áurea está formulada ya en los Elementos de Euclides ${ }^{284}$ (s.-III), en una construcción geométrica denominada División de un segmento en media y extrema razón.

Sobre la base de la relación de la línea de Euclides, podemos dibujar un rectángulo ${ }^{285}$ con un lado que mide 1 y el otro $\Phi$. $Y$ un pentagrama en el que los segmentos $A, B, C$ y $D$ tienen longitudes decrecientes en una proporción igual a $1,618 \ldots$...es decir, el valor de $\Phi$.

Para construir el pentágono regular, bien a partir del lado base, bien circunscrito en una circunferencia, siempre tenemos que recurrir a la proporción áurea, porque todos los elementos están relacionados entre sí por esta proporción.

En fachadas de templos y otras construcciones se pueden detectar rectángulos áureos: Partenón de Atenas, Nôtre Dame de París, y un caso digno de mención es el Hombre vitrubiano de Leonardo da Vinci ${ }^{286}$. Vitrubio, arquitecto romano, en su tratado De Arquitectura da unas referencias sobre la figura humana basadas en divisiones simples, y además dice que la altura es igual a la envergadura y que un hombre echado, al extender brazos y piernas describe un círculo (no alude a la proporción áurea, sino a las formas perfectas). Muchos artistas intentaron ilustrar en un mismo dibujo las tres

\footnotetext{
${ }^{284}$ Op.Cit. Ant.capll-II.1. Antecedentes.

${ }^{285}$ Op.Cit. Ant.capll-II.6. Rectángulo áureo.

${ }^{286}$ Op.Cit. Ant. Cap.V-V.7. Arquitectura Renacentista.
} 
formas: humana, cuadrada y circular, con resultados pintorescos pero poco afortunados. P Partenó Leonardo dio una solución original y mucho más elegante descentrando cuadrado y circunferencia. El pubis es el centro del cuadrado, y el ombligo el de la circunferencia. Es fácil comprobar que su radio es sección áurea de la altura del cuadrado.

En las obras de muchos otros artistas ${ }^{287}$ del Renacimiento se han buscado relaciones áureas, sin conclusiones sobre su uso consciente. Sir Theodore Cook, en el siglo XIX, describió una escala simple de divisiones áureas aplicable a la figura. El modelo anterior encajaría perfectamente en las obras de algunos pintores, como en ésta de Boticelli: Detalle de "El nacimiento de la Primavera" o "La Gioconda" de Leonardo da Vinci. También la "La Anunciación" Leonardo da Vinci o "Martirio de San Bartolomé" José de Ribera. "Las Meninas" o La Venus de Milo.

Fidias fue un escultor griego y también un matemático que ayudó a dirigir la construcción del Partenón. Se dice que aplicó la proporción áurea al diseño de las esculturas que se encontraron en el templo. El número de oro lleva la letra griega $\Phi($ phi ) en honor a la primera letra de su nombre ( phi ).

En el Timeo, Platón( heredero de la Armonía de Pitágoras: "todo es número") ${ }^{288}$ describió cinco posibles cuerpos regulares que, en su opinión, podían constituir la base de la estructura armoniosa del universo. La proporción áurea determina las dimensiones y la formación de algunos de ellos.

Euclides (325-265 a. C.) En sus "Elementos", Euclides formuló la primera definición que se conserva de la proporción áurea. Este libro todavía se usa para enseñar Geometría. Simpatizaba con la filosofía de Platón y puso como final de los Elementos la construcción de los llamados sólidos platónicos.

\footnotetext{
${ }^{287}$ Op.Cit. Ant. Cap.IV-IV.8. Arte Renacentista..

288 Op. Cit. Ant. Cap.III-III.1. Armonía Pitagórica:" Todo es número".
} 
Fibonacci (1170-1250) Leonardo Pisano, Fibonacci ${ }^{289}$ ideó la sucesión numérica que lleva su nombre $(0,1,1,2,3,5,8,13,21,34 \ldots)$. Estos números guardan una relación intrínseca con la proporción áurea.

Luca Pacioli (1445-1517) Geómetra y amigo de los grandes pintores del Renacimiento, "redescubrió" el "secreto de oro" y propuso en su libro De Divina Proportione Ilamarlo divina proporción. Leonardo da Vinci ilustró la obra con hermosos dibujos de los cinco sólidos platónicos.

Kepler (1571-1630) Johannes Kepler, descubridor de la naturaleza elíptica de las órbitas de los planetas que giran alrededor del Sol, reveló la relación que había entre la secuencia de Fibonacci y la proporción áurea, al demostrar que los cocientes que se dan entre los términos consecutivos de la serie, tienden a acercarse a la razón áurea.

$\mathrm{CH}$. Bonnet (1720-1793) Charles Bonnet describió la disposición de las hojas de las plantas ${ }^{290}$ y señaló que los números de espirales que giraban en uno u otro sentido en las filotaxis de las plantas, eran a menudo dos números consecutivos de la sucesión de Fibonacci.

Martin Ohm (fines del XVIII-fines del XIX) Matemático alemán, hermano de Georg Ohm, el físico que dio su nombre a la unidad de resistencia eléctrica, el ohmio, fue al parecer el primero en utilizar las palabras "sección áurea" para describir esta maravillosa proporción, marcando la primera aparición del término en una publicación, en este caso, de un libro suyo en el año 1835.

Ed. Lucas (1842-1891) Edouard Lucas, matemático francés que ideó la serie numérica que lleva su apellido, fue quien oficialmente bautizó la serie numérica conocida por el nombre de Sucesión de Fibonacci ${ }^{291}$.

Mark Barr (S. XX) empleó, a comienzos del siglo XX, la letra griega $\Phi$ (phi) para designar la proporción áurea. Phi es la primera letra en griego del

\footnotetext{
${ }^{289}$ Op.Cit. Ant. Capll-II.5. Sección de Fibonacci.

290 Op. Cit. Ant. CapVI-VI.1. Sección áurea de la naturaleza.

${ }^{291}$ Op.Cit. Ant. Capll-II.5
} 
nombre de Fidias. Es así mismo la letra equivalente a la f del alfabeto latino, como también la inicial de Fibonacci.

Roger Penrose (n. 1931) Físico y matemático inglés. En el ámbito de los mosaicos periódicos, halló una simetría basada en la proporción áurea que dio lugar a un descubrimiento sobre los cuasicristales. (Los cuasicristales son sólidos que violan uno de los preceptos básicos de la cristalografía: la no existencia de simetría pentagonal).

Completamos esta lista mencionando a Le Corbusier ${ }^{292}$ (1887-1965), arquitecto, diseñador y pintor suizo, nacionalizado francés. Ideó el Modulor, sistema de medidas basado en las proporciones humanas, en que cada magnitud se relaciona con la anterior por el Número Áureo, para que sirviese de medida de las partes de arquitectura. De esta forma retomaba el ideal antiguo de establecer una relación directa entre las proporciones de los edificios y las del hombre ${ }^{293}$.

"No hay nada placentero que no esté en armonía con lo más profundo de nuestra naturaleza divina." Heinrich Suso (h. 1295-1366) Místico alemán.

Pero si alguien ha estudiado, técnica y filosóficamente, las medidas áureas de manera reciente, estudiándose su tratado en las Escuelas de Arquitectura ése es Matyla C. Ghyka ${ }^{294}$.

Por todo cuanto hemos estudiado, consultado y visto convenimos en la necesidad de la realización de un recapitulación de conceptos que nos preparen para la comprender y abrir la mente ante el trabajo posterior que vamos a realizar.

Gran parte de los contenidos vertidos a continuación provienen de la conferencia sobre Matemáticas Áureas y Geometría Sagrada ${ }^{295}$. A nuestro

\footnotetext{
${ }^{292}$ Op.Cit. Ant. CapV-V.9.2. Le Corbusier.

${ }^{293}$ Op. Cit. Ant. CapV-V.5.1. Armonías humanas.

294 GHYKA MATYLA,C, El número de oro: I Los ritmos- II Los ritos", Traducción J. Bosch Bousquet, Ed. Poseidón, , 3ạ edición, Barcelona, 1978.

${ }^{295}$ GARCÍA, A, Conferencia de Matemáticas áureas y geometría sagrada, Psicólogo e investigador. COGNOS 2013.
} 
modo de ver, la concepción general de las cosas es fruto de la convergencia de diferentes elementos. A sí como nosotros nos creamos una opinión en base a la información que tenemos, lo mismo ocurre con el conocimiento.

El mundo de las matemáticas es tan tremendamente inmenso y complicado, que la comprensión del mismo requiere de una gran capacidad de conocimientos y habilidades numéricas. Pero hay otra manera de acercarse al vasto y amplio universo de las matemáticas y que está más relacionado con la filosofía que con los números propiamente dichos. Decía Nikola Tesla (1856-1943) físico, ingeniero matemático, ingeniero eléctrico e inventor: "Si deseas comprender el universo piensa en energía, frecuencia y vibración" habría que añadirle si piensas en el universo piensa en números, en matemáticas y en filosofía".

Ya desde la antigüedad las matemáticas han contenido las claves para que el hombre intente comprender cómo funciona todo.

Los egipcios fueron una civilización dónde la ciencia y el conocimiento de los números les permitió ver más allá, abrir las puertas de un cosmos que incluso ahora para nosotros resulta complicado, tanto es así que al mismo día de hoy singuen sorprendiéndonos sus legados.

Decíamos anteriormente que el universo es fractal y este hecho no está para nada alejado de las matemáticas áureas. Un fractal es una forma que se replica a sí misma y lo hace a distintos niveles de realidad. Este aspecto que queda demostrado con el ejemplo del brócoli es exportable al propio individuo. El hombre también es un fractal, nosotros salimos de nuestras madres y ellas lo hicieron de las suyas y así sucesivamente.

Las matemáticas áureas no son las que se explican habitualmente en las aulas, aspecto este que debería replantearse, ya que estas matemáticas son las inspiradas en Pitágoras quién pensaba que el mundo se podía entender con los números y si a ello le unimos la influencia que tuvo del mundo caldeo que dominaban las ciencias de la Astronomía y la Astrología, podemos entender la concepción cosmogónica que tenía. Aquella manera de entender y conocer implicaba una asociación de todas las ciencias por 
parte del intelecto, aspecto este que hemos perdido tras nuestra deriva disociativa de las ciencias, olvidando que los instrumentos científicos necesitan el compendio de todas las áreas del conocimiento para no olvidarnos del objetivo último de la ciencia.

Parece que en la actualidad estamos volviendo a esa integración de las diferentes ramas del conocimiento para poder explicar el universo en el que estamos insertos.

Al hombre le ha preocupado siempre la identidad de la unidad. Si estudiamos la unidad desde el punto de vista de la geometría, ésta siempre se ha representado con el círculo, ya que ayuda a delimitar algo en expansión. El círculo o la esfera siempre se han usado para referirse al todo.

La serie de Fibonacci, es fundamental para entender la realidad tal como la entendemos. ¿Y por qué es fundamental? porque si tomamos dos números (un número y lo dividimos con su anterior en la serie) y los dividimos siempre nos da Phi= 1,6180 que es la proporción áurea.

El número Phi y la secuencia de Fibonacci están implicados en determinar el número de pétalos que tienen las flores o en determinar el número de ramificaciones que tienen los árboles que tienen la misma frecuencia. La división de las ramas de los árboles sigue esa misma frecuencia y además es un fractal reflejado en sí mismo ya que tenemos las ramas y a la vez sus raíces que se desarrollan con la misma frecuencia. Nuestro cuerpo también está relacionado con esta proporción y se aprecia muy fácilmente en la proporción de la mano: El hueso de la mano tiene la medida de la suma de la falange y la falangina. Si dividimos la longitud del hueso de la mano entre la dimensión de la falangina nos da Phi en proporción áurea. Igual sucede para los otros huesos de la mano.

La espiral geométrica que se construye con los números secuenciales obtenidos por Fibonacci, es la que se la conoce como la "espiral áurea", identificada siempre con la "belleza perfecta". Esto nos interesa muchísimo para nuestros objetivos posteriores cuando construyamos dicha espiral en el botón charro. 
Pero las preguntas que nos hacemos son ¿por qué todos nos ponemos de acuerdo que hay belleza cuando el modelo incluye la espiral áurea? o ¿cómo somos capaces de reconocer la armonía y la coherencia de ése tipo de objetos? ¿Tiene algo que ver con el inconsciente colectivo del que hablábamos en capítulos anteriores? Realmente la respuesta está en que nos ponemos de acuerdo y reconocemos esas características porque realmente conocemos esas matemáticas que pertenecen al inconsciente colectivo de la humanidad. Estamos convencidos de que no es cuestión de casualidad sino de causalidad.

Tal vez no están tan desencaminados aquellos que piensan, entre los que compartimos teoría, que la proporción de la que hablamos la conocemos de forma innata y por eso la reconocemos todos cuantos observamos esos objetos sean o pertenezcan a cualquiera de las áreas de conocimiento: coincidimos en la belleza de un cuadro, en la belleza de una escultura, la belleza de un edificio, la belleza de la naturaleza, la belleza de una pieza musical y por supuesto la belleza de una joya. $Y$ las reconocemos porque tenemos la capacidad de reconocer en ellas esas relaciones matemáticas con la identidad de la unidad, de la que básicamente nosotros formamos parte y a la que nunca hemos dejado de pertenecer.

Para materializar la realidad, es importantísimo establecer una relación entre forma y número. Relacionar la secuencia de Fibonacci y las formas que conforman la realidad, las que Platón en el Timeo definió con los

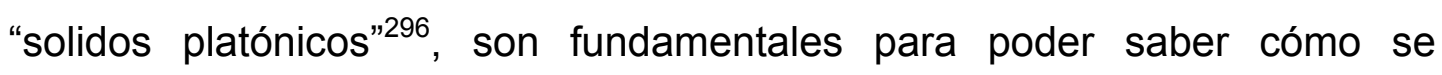
conforma la realidad. Las distintas realidades son imposibles de relacionar sino se reducen a un mismo lenguaje en el que el código sea el mismo para que emisor y receptor puedan realizar las semejanzas. Para ello hemos de reducir esas realidades a números y a formas que son el lenguaje universal y comprensible por todos, independientemente del lugar del que

\footnotetext{
${ }^{296}$ Platón en "El Timeo" habla de los sólidos como las formas geométricas que están detrás de todo cuanto vemos. Estos sólidos platónicos eran muy conocidos en el mundo griego aunque los chinos los conocían mucho antes.
} 
procedamos. Los números y las formas lo entienden igual los chinos, los americanos, los hindúes, los europeos...

La forma pone en relación el nacimiento de una estrella y el embrión humano pues ambos poseen la misma forma. Un tetraedro equilátero tiene la misma forma que la molécula del metano. Sería imposible enumerar los millones de elementos relacionados con sus formas y sus relaciones numéricas.

En este orden de cosas consideramos que ahora ya estamos preparados para comprender el trabajo que hemos realizado.

A la pregunta de por qué nos planteamos la posibilidad de que el botón charro tuviera o no la proporción áurea, la respuesta está en la cantidad de tiempo dedicado a la observación, en la seducción que desde niña me producía sin saber por qué, en la incomprensión de su desprecio generalizado en su propia tierra en contraposición con la fascinación que provocaba fuera de ella y en la búsqueda de respuesta a la pregunta de por qué un objeto sencillo rural y antiguo había permanecido a lo largo del tiempo sin alterarse dando además nombre a toda una provincia e incluso identificando el adjetivo gentilicio salmantino con charro, amén de atravesar el atlántico para identificar a una parte muy importante del pueblo mexicano con el adjetivo gentilicio "charro".

En un principio muchos fueron los escépticos, pero gracias a la colaboración directa y estrecha de los arquitectos Pablo Andrés Bravo ${ }^{297}$ y Marina Rocío Andrés Lucas ${ }^{298}$, concluir nuestra teoría inicial de las proporciones especiales y áureas del botón charro, fue una realidad con lo que ello conlleva de novedoso y a la vez extraordinario, en la medida de no haberse estudiado jamás.

\footnotetext{
${ }^{297}$ ANDRÉS BRAVO,P, Recóndita Armonía, Edita, Fundación Germán Sánchez Ruipérez. Madrid, 2014. (Arquitecto y colaborador directo en la conceptualización de la proporción áurea del botón charro). ${ }^{298}$ ANDRÉS LUCAS, M R, Arquitecto, colaboradora directa en la realización gráfica de la proporción áurea del botón charro.
} 
A continuación pasamos a presentar todos aquellos pasos que hemos llevado a cabo en el transcurso de la obtención de las medidas áureas del botón charro.

Es muy importante dejar claro que la base del dibujo del botón charro, sobre el que se han realizado los dibujos y mediciones áureas, está hecho del modelo realizado por el filigranistas José Luis Nieves, de quien hemos hablado ampliamente en este trabajo. El botón y sus medidas están ejecutados como mandan los cánones tradicionales ajustándose a las medidas heredadas de la tradición secular. 


\section{DIBUJO DE LAS MEDIDAS ÁUREAS EN EL BOTÓN CHARRO}

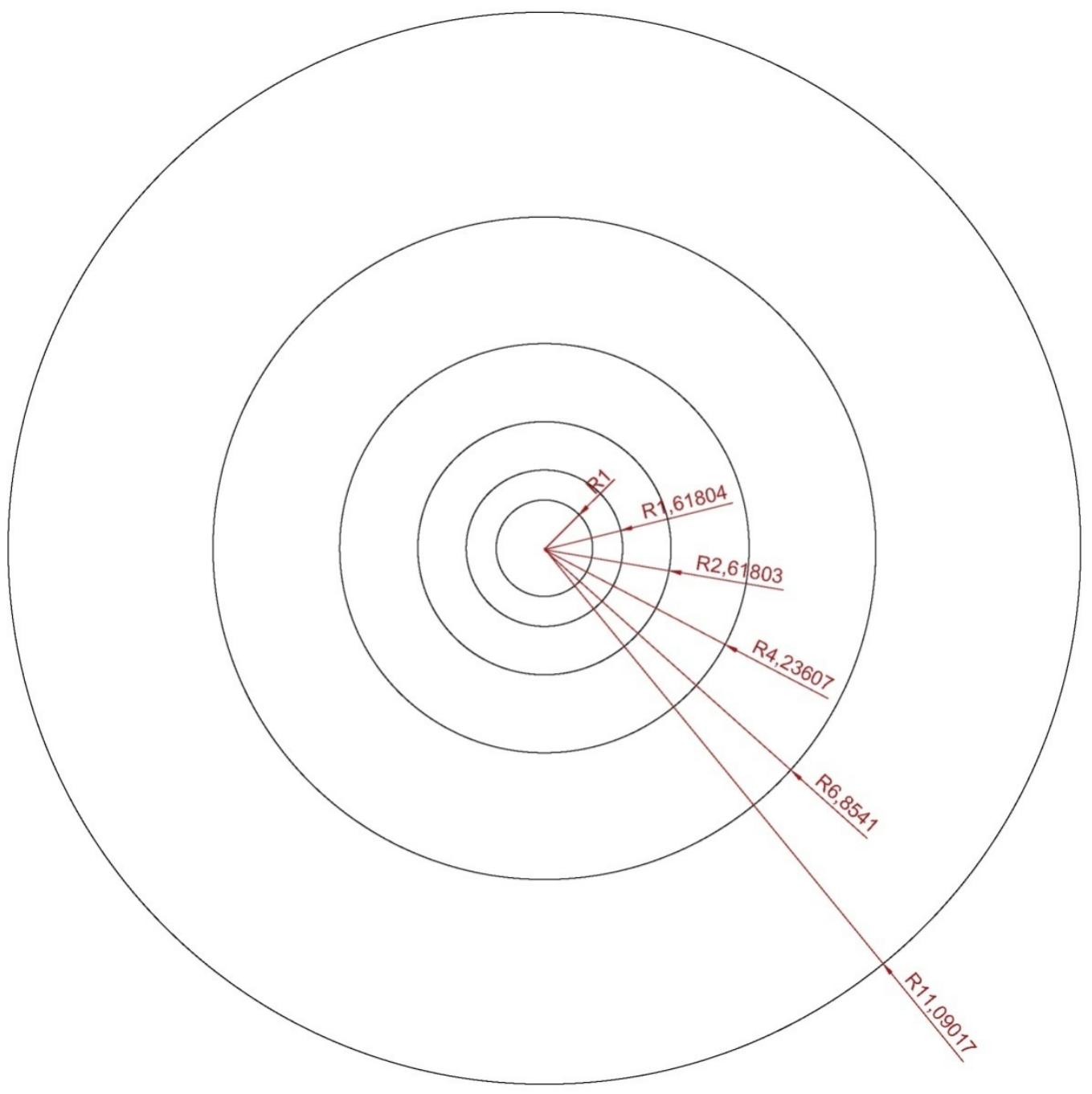

1. ${ }^{299}$ Se parte del círculo de radio la unidad y este se multiplica sucesivamente por el número áureo $=1,61803399$, obteniendo así la proporción de círculos concéntricos que servirá de base para el dibujo del botón charro. El espacio entre círculos concéntricos se denomina corona.

${ }^{299}$ Figura realización propia en colaboración con los arquitectos Pablo Andrés Bravo y Marina Rocio Andrés Lucas. No publicada. Realizada en Salamanca. Enero ,2015. 


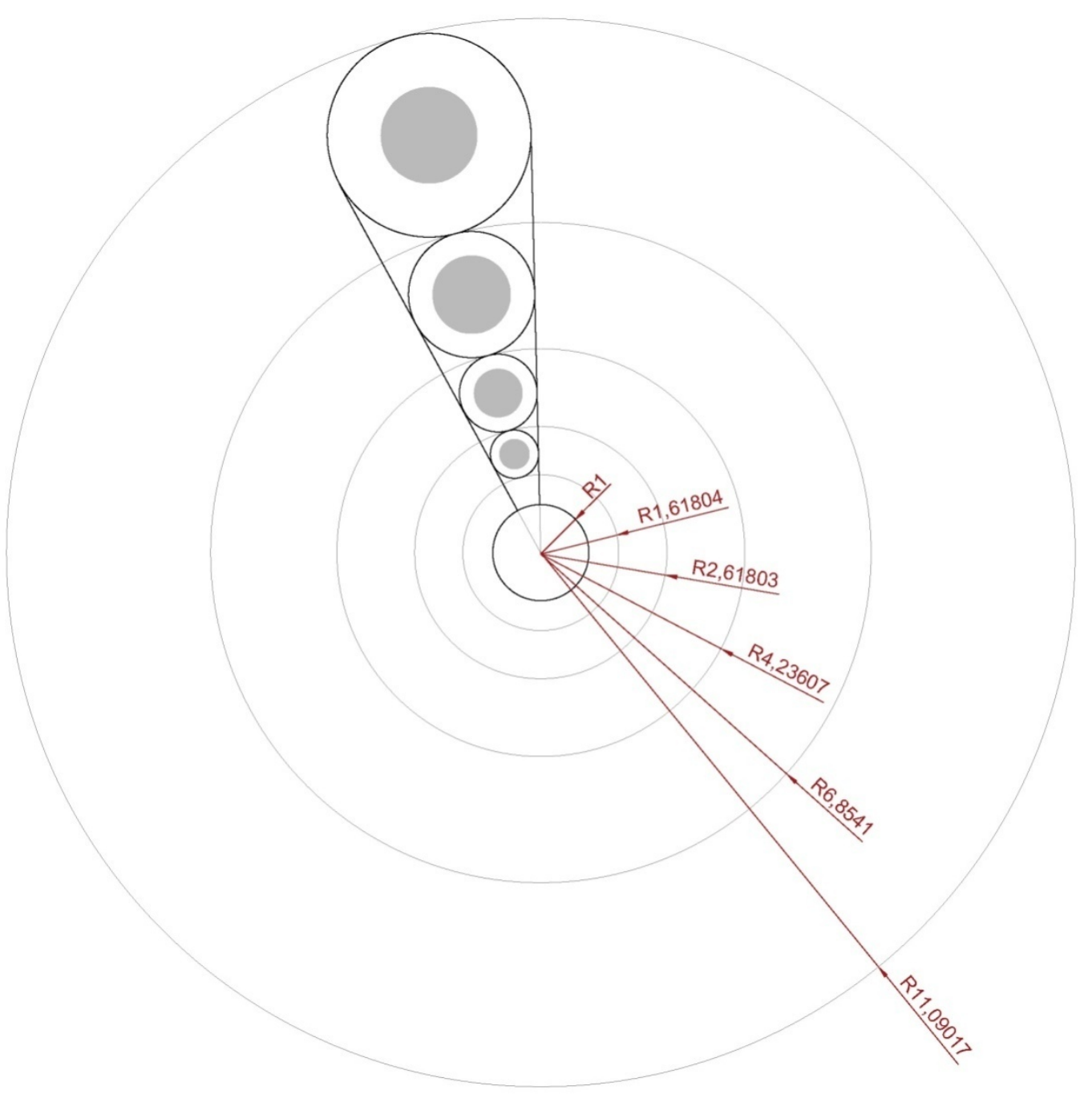

2. ${ }^{300}$ Se dibujan una serie de círculos tangentes a los concéntricos en la corona. Los círculos interiores son meramente decorativos y tienen el mismo radio que el tangente de la corona anterior.

${ }^{300}$ Figura realización propia en colaboración con los arquitectos Pablo Andrés y Marina Andrés. No publicada. Realizada en Salamanca. Enero ,2015. 


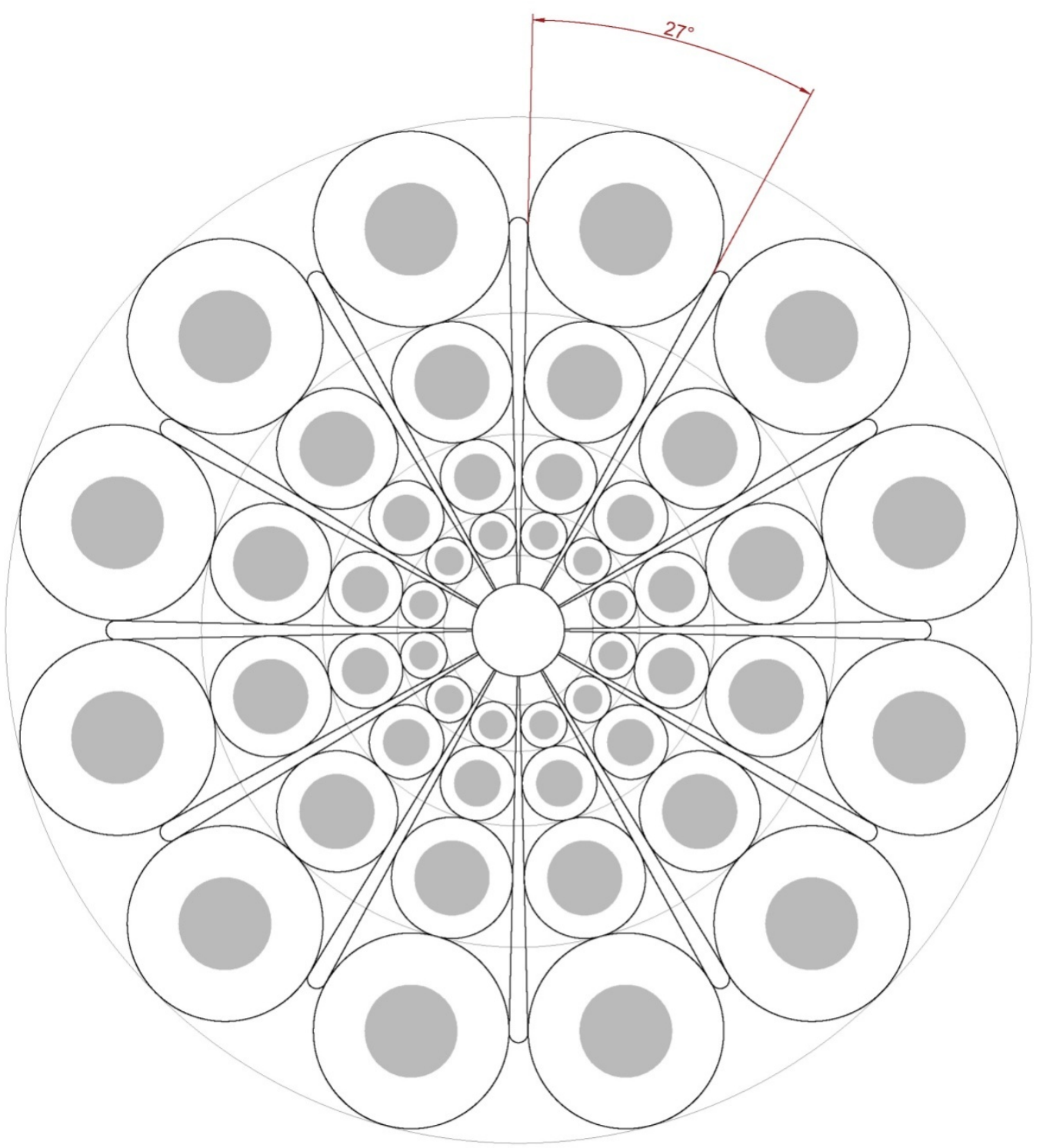

$3{ }^{301}$ Se realiza una matriz polar compuesta por 12 elementos, quedando entre los componentes de cada grupo un ángulo algo menor de $3^{\circ}$.

\footnotetext{
${ }^{301}$ Figura realización propia en colaboración con los arquitectos Pablo Andrés y Marina Andrés. No publicada. Realizada en Salamanca. Enero ,2015.
} 


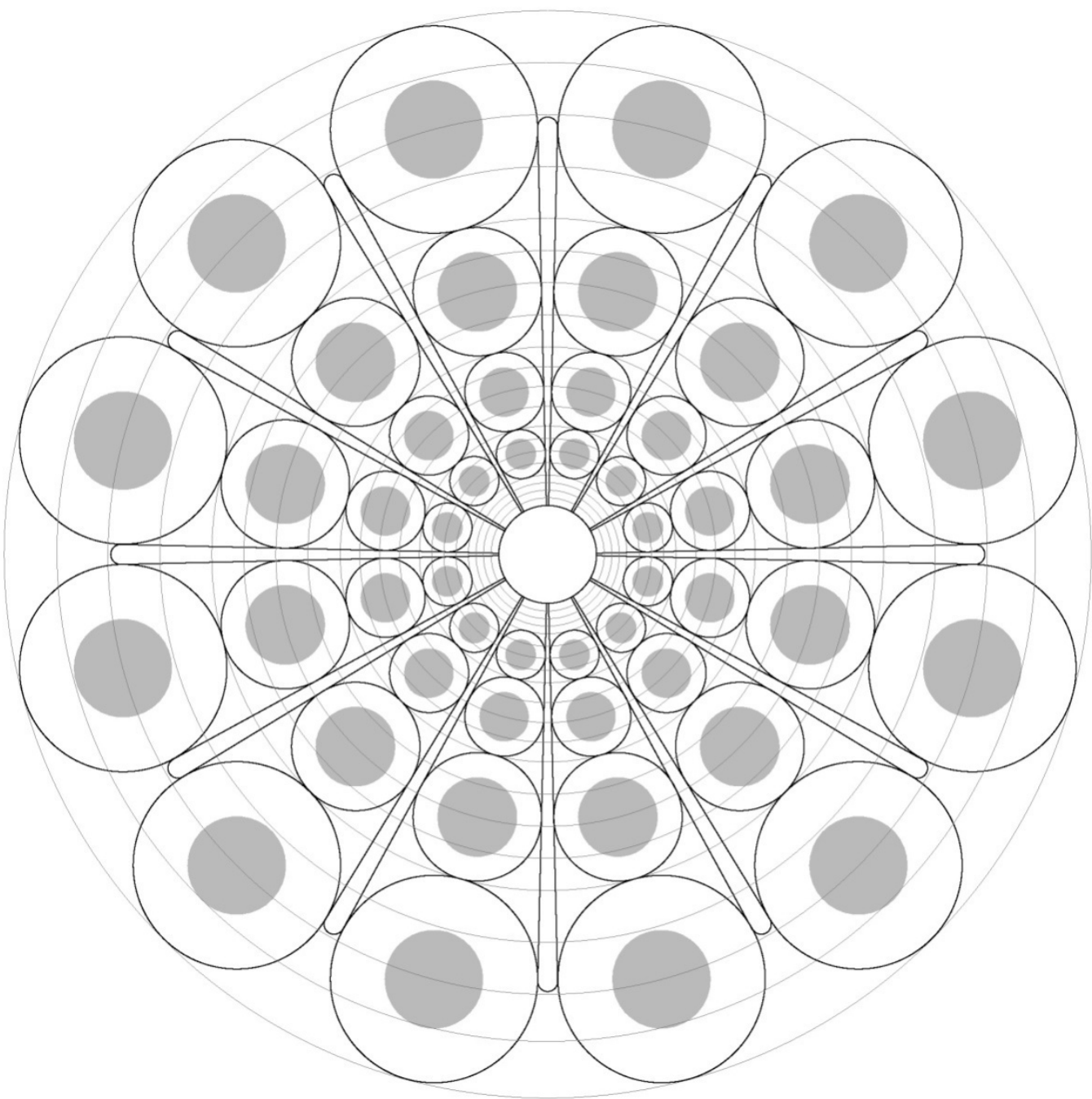

4. ${ }^{302}$ Cada corona resultante se divide en 4 nuevos círculos concéntricos.

\footnotetext{
${ }^{302}$ Figura realización propia en colaboración con los arquitectos Pablo Andrés y Marina Andrés. No
} publicada. Realizada en Salamanca. Enero ,2015. 


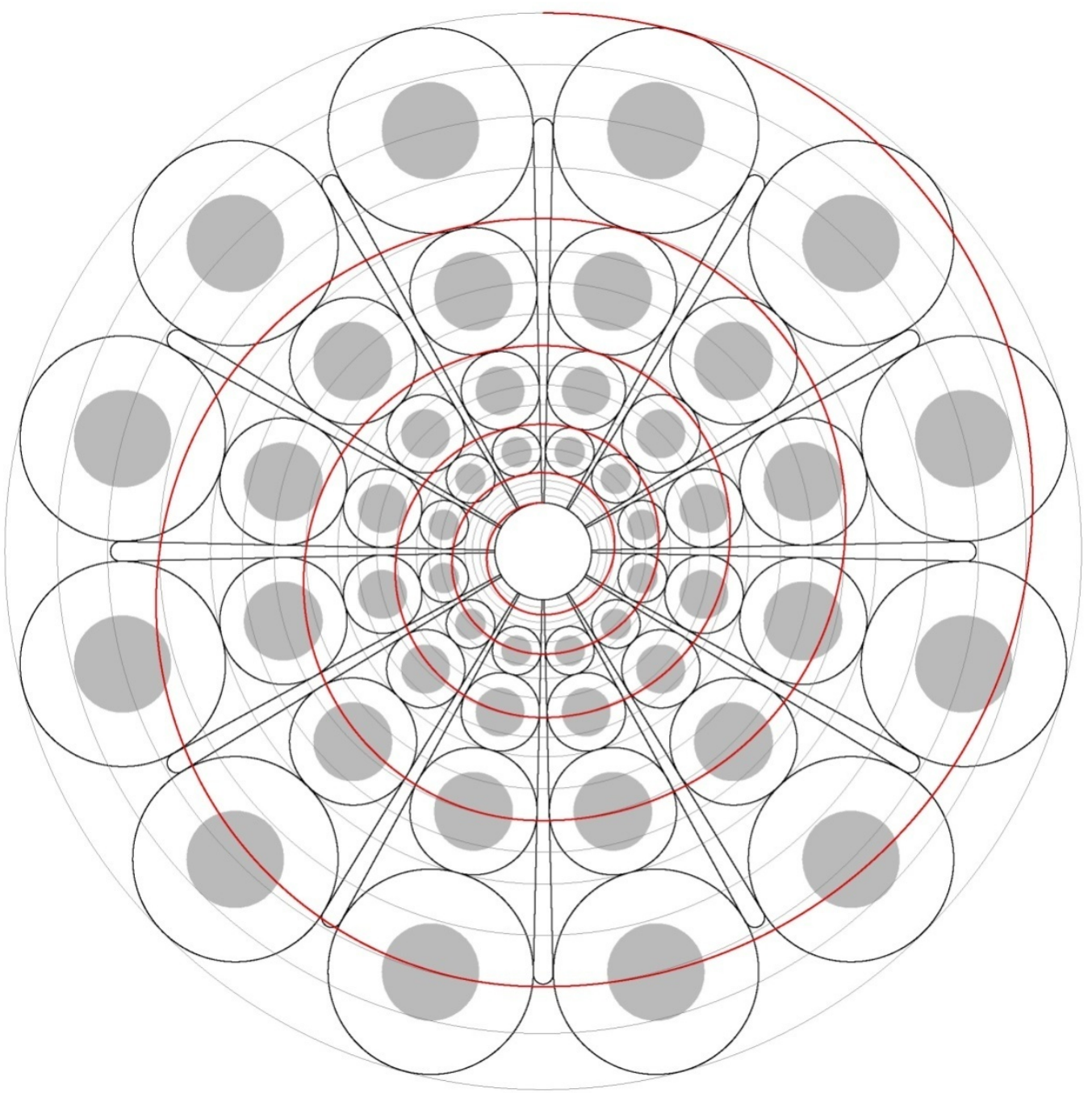

$5 .{ }^{303}$ Se dibuja una espiral logarítmica, siendo esta una curva que se inicia en un punto y se va alejando progresivamente del centro al mismo tiempo que gira alrededor de él, siendo su razón de crecimiento el número áureo , es decir la razón dorada.

\footnotetext{
${ }^{303}$ Figura realización propia en colaboración con los arquitectos Pablo Andrés y Marina Andrés. No publicada. Realizada en Salamanca. Enero ,2015.
} 


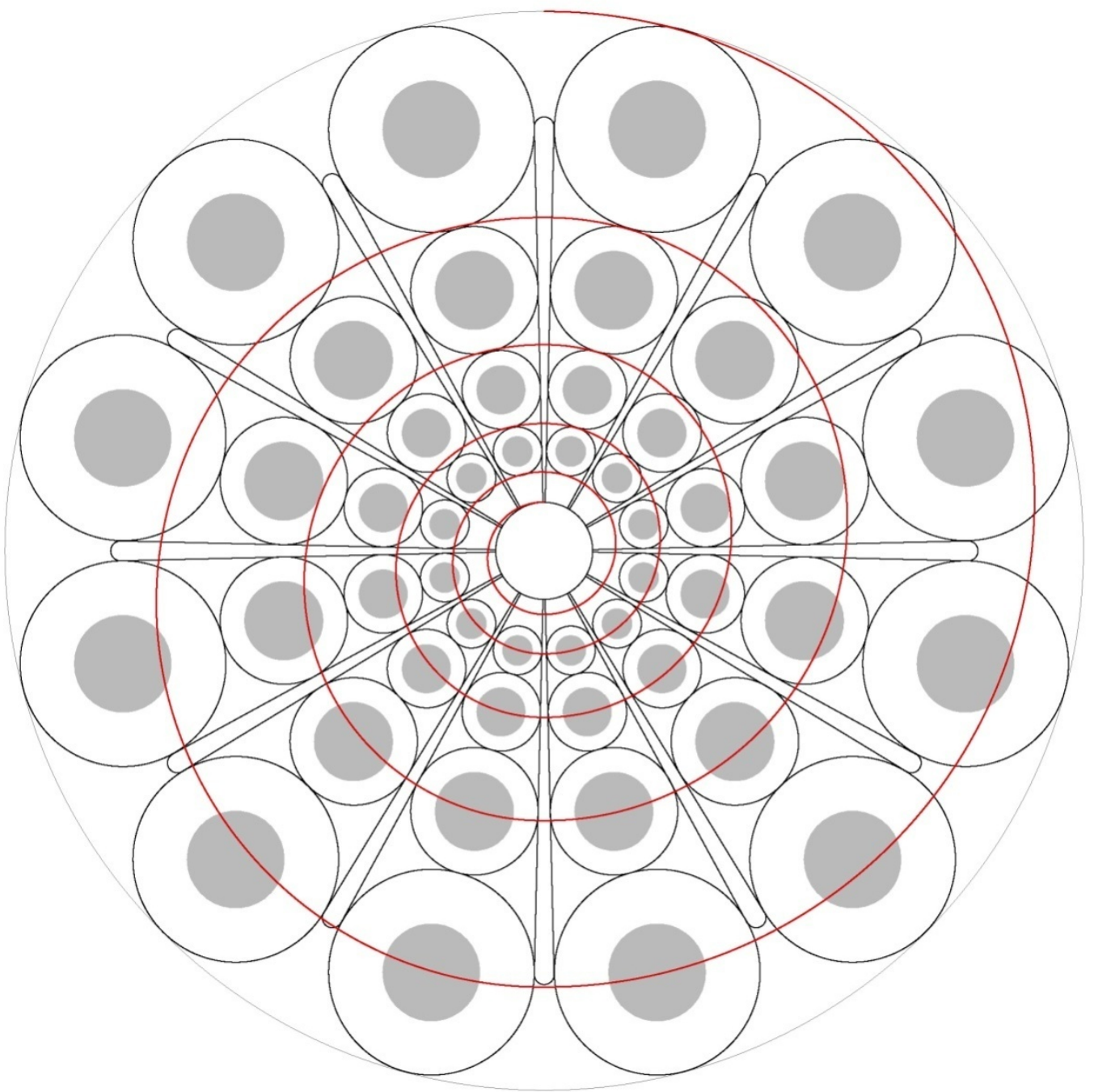

Es decir, en el botón charro ${ }^{304}$ de 12 sectores de círculo se inscribe perfectamente la espiral logarítmica que va creciendo en progresión geométrica obteniendo una secuencia en la que el elemento se obtiene multiplicando el elemento anterior por una constante denominada razón o factor de la progresión, que en este caso es el número áureo =1,61803399.

\footnotetext{
${ }^{304}$ Todas las figuras que hemos aportado en este apartado son de realización propia en colaboración con los dos arquitectos anteriormente mencionados. Nunca se han expuesto y nunca se han publicado. Salamanca. Enero 2015.
} 
A continuación aportamos algunos dibujos iniciales del proceso a mano alzada.

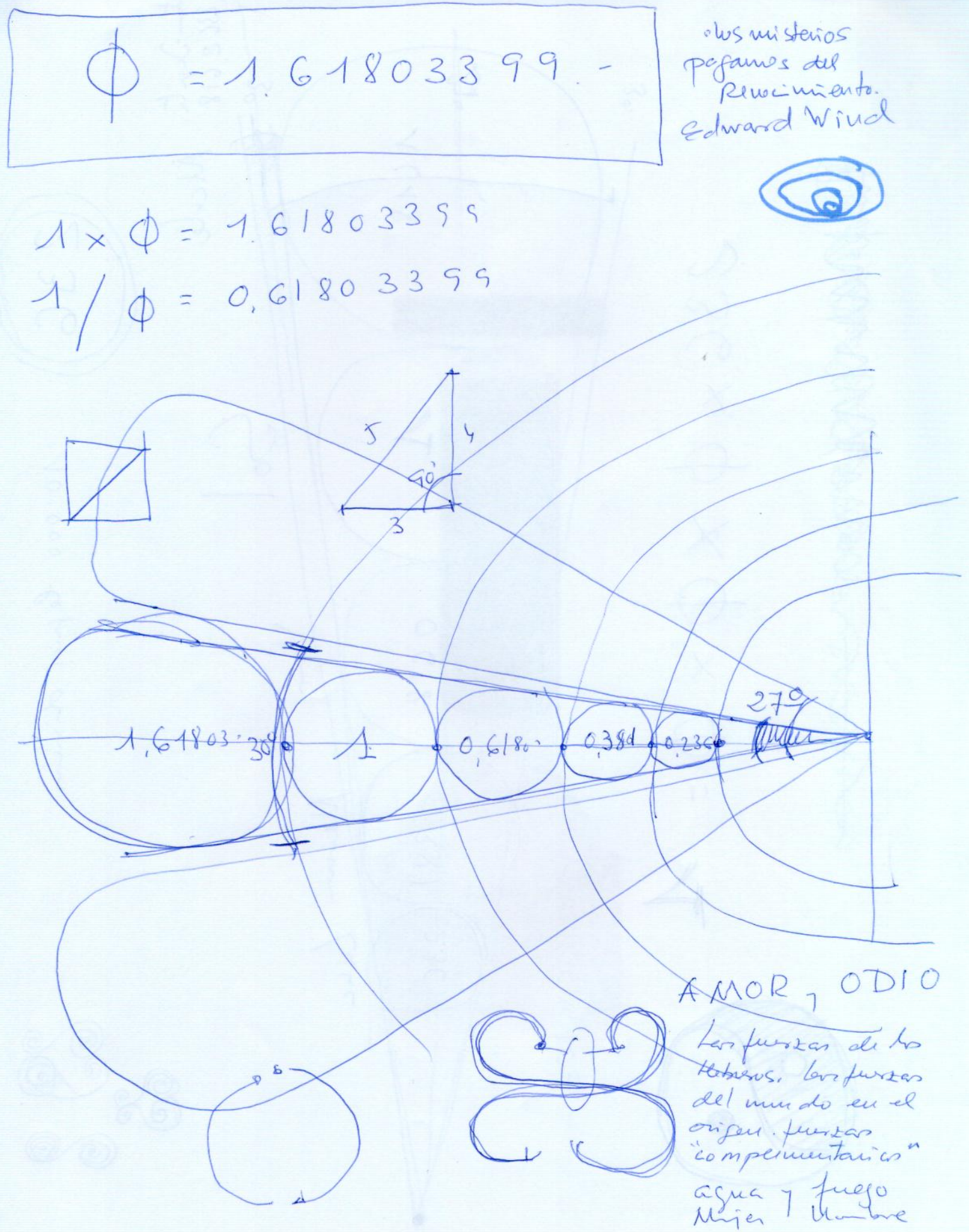




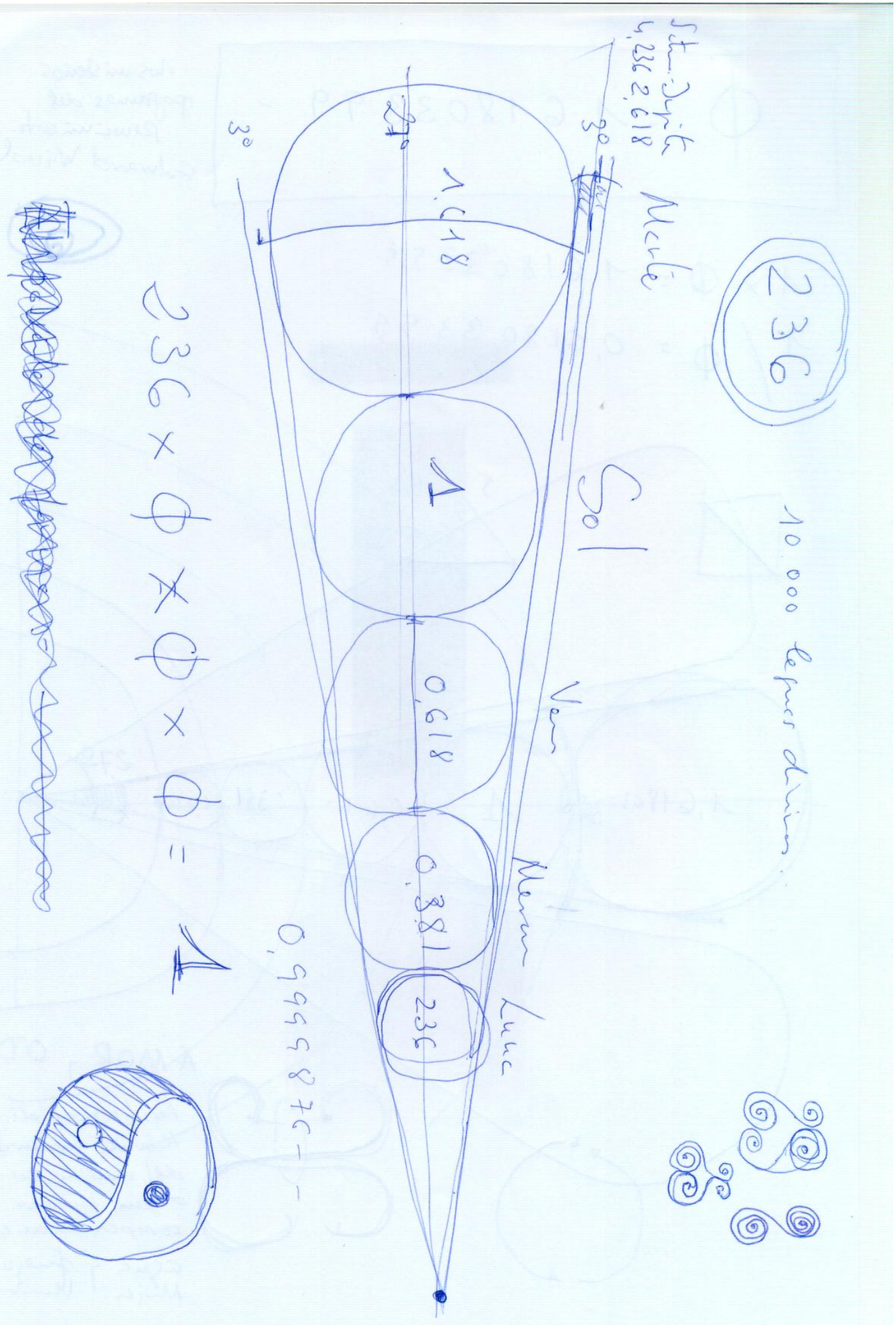


Una vez que ha quedado demostrada la proporción áurea del botón charro hemos llegado a la convicción de que evidentemente detrás de la forma podría encontrarse algún significado más.

Como venimos indicando a lo largo de nuestro estudio, en este capítulo, la observación es la base sobre la que se asienta el trabajo del conocimiento. Observamos como la figura, no sólo incluía la espiral áurea, sino que además conformaba un universo inmerso donde cabían el sol, la luna, los planetas, teniendo como centro la tierra. Cuál fue nuestra sorpresa cuando comprobamos que también incluía todos los signos del zodiaco. ${ }^{305}$

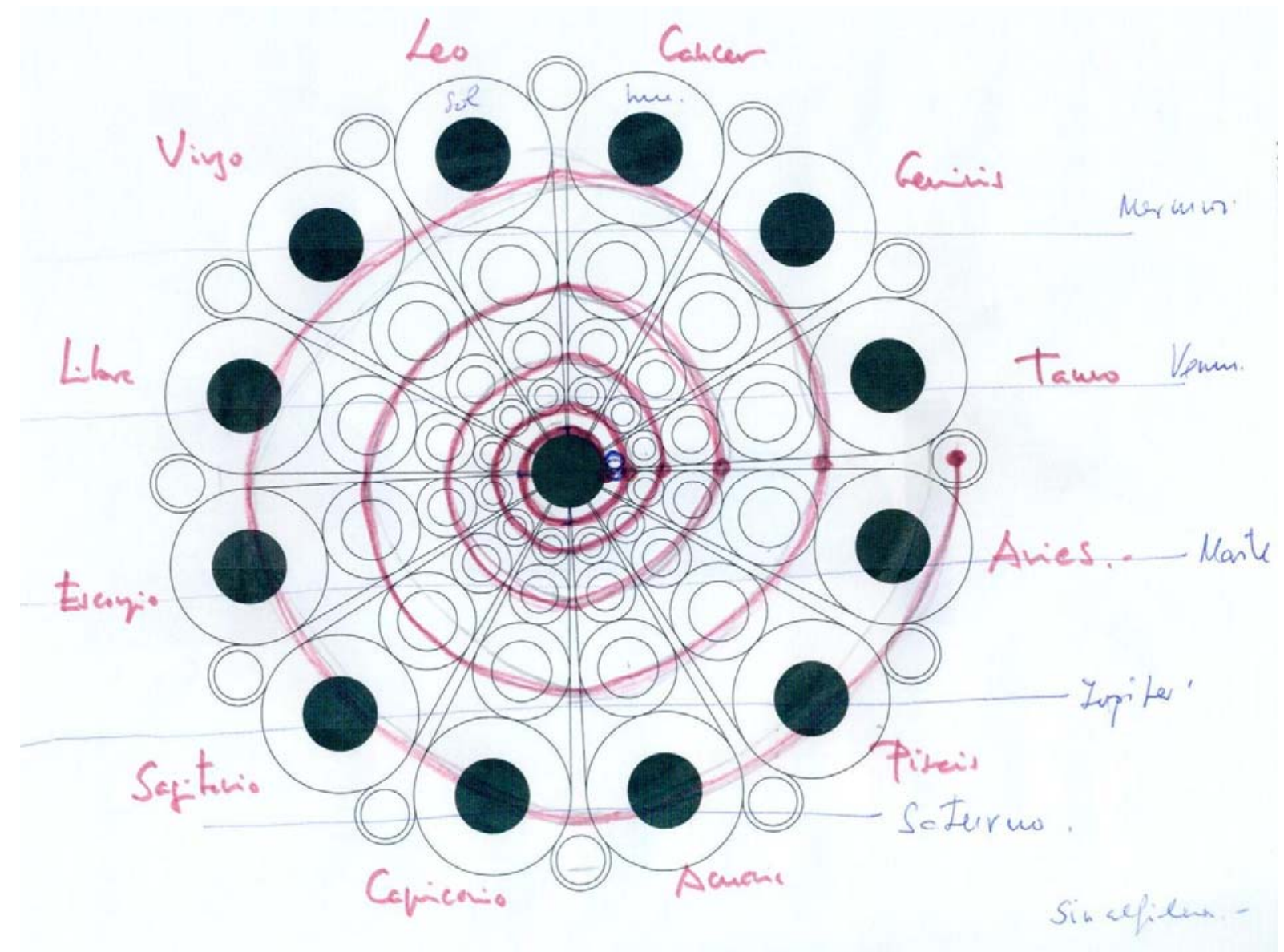

${ }^{305}$ Dibujo procedente de nuestro cuaderno de notas, realizado a mano alzada. Realización propia. Salamanca. Noviembre. 2014. 


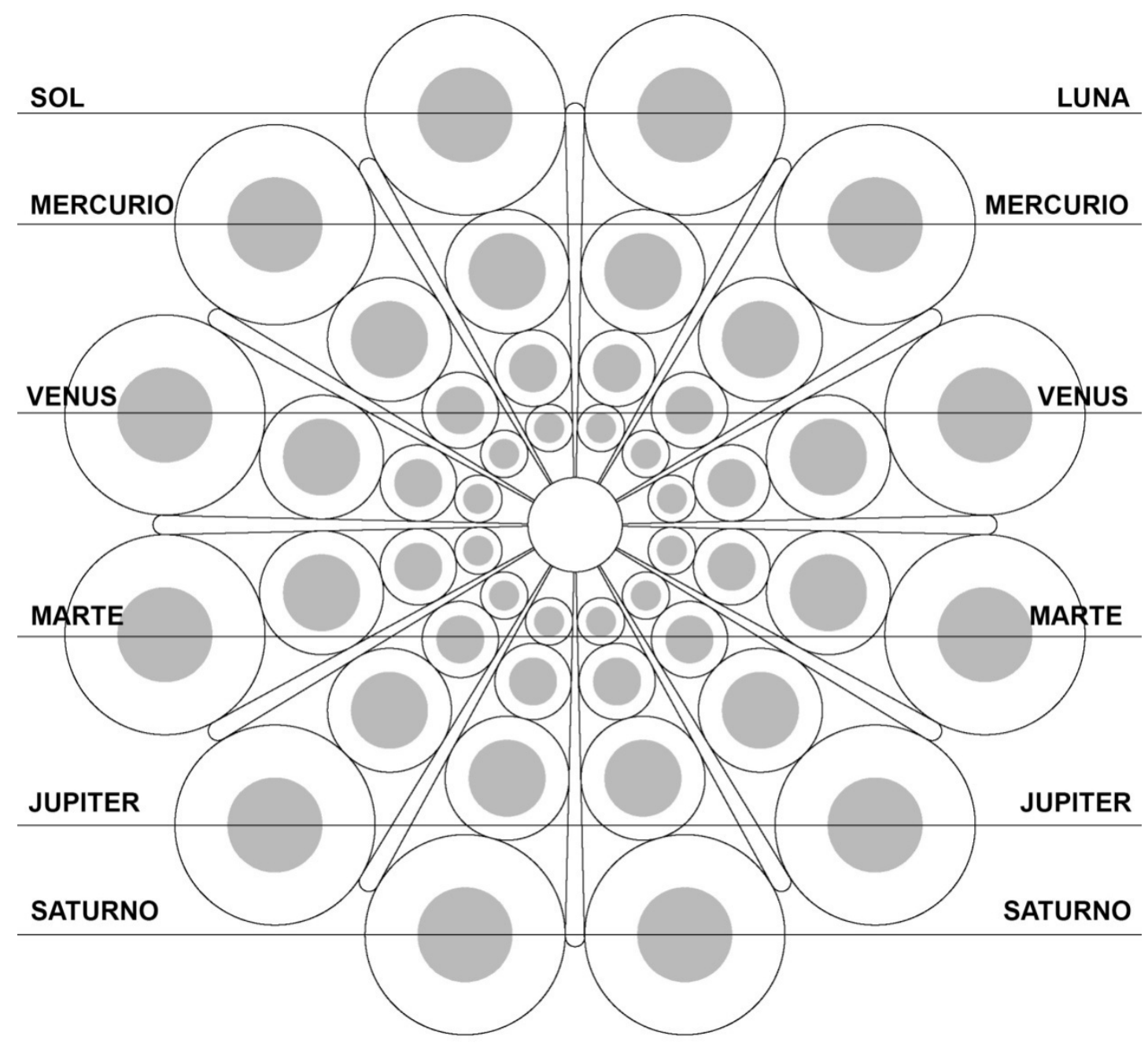

Como podemos apreciar en este dibujo ${ }^{306}$ realizado con precisión, aparecen todos los planetas de los que se tenía conocimiento exacto en la antigüedad.

Sorprende que esta forma que hemos heredado, sea sencillamente algo casual, más bien diríamos que es algo causal. Es una representación cosmogónica entroncada con la Astronomía como Ciencia que trata de cuanto se refiere a los astros, y principalmente a las leyes de sus movimientos.

\footnotetext{
${ }^{306}$ Dibujo realizado en colaboración de los arquitectos anteriormente mencionados. Inédito y no publicado. Salamanca. Enero. 2015.
} 
Pero más aún supuso de sorpresa el que contuviera los signos del zodiaco, como pasamos a exponer.

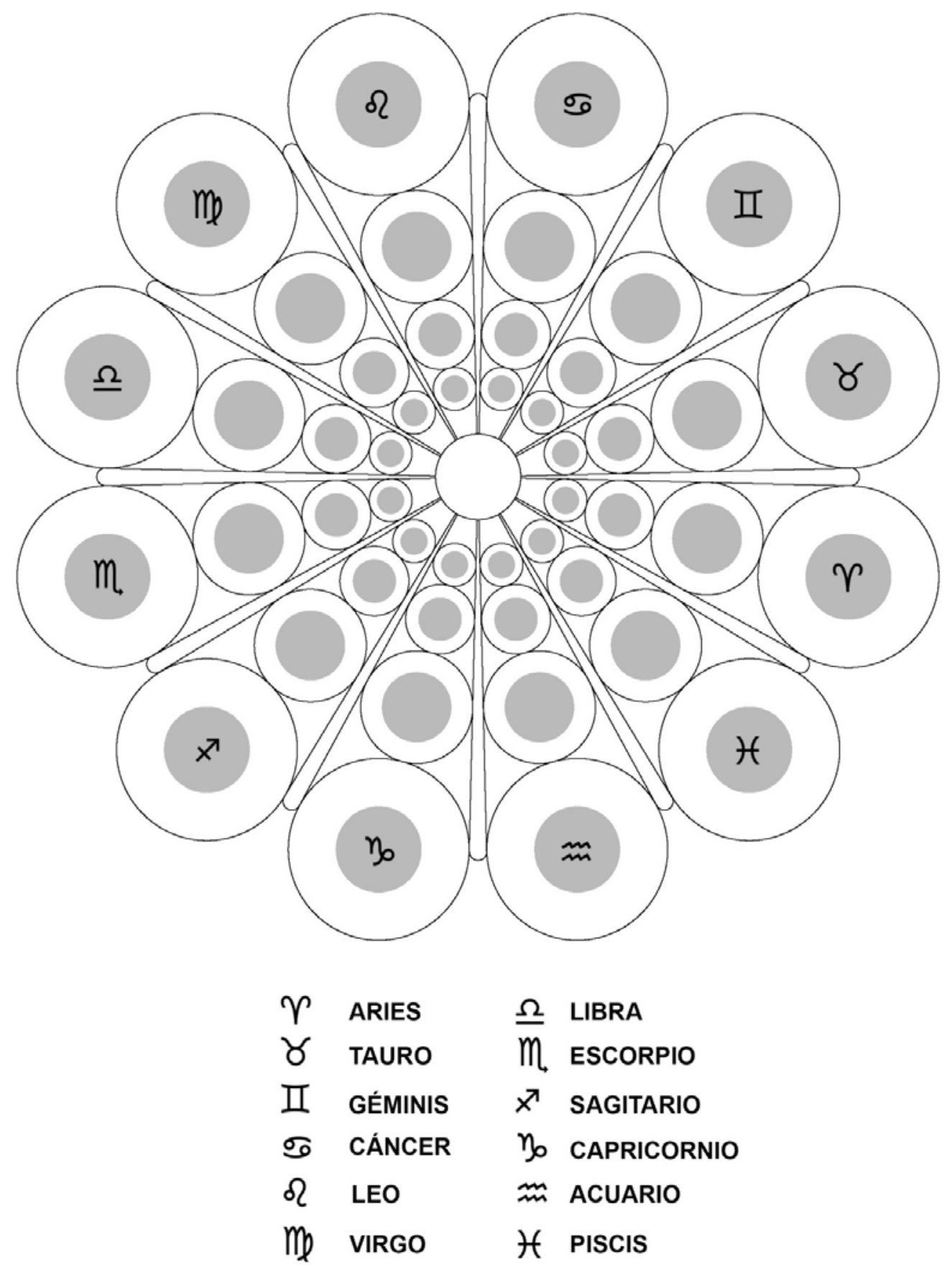

Como podemos apreciar en el dibujo ${ }^{307}$ hecho con precisión, aparecen contenidos en el botón todos los signos del zodiaco. Es la concepción

307 Dibujo realizado en colaboración de los arquitectos anteriormente mencionados. Inédito y no publicado. Salamanca. Enero. 2015. 
astrológica del cosmos. La incorporación de la Astrología, como ciencia de la antigüedad, implícita también en este objeto llamado botón charro, nos ha llevado a una valoración de este objeto totalmente diferente a la de nuestro punto de origen en el estudio.

Un objeto que tiene: Medidas Áureas, incluye Astronomía y Astrología, posee todos los elementos de los símbolos, su forma está incluida en la naturaleza, comporta los atributos de un mandala, su forma circular comporta desde la antigüedad una identidad con la unidad y el todo, que su forma semiesférica se identifica con la identidad de la fertilidad y la mujer desde los tiempos pretéritos, que está realizado con una técnica milenaria y que podemos considerarlo un fractal, nunca puede ser casual.

Hemos de hacer una observación muy importante para que nadie se lleve a situaciones de equivoco o controversia. Si partimos de la base

A partir de este momento convenimos en que estamos ante un objeto de dimensión superior a lo meramente estético. Que, independientemente de que lo podamos encontrar con otro número de elementos, nunca perderá ni sus proporciones ni su contenido, pues en vez de ser explicito como lo que hemos visto, lo llevará implícito. A veces los tamaños pueden variar en función de interpretaciones subjetivas del platero 0 de las propias necesidades de los usuarios. Pero su filosofía, a partir de ahora nunca más variará.

De ahora en adelante siempre utilizaremos la mayúscula para referirnos a él.

\section{Realidad o mito: hipótesis de globalización.}

Tal y como venimos estudiando la forma nos ha llevado a territorios de investigación hasta ahora impensables en esta materia. 
Hemos hablado de signos, de símbolos, de medidas áureas, del número de oro, de proporciones...también hemos visto la técnica de la joya “ la filigrana" como algo ancestral y referido a nuestro territorio desde tiempos muy antiguos y algo coetáneo y existente en muy diferentes partes del mundo.

Antes de continuar veamos dónde tiene sus raíces ${ }^{308}$ el Botón Charro que es una joya perteneciente al folclore tradicional y popular de la provincia de Salamanca en España. El botón charro tiene materiales metálicos, llegando a ser en su formato de más valor en oro, aunque lo más común es la plata. Tiene forma redonda aplanada siempre con el mismo grabado en la parte frontal. Es una de las principales piezas de lo conocido como "Filigrana Charra". Dicha frase va destinada a todo tipo de trabajo en plata, como son: cucharillas, alfiles de corbata, gemelos, broches, pendientes, llaveros etc.

Los orígenes del botón charro son extremadamente oscuros y de muy difícil explicación, existiendo varias teorías al respecto. Por su forma tradicional, hay quienes sostienen que es una deformación de un disco solar de carácter céltico o celtíbero ${ }^{309}$ y que pudo ser utilizado como ornamento o signo distintivo desde época del Alto Imperio, allá por los siglos II y I a.c.

Se sabe que determinados cargos romanos utilizaban pequeños ornamentos para unir piezas de vestir, como la toga y que se utilizaron por asimilación entre los visigodos, de modo que el aspecto de este botón podría ser una deformación de aquéllos ${ }^{310}$. Sin embargo, el hecho de que su ámbito espacial quede reducido a parte de la actual Provincia de Salamanca y sur de Zamora hace pensar en el botón como algún elemento propio que subsistió a la dominación musulmana. Desde el siglo XVII se usa

\footnotetext{
${ }^{308}$ www.wikipedia.org.charro.Enero,2015.

${ }^{309}$ Nosotros planteamos, apoyándonos en las similitudes de la forma, la semejanza existente entre la forma del aderezo y disposición del mismo en la escultura de la Dama de Elche y la disposición de la espetera rica de la Charra Central, en la que coinciden incluso la disposición de los rodetes que tapan o complementan la oreja. En este sentido también tendrían muchas similitudes con el aderezo y disposición del mismo en el traje valenciano o de fallera.

310 Incluso en la actualidad el botón charro sigue teniendo esa misma función de sujetar la ropa como lo hace en la capa charra.
} 
frecuentemente en los trajes charros como pieza de plata. Su relación con algunas formas de damasquinado hace pensar a otros en posibles derivaciones mudéjares, hecho que se sostiene por el carácter concéntrico de las bolitas que lo forman y la ausencia de espacios vacíos. Como pieza de orfebrería sobreviviría a la Reconquista, aunque reducido a ámbitos estrictamente rurales (no hay representaciones plásticas del mismo hasta el siglo XVII). De cualquier modo, cobró mucha relevancia a partir de esa fecha como elemento distintivo del ser y del sentir salmantino.

Pero tal vez en este momento la cuestión ha de pasar a la Hermenéutica como interpretación de todo cuanto hemos contemplado. Interpretar siempre desde lo subjetivo, porque ha sido lo subjetivo lo que nos ha llevado hasta el punto en el que nos encontramos.

Definición general de hermenéutica ${ }^{311}$ :

Lo primero que hay que hacer antes de analizar en profundidad el significado del concepto hermenéutica es determinar su origen etimológico pues de esta manera entenderemos el porqué de dicha acepción. En este sentido, podemos decir que aquel procede del griego hermeneutikos, que a su vez se conforma por la unión de tres "partículas". Así, es fruto de la suma de la palabra hermeneuo que puede traducirse como "yo descifro", la palabra tekhné que significa "arte", y el sufijo -tikos que es sinónimo de "relacionado a". De ahí que literalmente se puede exponer que este término que nos ocupa es el arte de explicar textos o escritos y obras artísticas.

De la misma forma, tampoco podemos pasar por alto que la hermenéutica está en relación con el dios griego Hermes que era el encargado en el Olimpo de llevar los mensajes secretos a sus destinatarios y una vez con ellos era el que debía descifrarlos.

Se define como hermenéutica al arte basado en la interpretación de textos, en especial, de aquellas obras que se consideran como sagradas. Desde la perspectiva de la filosofía defendida por Hans-Georg Gadamer,

${ }^{311}$ www.wordreference.com/definicion/hermenéutico 
este concepto describe a la denominada teoría de la verdad y constituye el procedimiento que permite expresar la universalización de la capacidad interpretativa desde la personal y específica historicidad.

De esta manera, es posible clasificar a la hermenéutica de diversas formas. Existe, por ejemplo, la de tipo filológico (variante que se originó en Alejandría a fin de determinar el carácter auténtico de los escritos antiguos); la hermenéutica bíblica (la cual surgió hacia los siglos XVII y XVIII con el propósito de lograr una adecuada, objetiva y entendible interpretación de la Biblia) y la hermenéutica de perfil filosófico (una modalidad que no depende de la lingüística y busca fijar las condiciones relevantes de toda interpretación).

En el caso concreto de la rama de la hermenéutica encargada de llevar a cabo la interpretación de textos sagrados que pertenezcan bien a la Biblia o bien a otras obras de carácter religioso que pertenezcan a diversas culturas es necesario subrayar que también se conoce con el nombre de exegética.

El origen de los estudios de carácter hermenéutico se halla en la teología cristiana, marco en el cual se distinguen dos interpretaciones diferentes de la Biblia: uno literal y otro de tinte espiritual, que a su vez se divide en análisis anagógicos, alegóricos y morales.

El mensaje literal de las Sagradas Escrituras es aquel que se desprende de la propia redacción y es captado por la exégesis filológica, que se desarrolla de acuerdo a las normativas de la correcta interpretación.

El valor espiritual, en cambio, es el generado por Dios en el ser humano, al proponer un contenido religioso que permite complementar a los signos. En este marco es posible distinguir entre el sentido alegórico (a fin de que las personas de fe logren profundidad interpretativa al leer los sucesos. Por citar un ejemplo concreto: el cruce del mar Rojo es un símbolo de la victoria de Cristo y el bautismo), el sentido moral (los episodios mencionados en la Biblia pueden servir como modelo e impulso para un 
accionar justo) y el sentido anagógico o místico (aquel que apunta a demostrar que los santos tienen la capacidad de observar realidades y hechos perdurables hasta la eternidad).

Entre los autores más importantes dentro del campo de la hermenéutica que han apostado por la misma y que la han desarrollado en sus distintas facetas destacan figuras de la talla de Friedrich Schleiermacher, el estudioso alemán Wilhelm Dilthey, Martin Heidegger o Paul Ricoeur.

Teniendo en cuenta lo anteriormente expuesto y el concepto de símbolo al que nuestra investigación nos ha llevado, el Botón Charro en sí mismo ha tomado una dimensión hasta ahora impensable e improbable, pero como ha quedado demostrado nos encontramos ante un objeto mítico en su forma y que su explicación como símbolo le da una dimensión que es necesario preservarle, protegerle y evitar que desaparezca o cambie su papel en la base de una joyería antigua de la que apenas conocemos sus orígenes pero que sin lugar a dudas ha sido la heredad concreta de una mujer rural que se pierde en la noche de los tiempos.

Será labor de las Administraciones Públicas velar por que éste patrimonio ocupe su lugar de privilegio en la nueva sociedad del XXI en la que la mujer que ha heredado esta fortuna cultural, no lo olvide o simplemente ignore parte importante de su legado femenino ancestral.

El que la base constructiva de las piezas joyeras de la zona de Salamanca, posea una técnica y una forma que proceden de miles de años atrás, nos coloca en una posición privilegiada que no debemos perder ni olvidar.

Pasar del mito a la realidad convierte a estos objetos en símbolos de nuestra identidad femenina por encima de su valor económico. Fue la mujer del pueblo, en su sensibilidad "acultural", la que se hizo portadora y guardiana de una identidad que ni ella misma intuyó. 
Tener la certeza de que el valor de nuestro Botón Charro nos iguala en proporciones áureas a edificios, pinturas, esculturas, composiciones musicales únicas en el mundo ( el Partenón, La Gioconda, La Venus de Milo, La Séptima sinfonía de Bettoven...) debe considerarse un acicate para que las AAPP tomen cartas en el asunto y protejan este patrimonio en vías de extinción.

Somos conscientes que habrá voces que estén en desacuerdo con nuestros planteamientos, pero no dejamos de pensar que cambiar una dinámica arrastrada desde el desconocimiento es muy difícil de variar. Proponemos que nuestras teorías se interpreten y se contemplen con una mente abierta a nuevas propuestas, que se haga un intento de comprensión en términos globales de conocimiento, donde la confluencia de muchas ramas del intelecto facilitan una interpretación multidisciplinar hasta ahora no contemplada.

De lo que no cabe duda es de que estos objetos que estudiamos y en concreto el Botón Charro (todos ellos creados en una técnica milenaria), han llegado hasta nosotros a pesar de nosotros y eso nunca es casual. 
CAPITULO IV.

\section{LA NECESARIA IMPLICACIÓN DE LAS ADMINISTRACIONES PÚBLICAS Y LA EMPRESA PRIVADA.}




\section{La necesaria implicación y tutela de las Administraciones Públicas}

La joyería tradicional con su divisa emblemática el "Botón Charro", en cuanto objeto artístico merecedor de protección, como bien queda demostrado en nuestro estudio a través de los capítulos precedentes, goza de un valor histórico y patrimonial inequívoco, constituyendo parte esencial de una sociedad consecuente y responsable, de un símbolo etnográfico, de un bien material e inmaterial, indivisiblemente vinculado con la cultura popular salmantina.

El diccionario de la Real Academia de la Lengua española ${ }^{312}$, conceptúa como cultura popular al "conjunto de las manifestaciones en las que se expresa la vida tradicional de un pueblo", como patrimonio la "Hacienda que alguien ha heredado de un pueblo" o cuando a la palabra patrimonio le añadimos la acepción "nacional", resulta la "suma de valores asignados, para un momento de tiempo, a los recursos disponibles de un país, que se utilizan para la vida económica". Dejando conceptualmente bien claro lo que debemos entender y esperar por cultura popular, como patrimonio artístico personal y nacional.

Conceptualmente entendemos también como Patrimonio artístico, la parte del patrimonio cultural y del patrimonio histórico que se manifiesta en las obras de arte, como bien puede ser considerado la joya salmantina charra constituyéndose como imagen de una zona geográfica específica de España.

La Ley 16/85, de 25 de junio, del Patrimonio Histórico Español, que regula esta materia, a pesar que no conceptúa lo que por patrimonio deberá

${ }^{312}$ www.rea.es, a la voz "cultura", "patrimonio" (13/12/2014) 
entenderse, si establece los elementos integrantes a través de su art.1.2 "Integran el Patrimonio Histórico Español los inmuebles y objetos muebles de interés artístico, histórico, paleontológico, arqueológico, etnográfico, científico o técnico. También forman parte del mismo el patrimonio documental y bibliográfico, los yacimientos y zonas arqueológicas, así como los sitios naturales, jardines y parques, que tengan valor artístico, histórico y antropológico."

Sin embargo, como afirma ABAD LICERAS ${ }^{313}$ de la combinación de los distintos factores presentes en el Preámbulo de la norma estatal es posible concebir esta institución jurídica como: Una riqueza colectiva, constituida por todos aquellos bienes de valor histórico, artístico, científico, paleontológico, arqueológico, etnográfico o técnico, que sin limitaciones derivadas de su propiedad, uso, antigüedad o valor económico, contienen las expresiones más dignas de aprecio en la aportación histórica de los españoles a la cultura y civilización universal, y a su capacidad creativa contemporánea.

A través de este epígrafe, estudiaremos la necesaria implicación y tutela de las Administraciones Públicas a través de su estudio normativo y documental más relevante, sin pretender por ello hacer cuerpo doctrinal alguno, sino una toma de conciencia de la relevancia del tema en estudio a través del ordenamiento jurídico, de las Instituciones del ámbito afectado, de la Jurisprudencia más notoria como "fuente de hecho" y siempre guiadas de la mano inestimable de la doctrina ${ }^{314}$ habida del tema.

313 ABAD LICERAS, J.M. EN EL DÉCIMO ANIVERSARIO DE LA LEY 16/1985 DEL PATRIMONIO HISTÓRICO ESPAÑOL(I) http://www.iaph.es/revistaph/index.php/revistaph/article/viewFile/209/209 314 Por todos, BARRERO RODRIGUEZ, I," La Ordenación Jurídico del Patrimonio Histórico. Civitas. 1990. ISBN 84-7398-745-4 


\subsection{Administración Pública Europea}

España como miembro de pleno derecho de la Unión europea desde la firma del Tratado de Maastrick, debe tenerse en cuenta lo establecido en el derecho comunitario.

A este respecto deberemos citar como documento más representativo y novedoso, a nuestro juicio, la Comunicación de la Comisión al Parlamento Europeo, al Consejo, al Comité Económico y Social europeo y al Comité de las Regiones. Hacia un enfoque integrado del patrimonio cultural europeo de $2014^{315}$, donde se dispone que:

El patrimonio cultural europeo, tanto material como inmaterial, es nuestra riqueza común, la herencia que nos han dejado las anteriores generaciones de europeos y el legado que dejaremos a las generaciones futuras. Bagaje insustituible de conocimientos y recurso valioso para el crecimiento económico, el empleo y la cohesión social, enriquece la vida privada de cientos de millones de personas, es una fuente de inspiración para los artistas y pensadores y un motor de las industrias culturales y creativas.

Nuestro patrimonio cultural y nuestra manera de preservarlo y valorizarlo son factores determinantes del lugar que ocupa Europa en el mundo y de su atractivo como lugar para vivir y trabajar, o para visitar.

El patrimonio cultural es un recurso compartido y un bien común. Al igual que cualquier otro tipo de bienes de este tipo, puede ser vulnerable a la sobreexplotación y a la escasez de financiación, hasta llegar a caer en el abandono, el deterioro y, en algunos casos, el olvido.

Cuidar nuestro patrimonio es, por tanto, nuestra responsabilidad común. Si bien la protección del patrimonio es fundamentalmente una competencia de las autoridades nacionales, regionales y locales, la Unión

${ }^{315}$ Bruselas, 22.7.2014. $\operatorname{COM}(2014) 477$ final. 
Europea debe desempeñar el papel que le corresponde con arreglo a los Tratados de la UE y respetando el principio de subsidiariedad.

El preámbulo del Tratado de la Unión Europea establece que sus signatarios se inspiran «en la herencia cultural, religiosa y humanista de Europa». Su artículo 3, apartado 3, dispone que la Unión deberá «velar por la conservación y el desarrollo del patrimonio cultural». El artículo 167 del Tratado de Funcionamiento de la Unión Europea (TFUE) reza como sigue: «La Unión contribuirá al florecimiento de las culturas de los Estados miembros, dentro del respeto de su diversidad nacional y regional, poniendo de relieve al mismo tiempo el patrimonio cultural común». EI TFUE también reconoce la especificidad del patrimonio para preservar la diversidad cultural, así como la necesidad de garantizar su protección en el mercado único ${ }^{316}$.

Desde la adopción de la Agenda Europea para la Cultura ${ }^{317}$, en 2007 el patrimonio ha sido una prioridad en los planes de trabajo del Consejo en el ámbito de la cultura, y la cooperación a nivel europeo ha avanzado gracias al método abierto de coordinación. El interés político a nivel de la UE ha ido aumentando y las partes interesadas en el sector de la cultura y el patrimonio han subrayado recientemente en la Declaración sobre un nuevo relato para Europa ${ }^{318}$ : «Europa como cuerpo político debe reconocer el valor del patrimonio cultural. El patrimonio cultural revela lo que ha significado ser

\footnotetext{
316 El artículo 36 del TFUE contempla prohibiciones o restricciones a la importación, exportación o tránsito de mercancías para la protección del patrimonio artístico, histórico o arqueológico nacional. La Directiva 93/7/CEE, relativa a la restitución de bienes culturales que hayan salido de forma ilegal del territorio de un Estado miembro, fue adoptada en virtud del artículo 114 del TFUE, con el fin de obtener la restitución de los bienes culturales clasificados como patrimonio nacional en el sentido del artículo 36 del TFUE. Dicha Directiva ha sido refundida por la Directiva 2014/60/UE. El Reglamento (CE) no 116/2009 del Consejo, relativo a la exportación de bienes culturales, establece disposiciones para garantizar que las exportaciones de bienes culturales estén sujetas a controles uniformes en las fronteras exteriores de la Unión. De conformidad con el artículo 107, apartado 3, letra d), del TFUE, las

ayudas destinadas a promover la cultura y la conservación del patrimonio pueden considerarse compatibles con el mercado interior cuando no alteren las condiciones de los intercambios y de la competencia en la Unión en contra del interés común.

$317 \operatorname{COM}(2007) 242$ final y Resolución del Consejo de 16 de noviembre de 2007, relativa a una Agenda Europea para la Cultura.

${ }^{318}$ ec.europa.eu/debate-future-europe/new-narrative/pdf/declaration_es.pdf
} 
europeo a lo largo del tiempo. Es un poderoso instrumento que ofrece un sentimiento de pertenencia entre los ciudadanos europeos».

No existe ninguna contradicción entre las responsabilidades nacionales y la acción de la UE: el patrimonio es siempre a la vez local y europeo. Se ha forjado no solo en el tiempo, sino también a través de fronteras y comunidades. El patrimonio está formado por historias locales que juntas configuran la historia de Europa.(...)

Esta Comunicación establece a través de cifras la infravaloración que se tiene sobre el crecimiento y la cohesión social, así declara que: el patrimonio presenta múltiples dimensiones: cultural, física, digital, medioambiental, humana y social. Su valor, tanto intrínseco como económico, es una función de estas dimensiones diferentes y del flujo de servicios asociados. El interés por el valor económico del patrimonio es reciente $^{319}$, pero solo disponemos de estimaciones parciales de su importancia.

No se dispone de datos, principalmente para el conjunto de la UE, pero algunos estudios sectoriales y por países indican que el sector del patrimonio aporta una contribución significativa a la economía.

El patrimonio tiene efectos indirectos en los demás sectores económicos. Por ejemplo, se calcula que el turismo contribuye con 415000 millones de euros al PIB de la UE, mientras que 3,4 millones de empresas turísticas generan 15,2 millones de empleos, muchos de ellos relacionados, directa o indirectamente, al patrimonio. El $27 \%$ de los viajeros de la UE declara que el patrimonio cultural es un factor clave a la hora de elegir un destino de viaje.

En 2013, el $52 \%$ de los ciudadanos de la UE visitó al menos un monumento o sitio histórico y el $37 \%$ un museo o galería de arte en sus respectivos países, mientras que el 19 \% visitó un monumento o sitio

\footnotetext{
${ }^{319}$ www.eenc.info/news/the-social-and-economic-value-of-cultural-heritage-literature-review
} 
histórico en otro país de la UE. El patrimonio puede, por tanto, ayudar a las ciudades y regiones a distinguirse y a atraer talento y turismo.

La tecnología añade valor económico al sector del patrimonio; el material cultural digitalizado puede utilizarse para mejorar la experiencia de los visitantes, desarrollar contenidos pedagógicos, documentales, aplicaciones turísticas y juegos.

El patrimonio dispone de una enorme capacidad para fomentar la cohesión y la integración sociales, a partir de la regeneración de zonas desfavorecidas, la creación de empleo local y la promoción del entendimiento mutuo y de un sentimiento de comunidad. El sector ofrece importantes oportunidades de formación y voluntariado a los jóvenes y las personas de edad avanzada, y favorece el diálogo intercultural e intergeneracional.

Sin embargo, para comprender mejor el papel real y potencial del patrimonio en la elaboración de las políticas, es importante mejorar la producción de datos sistemáticos sobre sus repercusiones económicas y sociales.

La UE apuesta fuertemente por el proyecto «El patrimonio cultural es importante para Europa: hacia un indicador europeo del patrimonio cultural», financiado por el Programa de Cultura de la UE y puesto en marcha en 2013, contribuyendo a abordar esta cuestión. Su objetivo es recopilar y analizar los datos y estudios existentes en el conjunto de la UE en relación con el impacto del patrimonio cultural en la sociedad y la economía. Se espera disponer de los resultados a mediados de 2015. Por lo que respecta a los datos relativos a la cultura en general, EUROSTAT ha empezado a elaborar un conjunto de estadísticas europeas periódicas, cuyos resultados también estarán disponibles en 2015.

Igualmente se aborda el patrimonio como fuente de innovación social servicio de un crecimiento inteligente sostenible e inclusivo, planteándose los siguientes retos, destacando entre otros: 
- La afluencia masiva de turistas tiene ventajas, pero también inconvenientes: un aumento de los ingresos a la par que presiones medioambientales y físicas.

- La digitalización y la accesibilidad en línea del material cultural modifican los modelos tradicionales, transforman las cadenas de valor y exigen una manera nueva de enfocar nuestro patrimonio artístico y cultural.

- El sector del patrimonio también debe adaptar sus modelos empresariales y de gestión, y desarrollar nuevas competencias profesionales, colaborando con las autoridades nacionales, no a través de medidas puntuales o intervenciones aisladas, sino incorporando la valorización y conservación del patrimonio a planes de desarrollo más amplios a largo plazo.

- Debe estudiarse también la participación de las partes interesadas del sector privado a través de asociaciones público-privadas.

- Es evidente que muchas políticas públicas tienen un impacto en el patrimonio y que este, a su vez, tiene numerosas repercusiones en otros ámbitos políticos. Por lo tanto, es preciso adoptar un enfoque más integrado de la conservación, promoción y valorización del patrimonio con el fin de tener en cuenta su contribución a múltiples objetivos económicos y sociales, así como su impacto sobre otras políticas públicas.

- El sector del patrimonio ya se está reinventando para hacer frente a los nuevos desafíos, fuentes de ingresos. Las herramientas de aprendizaje electrónico facilitan un acceso más amplio a los contenidos culturales en los hogares, las escuelas y las universidades, y permiten a las personas generar, reutilizar y añadir valor a los contenidos, aumentando el valor de los fondos culturales.

- A medida que los sitios del patrimonio se convierten en espacios públicos que producen capital social y medioambiental, las ciudades y regiones en las que están situados pasan a ser motores de actividad económica, centros de conocimiento, polos creativos y culturales y 
lugares de interacción comunitaria y de integración social; en pocas palabras, generan innovación y contribuyen a un crecimiento inteligente, sostenible e inclusivo, en consonancia con los objetivos de la Estrategia Europa 2020.

- Los museos se orientan cada vez más hacia las comunidades, sus gentes y sus historias, y proponen, por ejemplo, relatos inspirados en el patrimonio que inscriben las historias personales de miembros de la comunidad

- Las ciudades y los pueblos históricos se enfrentan al difícil problema de preservar la identidad europea y lograr al mismo tiempo un crecimiento sostenible generador de empleo. Lugares donde una gestión innovadora orientada a la comunidad puede mejorar significativamente su potencial económico y social.

Por todo ello la UE se plantea dentro de un enfoque integrado tres objetivos:

- Promoción de la diversidad cultural y el diálogo intercultural - por su valor intrínseco y social, el patrimonio constituye un componente esencial.

- Promoción de la cultura como catalizadora de la creatividad - el patrimonio contribuye a este objetivo a través de su potencial económico, directo e indirecto, incluida la capacidad para apoyar a nuestras industrias culturales y creativas e inspirar a pensadores y creadores

- Promoción de la cultura como elemento vital de la dimensión internacional de la Unión - la experiencia europea en materia de patrimonio cultural goza de reconocimiento a nivel internacional.

Si bien la responsabilidad de las políticas de conservación, restauración, accesibilidad y explotación del patrimonio cultural es principalmente nacional o local, el patrimonio cultural se aborda directamente 
en varias políticas de la UE: cultura, medio ambiente, educación, investigación e innovación, política regional y cooperación aduanera.

Con objeto de apoyar la Agenda Europea para la Cultura se ha desarrollado una nueva generación de instrumentos de la UE, empezando por los programas Horizonte 2020 y Europa Creativa, que deben conocerse y movilizarse mejor. La UE apoya:

- el fomento de la modernización del sector del patrimonio, aumentando la sensibilización y atrayendo a públicos nuevos;

- aplicar un enfoque estratégico a la investigación y la innovación, el intercambio de conocimientos y la especialización inteligente;

- aprovechar las oportunidades que ofrece la digitalización; llegar a nuevos públicos y atraer, en particular, a los jóvenes;

- identificar las necesidades en materia de competencias y mejorar la formación de los profesionales del patrimonio;

- seguir desarrollando modelos de interpretación y gobernanza más participativos y mejor adaptados a la Europa de hoy en día, a través de una mayor implicación del sector privado y de la sociedad civil.

- investigación e innovación

Convenimos plenamente con el comunicado en que para alcanzar estos objetivos, el sector del patrimonio europeo necesita más oportunidades de trabajo en red a gran escala y de aprendizaje interpares entre los Estados miembros y dentro de ellos. La puesta en común de los recursos con el fin de aplicar las últimas tecnologías y estimular nuevos enfoques científicos puede mejorar considerablemente la comprensión, la preservación y la difusión del patrimonio cultural.

La UE ha apoyado durante mucho tiempo la investigación relacionada con el patrimonio cultural en el contexto de sus programas marco de investigación, promoviendo la excelencia de la UE en la investigación del 
patrimonio $^{320}$. Destacar que en el Programa Horizonte 2020, programa marco de la UE para la investigación y la innovación, con una dotación de casi 80000 millones de euros para el período 2014-2020, contribuirá a reforzar la posición de la UE en el ámbito de la conservación, restauración y valorización del patrimonio cultural, apoyando la cooperación entre los investigadores con respecto a una amplia gama de temas. Dentro de cada uno de los tres pilares del programa (ciencia excelente, liderazgo industrial y retos sociales) se abrirán oportunidades de investigación e innovación en materia de patrimonio, como representa el presente estudio investigador.

La UE apoyará la utilización de herramientas científicas punteras para la protección del patrimonio, el desarrollo de interpretaciones más inclusivas del pasado y nuevos métodos de difusión e intercambio de conocimientos. La hoja de ruta europea para las infraestructuras de investigación da prioridad a la creación de una nueva infraestructura de investigación digital europea de arte y humanidades (DARIAH).

Una buena oportunidad de desarrollo de la investigación por nosotras realizada, se presenta desde la Plataforma Cultural Europeana (www.europeana.eu), ya que permite acceder ahora a unos treinta millones de objetos culturales de más de 2.500 organizaciones: los recursos de las instituciones culturales europeas están más adaptadas a internet y pueden reutilizarse en mayor medida. Europeana contribuye a desarrollar y a aplicar normas y a la interoperabilidad en este ámbito y ofrece un espacio donde los profesionales de la cultura intercambian conocimientos digitales.

Igualmente la UE pretende aprovechar el potencial del patrimonio cultural para el desarrollo local y regional. Las políticas de cohesión y desarrollo rural de la UE pueden contribuir a fomentar la restauración del patrimonio cultural, apoyar las industrias culturales y creativas y financiar la formación y la actualización de las competencias de los profesionales de la cultura. La conservación, la promoción y la gestión del patrimonio cultural

\footnotetext{
${ }^{320}$ Séptimo Programa Marco de Investigación y Desarrollo Tecnológico; «Patrimonio cultural y cambio mundial»; La Social Platform on Reflective Societies; entre otros.
} 
reciben actualmente un apoyo importante en el marco de los Fondos Estructurales y de Inversión de la UE (Fondos ESI) ${ }^{321}$.

La inversión en cultura y patrimonio debe formar parte de las estrategias de desarrollo económico integrado y sostenible en el marco del Fondo Europeo de Desarrollo Regional. Las inversiones pueden abarcar un amplio espectro de actividades en los sectores público, no lucrativo y privado (en particular, las PYME), contribuyendo directamente a la consecución de los objetivos del Fondo y a las prioridades de inversión. Las inversiones en pequeñas infraestructuras culturales como parte de una estrategia territorial deben contribuir tanto al desarrollo del potencial endógeno como a la promoción de la inclusión social y la calidad de vida, en particular entre las comunidades marginadas, mejorando su acceso a servicios culturales y recreativos en contextos rurales y urbanas.

Si todo el contenido del Documento de la UE hasta aquí traído es de aplicación directa o indirecta a nuestro estudio investigador, el apartado siguiente establece la diana de protección y tutela necesaria de la Administración Pública Europea al derecho a la conservación y modernización a la joyería tradicional y a nuestros objetivos planteados.

Revitalizar las antiguas competencias y desarrollar otras nuevas: ${ }^{322}$

Uno de los principales problemas a que se enfrenta el sector del patrimonio es la progresiva desaparición de los oficios tradicionales y la artesanía. La evolución demográfica agrava esta situación por lo que pronto

\footnotetext{
321 En 2007-2013, el Fondo Europeo de Desarrollo Regional asignó 3200 millones de euros a la protección y conservación del patrimonio cultural, 2200 millones de euros al desarrollo de infraestructuras culturales y 553 millones de euros a servicios culturales, que también beneficiaron al patrimonio cultural. En el período 2014-2020, las inversiones ESI en patrimonio cultural seguirán siendo elegibles en determinadas condiciones mediante financiación directa, pero también a través de inversiones en el sector de la regeneración urbana, el desarrollo sostenible y el apoyo a las pequeñas y medianas empresas (PYME).

${ }^{322}$ Pág. 12 Bruselas, 22.7.2014. COM(2014)
} 
podría producirse una penuria de trabajadores cualificados. Crece la demanda de nuevas cualificaciones, como, por ejemplo, en las tecnologías de la información, aunque a menudo la oferta es insuficiente.

Es necesario aumentar el atractivo de las profesiones relacionadas con el patrimonio y ofrecer más oportunidades de formación continua, aprovechando, por ejemplo, las posibilidades que ofrece el Fondo Social Europeo.

Basándose en los logros del Programa de Aprendizaje Permanente, el programa Erasmus+ proporcionará más oportunidades de movilidad con fines de aprendizaje y contribuirá a colmar la falta de competencias mediante su apoyo a las asociaciones transnacionales entre empresas, centros de enseñanza superior e instituciones de enseñanza y formación profesional.

Las alianzas para el conocimiento (para las instituciones de educación superior) y las alianzas para las competencias sectoriales (para la educación y la formación profesional) pueden ayudar a diseñar y ofrecer planes de estudios que respondan a las nuevas necesidades de los diferentes sectores y los vinculen mejor al mercado laboral. El sector del patrimonio cultural está bien situado para beneficiarse de estas iniciativas.

Los trabajos en curso sobre la elaboración de perfiles profesionales relación a clasificación europea de cualificaciones, competencias y ocupaciones (ESCO) también servirán para mejorar la transparencia de las cualificaciones y facilitará la movilidad transfronteriza de trabajadores especializados.

La cooperación a nivel de la UE puede contribuir, y contribuye, de manera decisiva a las políticas y la gobernanza del patrimonio a nivel nacional y local, inspirándose en el artículo 167 del TFUE («poniendo (...) de relieve el patrimonio cultural común») y estableciendo un marco multilateral y multidimensional. 
La Comunicación examina la acción que puede llevar a cabo la UE para aumentar el valor intrínseco del patrimonio y aprovechar su potencial económico y social. La experiencia europea demuestra que es posible pasar de una apreciación del carácter único de su propio patrimonio a un interés y respeto por el patrimonio de los demás.

La Comisión invita a todas las partes interesadas a reflexionar conjuntamente sobre la mejora de las políticas públicas a todos los niveles, incluido a nivel de la UE, a fin de explotar de manera sostenible y a largo plazo el valor del patrimonio cultural de Europa, así como desarrollar un enfoque más integrado de su preservación y valorización.

La normativa europea sobre patrimonio artístico se ha limitado a la regulación sobre la restitución a su territorio del patrimonio nacional con valor artístico, histórico o arqueológico enviado o exportado ilegalmente tras la supresión de los controles en las fronteras interiores, siendo referencia de esta materia la Directiva 93/7/CEE del Consejo, de 15 de marzo de 1993, relativa a la restitución de bienes culturales que hayan salido de forma ilegal del territorio de un Estado miembro, recientemente modificada por la Directiva 2014/60/UE del Parlamento Europeo y del Consejo de 15 de mayo de 2014 relativa a la restitución de bienes culturales que hayan salido de forma ilegal del territorio de un Estado miembro, y por la que se modifica el Reglamento (UE) $n^{\circ}$ 1024/2012, aunque poco o nada afecta a nuestro estudio, por ello simplemente se cita, por cuanto pone de manifiesto la escasez de normas sobre otro tipo de protección.

Claro queda que la UE tiene líneas de relevante implicación y aplicación donde tiene cabida la joyería tradicional y por ende sobre el emblemático Botón Charro, principal objeto de estudio en nuestro trabajo, abriéndose unas excelentes perspectivas de reconocimiento y promoción cultural, hasta ahora desaprovechadas. 


\subsection{Administración Pública del Estado}

Nuestro Ordenamiento Jurídico interno presidido por la Carta Magna de 1978, recoge en su art. 46 que "Los poderes públicos garantizarán la conservación y promoverán el enriquecimiento del patrimonio histórico, cultural y artístico de los pueblos de España y de los bienes que lo integran, cualquiera que sea su régimen jurídico y su titularidad. La ley penal sancionará los atentados contra este patrimonio.", otorgándole la relevancia de principio rector de la política social y económica ${ }^{323}$ y equiparando este principio a la sanidad, vivienda, medio ambiente, educación...

Los efectos de la inclusión del artículo 46 como uno de principios de la política social y económica, son recogidos en el artículo 53.3 de la Constitución. En concreto, según este artículo, los principios rectores de la política social y económica informarán la legislación positiva, la práctica judicial y la actuación de los poderes públicos, y sólo podrán ser alegados ante la Jurisdicción ordinaria de acuerdo con lo que dispongan las leyes que los desarrollen. Abundando en la importancia del régimen de protección de esta categoría tan heterogénea de principios, la doctrina ${ }^{324}$ ha señalado que es precisamente esa definición concreta de los efectos jurídicos de los principios del Capítulo III, lo que constituye el único común denominador entre todos ellos, ya que se trata de una conjunto de principios teleológicos, obligaciones a los poderes público y expectativas de derechos difícilmente subsumibles en una sola categoría jurídica.

El contenido de este artículo 46 no puede entenderse en toda su extensión si no se pone en conexión con otros preceptos constitucionales que regulan la materia cultura. Además de la declaración que se hace en el Preámbulo respecto a la promoción de la cultura como fin último de la Constitución y, por tanto del Estado, también el artículo 9.2, establece que

\footnotetext{
${ }^{323}$ Capítulo III ( Art. 39 a 52) de la Constitución Española de 1978

324 PÉREZ DE ARMIÑAN Y DE LA SERNA, A. "Competencia del Estado sobre el Patrimonio Histórico español y la Constitución de 1978", Civitas Ediciones, S.L., 1997
} 
corresponde a los poderes públicos facilitar la participación de los ciudadanos en la vida cultural.

Este principio, interrelacionado con el derecho a la cultura reconocido a favor de los ciudadanos en el artículo 44.1 de la propia Norma Suprema, informará la legislación positiva, la práctica judicial y la actuación de los poderes públicos mediante su reconocimiento, respeto y protección por parte de los distintos poderes públicos (conforme declara el artículo 53.3 de la Constitución). ${ }^{325}$

Por ello, debe entenderse que no puede llevarse a cabo ninguna actividad contraria a estos principios por parte de los poderes públicos, que además están obligados a actuar conforme a lo que establezcan. Como ha afirmado el Tribunal Constitucional en varias de sus sentencias, valga por todas ellas la 83/1984 de 24 de julio, estos principios del Capítulo III son un mínimo que debe ser respetado y realizado por los poderes públicos, los cuales pueden sobrepasar esas disposiciones iniciales superando esos puntos de partida.

Convenimos con la sinopsis institucional ${ }^{326}$ del art. $46 \mathrm{CE}$, cuando se argumenta que la cultura, y los concretos objetos artísticos o de valor histórico en que la cultura se manifiesta, son una necesidad de la vida social. El concepto cultura que recoge nuestra Constitución se puede afirmar que es poliédrico; aunque por lo que aquí interesa, y refiriéndonos sólo a la cultura material, podemos definirla como cualquier manifestación del patrimonio artístico, lingüístico, religioso y educativo que se concreta en objetos muebles o inmuebles. Se trata por tanto de un concepto anfibológico, tan amplio en acepciones y ámbito, y tan relevante para todas las ciencias humanas que incluso en el ámbito de la ciencia jurídica un autor como

\footnotetext{
${ }^{325}$ ABAD LICERAS, J.M. en

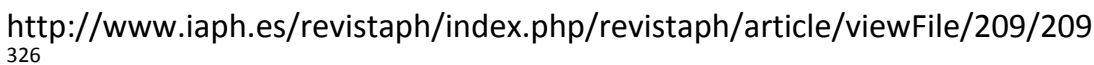

http://www.congreso.es/consti/constitucion/indice/sinopsis/sinopsis.jsp?art=46\&tipo=2(13/12/201 4)
} 
HÄBERLE ${ }^{327}$ habló de la posibilidad de construir una Teoría de la Constitución como ciencia de la cultura, la cual, estudiaría los artículos del Derecho constitucional que regulan la materia. Así, también entre nosotros, parte de la doctrina ha hablado de la coexistencia, dentro del propio texto de la Constitución de 1978, de una Constitución Cultural, junto con una Constitución Política y otra Económica.

El progreso de la cultura como valor central de los sistemas sociales occidentales ha sido una constante también en los sistemas políticos contemporáneos. Históricamente, es necesario un sustrato cultural para el funcionamiento real de la democracia. Ello es especialmente cierto en el caso de los Estados democráticos actuales, en los cuales, es entendido como un principio esencial de actuación de los poderes públicos y como una obligación de estos, ya que el progreso cultural de los ciudadanos es inseparable del progreso social, democrático y económico. La realización de los valores superiores del ordenamiento jurídico libertad, igualdad y pluralismo político contenidos en el artículo 1 de la Constitución, exige una acción positiva de los poderes públicos, siendo la realización de estos valores superiores condición radical para el pleno respeto a la dignidad de la persona y para el libre desarrollo de su personalidad, valores jurídicos fundamentales de nuestro Estado de Derecho como sostiene el artículo 10.1 de la Constitución. ${ }^{328}$

Llegado este punto nos preguntamos si nuestra joyería tradicional estudiada podría formar parte oficialmente de ese rico Patrimonio, por lo que debemos acudir primero a esclarecer cuáles son los bienes que deben entenderse como incluidos en el Patrimonio Histórico, Cultural y Artístico.

\footnotetext{
327 PETER HÄBERLE, maestro constitucionalista eminente por su contribución del Derecho Constitucional Europeo. 328

http://www.congreso.es/consti/constitucion/indice/sinopsis/sinopsis.jsp?art=46\&tipo=2(13/12/201 4)
} 
Encontramos una aproximación a esta cuestión en la STC 17/1991, de 31 de enero ${ }^{329}$ que afirma la existencia de "un estatuto peculiar de unos determinados bienes que, por estar dotados de singulares características, resultan portadores de unos valores que les hacen acreedores de una especial consideración y protección, en cuanto dichos valores, y hasta los mismos bienes, son patrimonio cultural de todos los españoles e incluso de la comunidad internacional por constituir una aportación histórica a la cultura universal".

Fundamental también resulta para nuestro estudio su pronunciamiento, en relación con la declaración de un determinado bien como integrante de la categoría Bien de Interés Cultural, otorgando sobre la preferencia sobre las Comunidades Autónomas frente al Estado como regla general.

(...) Los recurrentes alegan que este precepto, al prescribir la declaración de interés cultural para gozar de singular protección «mediante Real Decreto», relegaría a las Comunidades Autónomas a la mera tramitación del expediente. Coinciden en señalar que el Estado carece de competencias ejecutivas en esta materia que no sean las estrictamente encaminadas a la defensa contra la exportación y la expoliación, y que corresponde a las Comunidades Autónomas que estatutariamente hayan asumido competencias, la declaración de interés cultural de los bienes integrantes del Patrimonio Histórico Español radicados en cada Comunidad.

La calificación formal como bienes de interés cultural de «los más relevantes» del Patrimonio Histórico Español (art. 1.3 de la Ley) constituye un requisito para que puedan gozar de singular protección y tutela (art. 9.1) y también por tanto para su defensa contra la exportación y la expoliación; pero lo es asimismo para la sumisión a un régimen singular derivado de su importancia cultural y que en su propia complejidad abarca medidas de

\footnotetext{
329 STC 17/1991, de 31 de enero, recursos de inconstitucionalidad promovidos por el consejo ejecutivo de la generalidad de Cataluña, junta de Galicia, gobierno vasco y parlamento de Cataluña, contra determinados preceptos de la Ley 16/1985, de 25-6-1985, reguladora del patrimonio histórico español. (RTC 111\17)
} 
estricta protección y defensa junto a otras que no lo son y tienen naturaleza jurídica variada.

La amplitud de consecuencia de la resolución que califica y declara un bien de interés cultural tiene, por lo tanto, un alcance general respecto al régimen del mismo y no sólo en relación con su defensa frente a la expoliación y la exportación. La categoría legal de los bienes de interés cultural dentro del Patrimonio Histórico Español está integrada por los más relevantes del mismo, normalmente situados en alguna de las Comunidades Autónomas. $\underline{Y}$ a ellas, en cuanto la tengan asumida estatutariamente, debe corresponder la competencia para emitir su declaración formal, sin perjuicio de la del Estado en los supuestos singulares en que a éste le viene atribuida por la Constitución y se señalan en el apartado b) del citado art. 6. En consecuencia, el inciso final del art. 9.1 («Declarados de interés cultural mediante Real Decreto de forma individualizada») no se ajusta al bloque de la constitucionalidad más que si se entiende referido solamente a aquellos supuestos en que es competente el Estado para la ejecución de la Ley es decir, los mencionados en el párrafo b) del citado art. 6. Pero sería contrario a aquél si se le considerase aplicable en todo caso. Así depurado el precepto de su exceso competencial (incluso el inciso inicial del párrafo 2) el resto de sus normas no implican extralimitación y son aplicables a todos los expedientes de declaración tanto los de competencia del Estado como de las Comunidades Autónomas.

Cuestión distinta es la declaración «por ministerio de esta Ley» puesto que se trata de una medida legislativa cuyo objeto es el de remitirse a supuestos concretos contenidos en la propia Ley y no impugnados, donde se definen las categorías de esos bienes, o bien según la Disposición adicional primera (que tampoco se impugna), a atribuir la nueva denominación y las consecuencias derivadas de su inclusión en el régimen que la Ley establece para los que ya estaban declarados o incluidos con anterioridad en inventario. 
En conclusión, procede declarar que el inciso final del art. 9, párrafo primero, de la Ley («mediante Real Decreto de forma individualizada») es constitucional en relación con la declaración de interés cultural de los bienes sólo cuando ésta corresponda formularla a la Administración del Estado, o sea, en los supuestos del art. 6 b); y otro tanto cabe decir del apartado 5 del mismo artículo, puesto que su contenido es el mismo, aunque de signo contrario.

Idéntica conclusión debe aplicarse a la Disposición transitoria sexta, 1, en cuanto también en ella aparece como prescripción impugnada la de que la resolución tenga lugar en todo caso mediante Real Decreto. (F. 10) ${ }^{330}$

La propia Web del Congreso de Diputados ${ }^{331}$, reconoce que la defensa, conservación, promoción y enriquecimiento del patrimonio histórico, artístico y cultural, ha sido y es una manifestación evidente de esta preocupación constitucional por asegurar el progreso cultural y social de los ciudadanos españoles. Esta preocupación del poder público por la defensa del rico patrimonio español, ha sido una preocupación constante en la historia reciente de nuestro país, especialmente desde principios del Siglo $X X$, debido a la imperiosa necesidad de conservarlo y, al mismo tiempo, de protegerlo de los frecuentes expolios que sufría.

Prueba de esta preocupación son las distintas normas que intentaron crear mecanismos de salvaguarda de las obras de arte y de valor histórico, como el Real Decreto de 1 de junio de 1900, por el que se ordena la formación de un Catálogo monumental y artístico de la Nación. Posteriormente, el Decreto- Ley de 9 de agosto de 1926, sobre protección, conservación y acrecimiento de la riqueza artística, permitía una intervención directa del Estado para lograr la protección de la riqueza monumental, especialmente por lo que respecta a la permanencia de las obras artísticas o de valor histórico dentro del territorio nacional.

\footnotetext{
${ }^{330}$ STC 17/1991, de 31 de enero, Opus cit. anterior

${ }^{331}$ http://www.congreso.es/consti/constitucion/indice/sinopsis/sinopsis.jsp?art=46\&tipo=2 (13712/2014)
} 
Posteriormente, la Segunda República, reflejó constitucionalmente su especial sensibilidad e interés en la protección y difusión de la cultura y el arte. Así, el artículo 45 de la Constitución de 1931 establecía que "Toda la riqueza artística e histórica del país, sea quien fuere su dueño, constituye tesoro cultural de la Nación y estará bajo la salvaguardia del Estado, que podrá prohibir su exportación y enajenación y decretar las expropiaciones legales que estimare oportunas para su defensa. El Estado organizará un registro de la riqueza artística e histórica, asegurará su celosa custodia y atenderá a su perfecta conservación. El Estado protegerá también los lugares notables por su belleza natural o por su reconocido valor artístico o histórico.

Por tanto, el constituyente del $1931^{332}$ obliga al Estado a utilizar todos los medios para proteger ese patrimonio frente al expolio y, sobretodo, frente a la salida al exterior de esas obras, asunto este que constituía la preocupación central en ese momento ante las graves pérdidas de obras de arte, enajenadas a coleccionistas o museos extranjeros. Prueba de ello es que se habilita expresamente la potestad expropiatoria para convertir en bienes de dominio público las obras de arte en manos privadas. Además, se introduce el mandato al Estado para que organice un registro que permita el control de las obras de arte, tanto en manos de la Administración como en manos privadas, con el objeto de protegerlas y de asegurar su conservación $^{333}$.

Del tenor literal del artículo $46 \mathrm{CE}$, interpretamos con claridad que todos los poderes públicos están obligados a intervenir para garantizar la conservación y promover el enriquecimiento del patrimonio histórico, cultural y artístico de los pueblos de España, así como de los bienes materiales que lo integran, por ende del tema que nos ocupa. Por lo que uno de los fines del Estado será proteger a todos los españoles y pueblos de España en el

332 Artículo 45 de la Constitución de 1931 fue desarrollado por la Ley de 13 de mayo de 1933, sobre defensa, conservación y acrecentamiento del Patrimonio Histórico-Artístico Nacional, y por un Reglamento de 16 de abril de 1936.

${ }^{333} \mathrm{http}: / /$ www.congreso.es/consti/constitucion/indice/sinopsis/sinopsis.jsp?art=46\&tipo=2 $(13 / 12 / 2014)$ 
ejercicio de los derechos humanos, sus culturas y tradiciones y no cabe duda de que las Comunidades Autónomas, como poderes públicos, deben ser actores importantes a la hora de llevar a cabo esta tarea de protección y promoción del patrimonio, no en vano el artículo 148 en sus apartados $15^{a}$, $16^{a}$ y $17^{a}$, recoge distintas materias relacionadas con la cultura, de interés de la Comunidad Autónoma o fomento de la cultura, como asumibles por esta Administración regional.

La compleja distribución competencial estudiada por entre otros ${ }^{334}$, igualmente es referida en documentos del Congreso de Diputados, estableciendo que, fruto de esta complejidad en la distribución competencial, el Tribunal Constitucional en su Sentencia 84/1983, de 24 de octubre ${ }^{335}$ ya afirmó que existe en la materia cultura en sentido amplio un impreciso deslinde competencial por la amplitud de la materia en relación especialmente a lo que establece el artículo 149.2, el cual afirma que, sin perjuicio de las competencias que podrán asumir las Comunidades Autónomas, el Estado considerará el servicio a la cultura como deber y atribución esencial. Por todo ello, la doctrina ha subrayado que en esta materia más que un reparto competencial lo que se produce en realidad es la concurrencia de competencias entre Estado y Comunidades Autónomas

334 PÉREZ DE ARMIÑAN Y DE LA SERNA, A. “Competencia del Estado sobre el Patrimonio Histórico español y la Constitución de 1978", Civitas Ediciones, S.L., 1997

${ }^{335}$ Sentencia núm. 84/1983 de 24 octubre. RTC 1983\84 CONFLICTOS POSITIVOS DE COMPETENCIA PROMOVIDOS POR EL CONSEJO EJECUTIVO DE LA GENERALIDAD DE CATALUÑA, EN RELACIÓN CON EL ART. 50 DEL RD 988/1982, DE 30-4-1982, SOBRE CONCESIÓN DE SUBVENCIÓN DEL ESTADO PARA FINES CULTURALES: el TC declara la titularidad de la competencia controvertida en favor del Estado, sin perjuicio del informe preceptivo del Departamento de Cultura de la Generalidad de Cataluña en lo que afecte a su ámbito territorial. CATALUÑA: Fomento de la cultura: RD 988/1982, de 30-4-1982, sobre distribución de créditos que se consignen en los Presupuestos Generales del Estado para financiar inversiones de carácter cultural a realizar por las Corporaciones Locales en relación con la efemérides del V Centenario de la Unidad de España: art. 5o del RD 988/1982: los respectivos programas provinciales serán informados por el Ministerio de Cultura: competencia: en base a los arts. 148, apartados 15, 16 y 17 de la CE, 9, apartados 4, 5 y 6, del Estatuto Catalán y RD 1010/1981, de 27-2-1981, sobre traspaso de competencias del Estado a la Generalidad de Cataluña, con especial énfasis en el "fomento de la cultura», el Ente autonómico debe tener intervención: la titularidad de la competencia pertenece al Estado, pero el Ente autonómico debe participar en los supuestos de aprobación del programa de inversiones culturales a realizar en instituciones radicadas en su propio territorio, por medio de un informe preceptivo no vinculante. 
ordenada a un fin, que es la preservación y estímulo de los valores culturales, como ha afirmado la STC 49/1984, de 5 de abril ${ }^{336}$.

Esta concurrencia competencial impregna toda la materia cultura en sus múltiples manifestaciones, incluida evidentemente la de la protección y enriquecimiento del patrimonio histórico, cultural y artístico como es la joyería tradicional.

El texto fundamental que desarrolla el artículo 46 de la Constitución es la Ley 16/1985, de 25 de junio, del Patrimonio Histórico Español, desarrollada a su vez por el RD 111/1986, de 10 de enero, modificado por RD 64/1994, de 21 de enero, materializando su contenido al menos desde un punto de vista teórico.

Este legislador nacional de 1985, parte del reconocimiento de que Patrimonio Histórico Español es el principal testigo de la Contribución histórica de los españoles a la civilización universal y de su capacidad creativa contemporánea. La protección y el enriquecimiento de los bienes que lo integran constituyen obligaciones fundamentales que vinculan a todos los poderes públicos, si bien también forma parte de su objetivo al regula esta materia cubrir la necesidad con un verdadero código sobre nuestro Patrimonio Histórico, habida cuenta de la dispersión normativa existe y la

\footnotetext{
${ }^{336}$ Sentencia núm. 49/1984 de 5 abril. RTC 1984\49 RECURSO DE INCONSTITUCIONALIDAD PROMOVIDO POR EL CONSEJO EJECUTIVO DE LA GENERALIDAD DE CATALUÑA, CONTRA LA DISPOSICIÓN ADICIONAL SEGUNDA Y ARTS. 10 Y 70 DE LA LEY 1/1982, DE 24-2-1982, POR LA QUE SE REGULAN LAS SALAS ESPECIALES DE EXHIBICIÓN CINEMATOGRÁFICA, LA FILMOTECA ESPAÑOLA Y LAS TARIFAS DE LAS TASAS POR LICENCIA DE DOBLAJE: desestimación. RECURSO DE INCONSTITUCIONALIDAD: objeto: no será legítima su utilización con la finalidad de obtener declaraciones preventivas o previsoras ante eventuales agravios competenciales o interpretativos, que pongan a cubierto de aplicaciones contrarias al orden de competencias establecido en la Constitución Española y, dentro del marco constitucional, en los Estatutos de Autonomía. Y CONFLICTO POSITIVO DE COMPETENCIAS: distinción. CULTURA: competencia concurrente del Estado y de las Comunidades Autónomas: fomento de la cultura: preservación y estímulo de los valores culturales propios del cuerpo social desde la instancia pública correspondiente. CINEMATOGRAFÍA: arts. 1 y 7 de la Ley 1/1982, de 24-2-1982: calificación: es un medio dirigido a la consecución de fines opuestos, aunque obviamente, todos guiados por el logro de un interés que se estima digno de protección: principios: fomento de la cultura y protección a la juventud y a la infancia: películas de "arte y ensayo» y películas "X»; competencia: no puede negarse a la Administración del Estado, sin que esto prejuzgue el alcance del ejercicio de las competencias de esta naturaleza que puedan tener determinadas Comunidades Autónomas.
} 
nula actualización a principios democráticos, recomendaciones y convenciones internacionales habidas hasta la fecha.

No duda el legislador en afirmar en su preámbulo in fine que "el Patrimonio Histórico Español es una riqueza colectiva que contiene las expresiones más dignas de aprecio en la aportación histórica de los españoles a la cultura universal. Su valor lo proporciona la estima que, como elemento de identidad cultural, merece a la sensibilidad de los ciudadanos. Porque los bienes que lo integran se han convertido en patrimoniales debido exclusivamente a la acción social que cumplen, directamente derivada del aprecio con que los mismos ciudadanos los han ido revalorizando.

En consecuencia, y como objetivo último, la Ley no busca sino el acceso a los bienes que constituyen nuestro Patrimonio Histórico. Todas las medidas de protección y fomento que la Ley establece sólo cobran sentido si, al final, conducen a que un número cada vez mayor de ciudadanos pueda contemplar y disfrutar las obras que son herencia de la capacidad colectiva de un pueblo. Porque en un Estado democrático estos bienes deben estar adecuadamente puestos al servicio de la colectividad en el convencimiento de que con su disfrute se facilita el acceso a la cultura y que ésta, en definitiva, es camino seguro hacia la libertad de los pueblos."

Sobre el contenido de la Ley 16/1985, compuesto por IX Títulos, aun siendo todos ellos relevante para nuestro estudio, debemos igualmente detenernos en el Titulo VI, sobre Patrimonio Etnográfico y Titulo I, que recoge la declaración de Bien de Interés General, por ser ese a nuestro juicio, punto clave en nuestro estudio sobre la puesta en valor del Botón Charro como patrimonio artístico reconocido formalmente, al responder a preguntas, para nosotras esclarecedoras:

- Integración del Patrimonio Etnográfico en Patrimonio Histórico Español

Forman parte del Patrimonio Histórico Español los bienes muebles e inmuebles y los conocimientos y actividades que son o han sido expresión 
relevante de la cultura tradicional del pueblo español en sus aspectos materiales, sociales o espirituales. (art.46)

Son bienes muebles de carácter etnográfico, y se regirán por lo dispuesto en los Títulos III y IV de la presente Ley, todos aquellos objetos que constituyen la manifestación o el producto de actividades laborales, estéticas y lúdicas propias de cualquier grupo humano, arraigadas y transmitidas consuetudinariamente. (art.47.2)

Se considera que tienen valor etnográfico y gozarán de protección administrativa aquellos conocimientos o actividades que procedan de modelos o técnicas tradicionales utilizados por una determinada comunidad. Cuando se trate de conocimientos o actividades que se hallen en previsible peligro de desaparecer, la Administración competente adoptará las medidas oportunas conducentes al estudio y documentación científicos de estos bienes. (art. 47.3)

- Sobre el procedimiento declarativo de bien de interés general

La declaración mediante Real Decreto requerirá la previa incoación y tramitación de expediente administrativo por el Organismo competente, según lo dispuesto en el artículo $6^{\circ}$ de esta Ley. En el expediente deberá constar informe favorable de alguna de las Instituciones consultivas señaladas en el artículo 3 párrafo $2^{0337}$, o que tengan reconocido idéntico carácter en el ámbito de una Comunidad Autónoma. Transcurridos tres meses desde la solicitud del informe sin que éste hubiera sido emitido, se entenderá que el dictamen requerido es favorable a la declaración de Interés Cultural. Cuando el expediente se refiera a bienes inmuebles se dispondrá,

\footnotetext{
337 Art.3.2: "Sin perjuicio de las funciones atribuidas al Consejo del Patrimonio Histórico, son instituciones consultivas de la Administración del Estado, a los efectos previstos en la presente Ley, la Junta de Calificación, Valoración y Exportación de Bienes del Patrimonio Histórico Español, las Reales Academias, las Universidades españolas, el Consejo Superior de Investigaciones Científicas y las Juntas Superiores que la Administración del Estado determine por vía reglamentaria, y en lo que pueda afectar a una Comunidad Autónoma, las instituciones por ella reconocidas. Todo ello con independencia del asesoramiento que, en su caso, pueda recabarse de otros organismos profesionales y entidades culturales". Véase R.D. 111/1986, 10 enero, de desarrollo parcial de la Ley 16/1985: arts. 2 a 5.
} 
además, la apertura de un período de información pública y se dará audiencia al Ayuntamiento interesado. (art. 9.2)

El expediente deberá resolverse en el plazo máximo de veinte meses a partir de la fecha en que hubiere sido incoado. La caducidad del expediente se producirá transcurrido dicho plazo si se ha denunciado la mora y siempre que no haya recaído resolución en los cuatro meses siguientes a la denuncia. Caducado el expediente no podrá volver a iniciarse en los tres años siguientes, salvo a instancia del titular. (art. 9.3)

No podrá ser declarada Bien de Interés Cultural la obra de un autor vivo, salvo si existe autorización expresa de su propietario o media su adquisición por la Administración. (art.9.4)

\section{- Quien puede solicitar el Bien de Interés General}

De oficio o a instancia del titular de un interés legítimo y directo, podrá tramitarse por el Organismo competente expediente administrativo, que deberá contener el informe favorable y razonado de alguna de las instituciones consultivas, a fin de que se acuerde, mediante Real Decreto, que la declaración de un determinado Bien de Interés Cultural quede sin efecto. (9.5)

Cualquier persona podrá solicitar la incoación de expediente para la declaración de un Bien de Interés Cultural. El Organismo competente decidirá si procede la incoación. Esta decisión y, en su caso, las incidencias y resolución del expediente deberán notificarse a quienes lo instaron.(art.10)

La incoación de expediente para la declaración de un Bien de Interés Cultural determinará, en relación al bien afectado, la aplicación provisional del mismo régimen de protección previsto para los bienes declarados de interés cultural.(art.11.1)

La resolución del expediente que declare un Bien de Interés Cultural deberá describirlo claramente. En el supuesto de inmuebles, delimitará el entorno 
afectado por la declaración y, en su caso, se definirán y enumerarán las partes integrantes, las pertenencias y los accesorios comprendidos en la declaración.(art.11.2)

Los bienes declarados de interés cultural serán inscritos en un Registro General dependiente de la Administración del Estado cuya organización y funcionamiento se determinarán por vía reglamentaria. A este Registro se notificará la incoación de dichos expedientes, que causarán la correspondiente anotación preventiva hasta que recaiga resolución definitiva.(art.12.1)

A los bienes declarados de interés cultural se les expedirá por el Registro General un Título oficial que les identifique y en el que se reflejarán todos los actos jurídicos o artísticos que sobre ellos se realicen. Las transmisiones o traslados de dichos bienes se inscribirán en el Registro. Reglamentariamente se establecerá la forma y caracteres de este Título.(art.13.1)

Asimismo, los propietarios y, en su caso, los titulares de derechos reales sobre tales bienes o quienes los posean por cualquier título, están obligados a permitir y facilitar su inspección por parte de los Organismos competentes, su estudio a los investigadores, previa solicitud razonada de éstos, y su visita pública, en las condiciones de gratuidad que se determinen reglamentariamente, al menos cuatro días al mes, en días y horas previamente señalados. El cumplimiento de esta última obligación podrá ser dispensado total o parcialmente por la Administración competente cuando medie causa justificada. En el caso de bienes muebles se podrá igualmente acordar como obligación sustitutoria el depósito del bien en un lugar que reúna las adecuadas condiciones de seguridad y exhibición durante un período máximo de cinco meses cada dos años. (art.13.2)

- $\quad$ Sobre protección de este Patrimonio 
Los bienes integrantes del Patrimonio Histórico Español deberán ser conservados, mantenidos y custodiados por sus propietarios o, en su caso, por los titulares de derechos reales o por los poseedores de tales bienes.(art.36.1)

La utilización de los bienes declarados de interés cultural, así como de los bienes muebles incluidos en el Inventario General, quedará subordinada a que no se pongan en peligro los valores que aconsejan su conservación. Cualquier cambio de uso deberá ser autorizado por los Organismos competentes para la ejecución de esta Ley. (art.36.2)

Cuando los propietarios o los titulares de derechos reales sobre bienes declarados de interés cultural o bienes incluidos en el Inventario General no ejecuten las actuaciones exigidas en el cumplimiento de la obligación prevista en el apartado $1^{\circ}$ de este artículo, la Administración competente, previo requerimiento a los interesados, podrá ordenar su ejecución subsidiaria. Asimismo, podrá conceder una ayuda con carácter de anticipo reintegrable que, en caso de bienes inmuebles, será inscrita en el Registro de la Propiedad. La Administración competente también podrá realizar de modo directo las obras necesarias, si así lo requiere la más eficaz conservación de los bienes. Excepcionalmente la Administración competente podrá ordenar el depósito de los bienes muebles en centros de carácter público en tanto no desaparezcan las causas que originaron dicha necesidad. (art. 36.3)

El incumplimiento de las obligaciones establecidas en el presente artículo será causa de interés social para la expropiación forzosa de los bienes declarados de interés cultural por la Administración competente. (art.36.4)

Igualmente el Código Penal, se contempla la realización de actos delictivos respecto a bienes del patrimonio histórico artístico. Así, el artículo 235 , contempla la punición por delito de hurto con penas de prisión de uno a tres años si se sustraen cosas de valor artístico, histórico, cultural 0 científico. Además, debe tenerse en cuenta que en la regulación de otros delitos se considera circunstancia agravante el hecho de que el delito se 
proyecte sobre bienes que integren el patrimonio histórico artístico cultural o científico, como en el delito de estafa, artículo 250.1.5 del Código Penal, o el de apropiación indebida, regulado en el artículo 253 de la misma norma.

Interesante también nos resulta al estudio el contenido preceptuado en el Real Decreto 111/1986, de 10-1-1986 (RCL 1986/275 y 661), de desarrollo parcial de la Ley 16/1985, de 25-6-1985 (RCL 1985\1547, 2916 y ApNDL 10714), que regula el Patrimonio Histórico Español. ${ }^{338}$

La razón de esta modificación parcial es la necesidad de adaptar el Real Decreto 111/1986 a la doctrina sentada en la Sentencia del Tribunal Constitucional 17/1991, de 31 de enero (RTC 1991, 17). Asimismo, se ha aprovechado la oportunidad para introducir en el contenido de la disposición cambios aconsejados por la experiencia acumulada en los años de aplicación desde que fue aprobada.

El principal juicio sobre la constitucionalidad de la Ley del Patrimonio Histórico Español se refiere a la competencia estatal para legislar en materia de patrimonio histórico y, en particular, para legislar sobre las potestades de declaración de bienes de interés cultural y consecuente sumisión al régimen legal de estos bienes. El Estado, según el alto Tribunal, es competente sólo para los casos determinados en el artículo 6.b) de la Ley, es decir: bienes adscritos a servicios públicos gestionados por el Estado o integrantes del Patrimonio Nacional. Se ha procedido en consecuencia a la reforma del articulado del Real Decreto 111/1986 con arreglo a tal criterio y se suprimen las referencias al procedimiento administrativo que las Comunidades Autónomas deben seguir para la declaración de bien de interés cultural, inclusión y exclusión del inventario general y otros aspectos concordantes. De este modo, el Real Decreto es únicamente aplicable -en este ámbito primario de protección- a la Administración General del Estado.

${ }^{338}$ BOE 2 marzo 1994, núm. 52, [pág. 6780] 
Los motivos de oportunidad que fundamentan otras modificaciones, singularmente la inclusión de un nuevo capítulo tercero en el Título III con un único artículo, son los siguientes: el artículo 57 bis viene a desarrollar la competencia estatal sobre expoliación, desarrollo ausente en el Real Decreto 111/1986. Se ha redactado este artículo 57 bis de modo que las potestades de la Administración General del Estado sólo se ejerciten en caso de que otros poderes públicos -y singularmente las Comunidades Autónomas- no adopten medidas suficientes para evitar la expoliación. En este sentido, el nuevo artículo 57 bis parte del principio de intervención mínima, pero sin menoscabo de los títulos estatales sobre la materia.

Un segundo motivo de reforma reside en el mandato contenido en la disposición adicional tercera de la Ley 30/1992, de Régimen Jurídico de las Administraciones Públicas y del Procedimiento Administrativo Común (RCL 1992, 2512, 2775 y RCL 1993\246), que ordena la adaptación a este nuevo marco jurídico de los procedimientos administrativos. Al efecto se modifican los artículos 6,9 y 49 del Real Decreto.

En la elaboración del proyecto de reforma se han tenido en cuenta las observaciones que al borrador presentaron las Comunidades Autónomas que lo consideraron conveniente, por lo que puede decirse que el presente constituye un texto concertado entre las distintas Administraciones públicas competentes.

Respecto a la declaración de Bien de Interés Cultural esta disposición reglamentaria aplicable a los bines muebles, establece:

De acuerdo con lo previsto en el artículo 6.b) de la Ley 16/1985, corresponde al Ministerio de Cultura tramitar los expedientes para declarar de interés cultural los bienes integrantes del Patrimonio Histórico Español adscritos a servicios públicos gestionados por la Administración General del Estado o que formen parte del Patrimonio Nacional. Su tramitación por dicho Ministerio se efectuará de acuerdo con las normas establecidas en este capítulo. (art.11.1) 
Corresponde a las comunidades autónomas la declaración de interés cultural de los restantes bienes del Patrimonio Histórico Español, cuya tramitación se regirá por su propia normativa. (art.11.2)

El acto por el que se incoa el expediente deberá describir para su identificación el bien objeto del mismo. En caso de bienes inmuebles, el acto de incoación deberá además delimitar la zona afectada. (art.12.1)

La incoación se notificará a los interesados cuando se refiera a expedientes sobre bienes muebles, monumentos y jardines históricos y, en todo caso, al Ayuntamiento del Municipio en cuyo término éstos radiquen si se trata de inmuebles.

La incoación del expediente se efectuará de oficio o a solicitud de persona interesada y determinará en relación al bien afectado la aplicación provisional del régimen de protección previsto para los bienes de interés cultural.(art. 12.3)

La instrucción del expediente se ajustará a lo establecido en la Ley 16/1985 y en su tramitación serán de aplicación las normas generales del procedimiento administrativo. (art. 13.1)

El Ministerio de Cultura podrá recabar del titular del bien o del que por razón de cualquier título ostente la posesión, que facilite el examen del bien y proporcione cuanta información sobre el mismo se estime necesaria.(art.13.2)

En el caso de que el citado órgano solicite el preceptivo informe de una institución consultiva y ésta, por su especialidad, no se considere la adecuada para emitir el informe, lo denegará en el plazo de quince días a partir de la recepción de la solicitud, sin que ello impida que se continúe la tramitación. (art.13.3) 
En los supuestos previstos en el artículo 6.b) de la Ley 16/1985, la declaración de bien de interés cultural se efectuará por Real Decreto a propuesta del Ministro de Cultura. (art. 14.1)

El Real Decreto por el que se declara un bien de interés cultural deberá describirlo claramente para su identificación y en su caso contendrá las especificaciones a que se refieren los artículos 11.2 y 27 de la Ley 16/1985. (art.14.2)

Publicado el Real Decreto, el Registro General de Bienes de Interés Cultural inscribirá de oficio la declaración. (art.15.1)

En el caso de monumentos y jardines históricos, el Ministerio de Cultura instará de oficio la inscripción gratuita de la declaración en el Registro de la Propiedad. (art.15.2)

En los supuestos del artículo 11.1 de este Real Decreto corresponde al Ministerio de Cultura tramitar el expediente para dejar sin efecto la declaración de bien de interés cultural. (art.16.1)

La incoación del expediente para dejar sin efecto la declaración de interés cultural de un determinado bien se efectuará de oficio o a solicitud del titular de un interés legítimo y directo, y se notificará y publicará en los términos previstos en el artículo 12.2 de este Real Decreto. (art.17)

Instruido el expediente conforme a lo dispuesto en el artículo 13 de este Real Decreto, el Ministro de Cultura propondrá al Gobierno el Real Decreto por el que queda sin efecto la declaración de interés cultural de un determinado bien.(art.18)

El citado Real Decreto, que se publicará en el «Boletín Oficial del Estado», cancelará la inscripción del bien en el Registro General de Bienes de Interés Cultural. (art.19)(...) 
La Administración del Estado a través del Ministerio de Educación Cultura y Deporte crea un Instituto del Patrimonio Cultural de España ${ }^{339}$, dependiente de la Dirección General de Bellas Artes y Bienes Culturales y de Archivos y Bibliotecas y es a través de la Subdirección General de Protección del Patrimonio Histórico, la responsable del mantenimiento y actualización del Registro General de Bienes de Interés Cultural y del Inventario General de Bienes Muebles, donde se recoge la información de los bienes que las Comunidades Autónomas o el Estado han decidido establecer algún tipo de protección.

Sobre la base de datos de bienes muebles que tiene el Ministerio, en cada consulta se obtendrá una «ficha básica» de identificación y descripción del bien en la que se indica su situación jurídico-administrativa que contiene información sobre los bienes muebles inscritos en el Registro de Bienes de Interés Cultural ${ }^{340}$, hemos de apuntar que a la pregunta "Botón Charro" (Castilla y León) se obtiene la contestación "No se ha encontrado ningún resultado", asignatura pendiente del pueblo salmantino y de sus Instituciones Públicas.

\subsection{Administración Pública Autonómica: CyL}

El conflicto competencial entre el Estado y las Comunidades Autónomas celosas de poseer una competencia más amplia sobre su Patrimonio Cultural, pone en tela de julio lo promulgado en la Ley 16/1985, haciendo que el Tribunal Constitucional se pronunciara en más de una ocasión, valga como ejemplo:

\footnotetext{
${ }_{340}^{339}$ http://ipce.mcu.es/index.html (8/1/2013)

http://www.mecd.gob.es/bienes/cargarFiltroBienesMuebles.do?layout=bienesMuebles\&cache=init \&language $=$ es.
} 
"...pueda entenderse comprendida en más de una regla definidora de competencias, debe determinarse cuál de ellas es la prevalente, teniendo presente, junto con los definidos ámbitos competenciales, la razón o fin de la norma atributiva de competencia y el contenido del precepto cuestionado"(...) En todo caso, en esta materia debe tenerse presente, que la cultura es difícil de encuadrar en esquemas precisos, por lo que no sería posible, en abstracto, reconocer todas las competencias sobre la misma en un ente superior porque siempre quedará un espacio, un tipo de actuación, que pertenecerá a los entes menores más directamente ligados a determinados intereses de la comunidad." 341

Fruto de este conflicto jurídico, el Tribunal Constitucional pronunció su Sentencia 17/1991, de 31 de enero, en donde se reconoce las líneas maestras de la distribución competencial entre el Estado y las Comunidades Autónomas, en materia de Patrimonio Histórico.

De esta fundamental sentencia, mencionaremos los principios que han de regir las relaciones Estado- Comunidades Autónomas:

- Existe una competencia concurrente del Estado y de las Comunidades Autónomas en materia de cultura, ya que como el propio Tribunal señala en sus sentencias 49/1984, 157/1985 y 106/87, "la cultura es algo de la competencia propia e institucional, tanto del Estado como de las Comunidades Autónomas",(F.3º).

- La competencia autonómica deberá respetar las potestades atribuidas al Estado "sin que ello implique que la eventual afectación de intereses generales o la concurrencia de otros títulos competenciales del Estado en materia determinada no

341 STC153/1985, de 7 de noviembre, recoge como criterio general el de la finalidad específica a la que la norma pretende atender. 
deban también tenerse presentes como límites que habrá que ponderar en cada caso concreto, (así los títulos que resultan, v. gr. de los números 6 y 8 del artículo 149.1)". (F. $\left.3^{\circ}\right)$.

- En todo caso, "existe un deber general de colaboración entre el Estado y las Comunidades Autónomas que no es preciso justificar mediante preceptos concretos porque es de esencia al modelo de organización territorial del Estado por la Constitución", (F. 4). ${ }^{342}$

Nuestra Comunidad Autónoma Castilla y León, cuya Administración Pública la ostenta la Junta de Castilla y León, a la Dirección General de Patrimonio Cultural dependiente de la Consejería de Cultura y Turismo ${ }^{343}$, se le otorga las competencias, entre otras:

- La dirección de las actuaciones para la protección, conservación y restauración del patrimonio cultural.

- El impulso y desarrollo de investigaciones y proyectos para integrar la innovación en los procesos de conservación y puesta en valor de los bienes integrantes del patrimonio cultural.

- La gestión de las declaraciones de Bienes de Interés Cultural y de las del Inventario de Bienes del Patrimonio Cultural de Castilla y León

- El impulso y supervisión de la actividad de la Comisión de Patrimonio Cultural de Castilla y León y del Consejo de Patrimonio Cultural de Castilla y León, así como la dirección, seguimiento, apoyo y coordinación de las Comisiones Territoriales de Patrimonio Cultural.

\footnotetext{
${ }^{342}$ Opus cit. http://www.iaph.es/revistaph/index.php/revistaph/article/viewFile/209/209

343 Por Decreto 2/2011, de 27 de junio, del Presidente de la Junta de Castilla y León, de Reestructuración de Consejerías
} 
La Comunidad de Castilla y León ${ }^{344}$ tiene en su ámbito territorial competencias legislativas y ejecutivas en materia de patrimonio cultural, de acuerdo con lo que establece la Constitución Española (art.46) y su Estatuto de Autonomía (art.32.2.1). En el desarrollo de esas competencias, la Comunidad de Castilla y León aprobó en el año 2002 la Ley de Patrimonio Cultural, y un conjunto de reglamentos y normas dictados por la Junta y León en la ejecución de estas competencias.

La legislación del Estado, en este sector, cuya norma básica es la Ley del Patrimonio Histórico Español como ya hemos referido en el epígrafe anterior, es de aplicación en lo referente al expolio y exportación de bienes culturales, materias competencia de la Administración General del Estado, así como a los bienes adscritos a esa Administración. Es además supletoria en el ámbito de Castilla y León, en todo aquello que no esté legislado por la Ley Autonómica.

A estas disposiciones se suman las resoluciones y recomendaciones adoptadas por los Organismos Internacionales de los que España es miembro, cuyos principios se han ido incorporando habitualmente a las diversas normas ${ }^{345}$.

Debemos destacar entre la legislación autonómica sobre la materia:

- Ley 12/2002, de 11 de julio, de Patrimonio Cultural de Castilla y León:

\footnotetext{
344 http://www.patrimoniocultural.jcyl.es/web/jcyl/PatrimonioCultural/es/Plantilla100/1284181506987 /

$345 *$ Convención sobre la protección del patrimonio mundial, cultural y natural - UNESCO 1972 Tratado internacional aprobado por la Organización de las Naciones Unidas para la Educación, la Ciencia y la Cultura - UNESCO -, y ratificado por España, que tiene como finalidad promover la identificación, la protección y la preservación del patrimonio cultural y natural de todo el mundo considerado especialmente valioso para la humanidad.

*Convención para la salvaguarda del patrimonio cultural inmaterial - UNESCO La Conferencia General de la UNESCO -, en su 32. a reunión, celebrada en París, aprueba el de octubre de 2003 esta convención que es ratificada por España en el año 2006.
} 
Constituye la norma básica y de referencia en esta materia en la que se definen los bienes integrantes del patrimonio cultural de Castilla y León, se establece su clasificación y los procedimientos para reconocimiento de su relevancia cultural, el régimen de conservación y protección, las características de determinados bienes específicos - patrimonio arqueológico, etnológico, lingüístico, documental y bibliográfico, las medidas de fomento y el régimen sancionador e inspector.

La Ley tiene como finalidad la protección, acrecentamiento y difusión del Patrimonio Cultural de Castilla y León, así como su investigación y transmisión a las generaciones futuras. Contiene para su consecución un conjunto de normas rectoras de la acción administrativa dirigida a la protección y acrecentamiento del Patrimonio Cultural de la Comunidad, y concreta los derechos y deberes concernientes a quienes realicen actuaciones que afecten a los bienes que lo integran.

Nos interesa destacar para nuestro estudio, de este texto legislativo:

"Sin perjuicio de las competencias que correspondan a los demás poderes públicos, son deberes y atribuciones esenciales de la Comunidad de Castilla y León garantizar la conservación de su Patrimonio Cultural, promover su investigación y enriquecimiento, así como fomentar y tutelar el acceso de los ciudadanos a estos bienes".(art.2.2)

"Las entidades locales tienen la obligación de proteger y promover la conservación y el conocimiento de los bienes integrantes del Patrimonio Cultural de Castilla y León que se ubiquen en su ámbito territorial. Los Ayuntamientos comunicarán inmediatamente a la Consejería de la Junta de Castilla y León competente en materia de cultura cualquier hecho o situación que ponga o pueda poner en peligro la integridad de tales bienes o perturbar su función social y adoptarán, en caso de emergencia y dentro de su propio ámbito de actuación, las medidas cautelares necesarias para defender $y$ salvaguardar los bienes de dicho patrimonio que se encuentren amenazados." (art. 3.2) 
Decreto 37/2007, de 19 de abril, por el que se aprueba el Reglamento para la protección del Patrimonio Cultural de Castilla y León, dispone en su introducción:

El artículo 32.1.12 del Estatuto de Autonomía atribuye a la Comunidad de Castilla y León competencia exclusiva en materia de patrimonio histórico, artístico, monumental, arqueológico, arquitectónico y científico, correspondiéndole la potestad legislativa y reglamentaria, así como la función ejecutiva, incluida la inspección, en todo lo referente a dichas materias, que sea de interés para la Comunidad y no se encuentre reservado al Estado.

En el ejercicio de la potestad legislativa se dicta la Ley 12/2002, de 11 de julio, de Patrimonio Cultural de Castilla y León, cuya finalidad es la de proteger, acrecentar y difundir el Patrimonio Cultural de Castilla y León, así como su investigación y transmisión a las generaciones futuras. Pero la Ley no agota por sí sola la regulación en materia de patrimonio cultural, exigiendo para alguno de sus contenidos el correspondiente desarrollo reglamentario.

Así en virtud de la habilitación normativa contenida en la Disposición Final Tercera de la Ley 12/2002, de 11 de julio, se dicta este Decreto que consta de un único artículo que contiene el Reglamento para la protección del Patrimonio Cultural de Castilla y León, estructurado en seis títulos que tratan respectivamente de la organización administrativa, de los Bienes de Interés Cultural e Inventariados, de la conservación y protección de los bienes integrantes del Patrimonio Cultural de Castilla y León, del patrimonio arqueológico, de los espacios culturales y por último del régimen inspector, además de una parte final compuesta por siete disposiciones adicionales, siete transitorias, una derogatoria y dos finales.

El objetivo principal de este Reglamento es el desarrollo de aquellas materias que en la práctica requieren de una pronta regulación. Nos encontramos ante un texto normativo eminentemente práctico para la 
Administración y el ciudadano, que trata de evitar la dispersión y proliferación de normas. Pretende asimismo mejorar el funcionamiento de los órganos encargados de la protección del patrimonio, el procedimiento que han de seguir en su actuación y un mayor acercamiento en su relación con los ciudadanos, lo que en definitiva contribuirá a una mejora de la protección del Patrimonio Cultural de Castilla y León.

El Título I, bajo la rúbrica «Organización administrativa», pretende conseguir una adecuada distribución de las competencias recogidas en la Ley, diferenciando entre organización central, periférica y consultiva. Se crea la Comisión de Patrimonio Cultural de Castilla y León como órgano colegiado de carácter deliberante y decisorio, encargado de la tutela del Patrimonio Cultural de Castilla y León y destinado a asegurar la coordinación administrativa. Se desconcentran algunas competencias en órganos de la Administración periférica de la Comunidad. Se adaptan a la nueva legislación vigente las competencias, procedimientos y funcionamiento de los órganos territoriales encargados de la tutela del Patrimonio Cultural. Se regula la composición, competencias y funcionamiento del Consejo de Patrimonio Cultural de Castilla y León y se modifica la composición y funcionamiento de la ya existente Junta de Valoración y Adquisición de Bienes Culturales, creada por la Ley 10/1994 de 8 de julio, de Museos de Castilla y León, adaptándola a la normativa existente en la actualidad.

El Título II adecua a la Ley la tramitación de los procedimientos que en materia de declaración de Bienes de Interés Cultural se venía realizando, completándola en aquellos extremos que la práctica ha revelado como necesarios. Asimismo se detallan los trámites del procedimiento de inclusión de un bien en el Inventario de Bienes del Patrimonio Cultural de Castilla y León, y se regula la organización y funcionamiento del Registro de Bienes de Interés Cultural y del citado Inventario.

El Título III regula los deberes y obligaciones de todo titular o poseedor de bienes integrantes del Patrimonio Cultural de Castilla y León así como los procedimientos en materia de acceso al Patrimonio Cultural, 
ejercicio de los derechos de tanteo y retracto, expropiación forzosa, ordenación del territorio y evaluación de impacto ambiental, medidas cautelares, declaración de ruina y planeamiento urbanístico.

Con el Título IV, que lleva por rúbrica «Patrimonio Arqueológico», se potencia la protección y conservación del Patrimonio Arqueológico en la Comunidad y se adecua a la normativa vigente la materia relacionada con la actividad arqueológica, desarrollando lo relativo al régimen de autorizaciones administrativas para la realización de actividades arqueológicas, el procedimiento para la tramitación de su concesión, así como el registro de lugares arqueológicos y el régimen de los hallazgos casuales.

El Título $V$ desarrolla la exigencia que la Ley prevé para los espacios culturales, como es el procedimiento de declaración de espacio cultural de aquellos inmuebles declarados Bienes de Interés Cultural que, por sus especiales valores culturales y naturales, requieran para su gestión y difusión una atención preferente; el contenido del plan de adecuación y usos y el funcionamiento y composición del órgano gestor responsable del cumplimiento de este último.

Y finalmente el Título $\mathrm{VI}$, que regula en materia de régimen inspector todo lo relacionado con la competencia, el objeto de la actividad inspectora, las funciones, facultades y deberes del personal encargado de la actividad inspectora, el contenido de las actas de inspección y de la tarjeta de identificación, entre otros.

Siguiendo la línea de investigación nos interesa sobremanera la literalidad de lo preceptuado sobre procedimiento de declaración de Bien de Interés Cultural, al ser ese uno de nuestros intereses principales.

“Artículo 39 Iniciación de procedimiento

1. La iniciación del procedimiento se realizará de oficio mediante resolución de la Dirección General competente en materia de de Patrimonio y Bienes Culturales, pudiendo ser promovida a instancia de cualquier persona física o jurídica. 
2. La petición se presentará en la oficina que realice las funciones de registro de la Dirección General competente en materia de Patrimonio y Bienes Culturales, o en cualquiera de los lugares previstos en el artículo 38.4 de la Ley de Régimen Jurídico de las Administraciones Públicas y del Procedimiento Administrativo Común.

3. Con anterioridad al acuerdo de incoación o no incoación, la Dirección General competente en materia de Patrimonio y Bienes Culturales podrá recabar toda aquella información que precise sobre el bien cuya declaración se pretende y realizará las gestiones y actividades de investigación e inspección necesarias para alcanzar una adecuada valoración del mismo. Asimismo, podrá recabar informe de los servicios técnicos, de la Comisión Territorial de Patrimonio Cultural, de órganos e instituciones consultivas o de otros Organismos e Instituciones que considere oportunos, según la naturaleza del bien del que se trate.

Artículo 40 Acuerdo de incoación, notificación, publicación y efectos

1. Concluida la información previa, se emitirá la decisión sobre la incoación del expediente, mediante resolución del titular de la Dirección General competente en materia de Patrimonio y Bienes Culturales.

2. Si el procedimiento se hubiera promovido por persona física o jurídica, la denegación de la incoación será motivada y notificada a los solicitantes. Contra dicha resolución cabe interponer recurso de alzada ante el titular de la Consejería competente en materia de Cultura.

3. Se entenderá desestimada la solicitud de incoación si en el plazo de seis meses desde la fecha en que hubiera sido recibida la petición, el titular de la Dirección General competente en materia de Patrimonio y Bienes Culturales no hubiera dictado acuerdo de incoación.

4. El acuerdo de incoación del expediente de declaración deberá contener una descripción que identifique suficientemente el bien y en el caso de monumentos y jardines históricos, propuesta de delimitación de un entorno que garantice de forma adecuada su protección, debiéndose relacionar las 
partes integrantes, pertenencias, accesorios y los bienes muebles cuya inclusión en la declaración se pretenda realizar.

Asimismo se deberá hacer constar, en su caso, la posibilidad de que, si durante la tramitación del procedimiento se demostrara que el bien no reúne de forma singular y relevante las características del artículo 1.2 de la Ley 12/2002, de 11 de julio, pero mereciera una especial consideración por su notable valor cultural y por tanto susceptible de ser incluido en el Inventario de Bienes del Patrimonio Cultural de Castilla y León, se continuará el expediente siguiendo los trámites previstos para su inclusión en dicho Inventario, conservando los trámites realizados.

5. El acuerdo de incoación será notificado a los interesados advirtiéndoles de lo previsto en el apartado octavo del presente artículo. Asimismo se comunicará al Ayuntamiento o Ayuntamientos en cuyo término municipal esté ubicado el bien. Cuando el procedimiento tenga por objeto la declaración de Bien de Interés Cultural con la categoría de Conjunto Histórico, Sitio Histórico, Zona Arqueológica, Conjunto Etnológico o Vías Históricas, la notificación se efectuará mediante la publicación del acuerdo en el «Boletín Oficial de Castilla y León» y su exposición en el tablón de edictos del Ayuntamiento o Ayuntamientos afectados.

6. El acuerdo de incoación se publicará en el «Boletín Oficial de Castilla y León» y en el «Boletín Oficial del Estado», sin perjuicio de su eficacia desde la notificación.

7. Dicho acuerdo de incoación deberá comunicarse al Registro de Bienes de Interés Cultural de Castilla y León para su anotación preventiva, dándose cuenta al mismo tiempo al Registro General de Bienes de Interés Cultural dependiente de la Administración General del Estado.

8. La iniciación del procedimiento determina, respecto al bien afectado la aplicación inmediata y provisional del régimen de protección que la Ley 12/2002, de 11 de julio, prevé para los bienes ya declarados. En caso de bienes inmuebles, la iniciación determinará la suspensión del otorgamiento de nuevas licencias municipales de parcelación, edificación o demolición en 
las zonas afectadas, así como de los efectos de las ya otorgadas. Dicha suspensión se mantendrá hasta la resolución del expediente o hasta que se declare la caducidad del mismo.

Artículo 41 Contenido del expediente de declaración

La Dirección General competente en materia de Patrimonio y Bienes Culturales ordenará e instruirá el expediente de declaración de Bien de Interés Cultural, que deberá contener los datos referidos en el Anexo I de este Decreto asegurándose que en el mismo obren las siguientes especificaciones:

a) Descripción clara y exhaustiva, con documentación gráfica, del bien objeto de la declaración, que facilite su correcta identificación.

b) En caso de inmuebles, las partes integrantes, pertenencias, accesorios y bienes muebles que, por su vinculación con el inmueble, hayan de ser incorporados a la declaración, los cuales se considerarán inseparables del inmueble declarado. Además habrán de figurar definidas sus relaciones con el área territorial a la que pertenezca y, en el caso de monumentos o jardines históricos, los elementos que conformen su entorno, que estará constituido por los inmuebles y espacios cuya alteración pudiera afectar a los valores propios del bien, su contemplación, apreciación o estudio.

c) La determinación de la compatibilidad del uso al que se dedique el bien que se pretenda declarar con su correcta conservación. Si el uso al que se viniera destinando el referido bien fuese incompatible con la adecuada conservación del mismo, podrá establecerse asimismo su cese o modificación.

d) Cuando se considere necesario para la adecuada conservación de los bienes declarados se incorporarán a la declaración criterios básicos, de carácter específico, que regirán las intervenciones sobre los mismos. 
Artículo 42 Informes

1. La Dirección General competente en materia de Patrimonio y Bienes Culturales recabará informe favorable de al menos dos de las instituciones consultivas a que se refiere el artículo 6 apartado 2 de la Ley 12/2002, de 11 de julio.

2. Transcurridos tres meses desde la solicitud del informe sin que este hubiera sido emitido, se entenderá favorable a la declaración de Bien de Interés Cultural.

Artículo 43 Trámite de información pública

Cuando el expediente de declaración de Bien de Interés Cultural tenga por objeto un bien inmueble, deberá abrirse un periodo de información pública por un plazo mínimo de un mes y se dará audiencia al Ayuntamiento o Ayuntamientos correspondientes.

Artículo 44 Trámite de audiencia

Instruido el expediente e inmediatamente antes de redactar la propuesta de resolución, se dará audiencia a los interesados para que en el plazo de diez días formulen las alegaciones y presenten los documentos que consideren oportunos.

Artículo 45 Conversión del procedimiento

Si durante la tramitación del procedimiento se demostrara que el bien no reúne de forma singular y relevante las características del artículo 1.2 de la Ley 12/2002, de 11 de julio, pero mereciera una especial consideración por su notable valor cultural y por tanto susceptible de ser incluido en el Inventario de Bienes del Patrimonio Cultural de Castilla y León, el titular de la Dirección General competente en materia de Patrimonio y Bienes Culturales dispondrá la continuación del expediente con los trámites previstos para la inclusión en dicho Inventario, conservándose los trámites realizados, comunicándose a los interesados, al Registro de Bienes de Interés Cultural de Castilla y León y al Registro General de Bienes de Interés Cultural dependiente de la Administración General del Estado. 
Artículo 46 Terminación del procedimiento

1. Vistas las alegaciones y documentación presentadas, se emitirá propuesta de resolución del procedimiento por el titular de la Consejería competente en materia de Cultura.

2. Si en algún momento de la tramitación del procedimiento se dedujera que los valores del bien no poseen relevancia suficiente para su declaración como Bien de Interés Cultural, el titular de la Consejería competente en materia de Cultura podrá dictar resolución denegatoria que será motivada y notificada a los interesados.

Dicha resolución deberá comunicarse al Registro de Bienes de Interés Cultural de Castilla y León para la cancelación de la anotación preventiva, dándose cuenta al mismo tiempo al Registro General de Bienes de Interés Cultural dependiente de la Administración General del Estado.

3. La declaración de Bien de Interés Cultural se efectuará mediante Acuerdo de la Junta de Castilla y León. En él deberá hacerse constar los datos y especificaciones recogidos en el artículo 41.

4. La resolución del procedimiento por cualquiera de las restantes formas previstas en la Ley se efectuará mediante Orden del titular de la Consejería competente en materia de Cultura y a propuesta del titular de la Dirección General competente en materia de Patrimonio y Bienes Culturales.

5. El procedimiento habrá de resolverse en el plazo máximo de veinticuatro meses a partir de la fecha de su incoación. De producirse la caducidad del expediente, el procedimiento no podrá volver a iniciarse en los tres años siguientes, salvo que lo solicitase alguna de las instituciones consultivas reconocidas por la Comunidad Autónoma o el propietario del bien.

Artículo 47 Notificación y publicación del Acuerdo de declaración

1. El Acuerdo de declaración de Bien de Interés Cultural será notificado a los interesados y deberá comunicarse al Ayuntamiento o Ayuntamientos en cuyo término municipal esté ubicado el bien, si éste fuera inmueble. Asimismo, y 
sin perjuicio de su eficacia desde la notificación, deberá publicarse en el «Boletín Oficial de Castilla y León» y en el «Boletín Oficial del Estado».

2. En el supuesto de conjuntos históricos, sitios históricos, zonas arqueológicas, conjuntos etnológicos o vías históricas, la notificación del Acuerdo de declaración de Bien de Interés Cultural se efectuará mediante la publicación del mismo en el «Boletín Oficial de Castilla y León», en el Boletín Oficial del Estado y su exposición en el tablón de edictos del Ayuntamiento o Ayuntamientos afectados.

3. Publicado el Acuerdo de declaración de Bien de Interés Cultural se procederá de oficio a su inscripción definitiva en el Registro de Bienes de Interés Cultural de Castilla y León y se comunicará al Registro General de Bienes de Interés Cultural del Estado. Cuando se trate de monumentos o jardines históricos, se instará de oficio la inscripción de la declaración en el Registro de la Propiedad, mediante la presentación de la correspondiente certificación administrativa expedida por la Dirección General competente en materia de Patrimonio y Bienes Culturales.

Artículo 48 Procedimiento para dejar sin efecto una declaración de Bien de Interés Cultural

1. La declaración de un Bien de Interés Cultural, en todo o en parte, únicamente podrá dejarse sin efecto siguiendo los mismos trámites establecidos para su declaración.

2. La iniciación del procedimiento se realizará de oficio, pudiendo ser promovida a instancia de cualquier persona física o jurídica, en los supuestos de desaparición del bien o pérdida de los valores culturales que motivaron su declaración.

3. En la tramitación deberá recabarse informe favorable de al menos dos de las instituciones consultivas a que se refiere el artículo 6 apartado 2 de la Ley 12/2002, de 11 de julio; deberá abrirse un periodo de información pública por un plazo mínimo de un mes y se dará audiencia al Ayuntamiento o Ayuntamientos en cuyo término municipal esté ubicado el bien al que se refiera el procedimiento, en los supuestos de que se trate de un bien 
inmueble. Inmediatamente antes de redactar la propuesta de resolución, se dará audiencia a los interesados para que en el plazo de diez días formulen las alegaciones y presenten los documentos que consideren oportunos.

4. El Acuerdo por el que se deja sin efecto una declaración de Bien de Interés Cultural, será notificado a los interesados y deberá comunicarse al Ayuntamiento o Ayuntamientos en cuyo término municipal esté ubicado el bien, si éste fuera inmueble. Asimismo, y sin perjuicio de su eficacia desde la notificación, deberá publicarse en el «Boletín Oficial de Castilla y León» y en el «Boletín Oficial del Estado». En los supuestos de conjuntos históricos, sitios históricos, zonas arqueológicas, conjuntos etnológicos o vías históricas, la notificación se efectuará mediante la publicación del Acuerdo en el «Boletín Oficial de Castilla y León», en el «Boletín Oficial del Estado» y su exposición en el tablón de edictos del Ayuntamiento o Ayuntamientos afectados.

5. Se deberá remitir una copia del Acuerdo por el que se deja sin efecto una declaración de Bien de Interés Cultural al Registro de Bienes Culturales de Castilla y León y al Registro General de Bienes de Interés Cultural dependiente de la Administración General del Estado. Asimismo, se instará de oficio la cancelación de la declaración inscrita en el Registro de la Propiedad mediante la presentación de la correspondiente certificación administrativa expedida al efecto por la Dirección General competente en materia de Patrimonio y Bienes Culturales."

Apuntar que de la interpretación literal de la disposición reglamentaria, se desprende un celo por la regulación de los bien de interés inmueble sobre los muebles, también como hemos apuntado la catalogación realizada y con publicidad de los bienes de interés cultural de Castilla y León son todos sobre bienes inmuebles. No obstante la regulación es clara sobre el procedimiento e instancias preceptivas que debe seguir el expediente declarativo de un bien mueble para ser declarado como bien de interés cultural de Castilla y León. 


\subsection{Administración Pública Local: Salamanca}

Bajo el concepto de Administración Local ha de incluirse la estructura tipificada, a nivel general, en el artículo $3^{\circ}$ de la Ley de Bases de Régimen Local de 2 de abril de 1985 (pese a utilizarse la terminología sinónima de "Entidades locales"), en desarrollo de las previsiones constitucionales de los artículos 137,140 y 141.3

El artículo $3^{\circ}$ de la Ley 7/1985, de 2 de abril, reguladora de las Bases del Régimen Local dispone:

"1. Son entidades locales territoriales:

a) El municipio.

b) La Provincia.

c) La isla en los archipiélagos balear y canario.

2. Gozan, asimismo, de la condición de entidades locales:

a) Las entidades de ámbito territorial inferior al municipal, instituidas o reconocidas por las Comunidades Autónomas, conforme al artículo 45 de esta Ley.

b) Las comarcas u otras entidades que agrupen varios municipios instituidas por las Comunidades Autónomas de conformidad con esta Ley y los correspondientes Estatutos de Autonomía.

c) Las áreas metropolitanas.

d) Las mancomunidades de municipios."

La primitiva Ley sobre defensa, conservación y acrecentamiento del Patrimonio Histórico-Artístico Nacional, de 13 de mayo de 1933, concibió un sistema en el que se primaba la actuación del Estado, a través de las 
funciones asignadas a la entonces Dirección General de Bellas Artes y demás órganos administrativos dependientes o relacionados con la misma. Dentro de ese esquema legal, a los Ayuntamientos se les atribuían funciones de complemento y auxilio a las intervenciones que realizase el Estado en el ámbito de la conservación y protección del patrimonio cultural históricoartístico. $^{346}$

La posición de las Administraciones Locales en la legislación sobre patrimonio histórico se ha caracterizado por ser consideradas como meros órganos colaboradores o cooperadores del Estado y de las Comunidades Autónomas en esa materia. ${ }^{347}$

Esa misma conclusión se desprende de la doctrina jurisprudencial mayoritaria, lo que en la práctica se traduce en una subordinación o condicionamiento de las Administraciones Locales. Un testimonio significativo en ese sentido se recoge en la sentencia de 25 de enero de 2000 (Arz. 662l2000), en cuyo Fundamento de Derecho Tercero, in fine, se afirma:

"(...) ya que sobre la materia del Patrimonio Histórico Artístico, como se ha referido y la Ley 16/1985 precisa, los Ayuntamientos sólo son órganos cooperadores y no tienen facultades decisorias, aunque sí están obligados a poner en conocimiento del órgano competente cualquier amenaza, daño o perturbación sobre los bienes a que se refiere la Ley 16/1985 e incluso a adoptar medidas cautelares, pero no obviamente a decidir, ni menos a utilizar las potestades que en materia de concesión de licencias tienen, para sustituir al órgano designado por la ley, en materia de ejecución, conservación y custodia del Patrimonio Histórico Artístico"

\footnotetext{
346 Aldanondo Salaverría, I.: "Las Comunidades Autónomas, el Estado y los bienes culturales eclesiásticos", Revista lus Canonicum, (1984), páginas 301 a 311.

${ }^{347}$ Benitez de Lugo, F.: El patrimonio cultural español. (Aspectos jurídicos, administrativos y fiscales), Ed. Comares (1995), página 87.
} 
La traducción normativa de ese postulado se consagraba en el artículo 36 de la Ley de 13 de mayo de 1933, en donde se afirmaba:

"Todos los Municipios españoles están obligados a velar por la perfecta conservación del patrimonio histórico-artístico existente en su término municipal. Para ello enviarán, en el plazo de seis meses, al Fichero Artístico informes detallados conforme al artículo 67 de esta Ley; además deberán denunciar en todo caso a la Junta local del Tesoro Artístico de su demarcación o a la Junta Superior del Tesoro Artístico los peligros que corran los edificios u objetos históricos por derrumbamiento, deterioro o venta, acudiendo en caso de urgencia a tomar las primeras medidas para evitar el daño. También están obligados a contribuir en la proporción que fije el Reglamento a la reparación de las construcciones.

El incumplimiento de cualquiera de estas obligaciones privará al Municipio de todo derecho sobre el inmueble u objeto de que se trate, que el Gobierno hará trasladar, cuando esto sea posible(...)"

Para completar el esquema competencial administrativo previsto en el ordenamiento jurídico, hemos de referirnos a la Administración Local, a la cual, el artículo 25.1.e) de la Ley 7/1985, de 2 de abril, reguladora de las bases del Régimen Local atribuye competencias en materia de patrimonio histórico-artístico de conformidad a los términos que al efecto señalen la legislación estatal y autonómica.

Este contenido ha sido puntualizado por el Fundamento Noveno de la Sentencia del Tribunal Constitucional número 17/1991, ya citado, en el sentido de que "las competencias y funciones que en esta materia puedan corresponder a aquellas (las Administraciones Locales) se determinarán por la legislación estatal o por la legislación autonómica atendiendo a las constitucional y estatutariamente determinadas para cada Administración pública. No es, pues, que la Ley atribuya esa competencia a los Ayuntamientos, sino que recuerda su deber constitucional de cooperación en este caso con quien ejerza las funciones de defensa, protección, 
conservación y custodia de aquellos bienes, mas no sólo el Estado sino todos los organismos competentes".

En este sentido, el artículo $7^{\circ}$ de la Ley 16/1985 contempla la actuación de los Ayuntamientos bajo un principio de cooperación orientado en un cuádruple sentido:

- Adoptando medidas para evitar el deterioro, pérdida o destrucción del Patrimonio Histórico.

- Notificando a los organismos competentes para la ejecución de la Ley cualquier amenaza, daño o perturbación de la función social de los bienes culturales.

- Comunicar las dificultades y necesidades que tengan para el cuidado de los bienes.

- Las funciones que les atribuyan expresamente la Ley 16/1985 (por ejemplo, la expropiación forzosa con carácter supletorio en el sentido previsto en el artículo 37.3 de la norma estatal). ${ }^{348}$

Al tratarse de la joyería tradicional charra, hemos de apuntar que no se vincula a un solo ayuntamiento o municipio sino a todos y a cada uno de ellos, por cuanto es patrimonio de la provincia de Salamanca ${ }^{349}$. Por ello, incompleto quedaría este apartado si no aludiéramos a la Institución Local que representa y vela por todos los municipios de la provincia: la Diputación Provincial, modelo administrativo tan cuestionado por unos ${ }^{350}$ y tan defendido por otros ${ }^{351}$, compartiendo lo argumentado por RIVERO ORTEGA cuando dice: "Evaluar críticamente la utilidad de nuestras instituciones no es en modo alguno un ejercicio innecesario. Si algo positivo ha tenido la propuesta de supresión de las diputaciones es el haber despertado un movimiento de defensa de su razón de ser y explicación de los motivos para

\footnotetext{
${ }^{348}$ Opus cit. http://www.iaph.es/revistaph/index.php/revistaph/article/viewFile/209/209

349 En este sentido ver obra de SANCHEZ BLANCO, A, sobre La Organización Intermunicipal, ISSBN:

978-84-96440-47-0

${ }^{350}$ Por todos Juan Luis Redondo, en http://hayderecho.com/2013/10/24/la-diputacion-provincialesa-gran-desconocida-con-algunos-numeros-para-empezar-a-conocerla/ (14/1/2015)

${ }^{351}$ Rivero Ortega R. , Catedrático de Derecho Administrativo de la Universidad de Salamanca
} 
su mantenimiento. En cierto modo, el ataque a las estructuras provinciales puede propiciar el paradójico efecto de su fortalecimiento.", a nuestro juicio es esta Institución pública, auxiliando a los Ayuntamientos en una de sus labores, quien debe coger las riendas del reconocimiento de una justicia social, de un derecho, de un apuesta en valor de la joyería tradicional charra de todo el pueblo salmantino.

Por otro lado y de conformidad a lo establecido en el artículo 36 LRBRL son competencias propias de las Diputaciones Provinciales ${ }^{352}$ :

- Las que les atribuyan, en este concepto, las leyes del Estado y de las Comunidades Autónomas.

- En todo caso, entre otras:

* La coordinación de los servicios municipales entre sí para la garantía de la prestación integral y adecuada a que se refiere el apartado a) del número 2 del artículo 31 (Asegurar la prestación integral y adecuada en la totalidad del territorio provincial de los servicios de competencia municipal)

*La asistencia y cooperación jurídica, económica y técnica a los Municipios, especialmente los de menor capacidad económica y de gestión.

*En todo caso garantizará en los municipios de menos de 1.000 habitantes la prestación de los servicios de secretaría e intervención.

*La prestación de los servicios de administración electrónica en los municipios con población inferior a 20.000 habitantes.

*Darán soporte a los Ayuntamientos para la tramitación de procedimientos administrativos y realización de actividades materiales y de gestión, asumiéndolas cuando aquéllos se las encomiende.

Sin olvidarnos que entre las competencias encomendadas a los municipios por la Ley 7/1985, de 2 de abril, reguladora de las Bases del

${ }^{352}$ Ley 7/1985, de 2 de abril, reguladora de las Bases del Régimen Local 
Régimen Local ${ }^{353}$ es la protección y gestión del Patrimonio histórico, como derechos de los ciudadanos ${ }^{354}$.

La Diputación Provincial de Salamanca en su página web institucional, recoge una pestaña dedicada a la cultura ${ }^{355}$ donde publicita la actividad del Instituto de Identidades (IDES) a través de tres áreas de trabajo (de documentación, didáctica y de consolidación y difusión) y un servicio de publicaciones, no encontrando mención, trabajo o documento alguno (al menos en el barrido por nosotras realizado) sobre la joya tradicional charra ni sobre el emblemático Botón Charro, aun siendo elemento identificativo por excelencia de la provincia de Salamanca.

Asignatura pendiente de las Instituciones públicas salmantinas constituye en aplicación de la norma, ponen en valor formal nuestra joyería tradicional y responsabilidad del pueblo salmantino su exigencia.

\section{2. "ARS GEMMARIA NOVA": un proyecto de actualización de la joya tradicional para la mujer del S. XXI.}

Desde el primer momento en que decidimos afrontar este estudio, de entre todos los objetivos planteados uno de los prioritarios fue poner en valor unas joyas de innegable belleza y técnica excepcional por su delicadeza, finura, elegancia... al día, que llegaron a enamorar a la mismísima Emperatriz del Japón ${ }^{356}$ en su primer viaje a Salamanca y que veíamos que se encontraban en peligro cierto de extinción.

\footnotetext{
${ }^{353}$ Art.25.2 "El Municipio ejercerá en todo caso como competencias propias, en los términos de la legislación del Estado y de las Comunidades Autónomas, en las siguientes materias: a)(...) Protección y gestión del Patrimonio histórico.(...)

${ }^{354}$ RIVERO ORTEGA, R. Los derechos de los ciudadanos en sus relaciones con la Administración en España", Revista de la Facultad de Derecho de la Universidad Católica Andrés Bello (Venezuela), 2009 ${ }^{355}$ http://www.dipsanet.es/cultura/

${ }^{356}$ En el 1988 la entonces princesa Michiko pasó por nuestras aulas como estudiante de español. En 1994 los emperadores, encargaron una copia de las fachadas de la Universidad Antigua, y de la fachada Oeste de la Catedral Nueva, llevándoselas al Japón donde se creó el "Salamanca Hall" en la ciudad de Gifu. Decidieron junto con el entonces Rector de la USAL Ignacio Verdugo, abrir un centro destinado a favorecer la relación entre los países.

En 1999 se inauguró el centro, y se inauguró la sala de exposiciones "Emperatriz Michiko", la única autorizada en el mundo hasta hoy por la Emperatriz para llevar su nombre.
} 
Le suponíamos a esta joyería, el valor de ser la única herencia de la mujer rural del conocido Campo Charro. De esa mujer, que sin nombre ni apellidos, se esforzó in extremis para poder dejar su heredad a sus hijas, a sus nietas...y así sucesivamente.

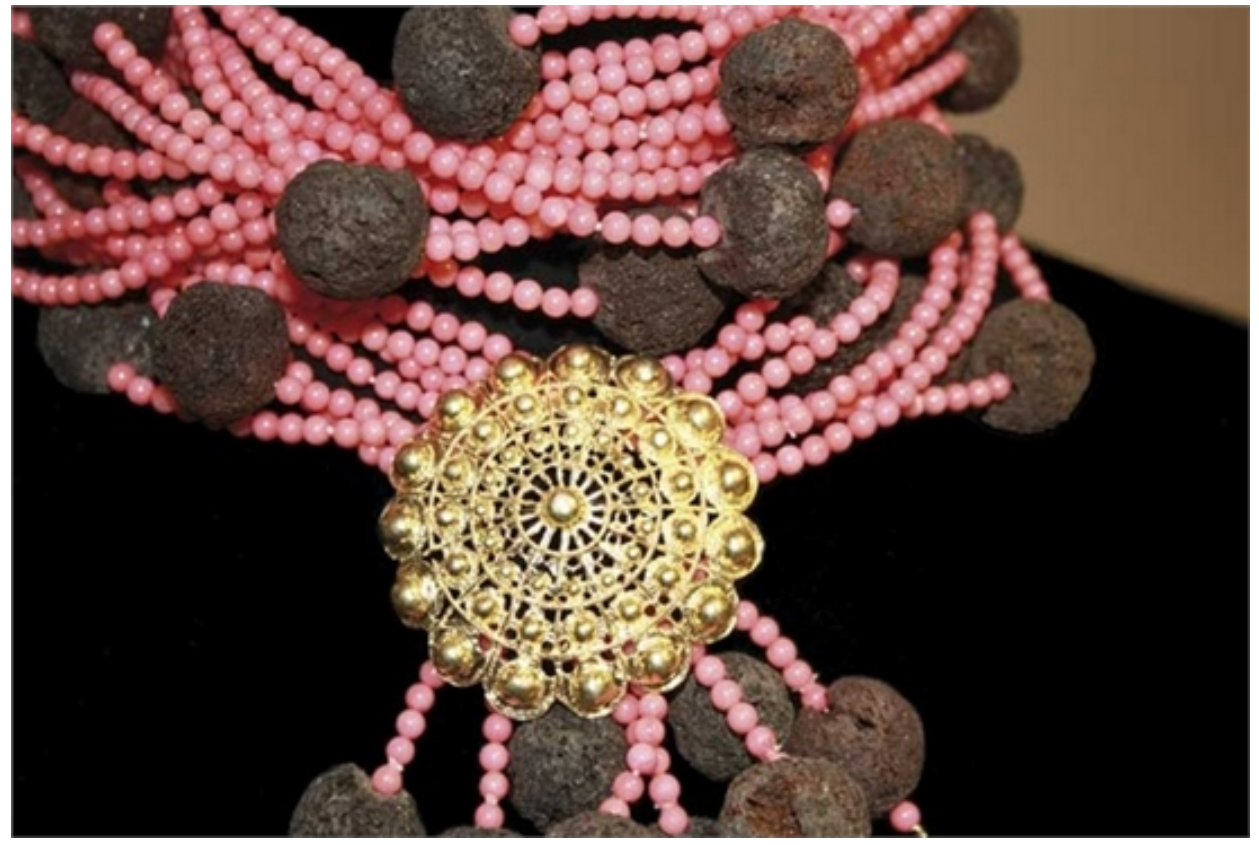

Éramos conscientes desde el principio del desprestigio y escasa consideración en la que habían caído estos objetos, que de no haber sido por las y los abanderados del Traje Charro, habrían llevado un destino más bien trágico y nada alentador.

No entendíamos como objetos, que en otros tiempos nos identificaron, estaban postergados al ámbito del "recuerdo típico de Salamanca" ocupando un escalafón muy muy inferior al embutido de Guijuelo o a los famosos dulces conocidos como "Chochos Típicos de Salamanca" o al famoso "Hornazo Salmantino".

Hemos de reconocer que encontrar en las tiendas de souvenires, de las muchas que tenemos en nuestra ciudad, reproducciones que nada tienen que ver con el valor real de estos objetos, nos dolía en lo más profundo del corazón. Encontrarlos entre la amalgama de objetos insustanciales y 
abigarrados unos con otros, nos ofendía a los ojos que veían en todos ellos la herencia de nuestras antepasadas.

Lo consideramos como un ataque a nuestra identidad, lo que conllevaba la lógica indignación contra nuestras Instituciones que no hacían nada por evitar ese descalabro, que suponía a nuestro parecer no protegerlo en absoluto, y al que sin remedio estaba abocado esta parte del patrimonio femenino local.

Fue entonces cuando nos preguntamos qué estaba sucediendo para que algo tan hermoso y de lo que en una etapa muy larga e importante de nuestra historia nos había representado y enorgullecido, hubiera caído en semejante desgracia?. En el documento ${ }^{357}$ que aportamos, en la introducción que hace el Comisario ${ }^{358}$ de la misma alude concretamente a este aspecto.

Lo primero que detectamos fue que había un desconocimiento general de nuestro patrimonio joyero tradicional, sus técnicas y sus imbricaciones con el territorio salmantino.

En segundo lugar, nos preguntamos si como mujeres del Siglo XXI nos pondríamos para nuestra vida diaria estas piezas igual que se las ponían las abuelas. La respuesta fue indudable: NO.

En tercer lugar, veíamos claro que estos objetos se habían quedado anclados en el traje regional. Si nosotras no vestíamos traje regional a diario, lógicamente tampoco lo haríamos con su complemento o aderezo.

En cuarto lugar, éramos conscientes del desprestigio de estas piezas por las propias mujeres de esta tierra, no por todas por supuesto, pero sí por la gran mayoría de las jóvenes generaciones que se identificaban más con el osito de Tous que con su Botón Charro o cualquiera de las piezas de nuestra joyería tradicional.

\footnotetext{
357 Anexo DVD, Catálogo Exposición “Ars Gemmaria Nova”(archivo pdf)

${ }^{358}$ El Comisario de la Exposición fue el arquitecto D. Fernando Población Íscar.
} 
En quinto lugar, si la fachada de la Universidad de Salamanca es mucho más que la rana, nuestro patrimonio joyero tradicional era más que el denostado Botón Charro.

Frente a estas consideraciones fue por lo que decidimos hacer una labor de empresa, para dar a conocer su valor real e histórico de este patrimonio femenino y ponerlo al día. Solamente desde el conocimiento, estudio, innovación y desarrollo, se pueden hacer propuestas de inversión serias de futuro y reivindicar unos objetos que van mucho más allá de una mera pieza.

Consideramos que caminos deberíamos tomar para que nosotras mismas pudiéramos volver a ponernos sin prejuicios, estas piezas. Fue cuando empezamos a estudiarlas con otros ojos, para adaptarlas a los gustos y la vida de la mujer del S.XXI., una mujer que ha cambiado, no solo los usos de los objetos sino que ha cambiado sus hábitos de vida, incorporada al mundo del trabajo, con poder adquisitivo por primera vez para comprarse sus complementos, que la gusta cambiar con asiduidad los objetos que la adornen, que sale de casa a las siete de la mañana y muchas veces son las once de la noche y no ha regresado. Que comparte sus complementos más con la bisutería que con la joyería...

La tarea no era fácil y parecía imposible poner estos objetos en la preferencia del gusto femenino.

Cuanto más investigábamos y más sabíamos de nuestro patrimonio más necesidad teníamos de darlo a conocer y ponerlo en valor. Cada paso que dábamos en la investigación, ésta nos desvelaba muchas más raíces del tiempo de lo que en un principio pensábamos. Se estaba abriendo ante nosotros un mundo nuevo que se debía proteger para no perder y poderlo trasmitir a las generaciones venideras, de forma atractiva, para que ellas estuvieran tan orgullosas de esa herencia como lo estuvieron nuestras madres, abuelas, tatarabuelas... 
Fue entonces cuando nos surge la idea de la "descontextualización de los objetos" 359 . En el arte moderno ${ }^{360}$ este concepto no es nuevo, aunque si es reciente. Empezaron las preguntas ¿Por qué los objetos han de estar sujetos "per se" a un determinado contexto? ¿Por qué si otras artes habían sido capaces de decostruirse y fusionarse con otros elementos y había funcionado por qué no iba a suceder lo mismo con la joyería tradicional? ¿Por qué si había triunfado la deconstrucción del cocido, base de la dieta mediterránea, en los mejores restauradores, por qué no iba a triunfar la deconstrucción de nuestra joyería tradicional? Y si ello nos había llevado a poner de moda nuestras más antiguas recetas por qué no iba a suceder lo mismo con nuestros antiguos objetos joyeros. $Y$ si se había acuñado el término "Nouvelle cuisine" ${ }^{361}$ (nueva cocina) porque no acuñar nosotros "Nouveau bijou" ${ }^{362}$ (nueva joya) como eje trasformador y exportable a todas las joyerías tradicionales del territorio Ibérico.

Lo que siempre tuvimos muy muy claro que al igual que en la nueva cocina no se alteraban para nada los ingredientes tradicionales, en nuestro caso no se alteraría para nada la forma de los objetos, ya que ello supondría un ataque en toda regla a la tradición y al significado intrínseco y extrínseco de cada objeto.

Desgraciadamente, hemos sido testigos de alteraciones subjetivas en la forma e incluso reinterpretaciones de los objetos como bandera de modernidad, y el resultado, lejos de ser interesante, se ha convertido en una verdadera aberración respecto del original y de la tradición.

En nuestro proyecto tan solo pretendíamos y pretendemos, separar aquello que en su construcción se hace en diferentes piezas y que luego se

\footnotetext{
${ }^{359}$ MEDERUELO, J,Descontextualizar,art.El Pais, 22-nov-2003.

${ }^{360}$ BALDACCI, P,Teoría y Método de Giorgio De Chirico, Cahiers du Musée Nacional d’art Moderne, № 11. París, 1983.

${ }^{361}$ www.wikipedia.org. El término "nouvelle cuisine" fue inventado por los críticos gastronómicos Henri Gault y Christian Milleau. La nouvelle cuisine se hizo popular a fines de los 1970s y en los 1980 s.

362 "Nouvelle bijoux" Término acuñado por nosotros por primera vez en la historia, implica las mismas concepciones de levedad y transformación que el gastronómico referido a la cocina tradicional pero con la diferencia de para nuestro caso, este término está referido a la joyería tradicional.
} 
ensamblaban. De esta manera se abarata la pieza resultante y por otro lado se quita la importancia psicológica de la joya como elemento grande y de gran valor.

Pero hay que puntualizar que si la pieza en su filosofía originaria era llevar elementos colgantes, como es el caso de la tembladera, lo que hacemos es sustituir los pendentiles por piedras colgantes o cualquier otro tipo de elemento que haga la misma o parecida función.

Cuando el proyecto conceptual estaba perfectamente definido, nos pusimos en contacto con una extraordinaria artesana y diseñadora de joyas Verónica Marín Gómez de Liaño ${ }^{363}$, a la que planteamos este ambicioso proyecto de recuperación y puesta en valor de nuestro patrimonio joyero tradicional. Si bien en un principio le supuso una duda importante, no tardó en encontrar los caminos de actualización y fusión con otros elementos que engrandecieran y dieran vida actual a objetos antiguos. Desde aquí reconocemos la extraordinaria colaboración en todo este proyecto.

El modo de trabajar consistía y consiste en bucear y en encontrar piezas, que una vez reproducidas por el oribe, (el artesano joyero encargado de la Microfusión o el joyero), nosotras las estudiábamos, veíamos e investigábamos las posibilidades estéticas y compositivas de la pieza y posteriormente las descontextualizábamos para las darlas una función y una visión distinta a la que tradicionalmente ocupaban en el traje. Así fue como hicimos dentro de Exposición una parte dedicada exclusivamente a las Reinas que habían reinado en España (no consortes) a lo largo de la Historia, que curiosamente la mayor parte de ellas fueron Castellanas.

Tenemos que mencionar de manera muy especial al joyero salmantino Aurelio ${ }^{364}$, que siempre ha puesto y pone a nuestra disposición la

\footnotetext{
${ }^{363}$ Marín Gómez de Liaño, Verónica. Artesana titulada por la Comunidad Autónoma de Castilla y León.

Llevamos trabajando en equipo para este proyecto en Salamanca desde 2005.

${ }^{364}$ Aurelio Díez Melchor. Joyero desde los catorce años, lleva ejerciendo la profesión desde hace cincuenta años en Salamanca. Es un gran conocedor de la joyería Charra. Realiza todos los trabajos de la joyería charra: talla, filigrana y Microfusión. Es presidente de la Asociación de Joyeros y
} 
multitud de moldes de Microfusión que tiene de la joyería charra, ya que él es uno de los joyeros salmantinos que siempre ha tenido en lugar preferente de su trabajo la dedicación a la joyería charra.

De esta manera subimos hebillas de zapatos al cuello de la mujer, como vemos en el dibujo ${ }^{365}$ adjunto, haciendo un collar fusionado con amatistas de distintos tamaños y cintas de raso consiguiendo una pieza de gran belleza y tremendamente moderna y vanguardista. Tal fue el resultado que incluso la pieza perdía su funcionalidad originaria, para pasar a otro nivel en el concepto estético. Una gran parte del público no reconocía en el collar una hebilla de zapato.

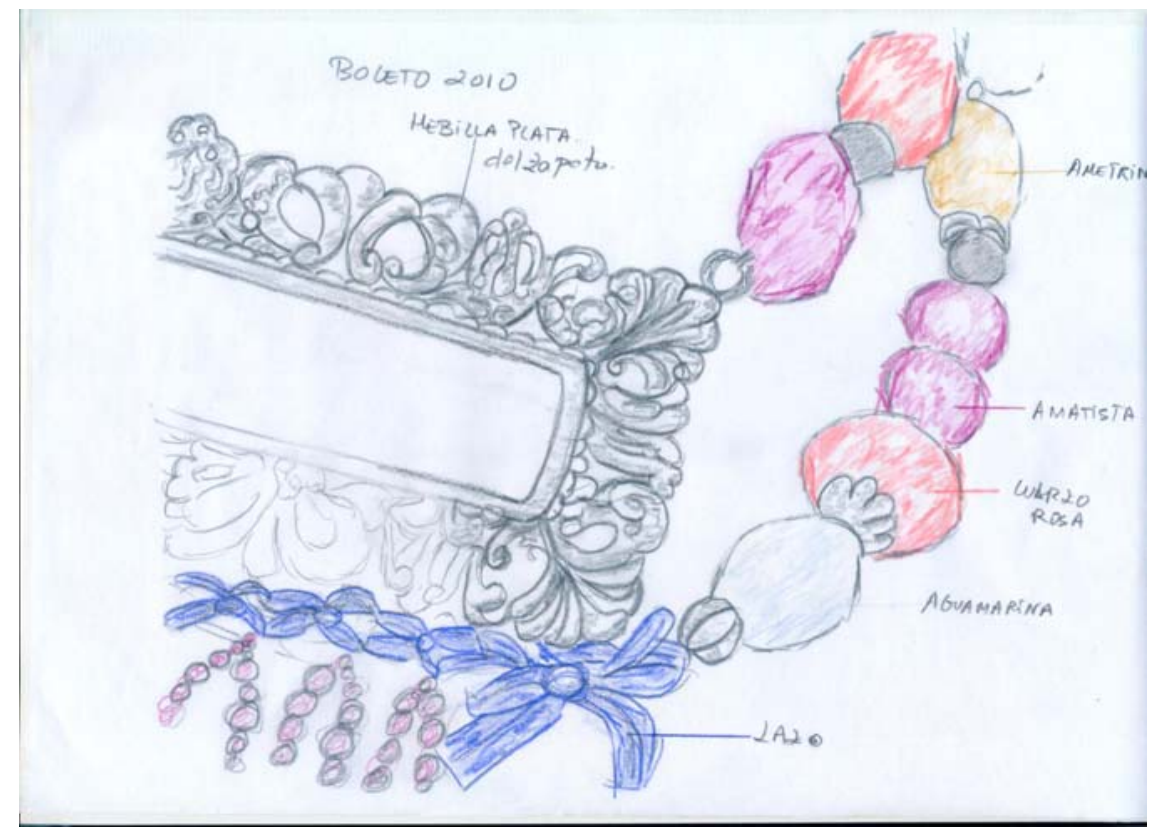

Las arracadas o pendientes serranos de gran tamaño, como vemos en el dibujo ${ }^{366}$ adjunto, abandonaron las orejas para adornar el cuello de la mujer con el fin de que, al descontextualizar la pieza, aparecieran de manera frontal al espectador ofreciendo y luciendo su esplendor máximo y una belleza hasta ahora poco valorada ya que su visión lateral diluía la

\footnotetext{
Relojeros de Salamanca y Provincia desde hace doce años. Su colaboración este proyecto ha sido fundamental y continúa siéndolo.

${ }^{365}$ Dibujo elaboración propia.

${ }^{366}$ Dibujo elaboración propia.
} 
apreciación de la joya en plenitud. Por el contrario la frontalidad del objeto maximiza su visibilidad y belleza exterior.

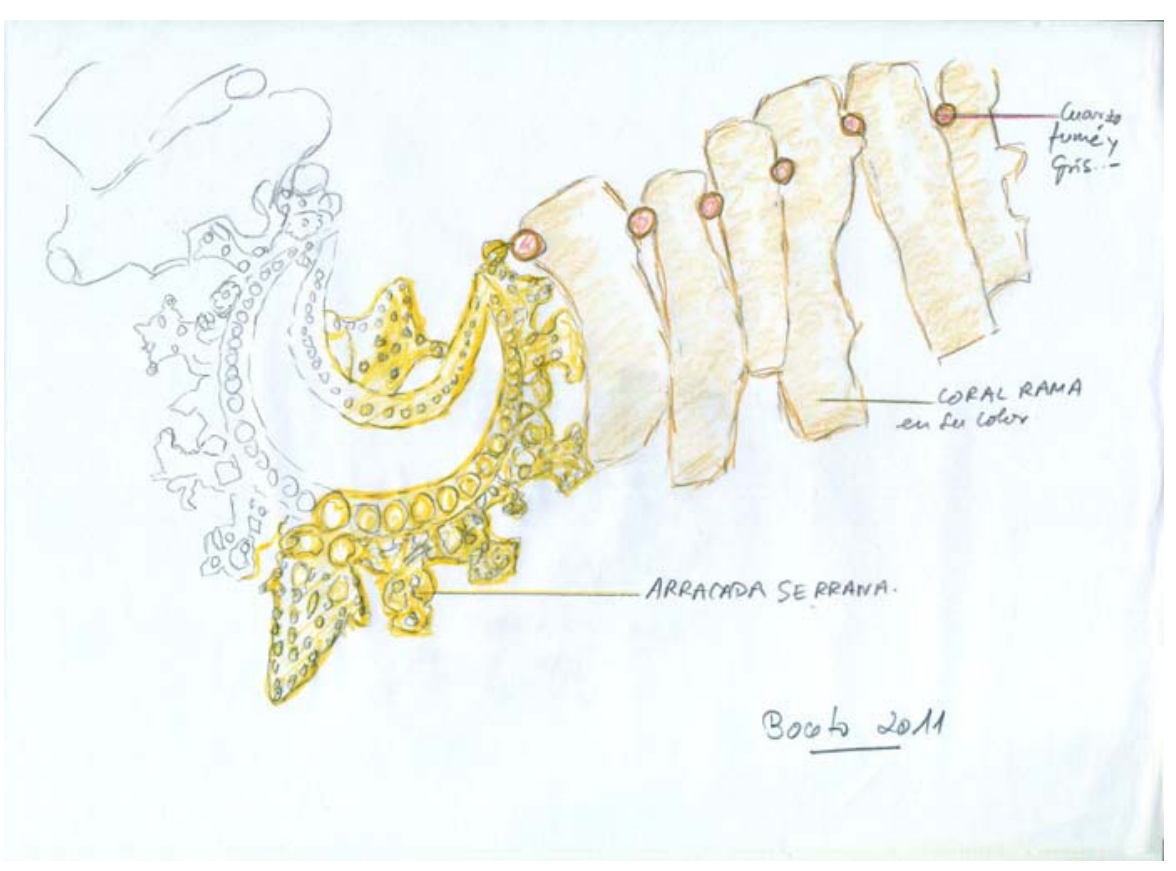

El lazo de una venera, se separa de su cuerpo principal para abandonar el pecho o espetera de la charra y subiendo casi a la garganta a modo de camafeo renacentista, se fusiona con cuero, cuerda y piedra preciosa rememorando el nombre de Juana La Loca. Esta pieza se estudió a la perfección, hasta tal punto que ninguno de los elementos empleados si eligió al azar. Los nexos de la pieza se hacen con cuero, símbolo de los grilletes de una reina incomprendida, la cuerda utilizada es la remembranza de una cordura perturbada por un amor desmedido, el color verde de las piedras semipreciosas preconizan la esperanza de un futuro de esplendor a Carlos V y el Lazo de Filigrana representa el espíritu de la Reina Juana. EI resultado es una pieza de delicadeza extrema y única capaz de acompañar a un traje de alta costura o a un simple pantalón vaquero. Dibujo ${ }^{367}$

${ }^{367}$ Dibujo elaboración propia. 


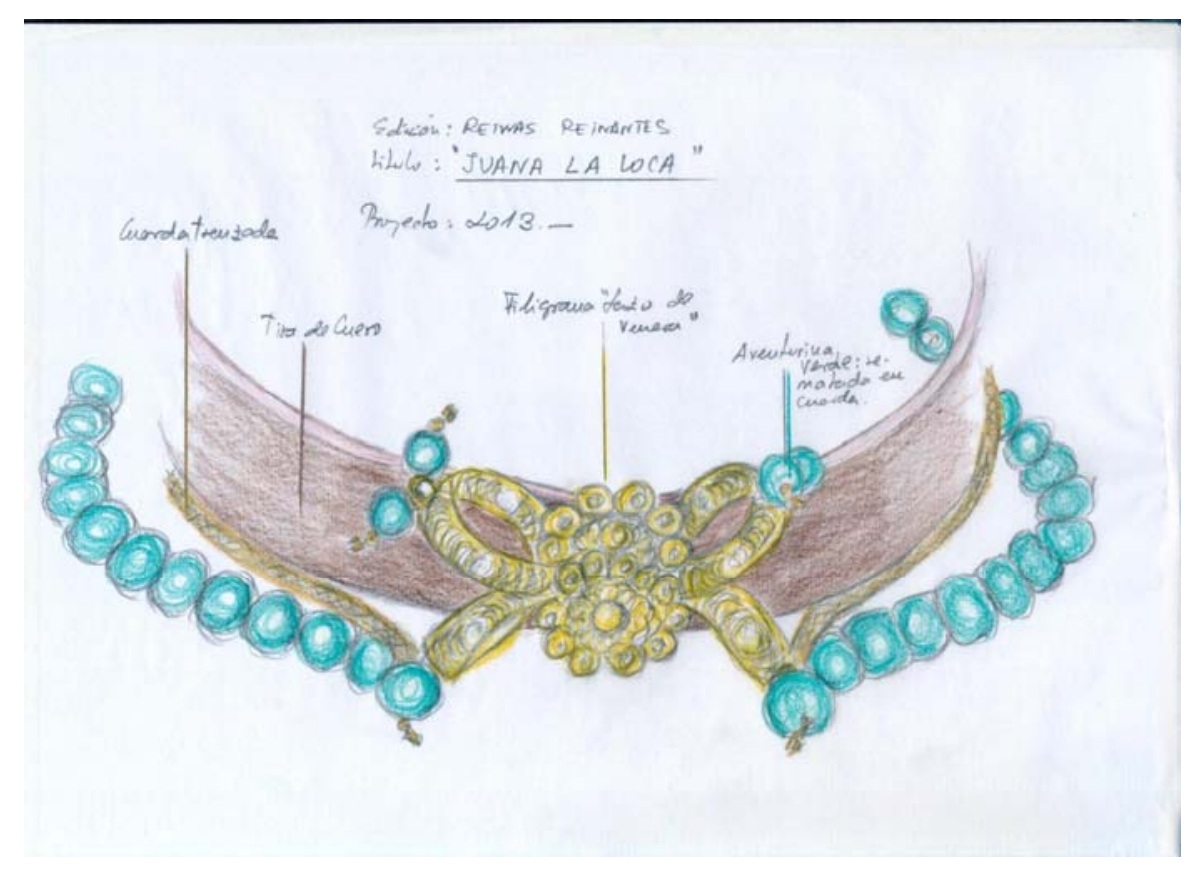

Y no digamos el trabajo realizado con nuestro recién estrenado Botón Charro áureo que al fusionarlo con piedras semipreciosas: amatistas, aguamarinas, citrinos...adquiere una belleza hasta ahora desconocida. Por primera vez se convierte en el centro del universo de la mujer en el S.XXI. Dibujo $^{368}$

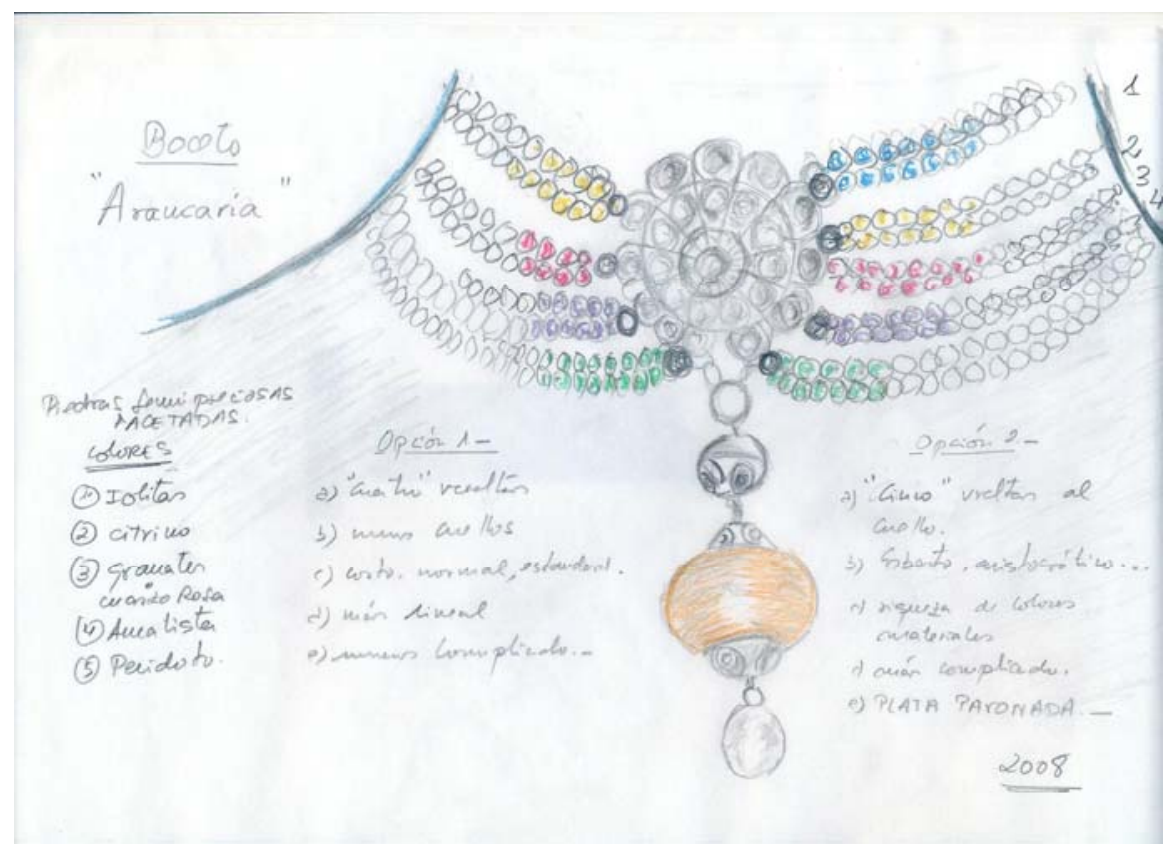

${ }^{368}$ Dibujo elaboración propia. 
Después de varios años de trabajo callado, de investigación, de muchas horas de taller y discusiones intelectuales, (dónde incorporábamos aspectos histórico a las piezas como por ejemplo: para seguir la tradición nuestras piezas muchas se cierran atrás con cintas de seda de falla, ya que las antiguas así lo hacían pues era la única manera de asegurarse que la portadora de la joya, fuera la propietaria original o la heredera, podía ponérsela sin problema de si su cuello era más largo o más corto o si era más grueso o más delgado), siempre intentamos ser fieles al uso de materiales antiguos como el coral, puesto que aparece habitualmente en determinadas joyas de nuestro patrimonio antiguo, si bien incorporamos nuevos colores que se dan en la actualidad al coral mediante tintes que lo hacen muy novedoso, atractivo y que antiguamente no existía.

También experimentamos la fusión con la tela obteniendo resultados muy interesantes, en la idea de hacer del paño del traje una continuación al aderezo. Utilizamos telas de hilo egipcio que por su textura natural al aplicarle los tintes, nos da como resultado unos tonos muy difíciles de igualar por otro procedimiento que no sea el manual.

Y en este camino de valoración actual incorporamos algo que hasta ahora jamás se había hecho por nadie. Incorporamos el color. Consideramos que ha sido un paso de gigante, atrevido sin duda, pero con un resultado increíble. Hasta ahora el acabado de nuestra joyería era el pavonado (como hemos estudiado en el capítulo II cuando hablamos en la Microfusión del acabado de las piezas) y el sobredorado. Pues bien, para la mujer del S.XXI que es el siglo del color, hemos incorporado a nuestra joyería la terminación con colores que llevamos a cabo con esmaltación en frío. El resultado ha sido maravilloso.

Hay que aclarar que todo cuanto hemos realizado y podamos realizar no entra en competencia con la tradición de los objetos sujetos a su contexto tradicional. Muy por el contrario, somos tremendamente puristas en cuanto al aderezo joyero vinculado al traje típico. Pero consideramos que dando una 
visión e interpretación actualizada de las mismas ha de valer para evitar que desaparezcan las técnicas, las formas y la identidad con una mujer nueva que, conocedora de su patrimonio le respeta y se siente orgullosa de portarlo con las nuevas características que le confiere la realidad a la que pertenece. Haciendo una diferenciación constructiva de estas nuevas piezas no solo las actualizamos haciéndolas más atractivas para la nueva mujer del XXI, sino que enfatizamos lo puro de aquellas piezas que van tradicionalmente sujetas al traje tradicional charro. Es muy importante que la espetera de la charra en el traje típico, no se vea trasgredido por elementos que nada tienen que ver con la tradición de esta tierra.

Nos comentaba Feli Cañada que en los últimos tiempos había quienes incorporaban al traje charro elementos que no son de nuestra tierra y que pertenecen a zonas periféricas a nuestra provincia e incluso elementos (que por su parecido por ejemplo cosas indias) que no pertenecen a nuestra cultura. Es importantísimo evitar esas intoxicaciones que tan solo valdrían para equivocar. Poe ello es primordial la intervención de las AAPP para evitar este incipiente, pero real, problema.

Cuando tuvimos suficientes piezas hechas en nuestro taller, surgió la idea de dar a conocer nuestro trabajo mediante una exposición:" Ars Gemmaria Nova" que visualizara al público los avances obtenidos y la puesta en marcha de un proyecto empresarial: "No hay 2 igual" que pudiera comercializar las piezas nuevas de la joyería Charra del Siglo XXI.

Con ambos aspectos pondríamos en valor todo nuestro proyecto investigador.

Con estas perspectivas hicimos una propuesta al Ayuntamiento de Salamanca que vio con buenos ojos nuestro proyecto. Le remitimos por escrito un documento explicativo y en junio de 2012, tras varias reuniones, se materializó la aceptación de una exposición en la Sala de Sto Domingo propiedad del Consistorio. 
La Institución del Ayuntamiento de Salamanca, a través de la Fundación Salamanca Ciudad de Cultura y Saberes, aprobó el proyecto y se editó un catálogo ${ }^{369}$ (ISBN: 978-84-96603-99-8 Depósito legal: S 342-2013) 370. La exposición se llevó a cabo en la Sala de Exposiciones de Santo Domingo, espacio público de propiedad municipal que en aquel entonces ,39-2013, se utilizaba como escaparate de los artistas salmantinos.

Esta exposición va de la tradición al presente, donde las mujeres se convierten en portadoras no sólo de la herencia, sino de la belleza que nosotras mismas decidimos. Con esto se inaugura una nueva manera de ver, de concebir, de expresar. Desde la "armonía", la voluntad creadora de esta firma aúna la creatividad del artista y el pensamiento filosófico-cultural, para concebir aspectos esenciales de una joya antigua que deriva en una nueva. Redescubre los principios etnográficos de la mujer del pueblo y con ingenio, imaginación y equilibrio, los redistribuye para la mujer del siglo XXI.

\footnotetext{
${ }^{369}$ ANEXO CD II 2.2 Ars Gemmaria Nova. Los textos firmados como No Hay 2 Igual pertenecen a la autora de esta Tesis así como todas las fotografías del catálogo. Salamanca. 2013

${ }^{370}$ FUNDACION SALAMANCA CIUDAD DE CULTURA Y SABERES, “Ars Gemmaria Nova” ISBN: 978-8496603-99-8 Depósito legal: S 342-2013, Salamanca, 2013.
} 


\section{La Sala de Exposiciones de Santo Domingo acoge desde hoy una muestra sobre la transformación de la artesanía y la filigrana charra que lleva por título "Ars Gemmaria Nova"}

- Las artistas $M^{a}$ Eugenia Bueno y Verónica Marín quieren rendir un homenaje con esta exposición a la mujer charra de todos los tiempos, por haber conservado y transmitido una parte de nuestro patrimonio cultural, la joyeria charra

- Las piezas que se muestran en esta exposición supone una transformación de la filigrana charra ya que, por primera vez en la historia, se ha introducido el color y se han combinado las joyas tradicionales con tela, hilo y piedra

- Se muestran también piezas únicas dedicadas a las Reinas que, sin ser consortes, reinaron en España. E incluye también un collar que lleva el nombre de la Infanta Leonor, futura reina

- La exposición permanecerá abierta el público hasta el 27 de octubre. Todos los martes y jueves, a las seis de la tarde, $M^{a}$ Eugenia Bueno y Verónica Marín ofrecerán visitas guiadas gratuitas

El alcalde de Salamanca, Alfonso Fernández Mañueco, ha presentado esta mañana la nueva exposición que abrirá mañana sus puertas en la Sala de Santo Domingo de la Cruz. Una muestra sobre la nueva joyería charra, "Ars Gemmaria Nova", comisariada por Fernando Población, en la que se exponen 60 obras diseñadas por $\mathrm{M}^{\mathrm{a}}$ Eugenia Bueno y por Verónica Marín.

Ambas artistas han manifestado que con esta exposición buscan un doble objetivo: por un lado rendir homenaje a la mujer charra de todos los tiempos, que ha transmitido de generación en generación un patrimonio cultural tan importante como es la filigrana charra; y por otro aportar su granito de arena para que esa herencia no se pierda y se adapte a los gustos y a la moda del siglo XXI.

"Por esta última razón las formas tradicionales se combinan en esta muestra con elementos novedosos, como la piedra o la tela, y se introduce el color por primera vez en la historia, lo cual supone un avance e incluso una revolución", como explica Ma Eugenia Bueno. 
La evolución o revolución que se muestra en las 60 obras de joyería que se exponen consiste en redescubrir los valores y los principios etnográficos de la mujer del pueblo, que ha transmitido ese patrimonio de la joyería tradicional charra a través de los siglos y, con ingenio, imaginación y equilibrio las dos artistas lo han transformado para que los pueda lucir la mujer del siglo XXI.

"Ars Gemmaria Nova" permanecerá abierta al público desde mañana, 4 de septiembre, hasta el 27 de octubre, en horario de 17'00 a 21'00 horas, de martes a viernes; y de 12'00 a 14 '00 y de 17 '00 a 21'00 horas, sábados, domingos y festivos. Además, todos los martes y jueves, a las seis de la tarde, $\mathrm{M}^{\mathrm{a}}$ Eugenia Bueno y Verónica Marín realizarán visitas guiadas gratuitas a la exposición.

Esta muestra cuenta con un catálogo que se puede adquirir desde mañana en la Sala de Exposiciones y en el que se incluyen textos de las dos artistas, del arquitecto y comisario de la exposición Fernando Población, del escritor Antonio Colinas, de la galerista Adora Calvo y del pintor y etnógrafo Carlos Piñel.

\section{Reinas}

Dentro de la exposición, hay un espacio dedicado en exclusiva a las Reinas que, sin ser consortes, reinaron en España mostrando piezas de artesanía dedicadas a ellas. Las reinas homenajeadas son Urraca de Castilla (1109-1126), Petronila de Aragón (1137-1164), Berenguela de Castilla (1217), Isabel I de España (1474-1504), Juana I de Castilla (15041516), Jeanne III de Navarra (1555-1572), Isabel II de Castilla (1833-1868).

A todas ellas "Ars Gemmaria Nova" les rinde homenaje exponiendo una pieza exclusiva que lleva el nombre de cada una. Y que incluye, además, una pieza única dedicada a la Infanta Leonor, futura Reina de España.

Tal como explica una de las diseñadoras, Ma Eugenia Bueno, "la joya hace a cualquier mujer reina, y a la reina la iguala en sentimiento a la mujer que gobierna, entendiéndola e identificándose con ella". 


\subsection{Proyecto empresarial.}

Si hay algo que habitualmente se viene criticando a determinados proyectos académicos es la falta de sensibilidad por parte de los investigadores para abordar estudios que conecten con las necesidades de una sociedad que tiene frente a ella problemas que muchas veces se le escapan, bien por falta de conocimientos bien por falta de comprensión social.

Realizar un estudio en profundidad cuando se detecta un problema en una sociedad en concreto, es la labor del investigador ávido de analizar, diagnosticar y plantear soluciones a los diferentes estamentos públicos y privados con la intención de buscar soluciones a los problemas estudiados.

Pero hemos de ser conscientes que muchas veces la falta de cintura social hace que particularmente sean los individuos los que, a través de soluciones empresariales de riesgo, asuman ser los garantes de soluciones que impliquen innovación.

Después de unos cuantos años dedicándonos a ver, estudiar, diseñar, proyectar...convinimos que un buen equipo ha de intentar llevar a cabo los objetivos que desde el principio supusieron la causa de colaboración.

El lanzarnos a la aventura empresarial vino de la mano de la fe absoluta que teníamos y tenemos en un proyecto económico-cultural que tarde o temprano estábamos y estamos seguras que ha de triunfar.

El llamar NO HAY 2 IGUAL $^{371}$ a este proyecto, hunde sus raíces en la convicción de que en un momento tan globalizador como el que vivimos, hay muchas mujeres que necesitamos identidad propia y diferenciarnos de la monotonía que nos ofrece un mercado dónde la igualdad de lo que nos brinda para ponernos, no nos interesa.

${ }^{371}$ http://www.nohaydosigual.com 
Consideramos que si en tiempos no muy lejanos, según la joya que se portara identificaba un rol diferenciador, no se debería perder esa cualidad diferenciadora estética que proporciona la joya.

Así nació el espíritu de no igualdad estética, pero sin perder el de identidad. Ser portadoras de la tradición Charra sí, pero cada una con un objeto único, por eso el nombre de NO HAY 2 IGUAL porque ni hay mujeres ni hay piezas iguales.

Todas las piezas de la Exposición son diferentes y no reproducibles. Puede que mantengamos el diseño, pero no el color, ni las piedras, ni los complementos... esos elementos que hacen a una pieza única.

NO HAY 2 IGUAL es un proyecto de Joyería que sale al mundo empresarial de la mano de dos diseñadoras salmantinas, cuyo objetivo es la recuperación del espíritu joyero tradicional salmantino.

Para ello se ha realizado un estudio de mercado, con el objeto de respetar el pasado, pero dando a la joyería una vertiente nueva que la ponga a disposición de la mujer del S.XXI. La mujer de este nuevo espacio temporal dista mucho de la mujer de la primera mitad del S.XX. Independiente, trabajadora en ámbitos muy diferentes el estricto ámbito familiar, la colocan en el mundo con independencia económica y roles muy diferentes a los de su pasado inmediato. Su propia versatilidad de vida la hacen demandante de objetos que se adapten a su nuevo estilo de vida. Pero ello no debe entrar en conflicto con su propia identidad cultural. Es más, está deseosa de llevar con orgullo algo que la identifique y ponga en valor una historia nada exenta de dificultades y calamidades.

Solamente la apetencia de nuevos retos, pueden evitar el estancamiento de unos elementos tan identificados con nuestras raíces, y que con una nueva interpretación forme parte de nuestro futuro y no sólo de nuestro pasado.

Con esta manera de entender acometimos la inversión en esta empresa que, aunque comercializa, reconoce la dificultad de competitividad 
en un mundo dónde solo las grandes inversiones en publicidad y márquetin te dan un mínimo de posibilidades comerciales.

Somos conscientes que el proyecto que hemos acometido al poseer la dualidad de cultura y rentabilidad económica, le coloca en una dimensión más de la utopía que de la realidad.

La empresa se encuentra en los inicios, si bien son ya varios empresarios quienes parecen empezar a interesarse por estos productos. Pero muy lentamente. Curiosamente todo el mundo nos recomienda la comercialización fuera de la ciudad, al considerar que somos nosotras mismos como clientes, un hándicap y un lastre para el desarrollo del proyecto. Estaríamos en el "nadie es profeta en su tierra" y nos resistimos a creerlo.

Esta empresa pretende colaborar en dar a nuestra tierra una imagen que sume a las imágenes que ya tiene nuestra ciudad y nuestra tierra, convirtiéndola también en referente de nuevas tendencias en el complemento de la mujer, sin olvidar jamás nuestra identidad "Charra", teniendo como objetivo recuperar a nuestros homólogos de la "Charrería" mejicana, a los que desde nuestra tierra les importamos técnica y objetos joyeros y hasta el punto de que a ellos también se les denomina "Charros".

Nuestro objetivo es hacer de esta nueva visión de joyería una embajadora más, de la provincia de Salamanca que a su vez, identifique el nuevo perfil de las mujeres que habitan esta ciudad milenaria.

Este proyecto personalizado, por una parte en la autora de esta Tesis y por otra en la artesana Verónica Marín, ha conseguido aunar dos mundos muchas veces imposibles de aunar: La teoría (de la primera) y la práctica (de la segunda) que deberían ser consecutivas, no siempre forman parte de una misma realidad.

El estudio, la creatividad y técnica, se han encontrado en un territorio nuevo: "NO HAY 2 IGUAL". 
Nada entre sus creadoras es parecido, aunque curiosamente el punto de encuentro es más evidente de lo que parece. La riqueza individual de las personalidades creadoras de este proyecto muchas veces antagónicas, pone de manifiesto que si hay un buen proyecto, los resultados que se obtienen pueden llegar a ser sorprendentes.

Estudio, conceptualización, teoría y filosofía (María Eugenia) + creatividad, diseño, gusto y composición (Verónica) dan como resultado un binomio que, unido al trabajo y al esfuerzo, se convierte en el pilar de esta nueva interpretación de lo antiguo que entra en el mercado con modestia, pero con mucho que decir: "NO HAY 2 IGUAL".

\subsection{Valoración popular.}

Para llevar a cabo la valoración popular de nuestro trabajo pasamos a realizar la transcripción de los comentarios que los visitantes dejaron escritos en el Libro de Firmas de la Sala de Santo Domingo sobre la Exposición de Ars Gemmaria Nova, donde fue visitada por 7.734 personas, $2^{\circ}$ exposición más visitada del año 2013 , según datos oficiales de la Fundación Salamanca ciudad de Cultura y Saberes.

"ARS GEMMARIA NOVA"

(3 de septiembre a 30 de octubre de 2013)

Pág. 1

1. "Francamente impactante, conjugar el pasado, la artesanía, el glamour y la historia salmantina es algo tan difícil como verdaderamente logrado. Enhorabuena". 3 de septiembre de 2013. M. L. R.R.

2. "Espectacular, es maravilloso y el trabajo... miles de felicidades a las dos". M.M.

Pág. 2 
3. "Verónica, $\mathrm{M}^{\mathrm{a}}$ Eugenia, felicidades por esta preciosidad que habéis conseguido". M.

4. "Verónica: qué pedazo de artista, qué maravillosa exposición. Y $M^{a}$ Eugenia: iqué historia tan bonita! Éxito seguro. Muchas felicidades. R.

5. "Vero no puedo más que darte la enhorabuena. Es maravillosa...Muchas felicidades". M.G.

6. "Los sueños se acaban cumpliendo y tu trabajo... dan sus frutos. Enhorabuena. Estoy orgullosa de ti". P.

Pág. 3

7. "Qué decirte, te admiro mucho. Felicidades por todo tu trabajo... ". O. G.

8. "Muchas felicidades por esta gran obra, me ha encantado. Que sea el comienzo de una gran carrera llena de éxitos". F. G.

9. "Muchas felicidades por este gran trabajo. Increíble todo". M.B.

10. "Sin palabras". B.

Pág. 4

11. “Espectacular. Todo este trabajo tendrá una recompensa...". M.

12. "Enhorabuena. I.

13. "Todo espectacular y muy bonito". I.

14. "Todo muy bonito". M. P.

15. "Felicitaciones, es preciosa esta exposición. Deseo un final con éxito. I.S.

16. "Un ejemplo para no perder la tradición y el amor a esta tierra charra. Sería bueno lucirlo en la calle. Yo llevo un botón en lapislázuli. Enhorabuena. M. L.

Pág. 5

17. "Exposición muy interesante por su creatividad y belleza". M.

18. "Me ha encantado. A ver si me diseñas una pieza muy charra para mi". D-G. C. 
19. "Enhorabuena. Me ha gustado mucho. Tradición y diseño unidos por la belleza de las piezas y de sus autoras". P. G-R.

20. “Todo precioso. Qué gusto tenéis". Una admiradora. P.

21. "Me ha encantado... ojalá las actrices llevaran vuestros collares. P. C. Pág. 6

22. "Bonita exposición. Botón charro en broche excepcional. Mi elogio. Una palentina". C.F. R.

23. "Enhorabuena. La exposición preciosa". A. P.

24. “... qué maravilla de exposición...”. C. P.

25. "Mil enhorabuenas. No hay dos igual, porque sois únicas". R.Z.

26. "Me ha encantado. Enhorabuena". C. V-M

27. "Qué arte tenéis...impresionante. Se nota que está hecho con todo el corazón". J.V-M

28. "Una exposición muy bonita". C. V-M

Pág. 7

29. "Habéis demostrado que la filigrana charra es algo no del pasado si no actual, con imaginación y gusto". Una salmantina. Gracias.

30. "Me encanta, me recuerda a mi niñez. Mi padre era joyero filigranista". M. T.P. S.

31. "Preciosa combinación entre lo moderno y lo tradicional. Un exposición preciosa, sus diseños son de una naturalidad y sofisticación excepcionales. Enhorabuena". R. F. S.

32. "Enhorabuena, una exposición preciosa, llena de luz y alegría. Obra de gran belleza". M.V.

33. "Me encanta el aire tan moderno. Es una preciosidad". P.

34. "Preciosa exposición en una ciudad acogedora y bella". C.

Pág. 8

35. "Une colección magnifique de collier á voire".

36. "Ha sido una maravilla todo". S.R. 
37. "Maravillosa conjunción de tradición, arte, sensibilidad y creación. Enhorabuena. Gracias".

38. "Preciosa exposición y trabajo".

39. "Una maravilla junta la creatividad y el diseño". C.

40. "Simplemente espectacular. Seguid adelante". M.

Pág. 9

41. "Después de tantos años, reencuentro espectacular. Mucha suerte. Ha sido un placer". M.

42. "Sólo puedo decir que es: increíble. Mucha suerte". M.

43. "Con todo el cariño por vuestra magnífica exposición". F.

44. "Enhorabuena: es preciosa". G.C.

45. "Me gusta, es una manera de poner la filigrana charra".

46. "Magnífica. Espero que Salamanca os reconozca lo que hacéis por ella. Sólo puedo deciros, adelante". I.

Pág. 10

47. "Un trabajo muy bonito". P.R.

48. "Una manera de ver el botón charro tan nuestro y a la vez tan poco elogiado par que todo el mundo sepa cómo podemos ver al botón charro". P.

49. "Precioso, origina, elegante, cotidiano. Qué más puedo decir...nos ha gustado un montón". R. - J.

Pág. 11

50. "Me ha gustado. Es todo un éxito. Alabo vuestro trabajo". M.

51. "Muy bonito".J.

52. "Me ha encantado, son todas las piezas únicas y maravillosas". P.G.

53. "Sencillamente genial". N.

54. "Una exposición magnífica". M.C.

55. "A mi antes no me gustaba el botón charro, pero viendo esta colección he cambiado de opinión". C. 
Pág. 12

56. "Es una recuperación artística de lo autóctono". P.

57. "Es una manera de pasear nuestro patrimonio por toda España, recuperar el botón charro". L.

58. "Os deseo mucho éxito. Precioso". B.

59. "Ha sido un placer la exposición". J.

60. “Tres belle exposición”. J.

61. “...con gusto e inspiración...”. M.J.

62. "Me ha gustado mucho la exposición". C.

63. "Otra buena exposición en una sala sin igual". T.

Pág. 13

64. "El ayer y el hoy en una joya única: inspiración". E.

65. "Una maravilla". P.

66. "Genial". B.

67. "Muy bonito todo". S.

68. "Excepcional, conmovedora. Estoy exhausto". R.

69. “...expresiva y graciosa...". P.

70. "Maravillosa. Enhorabuena a las artistas. Salamanca necesita personas como vosotras". C.M.

71. "Preciosa. Me encantan todas las piezas, en especial las históricas". M.

\section{Pág. 14}

72. "Preciosa, una trabajo impresionante, gusto y arte charro. Felicidades". P. M.

73. "Maravillados por el arte desplegado, el saber hacer y la buena combinación de colores y afectos. Nuestra más afectuosa enhorabuena". M. y N.B.

74. “...me ha gustado tanto que os deseo mucho éxito...”. C.J. 
75. “...el éxito se ha realizado pues lo merecéis por valentía y saber”. R.J.

76. "Me ha gustado mucho. Os deseo mucha suerte". E.

Pág. 15

77. "Es una preciosidad y un trabajo enorme. Felicidades a las dos artistas". I.

78. "Es una maravilla de exposición, esto demuestra que la juventud tiene grandes inquietudes y preparación para desarrollar proyectos". M.

79. "La exposición ha sido sorprendente, con mucho gusto y estilo. Felicidades". M.

80. “...me ha encantado y lo vivís...Mucho éxito”. M.B.

81. “...me fascina tu exposición...”. F.

82. "Mucho éxito para tu tesis". M.T.

83. "Un placer escuchar". C.

Pág. 16

84. "Un arte precioso, original y poco visto. Gracias por un espectáculo precioso". D.

85. "Gracias por mantener y mimar nuestro arte. La superación y el esfuerzo es envidiable". D. , V., V.

86. "Mi cariñosa felicitación por la maravilla de exposición y su presentación". M.A.

87. "Enhorabuena una exposición de maravilla". M.J.

Pág. 17

88. "Preciosa exposición". P.

89. "Muy espectacular, es buena. Demostrar lo que se puede hacer con nuestro arte y nuestro ingenio". T.

90. "Me ha encantado nuestra exposición. Seguid así. Maravillosa". I.

91. "Me gusta muchísimo..”. M.

92. "Me gusta". C

Pág. 18 
93. "El contraste del color con la filigrana charra me parece excesivo, pero la creatividad me gusta". G.

94. "Enhorabuena. Qué preciosa interpretación de nuestra filigrana, de nuestra tradición. Un homenaje a la mujer charra. Me ha encantado". P. T. , J.

95. "Preciosa". D.

96. "Una gran obra". M., F.

Pág. 19

97. "Un trabajo espectacular, no sé si se pondrán a la venta". I.

98. "Un trabajo con gusto. Es toda una preciosidad, enhorabuena". P.

99. "Nunca pensé que a un botón charro se le pudiera sacar tanto partido. Maravilloso trabajo". T.

100. "Hermosa la exposición, maravilla y fantasía. Coral rojo a discreción y colores a porfía". E.

101. "Genialidad". D.

102. "Muy creativo pero recargadísimo". A.

103. "Me ha encantado y me gustaría poder lucir algún día alguno". M.

104. "Muy, muy bonitas... algunas son preciosas y originales”. Y.

Pág. 20

105. "Muy interesante, la mezcla charra y moderna es espectacular". D.

106. “... valor, entusiasmo, tenacidad, hacen una joya única...”. L.

107. "Precioso. Nos ha encantado. Continuad así". C. M.

108. "Todo es muy bonito". M.

109. "La composición de las joyas me ha parecido preciosa y la visita guiada nos ha dado una clase de historia y de arte magistral". L.

Pág. 21

110. "Adelante, tenéis mucho gusto". B.

111. "Gracias por llevar nuestro arte por todo el mundo". C. 
112. "Me ha gustado muchísimo muestra una gran delicadeza y mucha clase. Gracias por hacer arte tan bonito". E.

113. "Nos ha gustado mucho. Buen trabajo". A. y C.

114. "Me ha parecido una: tomadura de pelo a Salamanca". M.P.

115. "Mi querida M.P. es extraordinario que el arco iris tenga tantos colores para que cada uno pueda elegir de entre ellos. Gracias "Charras" que habéis dado una nueva visión a nuestro patrimonio". M.

Pág. 22.

116. "La oportunidad de recrearse es escasa, gracias a vosotros nos hemos enriquecido amablemente pues como es la vida laboriosa y como la vida sencilla que nada hay que oponer. Gracias por esforzaros por nosotros y por todas esas cosas doradas y coloridas que alimentan el espíritu de los quehaceres cotidianos. Nada hay más perfecto que entretenerse cosiendo las cuentas entre telas y metal". $\mathrm{S}$.

117. "Simplemente uno no permanece impasible después de pasear entre vuestra obra. Suerte". M.

118. "Sobrecogedor, fantástico". J.

119. "Lindas joyas, como lindas personas...". W.

120. "Una forma muy elegante de recuperar las tradiciones". N. y R.

\section{Pág. 23}

121. "Me ha parecido interesantísima. Una exposición única nunca vista. Suerte". M.

122. "Una preciosa exposición, con gracia y conservando la identidad charra con mucho acierto. Enhorabuena". C. y N.

123. "Enhorabuena, mi opinión es que funciona muy bien el binomio. También sería interesante ver cómo podríais hacer algo más leve, lo echo de menos, aunque lo barroco se marida bien en esta dinámica de filigrana. Me encantaría ver algo más descargado. Valga como contrapunto constructivo. Genial mestizaje". F. L.

Pág. 24 
124. "Diseño muy original y atractivo". C.

125. "Muy original. Me encanta la exposición de clásico con moderno". P.P.

126. "Ha sido un atrevimiento que ha merecido la pena. Felicidades". E. y $\mathrm{V}$.

127. "Muy bonita y colorista. Interesante el modernismo". C.

128. "Me ha gustado mucho el collar del cuero y botón charro pintado". C. (12 años)

129. "Muy original, la mezcla, la composición. Felicidades". R. M.

Pág. 25

130. “Francamente preciosa exposición. Mil enhorabuenas”. R.S.

131. "Enhorabuena, me ha aportado mucho... “. A.

132. "Enhorabuena". J. H.

133. "Me ha gustado mucho y es muy original". L. (9 años)

134. "Trabajo impecable. Enhorabuena. Tenemos joyas para rato. Forma de que no se pierda la tradición con lo moderno". M.T.

135. "Precioso, espectacular. Qué pena no poder lucirlo”. S.M.

136. "Fantástico. Volveré”.

137. "Excitante y espectacular".

Pág. 26

138. "Gracias por recuperar esto que siempre se ha escondido siendo tan nuestro y tan precioso". T.T. y P.G.

139. "Me encanta la creatividad el buen gusto y además una excelente explicación. Enhorabuena". M.

140. "Enhorabuena por las joyas tan estupenda que presentáis...”. A.

141. "Muchas felicidades por el buen gusto y mucho ánimo". C.J.

Pág. 27

142. "Espectacular. Yo quiero por lo menos uno. Por el diseño, la joya, enhorabuena". E.R. 
143. "Qué preciosidad. Verdaderas joyas". M.E.

144. "Es un auténtico placer, ver y mirar y volver a mirar, esta creación tan maravillosa". C.

145. "Me encanta, son preciosas y merecen el sitio que le corresponde en Salamanca". T. H.

146. “Una maravilla, muy logrado, muy lograda la combinación”. L.

Pág. 28

147. “... es especial, un tándem fantástico”. C. y S.

148. "Sencillamente fantástica". R. y J.

149. “Muy original, ánimo y adelante”. J. y P.

150. "Entrar aquí hoy ha sido como entrar en otro mundo. Maravillosa. Fantástica. No hay palabras... muchas gracias por ofrecernos cosas tan... no hay palabras. Atentamente". A.

151. "Realmente impresionado por la exposición, donde se aúnan el criterio, el gusto, la simbiosis, la calidad y la nueva línea de trabajo donde parecía que no se podía indagar más". J. G-P.

152. "Habiendo seguido el proceso de creación de algunos trabajos y habiendo conocido los bocetos de alguna de estas obras de arte, no nos ha sorprendido el resultado de esta maravillosa colección. Supera con creces todo lo que imaginábamos, ya que era mucho... enhorabuena y ánimo". A. J. y D. P-T.

153. "Entré con curiosidad y salgo orgullosa de nuestro maravilloso patrimonio. Muchas gracias por iniciativas como ésta". P.R.

154. "Es un honor participar en el éxito de esta exposición que es sencillamente magnífica". M. S.P.

Pág. 29

155. “...fenomenal, gracias por el esfuerzo que habéis hecho”. M.A.C.

156. "Charro, charrísimo". M.

157. "Sencillamente maravilloso". B.

158. "Sencillamente gracias por la exposición”. F. y S. 
159. "Bellísimas las composiciones y muy interesante y amena la charla". M.

160. "He disfrutado mucho de esta maravilla. Os felicito y explicación magnífica". M.A.

Pág. 30

161. "Muy bien construida la idea". M.L.

162. "Muy bonita". E. H.

163. "Me ha encantado la exposición. Siento no estar más días y disfrutarla más. Enhorabuena". S.S.

164. "Muy bonita la exposición digna de admiración y explicación de la diversidad de joyas preciosas". M.

165. "Una exposición preciosa y muy original. Mezcla del charro con la actualidad". J.

166. "Me ha gustado muchísimo. Es muy bonita". I.C.

Pág. 31

167. "Enhorabuena por esta nueva exposición con las cuales siempre nos sorprende. Compendio de conocimiento y creatividad y de un paseo por la historia y el hoy. Gracias". A.

168. "Felicidades por tanta maravilla. Gracias". L. R.

169. "Fantástica exposición. Muy moderna". Y. y M.

170. "Precioso y espectacular. Gracias". J.

171. "Fantástica". G.

172. "Me ha gustado mucho". M.J.

Pág. 31

173. "Es precioso, ánimo, me gusta”. S.

174. "Me ha parecido una preciosidad. Enhorabuena. Super bonito. Por fín... llegó alguien tan creativo con la filigrana charra". C.

175. "Enhorabuena, son muy bonitas y muy creativas. Adelante con el arte". A. 176. "Siempre adelante. Ánimo". A. 
177. “Cuánta belleza. Una exposición única y muy recomendable”. C. y V. Pág. 32

178. “Ánimo, sois unas artistas”. M.L.

179. “...nos ha encantado, no conocíamos esta faceta. Gracias por vuestro trabajo...". J. M. y L.

180. "Felicidades por vuestra valentía y originalidad". M.

181. "Me ha impactado". M.

182. “Enhorabuena. Magnífico trabajo que tenga continuación”. N-C y G.

183. "Precioso, belleza que embellece a quien la mira y a quien la lleva, gracias por exponer y que podamos disfrutar". L.

Pág. 33

184. “Qué original, qué creativo, qué manos! Bonito de verdad”. A.

185. “...ha sido una auténtica sorpresa de una creatividad increíble, sigue cultivándola...". B.

186. "A las autoras con mi espléndida enhorabuena por poner en valor nuestro legado cultura femenino y joyero. Gracias". J.

187. "Hoy he disfrutado como uno de los mejores días de mi vida, pues mis ojos de "Gran Charra" desde mi infancia, he visto en esta exposición conjugado el botón charro clásico con la actualidad de la mujer en el S. XXI". I.

Pág. 34

188. “.. ya marcabas estilo en las "Trini”. Eras una gran artista”. L.

189. “... realizadoras de una auténtica obra de arte dedicada a la mujer charra. Mi más sincera felicitación y agradecimiento deseándoles mucha difusión de su maravilloso trabajo". S.

190. "Enhorabuena. Me ha encantado. Soy gemóloga y habéis colaborado de forma magnífica con nuestra filigrana charra. Con mi admiración”. M. C.

Pág. 35

191. "Qué orgullo siento de ver esta exposición. Habéis conseguido potenciar de manera impresionante esta joya salmantina. Felicidades”. C. G. 
192. "Cada día que vuelvo acompañando amigos me gusta más. Sois únicas". J. G.

193. "Un gran placer visitar esta exposición. Enhorabuena.”. A.

Pág. 36

194. "Una exposición preciosa. Unos diseños inteligentes...enhorabuena". S. B.

195. "Sois únicas. Qué preciosidad de exposición, no cabe más”. M.

196. “Enhorabuena por la magnífica exposición”. F.F.

197. "Me ha gustado todo mucho". A. R.

198. "Hay que verlo otra vez por lo bonito que es y lo bien que nos lo han explicado". D.

199. "Me ha gustado mucho". B. D.

200. "Una exposición preciosa y muy original. La explicación dada en la visita guiada nos ha aclarado muchas cosas y nos ha motivado para valorar más nuestro patrimonio charro". AULA MUJER ZONA CENTRO.

Pág. 37

201. "Me ha gustado muchísimo. Estoy encantada de haber podido verla". P. M.

202. "Muchas gracias por lo bonito y el trabajo tan estupendo que han hecho". R.

203. "Me ha gustado mucho y me ha recordado mis antepasados". F. D.

204. "Ha sido muy bonito e interesante". P. M.

205. "La exposición es preciosa, es una maravilla y una joya como las piedras preciosas que se exponen. No hay palabras para dedicarles". D. N.

206. "Bonita, pero es más para mujeres". L. H.

207. "Me ha gustado mucho". D. S. y A.

Pág. 38

208. "Una exposición y explicación muy interesante que nos hace reflexionar sobre el valor de lo nuestro". 
209. "Gracias por unir dos de las cosas que más me gustan en joyería: lo charro y las piedras. Gracias y mucha suerte".

210. "Enhorabuena por esta magnífica exposición. Sé que han trabajado mucho. Deseo toda la suerte del mundo". S. y M.

211. "He disfrutado mucho de la belleza de cada una de las piezas". F.

212. "Enhorabuena por una exposición tan sorprendente. Se ha dado una versión tan moderna del botón charro, que lo volveremos a sacar del baúl. Mil gracias". B.

Pág. 39

213. "Me ha sorprendido gratamente esta exposición donde todo tiene un estudio o una explicación, por eso respeta el límite de lo bonito. Enhorabuena". T.

214. "Me ha emocionado. Arte, sabiduría y sensibilidad. Preciosa. Ha sido tan interesante como sentimental. Lo tradicional es lo más moderno. Enhorabuena". R. M.

215. "Me ha encantado y emocionado". A.

216. "La exposición es muy creativa y bonita. Tenéis mucho gusto”. M. C.

217. "Una exposición preciosa. Me hubiera gustado veros puesto algo charro a vosotras y he visto dos días la exposición y en ninguna teníais puesto ni un anillo, con las preciosidades que hacéis deberíais llevar algo puesto". M. S. B.

Pág. 40

218. "En nombre de la Asociación de Vecinos "ZOES" Barrio del Oeste, agradecer-reconocer esta exposición que nos da identidad y autoestima, fundamental creatividad y trabajo, os permite transmitirnos que ese es el camino, en ZOES, también esa es parte de nuestra apuesta (ah e innovación) Gracias". ZOES.

219. “En el jardín el rumor del agua y de la piedra, pero aquí dentro las piedras de lo bello joyas que están esperando un rostro, un cuerpo. Enhorabuena y los mejores éxitos para esta aventura de lo bello-verdadero". A.C. y M. J.

220. "Enhorabuena por esta magnífica exposición. Donde han sabido conjugar modernidad y tradición, quedando patente una gran sensibilidad. Me ha 
encantado y estoy segura que será el comienzo de un gran camino". A. y M.

\section{Pág. 41}

221. "Felicidades por el gusto y el contraste de la piedra con la silueta de satén negro. El que más me ha gustado el ágata naranja, ónix, nácar rojo, nácar blanco, charro plata...". T. M.

Pág. 42

222. "Enhorabuena por esta exposición de gran gusto y valor". M.R.

223. "Suerte y enhorabuena". I.

224. "Está hecho con un gusto exquisito". L.

225. "Todas las piezas son elegantes y exquisitas". J.D.

226. "Todo de mi gusto". M.B.

Pág. 43

227. "Una combinación perfecta de nuestra joyería tradicional con los estilos más actuales, una preciosidad". J.

228. "Menos mal que no me lo he perdido. Sabía que la sensibilidad... tenía que dar este resultado espectacular, delicado y único". M.

229. "Poco entiendo de arte, sólo puedo opinar al ver una pieza si es linda, pero al escuchar la explicación uno se transporta e imagina y eso es ser un verdadero artista, expresar y compartir". A.

230. "Muy bonita la colección. Preciosa”. A. E.

Como valoración global, aunque más propio sería que hubiera sido realizada por un órgano externo a la organización, sí podemos afirmar, sin temor a equívoco, que la innovación planteada en nuestro proyecto empresarial goza de la aprobación de la totalidad de los visitantes de exposición, ya que como en toda regla tiene que haber una opinión dispar sobre 230, para confirmar su validez. 
CONCLUSIONES 
De todo lo estudiado, hemos llegado a las siguientes conclusiones:

I. La joyería tradicional artesanal constituye una expresión esencial identificativa de la cultura de un pueblo, pudiendo afirmar sin temor a equivocarnos, que la Filigrana Charra, es la representación viva de este arte, no siendo fruto de la casualidad en el espacio geográfico de Salamanca, ya que en esta área provincial confluyen una serie de ejes de influencias histórico-económico-culturales y sociales, que hacen de nuestra zona un foco de localización de este tipo de arte joyero.

II. Tras el estudio de la forma, su contenido y la estética, se puede afirmar que nuestra joyería tradicional charra y en concreto el Botón Charro, al poseer las medidas áureas y ser arquetipo, símbolo y mándala, forma parte de la cultura y memoria colectiva universal de la humanidad, justificándose a si nuestra teoría sobre la globalización de este objeto.

III. Estamos en un momento complejo, donde la multitud de vías de comunicación poco ayudan y pueden alterar o adulterar el origen y la veracidad de los objetos joyeros. El "todo vale, y de cualquier manera", poco o nada favorecen a que nuestras raíces culturales perduren en el tiempo venidero. Sólo desde el conocimiento exacto se puede evolucionar, pero siempre dejando muy claros los orígenes y sus significados. La Filigrana Charra no ha quedado exenta de las transformaciones del consumo y de la moda que se produjeron en la década de los 60 y 70. La evolución de las clases sociales 
tradicionales hacia otras más amplias procedentes de la importancia de nuevos sectores productivos, han causado una agresión y destrucción importante de este tipo de joyería por considerarla como "paleta", en el sentido despectivo del término.

IV. A partir de los años 70 del siglo pasado se produce la incorporación del proceso industrial de la Microfusión como elemento fundamental para la comercialización de la Filigrana Charra, superando o sustituyendo la técnica artesanal, preindustrial y precapitalista, por otra industrial y capitalista. Gracias a la Microfusión se pudo dar una vertiente industrial a un sector puramente artesanal, para poder satisfacer la demanda de una sociedad mucho más consumista. La Microfusión le ha dado a la Filigrana Charra, la posibilidad de ser competitiva en precio y en cantidad en los mercados nacionales y extranjeros. Si este proceso industrial se realiza con la debida profesionalidad, no sólo no fagocitará a la Filigrana, sino que asegurará esta técnica tradicional y milenaria de la joyería. Potenciar ambas técnicas (Filigrana y Microfusión de Filigrana Charra), favorecerá a nuestro juicio, a un sector que en nuestra provincia está en vías de extinción.

V. Del estudio realizado podemos afirmar la importancia que ha tenido la mujer en este sector, como hacedora, heredera y transmisora de una cultura que hoy está en vías de desaparición, la mujer ha de volver a considerarse la "guardiana" de la cultura tradicional, siendo de justicia reivindicar este derecho. Reconocer la importancia y mantener la joyería tradicional como testimonio de referencia futura, colocaría a Salamanca en la punta de lanza de lo que nosotros denominamos la "Nueva Joyería" o "Nouveau bijou", que pretende volver a poner a nuestro territorio, en un lugar con futuro para no perder la identidad propia y ganar proyección internacional. 
VI. Es necesario desterrar de una vez por todas, la identificación que injustamente se ha hecho del término Charro con mal gusto. Tras el estudio realizado afirmamos que la Filigrana Charra, en el espacio geográfico que nosotras hemos estudiado, puede definirse como "la joya extraordinaria del pueblo llano". Podemos refrendar, que la encina es al Campo Charro, lo que la Filigrana Charra y el Botón Charro, es al alma de la cultura tradicional de la provincia de Salamanca. Proponiendo, sea rectificado la acepción 3 que la RAE hace sobre el significado de la palabra Charro-a, con mal gusto.

VII. La preservación, valorización y publicidad del Patrimonio histórico y cultural que representa la Joyería tradicional Charra, debe ser reconocido por todas las Administraciones Públicas, ya que el Ordenamiento Jurídico así lo establece, al constituir Patrimonio cultural etnográfico e incluso inmaterial. La extensa declaración legislativa, europea, estatal, autonómica y local sobre protección y tutela que deben ejercer los Poderes Públicos, no colisiona, en modo alguno, con el objetivo de nuestro estudio, poner de manifiesto y en valor, el derecho de la mujer a la joyería tradicional charra como emblema de su identidad, bien por el contrario, constituye una obligación y una asignatura pendiente a día de hoy. Sobre esta línea se plantea como necesario, legitimar lo más prontamente posible "el Botón Charro como Bien de Interés General", y demandar de nuestras Instituciones Locales y Autonómicas, Políticas públicas que hagan más visibles los objetos patrimoniales muebles y los bienes culturales inmateriales, de este Patrimonio cultural del pueblo Charro, ergo Castellano Leonés, ergo español. 


\section{BIBLIOGRAFÍA}


ABAD LICERAS, J.M. En el Décimo aniversario de la Ley 16/1985 Del Patrimonio Histórico Español(I) Disponible en:

http://www.iaph.es/revistaph/index.php/revistaph/article/viewFile/209/209

ALDANONDO SALAVERRÍA, I., "Las Comunidades Autónomas, el Estado y los bienes culturales eclesiásticos", Revista lus Canonicum, (1984)

ALONSO MENESES, G., Cultura Amazigh e identidad étnica, Rev, África Internacional, nº 19, lepala, Madrid, 1997.

ALONSO PEÑA, J.R. Nuevos modelos de gestión cultural en la crisis del siglo XXI, en http://jralonso.es/conferencias/ ( 21/2/ 2014)

ALSINA BENAVENTE, J, La fundición a la cera perdida: la microfusión, Ed Alsina, Barcelona, 1992.

ANDRÉS BRAVO,P, Recóndita Armonía, Ed Fundación Germán Sánchez Ruipérez. Madrid, 2014.

ANDRÉS PÉREZ, R, La Cueva de Salamanca y la Magia del Marqués de Villena, Ed Atlantis, enero, 2013

BALDACCI, P,Teoría y Método de Giorgio De Chirico, Cahiers du Musée Nacional d'art Moderne, N 11. París, 1983.

BARRERO RODRIGUEZ, I,La Ordenación Jurídico del Patrimonio Histórico. Civitas. 1990. ISBN 84-7398-745-4

BENITEZ DE LUGO, F., El patrimonio cultural español. (Aspectos jurídicos, administrativos y fiscales), Ed Comares (1995)

CASSIRER, E, Filosofía de las formas simbólicas I el lenguaje. Ed Fondo de Cultura, México, 1985.

CEA GUTIÉRREZ, A, Sobre Magia y Brujería, Revista de dialectología y tradiciones populares, Vol, LIX, Madrid, 2004. pp.3 y ss.

CEA GUTIÉRREZ, A, Entre el tópico urbano y la realidad rural..., Nuevas y viejas tradiciones en ámbitos urbanos, Anthropos, vol. No volumen, Barcelona, 2004. 
CEA GUTIÉRREZ, A., Sobre magia y brujería, Rev de Dialectología y Tradiciones Populares, vol. LIX, 2004.

CEA GUTIÉRREZ, A, La Protección contra el mal en la cultura popular Salmantina. Las joyas, L'espai del mal. Vol 1. 2005

CEA GUTIÉRREZ, A, La protección contra el mal en la cultura popular salmantina: Las joyas, L'espai del mal, Vol I, Madrid, 2005.

CHINCHILLA SÁNCHEZ, K, Conociendo la mitología, Universidad de Costa Rica, 2003.

$\operatorname{COM}(2007) 242$ final y Resolución del Consejo de 16 de noviembre de 2007, relativa a una Agenda Europea para la Cultura.

COMUNICACIÓN de la Comisión al Parlamento Europeo, al Consejo, al Comité económico y social europeo y al Comité de las Regiones. Hacia un enfoque integrado del patrimonio cultural europeo de 2014. Bruselas, 22.7.2014. COM(2014) 477 final.

COROMINAS, J, Diccionario Crítico Etimológico Castellano e Hispano, Vol. III.

DAMBRIM, P, Teoría ancestral de la tierra, Conferencia sobre domoterapeute, biología y medicina, París, 2013.

DE LA BANDERA ROMERO, M,L, El atuendo femenino ibérico, Rev, Habis, 9, 1978.

DE LA BANDERA ROMERO, M, L, Orfebrería Gaditana: técnicas y decoración, Boletín del Museo de Cádiz, III , 1981-82.

DE LA BANDERA ROMERO, M, Introducción al Estudio de la Joyería Prerromana Peninsular: técnicas, Revista Habis, 17 515-135 , Universidad de Sevilla, 1986.

DE LA BANDERA ROMERO, M.L, Introducción al Estudio de la Joyería Prerromana Peninsular: técnicas, Revista Habis, 17 515-135, Universidad de Sevilla, 1986. 
DE LA BANDERA ROMERO, M.L, La joyería orientalizante e Ibérica, mital sur penínsular. Tesis doctoral, Sevilla 1987

DIAS, P., Portugal e Espanha entre a Europa e alem mar, IV Simposio LusoEspañol de Historia de Arte, Instituto de Historia da Arte, Universidad de Coimbra, 1988.

ECO, U, Semiótica y filosofía del lenguaje, Ed Lumen, Barcelona, 1990.

ECO, U, Semiotica y filosofia del lenguaje (2a ed.) Ed Lumen, 1995.

ELIADE, M, Imágenes y símbolos, Ed Taurus, 1999.

ELIADE, M, Mito y realidad, Ed Kairós, S.A, Barcelona, 1999.

ELIADE, M, Tratado de Historia de las religiones, morfología y dialéctica de lo sagrado, Ed Cristiandad, Madrid, 2009.

ELIADE, M, Una nueva filosofía de la luna, Ed Trotta, 2010.

FIGUEROA, HERRADON, M,A, Joyas para el ama de cría, Art, Altamira, Rev del Centro de Estudios Montañeses, n 79, 2010. pp 227-246.

FIGUEROA HERRADON, M,A, Vestir la joyas, Museo del Traje, Centro de investigación de patrimonio etnológico, Ministerio de E.C.D., Madrid, Sept 2014.

FOMENTO CULTURAL BENAMEX, Charrería, Arte y Tradición. Fundación Pedro y Elena Hernández, 2008.

FREUD, S, La interpretación de los sueños, Obras completas Ed Amorrotu, Buenos Aires, 1976.

FREUD, S, Introducción al psicoanálisis, Ed Alianza, Madrid, 1986.

FREUD, SIGMUND, Obras completas, Ed Amorrortu, Buenos Aires, 1996. 
FUNDACIÓN ANTONIO ALMEIDA, Actas do Coloquio ourivesaria do Norte de Portugal, 1984.

FUNDACION SALAMANCA CIUDAD DE CULTURA Y SABERES, "ArS Gemmaria Nova" ISBN: 978-84-96603-99-8 Depósito legal: S 342-2013, Salamanca, 2013.

GARCÍA CRUZ, J A, Las Matemáticas de Luca Pacioli,Seminario Orotava de Historia de la Ciencia, año X. La Orotava. Fundación Canaria Orotava de Historia de la Ciencia, Las Palmas de Gran Canaria, 2001

GARCÍA GONZÁLEZ, L, Los grandes ejes territoriales turísticos peninsulares: la dificultar de planificar, articular y consolidad productos turísticos espaciales: ejemplo de la Vía de la Plata, Cuadernos geográficos de la Universidad de Granda. N 34, 2004

GARCÍA, A, Conferencia de Matemáticas áureas y geometría sagrada, Psicólogo e investigador. COGNOS, 2013.

GHYKA, MATICA, C.,Estética de las proporciones en la naturaleza y en las artes, Ed Poseidon, S.L.,Barcelona, 1977.

GHYKA MATYLA,C, El número de oro: I Los ritmos- II Los ritos",Traducción J. Bosch Bousquet, Ed Poseidón, , 3ª edición, Barcelona, 1978.

GIRALT, JOSEP, Las joyas, exponente de la cultura amazigh, Diálogos, Rev, Afkarjideas, Barcelona, 2005.

GONZÁLEZ DEL CAMPO, J, Notas sobre técnicas protohistóricas. Técnicas del granulado en la joyería antigua, Pyrenae, 1968.

HERNÁNDEZ MARCOS, L, Los charros, Etnografía Histórica e Identidad Cultural, Bubok Publishing, S.L., 2009.

HERRADÓN FIGUEROA, M,L, Joyería Charra, Museo del Traje, Ministerio de Educación y Ciencia, Madrid, 2005. 
HIGGINS, R, Greek and Roman Jewellry, Londres, 1961.Pág.

JACOBI, J, La psicología de C.G. Jung, Ed Espasa Calpe, segunda edición corregida y aumentada, Madrid, 1963.

JACOBI, J, Complejo, arquetipo y simbolo: en la psicología de C. G. Jung, Fondo de Cultura Económica, México, 1983.

JUNG CARL, G, El yo y el inconsciente, Luis Miracle, $2^{a}$ edición, Barcelona, 1950.

JUNG CARL, G, El secreto de la flor del oro. Un libro de la vida china, Ed Paidós, Buenos Aires, 1961.

JUNG CARL, G, Símbolos de transformación, Ed Paidós, $2^{\text {a }}$ Edición, Buenos Aires, 1962.

JUNG CARL, G, Símbolos de transformación, Ed Sudamericana, Buenos Aires, 1964.

JUNG CARL, G, El hombre y sus símbolos, Ed Aguilar, Madrid, 1966.

JUNG CARL, G, Arquetipos e inconsciente colectivo, Ed Paidós, Buenos Aires, 1970.

JUNG CARL, G, Energía psíquica y esencia del sueño, Ed Paidós, Buenos Aires, 1982.

JUNG CARL, G, Arquetipos en consciente colectivo, Ed Paidós, Buenos Aires, 1989.

JUNG CARL, G, El hombre y sus símbolos, Ed Paidós, Barcelona, 1995.

MALEXEVERRÍA, I, Bestiario Medieval, Ed Siruela, Madrid, 2002.

MEDERUELO, J,Descontextualizar,art.El Pais, 22-nov-2003. 
MONTAÑÉS, FONTENLA, L, Joyas, Diccionario Antiquaria. Ed Antiquaria, S.A., Madrid, 1987.

NEDELSKY, J ,Reconceiving Autonomy: Sources, Thoughts and Possibilities, Yale Journal of Law and Feminism. 1989

ORTIZ ECHAGUE, J, España tipos y trajes, Ed Mayte, Bilbao, 1950.

PÉREZ DE ARMIÑAN Y DE LA SERNA, A. "Competencia del Estado sobre el Patrimonio Histórico español y la Constitución de 1978”, Civitas Ediciones, S.L., 1997

PICARDY, S, B, Salla oreticeri granulate etrusca, Studi Etrusqui, 1955.

PIÑEL, C, La joyería popular zamorana, Ed Caja de Ahorros Provincial de Zamora, 1985.

PLA BALLESTER, E, Instrumentos de Trabajo Ibéricos en la Región Valenciana, Primera Reunión de Historia de la Economía Antigua de la Península Ibérica, Valencia, 1968

REDONDO, J.L. en http://hayderecho.com/2013/10/24/la-diputacionprovincial-esa-gran-desconocida-con-algunos-numeros-para-empezar-aconocerla/ (14/1/2015)

RICOEUR, P, Teoría de la interpretación. Discurso y excedente de sentido, Ed Siglo XXI, México, 1999.

RIVERO ORTEGA, R., Los derechos de los ciudadanos en sus relaciones con la Administración en España, Revista de la Facultad de Derecho de la Universidad Católica Andrés Bello (Venezuela), 2009

ROJO PÉREZ, N, La investigación cualitativa, aplicaciones en salud, MINSAP, ENSAP La Habana, 2002.

SANCHEZ BLANCO, A., La Organización Intermunicipal, ISBN 978-8496440-47-0 
SARDUY DOMÍNGUEZ, Y, El análisis de información y las investigaciones cuantitativa y cualitativa, La Habana, 2006

SÉPTIMO Programa Marco de Investigación y Desarrollo Tecnológico; «Patrimonio cultural y cambio mundial», www1.dicoruna.es/...programa_marco/programas/vii_progr_marco.htm

SILVA MALDONADO, B, El inconsciente colectivo en la pintura moderna. La exaltación del "objeto" y la animalidad: aportes desde la psicología de Jung, Pontificia Universidad Católica de Perú, julio, 2012.

SPENGLER, O, La decadencia de occidente, Ed Espasa Calpe, 2007.

STC 17/1991, de 31 de enero, recursos de inconstitucionalidad promovidos por el Consejo ejecutivo de la generalidad de Cataluña, junta de Galicia, gobierno vasco y parlamento de Cataluña, contra determinados preceptos de la Ley 16/1985, de 25-6-1985, reguladora del patrimonio histórico español. (rtc 111\17)

STC153/1985, de 7 de noviembre, recoge como criterio general el de la finalidad específica a la que la norma pretende atender.

THOUVENIN, A, La Soudre dans la Construction des oeuvres d'orfevrerie Antique et ancienne, Revue Archeologique de l'Est et Centre-Est, 1973.

TOLEDO AGÜERO, Y, Sección Áurea en Arte, Arquitectura y Música,cap. VV.5. www.matematicas.uclm.es octubre 2014.

VAZQUEZ FRAILE, A, Diccionario Latín-Españo.I

VERNIER, F, La Bijouterie et la Joaillerie Egytiennes, El Cairo, 1907.

VON FRANZ, M L, Conclusión. La ciencia y el inconsciente en Jung. Ed Paidós, 1965.

http://www.congreso.es/consti/constitucion/indice/sinopsis/sinopsis.jsp?art=4 $6 \&$ tipo $=2(13 / 12 / 2014)$

http://www.dipsanet.es/cultura/

http://www.patrimoniocultural.jcyl.es/web/jcyl/PatrimonioCultural/es/Plantilla1 00/1284181506987/ 
www.Googleimagenes.es

www.ec.europa.eu/debate-future-europe/newnarrative/pdf/declaration_es.pdf

www.eenc.info/news/the-social-and-economic-value-of-cultural-heritageliterature-review

www.rea.es

www.wikipedia.es

www.wordreference.com 
Anexo.... DVD adjunto 


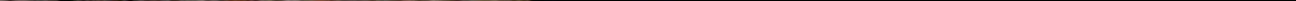


arsgemmarianova 



\title{
arsgemmarianova salamanca
}

\author{
nohay2igual
}

Sala de exposiciones Santo Domingo de la Cruz 2013

Salamanca

Ciudad de Cultura y Saberes

AYUNTAMIENTO DE SALAMANCA 
No hay 2 igual, agradece a los patrocinadores:

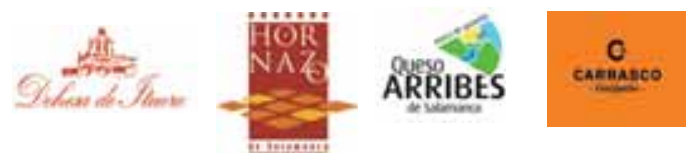

Editado por:

Fundación Salamanca Ciudad de Cultura y Saberes

(C) de esta edición:

Fundación Salamanca Ciudad de Cultura y Saberes y los autores

Imprime:

Gráficas Lope

ISBN: $978-84-96603-99-8$

Depósito Legal: S. 342-2013

Ninguna parte de esta publicación puede ser reproducida total o parcialmente, almacenada o transmitida en manera alguna ni por ningún medio sin permiso previo de los editores. 


\section{arsgemmarianova INDICE}

Fernando Población. Joyería tradicional salmantina. Su transformación

Joya \& piedra

$M^{a}$ Eugenia Bueno y Verónica Marín. Un juicio intrínsecamente

Joya \& hilo

Reinas

Joya \& color 



\section{JOYERIA TRADICIONAL SALMANTINA. SU TRANSFORMACIÓN}

Cuando me propusieron colaborar en este proyecto pensé no solo que era una broma, sino incluso una locura. Confesé mi total inexperiencia, discapacidad y lo que es más grave, una cierta aversión producida por la que es seguramente la pieza clave 0 , al menos, la más conocida de nuestra artesanía: EL BOTON CHARRO.

Abrumado desde niño por llaveros, gemelos, barandillas de balcones, labrados en fachadas y hasta cucharitas de plata que servían de recuerdo a turistas, llegué a desarrollar un efecto negativo que aún conservaba al inicio de este proyecto.

Tanto es así que los términos charro, charrería, etc., me producían un efecto rancio y desfasado que asocié injustamente a la piedra de Villamayor (no había construcción que se preciara que no fuese hecha de este material) y a nuestra encina, muy atractiva "per se", pero descontroladamente pintada, fotografiada, como si en nuestro campo no se pudiese plantar otro árbol. Sinceramente no me gustaba nada.

Ante este descontrol mental metí el botón, la piedra y la encina, en una caja, no de Pandora, como se puede suponer, sino de Fernando. Y la dejé estar mientras estudiaba en Madrid mi carrera de arquitectura. Habrán observado que tal y como está el patio, he puesto arquitectura con minúsculas. Debo confesar que durante ese periodo de mi vida cuando venía a Salamanca nunca intenté destapar la dichosa caja y la dejé arrinconada en mi memoria.

Soy de la teoría de que una década es casi una vida en lo que a la evolución de la manera de pensar se refiere, y tengo como prueba la caja en cuestión. De vuelta a Salamanca destapé la caja. Observé la piedra de Villamayor, la saqué, la estudié y me enamoré de ella y de Salamanca, aunque siga pensando que abusamos de nuestra piedra y que el desconocimiento de otros materiales desvirtúa en cierto modo el atractivo monumental e histórico del casco antiguo. 


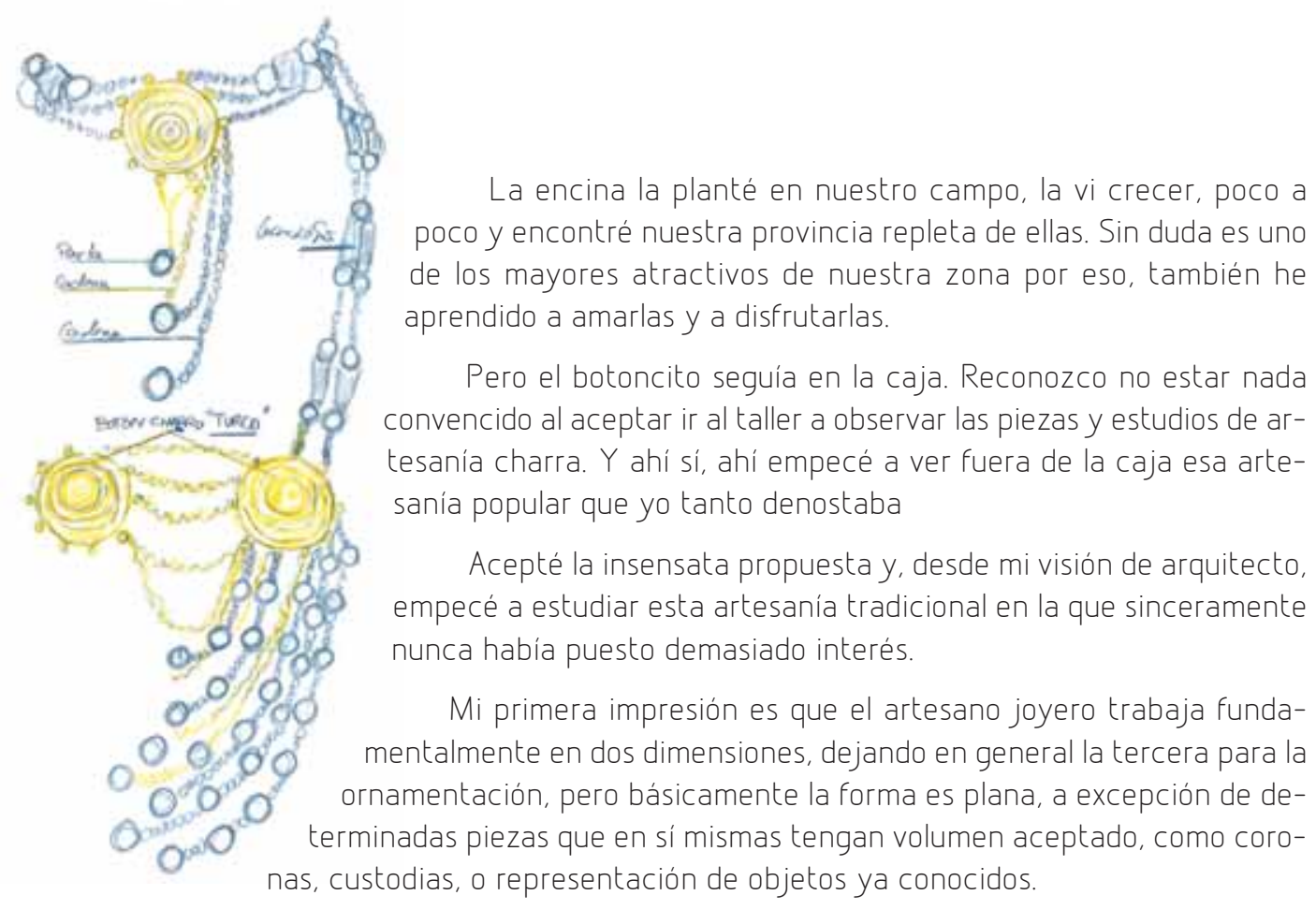

La base es geométrica regular y, partiendo de un centro, juega y se recrea con tres figuras fundamentales: el círculo, el cuadrado y el triángulo. Generalmente su composición se basa en unos ejes tanto verticales como trasversales, para reforzar la simetría y que a la vez le permite a la pieza básica ser repetida en uno o ambos sentidos. El juego de macizos y vanos forma parte de la capacidad del artista.

Partiendo de esta premisa geométrica encontramos en edificios emblemáticos de nuestra arquitectura, evidentemente seccionados, o en paramentos de los mismos, verdaderos diseños de artesanía tradicional popular. La Alhambra es un juego exquisito de cuadrados del que saldría el diseño para más de una pieza de artesanía. Sus paramentos labrados son diseños de altísima calidad en la que sus cuadrados ornamentados y seriados sirven de base para incorporar escritos de la cultura árabe.

Pero volvamos a nuestra tierra castellana, y observemos la Catedral de Astorga. En las bóvedas de su nave central se puede observar un juego de artesanía 
evidente, sustentada por una técnica constructiva para su cubrición de un atractivo espectacular. Dibujémoslo en planta y nos dará el diseño del mejor artesano.

Acercándonos a casa, en la Catedral de Ciudad Rodrigo, la bóveda de la Capilla Mayor de Gil de Hontañón, es un preciso y novedoso diseño de arquitectura y artesanía.

Tenemos en Salamanca la Torre del Gallo de nuestra Catedral que tiene muchísimas similitudes con el BOTON CHARRO al que evidentemente ya he puesto en valor.

Podríamos seguir comentando catedrales e iglesias de nuestra zona y observando en ellas extraordinarios diseños de filigrana artesanal, pero eso lo hace Peridis con enorme acierto.

Nuestra misión es actualizarnos. Hemos ganado en tecnología, pero no hemos perdido en capacidad e ingenio y esta exposición, es una clara muestra de ello. Démosle a la mujer frescura en sus complementos como lo tiene en su vestimenta, consecuencia de su actividad propia, de su gran capacidad.

La ruptura que supone esta exposición me hace invitarles a que la observen varias veces, para que aprecien el paso adelante que por primera vez se da en este tipo de artesanía, que a partir de ahora deja de estar anclada al pasado.

\section{Fernando Población}

Arquitecto

Comisario de la exposición 



\section{JOYAS DEL ORIGEN, JOYAS DEL FUTURO}

En el principio fue la tierra de origen: el amor hacia ella de sus gentes y dones muy especiales, como los minerales preciosos que estas tierras del oeste proporcionaban. Luego, fue la consolidación de la visión sagrada de la realidad, del querer los humanos ir más allá de una realidad primitiva que los ojos veían. Asi fue naciendo el arte en un nivel superior y las artesanías en el mismo nivel, pero más unidas a lo popular y al esfuerzo diario. Así, en estas tierras nuestras de Salamanca y de sus alrededores (León, Zamora, Portugal) fueron naciendo joyas preciosas -ya prerromanas en algunos casos-, que sintonizaban con las joyas de otras tierras (Galicia) o que estaban en sintonía (o eran resonancia) de las de Oriente Medio.

Luego, en esta tierra nuestra, se dio un cruce de caminos que estimulaba el ir y el venir en busca de esos preciados metales: el oro, la plata. La Vía de la Plata ascendía así en busca del Camino de Santiago, por donde Europa y otra cultura entraban en nosotros. Minas como las de Las Médulas, las mayores minas de oro del Imperio romano, estimularon sin duda el nacimiento de esa joyería tan especial que solo a esta tierra afecta y que en Salamanca posee en su artesanía uno de sus privilegiados centros. El valor económico, social, cultural, religioso, totémico de las piezas, se enriqueció aquí de manera excepcional.

Había como una atracción previa que facilitó este arte. El Dr. Julio Carro nos habló en uno de sus libros de una mitica ruta maritima que, llegando de Oriente, bordeaba la costa portuguesa y entraba, río Sil arriba, hasta los territorios mineros del oeste. Otra vía más directa es la que, desde el sur andaluz y la mítica Tartesos, ascendía por la ya mentada Vía de la Plata, ruta a la que debemos seguir prestando atención y promocionándola por sus muchos valores arqueológicos, históricos, etnográficos. Así que ahí están, ya desde el origen, a lo largo de los siglos, esos testimonios preciosos de la joyería salmantina. 
Pero algo había que hacer para que ese rico fondo no se quedara en pasado, en costumbrismo anclado en el tiempo, transmitido, eso sí, ejemplarmente, de familia a familia en el tiempo, de padres a hijos, preservado, amado. Ahí es donde intervienen -mágicamente, casi como un milagro diría yo- las ideas y las nuevas obras debidas a María Eugenia y Verónica. La investigación, lo empresarial, el diseño, el arte, se han fundido no solo para metamorfosear la artesanía del pasado, sino para llevar -sorprendentemente, inesperadamente para nosotros- la esencia de formas y materiales charros al siglo XXI.

Creo que la persona que contemple las imágenes de este catálogo, o quien vea las piezas expuestas, en su más vistosa realidad, se sentirán sorprendidos de encontrarse, ante todo, con arte y artesanía, con la obra nueva. Me refiero a que el arte verdadero de nuestro tiempo es el fruto de unas raíces auténticas, de formas y mensajes remotos; pero, a la vez, las piezas de nuestro tiempo no adquirirían valor sin esa característica primordial de ser obras nuevas, originalísimas. Es decir, el diseñador y las personas que aman hoy esas obras, las fomentan y protegen, han tenido el don y la capacidad de trasladar lo clásico a otra dimensión, sin que la obra pierda su esencia.

Nacen así -insisto: de manera tan sorprendente como bellísima- estas piezas en las que otros factores -color, riesgo formal, imaginación, fantasía, esplendor de la representación, creatividad, fecunda abstracción- se funden para dar lugar a una exclusiva joyería de nuestros días, que perpetúa la pasada, pero enriqueciéndola, arriesgando mucho en busca de un fulgor nuevo. Pero de ese riesgo también nace lo auténtico.

La joyería tradicional charra, sus finisimas filigranas, están en los orígenes, como hemos dicho: encontramos su resonancia en las piezas de Oriente y en las arracadas ibicencas, mas la hallamos proyectada mucho después hacia América en la charrería mexicana y en muchos otros lugares por donde se ha propagado su fama. Siempre Salamanca y su tierra, nuestro fecundo oeste, es el centro vigoroso de este arte que irradia del universal "mandala" del botón charro, por citar solo uno de los frutos más universalizados de esta cultura de la joyería. 
Porque sí, en definitiva, nos encontramos ante una muestra de cultura excepcionalmente vivificada en nuestros días gracias al amor y a la maestría de quienes han sabido perpetuarla. Protejámosla, mimémosla, promocionémosla. Esta exposición que se celebra en la sala de exposiciones Santo Domingo de la Cruz de Salamanca, es la primera y más contundente prueba de que estos tres deseos míos para un arte magistralmente vivificado, son una realidad plena.

Antonio Colinas

Escritor

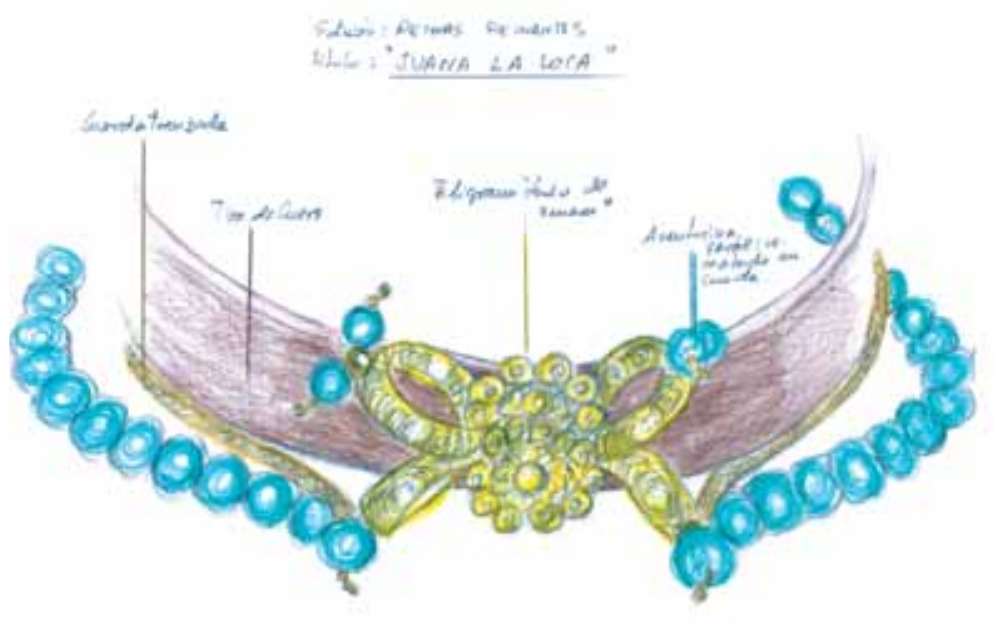





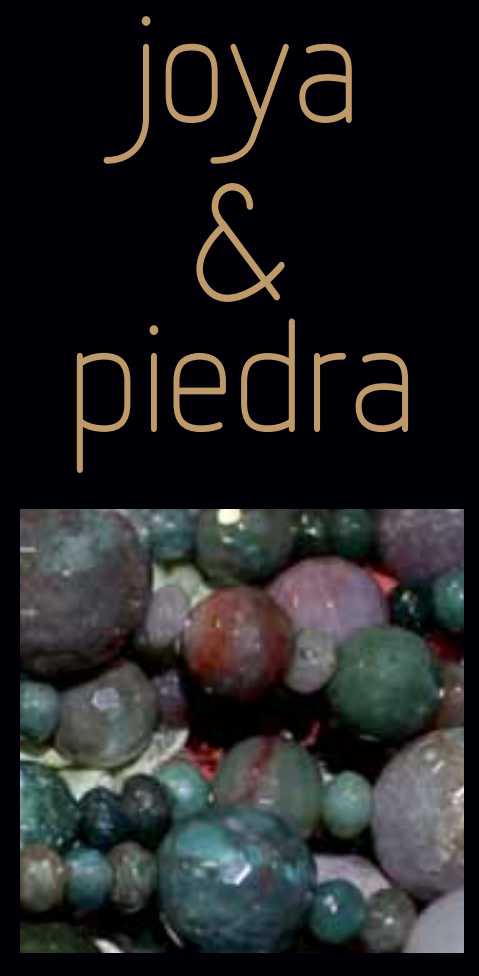





\section{UN JUICIO INTRINSECAMENTE DESINTERESADO... DESDE LA PIEDRA}

No hay 2 igual, inaugura una nueva manera de ver, de concebir, de expresar. Desde la "armonía", la voluntad creadora de esta marca aúna la creatividad del artista y el pensamiento filosófico-cultural, para concebir aspectos esenciales de una joya antigua que deriva en una nueva.

Razón de historia + razón de futuro = Razón nueva y creadora .

Plenitud, seguridad y elegancia conforman el resultado final, para llegar a una estética madura pero juvenil a la vez. Incorporando nuevos elementos a formas heredadas de la noche de los tiempos.

Aquí el gozo estético es radicalmente lírico: habla un pueblo en reposo del tiempo y le da la palabra a un pueblo nuevo que desea movilidad para el futuro.

Sembramos la idea a favor de la propia idea y así, difundimos su uso "nuevo".

El buen artista siembra y espera a que el espectador anónimo con su valentía e ingenuidad valore, sopese y comprenda el alma misma del creador de objetos plagados de simbolismos.

No hay 2 igual redescubre los principios etnográficos de la mujer del pueblo, haciendo saltar las lágrimas de admiración de ese patrimonio que guarda y oculta este territorio antiguo del oeste ibérico.

Se hace fuerte en el deseo de supervivencia a través de la humildad, pero sin olvidar la belleza intrínseca de los elementos con los que trabaja, dándoles un futuro con un uso moderno. No hay nada pretencioso, simplemente "creencia" en lo nuestro, en nuestros propios orígenes sin tener que ir a buscar nada fuera de nuestras propias fronteras, llenas de infinidad de recursos sin explorar. 
Pretende en este tiempo lleno de "Artes" incorporar fundamentalmente el amor de lo único, de lo manual, de la representación estética de una herencia para poder atisbar un "...a ver qué sucede...", "qué siente el ojo observador", ese que mira para luego ver más allá de la simple forma o la composición.

Este proyecto, como todos, ha pasado por diferentes periodos de creación y de expectación, de tormentas y calmas chichas, pero jamás desesperó, al contrario, continuó

Siempre hemos buscado, investigado para poder sorprendernos y sorprender.

Lo esencial es buscar y a través de la búsqueda crear... así, se fusionó la joya con la piedra, creando, diseñando, aunando, experimentando, en definitiva, intentando aportar.

La joya llegó a la piedra, esa que en el inicio nos anclaba al origen, a la tierra madre.

Deconstruimos los elementos antiguos, desmembrándolos, observándolos individualmente a cada uno para darles una identidad propia, pues comprobamos la hermosura de las partes, origen del todo.

Esas partes se fusionaron con elementos diferentes para buscar la poética de un espacio nuevo, donde la mujer interviniera desde el remoto tiempo; y descubrimos que allá en el pasado el azabache, el coral, la piedra, incluso piedras sospechosas de pureza, se ensamblaban misteriosamente con la joya para dar un rito antiguo a esa mujer temerosa de ser mujer.

Nosotras conjugamos sus elementos de manera nueva y dimos notas diferentes a la sinfonía antigua. Sorprendentemente encontramos las piedras que nos identificaban con esta tierra: los rojos de las amapolas, los verdes de la ribera charra, los oscuros de nuestros quercus, los azules brillantes de nuestro cielo castellano, la paleta de ocres de nuestra tierra. Y con habilidosas manos se construyeron micromundos para una nueva mujer, esa que ya no es temerosa, esa que elige su propia joya, esa que nunca olvida su identidad y su origen. 
Piedra, hilo, tela y color buscan lo universal, lo cósmico, lo espiritual, para completar emociones, esas que desde aquí esperamos que a la mujer que observa también se las provoquen.

Utilizamos el camino sencillo, la simbología, la estética, la palabra intuida para mezclarlo con un pensamiento abierto dando a nuestra artesanía antigua esa dimensión que la saca fuera de las tinieblas.

\section{Ma Eugenia Bueno y Verónica Marín \\ No hay 2 igual}

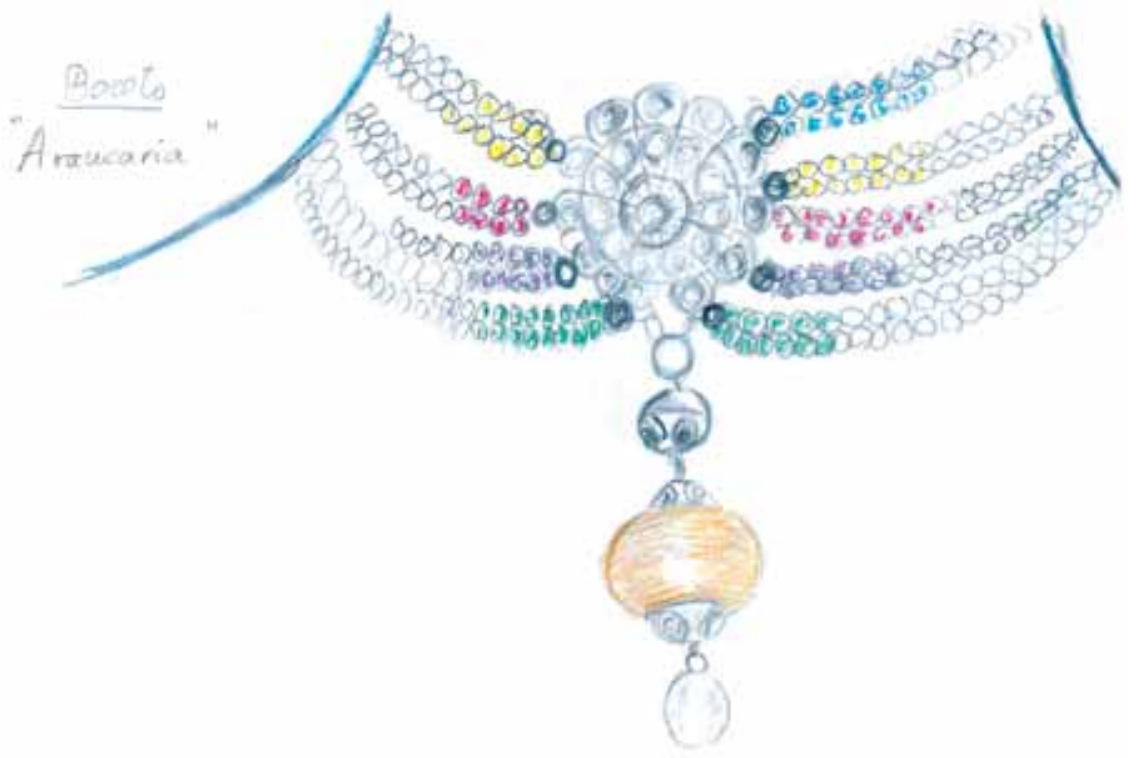




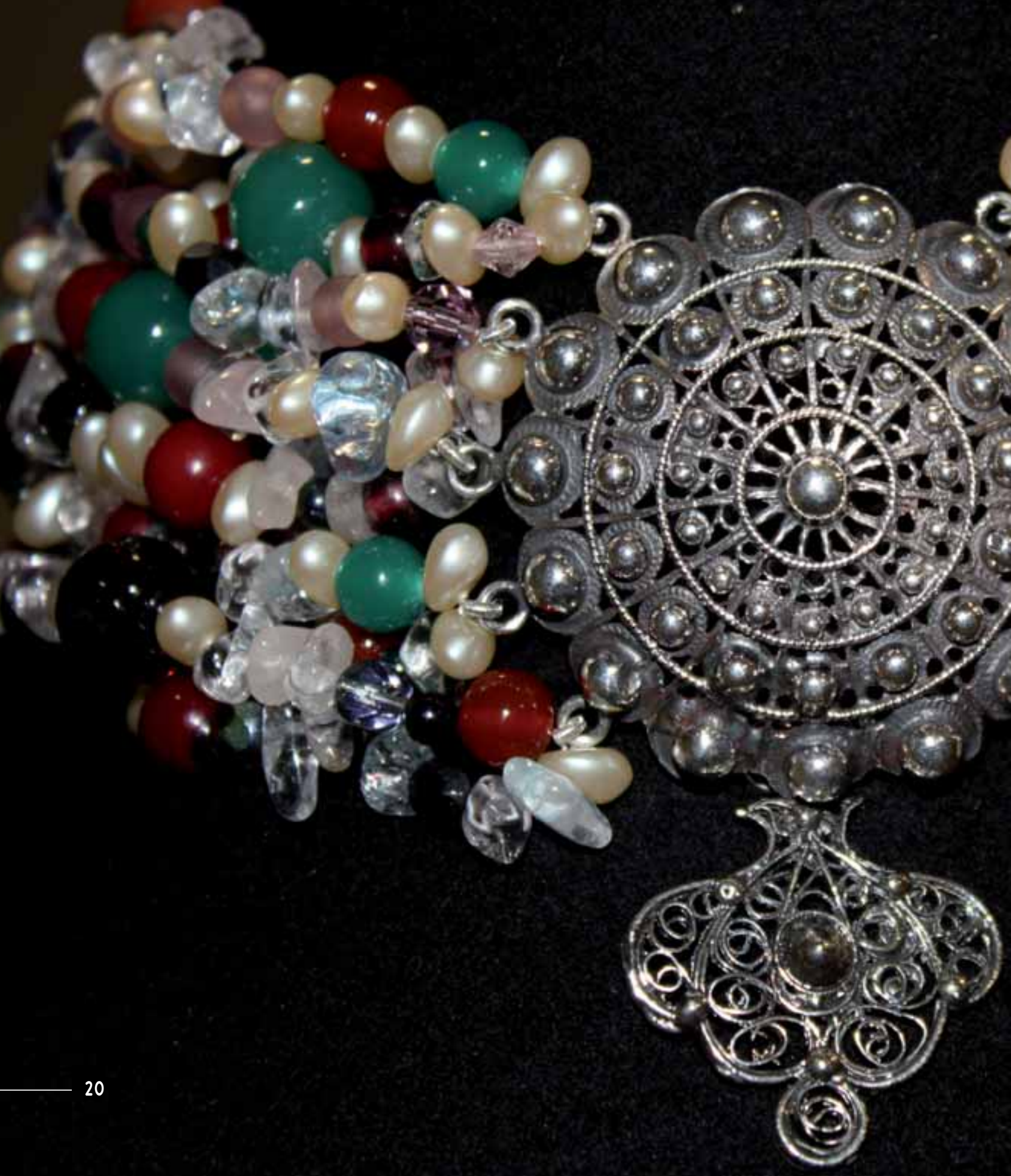




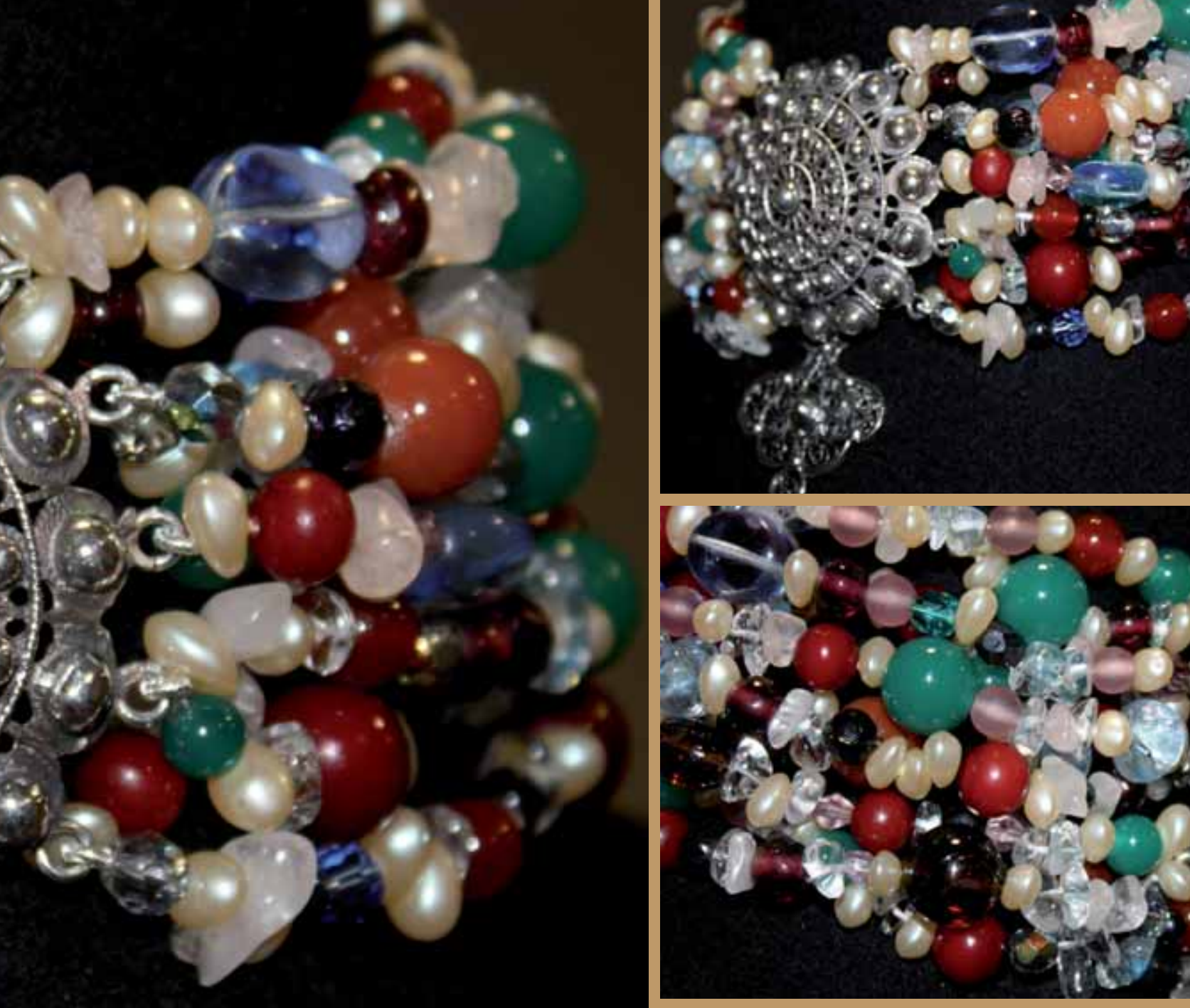




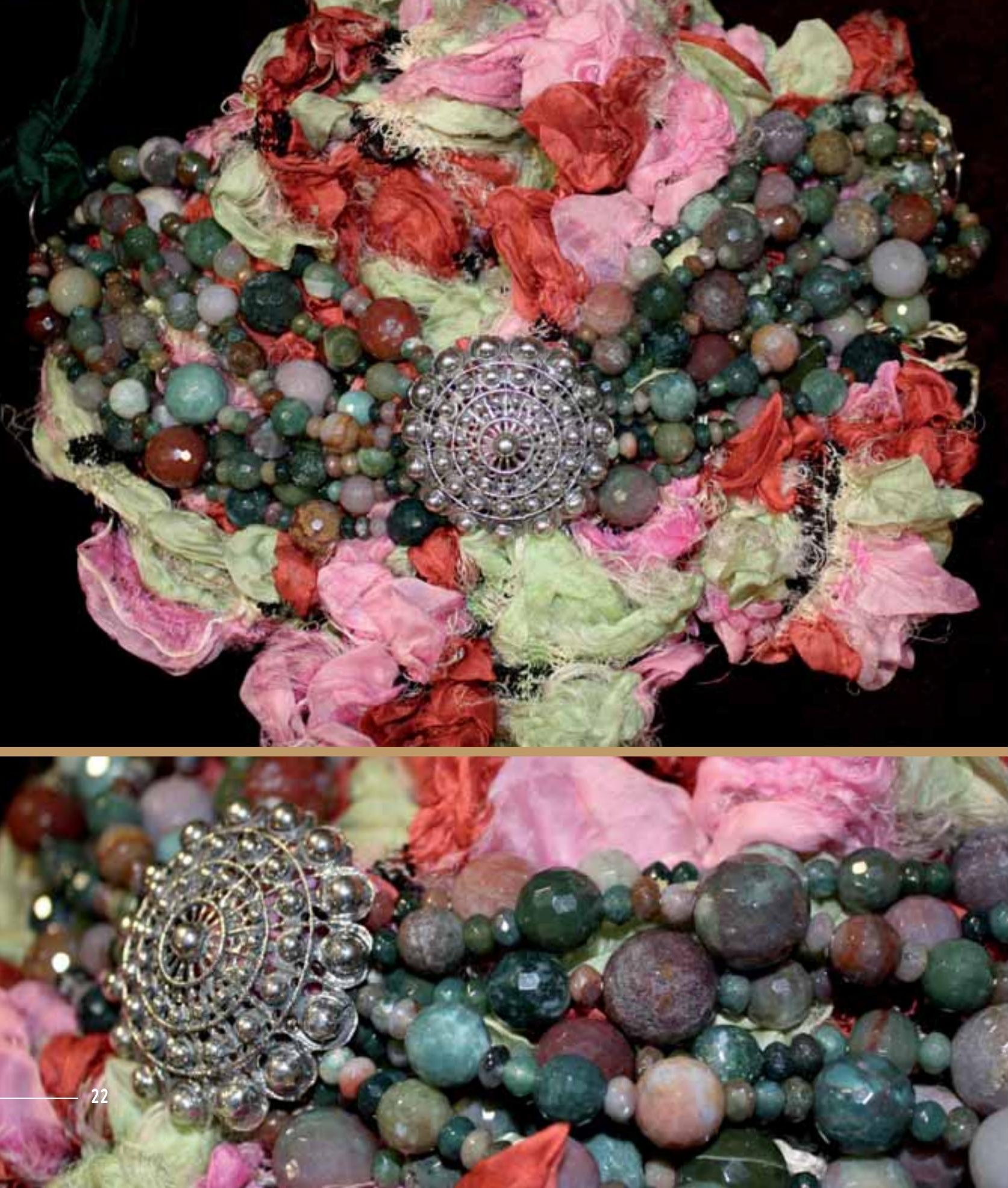




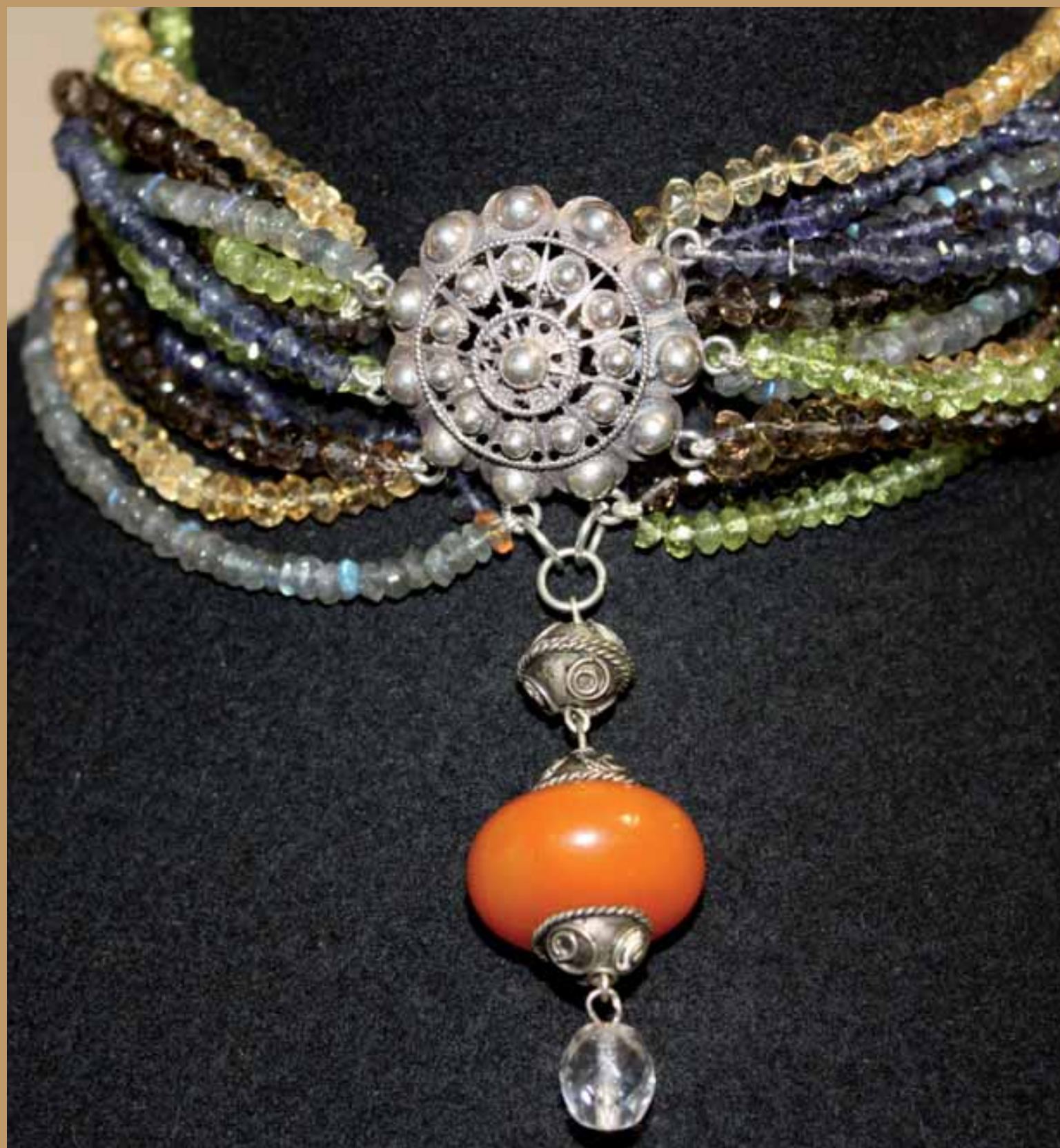





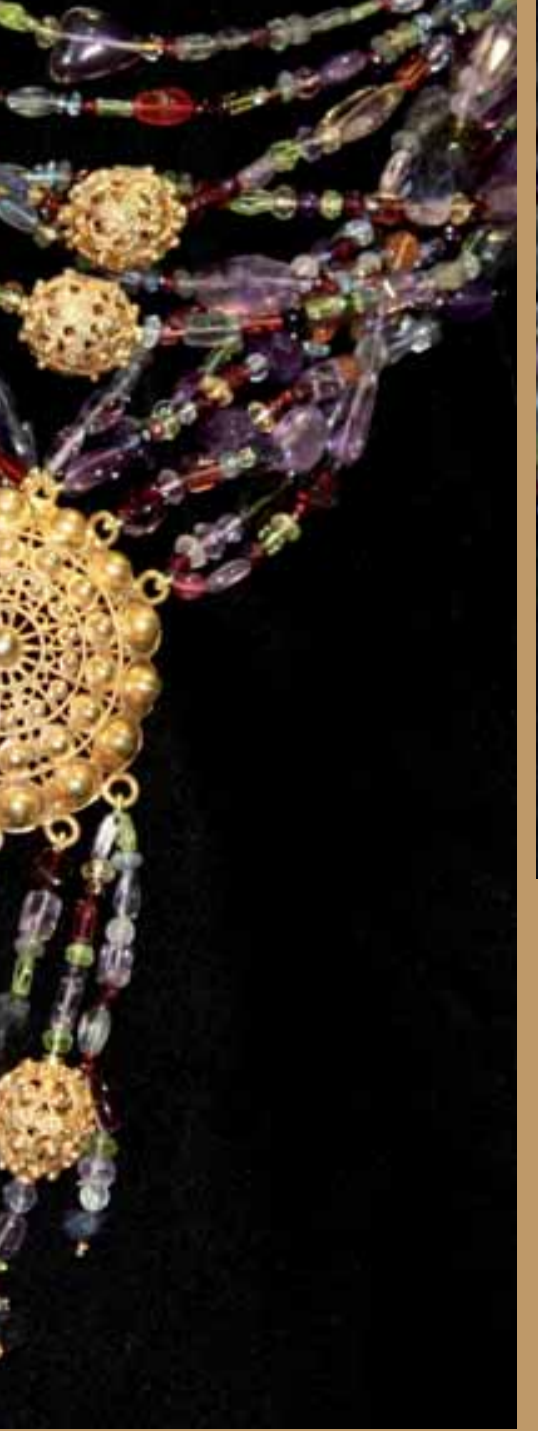

(A)

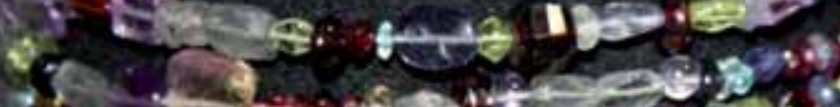

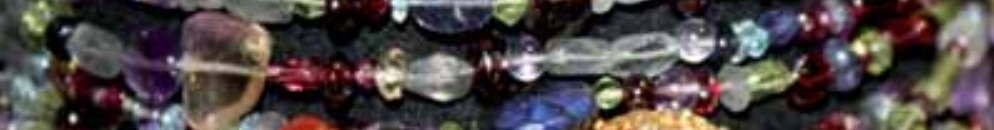

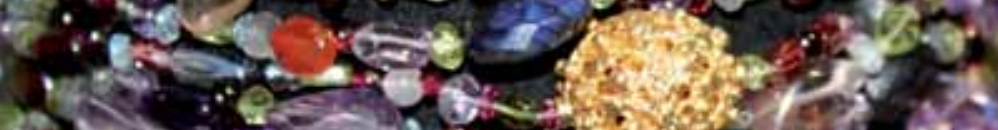

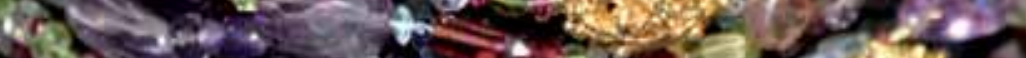

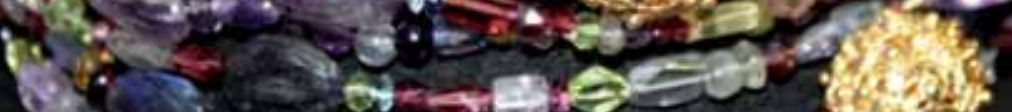

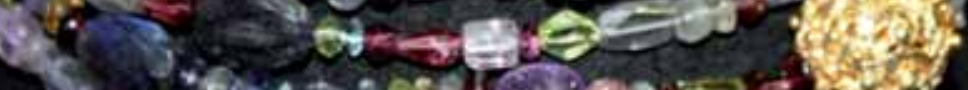

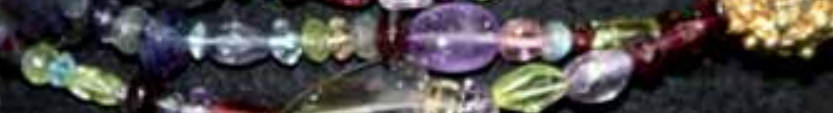

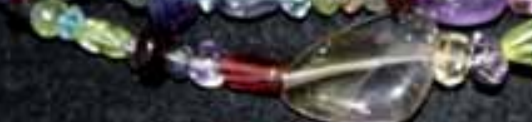





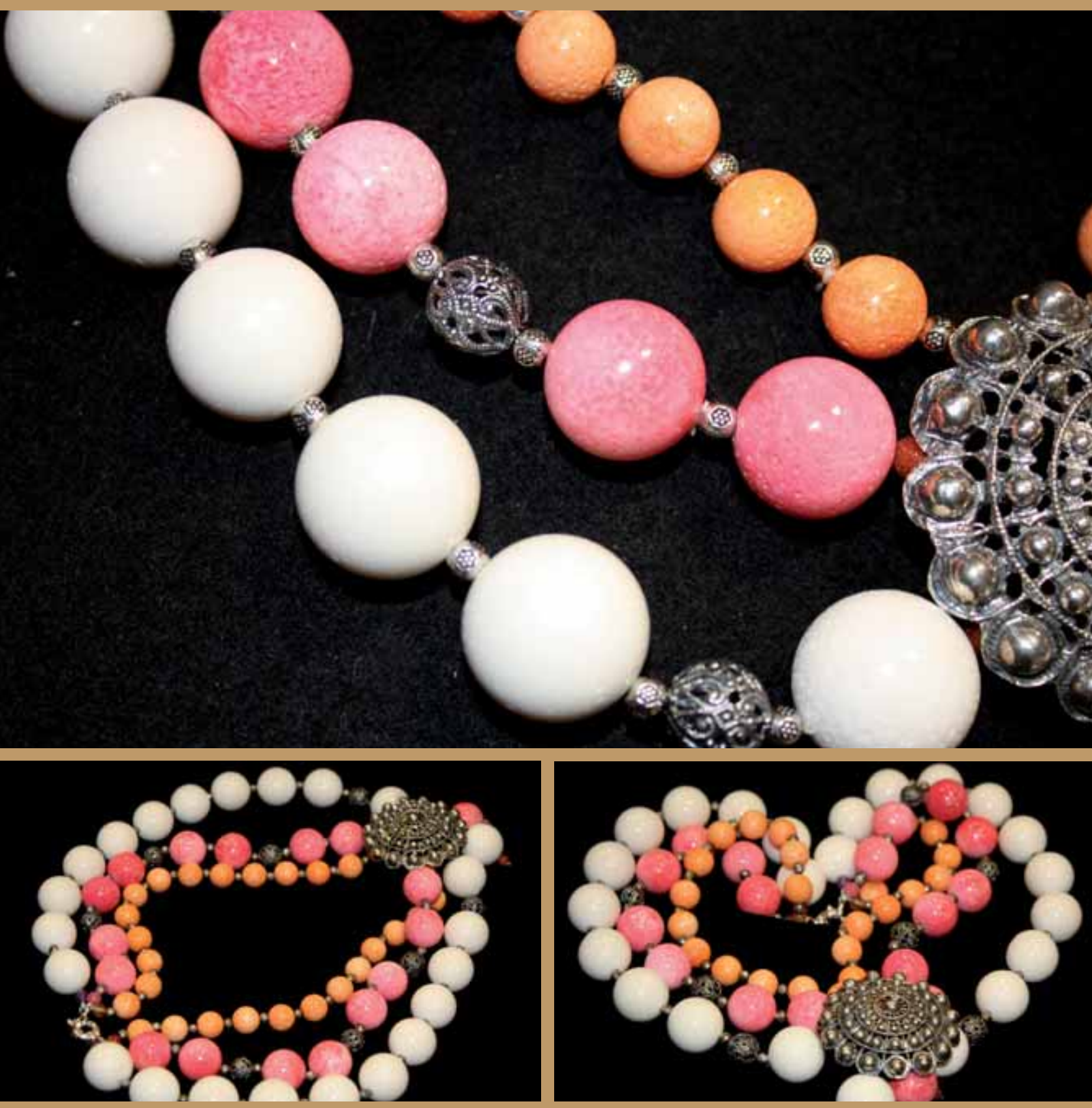




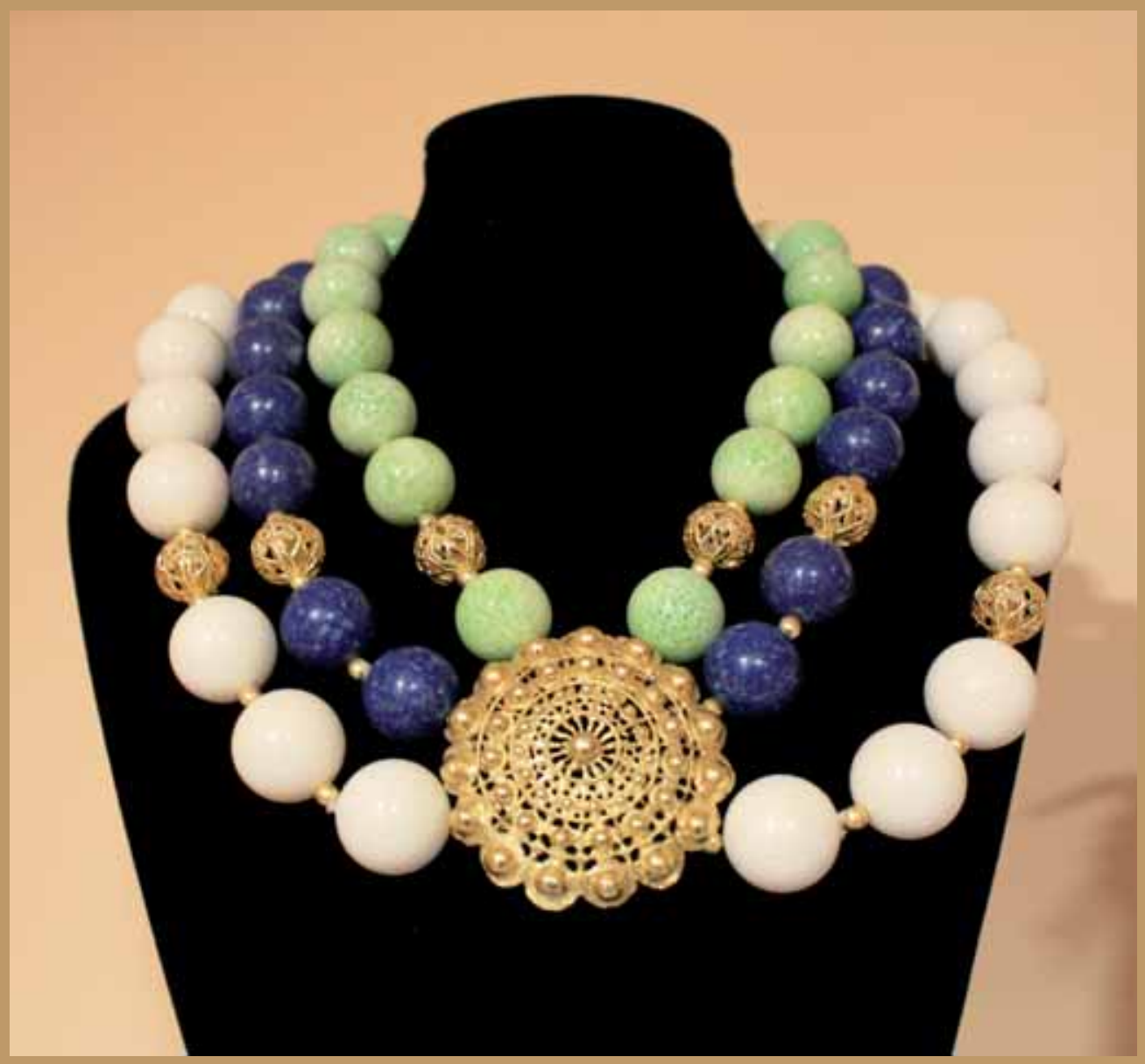





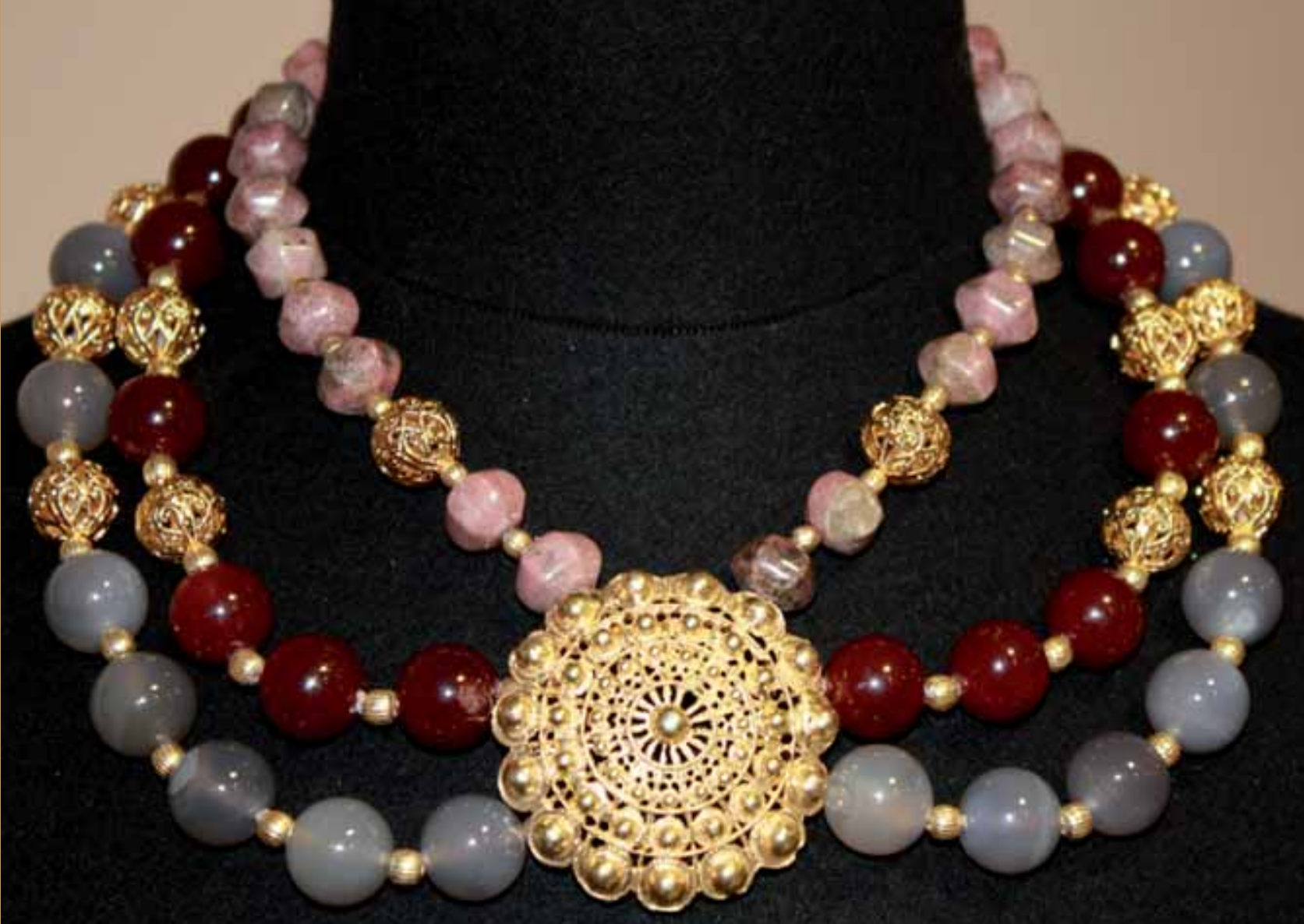




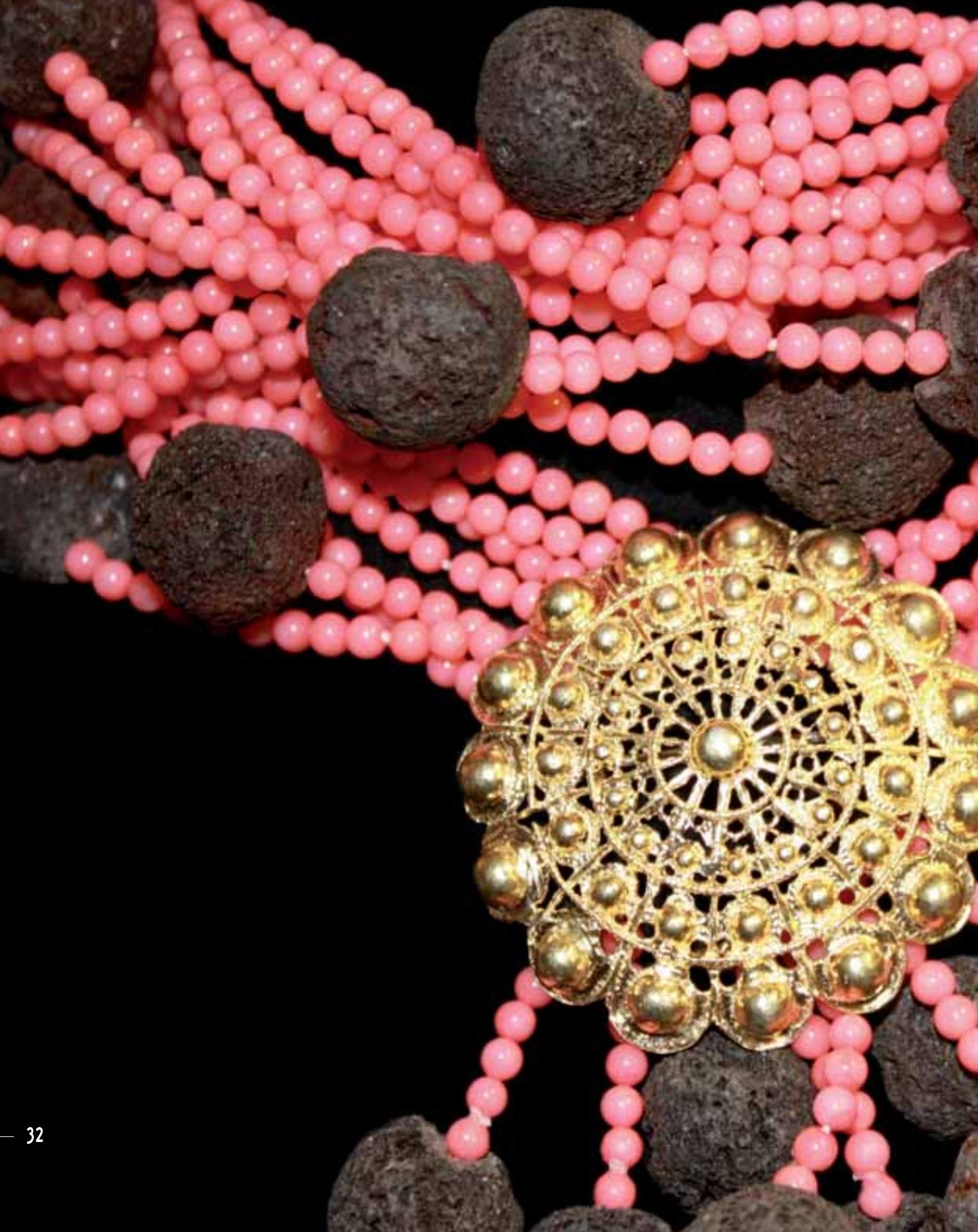




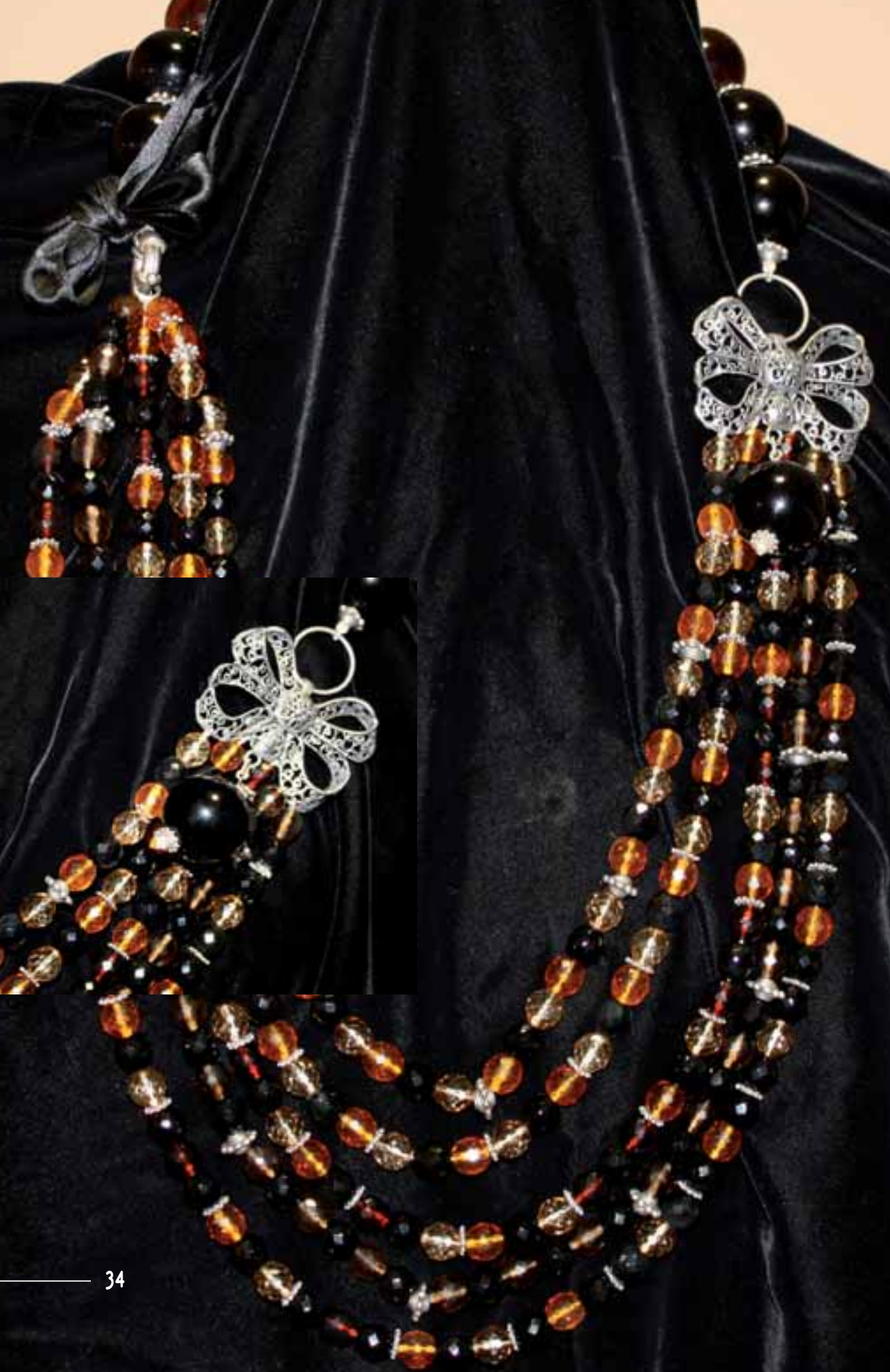




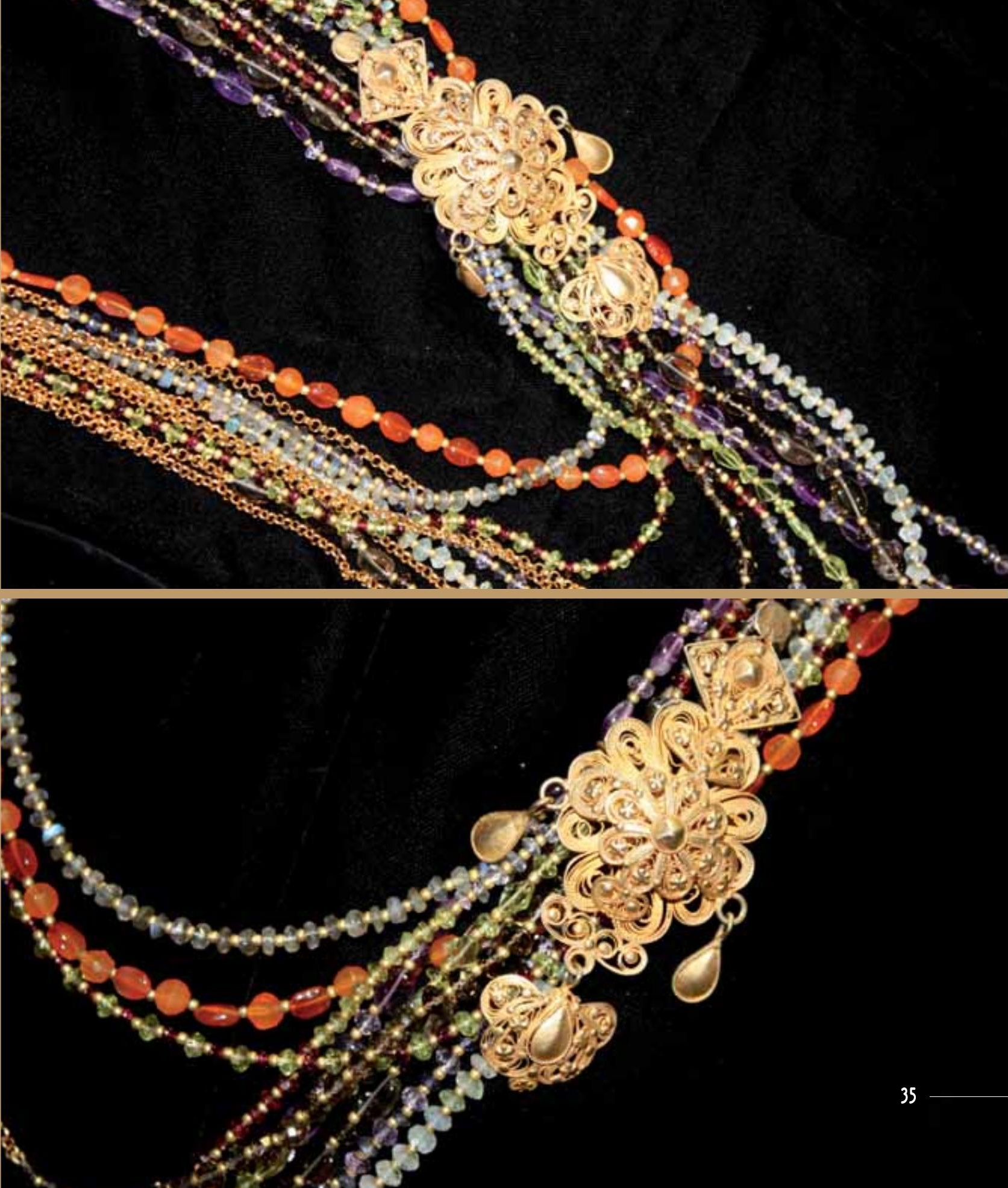





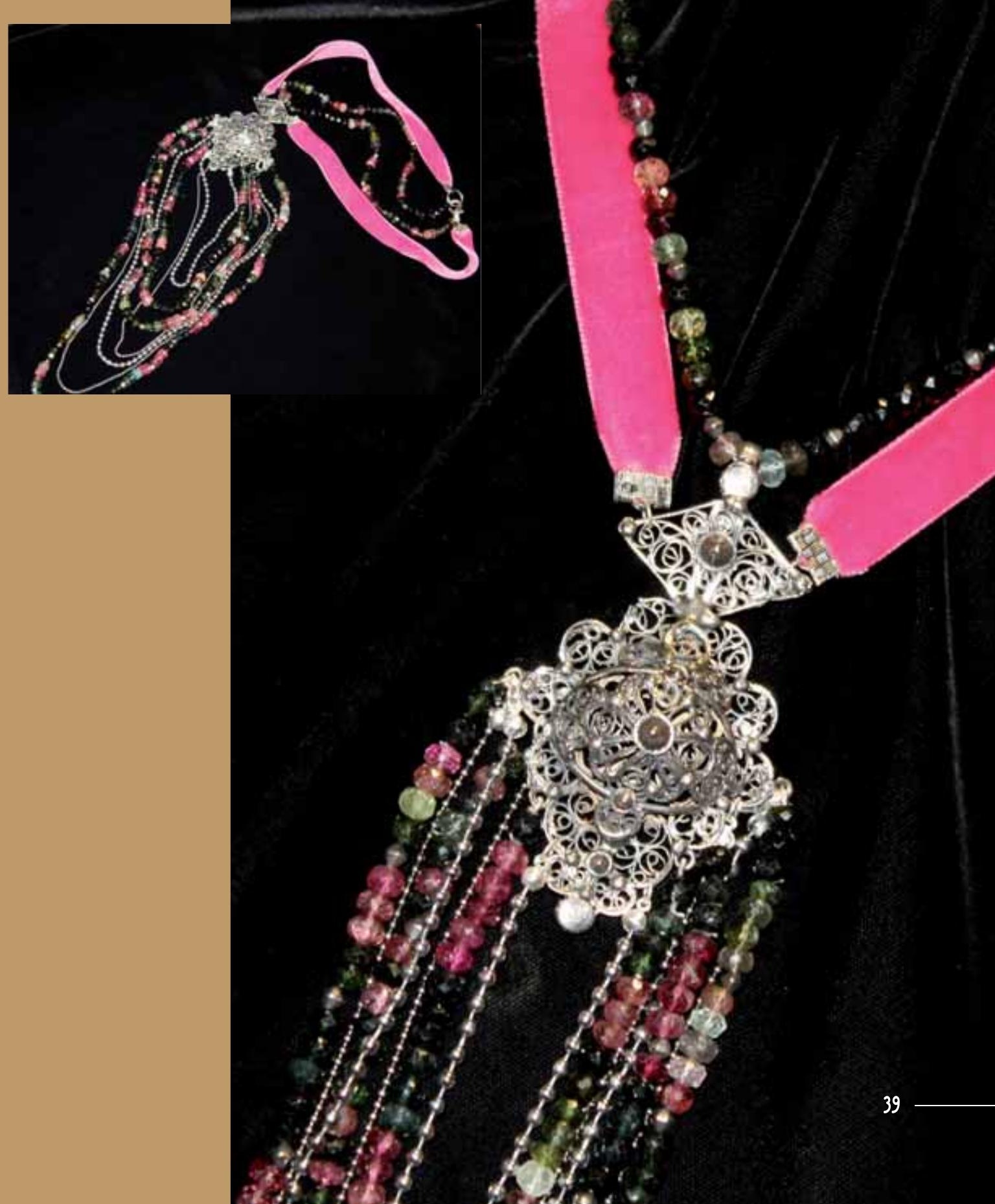




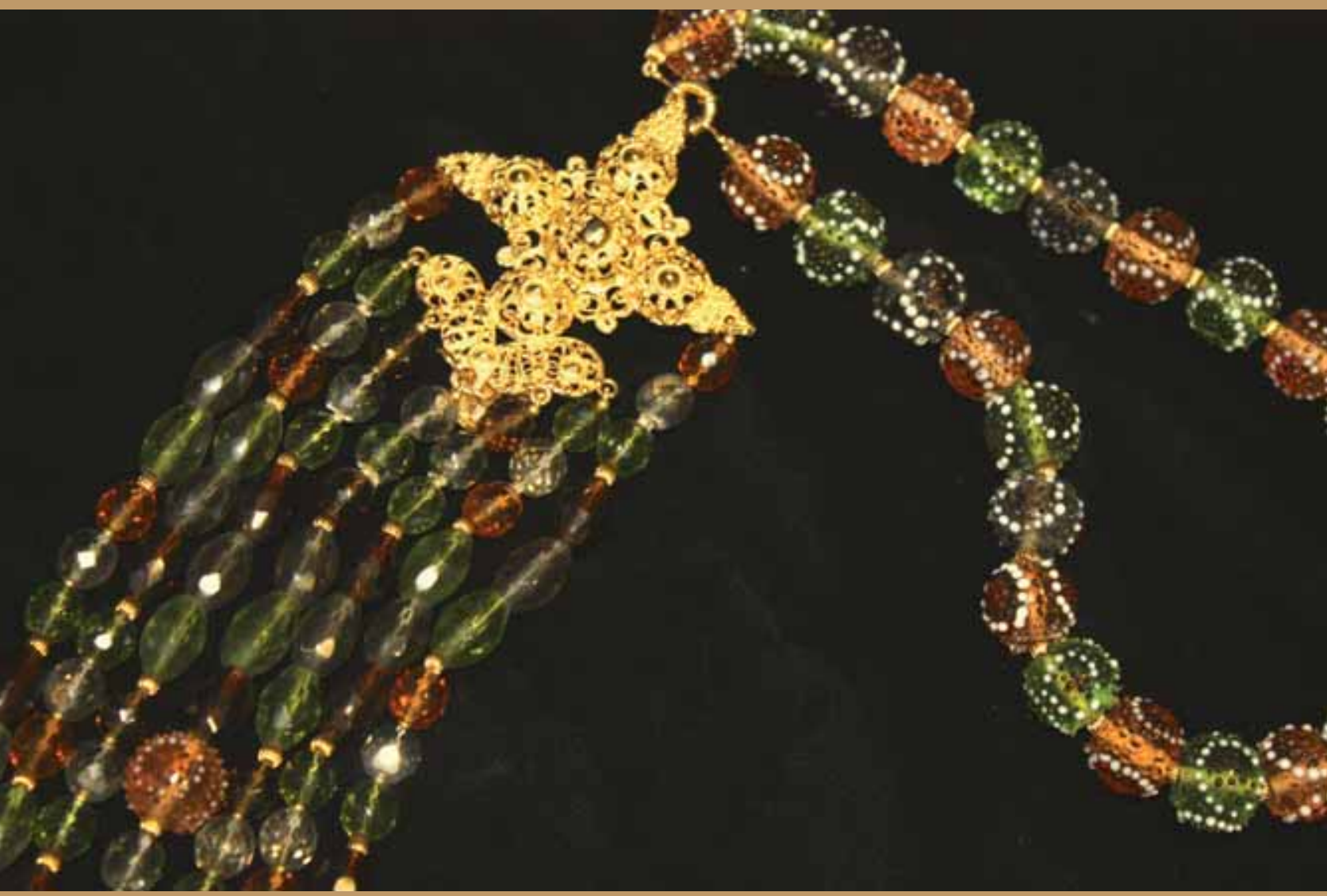




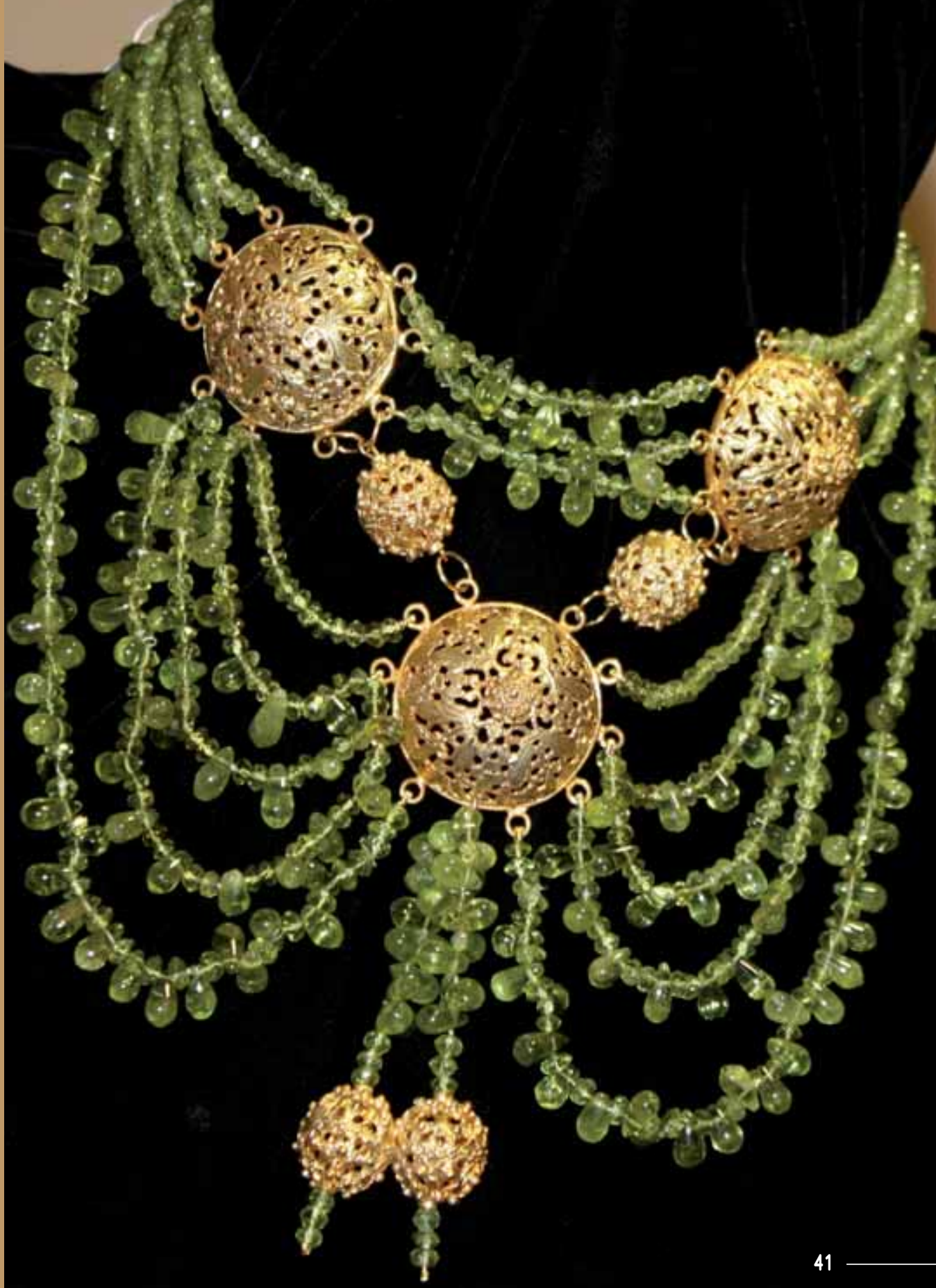




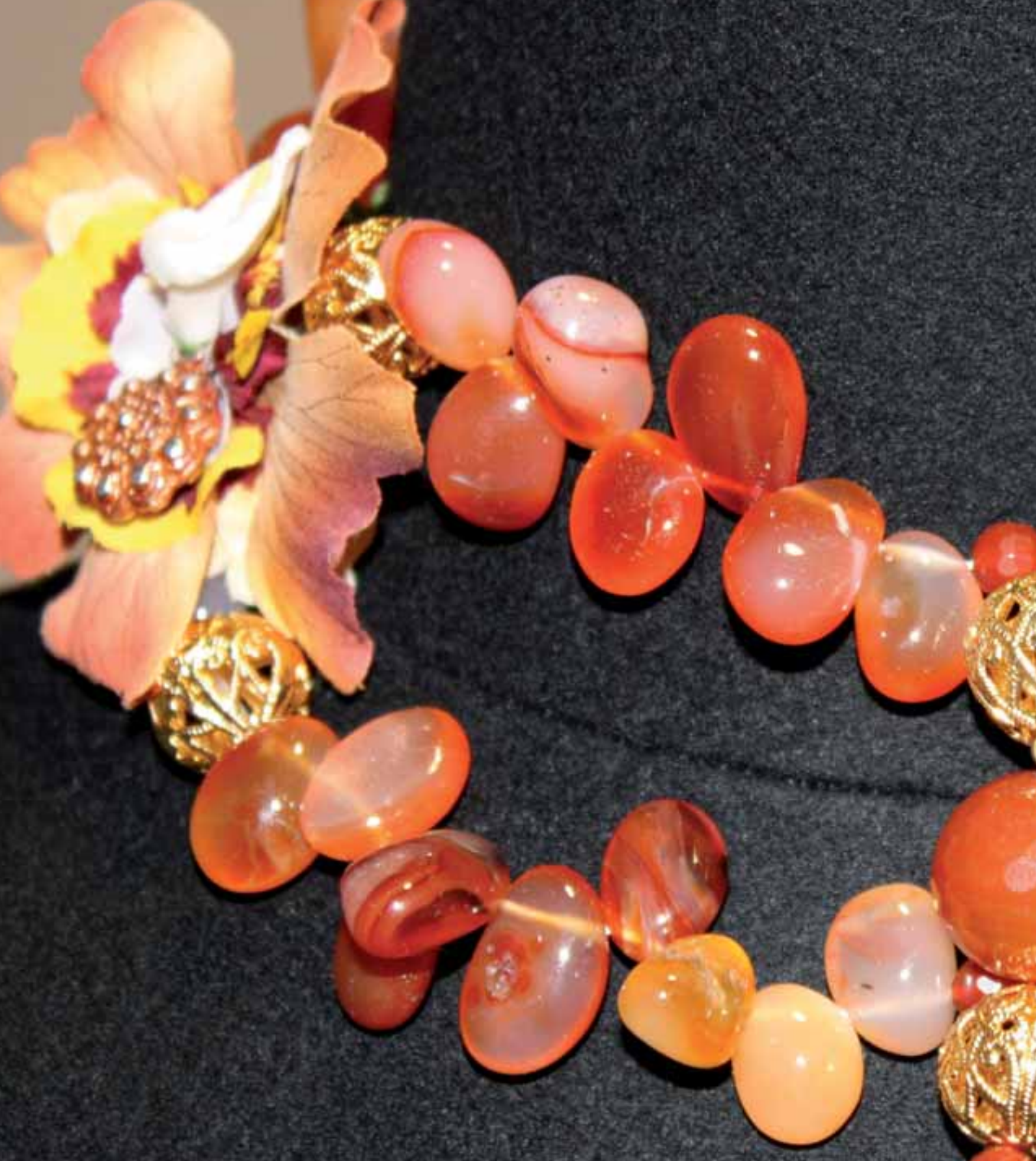





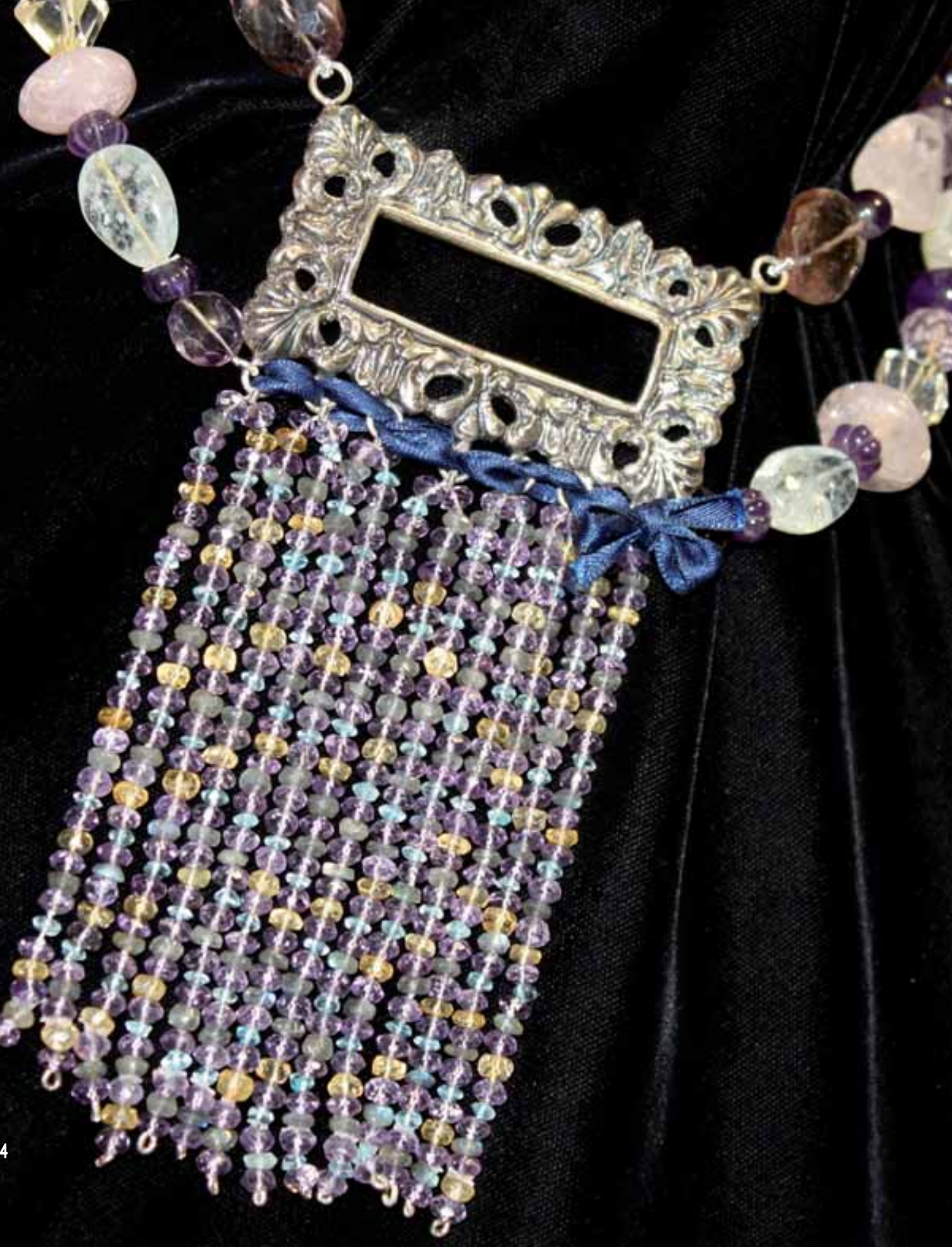



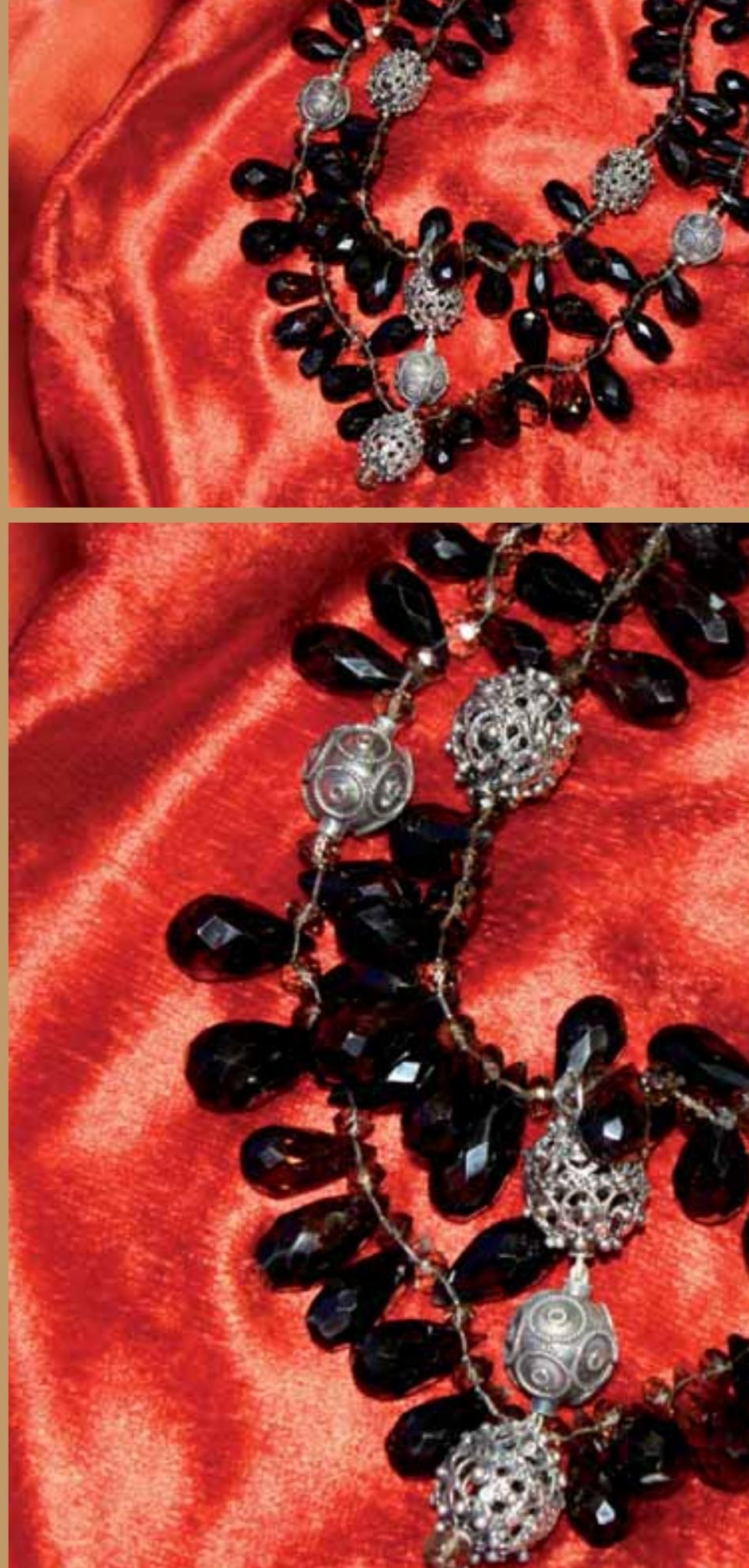


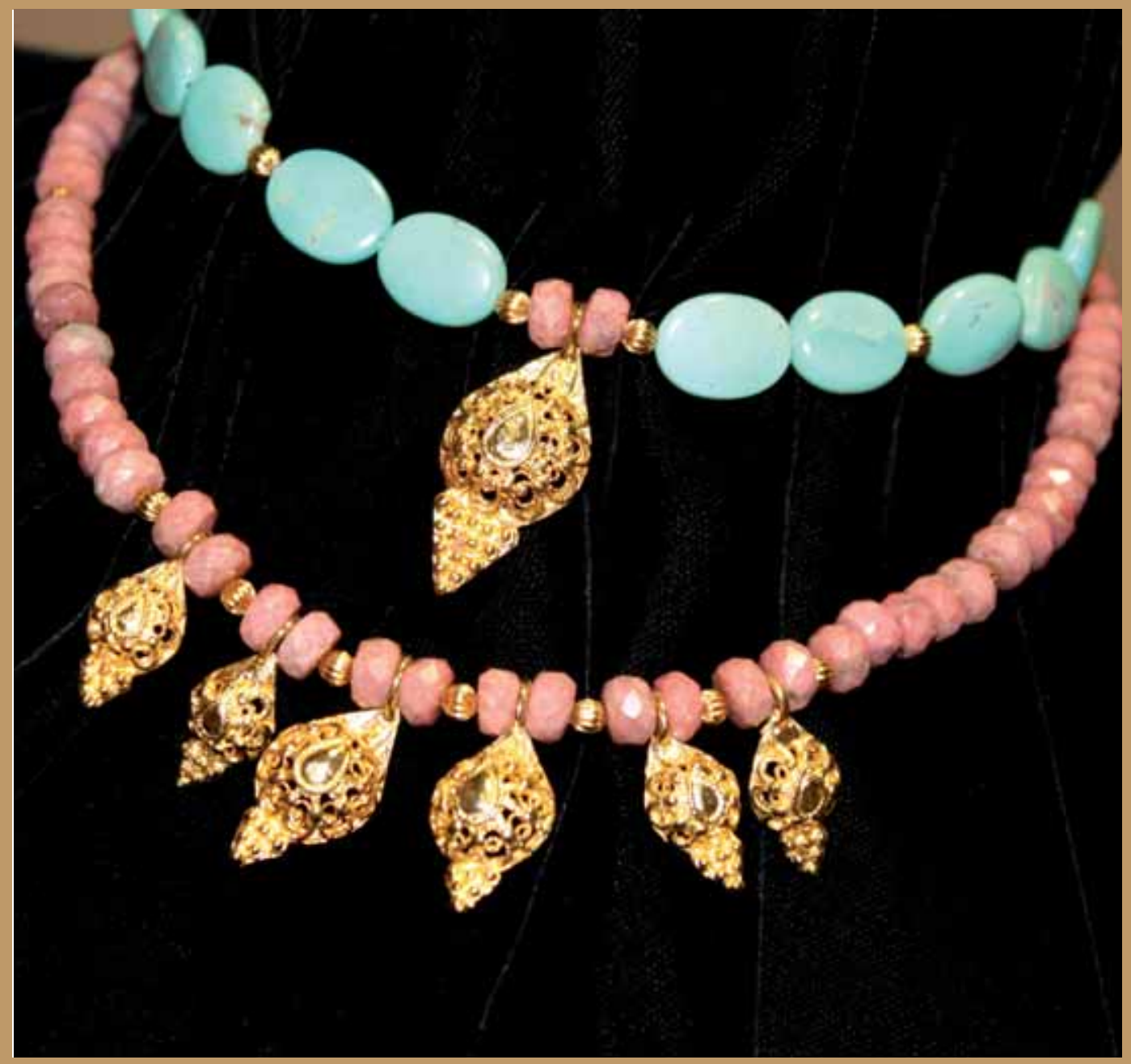




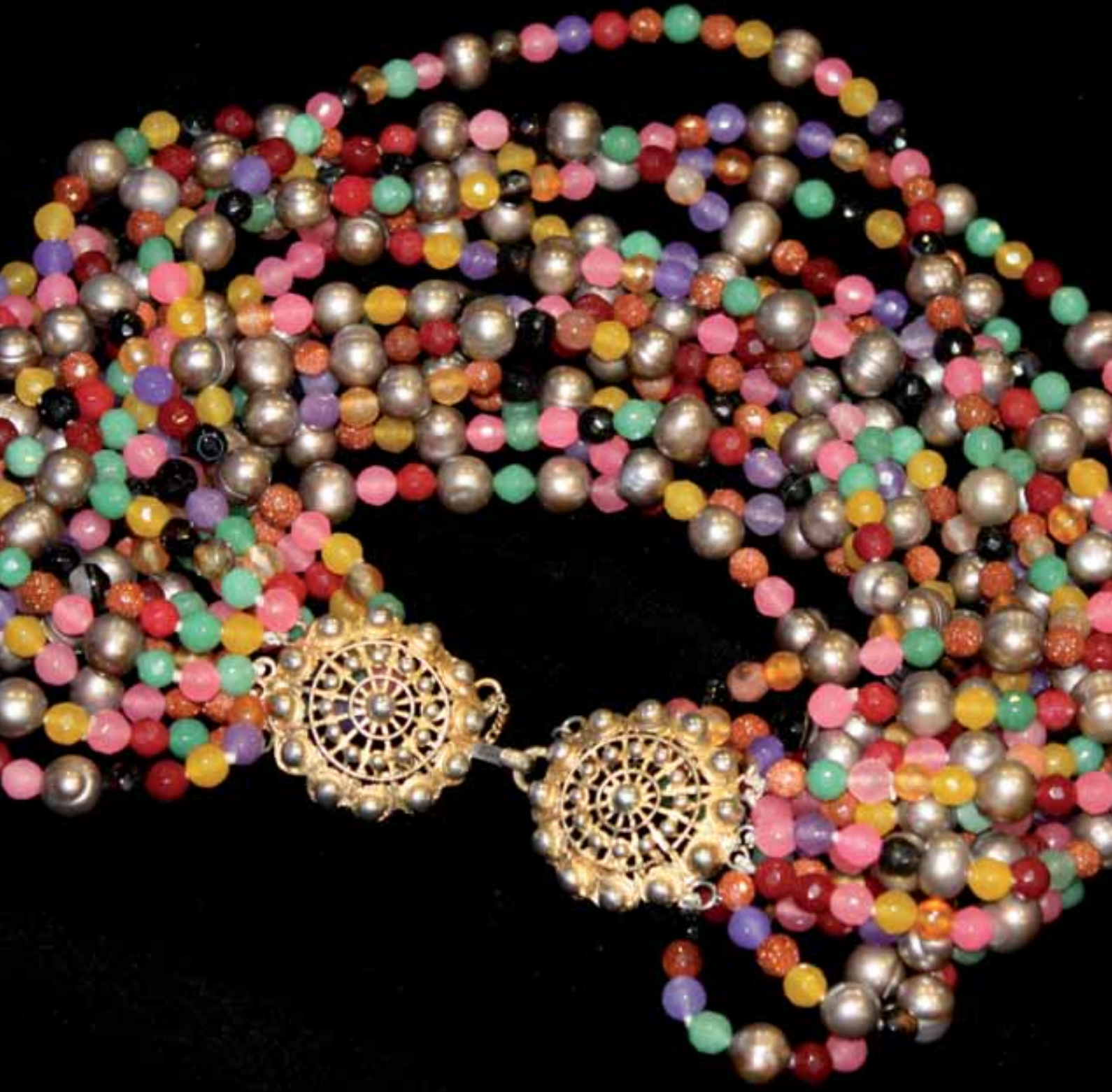




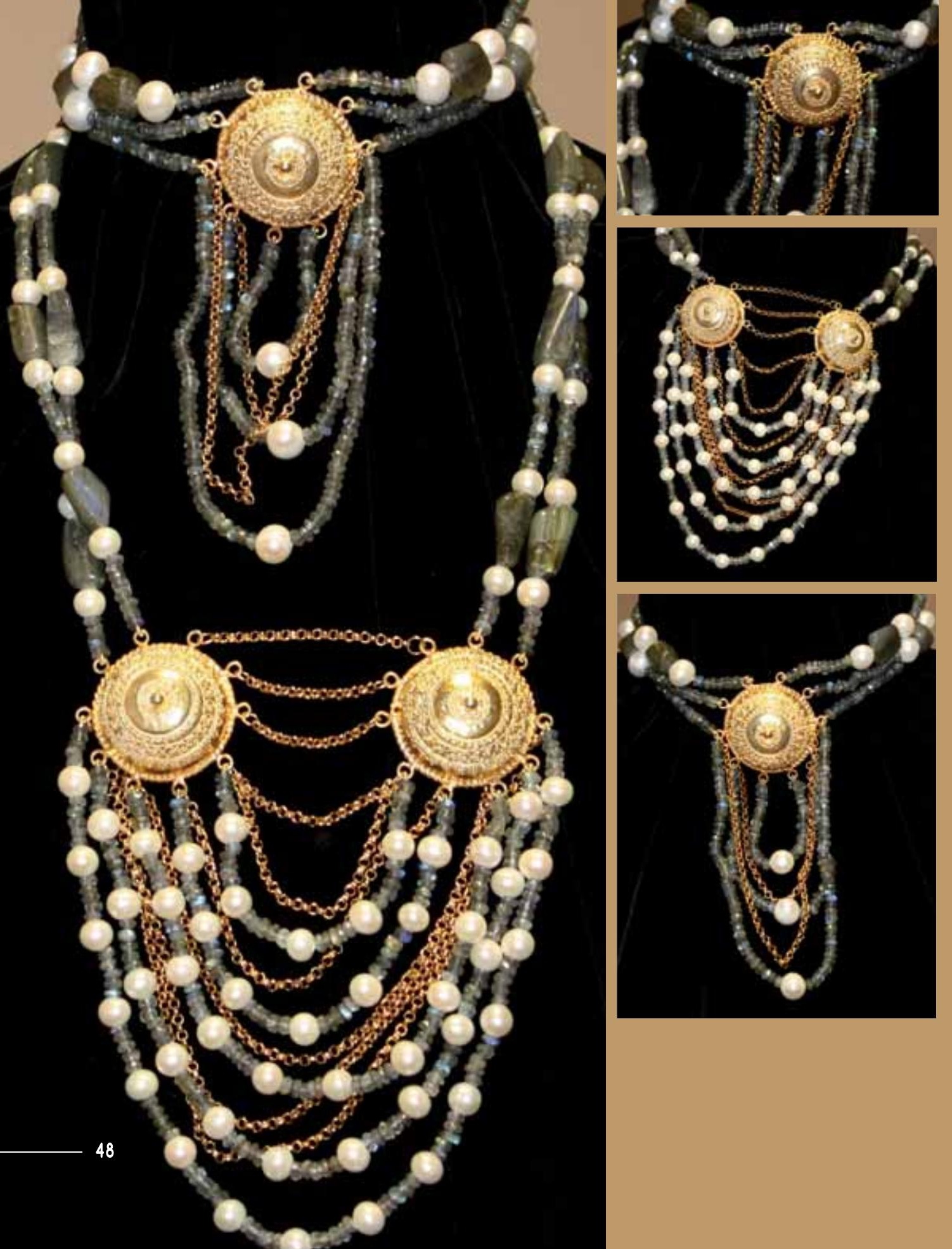



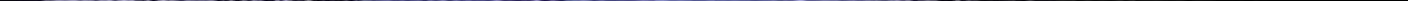
4. 01

1. 4

is

at nos:

1200

1) 201

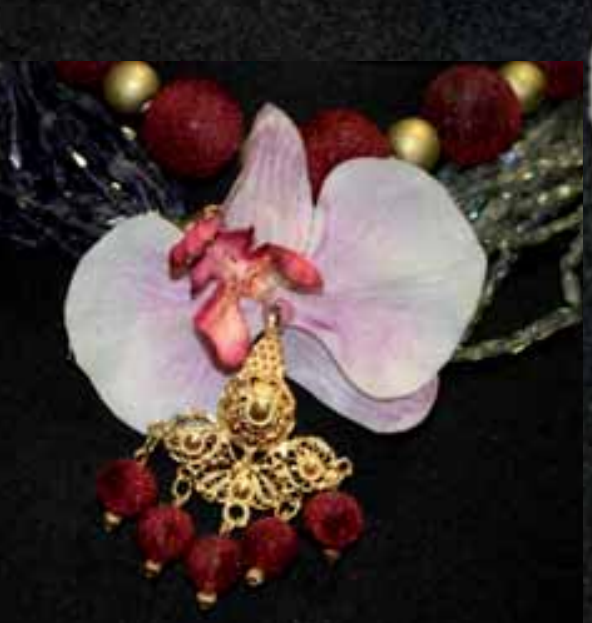

50

sis 


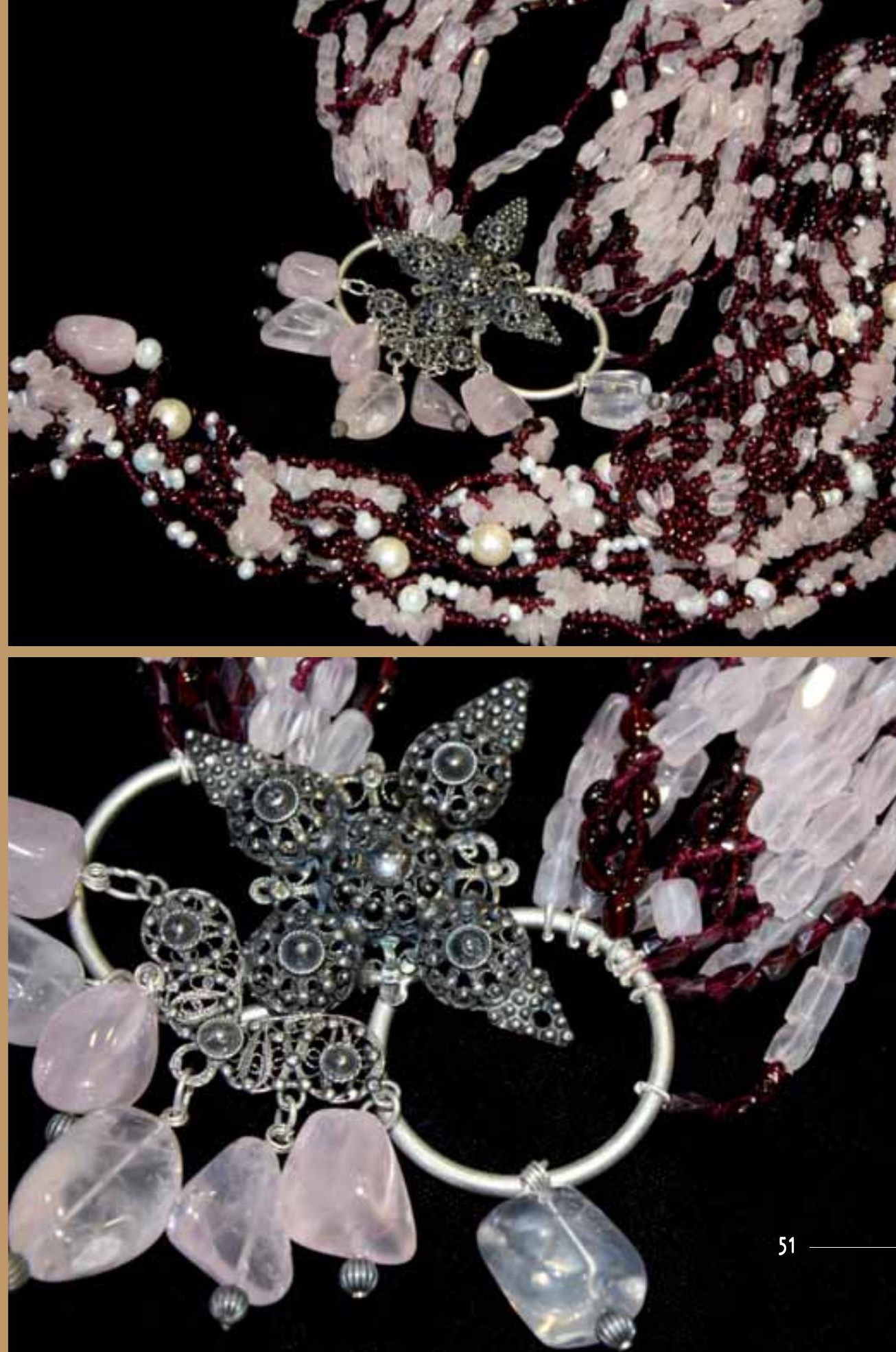

Din Ax 


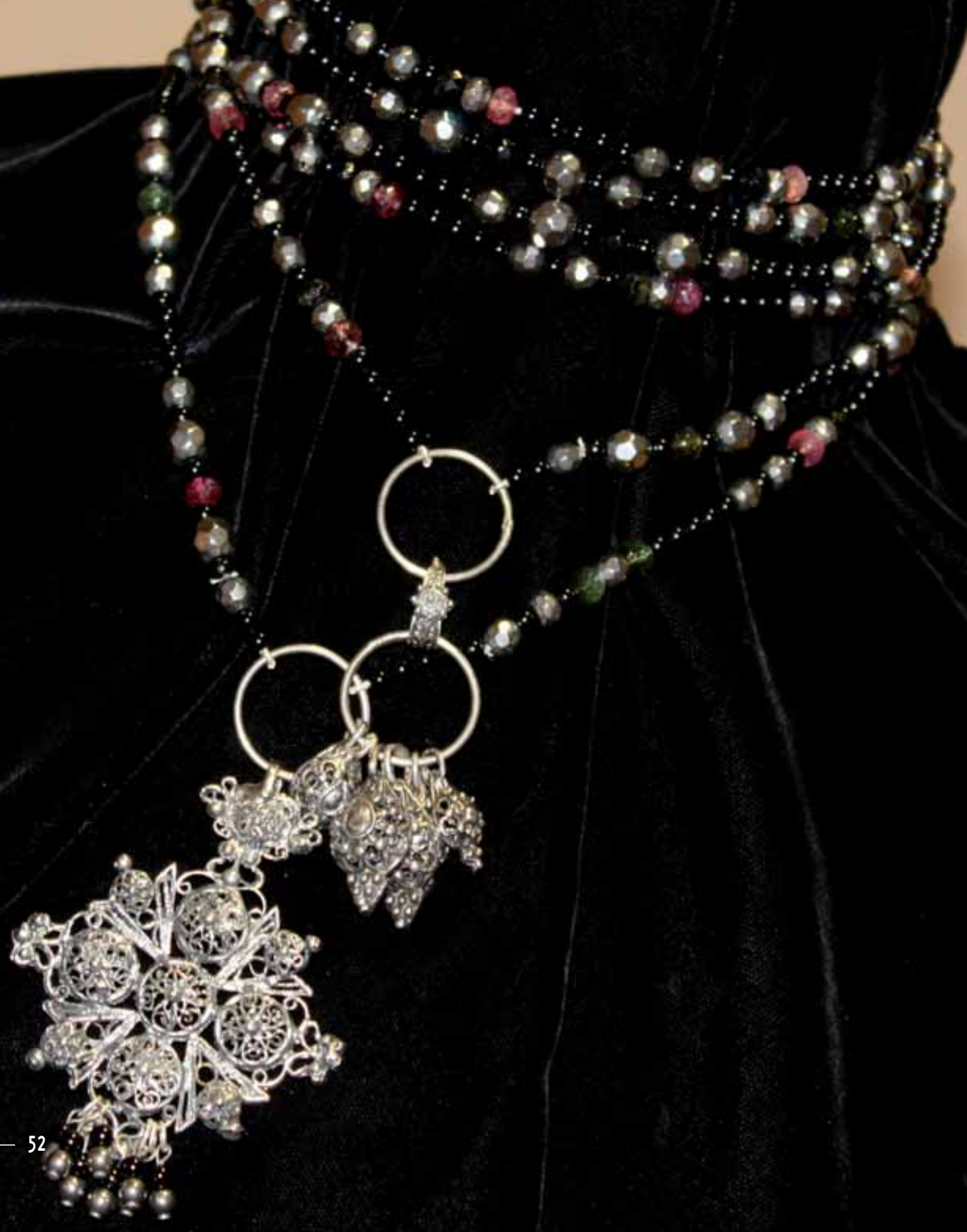



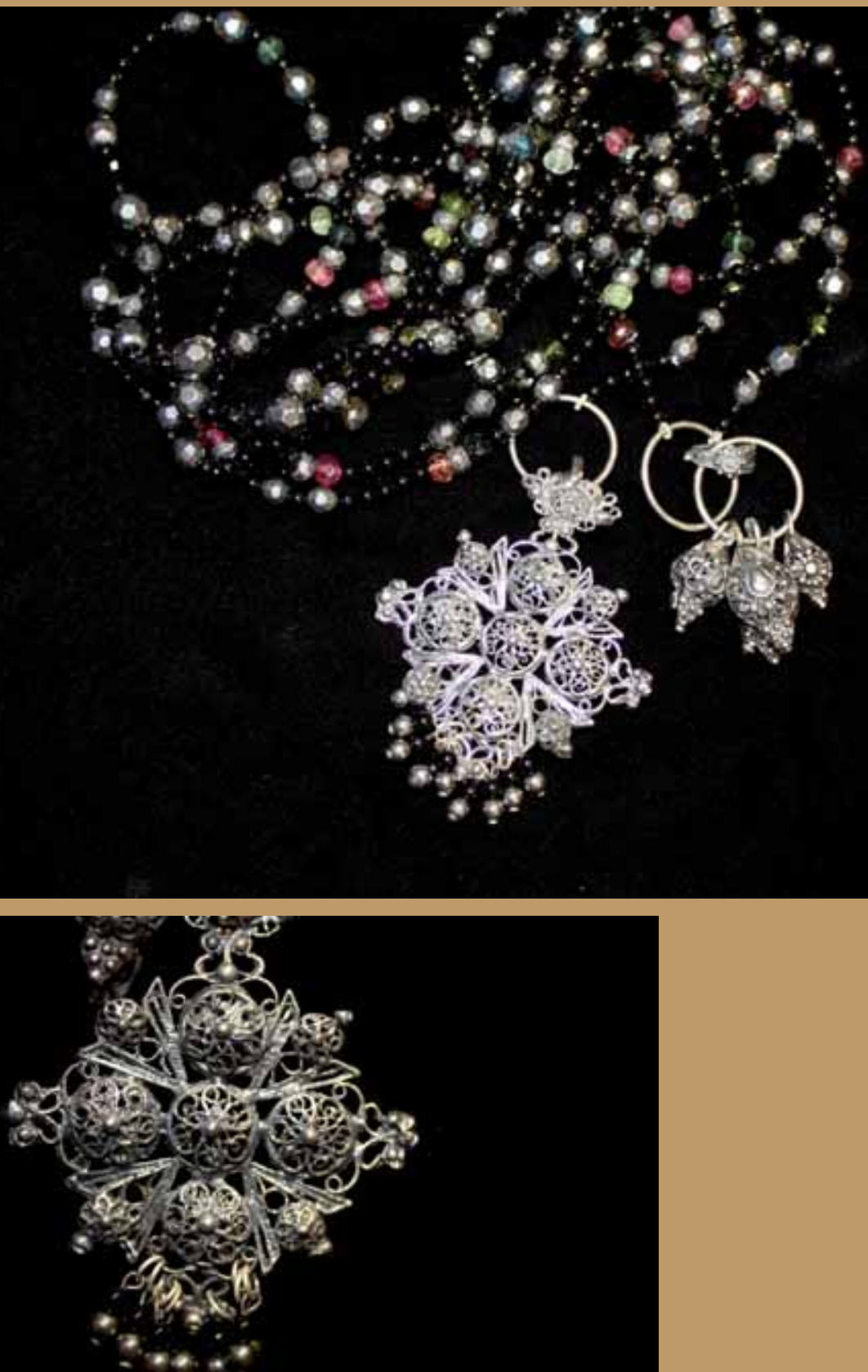

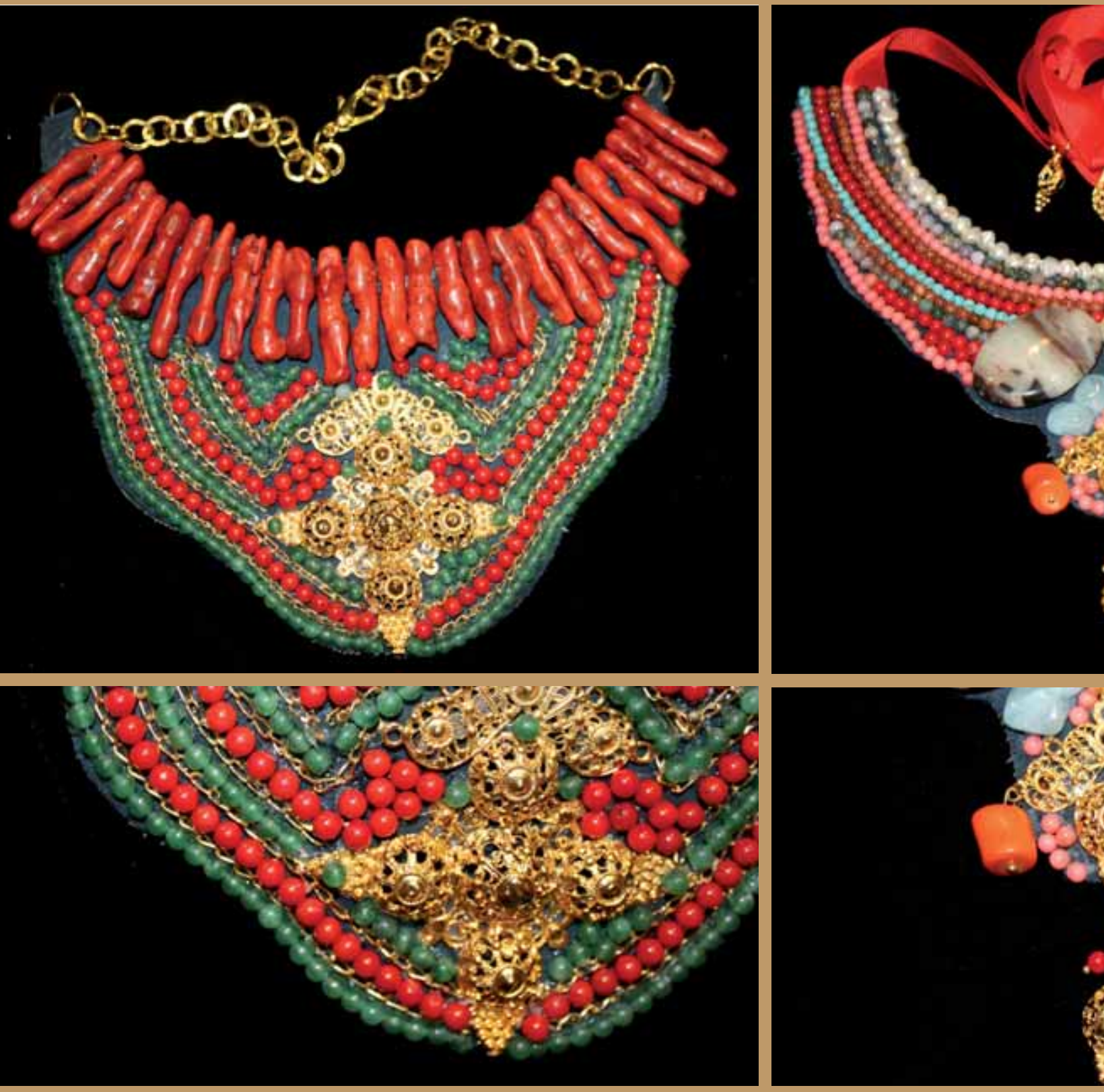

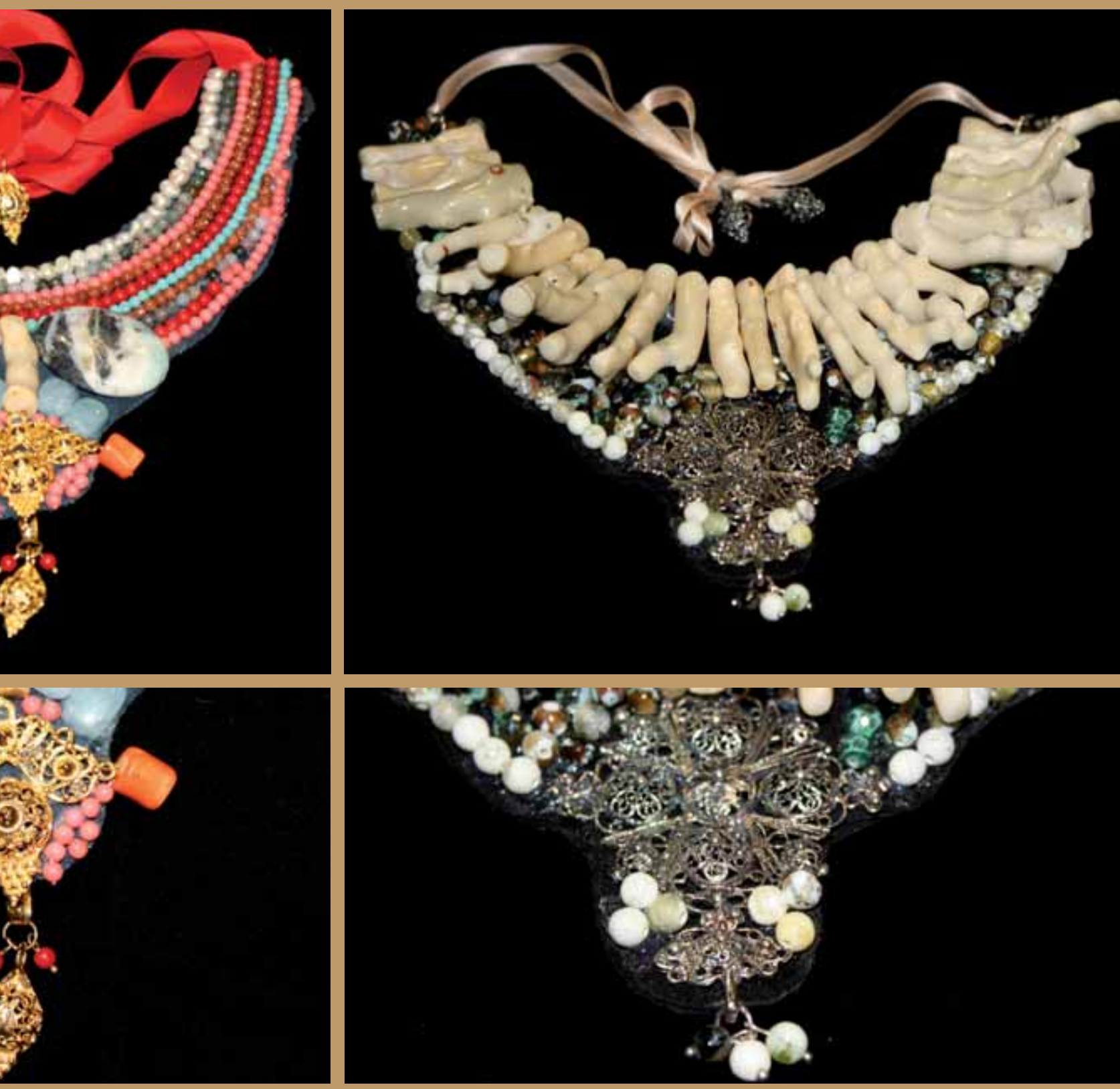


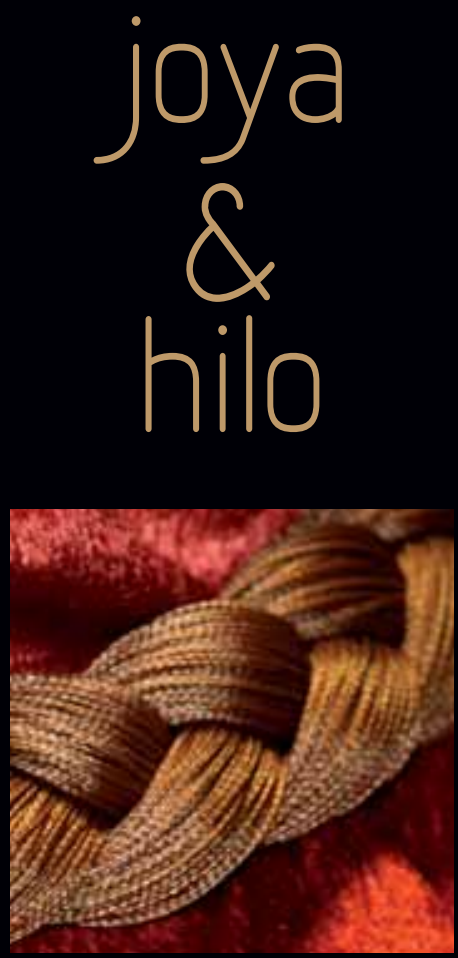



\section{LA POÉTICA DEL HILO Y LA TELAI}

Hilo y tela vinieron para no ahogar la joya, para dar calidad a la pieza-metal. En definitiva, darle un volumen cálido.

Esa necesidad dio lirismo, un juego extraordinario y dinamizador proponiendo y resolviendo la complicación técnica de su desarrollo y ensamblaje, creando y conformando estética y composición, aunando mundos; utilizando de soporte unos elementos que a su vez creaban y daban forma al bordado o al vestido.

Se descontextualizaron sus usos y se transformaron en eje del objeto nuevo. Más color, nueva textura, nuevo fin.

La armonía se alcanza integrando y complementando elementos no necesariamente procedentes del mismo origen. Búsqueda de la mezcla exacta.

Así esos elementos (joya, hilo y tela) no se subordinan entre sí, si no que se complementan.

Todos se convierten en soportes y a su vez en elementos soportados.

Así la composición debe estar estudiada y técnicamente resuelta, llegando a sostener sin apoyarse, llegando a una inserción casi perfecta, buscando la creación estética. 
No hay 2 igual, busca y halla la inquietud y la tensión intelectual para dirigir la joya hacia un territorio nuevo donde albergar otros elementos con los que fusionarla y construir así una obra entera.

Cuidamos la forma, la ensalzamos, la maximizamos, sujetándola con energía creadora nueva. Savia nueva. Pero no solo basta con la creación nueva, hay que asirla a la historia, hay que cerrar el círculo para no desconectar al espectador. De ahí la importancia de la armonía, de lo no estridente aunque sea profundamente novedoso.

Concesión al pasado proyectado en la esperanza del futuro.

No hay 2 igual 


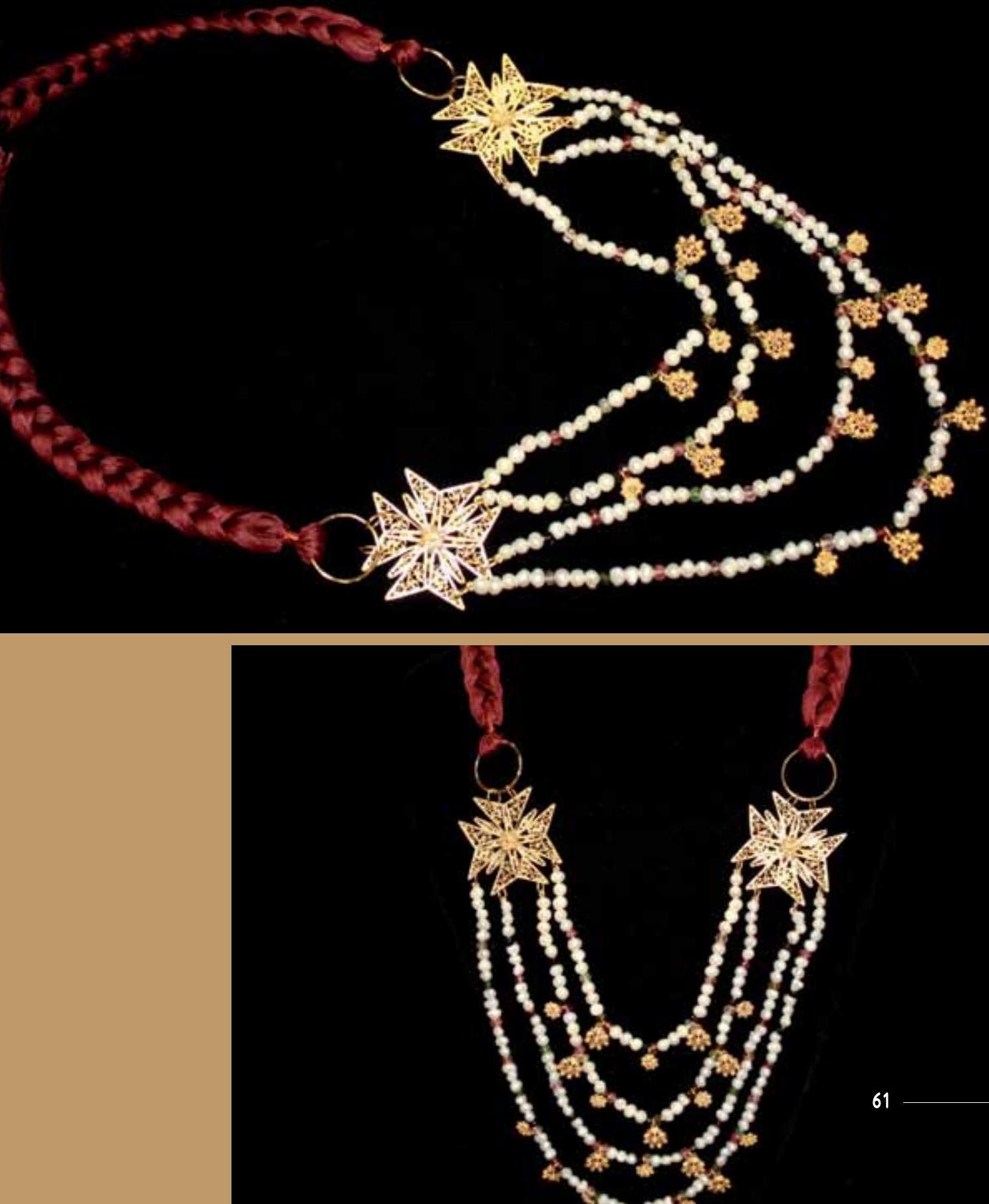


$=\sin =2$

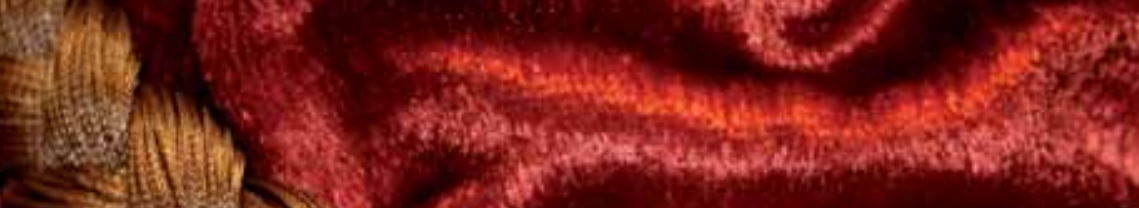
$y 11 x$.
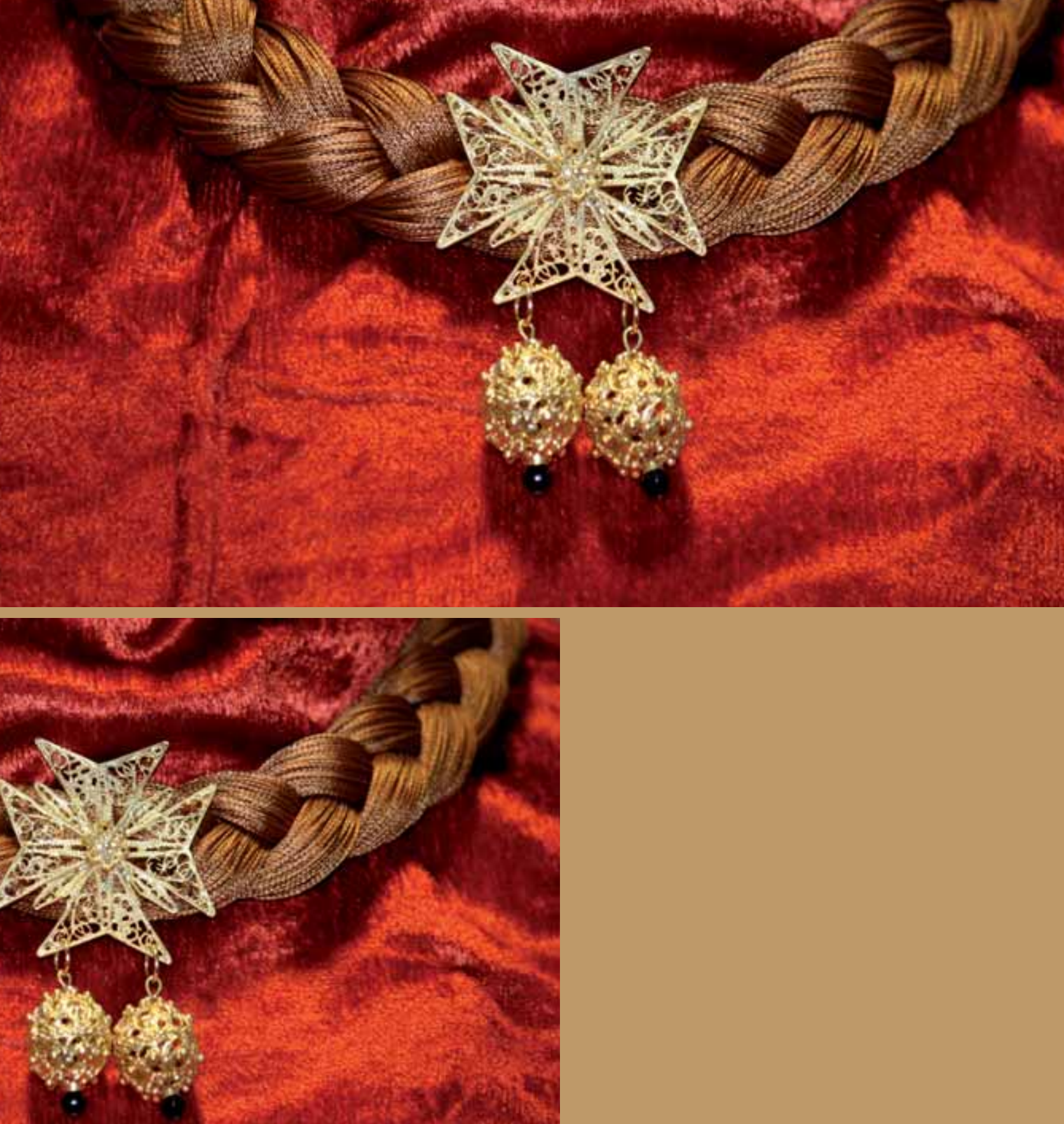


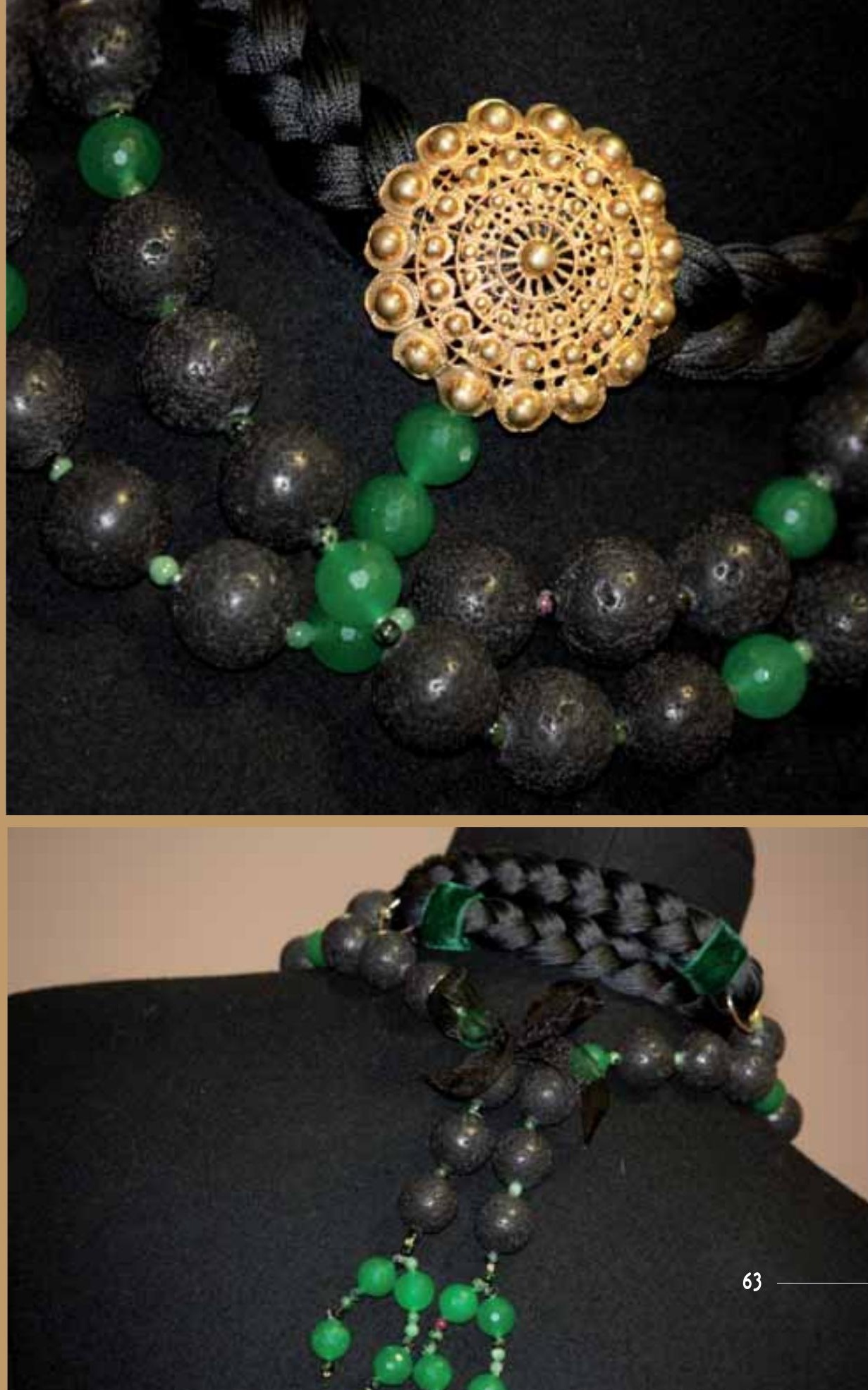



reinas

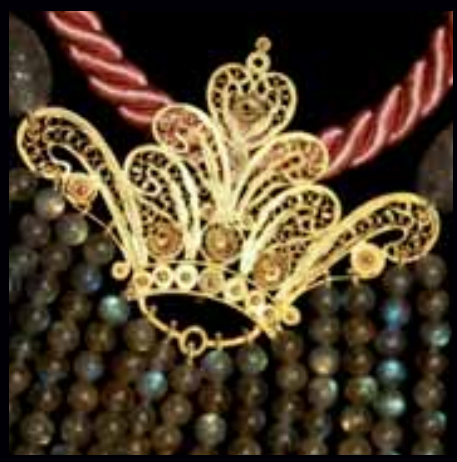





\section{REINAS}

El corazón de España es Castilla. Aquí late la mujer antigua de la Meseta, esa que es austera, dura y luchadora. Así es la charra. La mujer de la Meseta está enraizada en todas las culturas de la Península Ibérica y ella, ha dejado un legado no escrito a su tierra, a su cultura y a sus mujeres: la filigrana charra, la que nosotros llamamos la joya del pueblo. Hasta hace muy poco esta artesanía no ha llamado la atención, al igual que tampoco lo ha hecho su portadora: la mujer del pueblo.

España, que tiene una tradición de alta joyería extraordinaria, poco caso ha hecho a este pariente pobre que por el contrario tiene un valor y una belleza incalculables. Desgraciadamente este "patrimonio cultural" del noroeste español, se ha ido perdiendo poco a poco y de no haber sido por el traje tradicional, se habría perdido en la noche de los tiempos.

Nuestra artesanía joyera está herida de muerte, mientras el mundo nos inunda con piezas traídas de otros lugares que en nada pueden compararse con la belleza y la historia de esas piezas que nos identifican. La técnica artesana de la filigrana salmantina está muy hermanada con la tradición joyera de nuestro vecino Portugal, con los que nos unen más elementos de los que los que nos separan.

Estas piezas han sido la única herencia que durante siglos la mujer de estas tierras han legado a su prole. La belleza y la delicadeza de estas mini obras de arte, enamoraron a la emperatriz del Japón, como lo hizo nuestro plateresco.

El proyecto que en estos momentos lideramos es, respetando la tradición en su totalidad, descontextualizar las piezas para poder adaptarlas a la mujer del siglo XXI, dándoles nueva vida y evitando su extinción. 
La evolución forma parte de la propia vida de los objetos y, hoy más que nunca, cada parte de la vertebrada España necesita hundirse en sus raíces y buscar desde ellas expectativas de futuro. Asi se combaten las crisis.

Esta mujer de la Meseta que calladamente trabaja para la España venidera, como siempre lo ha hecho, hace una elegía (de la mano de No hay 2 igual) a las raíces femeninas ancladas en este territorio desde el siglo VII antes de Cristo, donde la técnica de creación queda patente gracias a los estudios recientemente realizados. De la mujer castellana se dice que es más "hacedora" que "emprendedora", pero nada más lejos de la realidad. En estas tierras se ha forjado el Pensamiento, la Reconquista, la aventura del Nuevo Mundo, el nacimiento de nuestra Nación, la Transición... Y fueron sus mujeres, junto con las reinas que ha dado esta tierra, las artifices, entre otros, de esta singladura aportando: bien su sacrificio, bien su poder.

Este proyecto transforma la herencia cultural haciendo que permanezca su espíritu, pero lo fusiona con otros aires nuevos, otras tendencias, otros elementos, con la intención de descubrir así otros territorios, a semejanza de "Isabel la Católica", para poder asentar en ellos nuestro antiguo y riquísimo patrimonio.

Dentro de esta exposición hay un espacio dedicado en exclusiva a las reinas que, sin ser consortes, reinaron en España y que son: Urraca de Castilla 1109-1126, Petronila de Aragón 1137-1164, Berenguela de Castilla 1217, Isabel I de España 14741504, Juana I de Castilla 1504-1516, Jeanne III de Navarra 1555-1572, Isabel II de Castilla 1833-1868.

A todas ellas No hay 2 igual rinde homenaje con la realización de una pieza exclusiva que llevará el nombre de cada una. En este espacio se presentará una pieza única dedicada a la Infanta Leonor, futura Reina de España.

Desde este territorio origen, consideramos que nuestra futura Reina Leonor, será la primera reina que por línea directa sanguínea y heredada, llevará los destinos de este país en algún momento del siglo XXI.

La joya hace a cualquier mujer reina, y a la reina la iguala en sentimiento a la mujer que gobierna, entendiéndola e identificándose con ella. 

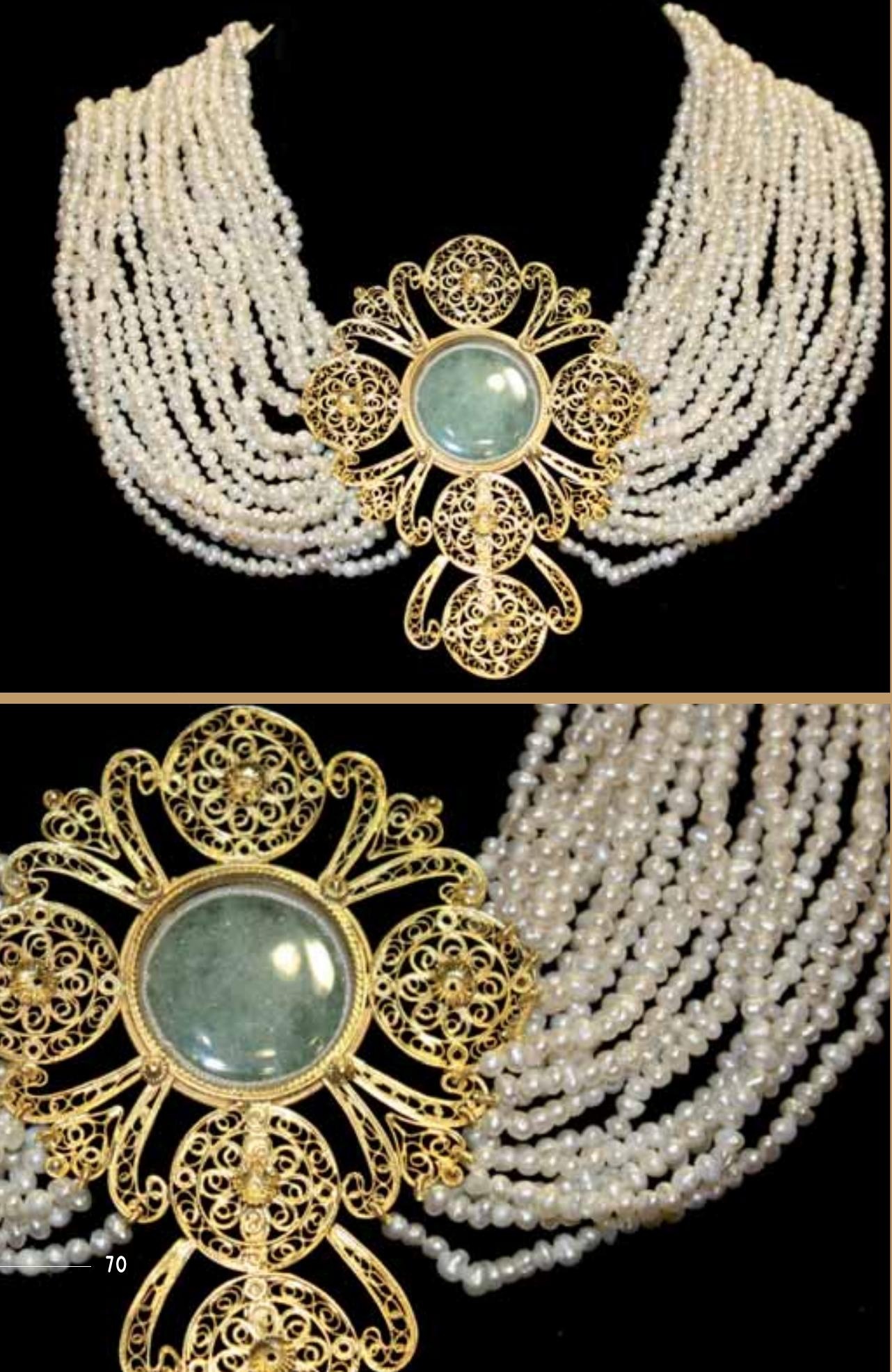


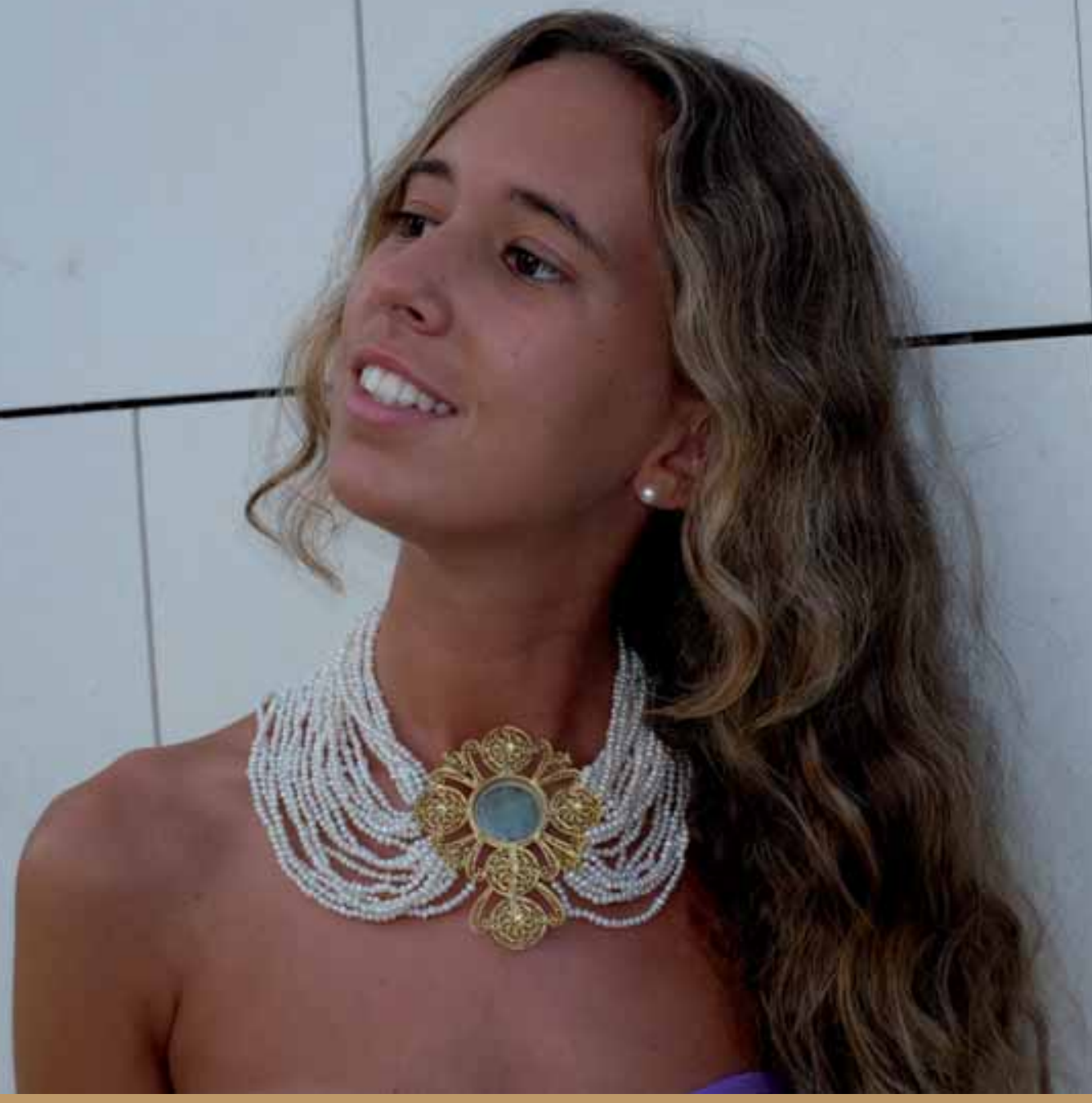

Isabel I de España 1474-1504 (Isabel la Católica) 

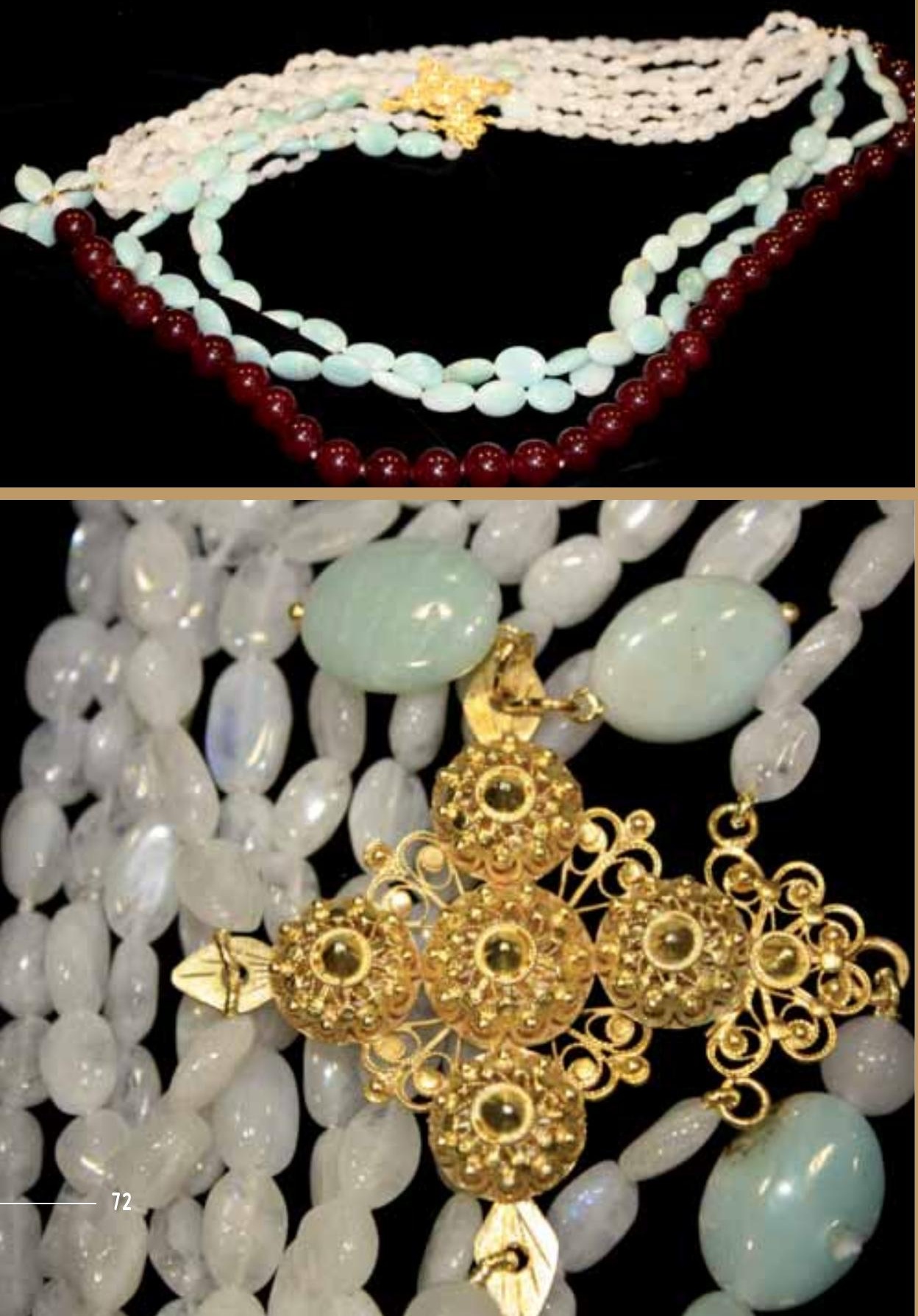

Isabel II de Castilla 1833-1868 


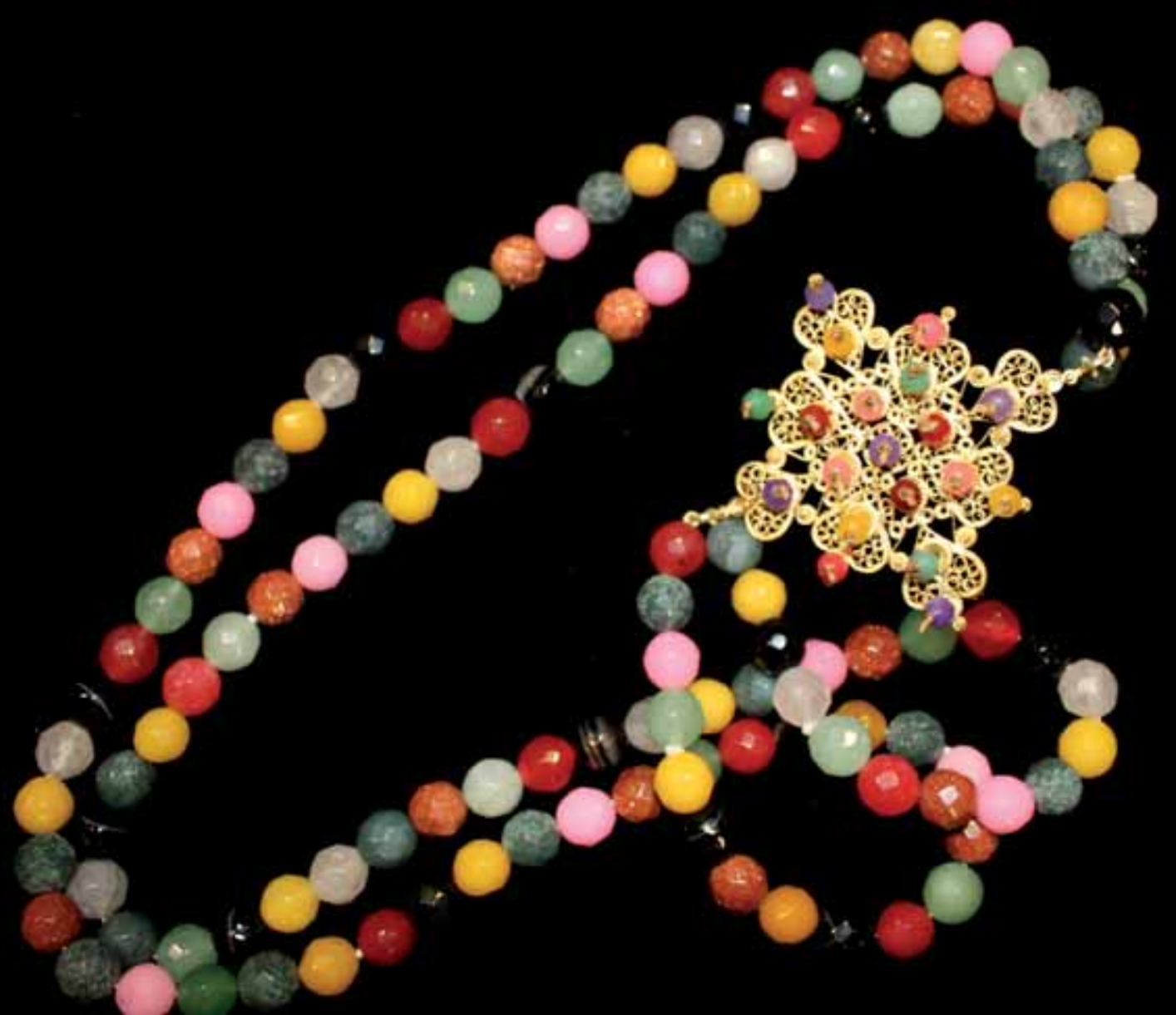

Berenguela de Castilla 1217

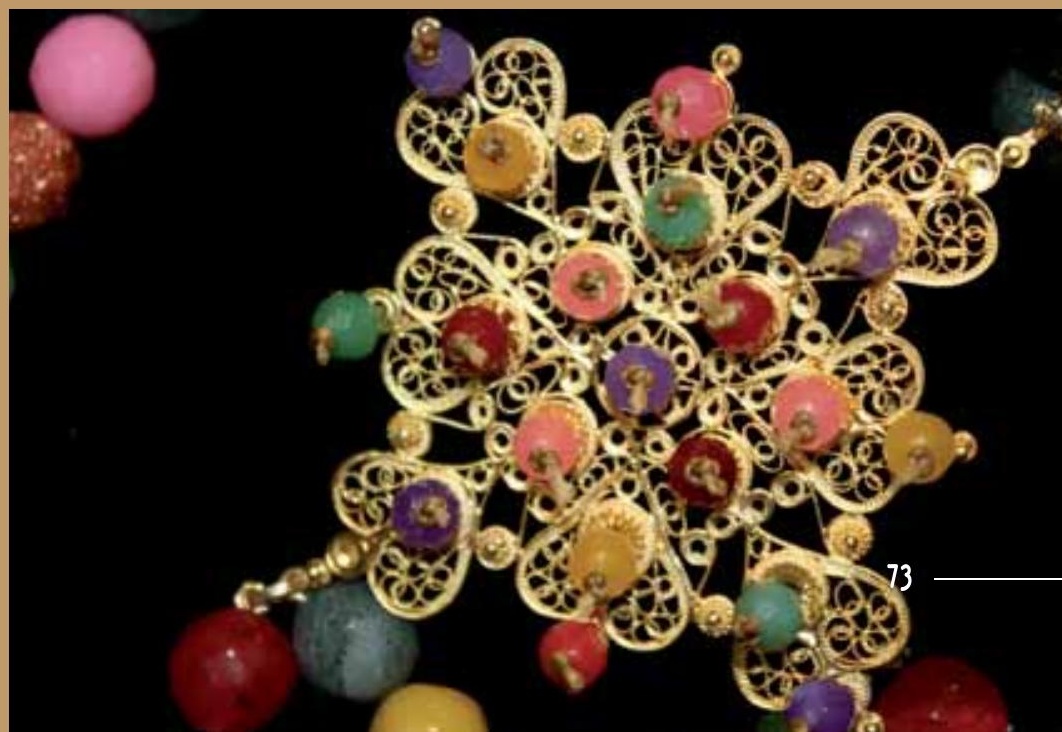



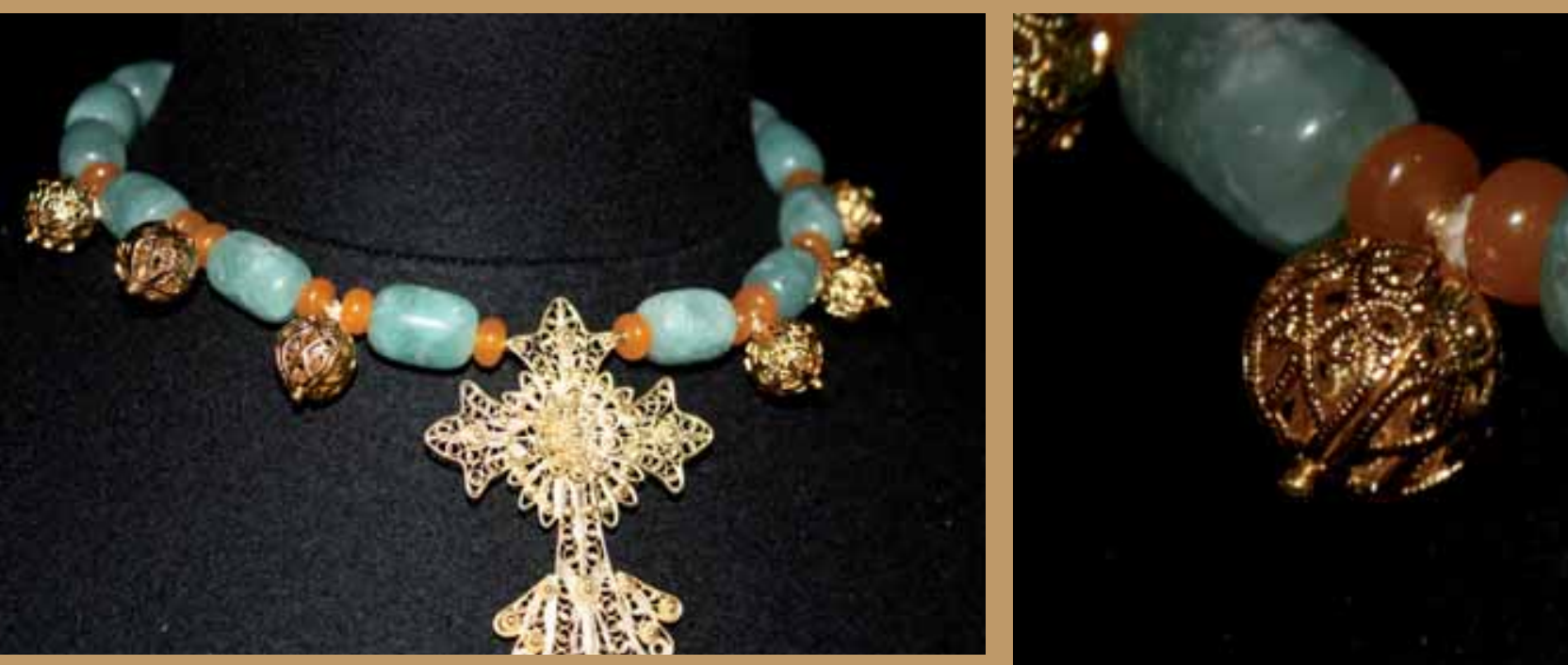

Jeanne III de Navarra 1555-1572 


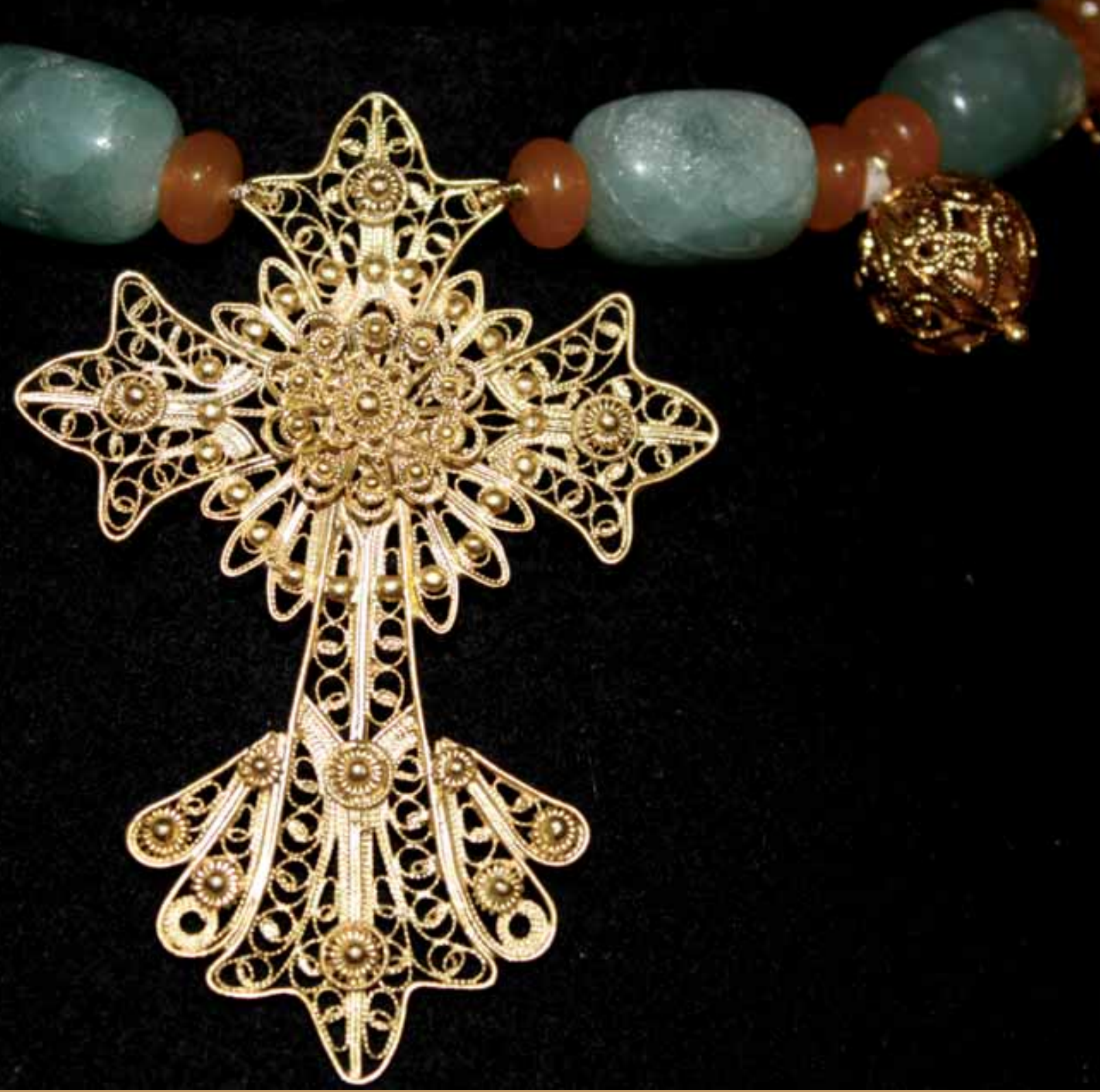




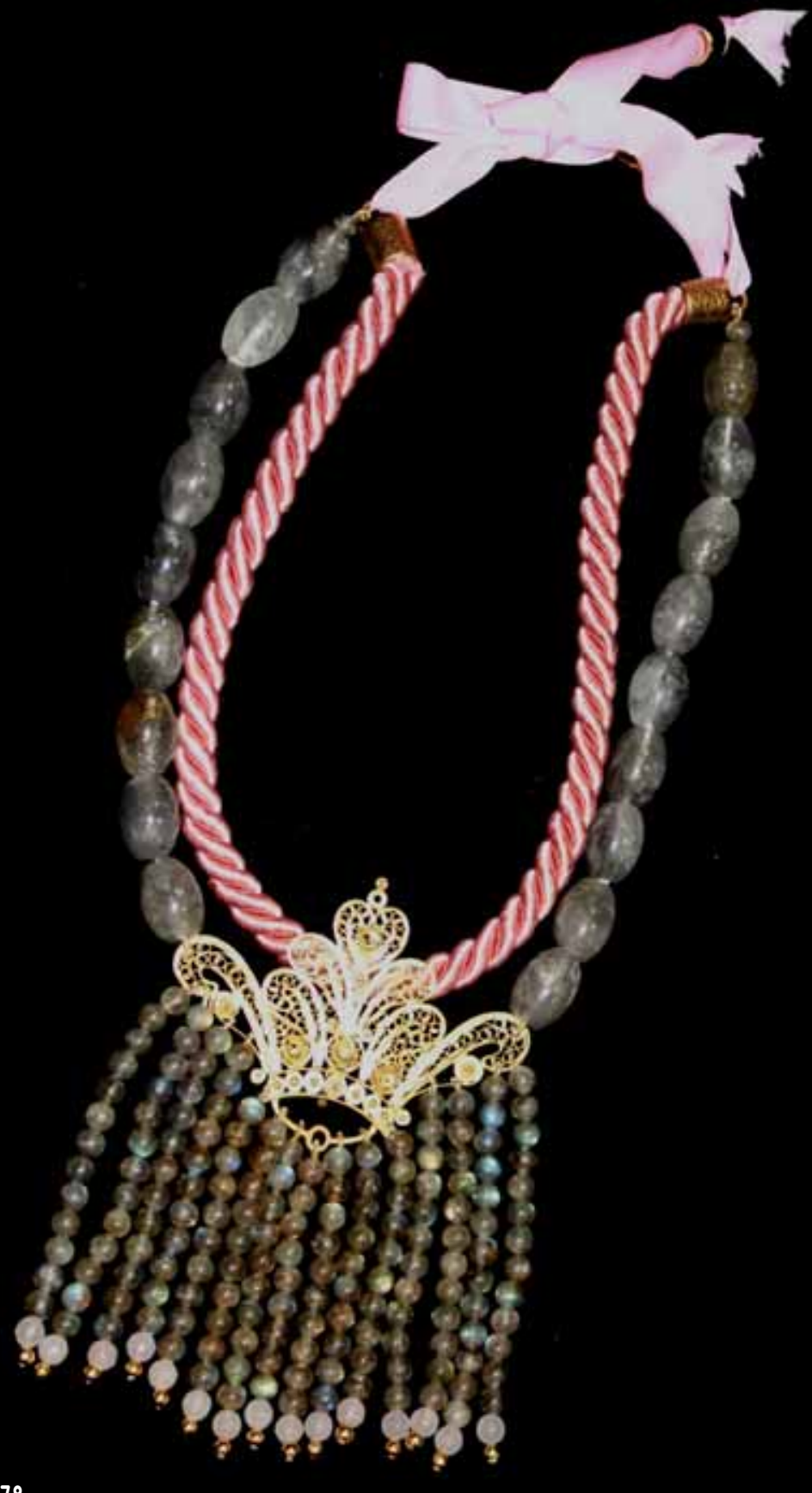




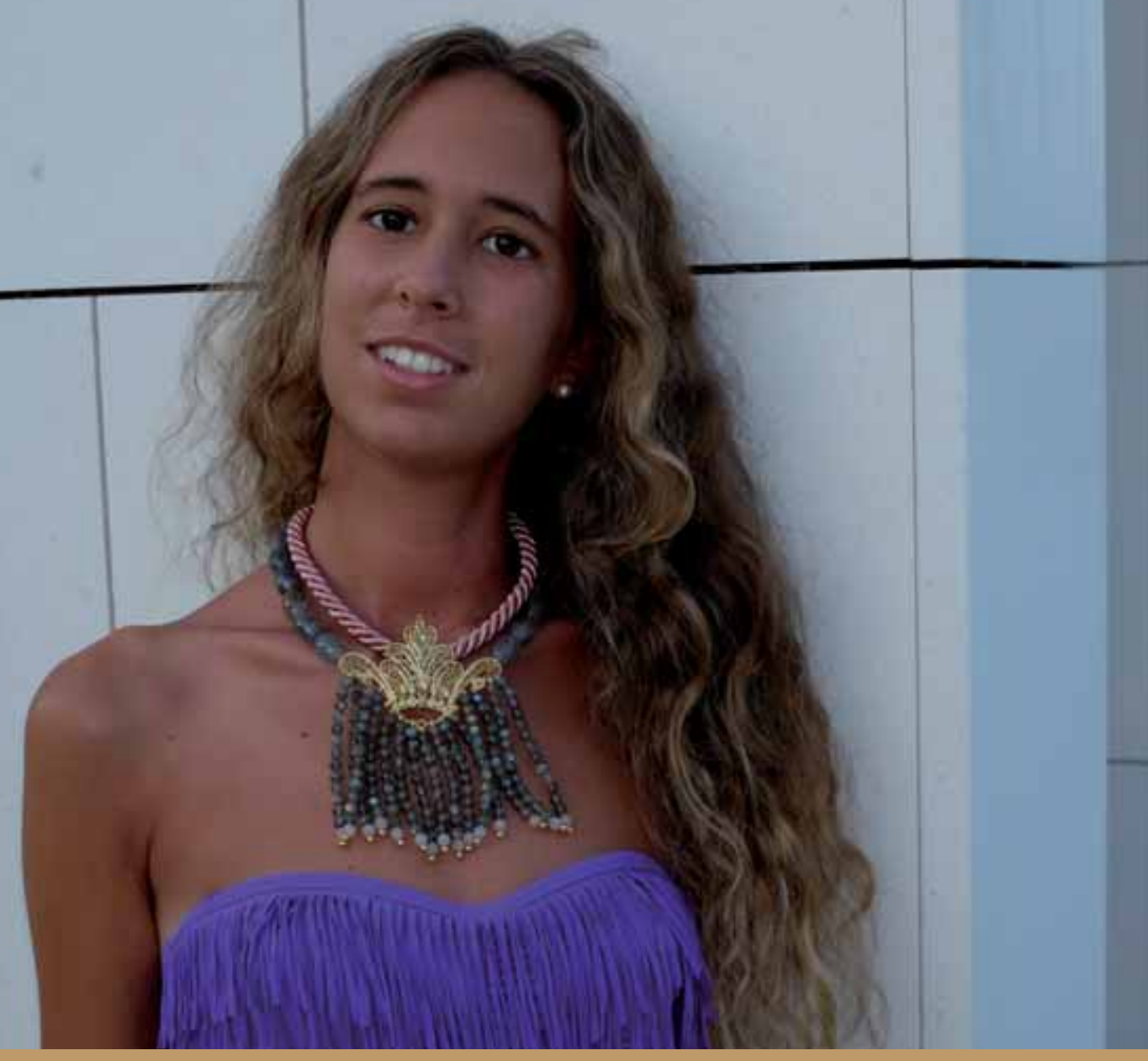

Infanta Leonor 


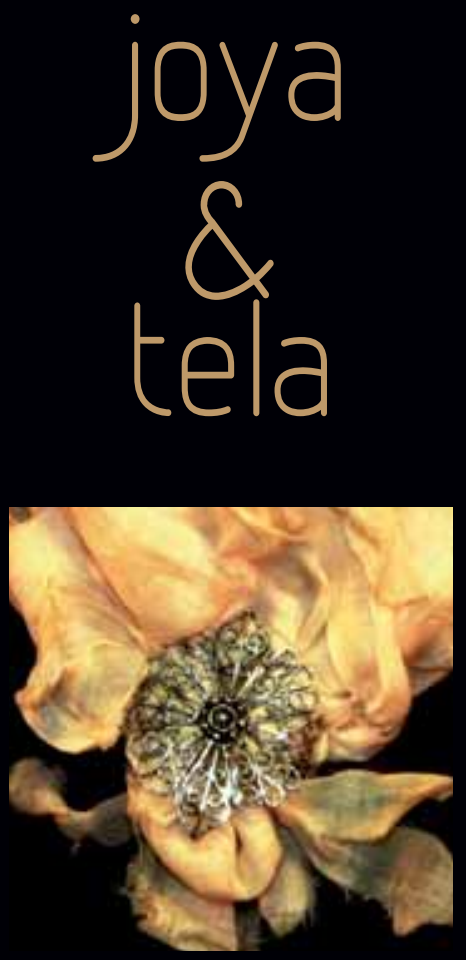



\section{LA POÉTICA DEL HILO Y LA TELA \|}

El hilo y la tela en esta parte del proyecto tienen una elevada función rectora, como generadores de lo nuevo, abandonando la parte instrumental.

Así entre hilo-tela y joya, de su expansión y relación, brota un ámbito nuevo, libre y recogido con una función tremendamente plástica.

Hilo y tela capturan escenas plagadas de sueños como sueños distintos y complementarios con la joya para ofrecernos elementos dinámicos y no quedos, que suspendidos en el tiempo ahora adquieren una vitalidad y un movimiento nuevo y pasan a flotar entre los nuevos senos diferentes de los de la antigua historia, macizando los escotes del siglo XXI.

Sueños de textura, color y movimiento ansiosos de nuevas portadoras distintas a la tradición y el traje típico. Luchar contra el lastre del tiempo, desarrollando una técnica laboriosa y refinada que intente disimular o maximizar (quién sabe), las conexiones con lo tradicional y lo etnográfico, aligerando apoyos, desvaneciendo juntas para catapultar la joya a otros territorios de mujeres nuevas.

Así lo fronterizo de los mundos se diluye, para alcanzar en este futuro-presente, nuevos recursos que unidos a nuevos materiales y nuevos apoyos, nos conduzcan a una "solución novísima", que trascienda con mucho su mera función decorativa clásica, para convertirse (sin abandonar aquella función y respetándola) en un ámbito propio, independiente, con elevado contenido receptor.

Al final, obras así, luchan siempre por liberarse de su pasado y será el espectador el único que pueda, a base de abstracción y descontextualización, dejarse capturar y secuestrar por esta: ARS GEMMARIA NOVA de Salamanca. 


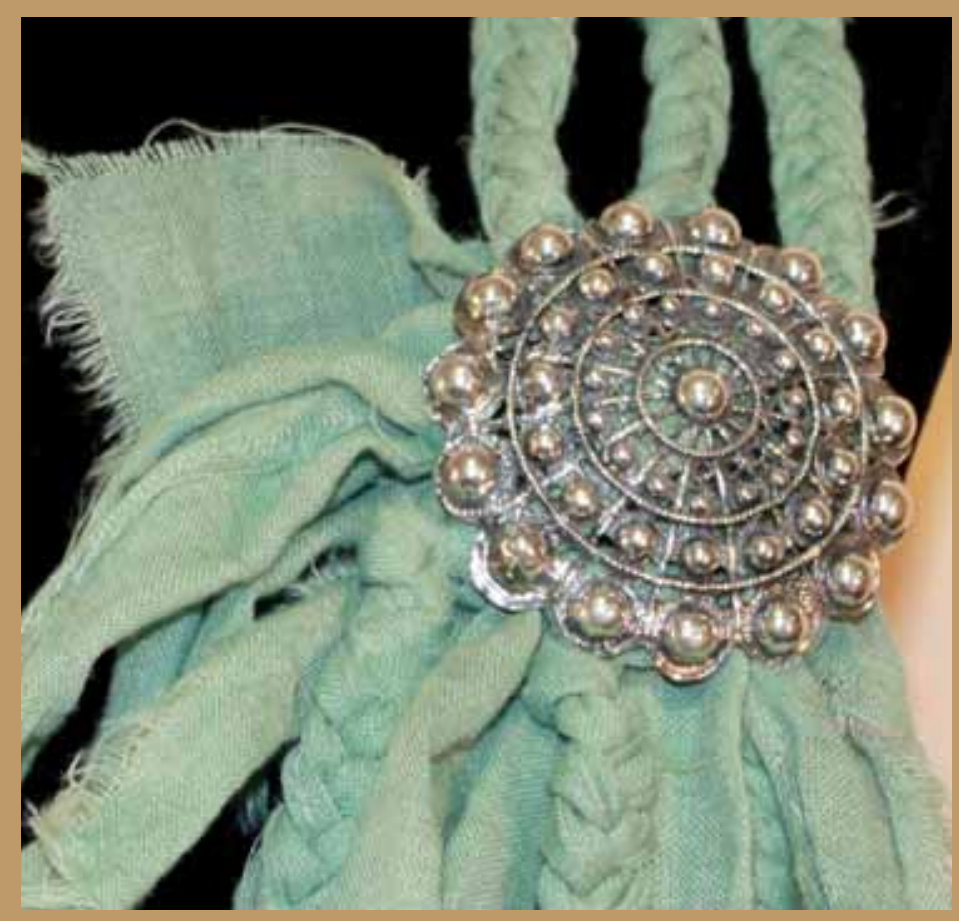




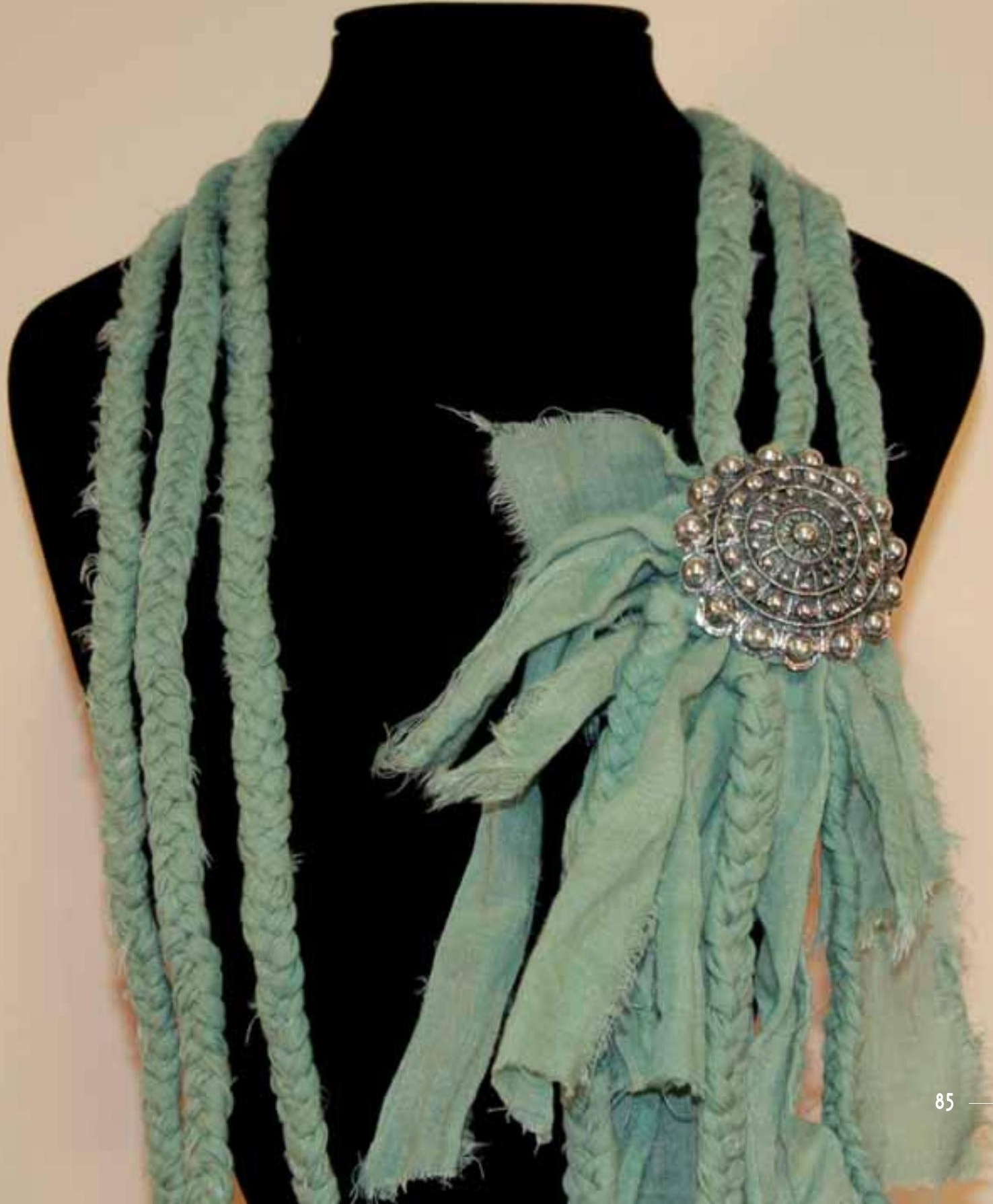




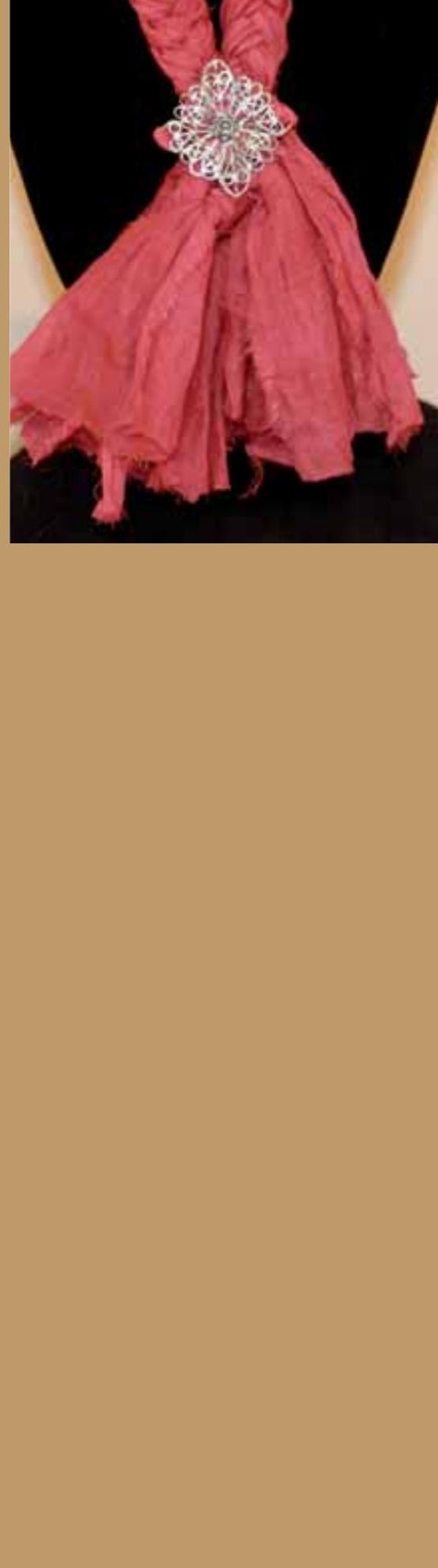




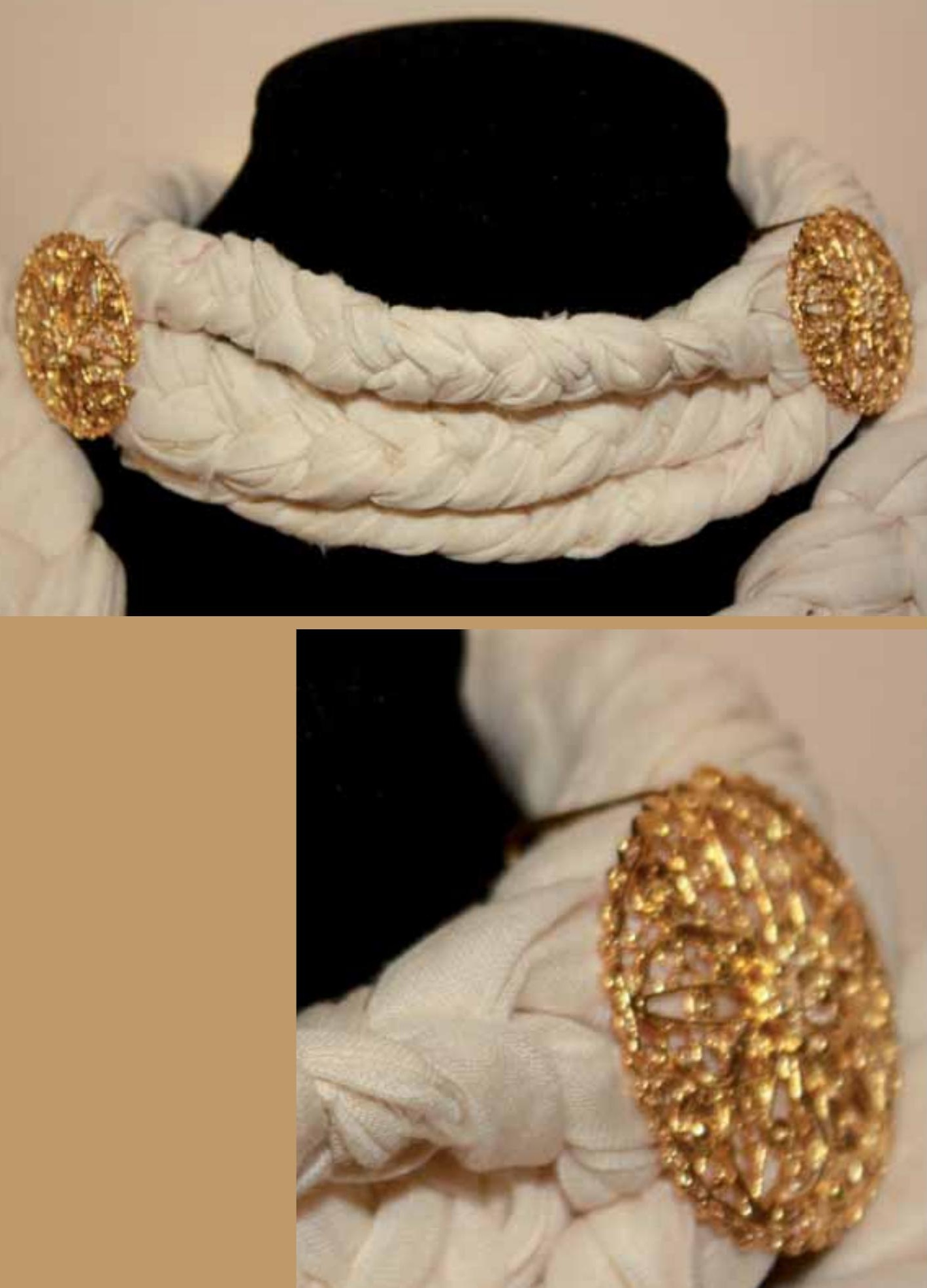




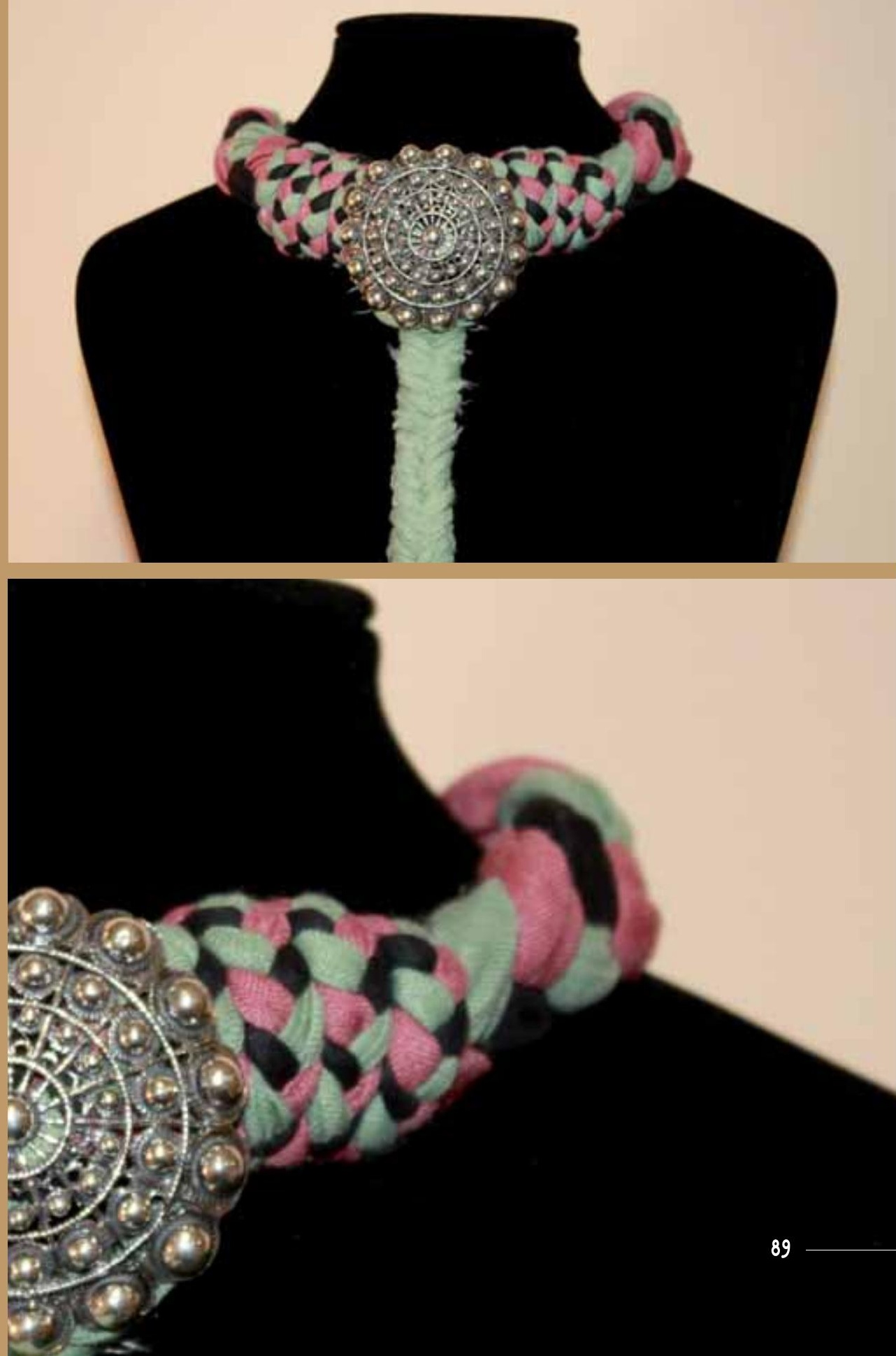




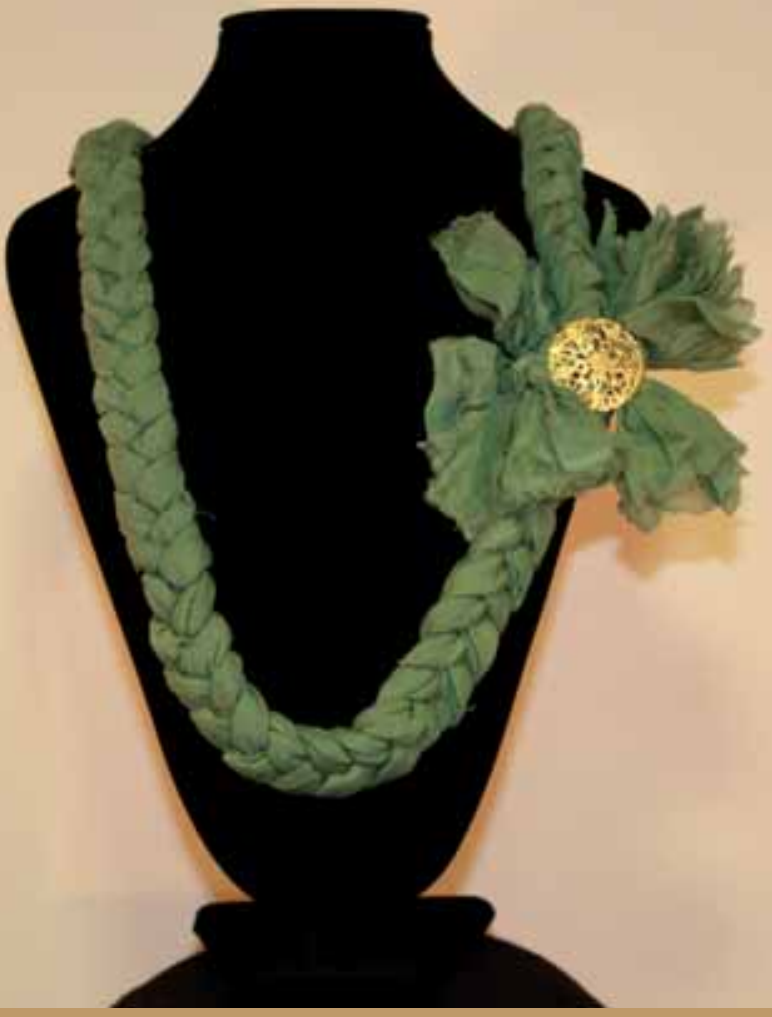

90 

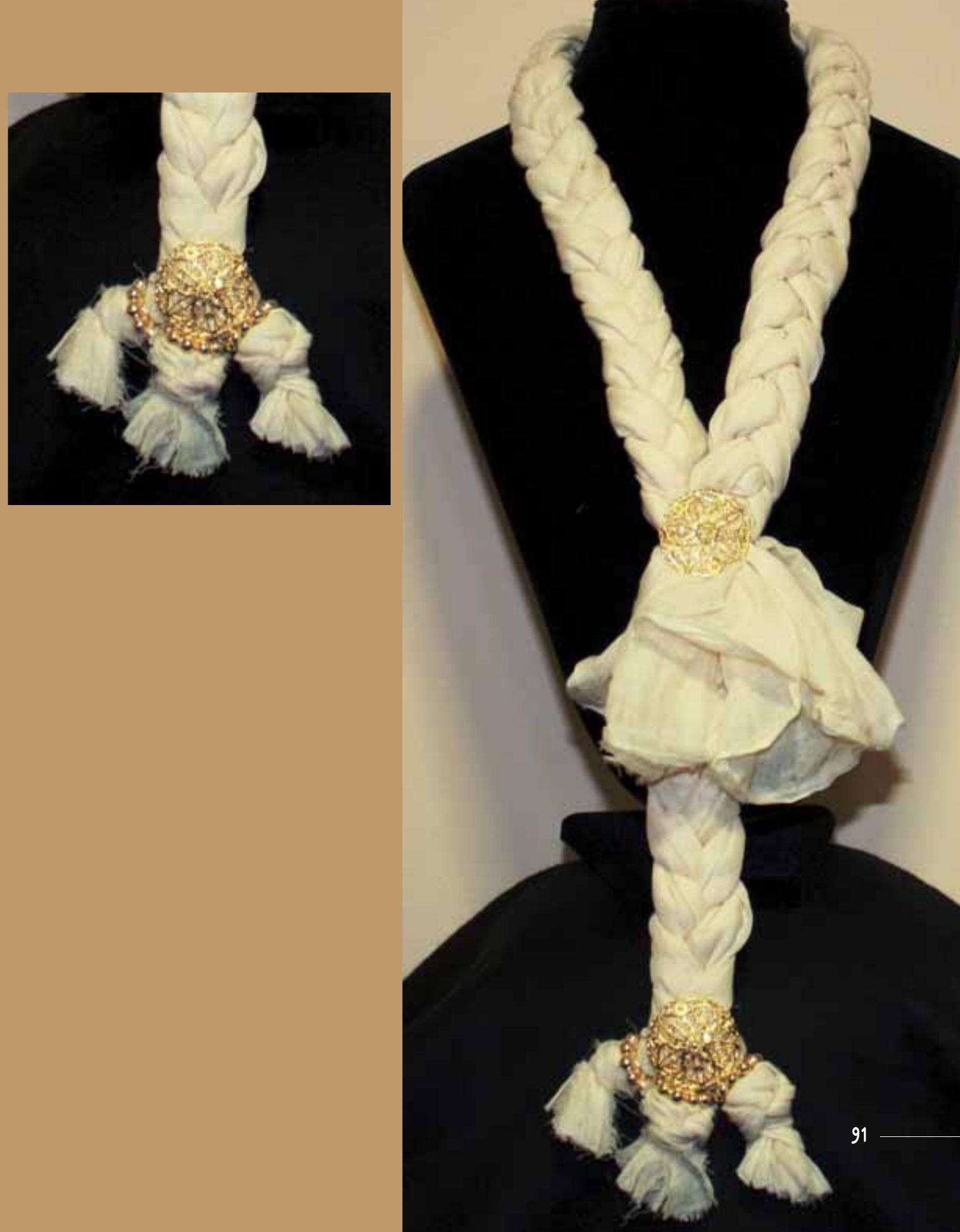



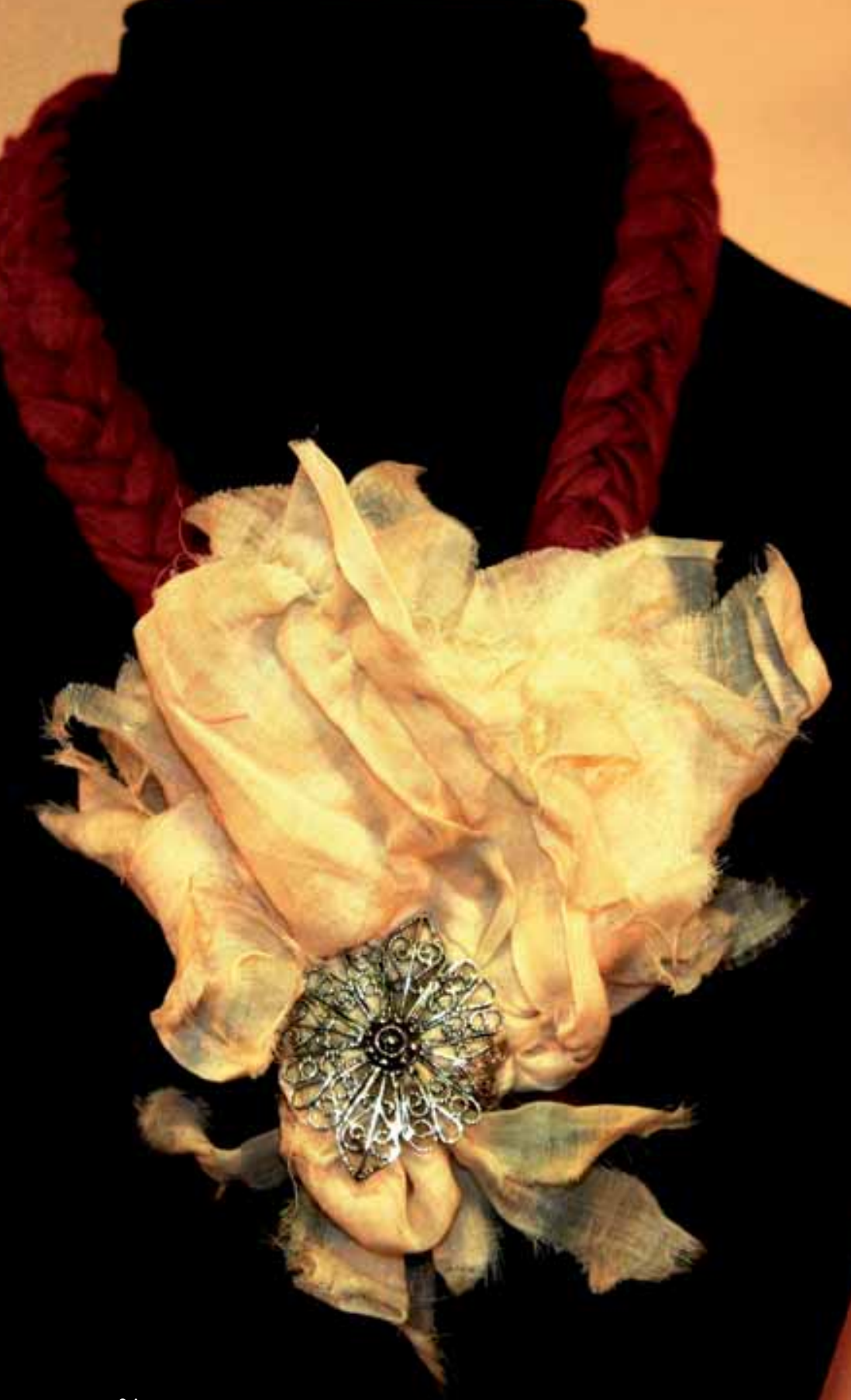

94 


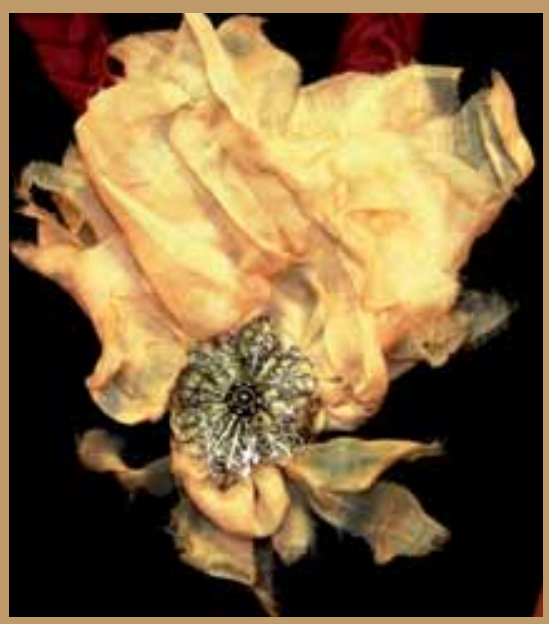




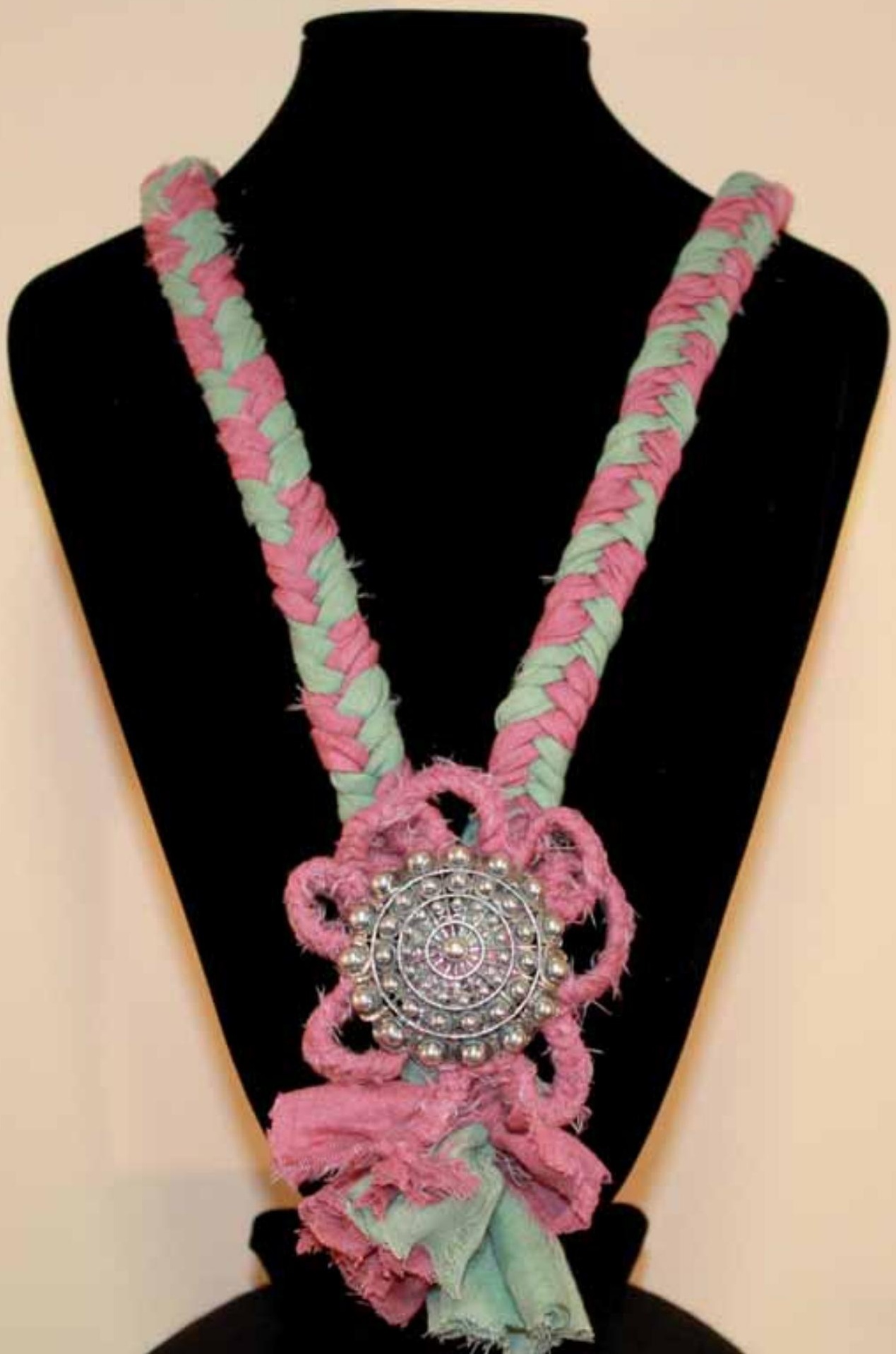




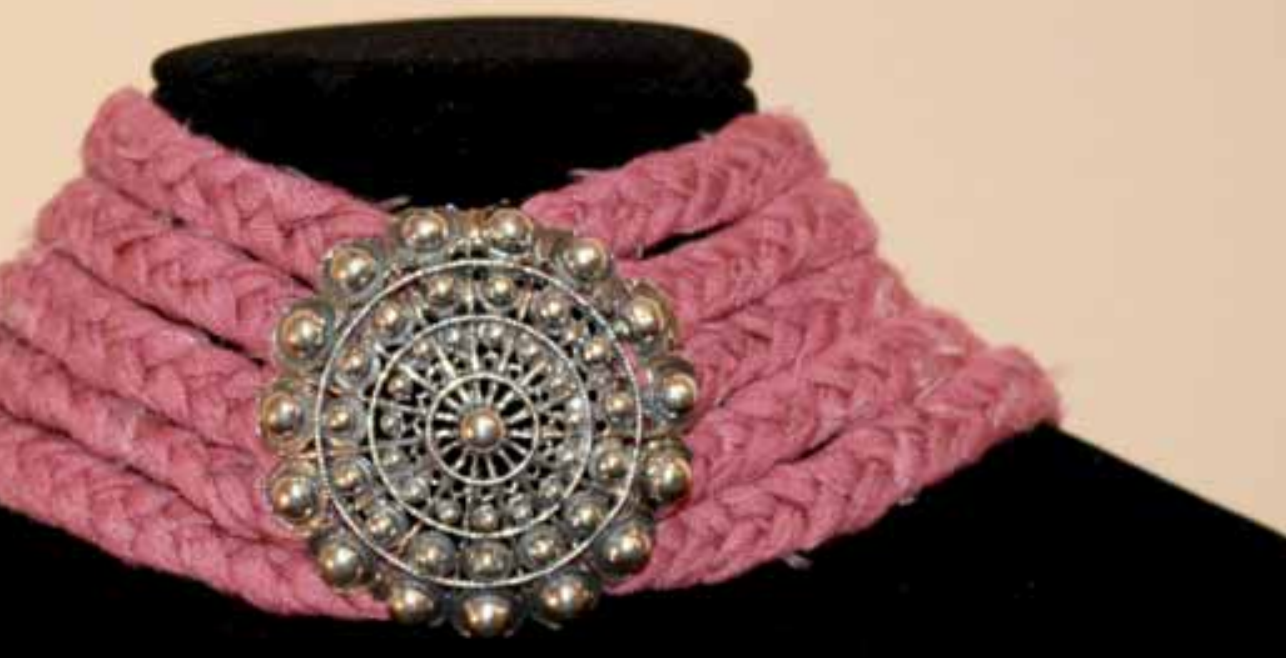



joya
$\&$
color

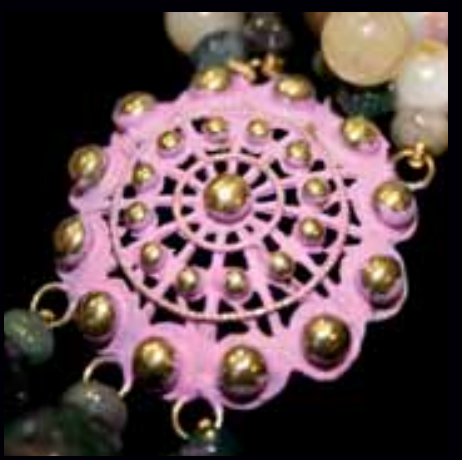





\section{EL COLOR}

Los tonos de los colores, al igual que los de la música, son de naturaleza más matizada, despiertan vibraciones anímicas mucho más finas que las que podemos expresar con palabras. Cada tono encontrará con el tiempo su expresión en la palabra material, pero siempre quedará un residuo, no expresado por ella, que no constituye un rasgo accesorio del tono sino precisamente su esencia. Por eso las palabras son y serán siempre meros indicadores, etiquetas externas de los colores.

WASSILY KANDINSKY

En la muestra que se presenta hay un trabajo nacido de la voluntad de crear, utilizando el color como medio de expresión, desde la sensación y experiencia humana.

Una armonía de colores que ejerce una influencia directa en nuestro interior.

Situados frente a las joyas sin ningún tipo de información podríamos pensar que se aborda el diseño de una manera intuitiva, guiada por emociones.

Sin duda las piezas que aquí se muestran nos evocan a la naturaleza, a un mundo de sensaciones e impresiones a través del color.

La obra es el resultado de varias piezas que crean diferentes sinfonías. Gamas de emociones delicadas, combinaciones de colores jubilosas, soñadoras, transparencias evanescentes y etéreas, así como sorprendentes contrastes. Diseños creados con una gran sensibilidad y equilibrio. 
Nuevas combinaciones que al mezclarse crean una variedad de mundos nuevos.

El territorio que abre esta colección con técnicas, materiales, manera de colocar los diferentes elementos, lo mate, lo brillante, la lisura, el relieve es amplio, utilizando un lenguaje de formas en el que el color es el elemento fundamental.

El rojo, el naranja, el blanco, los verdes maravillosos, el azul, el lila y multicolores aplacados que huyen de toda forma de turbación, cuya emoción es la calidez, gamas delicadas, contrastes vigorosos.

En cada modelo entra en juego toda creatividad, sensibilidad y experiencia consiguiendo un resultado puramente sensual.

Adora Calvo

Galerista

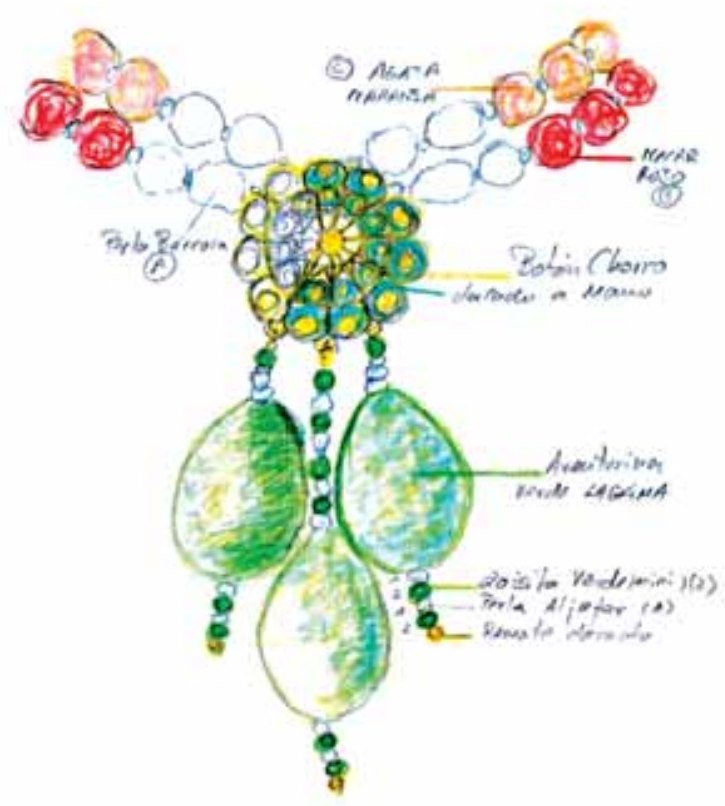




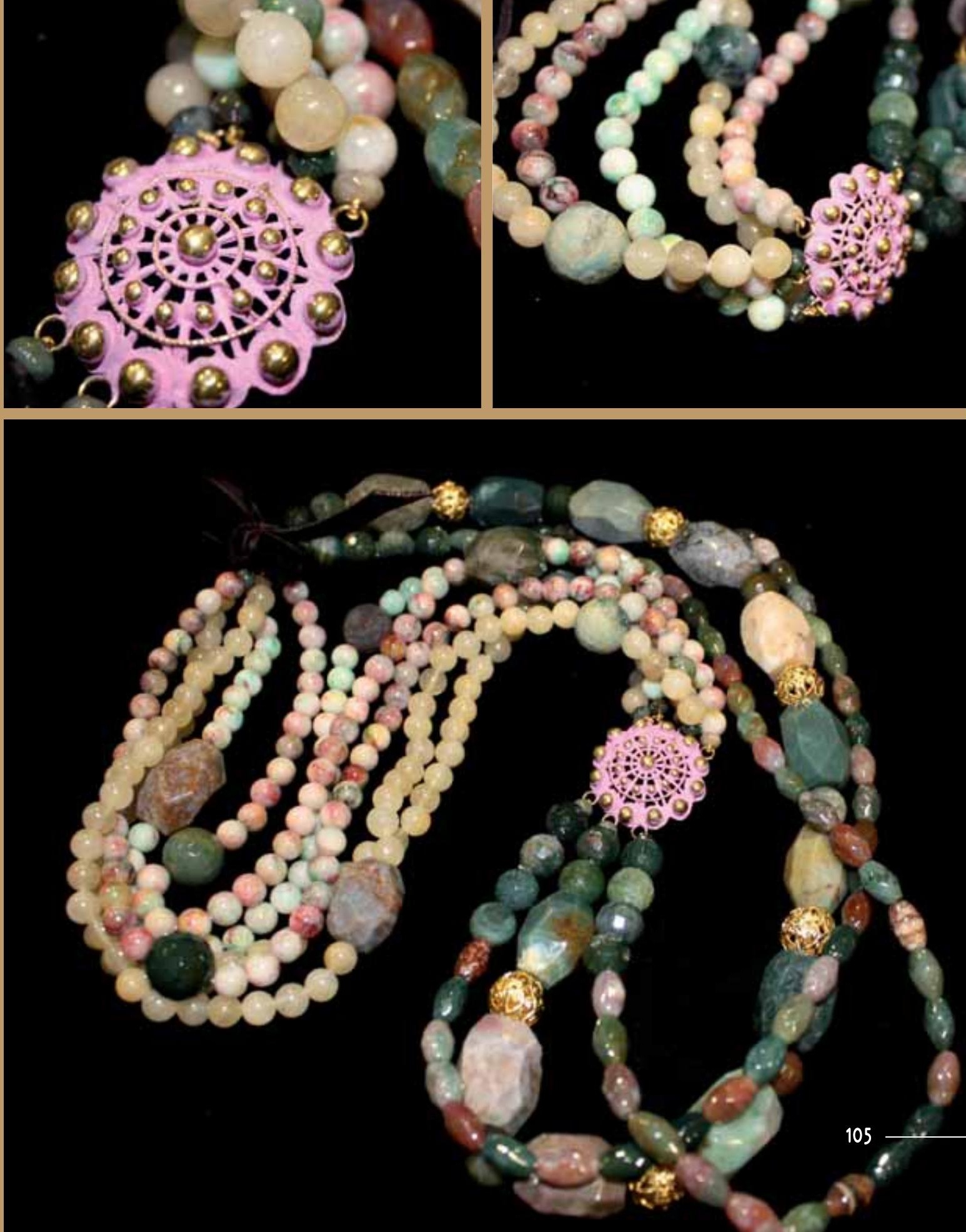

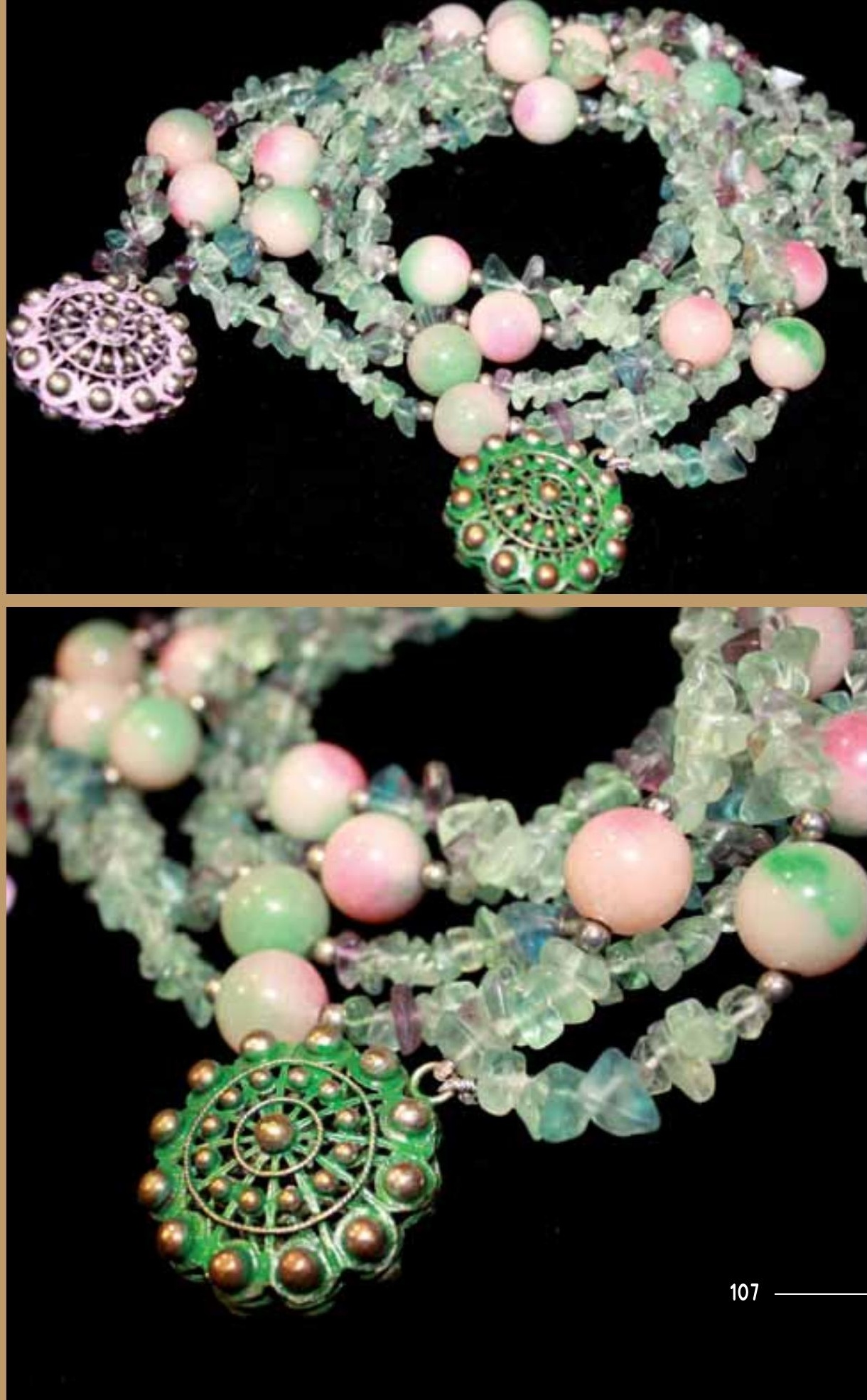

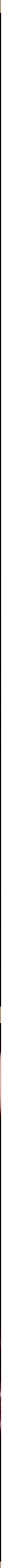

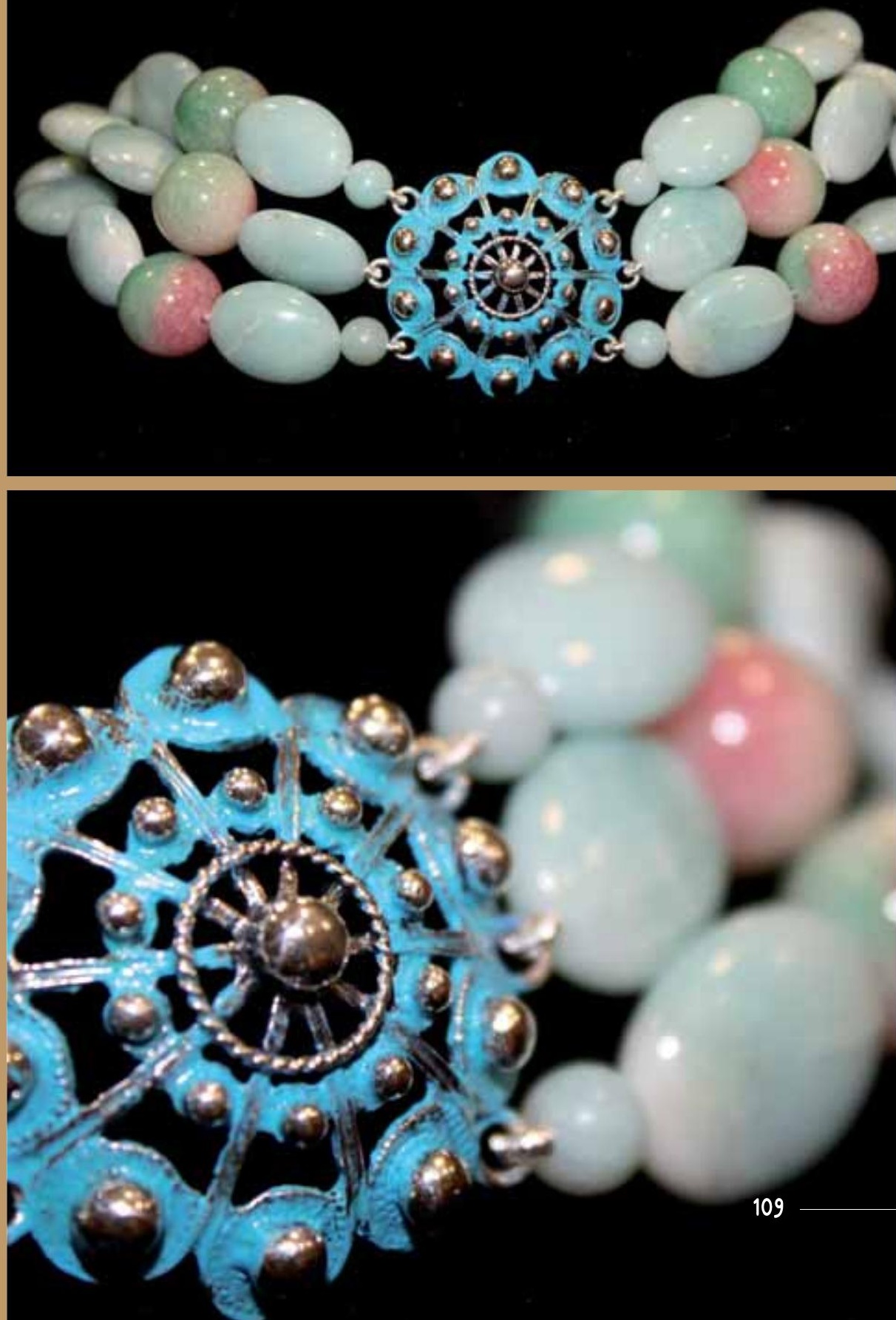


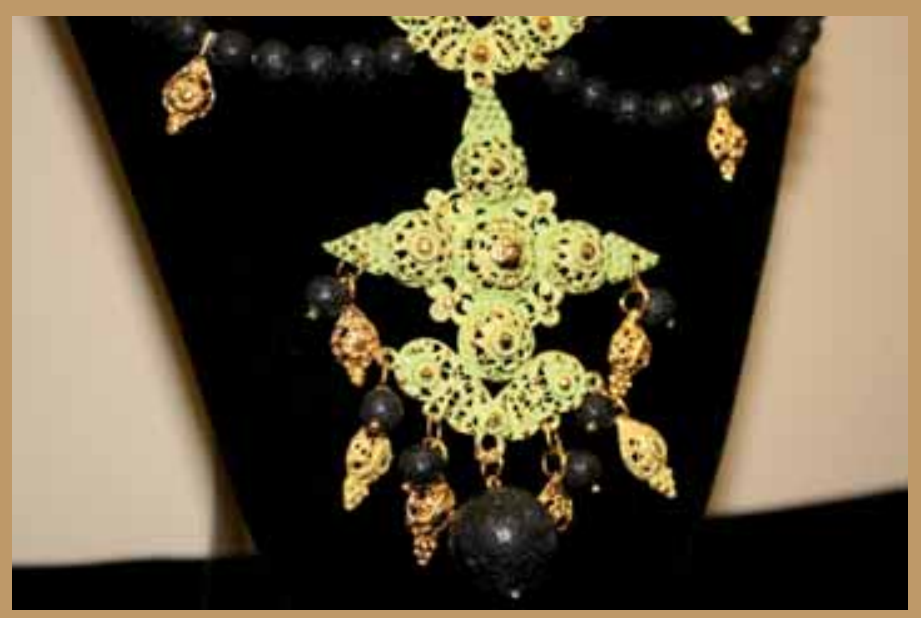




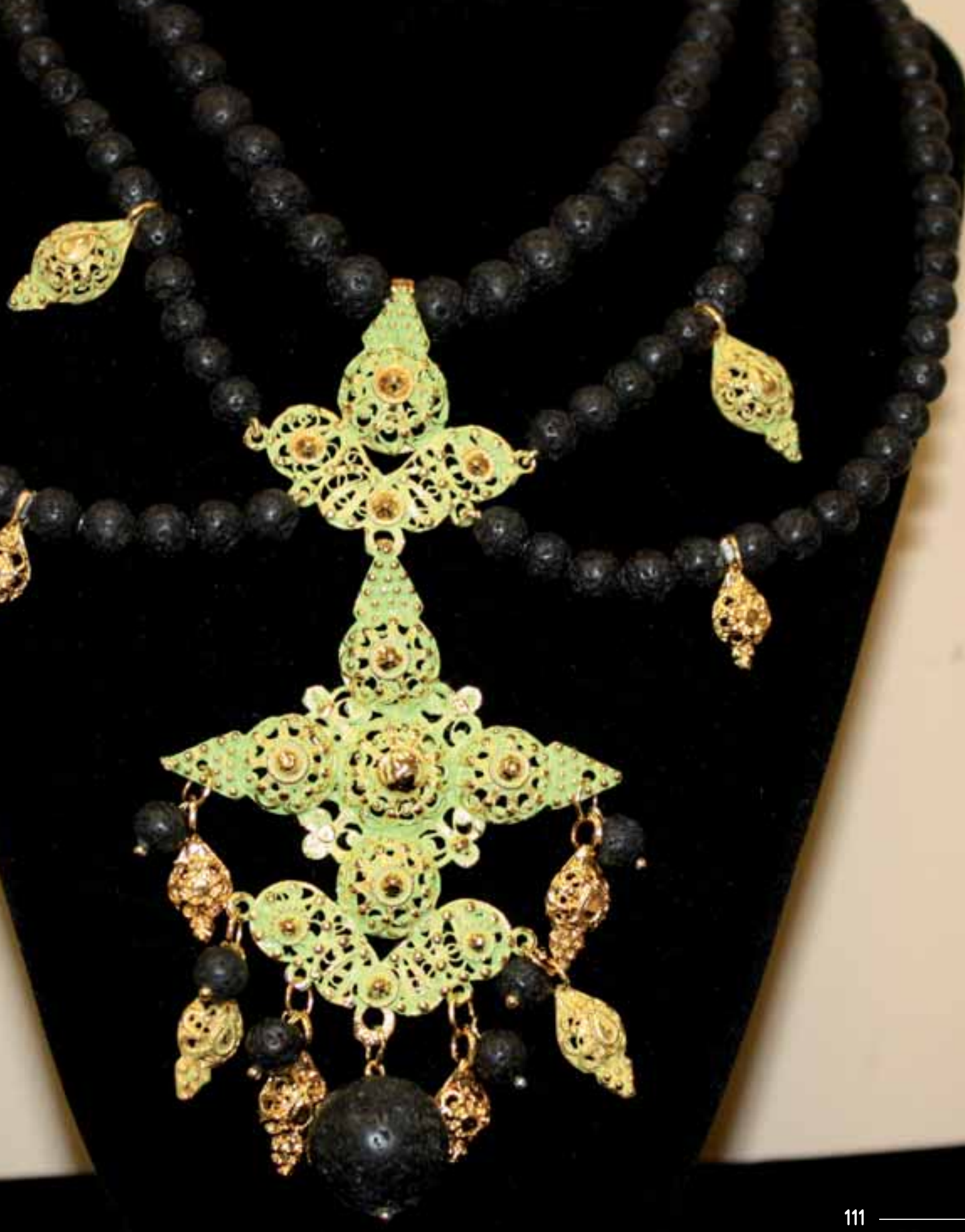





\section{epílogo}

\section{CADA TIEMPO TIENE SUS ICONOS}

¿Son las joyas un complemento de la indumentaria? ¿O más bien resultado evidente (elementos representativos y reconocibles) de un tiempo, de una época concreta? ¿Nos aportan datos acerca de la propia persona que porta una determinada joya? ¿Podemos ubicarlas incluso dentro del sistema expresivo, de un peculiar lenguaje?

Las joyas son algo más que pequeños objetos artísticos, intrínsecamente valiosos. Escribíamos hace ya algunos años un texto monográfico titulado La belleza que protege, en clara alusión a ciertas connotaciones que deben estar presentes al hacer reflexiones acerca de la joyería popular, tradicional, aquella que conocemos como representativa de un espacio cultural, el charro, el de Salamanca y su entorno, con unas caracteristicas muy peculiares y diferentes en gran medida a aquellas otras que podíamos encontrar en áreas geográficas incluso cercanas. Su estudio puede abordarse desde muy diversos ángulos; la joyería es portadora de numerosos significados. Entre ellos, en muchos casos, el de la protección frente a hipotéticos sucesos, como una enfermedad, un accidente, o el temido mal de ojo, mediante el uso habitual de signos, símbolos, y aditamentos que sintetizan o representan creencias: amuletos, relicarios o cruces, higas, medias lunas, peces.., materias como el coral o el azabache, y muchos más. También el oro y la plata, considerados tradicionalmente como materiales portadores de ciertas potenciales virtudes.

1. No debe engañarnos el hecho de que, como el traje, de la misma manera que la indumentaria, las joyas se colocan directamente sobre el cuerpo, algo que ha venido sucediendo desde los albores de la humanidad. Acompañan al traje, puede que formen parte de la propia indumentaria, pero no son estrictamente complemento 
de la misma. Lo cierto, aquello que realmente ocurre, es que nos ofrecen en ambos casos, trajes y joyas, información muy precisa a veces acerca del tiempo, del momento histórico y del contexto social, cultural, vital en suma, en el cual se utilizan. Lo mismo que sucede con cualquier otro elemento, sea este material como los utensilios, los enseres, los objetos cotidianos. También observamos algo paralelo con la inmaterialidad (como las peculiaridades del habla o las formas de expresión, por ejemplo). Todo ello es, en su forma externa, en aquello que percibimos, notablemente diferente si analizamos periodos temporales, que no tienen por qué ser muy lejanos. Veamos:

Un solo golpe de vista, poco más que algunas décimas de segundo, nos ubica con precisión en el tiempo, puede que de forma no consciente, nos permite conocer, por ejemplo al observar unas imágenes (fotografía, película, obra pictórica), que estamos ante una escena de los años sesenta del siglo XX, quizá antes de la Guerra Civil, incluso precisar si se trata de una imagen de tan solo 20 años atrás. Reflexionando un poco, constatamos que lo que nos lleva a tales certeras conclusiones en tan brevísimo espacio de tiempo será el tipo de indumentaria, o bien el peinado; quizá la apreciación de un tipo de joya, cómo y dónde esta se coloca, y por supuesto el estilo (decimos "la época"). Incluso a veces algo tan sutil como la actitud, el gesto o la pose del o los personajes.

\section{La reutilización}

Desde hace mucho tiempo, en nuestros estudios sobre la joyería tradicional hemos constatado la frecuencia de la reutilización de elementos o joyas anteriores, o bien contemporáneas al hecho, formando parte de diferentes conjuntos, sobre todo en collares y elementos colgantes, aunque no solo. Muy probablemente, se trata de un hecho consustancial a la propia entidad de las joyas, al menos a un importante grupo de ellas, como los elementos colgantes en los collares y grupos de piezas articuladas como conjunto (por ejemplo las brazaleras, o los rosarios), y también, aunque en menor medida, en las piezas que se colocan sobre las prendas de indumentaria, como broches, etc. No hay ninguna duda de que ya en los primeros momentos de los lejanos tiempos en que era habitual su uso (podemos sin ningún 
problema remontarnos a la Prehistoria), hay cantidad de piezas y elementos que se incorporan y se reinsertan, muchos de ellos reutilizados y procedentes de orígenes diversos en el tiempo y el espacio, tanto por lo que respecta a los fragmentos más singulares del conjunto (símbolos religiosos y profanos, por ejemplo), como a los que son homogéneos (sartas o cuentas de un collar).

Y cuando decimos reutilización, la palabra no tiene en absoluto con-

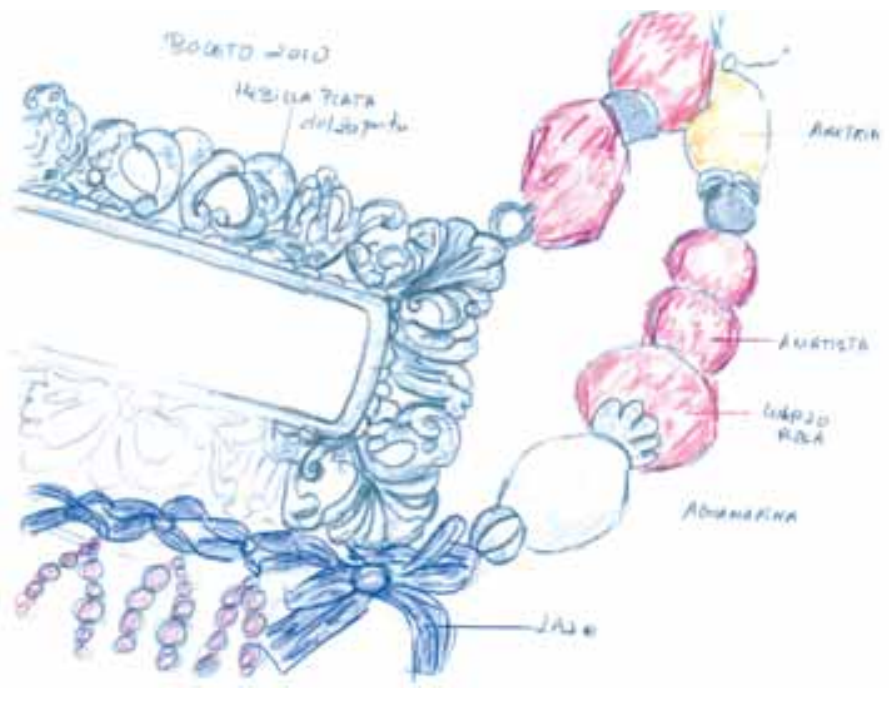
notaciones negativas, todo lo contrario. El hecho de incorporar piezas anteriores, incluso antiguas, en una joya de nueva estructura quiere decir que existe especial interés en su utilización. Puede, y de hecho en muchos casos es así, ser incluso la parte del todo más destacada, el centro en torno al que se construye la joya. Creo que esto es así en el caso que tratamos del proyecto No hay 2 igual, de María Eugenia y Verónica. Aquí, el elemento que podemos denominar clásico o tradicional, forma parte esencial del todo, del conjunto. Digamos que es -sigue siendo- la base y el centro de atención.

La tradición continúa, con nuevas formas expresivas, con otra intención sin duda, que va pareja a los tiempos en que se diseña y se construye, para dar satisfacción a unas personas que llegan a identificarse con sus formas, con la disposición de las mismas, con lo que representan en suma.

\section{El color y nuevas formas (¿viejas?)}

Nuevo también me parece, y me ha causado cierta sorpresa, sin duda positiva, el uso del color en los trabajos de Verónica y María Eugenia. Novedoso en un sentido: durante mucho tiempo en la joyería charra, esa larga tradición que en ocasio- 


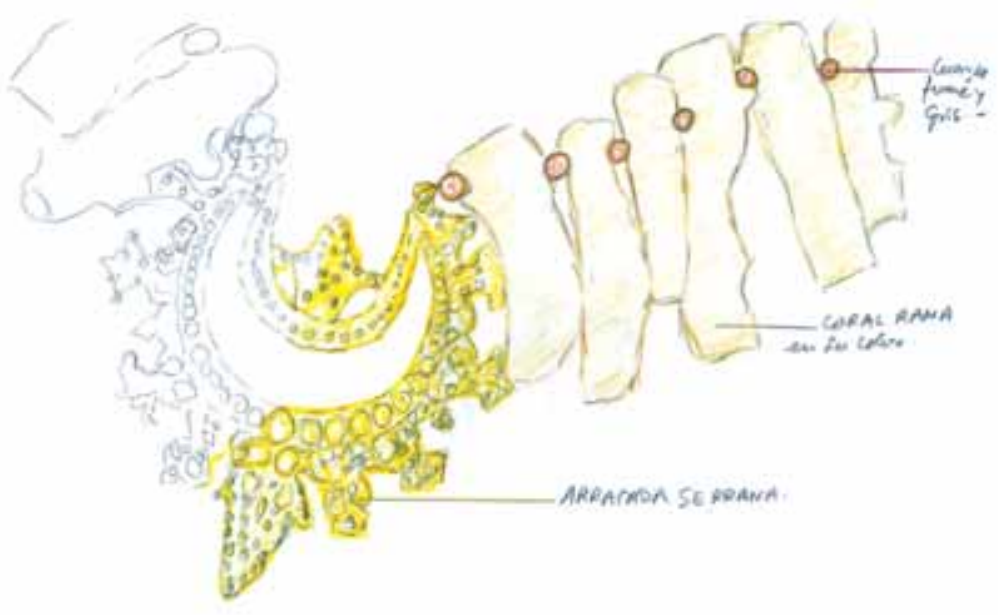

nes constatamos se remonta a tiempos muy lejanos (yo mismo he hablado de milenios, refiriéndome a técnicas y formas), el tono monocromo ha predominado: oro, plata dorada, plata en su color en mucha menor medida. La presencia del aljófar nacarado junto al oro, también los diamantes "de tabla", enriquecían estéticamente, con su tono, su textura y sus brillos tamizados, esa cierta monotonía. Al tiempo que no entraban en competencia con el rico colorido de la indumentaria. O quizá precisamente por eso, pues, ¿cuál era el efecto de sartas de bolas, cruces y grandes pendientes dorados acompañando a diario vestidos totalmente negros de nuestras abuelas?

Sin embargo, si nos remitimos algunos años atrás, al siglo XVIII, encontramos que las joyas tienen mucho color: verdes esmeraldas, rojos rubíes, cristales polícromos, destacan como caracteristica de esta época. Si miramos hacia épocas aún más lejanas, el periodo que abarca desde el siglo XVI hasta finales del XVII, y en mayor grado en la joyería de la Edad Media, constatamos que el color forma parte de la propia esencia de las joyas a través de una rica policromía, con una presencia arrolladora que tiene su origen en este caso en tradiciones importadas de la Europa Central, "bárbara".

El color hoy en día, en el 2013, quizá ya por este motivo no nos parecerá tan novedoso. Sí, en cambio, la preferencia y su uso en composiciones diferentes, sabiamente matizadas, su utilización en este caso en el que las interesantes propuestas se identifican nitidamente con los tiempos en los que se les da forma, es decir, hoy. 
4. El proyecto No hay 2 igual, no es algo insólito por novedoso, pues muchos joyeros, incluso alguno de los poquísimos que continúan la técnica de la filigrana y el granulado con las técnicas más arcaicas, están haciendo propuestas innovadoras, construyendo formas y piezas al modo y estilo actuales. Lo que sí es absolutamente nuevo y creo que ahí radica su interés, es el hecho de que en el caso presente se ha realizado -está en proceso- un planteamiento sosegado, que abarca cuestiones que van desde el detalle y el elemento primario, profundizando en el conocimiento de sus orígenes y su porqué, hasta lograr conseguir un estilo característico que, en este caso sí es una aportación diferente, bien asentada en su conjunto y muy coherente. La diversidad de materiales, de formas y de intenciones busca, y a menudo lo encuentra, una armonía que logra conjugar esa multiplicidad de significados en unas formas expresivas quizá comprensibles, con las que las personas a que se destinan deben sentirse identificadas.

Quiero recordar aquí las palabras de un gran artista joyero y buen amigo, Ramón Puyg Cuyás, refiriéndose a su propia actitud en el proceso de ejecución de las joyas, que considero pueden aportar claridad al respecto:

Lo importante es hacer, pero no un hacer deslumbrado por el dominio de una técnica, sino para encontrarnos con esos momentos mágicos e inquietantes en los que nos damos cuenta de que somos capaces de infundir ese entusiasmo del espíritu a la materia, y de vivir la experiencia de reconocernos a través del objeto que ha salido de nuestras manos. Un hacer impulsado por la necesidad, no de crear, sino de instaurar un orden en nuestro universo de caos. Un hacer que siempre se mueve en el horizonte que es límite entre la luz y la oscuridad. Que está unido a un proyecto vital.

Las joyas acompañan a la mujer, también al hombre (recordemos las grandes y bellas piezas de oro que cierran la camisa de lino, el tintineo argentino de las botonaduras en las perneras y sobre el chaleco). Nos hablan de muchas cosas, si que- 
remos escuchar; nos transmiten actitudes, emociones y sentimientos. Materiales e ideas ordenadas en forma de joyas no son materia inerte, sino que en ellos palpita la vida. Y no es dificil comprender lo que nos dicen.

\section{Carlos Piñel}

Pintor y etnógrafo

Director del Museo Etnográfico de Castilla y León 
Verónica y Ma Eugenia, Ma Eugenia y Verónica han conseguido aunar dos mundos imposibles. La teoría y la práctica, que deberían ser consecutivas, no siempre forman parte de una misma realidad. El estudio de una y la creatividad y técnica de la otra, se han encontrado en un territorio nuevo:

\section{NO HAY 2 IGWAL}

Nada entre ellas es parecido, aunque curiosamente el punto de encuentro es más evidente de lo que parece. La riqueza individual de sus personalidades antagónicas, pone de manifiesto que, si hay un buen proyecto, los resultados que se obtienen pueden llegar a ser sorprendentes. Estudio, conceptualización, teoría y filosofia + creatividad, diseño, gusto y composición, dan como resultado un binomio, que unido al trabajo y el esfuerzo, se convierte en la clave de esta "firma", que entra en el mercado con modestia, pero con mucho decir. 

